\title{
TRAJETÓRIAS DE VIDA E SEXUALIDADES: \\ um estudo a partir de depoimentos de homens e mulheres atendidos no Plantão Psicológico do Serviço de Aconselhamento Psicológico do IPUSP
}

Tese apresentada ao Instituto de Psicologia da Universidade de São Paulo como parte dos requisitos para obtenção do título de Doutor em Psicologia

São Paulo 


\section{TRAJETÓRIAS DE VIDA E SEXUALIDADES:}

um estudo a partir de depoimentos de homens e mulheres atendidos no Plantão Psicológico do Serviço de Aconselhamento Psicológico do IPUSP

Tese apresentada ao Instituto de Psicologia da Universidade de São Paulo como parte dos requisitos para obtenção do título de Doutor em Psicologia

Área de concentração: Psicologia Escolar e do Desenvolvimento Humano

Orientadora: Profa. Dra. Maria Luisa Sandoval Schmidt

\section{São Paulo}


Toniette, Marcelo Augusto.

Trajetórias de vida e sexualidades: um estudo a partir de depoimentos de homens e mulheres atendidos no Plantão Psicológico do Serviço de Aconselhamento Psicológico do IPUSP / Marcelo Augusto Toniette; orientadora Maria Luisa Sandoval Schmidt - São Paulo, 2009.

$350 \mathrm{p}$.

Tese (Doutorado - Programa de Pós-Graduação em Psicologia. Área de Concentração: Psicologia Escolar e do Desenvolvimento Humano) - Instituto de Psicologia da Universidade de São Paulo.

1. Sexualidade 2. Gênero 3. Comportamento psicossexual 4. Identidade sexual 5. Medicalização 6. Relatos verbais 7. Plantão psicológico 8. Aconselhamento psicoterapêutico I. Título.

HQ21 


\section{TRAJETÓRIAS DE VIDA E SEXUALIDADES:}

um estudo a partir de depoimentos de homens e mulheres atendidos no Plantão Psicológico do Serviço de Aconselhamento Psicológico do IPUSP

\section{MARCELO AUGUSTO TONIETTE}

\section{BANCA EXAMINADORA}

Prof. Dr.

Instituição:

Assinatura:

Prof. Dr.

Instituição:

Assinatura:

Prof. Dr.

Instituição:

Assinatura:

Prof. Dr.

Instituição:

Assinatura:

Prof. Dr.

Instituição: Assinatura:

Dissertação defendida e aprovada em: 
Ao meu pai (in memorian) e à minha mãe com meu amor, carinho e gratidão 


\section{AGRADECIMENTOS}

À Profa. Dra. Maria Luisa Sandoval Schmidt, minha orientadora, pela amizade, confiança, e inspiradora presença ao longo de toda esta trajetória.

À Profa. Dra. Vera Silvia Facciolla Paiva, na ocasião do exame de qualificação, ter sugerido o aconselhamento psicológico como caminho para continuar a trajetória da pesquisa.

Ao Prof. Dr. Hugues Costa de França Ribeiro, pela amizade, e pelas atentas e valiosas contribuições no exame de qualificação.

À Profa. Dra. Maria Júlia Kovács, pela amizade e apoio.

Ao Prof. Dr. Luiz Alfredo Lilienthal, pela amizade e sempre incentivo.

Aos colaboradores Jorge, Thiago, André, Melina, Sofia e Mariana, pela disposição e generosidade de compartilhar suas trajetórias.

Ao meu saudoso e amado pai, o "seu" Augusto, que partiu antes da conclusão deste trabalho; à minha amada mãe, a dona Áurea, queridos pais, a quem rendo o meu eterno carinho e agradecimento; ao Marcos e à Márcia, queridos irmãos e companheiros de jornada; e aos meus cunhados Hélcio e Felícia, e sobrinhos Alan, Meire, Luana, Bruno, Victor, Guilherme e Lucas. Agradeço a todos pelo amor, compreensão e apoio.

À Maria Gertrudes Eisenlohr - a "Dgê" -, pela amizade e generosidade em compartilhar sua experiência do Plantão Psicológico.

À Vera Vaccari, pela inestimável amizade, apoio, e pela paciente revisão do texto final.

À dona Iracema, Carmela, e Tuca, pela amizade e apoio espiritual.

À Ana Salvato, do Patronato Acli, pela revisão do resumo na língua italiana, atendendo ao meu pedido de homenagem aos miei antenati. 
À Olívia e à Sandra, pelo atento e eficiente trabalho na secretaria.

Aos amigos que, direta ou indiretamente, colaboraram para a concretização desse projeto, em especial Heloísa Hanada, Maria Cristina Rocha, Ana Claudia Oliveira, Nabil Ali, Ralmer Rigoletto, Mauro Cherobim, e Liz Verônica Luisi.

À Coordenação de Aperfeiçoamento de Pessoal de Nível Superior - CAPES -, pelo financiamento que possibilitou a realização desta pesquisa. 


\section{SUMÁRIO}

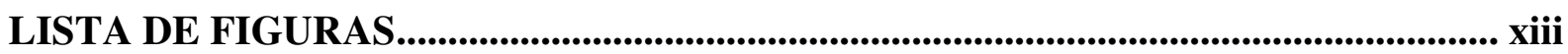

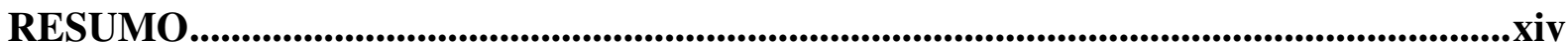

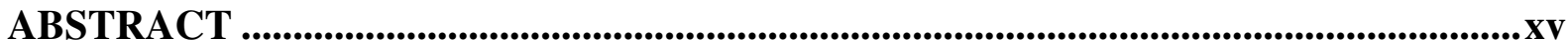

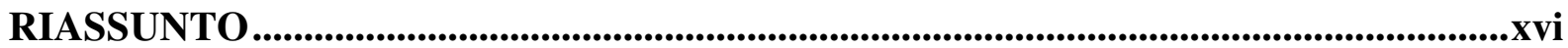

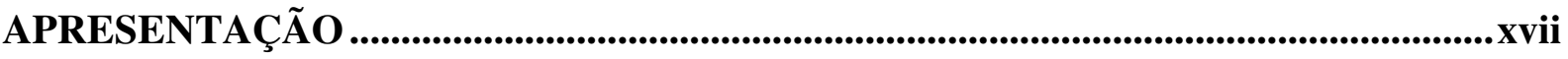

\section{CAPÍTULO I}

ALTERIDADE, EDUCAÇÃO E SAÚDE .......................................................................1

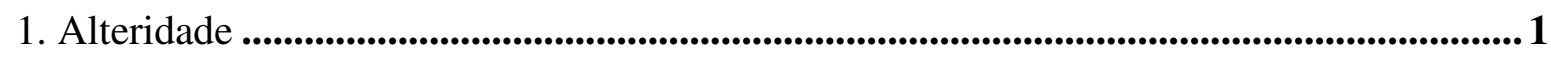

2. Educação e Saúde ..........................................................................................................6

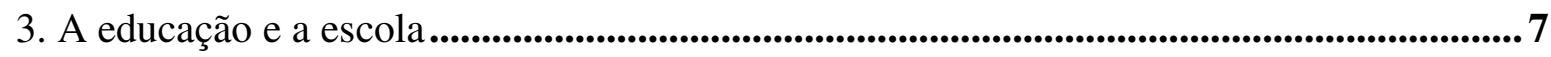

\section{CAPÍtULO II}

COMPREENDENDO AS DIMENSÕES DA SEXUALIDADE E DO GÊNERO ............16

1. A dimensão da sexualidade .................................................................................17

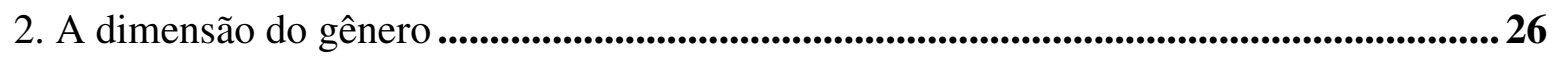

\section{CAPÍTULO III}

NASCIMENTO DA SEXOLOGIA: UMA NOVA ÁREA DO SABER E DO CONTROLE 


\section{CAPÍTULO IV}

O CAMINHO ADOTADO PARA CONHECER AS EXPERIÊNCIAS.

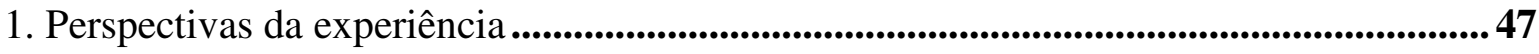

2. Algumas referências teóricas............................................................................47

3. Enfocando o método .........................................................................................................................51

4. Os relatos orais e os roteiros sexuais e de gênero................................................................54

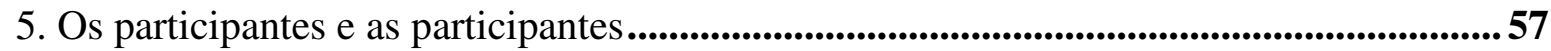

6. O modo de acessar as experiências a partir dos relatos orais ...............................................58

7. Algumas considerações sobre ética e pesquisa participante..............................................60

\section{CAPÍtULOO V}

ESCUTANDO HISTÓRIAS, CONHECENDO EXPERIÊNCIAS

1. "A sociedade espera mais que um indivíduo seja mais um macho do que um homem": o depoimento de Jorge.............................................................................62 62

1.1. Jorge na família: "se não fala, é melhor eu não falar também” ..............................63

1.2. Jorge na escola: “tinha poucas pessoas para conversar sobre isso...”.................... 65

1.3. Jorge no mundo virtual: “A internet abriu muito mais, tinha muito mais opções"

1.4. Jorge e os jogos on-line: "era uma outra vida, quase que completa ali no jogo, e com um personagem feminino"

1.5. Jorge na faculdade: “...pronto, eu sou uma garota”................................................ 75

1.6. Jorge e a busca de ajuda: a procura do SAP ........................................................ 75

1.7. Jorge se localiza: a assunção das dúvidas e do modo-de-ser singular ..................... 77

1.8. Jorge e a concepção de masculino e de feminino .................................................... 78

2. "Hoje eu me considero homossexual passivo": o depoimento de Thiago.

2.1. "Os outros garotos tinham um jeito mais... de garoto, (...) eu tinha uma delicadeza maior": Thiago na infância e o começo do enfrentamento do preconceito

2.2. "Em vez de ficar no meu quarto, sozinho, eu resolvi me converter": a experiência reliosa de Thiago 
2.3. "Eu não me aceitava homossexual, eu não era, não era": o preconceito internalizado

2.4. "Quando ela soube ficou, assim... nós nos conhecemos aqui na faculdade, e eu na época eu ainda não me aceitava como eu era": a experiência heterossexual.

2.5. "E nesse dia, na Parada desse ano, eu resolvi assumir": Thiago assume-se homossexual

2.6. "Foi fácil encontrar o grupo, na internet tem alguns grupos": Thiago encontra um terreno fértil para ampliar sua rede social

2.7. "Ainda ficaram marcas disso, eu ainda não superei todas": Thiago hoje 100

2.8. "Ser masculino ou feminino é questão de comportamento, havendo influência de padrões culturais": a concepção de gênero na perspectiva de Thiago.

3. “Eu realmente só estudava (...), eu não tinha vida no cursinho... não curtia as coisas, era uma máquina": o depoimento de André.

3.1. "Acho que eles não entendem o problema psicológico que eu tenho...": o relacionamento de André com os pais.

3.2. "Passou, e aí? O que a gente faz agora?": o ingresso na faculdade

3.3. "Foi uma sensação... estranha, não parecia que eu tinha transado": a primeira relação sexual com uma prostituta.

3.4. "A gente estava os dois descobrindo juntos": o primeiro namoro e o início da sua vida sexual com sua namorada

3.5. "Pô, vai falhar de novo?": o padrão de qualidade no sexo.

3.6. "Existe uma ciência por trás disso, então eu confio mais": André procura o Plantão Psicológico

3.7. "A saída: eu falei 'Foda-se!"': novos significados e sentidos para sua sexualidade

3.8. "O que mudou comigo não é só com o sexo": apropriando-se da sexualidade enquanto parte de si

3.9. "A camisinha é o tempo de pensar, dá prá quebrar o clima": a percepção do sexo protegido e da resposta sexual

3.10. "Ser homem, eu acho que... é... sei lá... homem é difícil, pô! Eu que sou homem, então falar isso...": a percepção do ser homem..... 
3.11. "A mulher tá mais pra aconchegar, tá... tá ali de braços abertos": a percepção do ser mulher.

3.12. “"Ele homem e ela mulher'. Quem vai ser o presidente?”: o gênero e papel de gênero

3.13. "Acho que a liberação ajudaria as pessoas na sua sexualidade": a sugestão de André para a vivência mais gratificante da sexualidade

4. "Você tem que ser maduro, vai ter que ter responsabilidade e coragem de assumir": o depoimento de Melina

4.1. "Talvez até por isso é que eu tenha passado durante vários anos por abuso e não falava para ninguém, porque sexo é uma coisa que não se comenta": Melina e o abuso sexual na infância.

4.2. "O Brasil começou com um patriarcalismo muito grande e essa questão do homem como senhor vem desde sempre, e até hoje, ainda": olhares sobre a diferença de gênero

4.3. "Vou seguir a minha vida porque não dá pra ficar a vida inteira parada, foi algo que aconteceu, mas acabou": lançando novos olhares sobre o abuso sexual.

4.4. "Agora já passou o período tenebroso, agora vou viver a minha vida": libertando-se das amarras

4.5. “'Vem cá, se você me beijar a gente namora, porque eu não vou ficar, não'. Aí ele beijou e a gente começou a namorar e está bem até hoje": o início do relacionamento com o noivo

4.6. "Ser homem, ou ser mulher, é o ápice de um amadurecimento": a concepção de masculinidade e de feminilidade

5. "Uma coisa que, tudo bem, foi tardia (...), pensando socialmente, mas para mim acho que foi meu momento": o depoimento de Sofia

5.1. "Eu queria, mas não conseguia namorar": o início dos relacionamentos.

5.2. "Eu acho que tem um problema porque não é bom, e as pessoas acham bom": a primeira relação sexual de Sofia

5.3. Sofia e a relação com o(s) pai(s): “...eu não sou filha dele, eu sou filha de uma outra pessoa...". 
5.4. "Eu estava preocupada com essa questão de que eu queria arrumar namorado (...) mas eu não conseguia fazer essa aproximação": Sofia procura o Plantão Psicológico

5.5. “...Meus desejos ficaram incontroláveis, mas eu achava que tava controlando...": a experiência com drogas e expressão afetivo-sexual

5.6. "Eu não lembro se tive uma experiência sexual boa...": Sofia e a vivência sexual

5.7. "O trabalho aqui (...) foi o que eu fiz por menos tempo, mas o que mudou mais alguma coisa": Sofia avalia o atendimento no Plantão Psicológico.

5.8. "Uma fragilidade que esconde uma coisa determinada": a representação de mulher para Sofia

5.9. “...Uma coisa mais autêntica do que a mulher": a representação de homem para Sofia.

5.10. "[O homem] sempre teve mais liberdade do que a mulher, em vários sentidos": as diferenças entre os gêneros

5.11. "Não tem nada de marcante, nem quando eu perdi a virgindade": Sofia fala de sua vida sexual.

5.12. “...As pessoas entendendo que elas são diferentes umas das outras": possibilidades de as pessoas viverem a sua sexualidade pela autoconhecimento.

\section{6. "Eu acho que a minha vida sexual foi muito complicada. Eu acho que ainda}

6.1. "Nas aulas você aprende sobre o que é, pra o que que serve, (...) não se fala do que é um ato de amor": as primeiras informações sobre sexo.....

6.2. "O que mudou, eu acho, que eu, eu ir atrás de algumas informações", a religião e a especialidade.

6.3. "Não percebo que a necessidade que eu tenho de sexo, $e$ [a necessidade de sexo] que meu marido tem, seja a mesma": a dificuldade do casal

6.4. "A minha sexualidade eu venho descobrindo agora... agora mesmo, é coisa bem recente": Mariana chega ao SAP.

6.5. "Essa melhora da nossa vida sexual, olha, eu comecei a perceber a partir desses testes que a gente costuma conversar e fazer, eи e meu marido...": Mariana e Carlos experimentam novas possibilidades na relação. 
6.6. "Mas eu acho que é essa falta de conversa, de repente, de mostrar que a sexualidade é algo bom, enfim, não tem nada de ruim no sexo": o sexo no contexto social.....

6.7. "Ter o poder maravilhoso de ter filhos": o ser mulher para Mariana.....................2 211

6.8. "Ser o forte de casa (...), ser o forte da família": o ser homem para Mariana.......213

6.9. "O que mais marcou minha sexualidade, na verdade, foi o namoro": o olhar para os caminhos trilhados

6.10. "Minha vida toda foi muito precoce (...), eu poderia ter brincado mais": os contraceptivos e a gravidez não planejada

6.11. "As pessoas deveriam ter um acesso mais facilitado com um especialista": Mariana aponta aquilo que acredita contribuir para a vivência sexual das pessoas

\section{CAPÍTULO VI}

SIGNIFICADOS E SENTIDOS DAS EXPERIÊNCIAS

1. Impressões iniciais sobre a sexualidade

2. A percepção das figuras maternas e paternas

3. Os contatos com o mundo social na infância, a escola e a percepção da sexualidade

4. A masturbação e a descoberta de sensações prazerosas com o corpo

5. A escola como referência de roteirização. 256

6. O enamoramento e a vivência dos roteiros sexuais. 260

7. A internet e a vivência afetivo-sexual 266

8. A mídia como referência para os roteiros sexuais e de gênero 273

9. A religião e a manutenção de normas e padrões 276

10. $\mathrm{O}$ ingresso na faculdade e o contato com pares. 282

11. Namoros e vida afetivo-sexual na fase adulta 285

12. Ser homem, ser mulher: a percepção dos gêneros 294

12.1. Percepção de masculinidades e a associação com o domínio 295

12.2. Percepção de feminilidades e a associação com a passividade. 300

13. A busca pelo atendimento no Plantão Psicológico 306

14. A passagem pelo Plantão Psicólogo: o olhar para a experiência 
15. Propostas para uma vivência mais plena da sexualidade

\section{CAPÍTULO VII}

CONSIDERAÇÕES FINAIS.

REFERÊNCIAS BIBLIOGRÁFICAS .336

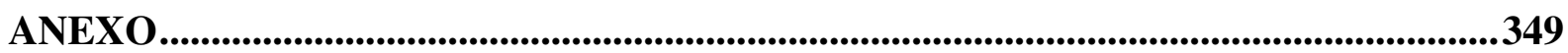

Termo de Consentimento Livre e Esclarecido .................................................................350 


\section{LISTA DE FIGURAS}

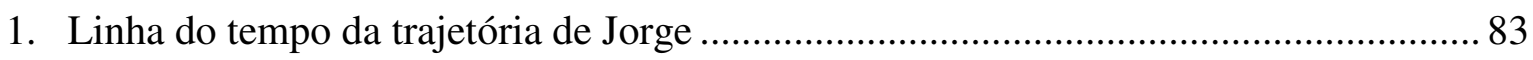

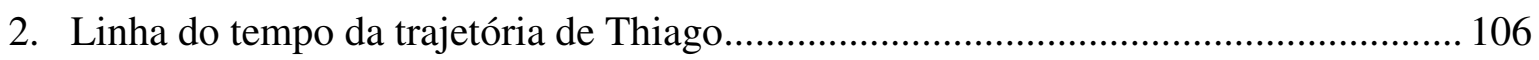

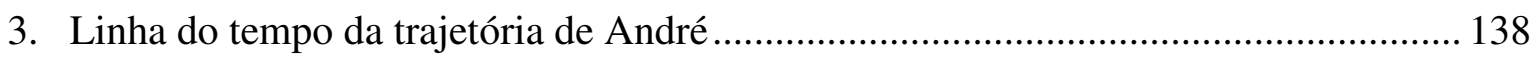

4. Linha do tempo da trajetória de Melina..................................................................... 162

5. Linha do tempo da trajetória de Sofia .................................................................... 190

6. Linha do tempo da trajetória de Mariana................................................................... 221 


\section{RESUMO}

TONIETTE, Marcelo Augusto. Trajetórias de vida e sexualidades: um estudo a partir de depoimentos de homens e mulheres atendidos no Plantão Psicológico do Serviço de Aconselhamento Psicológico do IPUSP. 2009. 350p. Tese (Doutorado em Psicologia) Instituto de Psicologia, Universidade de São Paulo, São Paulo. 2009.

Propõe-se conhecer significados e sentidos da construção social de sexualidades e de gêneros a partir da experiência emocional e social de três homens e de três mulheres, entre 21 e 27 anos, que buscaram atendimento no Plantão Psicológico do Serviço de Aconselhamento Psicológico - SAP -, do Instituto de Psicologia da Universidade de São Paulo - IPUSP, com queixas afetivo-sexuais. Essas queixas afetivo-sexuais fornecem elementos para reflexão sobre códigos de conduta vigentes com relação aos gêneros e ao exercício da sexualidade. A pesquisa adota perspectiva qualitativa tendo como base o método dos relatos orais na forma de depoimento. Os depoimentos revelam vivências singulares e diferentes formas de negociação no contexto social, sendo a sexualidade imbricada nesta dinâmica de forma problematizada. Os significados e sentidos relacionados com a vivência afetivo-sexual partem de códigos, normas e valores em vigor no contexto social - família, escola, meios de comunicação, saber especializado, entre outros -, que fornecem contornos para sensações, situações, palavras e estados corporais. As concepções de gênero partem de versões associadas aos estereótipos vigentes, sendo que o ser homem e o ser mulher, respectivamente, são relacionados à atividade e à passividade. Os depoimentos revelam a tensão entre a experiência afetivo-sexual idealizada e a experiência afetivo-sexual vivida, intensificando a angústia e o sofrimento. O modelo de atenção psicológica oferecido pelo Plantão Psicológico prioriza a valorização das experiências vividas a partir do encontro, do cuidado e da atenção, afastando-se de um enfoque normativo do atendimento psicoterapêutico.

Descritores: sexualidade; gênero; comportamento psicossexual; identidade sexual; medicalização; relatos verbais; plantão psicológico; aconselhamento psicoterapêutico. 
TONIETTE, Marcelo Augusto. Trajectories of life and sexualities: a study based upon s of men and women attended to the Psychological Stand by Attendance of the Psychological Counseling Service of IPUSP. 2009. 350p. Thesis (Psychology Doctorate) - Psychology Institute, University of São Paulo, São Paulo. 2009.

The present work proposes to know the meanings and senses of the social construction of sexualities and genders based upon the emotional and social experiences of three men and three women, aged 21 to 27, who had sexual-affective complaints and sought help at the Psychological Counseling Service (SAP) Stand by Attendance of the Psychology Institute of the University of São Paulo (IPUSP). These complaints provide elements for reflexion about current behavior codes which are related to genders and to the exercise of sexuality. This research adopts a qualitative perspective based upon the method of oral description in the form of depositions. The depositions reveal singular life experiences and different forms of negotiation in the social context in which the sexuality is concealed in this dynamic in a problematic way. The meanings and senses related to the sexual-affective life experience derive from codes, rules and values which are present in the social context - family, school, media, specialized knowledge, among others -, and provide framework for sensations, situations, words and body states. The conceptions of gender derive from versions associated with the current stereotypes in which the men-being and the woman-being are related to activity and passivity, respectively. The depositions also reveal the tension between the idealized sexual-affective experience and the lived sexual-affective experience, intensifying anguish and suffering. The model of psychological care offered by the Psychological Stand by Attendance prioritizes the valorisation of lived experiences through meeting, care and attention, moving away from a normative approach of the psychotherapeutic service.

Keywords: sexuality; gender; psychosexual behavior; sexual identity; medicalization; verbal reports; psychological stand by attendance; psychological counseling. 


\section{RIASSUNTO}

TONIETTE, Marcelo Augusto. Traiettoria di vita e sessualità: uno studio partendo da testimonianze di uomini e donne assistiti durante la Pronta Assistenza Psicologica del Servizio di Counseling Psicologico del IPUSP. 2009. 350p. Tesi (Dottorato Psicologia) Istituto di Psicologia, Università di São Paulo, São Paulo. 2009.

Si propone la conoscenza dei significati e sensi della costruzione sociale della sessualità e dei generi partendo dall'esperienza emozionale e sociale di tre uomini e tre donne, di età compresa fra 21 e 27 anni, che hanno cercato la Pronta Assistenza Psicologica del Servizio di Counseling Psicologico, dell'Istituto di Psicologia dell'Università di São Paulo - IPUSP -, con lagnanze affettivo-sessuali. Le lagnanze hanno fornito elementi per riflessioni su codici di condotta vigente rispetto ai generi ed all'esercizio della sessualità. La ricerca adotta la prospettiva qualitativa che ha come base il metodo del racconto verbale in forma di testimonianza. Le testimonianze rivelano esperienze singolari e le forme differenti della trattativa del contesto sociale, essendo la sessualità intrinseca in questa dinamica di forma del problema. I significati e sensi relativi al modo di vivere affettivo-sessuale partono da codici, norme e valori in vigore nel contesto sociale - famiglia, scuola, mezzi di comunicazione, sapere specializzato, tra altri -, che forniscono contorni per sensazioni, situazioni, parole, e stati corporali. Le concezioni del genere, partono da versioni associate agli stereotipi vigenti, dove l'essere uomo e l'essere donna, rispettivamente, sono legati all'attività e alla passività. Le testimonianze rilevano la tensione fra l'esperienza affettivo-sessuale idealizzata e l'esperienza affettivo-sessuale vissuta, intensificando l'angustia e la sofferenza. Il modello di attenzione psicologica offerto dalla Pronta Assistenza Psicologica dà la priorità alla valorizzazione delle esperienze vissute partendo dall'incontro, dalla accuratezza e attenzione, allontanandosi da un parametro normativo della assistenza psicoterapeutica.

Parole-chiave: sessualità; genere; comportamento psicosessuale; identità sessuale; medicalizzazione; racconti verbali; pronta assistenza psicologica; counseling psicoterapeutico. 


\section{APRESENTAÇÃO}

Cada vez mais faz sentido para mim a proposta defendida pelo sociólogo francês Bruno Latour (1994) que, a partir de uma perspectiva em que privilegia o discurso científico e a sociedade, afirma que não existe uma ciência neutra, visto que as “...pesquisas não dizem respeito à natureza ou ao conhecimento, às coisas-em-si, mas antes ao seu envolvimento com nossos coletivos e com os sujeitos" (p.9). Assim como a religião, a ciência é feita por e para homens e mulheres. Em alguns momentos, contestar alguma idéia em determinado contexto pode representar uma heresia, provocando as mais diferentes reações. Falar sobre sexualidade é falar de um tema controverso, complexo e fortemente vinculado a uma agenda política num contexto histórico e social. É justamente nesse ponto que foco a minha reflexão, na tentativa de suspensão dos diversos discursos vigentes para conhecer como pessoas comuns, homens e mulheres, se apropriam da sexualidade, e quais os significados e sentidos atribuem a ela.

Enquanto pesquisador, considero importante explicitar alguns momentos da minha trajetória até chegar ao tema da presente pesquisa. Quando do meu ingresso no curso de Psicologia, em 1990, meu interesse já era voltado para a clínica psicológica. Ao longo da graduação, a abordagem cognitivo-comportamental foi ao encontro do meu interesse, por fornecer um panorama mais racional e objetivo sobre a superação do sofrimento, mais do que outras linhas de psicoterapia com que tinha tido contato. Acreditava desde então que a Psicologia poderia ir além da teoria psicanalítica e, até aquele momento, a perspectiva cognitivo-comportamental respondia a parte das minhas questões e ia ao encontro dos meus objetivos. Passei a freqüentar cursos e eventos nessa abordagem. No último ano da graduação - aquele ano em que o aluno já se sente psicólogo -, passei a ter contato com a Gestalt e a Fenomenologia, no estágio de Orientação profissional e planejamento de carreira, sob coordenação do Prof. Luiz Lilienthal. Ainda me lembro do choque e do estranhamento da nova proposta de trabalho, nada condizente com tudo aquilo que até então tinha visto. Ao longo da graduação, tive contato muito rapidamente com a proposta teórica humanista, mas naquele momento tornava-se uma perspectiva de trabalho que nortearia o fazer dentro daquele estágio. Ou seja, não tinha como me esquivar. Aquele aluno até então proponente 
determinado a psicoterapeuta cognitivo-comportamental teria de se submeter à nova abordagem e veria abaladas suas bases ilusoriamente sólidas.

Felizmente - ou angustiosamente -, a Vida não segue uma linha reta e apresenta diversas oportunidades de nos situarmos. Aos poucos aquilo que me exigia uma atitude de tolerância - e, por conseguinte, preconceituosa - foi dando espaço para o interesse e a inquietação diante daquela nova perspectiva de trabalho que não tinha como meta fornecer respostas prontas e objetivas àquilo que eu experienciava no atendimento junto aos clientes da clínica-escola. Fui descobrindo novos sentidos do fazer clínico. O interesse foi crescendo a ponto de eu, juntamente com os colegas de turma do núcleo cognitivo-comportamental propor a continuidade dos estudos sobre a Gestalt, depois de finalizada a graduação. Assim surgiu em 1996 um grupo de estudos sobre Gestalt-pedagogia. O grupo teve a duração de um ano, sob coordenação do Prof. Luiz, tendo como base central a obra Gestaltpedagogia: um caminho para a escola e a educação, de Olaf Axel Burow e Karlheinz Scherpp (1985).

Naquele ano de 1996 dei início a uma série de atividades que ajudariam a dar mais contornos - agora mais flexíveis - àquilo que nortearia a minha trajetória profissional. Dentre essas atividades estava o grupo de estudos em Gestalt-pedagogia já mencionado, a atividade de monitoria na disciplina de Orientação profissional e planejamento de carreira, na Universidade São Judas Tadeu, e a minha almejada atividade enquanto psicoterapeuta em consultório particular. A abordagem teórica estava em plena e bem-vinda - e angustiante metamorfose, estimulada pelas novas possibilidades de olhar o humano. Fui aos poucos dando menos ênfase à técnica e mais ênfase ao humano na sua singularidade.

Nos primeiros anos de formado, a auto-cobrança de uma identidade teórica era grande. Lançando um olhar para o passado, vejo que aos poucos fui me deixando levar pelo fazer a partir do contato com as experiências, tocando e sendo tocado. O interesse já não era apenas o "tratar" ou "curar" o outro. A partir de uma atitude mais humilde, o foco voltou-se de forma mais intensa para o facilitar o contato, compreender, de algum modo e estar junto ao outro no encontro de novas possibilidades que, de certo modo, ia ao encontro da superação da queixa ou dificuldade que levou as pessoas ao consultório. Nessas três atividades pude dar os passos iniciais para concretizar o meu intento de aprimorar o trabalho clínico e iniciar a trajetória acadêmica vinculada ao ensino e à pesquisa. Ao final do grupo de estudos e da monitoria, em 1996, passei a dedicar-me exclusivamente ao consultório. 
No consultório particular, assim como já vinha acontecendo desde a graduação, continuaram surgindo clientes trazendo queixas das mais diversas, dentre elas, em particular, aquelas relacionadas à sexualidade de um modo geral - disfunções, crises de identidade, conflitos conjugais... No primeiro semestre de 1998, recebi convite para fazer parte de uma clínica de psicologia especializada em questões relacionadas à sexualidade e, concomitante a isso, participei da fundação de um grupo quando foi registrado oficialmente enquanto uma ONG - organização não-governamental. A ONG agregava profissionais de diversas áreas que nutriam interesse no estudo e pesquisa da sexualidade. Foi nesse ano de 1998 que passei a focar na questão da clínica voltada para o trabalho com sexualidade, mais especificamente com a modalidade da terapia sexual, voltada para o tratamento das disfunções sexuais. A ONG foi um espaço privilegiado que oferecia diversos olhares para o humano e provocava as mais variadas discussões. Foi lá que tive a oportunidade de conhecer profissionais que reforçavam o trabalho voltado para a sexualidade sem perder de vista a figura do humano e do seu sofrer. Dentre essas pessoas as quais são bem-vindas e constantes companheiras de amizade e trajetória profissional destaco Vera Vaccari, Hugues França Ribeiro e Mauro Cherobim. Foi nesse contexto que a idéia de gênero foi se fazendo mais presente, conferindo ainda mais possibilidades de formas para se compreender a expressão afetivo-sexual.

$\mathrm{Na}$ clínica senti que as marcas deixadas pela perspectiva cognitivo-comportamental davam sinais de vida, até mesmo pelo fato de a modalidade da terapia sexual ser fortemente enraizada nessa abordagem teórica, sendo seus principais precursores os psicólogos americanos William Masters, Virginia Johnson, Helen Kaplan, entre outros. Todavia, continuava presente a minha inquietação de olhar o outro não só na perspectiva sexual - ou de sua "disfunção" -, mas na perspectiva do humano, compreendendo aquela expressão sexual enquanto parte da expressão de um sofrer inerente à condição humana, de um modo-de-ser singular daquele organismo ${ }^{1}$.

A experiência clínica foi fundamental para fornecer sentidos para a postura psicoterapeutica. Ao longo dos anos, trabalhando com adultos, adolescentes, casados, solteiros, com os objetos de desejo mais diversos - homens, mulheres, ambos, e até outros

\footnotetext{
${ }^{1} \mathrm{O}$ conceito de organismo é citado aqui no sentido holista integral proposto por Kurt Goldstein (apud Hall \& Lindzey, 1973) e de Perls (1976 apud Burow \& Scherpp, 1985) do ser humano enquanto uma unidade de corpo-alma-mente.
} 
objetos - fui tendo contato com diferentes singularidades, com diferentes realidades, e com as diferentes formas pelas quais as queixas afetivas e/ou sexuais iam sendo constituídas nos diferentes cenários nos quais os clientes viviam enquanto atores. Fui me dando conta no consultório da carência de informação a respeito da sexualidade - inclusive minha - e da carência de um interlocutor com quem pudesse compartilhar as vivências e/ou conflitos. Notava uma tendência de se lidar com a sexualidade enquanto verdade única que acaba por ser introjetada sem a devida crítica. Claro que quem vive a vida não pensa a vida, mas aquela forma de viver gerava ainda mais sofrimento. Fui observando que muitas das dificuldades e queixas levadas ao consultório estavam intimamente relacionadas com a trajetória e/ou limitação da expressão da singularidade da pessoa. Inquieto como sempre, em 1999, retomei meu lugar de supervisionando, a fim de refletir e ampliar horizontes, compreender melhor e, enquanto terapeuta, encontrar outras maneiras de facilitar de algum modo a expressão daquelas singularidades com o propósito de auxiliar o cliente na superação da dificuldade ou queixa apresentada. Foi quando recorri novamente ao Prof. Luiz Lilienthal, que estruturou um amistoso e enriquecedor grupo de supervisão.

Ao longo desse trabalho coletivo da supervisão, a idéia de educação, cujas sementes foram plantadas lá no meu último ano de graduação, foi se fortalecendo enquanto elemento importante e significativo, fornecendo sentidos para a proposta da clínica vinculada ao processo educativo que convencionamos chamar de clínica-educação. Desse modo, ficou mais clara a questão de que as dificuldades ou queixas sexuais pudessem ser vistas como possibilidade de expressão de uma singularidade parte de um contexto pluralístico maior e, por que não, reflexo desse contexto. Mesmo que taxadas de "disfuncionais" - termo que evito adotar por considerá-lo taxativo -, aquelas formas de expressão traziam consigo a dor e o sofrimento, mais também um significado e um sentido particular daquele modo-de-ser da pessoa no seu meio social. Aos poucos, o foco foi se deslocando da "disfunção" em si, abrindo espaço para uma compreensão maior dos significados e sentidos daquele organismo que apresentava queixa e/ou dificuldade sexual, e daquele modo-de-ser singular do organismo em relação com o mundo. Esse novo olhar para o fenômeno da sexualidade ganhou um sentido de algo imbricado com a experiência humana, sem restringi-lo, ou fazê-lo girar em torno da resposta sexual base da terapia sexual - desejo, excitação e orgasmo -, ou de outro

\footnotetext{
${ }^{2}$ De acordo com Zinker (2001), "a vida é um processo constante de solução de problemas, desde a inspiração do ar que nos sustenta até o lamento da perda de alguém amado. Enxergar esse processo apenas como um sintoma, uma patologia, ou meramente como uma resposta mecânica é ser reducionista" (p.52). Desse modo, no lugar de "disfunção sexual" opto por adotar "dificuldade sexual".
} 
modelo qualquer. Nessa nova perspectiva, passei a privilegiar os referenciais, os significados atribuídos pelo cliente do lidar com a experiência da resposta sexual "disfuncional".

Com meu ingresso no programa de doutorado e com o objetivo de dispor de mais tempo para a pesquisa, optei por fazer algumas mudanças na esfera profissional, afastando-me da ONG e da clínica na qual eu exercia meu trabalho. Essa resolução levou-me a revisar algumas partes do projeto da pesquisa, no que dizia respeito aos participantes, pois, a priori, eles seriam buscados entre aqueles que procuravam os serviços ambulatoriais daquela clínica.

Meu interesse voltou-se para estudar os usuários que buscavam atendimento no Plantão Psicológico, do Serviço de Aconselhamento Psicológico - SAP -, do Instituto de Psicologia da Universidade de São Paulo. Essa mudança do projeto inicial foi bem-vinda, por privilegiar os usuários e os serviços oferecidos pelo SAP. As pessoas que buscam os serviços do SAP não buscam uma especialidade em si. O trabalho no plantão é basicamente fundamentado na idéia do cuidado e da atenção àqueles que buscam algum tipo de ajuda, com o intuito de esclarecimento da demanda. A equipe do SAP teve papel fundamental na contribuição em vários aspectos da pesquisa, seja na proposta de trabalho fundada na abordagem centrada no cliente e na fenomenologia, seja no levantamento dos participantes da pesquisa, seja na oportunidade do compartilhar e do fazer no cotidiano do serviço. Foi no SAP que me familiarizei com a supervisão na Abordagem centrada na pessoa, com a significativa experiência de co-supervisão - ou carona, como eu costumava chamar - e amizade com Maria Gertrudes Eisenlohr.

Encontrei na proposta da Abordagem Centrada na Pessoa possibilidades de dar novos contornos a um modo-de-ser psicoterapeuta. A empatia, a aceitação incondicional, a congruência, tornaram-se alicerces na promoção do encontro terapêutico privilegiando a dialogia. Dialogia. Encontro. Equilíbrio. Respeito. Sinto que aquele que procurava o consultório deixa de ser o paciente, ou até mesmo o cliente, para surpreender-se enquanto Pessoa.

Minha aproximação do SAP acabou intensificando minha ebulição interna e inquietação teórico-prática. A priori, minha intenção seria apenas atender voluntariamente alguns clientes do Plantão Psicológico, a fim de manter meu contato com a clínica psicológica. No entanto, dada a minha experiência anterior em supervisão e inegável simpatia 
pela proposta de trabalho do SAP, a Profa. Maria Luisa Schmidt - a Malu - e a equipe convidaram-me para acompanhar mais de perto os trabalhos nas reuniões semanais, além de supervisionar alguns casos, seja no plantão, seja nos grupos de supervisão. Aceitei de pronto o desafio o qual, mais uma vez, contribuiu para eu dar contornos ao meu interesse principal na proposta clínica-educação, e agora social, que é justamente auxiliar pessoas a conhecerem os significados e sentidos para a sua dor, sofrimento, angústia, e, de uma forma responsável e cidadã, encontrar saídas a fim de ampliar possibilidades do viver, do estar-no-mundo-emrelação.

Os capítulos da pesquisa estão dispostos da seguinte forma: no Capítulo III - Compreendendo as dimensões da sexualidade e do gênero, são apresentadas as referências adotadas sobre os significados e os sentidos das sexualidades e as suas transformações ao longo dos tempos. No Capítulo IV - Nascimento da sexologia, apresenta elementos para a compreensão dos discursos acerca das condutas sexuais. O Capítulo $V-O$ caminho adotado para conhecer as experiências, aborda as bases metodológicas, indicando as contribuições do método dos relatos orais para o estudo das sexualidades e dos gêneros. O Capítulo VI - Escutando histórias, conhecendo experiências, os depoimentos dos colaboradores serão apresentados. No final de cada sub-capítulo, o leitor encontra uma figura síntese no formato "linha do tempo" de cada depoimento. Caso o leitor escolha não fazer uma leitura seqüencial dos capítulos, ele tem a opção de seguir para o Capítulo VII - Significados e sentidos da experiência, no qual são destacadas algumas passagens e temas trazidos pelos colaboradores. Deste modo, caso o leitor queira ter contato com as entrevistas em maior profundidade, ele tem a opção de remeter-se ao Capítulo VI conforme faz a leitura do Capítulo VII. 


\section{$\begin{array}{llllllllllll}\text { C } & \text { A } & \mathbf{P} & \mathbf{I} & \mathbf{T} & \mathbf{U} & \mathbf{L} & \mathbf{O} & \mathbf{I}\end{array}$}

\section{ALTERIDADE, EDUCAÇÃO E SAÚDE}

\section{Alteridade}

De acordo com Hannah Arendt (1981), somos plurais e vivemos em um mundo plural, cuja diversidade se atualiza a cada instante: "Mas os homens no plural, isto é, os homens que vivem e se movem e agem neste mundo, só podem experimentar o significado das coisas por poderem falar e ser inteligíveis entre si e consigo mesmos" (p.13). Nessa perspectiva, Marc Augé (1997) aponta para a necessidade de se falar dos mundos e não do mundo. Essa pluralidade deve ser compreendida em diversos sentidos, considerando que "todos aqueles que pertencem a um mesmo mundo não compartilham, necessariamente, os mesmos valores" (Augé, 1997, p.143).

Falar de pluralidade é falar de diferenças e de diferentes, daquilo que é o outro, mas, que, ao mesmo tempo, sou eu naquele outro. A noção de $e u$ somente é formada a partir desse contato, desse estar-com o outro. Nessa inter-relação entre pessoa e mundo, Augé (1997) mostra que a dimensão individual constitui em si mesma um mundo, formado por mensagens políticas, econômicas e da mídia; e os mundos sociais que essa dimensão individual atravessa não são homogêneos.

Para a compreensão dessa questão, torna-se fundamental reportar ao conceito de alteridade. A alteridade é entendida enquanto uma idéia que diz respeito à natureza ou condição do que é outro, do que é distinto. Alteridade e diferença se relacionam, pois o diferente é o outro, e a consciência da alteridade é o reconhecimento desta diferença 
(Brandão, 1986). Por que o novo, a diferença, o diferente, nos atrai, mas ao mesmo tempo nos atemoriza? Uma resposta razoável a esta pergunta seria: porque não vai ao encontro daquilo nos é familiar, aquilo que estamos habituados, aquilo que conhecemos no cotidiano. $\mathrm{O}$ familiar está relacionado àquilo que "já foi muitas vezes visto, praticado ou estudado; habitual" (Houaiss, 2001), e que de algum modo já faz parte de nossas vidas ou do nosso cotidiano.

Aquilo que é familiar constitui elemento importante para que a pessoa se organize e se posicione no contexto social de que faz parte. Por outro lado, a fixição naquilo que é familiar pode ser porta de entrada para o preconceito e incentivo ao totalitarismo, pois a tendência é não admitir que a realidade seja mutável.

A partir da inter-relação de identidade, alteridade e sentido, Augé (1997) põe em evidência a crise identitária do mundo contemporâneo. $\mathrm{O}$ autor aponta que a construção da identidade se dá a partir da oposição ou comparação com o outro. Neste sentido, a crise de identidade também se constitui como crise de alteridade. Fica explicitado que identidade, alteridade e sentido se constituem no interjogo das relações sociais. Augé (1997) compreende que alguns fenômenos sociais, a exemplo dos fundamentalismos, racismos, nacionalismos, entre outros, enquanto desdobramentos da "crise de alteridade" e, por conseguinte, "crise de identidade", estão intrinsecamente relacionadas a uma "crise do sentido". Esses desdobramentos tendem a cristalizar ou tornar não simbolizável o outro (Schmidt, 2006).

Lidar com a alteridade consiste em reconhecer-se e compartilhar a vivência com aquilo que é o diferente, e com aquela diferença, que ou não nos é familiar, ou nos é familiar de forma limitada - o pré-conceito - ou distorcida e reacionária - o preconceito. O préconceito está em todos nós e refere-se às percepções, experiências ou conceitos, além das nossas necessidades emocionais presentes diante de uma nova experiência. O pré-conceito é algo útil e necessário de conhecimento, informações, e de visões de mundo que internalizamos ao longo da nossa trajetória de vida.

No contato com uma nova experiência, os pré-conceitos são evocados e (re)significados a partir do novo que se apresenta. Até mesmo para reconhecer esse novo torna-se necessária a flexibilidade para rever aquilo que é familiar - pré-conceito -, para 
provocar uma desfamiliarização, a fim de construir uma nova compreensão - (re)significação - dessa nova experiência (Crochík, 1997).

É tênue o limite entre pré-conceito e o preconceito e ambos se inter-relacionam. Uma pessoa pré-conceituosa não necessariamente é uma pessoa preconceituosa. No entanto, uma pessoa preconceituosa apresenta rígidos pré-conceitos. De acordo com o psicólogo José Leon Crochík (1997), o preconceito

(...) se remete à proposta de eliminação do desconhecido para se manter aquilo que já é conhecido. É reação às mudanças, quer individuais, quer sociais, paradoxalmente manifestada tanto por aqueles que se beneficiam da situação, quanto por aqueles que não têm seus interesses racionais mais imediatos atendidos por ela (p.101).

Nesse sentido, o preconceito está vinculado à dificuldade e até ao desrespeito para com o novo, que não corresponde aos modelos internalizados, aquilo que é familiar. $\mathrm{O}$ preconceito nem sempre ocorre de forma explícita e pode estar sutilmente presente em algumas ações, como quando alguém propõe estabelecer seu ponto de vista reducionista e limitante, sem (re)conhecer o espaço do outro, ou cerceando esse espaço. De acordo com a filósofa Marilena Chauí (1996/1997), o preconceito está fundado em causa econômica-social, ou social-política, sendo que ele leva a um deslocamento do foco das reais questões que prejudicam o bem-estar social, direcionando-o para pessoas ou segmentos sociais que, de certa forma, não correspondem àquilo tido como "normal".

Como veremos adiante, especificamente na esfera da sexualidade, há muito se busca uma "norma" para o humano, uma forma adequada de ser. A norma surge como tentativa de homogeneização da singularidade do outro, impondo de forma tirânica crenças, idéias e valores que nem sempre fazem parte daquela realidade vivida pelo outro. Desse modo, o reconhecimento da singularidade do outro vai muito além da idéia de tolerância. A tolerância pode ser uma forma velada de discriminação, pois, quando se tolera algo, esse algo não é necessariamente reconhecido, e aceito.

A consciência do diferente ou da diferença do outro não significa que sou mais ou menos que esse outro, mas reconheço que o outro também pode ser $e u$, e $e u$ também posso ser 
o outro. Nesse sentido, a idéia de alteridade pode ser uma via importante para a promoção da inclusão.

Cabe uma ressalva de que a alteridade consiste no reconhecimento do outro, porém, não implica na aceitação, ou não, deste outro. Ao falar em reconhecer o outro em mim, e eu me reconhecer no outro, abrimos campo para abordar a questão da singularidade e da subjetividade. De acordo com Pedrinho Guareschi (1998), a singularidade aponta para o fato de sermos diferentes e a subjetividade aponta para o fato de "sermos os outros", pois a singularidade refere-se à

(...) dimensão do ser humano enquanto um ser único, irrepetível, absolutamente singular. Isso porque no processo de estabelecimento de milhões de relações, cada um se apropria diferentemente de partes diversas do fenômeno ou da realidade com a qual entra em contato (p.154).

Já a construção da subjetividade consiste no dar conta de toda aquela realidade que constitui o "conteúdo" do nosso ser, da nossa singularidade. Isso significa que a realidade que perfaz nossa "carga" existencial são os milhões de relações que estabelecemos no decorrer de nossa vida, e que vivemos todos os dias (Guareschi, 1998), em contato com diferenças e diferentes, familiarizando-nos e nos desfamiliarizando-nos a todo o instante.

A idéia de alteridade, considerando singularidade e subjetividade, fornece uma base significativa para a compreensão de como lidar com as diferentes formas de manifestação da orientação afetivo-sexual, seja ela heterossexual, bissexual ou homossexual, seja no âmbito escolar, seja no social, a fim de compreender fenômenos quase sempre associados à diversidade sexual, a exemplo da manifestação de violência, injustiça, exclusão, marginalização; e viabilizar ações em prol da inclusão social, compreendendo o ser humano enquanto relação, em um contexto solidário e responsável.

Nesse momento, ater-me-ei em provocar algumas reflexões sobre o motivo de no campo da sexualidade, principalmente no âmbito educacional, sermos ávidos por modelos e padrões de condutas, sendo que o que deveria imperar seria o compreender os fenômenos que se apresentam. Cabe um adendo de que a norma é território da educação. Hannah Arendt (2001) mostra que atividade educacional é essencialmente conservadora, sendo sua tarefa 
"abrigar e proteger alguma coisa - a criança contra o mundo, o mundo contra a criança, o novo contra o velho, o velho contra o novo" (p.242).

Todavia, é importante que modelos e padrões não provoquem um olhar enviesado da realidade vivida pelo educador, dificultando a escuta e a compreensão das singularidades e necessidades do seu público, e restringindo possibilidades do estar no mundo das novas gerações. Desse modo, nas palavras de Arendt (2001), a criança, para o educador possui um duplo aspecto: "é nova em um mundo que lhe é estranho e se encontra em processo de formação; é um novo ser humano e é um ser humano em formação” (p.235).

A educação consiste em um processo que se atualiza ao longo do nascimento de novos seres humanos, que estão em um estado de vir a ser, portanto, em processo de formação. A educação, desse modo, está entre as atividades mais elementares e necessárias das sociedades humanas (Arendt, 2001).

A tarefa do educador, de acordo com Arendt (2001), deve estar fundada na sua capacidade de "conhecer o mundo e ser capaz de instruir os outros acerca deste, porém sua autoridade se assenta na responsabilidade que ele assume por este mundo" (p.239). Nessa perspectiva, além de um mero reprodutor de informações, a compreensão é uma das habilidades mais importantes para o educador. Compreender está relacionado ao "conter em si, em sua natureza; estar ou ficar incluído; abranger(-se)" (Houaiss, 2001). Desse modo, compreender seria aquilo que apreendemos em nós, e não apenas tomamos ciência no plano racional, da hipocrisia tolerante do politicamente correto, do simplesmente "tenho de aceitar", ou mesmo categorizar pessoas ou ações a partir de uma postura moral $/$ moralista do bem/mal, certo/errado. Exemplo disso é que se eu compreendo e aceito uma pessoa que pratique o sadomasoquismo, não quer dizer que eu concorde com tal prática, ou mesmo que eu a estimule, mas que eu a reconheço como parte do universo de uma pessoa, que por sua vez faz parte do meu universo. 


\section{Educação e Saúde}

A partir da idéia de alteridade, o sentido de educação pode ser ampliado para se compreender o sentido da idéia de saúde, sendo que uma está intrinsecamente relacionada com a outra. A saúde aqui não é compreendida enquanto a ausência de doença, mas enquanto um direito inerente ao exercício da cidadania, em um estado que agrega os aspectos biológico, psicológico e social. A percepção de saúde/doença varia historicamente e de cultura para cultura, de acordo com fatores econômicos, sociais e legais.

A Organização Mundial da Saúde - OMS - define a saúde não apenas como a ausência de doença, mas como a situação de perfeito bem-estar físico, psicológico e social.

A definição de saúde sofre diversas críticas das quais destaco Dejours (1986), que aponta para duas razões para a sua crítica:

(...) a primeira é que esse estado de bem-estar e de conforto, se no aprofundarmos um pouco mais, é impossível de definir. Gostaríamos que nos dessem uma definição desse perfeito estado de bem-estar e de conforto. Não sabemos o que é e cremos que não haja esclarecimentos consideráveis sobre a questão. É muito vaga. Implícita e intuitivamente sabe-se que isso significa alguma coisa, mas quanto se trata de defini-la, não é muito simples. E a segunda crítica a fazer é que, no fundo, esse perfeito e completo estado de bem-estar não existe! (p.8).

Compreender a saúde de uma forma linear acaba favorecendo ainda mais para a não compreensão do seu sentido. A contextualização é fundamental para a compreensão o que viria a ser saúde. De acordo com a psicóloga social Mary Jane Spink (2003), as representações sobre o processo de saúde/doença englobam três fatores principais, a saber:

(1) A compreensão da doença como fenômeno coletivo, ou seja, privilegiando o discurso de uma dada sociedade sobre as enfermidades e os enfermos (...); (2) A construção do saber leigo, ou seja, os modelos explicativos que embasam as diferentes interpretações das doenças e a busca de alternativas terapêuticas (...); e (3) A interface entre o saber oficial - mediado pela 
constituição do campo da prática médica e das instituições médicas - e a representação da doença prevalecente em determinadas épocas e/ou grupos (p.38).

Desse modo, a idéia de uma saúde perfeita atende mais a uma perspectiva normativa. $\mathrm{O}$ conceito de saúde não consiste em algo vazio, mas ganha contornos de acordo com os campos que atravessa em um dado contexto social.

\section{A educação e a escola}

O contexto escolar é lugar privilegiado de diferenças e de construção dessas diferenças, distinções e desigualdades. De acordo com Guacira Lopes Louro (2001), a escola incumbiu-se de separar os sujeitos, tornando aqueles que nela ingressam distintos dos outros que a ela não tinham acesso. Essa distinção também acontece internamente, por meio de mecanismos de classificação, ordenamento e hierarquização. Para a autora, a escola ocidental separa adultos de crianças, católicos de protestantes, ricos de pobres, e meninos de meninas.

Ainda na perspectivas de Louro (2001), "os sentidos precisam estar afiados para que sejamos capazes de ver, ouvir, sentir as múltiplas formas de constituição dos sujeitos implicados na concepção, na organização e no fazer do cotidiano escolar” (p.59). A ordem e a disciplina se fazem presentes determinando aquilo que é adequado, apontando o lugar dos pequenos e dos grandes, dos meninos e das meninas.

A disciplina é um conceito aprofundado por Foucault (1987) em sua obra Vigiar $e$ punir. De acordo com ele,

o momento histórico das disciplinas é o momento em que nasce uma arte do corpo humano, que visa não unicamente o aumento de suas habilidades, nem tampouco aprofundar sua sujeição, mas a formação de uma relação que no mesmo mecanismo o torna tanto mais obediente quanto é mais útil, e inversamente (p.127). 
Nessa política de coerção, "a disciplina fabrica corpos submissos e exercitados, 'corpos dóceis"” (p.127). Nesse sentido, o poder disciplinar tem como proposta adestrar e se apropriar ainda mais e melhor. Ao entrar no delicado território da educação faz-se necessário considerar o "adestramento" apontado por Foucault, e a "discriminação" apontada por Louro.

$\mathrm{Na}$ proposta da educação libertadora, de Paulo Freire (1987), a educação está intrinsecamente vinculada à cidadania, que consiste na consciência da presença do outro, o diferente, de uma forma solidária. Nesse sentido, o ato de educar não deve ser o enquadramento do outro em moldes pré-estabelecidos. Educar seguiria um sentido de apresentar valores culturais, representações, normas e valores sociais, entre outros, e incentivar a criação de novas possibilidades de vivência com aquilo que já existe na realidade, de uma forma responsável e cidadã.

Os desdobramentos da educação na compreensão da construção da sexualidade e do gênero podem ser mais bem compreendidos na proposta de Paulo Freire, de educação libertadora, em contraste com a que ele denomina educação bancária. A educação libertadora para Freire (1987) está relacionada àquela que possibilita "mover pelo ânimo de libertar o pensamento pelas ações dos homens uns com os outros na tarefa comum de refazerem o mundo e de torná-lo mais e mais humano" (p.65). Essa concepção de educação contrapõe-se a outra, mais limitante, que é a educação bancária, fundada num "conceito mecânico, estático, espacializado da consciência e em que transforma, por isto mesmo, os educandos em recipientes, em quase coisas" (Freire, 1987, p.65). Essa educação está fundada no "controle do pensar e da ação, levando os homens ao ajustamento ao mundo" (Freire, 1987, p.65), inibindo o poder criativo e de atuação. Como lembra Freire, a educação bancária funciona como obstáculo para a atuação de homens como sujeitos da ação, como seres de opção, frustrando-os e levando ao sofrimento.

A educação consiste no processo de apresentar o mundo às novas gerações, estimulando possibilidades, considerando a aceitação e convivência de diferenças e de diferentes, de forma que auxilie na superação do individualismo, abrindo espaço para a dimensão coletiva. Nesse sentido, a educação consiste em um significativo recurso para a inserção do educando no cotidiano, auxiliando-o a compreender e participar das questões sociais da realidade. 
Dentre as questões sociais, destaco aqui aquelas relacionadas à sexualidade. $\mathrm{Na}$ educação bancária, a prioridade é transmitir a informação de forma mecânica, sendo depreciado o contato do professor com seu aluno. A educação libertadora estaria relacionada a conscientização, e o encontro entre professor e aluno consiste em um pressuposto para que a educação ocorra. A sexualidade, enquanto uma construção social, é desenvolvida nas pessoas a partir do contato com contexto social em que vivem, seja nos encontros, seja nos desencontros vividos no cotidiano (Boarini, 2004).

De acordo com Mary Neide Figueiró (2004), a sexualidade é um dos temas que mais tem trazido dificuldades, desafios e problemas para os educadores, no seu cotidiano. Figueiró aponta para dois aspectos da sexualidade para se constituir uma fonte problemática: de um lado existe a manifestação da sexualidade e o desejo de saber dos alunos cada vez mais acentuado; do outro lado existe o fato de o educador, na maior parte das vezes, não saber a trabalhar a sexualidade com seus alunos. Este educador carrega consigo as marcas de sua trajetória de vida e da restrita educação sexual, onde quase sempre é presente insegurança, dúvida, desconhecimento, medos e tabus.

Maria Boarini (2004) iniciou trabalho nas escolas, a pedido da direção, para desenvolver atividades na área da sexualidade. Uma das conclusões que a pesquisadora chegou é de que é falsa a idéia de que o apelo sexual da mídia - TV, internet... - garante o esclarecimento suficiente sobre o tema, aponta para a alta incidência de gravidez precoce, mortes e sequielas a partir de abortos clandestinos, do crescente número de recém-nascidos infectados pelo vírus HIV. Outra conclusão importante e que revela uma realidade é que

(...) entre as várias razões que geram e nutrem os atropelos na vida sexual do adolescente, talvez a principal seja o desconhecimento dos segredos do próprio corpo, de suas demandas tanto físicas quanto psicológicas. Essa ignorância, sem dúvida, impossibilita qualquer negociação, quer seja sobre o corpo, quer seja sobre a própria alma (p.196).

E mais adiante complementa:

(...) ao negar as dúvidas tão necessárias ao crescimento humano e ao aconchegar a vergonha, damos lugar ao preconceito e à desinformação que, 
seguramente, favorecem o obscurantismo da percepção e da compreensão do homem em seus limites e possibilidades (p.197).

Recentemente, o Ministério da Saúde, a partir do Censo Escolar ${ }^{3}$ de 2005, divulgou alguns dados que apontam que a educação sexual continua à margem do currículo escolar. De acordo com a pesquisa, das 97,6 mil escolas estudadas, 5,5\% trabalham semanalmente algum tema relacionada à sexualidade - e $29,7 \%$ fazem atividades mensais. Os temas mais abordados em sala de aula foram DST/Aids (60,4\%), gravidez na adolescência (52\%) e saúde sexual e reprodutiva $(45 \%)$. Somente $9 \%$ das escolas pesquisadas fornecem preservativo para seus alunos. Apenas $43 \%$ dos professores entrevistados declaram-se capacitados para trabalhar atividades relacionadas à discussão de DST/Aids na sala de aula (Brasil, 2005).

A pesquisa do Censo Escolar revela o quanto a sexualidade na escola ainda está fortemente relacionada à gravidez na adolescência e às doenças sexualmente transmissíveis. Esses temas são importantes e úteis, mas consistem em parte da discussão e não abarcam outros aspectos da sexualidade associados à cidadania que resultem em uma formação emancipatória e crítica. Ana Claúdia Maia (2004) observa que na história social da sexualidade humana os significados atribuídos dizem respeito à função reprodutiva, prazer ou mercadoria, fortalecendo o aspecto genitalizado, em detrimento da dimensão psicossocial e sua historicidade. Fundamentando-se em Foucault, a autora aponta que essa abordagem reducionista é enraizada na ciência eugenista e no início da sexologia que tinha o sexo como estudo para melhor controlá-lo e para combater os seus males.

\section{$* * *$}

A partir da afirmação de Freire (1999) de que "ninguém educa ninguém, ninguém educa a si mesmo, os homens se educam entre si, mediatizados pelo mundo" (p.68), abre-se espaço para se compreender a educação - e a educação sexual - enquanto algo que vai além dos muros da escola, sem desconsiderar esse lugar como espaço importante e privilegiado para o desenvolvimento pessoal e social. Nesse sentido, como pontua Maria Porto (1987), a

\footnotetext{
${ }^{3}$ O Instituto Nacional de Estudos e Pesquisas Educacionais Anísio Teixeira - Inep/MEC - anualmente realiza o Censo Escolar abrangendo escolas públicas e privadas do país. Os dados da pesquisa fornecem parâmetros para formular políticas públicas e definir repasses de recursos.
} 
educação é um processo anterior àquele compreendido pela escola e se dá em todas as instâncias sociais, na família, na igreja, no local de trabalho, no lazer, entre outros.

A educação acontece de forma difusa ou sistemática com o propósito de "transmitir às novas gerações crenças, idéias e valores, o saber comum, os modelos de trabalho, as relações entre os membros, o modo de vida de cada sociedade ou grupo social, enfim a forma peculiar como estes entendem e materializam seu dia-a-dia" (Porto, 1987, p.36). A situação historicamente datada e culturalmente determinada de uma sociedade é que determina naquele contexto o que se entende por educação.

O processo de socialização se dá nas mais diferentes instâncias: na escola, na família, na religião, nos meios de comunicação, fornecendo referenciais, normas e valores, inclusive para a construção de noções de masculinidade e feminilidades ${ }^{4}$, formatando corpos sexuais. Na perspectiva de Freire, o ato de educar não está circunscrito a mudar o conhecimento de lugar, mas está embasado na criação de possibilidades para que o próprio conhecimento seja construído.

Apesar de o foco nessa pesquisa não ser necessariamente a educação compreendida enquanto aquela que acontece no âmbito escolar, mas aquela que acontece no contexto social mais amplo, cabe uma afirmação de Louro (2001) de que é indispensável reconhecer que a escola ao mesmo tempo produz e reflete concepções de gênero e sexualidade que circulam na sociedade. Desse modo, independentemente de existir, ou não, uma disciplina de educação sexual na escola, a sexualidade é parte do conjunto, sendo impossível deixá-la para fora dos portões. Na perspectiva da escola enquanto espaço político, Louro (2001) afirma que por meio da linguagem o exercício do poder se faz presente através das disciplinas, currículos, regulamentos, instrumentos de avaliação e ordenamentos que "dividem, subordinam, legitimam ou desqualificam os sujeitos" (p.85), enfatizando a reprodução das diferenças e desigualdades sociais.

O Ministério da Educação, por meio dos Parâmetros Curriculares Nacionais - PCN (Brasil, 1998), propõe que educação tenha a cidadania como eixo principal. Baseado na

\footnotetext{
${ }^{4}$ A noção de gênero - masculinidades e de feminilidades - será aprofundada no próximo capítulo.
} 
Constituição, os PCN apontam os seguintes princípios norteadores que devem perpassar o processo educativo:

Dignidade da pessoa humana. Implica respeito aos direitos humanos, repúdio à discriminação de qualquer tipo, acesso a condições de vida digna, respeito mútuo nas relações interpessoais, públicas e privadas.

Igualdade de direitos. Refere-se à necessidade de garantir a todos a mesma dignidade e possibilidade de exercício de cidadania. Para tanto, há que se considerar o princípio da eqüidade, isto é, que existem diferenças (étnicas, culturais, regionais, de gênero, etárias, religiosas etc.) e desigualdades (socioeconômicas) que devem ser levadas em conta para que a igualdade seja efetivamente alcançada.

Participação. Como princípio democrático, traz a noção de cidadania ativa, isto é, da complementaridade entre a representação política tradicional e a participação popular no espaço público, compreendendo que não se trata de uma sociedade homogênea e sim marcada por diferenças de classe, étnicas, religiosas etc. É, nesse sentido, responsabilidade de todos a construção e a ampliação da democracia no Brasil.

Co-responsabilidade pela vida social. Implica partilhar com os poderes públicos e diferentes grupos sociais, organizados ou não, a responsabilidade pelos destinos da vida coletiva (p.21).

Nesse sentido, a educação seria aquela compromissada com a cidadania, apresentando a realidade social aos estudantes com vias à reflexão e aprendizado. De acordo com os PCN, a educação comprometida com a cidadania seria aquela orientada para a construção de uma sociedade democrática e inclusiva, ou seja, o direito à cidadania não é restrito a grupos privilegiados.

A orientação sexual foi incluída nos PCN como tema transversal, assim como a ética, o trabalho e consumo, o meio ambiente, pluralidade cultural e saúde. O primeiro ponto que destaco é a exigência para que professores trabalhem a temática da sexualidade em sala de aula, mesmo que, na maior parte das vezes, não lhes seja dado o suporte necessário para o desenvolvimento dessas atividades. O segundo ponto, já abordado anteriormente, é que o trabalho com sexualidade não deve ser restrito ao trabalho com DSTs e AIDS, e prevenção de gravidez indesejada, sendo que os PCN também contemplam temáticas que envolvem prazer, 
masturbação, homossexualidade, amor, afeto, namoro, medos, tabus, preconceito, gênero, entre outros temas que envolvem os relacionamentos humanos.

A utilização do termo orientação sexual recebe algumas críticas, pois pode suscitar ambigüidades na sua compreensão, a exemplo da orientação do desejo sexual que pode ser heterossexual, homossexual e bissexual (Werebe, 1998). É a perspectiva da educação sexual, enquanto um processo amplo presente na coletividade, que adoto para fundamentar a presente pesquisa, considerando os relacionamentos humanos, mais especificamente o lidar com as diferenças e os diferentes tipos de expressão do humano, em um contexto de igualdade. Esta concepção tem como referência a abordagem política - ou emancipatória -, apresentada por Figueiró (2004), que compreende a educação sexual enquanto:

(...) caminho para preparar o educando para viver a sexualidade de forma positiva, saudável e feliz e, sobretudo, para formá-lo como cidadão consciente, crítico e engajado nas transformações de todas as questões sociais, ligadas direta ou indiretamente à sexualidade (p.119).

Neste sentido, a educação sexual política é definida por Figueiró (2004):

(...) uma educação sexual política é aquela que se pauta no questionamento das determinações rígidas do que é permitido e proibido, seja segundo a perspectiva religiosa ou a perspectiva médica, ou então segundo a perspectiva que se fundamenta nas diferenças de gênero (masculino e feminino). Também coloca-se criticamente frente à injunções da perspectiva do erótico (p.104).

Diante desta pluralidade que se apresenta, fatalmente temos de nos remeter à idéia de alteridade. E, no âmbito da alteridade, outro tema surge com intensidade, o preconceito, conforme já exposto anteriormente. Considerando nossa herança de uma sexualidade ocidental cristã e patriarcal, quais os caminhos a seguir no que diz respeito à sexualidade? Como as pessoas, a coletividade, se apropriam e quais os significados e sentidos de sexualidade e de gênero?

Fica evidenciado que o trabalho com a sexualidade pressupõe um processo mais abrangente que contempla a história de vida das pessoas, das famílias, das culturas, entre 
outros. Nesse sentido, é imperativo que a proposta da educação sexual parta de uma perspectiva pluralista da sexualidade, reconhecendo a multiplicidade de concepções, comportamentos sexuais, e valores a eles associados (Maia, 2004).

Muitas vezes parece que os esforços são voltados para que todos se tornem homogêneos na sua expressão sexual, tomando-se como base o modelo da heterossexualidade compulsória, surgido no século XIX. Porém, a diferença, a diversidade, é uma característica humana e, logo, deve ser valorizada e preservada, e combater para que essa característica não funcione como base para o estabelecimento de desigualdades. Querer formatar essa diversidade em um modelo pré-estabelecido de perfeição é desrespeitar e empobrecer a expressão humana. A diversidade sexual aqui é entendida englobando principalmente os aspectos relacionados ao gênero, englobando diferentes formas de ser masculino, diferentes formas de ser feminino, bem com as formas de negociação entre esses gêneros, aos quais prefiro me referir enquanto masculinidades e a feminilidades.

Do mesmo modo que a escola, a família, a mídia, a religião, são importantes fontes para a socialização e, logo, para a construção de masculinidades e de feminilidades, a educação também pode ser um meio de manutenção do status quo. Considerando marcante a influência da classe dominante sobre a classe dominada, a educação pode ser um meio para a transmissão de formas particularizadas de ver e compreender o mundo e de organizar o corpo de conhecimento à classe dominada (Porto, 1987). Desse modo, a educação - e a escola pode funcionar com meios de "domesticação", fabricando "corpos dóceis".

Como vemos, há algumas décadas, a sexualidade era considerada uma questão privada, sendo que sua abordagem na escola era restrita, e quase sempre fazendo parte da disciplina de biologia, limitando-se a aspectos orgânicos e fisiológicos. Hoje, a partir do aumento da gravidez na adolescência e a epidemia de HIV/AIDS, a sexualidade está mais do que ampliada para o aspecto social, político e cultural. Assim, o trabalho com sexualidade precisa ir além da informação, devendo perpassar a reflexão de atitudes e valores para o exercício da cidadania em um contexto plural.

Na perspectiva de compreender a articulação entre saúde e educação, Luiz Lilienthal (2004), a partir de definiçõos lingüísticas, tem como ponto de partida o existir, entendido 
como inerentes à condição humana o desamparo e sofrimento. Desse modo, tanto a ação educativa, quanto a ação clínica, perpassam o âmbito do cuidado e da atenção.

O cuidado e a atenção não se tornam possíveis em um contexto de intolerância, de preconceito, onde a desigualdade impera. Fingir que a sexualidade não existe, e o pior, fechar os olhos para as desigualdades e abusos entre gêneros, é restringir possibilidades do existir. A aceitação da pluralidade - inclusive a sexual -, em consonância com o direito ao exercício de cidadania em uma sociedade democrática, os esforços no âmbito da saúde e da educação devem privilegiar a valorização da coletividade e da solidariedade em um contexto democrático e cidadão.

Seguindo a proposta de Figueiró (2004), para quem a promoção de ações por parte dos educadores e profissionais deve ser embasada em uma postura positiva e humanizadora da sexualidade, é imperativo o desenvolvimento de atitudes positivas diante da própria sexualidade e atitudes positivas diante da pluralidade de manifestações da sexualidade no âmbito social. Atitudes essas que levem em consideração a noção de alteridade, sem excluir ou marginalizar, atitudes essas que levem a aceitação solidária, coletiva e responsável da pluralidade de possibilidades da expressão afetivo-sexual humana, tendo em mente a proposta de Hannah Arendt de que o homem só existe no plural. A proposta da educação seria, portanto, aquela que favoreça o desenvolvimento de potencialidades de singularidades e de coletividades em uma perspectiva de melhoria da qualidade de vida, promovendo e valorizando uma sociedade mais humana, justa e inclusiva. 


\section{$\begin{array}{lllllllllllll}\text { C } & \text { A } & \mathbf{P} & \mathbf{I} & \mathbf{T} & \mathbf{U} & \mathbf{L} & \mathbf{O} & \mathbf{I} & \mathbf{I}\end{array}$}

\section{COMPREENDENDO AS DIMENSÕES DA SEXUALIDADE E DO GENERO}

Sexualidade e gênero articulam-se na construção da identidade de cada pessoa. As dimensões sexualidade e gênero são originadas, afetadas e transformadas pelo modo como os valores sociais, sistematizados em códigos culturais organizam a vida coletiva em um dado momento histórico (Louro, 2001; Heilborn, 2005). Desse modo, pode-se afirmar que a referência à sexualidade e ao gênero em um dado momento histórico está intrinsecamente relacionada, de acordo com Weeks (2000), com questão crítica e política e que merece uma investigação histórica e sociológica cuidadosa. A investigação cuidadosa, apontada por Weeks, diz respeito ao fato de que

(...) nossas definições, convenções, crenças, identidades e comportamentos sexuais não são o resultado de uma simples evolução, como tivessem sido causados por algum fenômeno natural: eles têm sido modelados no interior de relações definidas pelo poder (p.42).

A sexualidade é produto tanto da história quanto da natureza, modelada pela interação humana que acaba se voltando para o caráter político. A regulação social é entendida pela relação sexo-sociedade que, por sua vez, apresenta duas representações: sexo e sociedade, como se fossem duas entidades separadas. 


\section{A dimensão da sexualidade}

Do mesmo modo que vive-se a vida não se pensa a vida, a sexualidade pode ser compreendida nessa perspectiva de que vive-se a sexualidade, e nem sempre reflete-se sobre a sexualidade. Em Atos de significação, Bruner (1997) mostra que:

Quando entramos na vida humana, é como se entrássemos em uma peça cuja
encenação já está em andamento, uma peça cujo enredo um tanto aberto
determina que papéis podemos desempenhar e em direção a que desfechos
podemos estar nos dirigindo. Outros, no palco, já têm uma noção do que trata
a peça suficiente para fazer negociações com um possível recém-chegado
(p.40).

Como se dão as negociações com o recém-chegado ao palco? A proposta da compreensão dos sentidos e dos significados do gênero já fornece idéias de caminhos para se compreender as negociações entre pessoas. Mas de onde parte e como é dada tanta ênfase à categoria sexualidade?

O erotismo sempre esteve presente na vida humana nas mais variadas formas, nas mais diferentes culturas. Talvez devido à facilidade de comunicação entre diferentes culturas em tempos de globalização, assistimos a uma explosão de discursos a respeito da sexualidade humana. Aquilo que convencionamos hoje chamar de sexualidade tinha outros sentidos e significados no passado e que foram se modificando ao longo dos séculos. Vale lembrar que o próprio conceito sexualidade foi ganhando contornos somente a partir dos séculos XVII e XIX. Até então, a "sexualidade" era compreendida dentro da ars erótica, conforme aponta Foucault (2001):

$\mathrm{Na}$ arte erótica, a verdade é extraída do próprio prazer, encarado como prática e recolhido como experiência; não é por relevância a uma lei absoluta do permitido e do proibido, nem a um critério de utilidade, que o prazer é levado em consideração, mas, ao contrário, em relação a si mesmo: ele deve ser conhecido como prazer, e portanto, segundo sua intensidade, sua qualidade específica, sua duração, suas reverberações no corpo e na alma (p.57, grifo meu). 
Dentre os exemplos dessa ars erótica temos o Kama Sutra, ou Livro do Amor, em sânscrito, que consiste em um tratado milenar indiano, de caráter erótico, sobre o amor, a moral, e a vida cotidiana. Na sua obra, Foucault mostra que o erótico está vinculado à relevância do prazer, que por sua vez está relacionado à prática e à experiência.

Baseado principalmente em Foucault (2001), apresentarei a seguir três momentos históricos que considero marcos importantes para a elaboração da área do saber da sexualidade: (1) o modelo do sexo único; (2) modelo do dimorfismo radical e da diferença biologicamente determinada entre os sexos; e (3) Re-significação da sexualidade perversa pela diversidade sexual.

Na Antigüidade, o grego Cláudio Galeno (130 a.C. a 200 a.C.), que realizou seus estudos sobre medicina e filosofia, propôs o modelo do sexo único. Tomando o corpo masculino como padrão para representar a espécie humana, Galeno afirmava que o corpo que não tinha "calor vital" suficiente para desenvolver os caracteres masculinos na embriogênese tornava-se feminino. Para ele, os ovários corresponderiam aos testículos; a vagina, ao pênis; o útero, ao escroto; e a vulva, ao prepúcio. Ficava assim marcada a ideologia patriarcal, concedendo autoridade e prestígio ao homem, e considerando a mulher como inferior, por lhe faltar o "calor vital" necessário para atingir a perfeição metafísica do corpo masculino (Costa, 1995).

Até o século XIX, as questões relacionadas aos corpos e ao comportamento sexual eram preocupações da religião e da filosofia moral. No final do século XIX, a sexologia entrou em cena, estabelecendo conceitos e critérios que tornaram a sexualidade foco da existência humana (Weeks, 2000).

Esse modelo prevaleceu até o século XVIII, quando surgiu o modelo do dimorfismo radical e da diferença biologicamente determinada entre os sexos. Segundo esse modelo, haveria igualdade entre os homens, com exceção de alguns naturalmente inferiores, ao passo que na mulher a desigualdade era determinada pelo sexo. Foucault e o historiador Thomas Laqueur, citados por Costa (1995), pontuam que "os ideais igualitários da revolução democrático-burguesa tinham que justificar a desigualdade entre homens e mulheres, com fundamento numa desigualdade natural" (p.7). Dessa forma, a nova proposta também estava 
relacionada com a manutenção do domínio masculino, legitimando assim o controle social das mulheres pelos homens, mantendo a desigualdade entre os gêneros - masculino e feminino -, entre os povos - a exemplo dos negros -, assim como outros povos colonizados.

Mais tarde, chegando ao século XIX, o marco para a patologização da sexualidade se deu com a publicação, em 1886, da obra Psychopathia Sexualis, de Richard von Krafft-Ebing. Esse período será mais bem aprofundado no próximo capítulo. No momento, quero apenas ressaltar que todas as formas de expressão sexual que não correspondiam ao modelo reprodutivo eram tidas como pecado contra a natureza, idéia fortemente difundida pelas correntes judaico-cristãs e autenticada pelas correntes biomédicas enquanto perversão. $\mathrm{O}$ termo perversão foi criado com propósito meramente moral-normativo e não terapêutico, fortalecendo a idéia de sexualidade vinculada à genitalidade e à heterossexualidade. Assim, em uma perspectiva higienista, os médicos dessa época reforçavam meios de autenticar a "verdadeira masculinidade", combatendo a "degeneração e outras ameaças a esse pensamento" em que "o ideal masculino era um bastião erigido contra a decadência; representava em palavras, em pinturas e em pedra um ideal de virilidade casta, o qual penetrou profundamente na consciência burguesa" (Mosse, 1998, p.304).

Sem dúvida o movimento de medicalização da sexualidade, entre os séculos XVIII e XIX, mesmo que em uma perspectiva higienista, teve papel fundamental para o estudo da sexualidade na atualidade. A perspectiva higienista, propagada nos meios médicos ${ }^{5}$, tinha como meta o estabelecimento de uma concepção saneadora da sociedade, a partir de focos de doença e de desordem, moralizando-os. Desse modo, no âmbito das "classes inferiores" pobres -, a degradação era entendida enquanto um problema de ordem moral e social. Na perspectiva higienista, era obrigação do Estado a garantia da paz e da saúde do corpo social.

Ao longo da história foi-se abrindo campo para resignificar a sexualidade perversa pela diversidade sexual. Em especial depois da década de 1960, os significados e sentidos atribuídos à sexualidade foram sendo desconstruídos, desfamiliarizando-se a idéia de uma sexualidade proveniente de pulsões internas, passíveis de serem controladas. É comum as pesquisas em sexualidade tornarem como objeto algumas expressões da sexualidade, a

\footnotetext{
${ }^{5}$ Cabe ressaltar que nem todos os médicos estavam voltados para as práticas ligadas à higiene, sendo que o uso do conceito higienista vai ao encontro da proposta de Costa (2004) para se referir aos profissionais da medicina que se propunham teóricos ou executores da política de higienização das cidades, da população e da família.
} 
exemplo do aspecto reprodutivo, DST/Aids, orientação do desejo afetivo-sexual homossexualidade, bissexualidade -, identidades sexuais e práticas sexuais -, entre outras, além de outras possibilidades de expressão que se tornaram objetos de estudo, a exemplo da travestilidade, transexualidade, sadomasoquismo, entre outros. A categoria sexualidade abre um leque de vastas possibilidades de categorias - ou de modos-de-ser - de formas de expressões afetivo-sexuais. Nessas expressões existem aquelas que se aproximam de uma hegemonia, porém, aquelas que se afastam acabam sendo alvo para a manutenção dessa hegemonia.

Mas de onde vem esse universo de conceitos e como as pessoas deles se apropriam, e qual o significado e o sentido desses conceitos em seu cotidiano? Como a sexualidade é vivida por pessoas que não necessariamente se identificam com grupos sociais, sejam eles homossexuais, sadomasoquistas, entre outros? De que modo é possível ter acesso a essas experiências, ou modos-de-ser, sem se ter como referência a perspectiva médico-normativista originada no século XIX?

Utilizo ta expressão grupos sociais, no lugar de minorias sexuais, pelo fato de que nesta idéia se pressupõe um modelo de sexualidade hegemônica. A idéia de diversidade sexual tem o sentido de englobar o modo singular da expressão afetivo-sexual independentemente de a pessoa identificar-se, ou não, com grupos ou segmentos sociais - ou sexuais -, mesmo tendo em vista que esses lugares são referências importantes para a construção da identidade e reivindicação de direitos ${ }^{6}$.

A diversidade sexual ao longo dos anos foi associada ao segmento GLBTTs - gays, lésbicas, bissexuais, travestis e transexuais. Muito se tenta construir um modelo de sexualidade normal fundado na perspectiva higienista do século XIX, que pregava como norma a heterossexualidade monogâmica tendo o sexo como finalidade reprodutiva. Mas o que assistimos na atualidade são expressões que afastam-se muito desse modelo normativo, principalmente a partir da década 1960, com a "revolução sexual", impulsionada pelos discursos sobre gênero promovidos pelo movimento feminista, e potencializada pelo advento da pílula anticoncepcional (Del Priori, 2006; Gagnon, 2006), que rompia, ou colocava em questão, o paradigma sexo-reprodução. Nesse sentido, adoto o termo sexualidades, incluindo

\footnotetext{
${ }^{6}$ Isso é aprofundado na dissertação Homossexualidade... (Toniette, 2003).
} 
a sexualidade na expressão e experiência humana, sem fechar em rótulos ou segmentos, mas contemplando essa experiência enquanto uma singularidade, ou modos-de-ser-sexual, e - por que não? - como uma diferença em si, em um contexto que, por sua vez, mostra-se plural e complexo.

Com referência à herança do século XIX, até que ponto não é dado ênfase, ainda hoje, àquilo que se julga diferente - desviante, bizarro... - e se negligenciam outras realidades ou expressões afetivo-sexuais? Até que ponto isso não fortalece um discurso higienista em uma roupagem mais atualizada? Nessa perspectiva higienista qualquer comportamento considerado como "desviante" é reprimido a fim de manter ou recuperar o "bom comportamento" (Fry \& MacRae, 1991). O referencial para se identificar aquilo que é desviante, um suposto "modelo normal de sexualidade", passa a ser questionado, pois no contexto que vislumbramos na atualidade não cabe compreender as sexualidades a partir de linhas estáticas e determinadas (Parker, 2002).

A questão principal que se apresenta talvez nem seja a inconveniência arrogante de uma conceituação unânime do que seja sexualidade, ou mesmo que seja a "boa sexualidade" e nem é essa a proposta presente -, mas de onde parte essa explosão de discursos sobre a sexualidade e quais os significados e os sentidos atrelados a esse conceito. Torna-se imprescindível o olhar histórico sobre como essa representação foi sendo construída ao longo do tempo incluindo seus meios, incluindo seus fins, formatando corpos e relações entre pessoas.

$$
* * *
$$

A vertente para a compreensão da sexualidade adotada aqui é aquela que a relaciona a uma construção social datada e culturalmente localizada, não se restringindo a um aspecto biológico ou fisiológico dos órgãos genitais. Vários outros fatores se relacionam à sexualidade, a exemplo do gênero - que vai muito além do que é tido como masculino e do que é tido como feminino -, fundamentando a necessidade da contextualização sobre a perspectiva de sexualidade a qual se está referindo. De acordo com Heilborn (1999), a sexualidade consiste em: 
(...) uma dimensão interna aos sujeitos (Vance, 1995), profundamente imbricada num modelo particular de construção de pessoa, no qual a interiorização e individualização são traços modeladores da subjetividade. Mais do que uma entidade universal, a sexualidade é uma unidade ficcional (Weeks, 1986, p.15), dependente de um determinado contexto cultural e historicamente instruída como um domínio portador de sentido em si mesmo (Foucault, 1977). (p.40-41).

Luiz Fernando Duarte (2004) afirma que:

(...) a compreensão de qualquer elemento discursivo ou analítico específico exige a aplicação de uma estratégia historicizante fundamental, que permita perceber as condições do surgimento e evolução tópicas nos meandros das 'escolas', movimentos e tendências epistemológicas enoveladas” (p.39).

A explosão atual de discursos sobre a sexualidade, de acordo com Foucault (2001), não vai ao encontro de uma suposta repressão sexual ${ }^{7}$, mas se constitui em diferentes formas essenciais de poder. A própria proibição faz parte da economia discursiva mais ampla que, por sua vez, produz ainda mais discursos sobre o sexo. Tais discursos funcionam como alicerce para o funcionamento de mecanismos de poder. No campo contemporâneo testemunhamos uma verdadeira polifonia daquilo que é e daquilo que não é sexualidade, daquilo que é saudável e daquilo que é patológico, daquilo que é certo e daquilo que é errado, tendendo sempre partir perspectivas biológicas e moralistas, mas sendo sempre presente a perspectiva político-social.

Rubin (1975) pontua que "a vida sexual humana sempre estará sujeita à intervenção humana. Nunca haverá de ser completamente 'natural', quando menos porque nossa espécie tem caráter social, cultural e articulado" (p.51). Isto faz sentido a partir do momento em que se reconhece a sexualidade enquanto um fenômeno dinâmico e político que se atualiza a cada instante nos mais diferentes contextos, de acordo com a situação historicamente datada e culturalmente localizada de uma dada sociedade.

\footnotetext{
${ }^{7}$ A repressão sexual aqui é entendida na definição de Chauí (1991) que consiste em "um conjunto de interdições, permissões, normas, valores, regras estabelecidas histórica e culturalmente para controlar o exercício da sexualidade" (p.9).
} 
Sendo a sexualidade uma construção social culturalmente localizada e historicamente datada, significados e sentidos são atribuídos a esta construção. Por significados compreendo conteúdos atribuídos a fenômenos que variam ao longo da história, de uma sociedade para outra e entre os diferentes grupos sociais de uma mesma sociedade. Os significados são advindos dos trocas dialógicas entre as pessoas a partir da linguagem verbal e não-verbal, da interação com os outros e consigo mesmo (Gergen, 1985; Grandesso, 2000). Estas narrativas, portanto, contribuem a percepção de limites - ou um conjunto de limites - com relação a algo, a fim de diferenciar esse algo de outras coisas ou de outros fenômenos (Zinker, 2001). Isto posto, os significados são flexíveis, ao longo da existência social, nos espaços comuns de diálogo, eles são atualizados no sentido de uma resignificação, gerando novos sentidos. A transformação dos significados visa a organização não apenas da experiência presente, mas também das passadas e das possibilidades futuras.

A compreensão do significado, portanto, não se encerra apenas em um processo de simbolização interna a partir da representação do mundo externo. Em uma perspectiva construcionista social, Gergen (1985) mostra que a compreensão do significado perpassa pelo relacionamento humano como gerador de linguagem e de compreensão. Deste modo, não é o indivíduo que preexiste ao relacionamento e inicia o processo de comunicação. A compreensão é alcançada a partir das convenções de relacionamento.

Adoto o conceito sentidos para me referir à apropriação de significados que acontece mediante a interação coletiva visando compreender e lidar com as situações e fenômenos do cotidiano. Deste modo, os sentidos aproximam-se da idéia de práticas de Bruner (1997) que as define como a apropriação e utilização dos significados nas relações sociais. Os significados e os sentidos se inter-relacionam, portanto, para a construção da consciência de si e da consciência do outro, viabilizando a constituição - além da sexualidade - de modos-deser fundados na existência social. Nessa perspectiva de atribuir significados e sentidos ao mundo, Mara Dulce Critelli (1996) afirma que:

Os homens não se dirigem direta ou simplesmente às coisas em sua mera presentidade, mas mediados por essa trama de significados em que as coisas vão podendo aparecer. Quando as coisas mudam, é porque mudaram nossas idéias a seu respeito, mudou a serventia que tinham para nós, nosso interesse 
por elas, nossos modos de nos referirmos a nós mesmos e uns aos outros (p.17-18).

Diversos são os fatores relacionados com a mudança - ou reconstrução - de significados e de sentidos do que convencionamos chamar de sexualidade na atualidade. De acordo com Marilene Grandesso (2000), as novas concepções de significado se relacionam com novas realidades lingüísticas, novas narrativas organizadoras e configuradoras de sentido, considerando que nessa reconstrução de significados "encontra-se o processo dialógico no qual coevolucionam a singularidade de uma produção individual e uma dimensão social dos atos da fala" (p.195). Portanto, cada pessoa é co-autora da trama de significados e de sentidos na existência social.

No tocante à sexualidade, a filósofa Marilena Chauí (1991) mostra que "nenhuma cultura lida com o sexo como um fato natural, bruto, mas já o vive e compreende simbolicamente, dando-lhe sentidos, valores, criando normas, interditos e permissões" (p.22). Lidar com a sexualidade enquanto um fenômeno natural que parte do interior de cada ser é atender a um discurso essencialista, mas também pensar a sexualidade enquanto um produto de interações sociais é outro discurso, agora de tendência construcionista.

O essencialismo e o construcionismo são duas perspectivas muito presentes ao longo da história da sexualidade. A perspectiva essencialista predominava nos estudos da sexualidade até a década de 1960, promovida principalmente pelas correntes biomédicas da época, que entendiam a sexualidade como um fenômeno de caráter universal, orgânico e independente de fatores sociais e culturais. Tal perspectiva procurava explicar os indivíduos como produtos automáticos de impulsos internos, ou de uma "essência" interior.

Estudos interdisciplinares posteriores, principalmente aqueles promovidos pelas ciências sociais, opuseram-se a essa visão essencialista da sexualidade e propuseram uma nova visão: a abordagem construcionista da sexualidade humana. Para essa abordagem a sexualidade é construída a partir da interação do indivíduo com o contexto socio-historicocultural do qual faz parte, e enfatiza a importância de considerar como se dá a compreensão desses lugares. Nesta abordagem, o sexo, assim como o ser humano, é contextual (Laqueur, 2001). 
Carole Vance (1995) critica a estreiteza de se considerar apenas aspectos biomédicos para compreender a sexualidade quando aponta que:

\begin{abstract}
A fisiologia do orgasmo e da ereção peniana explica tão pouco o esquema sexual de uma cultura quanto o alcance auditivo do ouvido humano explica a música. A biologia e o funcionamento fisiológico são determinantes apenas nos limites mais extremos, apontando o que é fisicamente possível (p.23).
\end{abstract}

Nesta perspectiva, a abordagem construcionista é enfática na crítica aos postulados do essencialismo frente à sexualidade, que difunde e funciona como base para a normatização médico-moral, e que vincula a sexualidade apenas às pulsões internas e à reprodução da espécie sem levar em consideração o papel das relações sociais na sexualidade.

Com este pensamento, ainda hoje, a sexualidade acaba sendo fortemente relacionada a padrões normativos, quase sempre vinculados à genitalidade e à heterossexualidade. Isso posto, com vias a abrir horizontes para a reflexão sobre a sexualidade, torna-se adequada a compreensão dos reflexos destes padrões no cotidiano, nos tipos de relacionamento, nas opiniões e valores das pessoas de como interagem com o contexto no qual fazem parte. $\mathrm{O}$ construcionismo social mostra ser um meio pertinente para a compreensão de convenções, práticas, e regras socialmente situadas (Spink \& Menegon, 2000).

Seria infrutífero o empenho sobre qual discurso é mais significativo, pois, independentemente de qual seja ele sempre será fruto de uma determinada época, dentro de uma determinada cultura, incluindo os seus mais diversos segmentos. O que chamamos de sexualidade, hoje, talvez tenha outros significados e sentidos daqui a alguns séculos. Por ora, o que fica ao nosso alcance é retomar alguns pontos do que convencionou-se chamar de sexualidade ao longo dos séculos e os significados e os sentidos a ela atrelados.

As ciências sociais, e principalmente a antropologia, contribuíram de forma significativa para mostrar que a sexualidade não é regida por formas e sentidos universais, idênticos em todas as sociedades. Desse modo, torna-se mais importante compreender as interações sociais do que o comportamento individual em si, pois as interações são necessariamente sociais e envolvem negociações complexas entre diferentes indivíduos (Parker, 1991; Rubin, 1989). Tentativas de generalização da expressão e de padrões sexuais 
atendem mais a uma perspectiva normativa que, além de não contemplar a pluralidade da expressão e vivência da sexualidade humana, propicia um campo fértil para o controle sobre os corpos e prazeres, assim como também a discriminação e o preconceito. Isso posto, surge a necessidade de se estabelecer uma política sexual que consiste principalmente no reconhecimento e na defesa dos direitos sexuais nas suas mais diversas formas de expressão.

\section{A dimensão do gênero}

O gênero é uma idéia emprestada da gramática que emerge da diferenciação sexual do reino animal e vegetal, baseado naquilo que não é idêntico, inscrito na biologia (Heilborn, 1990). O gênero faz referência mais à diferenciação do que qualquer outra propriedade intrínseca do objeto, consistindo em uma marca elementar da alteridade. Portanto, o gênero vai muito além da mera diferenciação sexual, assumindo status de categoria cultural, de forma que jamais se deve perder de vista a dimensão relacional entre homens e mulheres. Desse modo, é imperioso que se tenha o cuidado de considerar que masculino e feminino são construções sociais que possuem significados e sentidos distintos em cada cultura, sendo associadas atividades e objetos a essas categorias enquanto domínio e detentoras de tais qualidades (Heilborn, 1990), determinando, assim, aquilo que é tido como "coisa de homem" e "coisa de mulher".

A construção dos gêneros está baseada em um sistema particular de valores culturais, conjunto de práticas, formas simbólicas, representações, normas e valores sociais, que moldam o corpo humano e suas práticas em noções de masculinidade e feminilidade (Parker, 1991; Barbieri, 1991). Como aponta Scott (1995), o gênero refuta a idéia de diferenciação entre pessoa a partir do determinismo biológico implícito do uso de termos sexo e diferença sexual, sendo que o uso do termo gênero "enfatiza todo um sistema de relações que pode incluir o sexo, mas não é diretamente determinado pelo sexo, nem determina diretamente a sexualidade" (p.76). Portanto, o gênero não deve ser compreendido a partir de um pensamento dicotômico macho/fêmea; masculino/feminino; razão/emoção; público/privado, mas circunscrito em uma esfera relacional entre pessoas, homens e mulheres, sendo que o estudo de um implica no estudo do outro. 
Para a compreensão do gênero, Scott (1995) aponta a necessidade de volta a atenção para os sistemas de significado que consistem "aos modos pelos quais as sociedades representam o gênero, servem-se dele para articular as regras de relações sociais ou para construir significado para a experiência" (p.82). Deste modo, a ênfase no sexo - biológico - é ampliada para o gênero - psicossocial - o que torna possível compreender as desigualdades entre homens e mulheres. Nesse sentido, o gênero se remete à dimensão de atribuição cultural e de modelação dos corpos sexuados, indo muito além de se referir aos corpos apenas enquanto resultantes do funcionamento de hormônios, metabolismos específicos ou de pulsões, atribuindo significativamente maneiras particulares de socialização, as quais seguem as prescrições do gênero e classe social (Heilborn, 2006).

Os estudos de gênero realizados por feministas e ativistas tiveram forte impacto na noção de uma "natureza" da sexualidade, tendo com base a revisão crítica das teorias que partiam da reprodução como fonte para explicar gênero e sexualidade, legitimando a submissão das mulheres (Vance, 1995). A antropóloga Gayle Rubin (1975), em sua obra $O$ tráfego de mulheres, marco sobre a submissão das mulheres, mostra, a partir do sistema sexo/gênero, a forma com que as fêmeas se tornam matérias-primas para serem moldadas em um produto de mulheres domesticadas, tendo com base o parentesco. A autora define esse sistema como "uma série de arranjos pelos quais uma sociedade transforma a sexualidade biológica em produtos da atividade humana, e nos quais essas necessidades sexuais são satisfeitas" (p.3). Rubin mostra que, nesse processo, em um primeiro momento a feminilidade é reprimida, sendo que mais tarde isso muda, sendo tomada pelo mercado, camuflado em um discurso de liberdade sexual, atendendo apenas aos interesses dos homens. De acordo com Rubin, o gênero é socialmente imposto e faz referência ao sistema de parentesco que funciona com base no casamento, sendo, portanto, necessário que pessoas do sexo masculino e pessoas do sexo feminino sejam transformados em "homens" e "mulheres", tornando-se em uma metade incompleta do outro que somente a união traria a completude. Essa divisão entre os sexos certamente acarreta repressão de algumas características ou peculiaridades de homens e mulheres, moldando a diferenciação entre gêneros.

Em momento posterior, Rubin (1989) enfatiza que no campo dos gêneros é necessário o consenso e a democracia sexual, em um sentido mais libertador das formas de expressão. 
No sentido de ampliar horizontes na compreensão das existências sociais distintas, a autora enfoca na organização social e na política que mantém esta organização:

Assim como o gênero, a sexualidade é política. Ela está organizada em sistemas de poder que reprime e recompensa alguns indivíduos e atividades, ao mesmo tempo que punem e suprimem outros e outras. Da mesma forma que a organização capitalista do trabalho e da distribuição de recompensas e poderes, o moderno sistema sexual tem sido objeto de luta política desde o seu surgimento (1989, p.187).

Nesta nova perspectiva, Rubin volta-se para o surgimento de grupos sociais, a exemplo dos homossexuais e lésbicos, apontando para a hierarquização das expressões sexuais, além da necessidade do respeito aos seus direitos frente à opressão promovida pelos sistemas de poder.

Vance (1995), por sua vez, afirma que o estudo da sexualidade e do gênero reside em não encerrar em comportamentos e atitudes sexuais, mas no exame de tais mudanças a partir das bases de como estes conceitos se organizam e se articulam nas relações sociais mais amplas. O gênero deve ser visto mais como um construto e não apenas como mera relação entre homens e mulheres. O sistema apresenta múltiplas diferenças e não somente um aspecto binário de homem e de mulher, indo além, consistindo em um campo fértil de análise das desigualdades e hierarquias sociais (Scott, 1995).

A "norma" e a "não-norma" se fazem presentes nos discursos, sendo a sexologia, de acordo com Duarte (2004), "um saber mais limiar, mais ambíguo, mais institucionalizado, que deve merecer interpretações mais específicas” (p.40). Assim, retomo a questão apresentada acima sobre qual o lugar da pessoa singular em todos esses discursos, não enquanto uma entidade recortada de um contexto, mas parte integrante desse. Uma pessoa que acaba de certa forma absorvendo e (re)produzindo tais discursos e necessariamente interagindo com eles, seja oferecendo resistência, seja legitimando-o.

Apesar de Foucault não desenvolver suas obras em uma perspectiva de gênero, ele afirma que o conhecimento e os discursos, ancorados no século XVIII, atendem a uma necessidade de se controlar o sexo, porém travestido em uma proposta de se pensar "atos mais 
favoráveis". O foco do controle era até então o modelo matrimonial, sendo substituído ou dado mais enfoque ao controle das sexualidades periféricas (Foucault, 2001). O autor discute os dispositivos de controle sobre a sexualidade opondo-se às teorias baseadas no discurso da repressão sexual. Nesse sentido, a questão envolve o "discurso" e a "prática", a partir da formação discursiva que, mais adiante, chamaria de "dispositivos de controle" que articulam teorias, noções e tecnologia para a regulação da sexualidade. Foucault chama a atenção para a capilaridade que o poder possui de penetrar nas relações sociais. Vale lembrar que Foucault refere-se ao poder enquanto um fazer, uma relação, e não a uma substância, sendo que o poder sobre um não anula o poder do outro, sendo que um pode ter mais ou menos poder nessa relação com outro.

No tocante ao "mais poder" e "menos poder", Stuart Hall (2000) ressalta que "as identidades estão sujeitas a uma historicização radical, estando constantemente em processo de mudança e transformação" (p.108). A autora compreende a identidade enquanto:

(...) o ponto de encontro, o ponto de sutura, entre, por um lado, os discursos e as práticas que tentam nos 'interpelar', nos falar ou nos convocar para que assumamos nossos lugares como sujeitos sociais de discursos particulares e, por outro lado, os processos que produzem subjetividades, que nos constroem como sujeitos aos quais se pode 'falar'. As identidades são, pois, pontos de apego temporário às posições-de-sujeito que as práticas discursivas constroem para nós (p.112).

Daí a importância, segundo (Hall, 2000), de se compreender "quem somos" e "em que podemos nos tornar", no sentido de refletir sobre trajetórias na existência social, sendo a identidade social um ato de poder.

O dilema de Hall (2000) é para que os trabalhos não se voltem para o sujeito voluntarista que existe separadamente das normas regulatórias às quais ele se opõe. $\mathrm{Na}$ perspectiva da autora, não se pode pensar o sujeito sem pensar na estrutura do discurso, pois as subjetividades são variadas e o sujeito é conduzido pelo sistema simbólico. A performance, assim, estaria relacionada a rituais aos quais os corpos se submetem para a expressão do gênero, naquilo que Foucault chamou de "tornar os corpos dóceis". Considerando a não rigidez da norma, mas sim, uma norma que atende a uma agenda política, o sujeito não pode 
ser voluntarista e nem consciente. Butler (2000) também se refere a esse simbólico que constrói a realidade, e não a um discurso, sendo que a materialização nunca é completa, e aquilo que escapa, na encaixando em categorias pré-determinadas, cairia no campo da abjeção. Para ela, “o sujeito é constituído através da força da exclusão e da abjeção, uma força que produz um exterior constitutivo relativamente ao sujeito, um exterior abjeto que está, afinal, 'dentro' do sujeito, como seu próprio e fundante repúdio" (p.155-156). Em contraposição do domínio do desumano e do abjeto, o próprio humano hegemônico se estabelece.

Na segunda metade do século XX, com o ativismo dos movimentos feministas e homossexuais, e o advento da pílula anticoncepcional, houve uma nova mudança de paradigma da sexualidade, pois o sexo foi desvinculado da reprodução (Giddens, 1993; Heilborn, 1994). Assim, para as mulheres, bem como de forma indireta para os homens, passou-se a aceitar padrões mais flexíveis de expressão sexual, de forma que a sexualidade tornou-se, nas palavras de Anthony Giddens (1993), "propriedade' potencial do indivíduo" (p.37).

A revolução sexual que se seguiu, ou foi concomitante, à popularização da pílula anticoncepcional, favoreceu não só a prática sexual heterossexual sem vistas à reprodução, mas também o fortalecimento da autonomia sexual feminina e a visibilidade de outras expressões sexuais, a exemplo da homossexualidade. Com a desvinculação do sexo da reprodução e dos esforços das lideranças dos movimentos sociais para a mudança de paradigmas foi favorecida a re-significação da sexualidade, sendo possível a passagem daquilo que até então se considerava perversão sexual - a exemplo da homossexualidade para a aceitação da diversidade sexual, abrindo espaço para novos códigos relativos à sexualidade em geral.

Ao longo deste breve histórico temos que, a partir da década de 1960, passou-se a dissociar a sexualidade da reprodução biológica da espécie. Outro momento que funcionou como marco para a transformação da sexualidade foi o advento da epidemia do HIV/Aids, na década de 1980. Tais marcos históricos acabaram por contribuir para o surgimento de investigações relacionadas ao campo da sexualidade, constituindo-a enquanto um campo de investigação em si, dotado de certa legitimidade (Heilborn; Brandão, 1999). 
Dentre esses campos de investigação está situada a questão do gênero, que diz mais respeito ao reconhecimento das diferenças, denunciando as desigualdades associadas a essas diferenças. A adoção do conceito de gênero estabeleceu limites ao determinismo biológico até então associado ao conceito sexo ou diferença sexual, sendo que, por gênero enfatiza-se "o caráter fundamentalmente social das distinções baseadas no sexo" (Scott, 1995, p.72). Desse modo, o gênero traz à tona que a questão do masculino e do feminino, não vinculada apenas ao dimorfismo sexual da espécie humana, mas também à condição dada pela cultura (Heilborn, 1994). Nesse sentido, Louro (2001) afirma que a questão do gênero pretende-se "recolocar o debate no campo, pois é nele que se constroem e se reproduzem as relações (desiguais) entre os sujeitos" (p.22). A partir do gênero - psicossocial - torna-se possível compreender as desigualdades entre homens e mulheres como herança patriarcal que funciona como obstáculo para a eqüidade entre os gêneros e à promoção do bem-estar humano, incluindo aqui a saúde sexual.

Ao longo do processo da construção social são atribuídos, tanto à sexualidade, quanto ao gênero, os mais variados significados e sentidos, que ancoram a expressão da sexualidade de pessoas em um determinado contexto sociocultural. De acordo com Geertz (1989), o homem está envolvido por uma teia de significados que ele próprio teceu, sendo a cultura essa teia e a sua análise. Na pesquisa dessa construção social abre-se um campo para a compreensão sobre a manutenção e a reprodução de formas de controle sobre os corpos e os prazeres - dentre eles, o preconceito - voltado para os gêneros, no mais variados setores sociais, a exemplo da família, da escola, da religião, do Estado, conferindo uma ampla gama de possibilidade de constituição de sexualidades e de gêneros. 


\section{$\begin{array}{llllllllllllllll}\text { C } & \text { A } & \mathbf{P} & \mathbf{I} & \mathbf{T} & \mathbf{U} & \mathbf{L} & \mathbf{O} & \text { I } & \mathbf{I} & \mathbf{I}\end{array}$}

\section{NASCIMENTO DA SEXOLOGIA: UMA NOVA ÁREA DO SABER E DO CONTROLE}

Em sua obra A história da sexualidade, Michel Foucault (2001) mostra a sexualidade enquanto construção cultural que consiste em um processo complexo e dinâmico, resultante de múltiplos elementos discursivos. De acordo com esse autor, à primeira vista, nossa civilização não possui uma ars erótica, mas uma scientia sexualis. A ars erótica é entendida com a apropriação da sexualidade a partir do prazer e da subjetividade. Em contrapartida, a scientia sexualis corresponde a uma verdade estabelecida sobre a sexualidade, que se desenvolveu ao longo dos séculos, a partir de uma forma de poder-saber rigorosamente oposta à arte das iniciações e a segredo magistral. A tônica da scientia sexualis é o discurso científico e a preocupação com a reprodução, legitimando o lugar da medicina no disciplinamento dos corpos e prazeres. A passagem de uma ars erótica para uma scientia sexualis se deu de forma gradativa, principalmente a partir da medicalização da sexualidade.

Como exposto no capítulo anterior, até o século XIX, as questões relacionadas aos corpos e ao comportamento sexual eram preocupações da religião e da filosofia moral. Segundo Foucault (2001), entre os séculos XVIII e XIX, a partir do discurso tanto da ordem civil quanto da ordem religiosa, houve uma consolidação da monogamia heterossexual, sendo que a sexualidade acabou sendo regida por normas rígidas, porém, silenciosas. $\mathrm{O}$ foco dos questionamentos recaiu sobre a:

(...) sexualidade das crianças, a dos loucos e dos criminosos; o prazer dos que não amam o outro sexo; os devaneios, as obsessões, as pequenas manias e as 
grandes raivas. (...) Daí a extração de uma dimensão específica da 'contranatureza' no campo da sexualidade (p.39-40).

No século XIX, os mecanismos de vigilância da Igreja ganharam o reforço da pedagogia e da terapêutica. Foucault (2001) afirma que:

(...) a medicina penetrou com grande aparato nos prazeres do casal: inventou toda uma patologia orgânica, funcional ou mental, originada nas práticas sexuais 'incompletas'; classificou com desvelo todas as formas de prazeres anexos; integrou-os ao 'desenvolvimento' e às 'perturbações' do instinto; empreendeu a gestão de todos eles (p.41).

Foi nesse âmbito que surgiu a sexologia, fornecendo modelos, concepções e formas simbólicas a respeito da sexualidade e, desse modo, influenciando de forma intensa a formatação de corpos e prazeres.

Seguindo a perspectiva histórica, Bozon (2004) afirma que até a segunda metade do século $\mathrm{XX}$ as principais preocupações das disciplinas da sexualidade eram voltadas para as então chamadas doenças venéreas e para as "aberrações" sexuais. A nosografia das perversões era mais focada do que a terapêutica em si. As perversões estavam intrinsecamente relacionadas ao desvio de comportamentos sexuais que se afastavam da finalidade reprodutiva da sexualidade, exemplo: as doenças venéreas consistiam em ameaça à ordem social e familiar.

Durante os anos próximos de 1960, William Masters e Virginia Johnson fundam a sexologia contemporânea, com o objetivo de tratamento das disfunções sexuais, estabelecendo uma perspectiva otimista da sexualidade enquanto fonte de bem-estar pessoal e coletivo (Bozon, 2004). A partir desse momento, o foco foi lançado para o funcionamento anormal e não tanto para as denominadas aberrações. Em um tom crítico, Bozon (2004) afirma que:

(...) os sexólogos substituem de fato a oposição estabelecida entre normalidade e anormalidade, por um continuum do disfuncionamento (...). De agora em diante, somos todos 'disfuncionantes sexuais' virtuais ou reais (p.144-145). 
O lançamento e o sucesso dos potencializadores de ereção, desde 1998, a exemplo do Viagra, aponta para dois fatos importantes: primeiro, do quanto o discurso sexológico influencia na percepção da sexualidade; segundo, do quanto a sexualidade vem sendo medicalizada com vias a fortalecer uma idéia de bom funcionamento sexual (Bozon, 2004). Não é de surpreender o sucesso dos potencializadores de ereção, por irem ao encontro da perfeita ereção, um dos maiores símbolos de virilidade em uma cultura machista e patriarcal. Neste contexto, o homem - com o auxílio da mulher - coloca-se dentro numa armadilha na qual ele próprio precisa constantemente garantir o seu papel de varão.

Foucault (2004) mostra que ninguém possui o poder, mas o exerce. Nesse sentido, quem tem o direito de intervir na sexualidade do outro? O questionamento recai, em se tratando da sexualidade humana, no território do que e para quem a intervenção atende: às necessidades inerentes à condição humana ou a uma perspectiva ideológica voltada para o individualismo, o consumismo e o descartável. Assim, o modelo normal é adotado como referência para o diagnóstico e tratamento de comportamento e atitudes que se afastam deste modelo, sem necessariamente perpassar pela compreensão de significados e de sentidos para aquela realidade singular mergulhada em um complexo tecido social.

A construção da sexologia está estreitamente relacionada com a perspectiva médica que se apropriou do conceito de saúde. Esse processo de apropriação está relacionado com “a crença na verdade absoluta das ciências naturais. Estando o saber médico embasado nessa verdade, a variância e o desvio da norma deverão ser buscados algures, ou seja, no paciente" (Spink, 2003, p.35).

De acordo com Lasch (1991), essa apropriação do campo da saúde pelo segmento médico se dá em um contexto em que comportamentos e atitudes, que até então eram equiparados com crimes ou pecado, passaram a ser equiparados com doença. De certo modo, a jurisprudência médica ocupou o lugar do poder da Igreja que até o século XIX constituía o centro simbólico da sociedade. O autor aponta os desdobramentos dessa medicalização da sociedade no âmbito doméstico, quando diz que a partir da difusão da nova ideologia de bemestar social os maridos e as esposas passaram a confiar na tecnologia e no conselho de especialistas externos, minando a capacidade de prover-se a si mesmos, justificando assim a contínua expansão dos serviços de saúde, educação e bem-estar. 
Com relação a esse disputado território dos serviços de saúde, Spink (2003) afirma que uma profissão é regulamentada depois de um contínuo processo de especialização entre relações de produção e evolução dos conhecimentos técnico-científicos. Dentro das relações de produção se inserem as divisões relacionadas à divisão técnica do trabalho. Ao longo desse processo, é inevitável o surgimento de fronteiras não claramente circunscritas e, consequentemente, a luta pela hegemonia em um dado campo de atuação.

No campo das profissões da área da saúde o corporativismo é um movimento presente, até mesmo para garantir a exclusividade ou o monopólio do exercício profissional de pessoas com determinados requisitos de formação, presumivelmente comprovados pela posse do diploma ou certificados específicos com a conseqüente exclusão de curiosos, autodidatas, diletantes e aventureiros (Spink, 2003). Fica aqui explícito o interesse das áreas profissionais, assim como das áreas do conhecimento, na disputa para si de assumir e de se autorizar no exercício de determinada atividade profissional em um discurso em prol da saúde e do bemestar. A sexualidade, enquanto um campo multidisciplinar, é palco de diversos discursos de viés político (Weeks, 2000).

Na perspectiva foucaultiana, o poder mais uma vez surge para mostrar qual profissão tem mais peso sobre outras. Como exemplo disto, basta apontar o corporativista Projeto de Lei que institui o Ato Médico - PL 25/2002 -, que regulamenta o exercício da Medicina, sendo que a pessoa deve passar por um médico antes de se submeter a qualquer tipo de tratamento, mesmo que não busque necessariamente um tratamento médico. Deste modo, o trabalho interdisciplinar na área da saúde fica ameaçado. Vemos, portanto, que cada área acaba delimitando para si o direito do exercício da atividade profissional. Creio que essa pequena introdução seja necessária para se compreender como se dá a medicalização da sexualidade.

No capítulo anterior, elenquei três principais passagens ao longo da construção da categoria sexualidade. Com relação ao poder, Foucault (2001) afirma que ele não é algo que um indivíduo concede a um soberano, mas sim uma relação de forças entre partes. Nessa perspectiva, de acordo com Foucault, não caberia falar de repressão sexual, considerando esse movimento como uma forma de produção de efeitos de verdade e saber, constituindo-se desse modo verdades, práticas e subjetividades. 
Para Foucault (2001), a repressão é mais um discurso em prol do controle da vida privada das pessoas, sendo que esse se sustenta pelo fato de ser facilmente dominado, fazendo parte da ordem burguesa. Deste modo, Foucault mostra que a repressão funciona como uma condenação ao desaparecimento de comportamentos, ao mesmo tempo que funciona como: “injunção ao silêncio, afirmação de inexistência e, conseqüentemente, constatação de que, em tudo isso, não há nada para dizer, nem para ver, nem para saber” (p.10).

A partir da apropriação da medicina, o campo da sexualidade foi absorvido pela família, mais especificamente pelos pais, incumbidos do controle da sexualidade das crianças (Foucault, 2001). $\mathrm{O}_{\text {dispositivo }}^{8}$ da sexualidade apresentado por Foucault desdobrou-se para a questão da medicalização da sexualidade. Mais tarde, o autor abordou a questão da medicalização do ângulo do biopoder e da biopolítica.

Foucault (2004) define o dispositivo da sexualidade enquanto aquele que tem uma função estratégica dominante que consiste em uma rede que estabelece o conjunto heterogêneo de discursos, instituições, decisões regulamentares, leis, enunciados científicos, entre outros, incluindo-se aqui aquilo que é dito e aquilo que não é dito.

São quatro os dispositivos da sexualidade que, enquanto linhas convergentes, sustentam a teoria da medicalização da sexualidade: a gênese religiosa do dispositivo da sexualidade; a constituição dos saberes psiquiátricos; a medicalização da família para exercer a vigilância da masturbação infantil; e a biopolítica, como forma de organização política de regulação das populações.

A gênese religiosa é apontada por Foucault como o primeiro dispositivo da sexualidade. Esse dispositivo está relacionado ao período em que a confissão-desvelamento passa a ocupar o papel da confissão-penitência na pastoral cristã. A confissão-desvelamento visa justamente explorar os pensamentos, sensações e comportamentos não-ditos dos

\footnotetext{
${ }^{8}$ De acordo com Foucault (2004), o dispositivo consiste em:

um conjunto decididamente heterogêneo que engloba discursos, instituições, organizações arquitetônicas, decisões regulamentares, leis, medidas administrativas, enunciados científicos, proposições filosóficas, morais, filantrópicas. Em suma, o dito e o não dito são os elementos do dispositivo. (...) sendo assim, tal discurso pode parecer como programa de uma instituição ou, ao contrário, como elemento que permite justificar e mascarar uma prática que permanece muda; pode ainda reinterpretar essa prática, dando-lhe acesso a um novo campo de racionalidade (p.244).
} 
penitentes. Concomitantemente a esse dispositivo, também se fazia presente a figura do modelo do discurso jurídico - do qual Foucault era grande crítico -, que tinha como foco a infração das normas que regem o casamento - dispositivo da aliança - e outros atos cometidos entre essas pessoas (Giami, 2005). Mais tarde, esse contexto formado pelo segmento jurídico e religioso voltado para a punição dos atos e pensamentos serviria como base para a constituição da medicalização da sexualidade, em um contexto no qual Foucault aponta a tecnologia do poder da "codificação clínica do fazer falar" (Foucault, 2001). Giami (2005) ressalta que não existiu uma ruptura entre o discurso religioso e a medicalização da sexualidade, mas sim, uma continuidade do plano dos métodos de trabalho, que consistiam na incitação e na interpretação da fala.

De acordo com Foucault (2001), a instituição pedagógica não impôs um silêncio geral sobre o sexo, mas promoveu formas de discursos do tema sobre crianças e adolescentes, concentrando o "falar de sexo com as crianças, fazerem falar elas mesmas, encerrá-las numa teia de discurso que ora se dirigem a elas, ora falam delas, impondo-lhes conhecimentos canônicos ou formando, a partir delas, um saber que lhe escapa" (p.32). Por volta do século XVIII até o século XIX, a medicina e o judiciário tomaram para si o domínio do sexo, fazendo aparecer novos discursos, submetendo o sexo das crianças e dos adolescentes a uma série de dispositivos institucionais e estratégias discursivas. A princípio, ganharam força a "doença dos nervos", a partir da medicina, e a "extravagância", a partir da psiquiatria, sendo também focos dos discursos o onanismo ${ }^{9}$, a insatisfação, as "fraudes contra a procriação", a etiologia das doenças mentais e o conjunto das perversões sexuais. A justiça, que até o século XIX ocupava-se de crimes "crapulosos" e antinaturais, passou a focar os pequenos atentados, entre outros, sobrecarregando de regras e recomendações o sexo dos casais, dos pais e dos filhos, dos adolescentes perigosos e em perigo (Foucault, 2001).

\footnotetext{
${ }^{9}$ Onanismo tem sua origem na história bíblica de Onan:

Filho de Judas, Onan tinha como irmãos Her e Scela. Her casou-se com Chamar, uma fenícia, e morreu pouco tempo depois sem ter deixado filhos. Seguindo a lei israelita, de que irmãos que vivem juntos, quando um morre, o irmão mais logo abaixo deve se casar com a cunhada viúva, Onan teve de casar-se com Chamar com quem teria de ter filhos. O filho primogênito dessa união sucederia o irmão morto, usando o seu nome. Caso o irmão se negasse a casar-se, depois dos conselhos dos mais velhos, a mulher teria o direito de tirar o sapato e escarrar no rosto do substituto do marido, por não honrar o irmão falecido. Onan casou-se com Chamar, mas como não queria ter filhos com ela, pelo fato de que os filhos não seriam seus e nem usariam seu nome (Garnier apud Reis \& Ribeiro, 2004, p.46-7),

deixava que a sua semente caísse fora da vagina da cunhada. Desse modo, praticava o que hoje se chama coito interrompido, que, como a masturbação, também representa o sexo estéril, sem reprodução.
} 
O terceiro dispositivo citado por Foucault (2001) está relacionado com a medicalização da sexualidade da família, no sentido de incitar uma vigilância da masturbação infantil. Médicos e pedagogos combateram o onanismo das crianças, considerando-o uma epidemia a ser extinta. A medicalização da masturbação inscreveu-se num processo de "somatização" da sexualidade voltada para a família, que ocuparia o lugar central no processo de medicalização, entendido como "controle disciplinar” (Giami, 2005).

É importante notar que na virada do século XIX para o XX a abordagem médica transformou aquilo que outrora era tido como sensualidade adicional e posterior à saturação de desejos normais em constituição psicopatológica, pois, a partir do estudo daquilo que era perverso ou psicopatológico, foi inevitável o estabelecimento de uma "sexualidade normal", até mesmo para funcionar como um referencial para os novos modelos desviantes. Nesse contexto nasceu a sexologia (Hekma, 1995). Até então, a masturbação e o amor socrático homossexualidade - não eram criminalizados, mas evitados. A luta contra a masturbação propiciava base para uma pedagogia nova e esclarecida, pois considerava-se que a criança era portadora de uma "pureza natural" que somente a educação ruim poderia deturpar (Hekma, 1995).

Nesse momento, diversas obras médicas foram publicadas, sendo a mais célebre a Psychopathia Sexualis, em 1886, do médico católico Richard von Krafft-Ebing. O autor defendia que "o erotismo deveria ser regulado pela exigência de reprodução da espécie e dos ideais de amor a Deus e à família" (Loyola, 1999, p.32-33). Com o advento da psicopatologia sexual, a classificação dos até então chamados vícios foi suplantada por uma psiquiatria das perversões (Hekma, 1995). Goerge Mosse (1995) aponta que nesse período o segmento médico reforçava os meios de autenticar a "verdadeira masculinidade", combatendo a degeneração e outras ameaças a esse pensamento. Para o autor, "o ideal masculino era um bastião erigido contra a decadência; representava em palavras, em pinturas e em pedra um ideal de virilidade casta, o qual penetrou profundamente na consciência burguesa” (p.304).

O surgimento do termo sexualidade fornece significados e sentidos para a reflexão e para o discurso sobre o sexo na vida humana, estabelecendo conceitos e critérios que tornaram a sexualidade foco da existência humana. Nesse período, o padrão de normalidade da manifestação de uma sexualidade estava relacionado com a tríade: heterossexualidade, monogamia e a prática sexual visando a reprodução. Em momento posterior, esse paradigma 
começou a sofrer uma mudança, a partir da teoria do inconsciente dinâmico de Freud, ao questionar a solidez do gênero, da necessidade sexual, e da identidade (Weeks, 2000). O auge da mudança desse paradigma ocorreu mais tarde, com o advento da pílula anticoncepcional, no século XX, que desvinculou o sexo da reprodução, abrindo espaço para novas concepções de sexualidade.

O processo de medicalização da sexualidade é embasado pelo saber médico e psiquiátrico - o segundo dispositivo da sexualidade - estabelecendo normas, recomendações e procedimentos que são difundidos na família, sendo os pais os depositários do papel da vigilância para se evitar, ou combater, qualquer forma de desvio. Porém, não só as crianças eram o foco dessa vigilância, mas todos aqueles potenciais portadores de algum tipo de perigo sexual, a exemplo dos desejos e comportamentos com relação às crianças que poderiam culminar em uma relação incestuosa (Foucault, 2001).

Diante dos dispositivos que levaram à medicalização da sexualidade, apresentados por Foucault, podemos identificar uma série de discursos que vislumbramos ainda nos dias de hoje a partir da explosão das especialidades que muitas vezes enfatizam uma sexualidade saudável. Mas que sexualidade saudável seria essa e a partir de que base se considera uma sexualidade saudável ou não? Discursos continuam sendo promovidos nos mais diferentes segmentos, sejam pedagógicos, sejam clínicos, nas áreas da psicologia, medicina, pedagogia... A pergunta que fica é: de que visão de humano se parte para falar em saúde? Em um humano que deve ser funcional como se espera - daí se falar em "disfunções”? -, ou num humano com uma história, com uma trajetória de vida, que faz parte de um contexto mais amplo e com ele está em relação?

Aqui entra em cena a idéia de biopolítica, o quarto dispositivo de medicalização da sexualidade que foi desenvolvida mais tarde por Foucault, em 1976, no seu curso Em defesa da sociedade. Nele, o filósofo aprofundou a questão da medicalização da sexualidade no contexto social, considerando não só o controle disciplinar, mas a produção social da vida, o direito “de 'fazer' viver e de 'deixar' morrer" (Giami, 2005). Desse modo, o papel higienista da medicina torna-se mais evidente, focando a sexualidade no organismo e na população. A dualidade da vigilância - exercida sobre os corpos dos indivíduos - e da biopolítica organizadora da gestão populacional e sua relação com a vida e com a morte - é que vão integrar as diferentes dimensões construídas sobre os saberes da sexualidade, que Giami 
(2005) aponta ser "a sexualidade reprodutiva e seu foco conjugal, as perversões e os crimes sexuais" (p.269).

$$
* * *
$$

Como visto, até o século XIX, a religião e a filosofia moral se preocupavam com as questões relacionadas aos corpos e ao comportamento sexual, sendo as queixas sexuais associadas a distúrbios psicopatológicos - aquilo que fugia à norma - nem sempre bem-vindas no contexto psicoterapêutico (Kaplan, 1977). No final do século XIX, em consonância com a psicanálise, numa proposta moral-normativa, surgiu a sexologia, estabelecendo conceitos e critérios que tornaram a sexualidade foco da existência humana (Weeks, 2000). O marco para a instituição da sexologia foi a publicação, em 1970, da obra Inadequação Sexual Humana, de William Masters e Virgínia Johnson (Leiblum \& Pervin, 1982). Com essa obra surgiu a terapia sexual como proposta terapêutica, porém ainda fortemente vinculada a critérios normativos, só que agora, em uma proposta de enfatizar a funcionalidade e/ou otimização da sexualidade.

Baseado na proposta foucaultiana, Giddens (1993) mostra que o sexo tornou-se de fato o foco principal do confessionário moderno. De acordo com Weeks (2000), os sexólogos ajudaram num certo sentido a "inventar" a importância dada ao comportamento sexual, ao estabelecerem uma esfera especializada de conhecimento, ao buscar "leis da natureza" que governam o mundo sexual, argumentando que a sexualidade tem influência sobre outros aspectos da vida e que o corpo fala uma verdade final. Até o século XVIII, o sexo era vivido enquanto uma expressão que se aproximava da idéia do erotismo. A partir de então, o sexo passou a ser incorporado por um novo conceito, o de sexualidade, tornando-se foco da experiência humana (Weeks, 2000). A sexualidade passou a ser compreendida predominantemente a partir de uma perspectiva essencialista, em que o sexo seria regido por pulsões internas, sendo a contenção dessas pulsões a proposta da medicina, da psicanálise e de outros segmentos normativos da época, a exemplo da Igreja. Luiz Fernando Duarte (2004) mostra que a Igreja católica passou a embasar seu discurso moralista nos saberes "científicos", em uma aliança com doutrinas materialistas e reducionistas, sendo o foco uma "natureza sexual", com implicações diretas sobre a vida humana, em uma perspectiva de "direito natural" e de uma "natureza humana". 
Hoje sabe-se que as tentativas de homogeneização da sexualidade, por meio da generalização de modelos, principalmente aqueles com enfoque "biologizista", sem levar em conta a pluralidade de vivências num contexto sócio-cultural complexo, contribui para a criação e manutenção de mitos e de tabus, além de outras distorções, estabelecendo de forma tirânica e dicotômica aquilo que é tido como "normal" ou "anormal", "aceitável" ou “inaceitável”, "saudável” ou "patológico", restringindo a expressão singular de homens e mulheres num contexto social pluralístico (Toniette, 2003). A homogeneização da sexualidade acaba por ser meio de moralização e de normativização que não contemplam a pluralidade do fenômeno da sexualidade humana.

Em termos gerais, mais especificamente na esfera da sexualidade, temos três aspectos que influenciaram significativamente para a sua desta área do saber: (1) pesquisa de caráter biológico, incluindo a reprodução; (2) resgate da diferença, a partir da teoria da degeneração, que estabelece os limites entre o normal e o patológico; (3) e a adoção do conceito de "perversão" para conduzir as pesquisas sobre as reações dos sistemas sensoriais. Desse modo a sexualidade foi sendo desentranhada, no seu caráter moral e valorativo, das práticas sexuais, sendo perseguidos o onanismo, a prostituição, a pornografia, a promiscuidade proletária, entre outros, tendo sempre como referência os saberes biomédicos e psiquiátricos (Foucault, 2001; Duarte, 2004).

De acordo com o exposto anteriormente, considerando que a visão de sexualidade não é única, fatores ideológicos continuam sendo fortemente atrelados a esse fenômeno como explicitado por Foucault. Apesar de que nos dias de hoje se fale de uma sexologia enquanto uma área que promove a melhoria da qualidade de vida sexual, muitos desconhecem a procedência da sua fundação e propósitos. Aliás, a que qualidade de vida sexual está-se referindo, se nem ao menos se dá conta de que sexualidade vivemos e de que sexualidade estamos falando? O resultado é a criação de significados e de sentidos que acabam funcionando, como aponta Foucault, mais como meios de formatar e de controlar a vida privada das pessoas, em nome de algo dito saudável, ou normal, do que necessariamente em promover o bem-estar individual e social.

Mesmo envolta em uma aura de saúde e de bem-estar, é emergente a reflexão sobre a área da sexualidade, conferindo como se dá a sua construção social, para evitar, na medida do possível, de se transformar em um campo semelhante ao religioso, de onde não se admite o 
questionamento, mas o acatar a ideologia proposta. A noção de ideologia que adoto é aquela proposta por Chauí (2002), que consiste na:

(...) elaboração intelectual sobre a realidade, feita pelos pensadores ou intelectuais de uma sociedade (...) que descrevem e explicam o mundo a partir do ponto de vista da classe a que pertencem e que é a classe dominante de sua sociedade (p.174).

Nesse sentido, remeto à classe dos especialistas que podem funcionar como meios de promoção da qualidade de vida, mas também podem tender ao controle e à moralização, ainda mais com o embasamento "científico", que legitima a sua verdade. Mas que verdade seria essa? Segundo Louro (2001), a agenda política relacionada ao sexo está mais embasada em uma direita moral do que em uma esquerda libertária.

A perspectiva de uma direita moral reforça a idéia de sexualidade enquanto resultante de fatores instintivos, associando o modelo de normalidade sexual àquele relacionado com a genitalidade e heterossexualidade. Não foram poupados esforços para que se autenticasse tal modelo, descortinando a vida privada de pessoas, rotulando-as conforme suas práticas sexuais: sádicas, masoquistas, zoofílicas, gerontofílicas, dentre vários outros considerados desviantes da natureza e pecaminosos diante dos ditames celestiais. Para fortalecer a "normalidade", nada melhor que patologizar, identificando e combatendo aquilo julgado como "anormalidade". Mesmo o sexo oral e o anal, eram tidos como desviantes, independentemente de o ato ser realizado entre homem e mulher, ou entre dois homens, ou entre duas mulheres, por não atenderem ao propósito reprodutivo. O sociólogo Michel Bozon (2004) mostra que a progressiva incorporação das perversões ao campo da sexualidade a partir das sexualidades periféricas amplia o campo descritivo, porém, paradoxalmente, reduz o espaço relativo à sexualidade normal.

A partir da publicação do documento Promoção da saúde sexual: recomendações para a ação ${ }^{10}$, pela Organização Pan-Americana de Saúde, em conjunto com a Organização Mundial da Saúde, com a colaboração da Associação Mundial de Sexologia, hoje se fala em saúde sexual compreendido enquanto "a experiência do processo permanente de bem-estar

\footnotetext{
${ }^{10}$ A Organização Mundial da Saúde, em 2006, apresentou um novo documento com discussões sobre a definição de saúde sexual (World Health Organization, 2006), que retomarei em momento posterior.
} 
físico, psicológico e sociocultural relacionado com a sexualidade" (Pan American Health Organization; World Health Organization, 2000, p.6). A saúde sexual consiste num bem, num direito humano fundamental, e não apenas na ausência de doenças, sendo que, para a promoção da saúde sexual, é fundamental o reconhecimento e a manutenção dos direitos sexuais.

Os direitos sexuais consistem em:

Direito à liberdade sexual - A liberdade sexual diz respeito à possibilidade dos indivíduos de expressar seu potencial sexual, excluindo-se todas as formas de coerção, exploração e abuso em qualquer época ou situações de vida.

Direito à autonomia sexual, à integridade sexual e à segurança do corpo sexual - Diz respeito à habilidade de uma pessoa em tomar decisões autônomas sobre a própria vida sexual num contexto de ética pessoal e social. Também inclui o controle e o prazer de nossos corpos livres de tortura, mutilação e violência de qualquer tipo.

Direito à privacidade sexual - Refere-se às decisões individuais e aos comportamentos sobre intimidade desde que não interfiram nos direitos sexuais dos outros.

Direito à igualdade sexual - Liberdade de todas as formas de amar sem discriminação, independentemente do sexo, gênero, orientação sexual, idade, raça, classe social, religião, deficiências mentais ou físicas.

Direito ao prazer sexual - Refere-se ao prazer sexual, incluindo autoerotismo, como uma fonte de bem estar físico, psicológico, intelectual e espiritual.

Direito à expressão sexual - A expressão é mais que um prazer erótico ou atos sexuais. Cada indivíduo tem o direito de expressar a sexualidade por meio da comunicação, toques, expressão emocional e amor.

Direito à livre associação sexual - significa a possibilidade de casamento ou não, ao divórcio, e ao estabelecimento de outros tipos de associações sexuais responsáveis.

Direito às escolhas reprodutivas livres e responsáveis - É o direito de decidir ter ou não ter filhos, o número e tempo entre cada um, e o direito total aos métodos de regulação da fertilidade. 
Direito à informação sexual baseada no conhecimento científico - A informação sexual deve ser gerada por meio de um processo científico e ético e disseminado em formas apropriadas e a todos os níveis sociais.

Direito à educação sexual abrangente - Este é um processo que dura a vida toda, desde o nascimento, pela vida afora e deve envolver todas as instituições sociais.

Direito ao atendimento de saúde sexual - O cuidado com a saúde sexual deve estar disponível para a prevenção e tratamento de todos os problemas sexuais, precauções e desordens. (World Association for Sexology's Declaration of Sexual Rights, 1999, p.37).

Neste mundo contemporâneo, algumas situações decorrentes de miséria, ou da herança patriarcal, ainda estão presentes, como a violência sexual, entre outros; no campo mais específico e velado, testemunhamos o uso abusivo de potencializadores de ereção - sendo utilizados apenas para ter o algo-a-mais na relação sexual -, a idealização do prazer sexual - o orgasmo idealizado e tão buscado pelas mulheres. Isso tudo sem mencionar um sério problema social relacionado aos corpos representados pelos transtornos alimentares - a anorexia e a bulimia -, tendo como base a construção de corpos ideais - leia-se, magros -, entre diversos outros fenômenos que apontam a inter-relação entre a saúde, a sexualidade, e as questões sociais, na construção os corpos e dos prazeres.

No tocante aos potencializadores de ereção vislumbramos um mercado que movimenta anualmente bilhões de dólares. A priori, tais medicamentos foram lançados para atender a um público masculino de idade avançada e com dificuldade de obtenção e de manutenção de ereção, mas é evidente que a indústria farmacêutica se vale da construção de gênero para o sucesso mercadológico desse tipo de medicação. É a idéia de que o homem deve sempre estar com o pênis em riste, pronto para penetrar. $\mathrm{O}$ cuidado que se deve tomar é com a mensagem de que todos e todas estejam condenados ao orgasmo múltiplo e sempre estejam prontos e prontas para a relação sexual, tornando-a um ato mecânico e performático, empobrecendo a idéia do compartilhamento do afeto, erotismo e prazer do encontro sexual.

Em pleno século XXI, o discurso moral-normativo marca sua presença no que diz respeito à conduta e expressão das pessoas nas mais variadas culturas, reforçado muitas vezes pelos segmentos da medicina. No lugar de perversões e desvios da sexualidade de séculos 
passados, hoje se fala em saúde sexual, educação sexual, orientação sexual, entre outros que, de certa forma, merecem o cuidado para não recair novamente no discurso normativo com vias à promoção da "saúde", moldando o pensamento e vivência da sexualidade nas mais variadas culturas do mundo ocidental.

Conforme apontado por Duarte (2004), todo um novo vocabulário se apresenta, aspirando ao reentranhamento político, tanto no nível nacional quanto no internacional, forjando as categorias "educação sexual", "satisfação sexual", "minorias sexuais", entre outras. $\mathrm{O}$ autor aponta que a sexualidade encontra-se em pleno processo de desentranhamento, entranhamento e reentranhamento. O "desentranhamento" estaria relacionado com o florescimento da sexualidade pelo meio médico e pela psicanálise, relacionando-a principalmente à reprodução, passando pela oposição entre "comportamento" e "identidade" sexuais. O "entranhamento" seria, para o autor, uma "construção propriamente moderna para falar dos modos pelos quais a sexualidade não existe autonomizada das demais instâncias das vidas humanas em outras culturas ou em períodos outros de nossa própria tradição" (Duarte, 2004, p.73). Já o "reentranhamento" seria uma:

(...) construção mais prospectiva, voltada para dois tipos de objetivos: seja o de afetar alguma manifestação específica corrente em suas implicações éticas e comportamentais (como no caso de J. F. Costa), seja o de constituir protocolos de consideração de fenômenos da sexualidade integrados em outras dimensões analíticas (Duarte, 2004, p.73-74).

O discurso normativo acabou sendo denunciado principalmente pelos movimentos feministas e homossexuais, que a ele resistiram, apontando as singularidades e os mais variados costumes e práticas sexuais nas diferentes culturas. A legitimização do sexo enquanto um produto a ser consumido atende certamente a segmentos que têm interesse identitário e mercadológico, reforçando a idéia de uma sexualidade que precisa ser "consertada", "melhorada", "potencializada" em uma perspectiva que muitas vezes, anula a pessoa, ou mesmo a cultura da qual ela faz parte.

A presente pesquisa tem o intuito de conhecer como homens e mulheres se apropriam, descrevem, compreendem e vivenciam os mais variados discursos acerca da sexualidade. As pessoas participantes da pesquisa apresentam alguma questão relacionada à própria 
sexualidade, seja na não correspondência a um padrão performático - número de relações sexuais, tempo de ereção, tempo de controle ejaculatório, qualidade do desejo e orgasmo, entre outros -, seja na não correspondência a um padrão de "normalidade" - desejo por pessoas do mesmo sexo, fetiches, número de parcerias, entre outros.

Em um tempo em que amplamente se fala em revolução sexual, regulação da sexualidade, mercantilização do sexo, aborto, homossexualidade, pornografia, Louro (2001) mostra o quão é indispensável o reconhecimento desses processos sociais. A proposta adotada nesta pesquisa é de justamente compreender como as pessoas lidam com essas temáticas no seu cotidiano, atribuindo significados e sentidos nos mais diferentes contextos. 
$\begin{array}{lllllllllllllll}\text { C } & \text { A } & \text { P } & \text { I } & \text { T } & \text { U } & \text { L } & \text { O } & \text { I } & \text { V }\end{array}$

\section{O CAMINHO ADOTADO PARA CONHECER AS EXPERIÊNCIAS}

\section{Perspectivas da experiência}

A partir de depoimentos de trajetórias de vida, a proposta principal da pesquisa é conhecer significados e sentidos da construção social de sexualidades e de gêneros a partir da experiência emocional e social de três homens e de três mulheres com queixas afetivosexuais, que buscaram atendimento no Plantão Psicológico. Neste sentido, a proposta também segue a perspectiva de compreender (1) a inter-relação das queixas afetivo-sexuais com os roteiros sexuais e de gênero vigentes; e (2) a contribuição do modelo de Plantão Psicológico para o atendimento de questões relacionadas à sexualidade.

\section{Algumas referências teóricas}

Considerando o enfoque da sexualidade enquanto fenômeno amplo e complexo construído socialmente, historicamente datado e culturalmente localizado, o referencial teórico do construcionismo social torna-se indicado para conhecer ${ }^{11}$ e compreender a experiência. Weeks (2000) reforça essa proposta afirmando que:

${ }^{11}$ Conhecer, do lat. cognoscere: "aprender a conhecer, procurar saber, tomar conhecimento de, reconhecer" (Houaiss, 2001) 
Só podemos compreender as atitudes em relação ao corpo e à sexualidade em seu contexto histórico específico, explorando as condições historicamente variáveis que dão origem à importância atribuída à sexualidade num momento particular e apreendendo as várias relações de poder que modelam o que vem a ser visto como comportamento normal ou anormal, aceitável ou inaceitável (p.43).

O enfoque da sexualidade enquanto fenômeno natural ou universal é derivado de modelos biomédicos, que consideram o corpo como supostamente universal, sendo que, num primeiro momento, foi dada ênfase à neurobiologia para explicar o dimorfismo cerebral e, num segundo momento, à biologia molecular para determinar o papel dos genes no comportamento humano (Vance, 1995; Rose, 1996). A abordagem construcionista é explícita na sua oposição ao determinismo do essencialismo (Barbieri, 1991; Vance, 1995; Foucault, 2001), porém, como lembra Richard Parker (2002), a discussão do enfoque construcionista não deve ater-se a tal oposição, mas, sim, reforçar a proposta compreensiva da sexualidade humana como fenômeno construído socialmente.

De acordo com Kenneth Gergen (1985), a abordagem construcionista social está embasada em um ou mais pressupostos, a saber: (a) posicionamento crítico diante do conhecimento concebido como 'verdade'; (b) os termos e as formas pelas quais se consegue compreender o mundo e cada um individualmente constituem-se artefatos sociais, produtos de inter-relações pessoais, com especificidade histórica cultural; (c) as descrições de mundo, ou de self, são sustentadas ao longo do tempo, não por validade objetiva, mas devido às vicissitudes do processo social; (d) o significado da linguagem deriva do seu modo de funcionamento dentro dos padrões de relacionamento; (e) a avaliação de formas de discurso existentes consiste ao mesmo tempo a avaliação de padrões de vida cultural.

$\mathrm{O}$ enfoque na linguagem, por meio dos relatos orais, mostra ser uma possibilidade para se conhecer e compreender a interação do indivíduo com o contexto sociocultural do qual faz parte (Spink, Medrado, 2000; Toniette \& Schmidt, 2002; Toniette, 2003). A linguagem deixa de ser um mero instrumento representacional da realidade para ser instrumento estruturante da própria experiência (Ferreira, 1999). As pessoas constroem termos, na dinâmica das relações sociais, visando compreender e lidar com as situações e 
fenômenos do cotidiano. A construção de termos está relacionada à linguagem em uso narrativas, argumentações e conversas -, que consiste na elaboração do fenômeno sociolingüístico da construção social (Spink \& Medrado, 2000). Nessa mesma perspectiva, Weeks (2000) afirma que a linguagem é um indicador valioso de que a sexualidade está em constante evolução. $\mathrm{O}$ autor exemplifica essa afirmação a partir da palavra sexo que, no passado, era utilizada apenas para designar o segmento homem e o segmento mulher, sendo que, nos últimos dois séculos, tal palavra passou a designar especificamente as diferenças anatômicas entre homens e mulheres. Outra palavra que pode ser utilizada como exemplo de fenômeno sociolingüístico da construção social é a palavra homossexual, pois, antes do século XIX a homossexualidade existia, mas o/a homossexual não, sendo que, até então, esse fenômeno era conhecido como "o vício que não tinha nome", e passou para "amor que não ousa dizer o nome" (Costa, 2002).

O construcionismo social propõe-se a privilegiar a experiência, a singularidade e a especificidade, tendo como cerne a compreensão de processos pelos quais cada pessoa descreve, explica ou compreende o mundo do qual faz parte, incluindo a si própria (Gergen, 1985). A pesquisa construcionista propõe-se a examinar e compreender as convenções, práticas e peculiaridades, na perspectiva de compreendê-las como regras construídas e socialmente localizadas, englobando as transformações sociais (Spink \& Frezza, 2000). Segundo Weeks (2000), a contribuição do construcionismo social para os estudos da sexualidade é que não se busca oferecer explicações dogmáticas sobre como os sentidos sexuais individuais são adquiridos, mas sim focar-se no problema do quê e como a nossa cultura privilegia determinadas formas de expressão e marginaliza ou discrimina outras, além de lançar uma questão do por que nossa cultura atribui tanta importância à sexualidade e como isso veio acontecer.

Para compreender a formação das identidades sexuais enquanto construção social farei referência à proposta de identidade metamorfose, de Antonio Ciampa (2001), e à proposta de identidade em sociedade em rede, de Manuel Castells (1999), ambas embasadas no materialismo histórico.

A identidade metamorfose consiste num processo, ao lado da atividade e da consciência, que "descreve a constituição de uma identidade, que representa a pessoa e a engendra" (Ciampa, 2001, p.243). A proposta de Ciampa está em consonância com o 
construcionismo social, pois mostra a pessoa enquanto um conjunto de relações sociais dentro da História, envolvendo aspectos sociais, políticos, econômicos, históricos, entre outros. Assim, além de representar, a identidade engendra, ou seja, origina, gera, produz a pessoa, sendo a "articulação da diferença e da igualdade" (Ciampa, 2001, p.243). Nessa proposta, a identidade está vinculada à concretude - articula-se com uma vida concreta, vivida por uma personagem concreta, alicerce de uma sociedade igualmente concreta e constituída por vidas vividas, e não a uma abstração ou mera representação do indivíduo; à temporalidade transforma-se ao longo do tempo; à socialidade - só pode existir num contexto social; à historicidade - vista como configuração localizada historicamente, inserida dentro de um projeto e que permite ao indivíduo alcançar um sentido de autoria na sua forma particular de existir.

A proposta de identidade em uma sociedade em rede, de Castells (1999), enfoca a inter-relação entre indivíduo e sociedade, considerando o impacto da globalização na formação de identidades, numa sociedade em rede. $O$ autor compreende a identidade enquanto “... um processo de significado com base em um atributo cultural, ou ainda um conjunto de atributos culturais inter-relacionados, o(s) qual(is) prevalece(m) sobre outras fontes de significado" (Castells, 1999, p.22). Mais adiante o autor pontua que podem existir identidades múltiplas, sendo que a pluralidade é "fonte de tensão e contradição tanto na autorepresentação quanto na ação social" (Castells, 1999, p.22). A identidade consiste numa construção social por excelência, organizando os significados vivenciados e provindos da "história, geografia, biologia, instituições produtivas e reprodutiva, pela memória coletiva e por fantasias pessoais, pelos aparatos de poder e revelações de cunho religioso" (Castells, 1999, p.23). Castells (1999) distingue três formas de identidade, tendo como referência as relações de poder: identidade legitimadora - introduzida pelas instituições dominantes da sociedade no intuito de expandir e racionalizar sua dominação em relação aos atores sociais; identidade de resistência - criada por atores sociais que se encontram em posições/condições desvalorizadas e/ou estigmatizadas pela lógica da dominação, construindo, assim, trincheiras de resistência e sobrevivência com base em princípios diferentes dos que permeiam as instituições da sociedade, ou mesmo opostos a estes últimos; identidade de projeto - quando os atores sociais, utilizando-se de qualquer tipo de material cultural ao seu alcance, constroem uma nova identidade capaz de redefinir sua posição na sociedade e, ao fazê-lo, de buscar a transformação de toda a estrutura social. Esse é o caso, por exemplo, do feminismo, que abandona as trincheiras de resistência da identidade e dos direitos da mulher para fazer frente 
ao patriarcalismo, à família patriarcal e, assim, a toda a estrutura de produção, reprodução, sexualidade e personalidade sobre a qual as sociedades historicamente se estabelecem.

O modelo patriarcal é um importante elemento na formação de identidades e na organização de ações sociais, sendo que grande parte das sociedades contemporâneas está assentada nele. Castells (1999) define o patriarcalismo como aquela estrutura caracterizada pela autoridade, imposta intencionalmente, do homem sobre a mulher e filhos no âmbito familiar. Para manter-se, essa estrutura deve permear toda a organização da sociedade, da produção e do consumo à política, à legislação e à cultura. Com a inevitável mudança de paradigmas da sexualidade e do gênero, homens e mulheres são convidados a rever seus papéis nos contextos sócio-culturais dos quais fazem parte.

Revisitando os modelos do passado para compreender a construção das sexualidades e dos gêneros, nota-se a influência do modelo essencialista em compreendê-la, reforçando como norma o modelo heterossexual, com atividade sexual vinculada à reprodução. $\mathrm{O}$ patriarcalismo assenta-se nesse modelo, o determina, especificando como deve, ou como não deve, ser a expressão sexual de homens e de mulheres. Essa imposição acaba por normativizar e limitar a expressão masculina e feminina, abrindo espaço para dificuldades interpessoais e, por sua vez, dificuldades afetivo-sexuais. O padrão médico-normativo criado no final do século XIX teve como meta o enquadramento em critérios diagnósticos, sem necessariamente buscar compreender o significado e o sentido da construção da dificuldade sexual de uma pessoa, ou mesmo visando a melhoria da interação dessa pessoa com o contexto no qual faz parte.

\section{Enfocando o método}

A modalidade de pesquisa adotada é a qualitativa, seguindo-se o método dos relatos orais na forma de depoimento (Queiroz, 1991; Toniette \& Schmidt, 2002). A pesquisa qualitativa tem como foco o específico, o peculiar, o individual, sempre privilegiando a compreensão e não a explicação dos fenômenos estudados, afastando-se da idéia de generalizações, princípios ou leis (Martins \& Bicudo, 1994). Após diversas leituras dos 
depoimentos serão identificadas unidades de significado com o intuito de apreender as semelhanças ou diferenças de apropriação dos participantes.

O método dos relatos orais torna possível o acesso à experiência, por meio do olhar singular, em que se pode conhecer o grupo social do qual uma pessoa faz parte. Nessa perspectiva, o método dos relatos orais, na forma de depoimento, é compreendido conforme a proposta de Maria Luisa Schmidt (1990), para quem o pesquisador coloca-se mais como um "recolhedor da experiência, inspirado mais pela vontade de compreender, do que como um analisador à cata de explicações” (p.70), sendo envolvido com a alteridade e compromissado com a linguagem que comunique o encontro. A proposta dos relatos orais vai ao encontro da idéia de que "a linguagem é, por definição, uma prática social. A pessoa não existe isoladamente, pois sentidos são construídos quando duas ou mais vezes se confrontam: quando a voz do ouvinte responde à voz do falante" (Spink \& Medrado, 2000, p.46).

A linguagem é reconhecida pelo construcionismo como elemento central nos processos de objetivação que constituem a base da sociedade de humanos (Spink \& Frezza, 2000), assumindo estatuto do objeto a partir do processo de construção lingüístico-conceitual. A linguagem torna-se veículo no qual são transportados elementos para a construção de termos para a descrição, explicação e compreensão de mundo do qual uma pessoa faz parte. Desta forma, o método dos relatos orais é um método que contribui para o reconhecimento de singularidades, evitando a generalização limitante de conceituações advindas de padrões cientificistas ou apriorísticos. José Bom Meihy (2002) ressalta a contribuição do método dos relatos orais para o estudo da singularidade que está envolvida com outras singularidades:

Com uma vocação de tudo e para todos, a história oral respeita as diferenças e facilita a compreensão das identidades e dos processos de suas construções narrativas. Todos são personagens históricos, e o cotidiano e os grandes fatos ganham equiparação na medida em que se trançam para garantir a lógica da vida coletiva (p.21).

O método dos relatos orais pode ser utilizado no trabalho com as diferentes formas de expressão da sexualidade. Nessa proposta, o/a entrevistado/a tem a oportunidade de elaborar a própria experiência, a partir do momento que necessita filtrar aquilo que lhe é significativo na sua trajetória de vida. A linguagem consiste em uma prática social, pois, conforme Halbwachs 
(1990), a memória individual e a memória coletiva estão interligadas, sendo que o relato funciona como uma espécie de ponto de vista construído por uma pessoa sobre o social do qual faz parte. Augé (1997) aponta que:

No face-a-face com o pesquisador, o pesquisado elabora seu relato e a representação da sua existência; ele unifica, ordena e hierarquiza as diversas situações à quais pertence. Constrói uma imagem de si mesmo que integra as representações que os fazem dele. Ele se produz, assim, como ator social e, poderíamos acrescentar, propõe ao mesmo tempo uma imagem da sociedade em que pertence (p.148).

Dessa forma, a fala de uma pessoa é sempre ancorada em sua existência social; porém, como ponto de convergência das influências sociais, a pessoa elabora sua visão singular e pode, portanto, impor um limite à tirania das imagens coletivas. $\mathrm{O}$ testemunho de pessoas tem valor, ora por seu caráter representativo de um grupo, ora por seu caráter exemplar.

A escolha do método dos relatos orais está embasada na riqueza dessa proposta em ter acesso à experiência, possibilitando o contato entre narrador e ouvinte para quem a experiência vai sendo descrita e explicada. O enfoque dado a este projeto é pelo conhecimento no sentido puro do termo, que é o "ato ou efeito de apreender intelectualmente, de perceber um fato ou uma verdade; cognição, percepção" (Houaiss, 2001). A compreensão do depoimento nesse estudo segue a proposta de práticas discursivas a que Spink e Medrado (2000) referem-se como: "momentos de ressignificações, de rupturas, de produção de sentidos, ou seja, corresponde aos momentos ativos do uso da linguagem, nos quais convivem tanto a ordem [discurso] como a diversidade [prática discursiva]" (p.45), como proposta à escuta da construção particular de sexualidades e gêneros a partir das dificuldades sexuais.

A narrativa a partir dos relatos orais demonstra ser um meio para conhecer recortes de uma realidade a partir do o acesso à elaboração da experiência vivida pelos participantes, tanto pelo narrador quanto pelo ouvinte. Peculiaridades de uma pessoa ou grupo podem ser trazidas à tona, não com o intuito de "verificação", "constatação", "comprovação", mas com o propósito principal de ter contato, abrindo possibilidades para o conhecer. 
A proposta do método dos relatos orais vai ao encontro da argumentação de Hilton Japiassu (1995), no sentido de que a psicologia que não leva em conta o homem como presença no mundo, como subjetividade, como um existente cujo sentido precisa ser manifestado, só pode ignorá-lo. De acordo com o autor, o estudo da relação do ser humano com o mundo e consigo mesmo, sua gênese, seus modos de realização e sua finitude, é uma das tarefas essenciais da psicologia: revelar, para o homem, o que significa "existir".

Bruner (1997) apresenta dois argumentos para fundamentar que o conceito principal de uma psicologia humana é o significado. O primeiro argumento é "que para entender o homem você deve entender como as suas experiências e seus atos são moldados por seus estados intencionais" (p.40). O segundo argumento é "que a forma desses estados intencionais se realiza apenas através da participação em sistemas simbólicos da cultura” (p.40). Nessa perspectiva, Bruner enfatiza a importância de uma psicologia popular como um instrumento de cultura. E, como instrumento de cultura, pode ser uma forma de produção de conhecimento no sentido apresentado por Joseph Zinker (2001) de que conhecimento não é estático, consistindo em um processo na fronteira de um sistema ou subsistema em uma unidade de espaço e tempo.

\section{Os relatos orais e os roteiros sexuais e de gênero}

Desde pesquisa anterior (Toniette, 2003) venho recorrendo às mais diversas fontes para apreender um sentido para trilhar o caminho da pesquisa qualitativa a fim de favorecer o processo de conhecer a pluralidade das sexualidades e dos gêneros.

Os relatos orais, na forma de depoimento, foram adotados como método, por funcionarem como um instrumento flexível e que permite a manifestação e, por conseguinte, o contato com as singularidades, apresentando suas formas de perceber, compreender e explicar o mundo do qual essas singularidades fazem parte, contemplando as formas de diálogo com as redes sociais, os valores, as crenças, desse universo particular, parte de uma rede social mais ampla. 
Além da flexibilidade, esse método foi escolhido por dar sentido a uma idéia de compreender as singularidades a partir dos próprios modos-de-ser, sem partir para classificações diagnósticas. Deste modo, não era o foco identificar aquilo que supostamente seria saudável/patológico, normal/desviante, bem/mal, pois a pessoa se tornaria um objeto de estudo passivo de uma especialidade, à mercê de um veredicto e de um rótulo final. O método dos relatos orais abre espaço para uma via de mão dupla aonde é dada à pessoa o direito de dialogar sobre uma suposta determinação que lhe é dada, a exemplo do diagnóstico.

Os depoimentos funcionam como meio privilegiado para se compreender a organização da experiência pessoal a partir do diálogo com as instâncias sociais das quais o indivíduo faz parte, construindo uma percepção de si e do outro, aqui compreendido enquanto identidade, que a pessoa traz de forma significativa naquele recorte de tempo e de espaço em que a concedia o depoimento.

O método dos relatos orais tem como proposta principal o contato com a pessoa, enquanto uma narradora das idas e vindas, das contradições, dos medos, dos anseios, das dificuldades, facilidades, estranhamentos, apropriações, significações, ressignificações, organizações e reorganizações, entre outros, que sentiu ao longo da experiência vivida singular em um meio social complexo. No entanto, cabe aqui a ressalva de que independentemente do método de pesquisa adotado, dependerá sempre do pesquisador definir a trajetória de sua pesquisa no que diz respeito principalmente à análise, motivo pelo qual na primeira parte explicitei algumas fases da minha experiência.

A escuta ativa a partir do depoimento sobre como a pessoa compreende e se localiza naquilo que chamamos de sexualidade, torna-se uma estratégia interessante de acesso à complexidade da formação do ser sexual, sem necessariamente "voltar à infância" para se compreender o agora. Nessa perspectiva a infância não determina a vivência do aqui-e-agora, no entanto, o narrador fica livre para esse acesso se isso lhe for significativo de alguma forma ou que lhe tenha ficado registrado daquela fase da vida. Essa perspectiva vai ao encontro do que Gagnon (2006) considerou como estratégia para a formulação dos roteiros sexuais. 
A teoria social dos roteiros sexuais foi proposta por Gagnon e Simon como uma alternativa às teorias biológicas ou às teorias psicanalíticas de compreensão do comportamento sexual. A teoria dos roteiros sexuais parte do pressuposto de que:

(...) os indivíduos usam sua habilidade interativa, bem como material da fantasia e mitos culturais, para desenvolver roteiros (com deixas e diálogos apropriados), como um modo de organizar seu comportamento sexual (Gagnon, 2006, p.21).

Os autores distinguem três níveis principais de roteirização, que seriam os cenários culturais - base de instruções e requisitos narrativos dos papéis sociais gerais; roteiros interpessoais que consistem em padrões institucionalizados de interação social cotidiana; e roteiros intrapsíquicos - dizem respeito aos detalhes que o indivíduo utiliza em seus diálogo interno com as expectativas culturais e sociais de comportamentos (Gagnon, 2006).

Nessa estratégia, Gagnon privilegia a complexidade, a novidade e a descontinuidade do desenvolvimento sexual tomando como estratégia o conhecimento do ciclo de vida e retroceder, em vez de adotar a infância como ponto de partida. $\mathrm{O}$ acesso à descrição do desempenho sexual do adulto, aqui compreendido enquanto sexualidade de uma forma geral, sem restrição ao desempenho sexual em si, é um meio para se examinar a implicação nos roteiros sexuais, a coordenação do comportamento concreto, processos fisiológicos, processos psicológicos, recursos culturais e acontecimentos sociais, abrindo campo até mesmo para se conhecer experiências ao longo do processo de socialização.

A interpretação dos depoimentos será feita depois da elaboração dos momentos significativos da experiência com base na linha narrativa do participante. A interpretação das trajetórias dos participantes terá como proposta central a descrição e a compreensão dessas diversas experiências vividas, nas formas de construção de sexualidade e gênero, no sentido de como descreve, compreende e explica esses fenômenos. Esta proposta vai ao encontro de Gergen (1985) para quem os processos pelos quais a pessoa descreve, a compreende e a explica o mundo que faz parte, incluindo a si mesma, é o cerne do construcionismo social. Essa proposta também vai ao encontro de Peter Berger e Thomas Luckmann (2004) que enfatizam que se deve priorizar aquilo que os homens conhecem como realidade em sua vida 
cotidiana, no sentido do senso comum, sendo que “precisamente esse 'conhecimento' que constitui o tecido de significados sem o qual nenhuma sociedade poderia existir" (p.30).

\section{Os participantes e as participantes}

Conforme já exposto anteriormente, os participantes ${ }^{12}$ da pesquisa se constituem de clientes que buscaram os serviços do Plantão Psicológico do Serviço de Aconselhamento Psicológico - SAP. Não foi adotado qualquer protocolo na escolha, a não ser pelo fato de terem procurado o plantão psicológico com alguma questão envolvendo aspectos da sexualidade e terem sido sugeridos pela equipe do SAP.

Elaborei uma lista a partir do levantamento dos possíveis participantes da pesquisa. Posteriormente iniciei os contatos apresentando-me como pesquisador e colaborador do $\mathrm{SAP}^{13}$ e explicando a proposta da pesquisa em conhecer a inter-relação entre educação e sexualidade. Caso a pessoa demonstrasse interesse em participar da pesquisa, prontamente agendava um dia para a entrevista. Repeti esse processo até alcançar o número de três homens e três mulheres. Desse modo, o critério de seleção do participante para a pesquisa não foi a queixa relacionada à sexualidade levou ao plantão. A questão levada ao plantão não foi mais importante do que a pessoa interessada em participar da pesquisa.

Foram convidados sete clientes para participar da pesquisa, sendo que apenas uma convidada desistiu, após demonstrar interesse e agendar entrevista justificando que o tema relacionava-se a "uma questão muito íntima".

\footnotetext{
${ }^{12}$ Ao longo do texto, o termo colaborador e participantes são adotados enquanto sinônimos.

${ }^{13} \mathrm{Na}$ época eu colaborava como psicólogo voluntário nas atividades do Plantão Psicológico enquanto supervisor e, em algumas vezes, enquanto plantonista.
} 


\section{O modo de acessar as experiências a partir dos relatos orais}

O caminho para se conhecer as experiências dos participantes foi se mostrando ao longo do processo, privilegiando sempre facilitar a expressão da experiência vivida da singularidade do participante ${ }^{14}$, sem prender-se a padrões metodológicos rígidos. No entanto, cabe explicitar o meu percurso e o modo que esses caminhos foram se desvelando ao longo da pesquisa e como foram dados contornos para essa experiência.

$\mathrm{Na}$ proposta dos relatos orais considera-se a flexibilidade e os diversos contextos e sentidos das sexualidades, contribuindo para apreensão da experiência. Sendo a linguagem considerada uma prática social por excelência, os relatos orais se mostram como método que torna possível o acesso, por meio da experiência singular, ao conhecimento do grupo social do qual a pessoa faz parte.

Os relatos orais se subdividem em: depoimentos - em que o narrador descreve e explica a sua experiência em uma esfera circunscrita da sua vida - e história de vida - que traça aquilo que é eleito como significativo para quem narra, podendo ser um conjunto de depoimentos. Seja na forma de depoimento, seja na forma de história de vida, o método dos relatos orais favorece a riqueza de sentimentos, opiniões e atitudes. Esse método ancora-se no trabalho do pesquisador-escritor, envolvido na busca da alteridade e compromissado com a invenção da linguagem que comunique o encontro.

Os relatos orais oferecem matéria-prima básica para o acesso à experiência de diferentes formas de expressão, inclusive a sexual, de forma singular e no sentido de reconhecê-las e legitimá-las, afastando formas óbvias de essencialismo e universalização (Toniette \& Schmidt, 2002, 2004). Por se tratar de um campo específico da esfera do gênero e da sexualidade, nesta pesquisa será adotado o relato oral na forma de depoimento.

As entrevistas foram realizadas em uma sala do Centro de Atendimento Psicológico CAP - onde está sediado o SAP. O contato tinha início com a apresentação da proposta da

\footnotetext{
${ }^{14}$ Usualmente costumo utilizar preposições e pronomes citando sempre o gênero masculino e o gênero feminino na mesma frase, porém, visando facilitar a leitura e a estética, em alguns momentos o uso do gênero masculino será generalizado para o gênero feminino.
} 
pesquisa e da leitura e preenchimento do Termo de consentimento livre e esclarecido ${ }^{15}$ TCLE. A duração média das 6 entrevistas foi de pouco mais de 2 horas. As entrevistas tinham início com uma questão disparadora: Fale-me sobre desde como foi a descoberta da sua sexualidade até chegar aos dias de hoje. A minha postura diante do participante foi de acompanhar o relato, sendo que, em algumas vezes, formulava uma questão a fim de compreender algum ponto que não tivesse ficado claro.

As reações diante da pergunta disparadora foram as mais diversas. No geral, o participante formulava sua resposta de forma breve e o silêncio alguma vezes imperava. Neste caso, visto que a minha proposta era basicamente facilitar a narrativa, optei por evitar formular perguntas, mas de fazer uma breve devolutiva do que eu havia compreendido da sua fala. Essas perguntas norteadoras foram feitas em termos de complemento, cuidando para privilegiar e não quebrar a linha narrativa do participante.

As entrevistas foram gravadas em meio digital, posteriormente transcritas e literalizadas. Após isto, o depoimento foi apresentado para os participantes para que fizessem as modificações que julgassem necessárias, seja suprimindo algumas passagens, seja complementando ou acrescentando outras.

Dada a longa duração das entrevistas, no lugar de apresentar os depoimentos na íntegra, eles foram trabalhados de forma a destacar temas ou lugares referenciados pelos colaboradores sem, contudo, mudar o sentido da narrativa. Considerando os depoimentos como parte central da pesquisa, e com o intuito de dar destaque a eles - portanto, não são considerados anexos -, eles serão apresentados no Capítulo VI - Escutando histórias, conhecendo experiências. Ao final de cada depoimento haverá uma figura com linha do tempo, constando temas ou lugares de destaque, e as citações diretas de cada colaborador. No Capítulo VII - Significados e sentidos da experiência, o recorte da análise consistirá, conforme já exposto, em reunir passagens e temas trazidos pelos colaboradores buscando compreender as diferentes experiências vividas.

\footnotetext{
${ }^{15}$ Vide em Anexo.
} 


\section{Algumas considerações sobre ética e pesquisa participante}

Vale a ressalva de que eu não possuía vínculo clínico com os participantes. Enquanto pesquisador, apesar de considerar que a pesquisa não apresentava nenhum tipo de risco aos participantes, assumi a inteira responsabilidade por possíveis desdobramentos do acesso a questões que possivelmente seriam fonte de angústia e de aflição por parte deles. Para facilitar um eventual contato, cada participante levou consigo a cópia do TCLE, onde contavam os meus contatos. Até o fechamento da tese, nenhum participante contatou-me, fora por ocasião da legitimação dos seus depoimentos, conforme descrito anteriormente.

Como amplamente discutido nos três encontros do grupo de trabalho "Relação pesquisador-pesquisado", no I Seminário sobre Ética nas Pesquisas em Ciências Humanas, na Saúde, em outubro de 2007, no IPUSP, a referência à pesquisa qualitativa do tipo participante remete-se ao interesse na democratização das formas de produção e transmissão de conhecimento, buscando, para isso, construir uma relação de colaboração e de interlocução entre o pesquisador e aqueles que são convidados a ingressar na pesquisa como "pesquisados". A pesquisa participante, enquanto uma possibilidade de construção compartilhada de conhecimento remete-se ao diálogo que se estabelece caso exista a disponibilidade entre pesquisador e interlocutor para criarem um contexto de cumplicidade, onde se viabilize a alteridade, criando o nós (Schmidt \& Toniette, 2008). É nesse espaço de interlocução que Schmidt (2006) mostra que a relação é marcada pelo legítimo respeito e atenção às diferentes vozes, assim como o interesse na "construção de discursos contrahegemônicos, baseados na polissemia e na polifonia das simultâneas representações de um mesmo fenômeno, grupo ou coletividade" (p.27).

Deste modo, nesta pesquisa, foi adotada uma perspectiva ética, conforme apontado por Schmidt e Toniette (2008), para quem a ética está implicada no método de pesquisa enquanto um processo que se constitui ao longo do processo, na contínua relação pesquisador e/ou interlocutor ou colaborador. Neste sentido, o pesquisador, de forma autônoma, é constantemente chamado para refletir, decidir e agir de forma ética, assumindo a responsabilidade pelos efeitos de suas idéias e atos. 
Os valores éticos surgem como forma de eliminar, diminuir ou controlar o risco permanente da violência. A violência pode apresentar os mais diferentes significados e sentidos nas mais variadas culturas e períodos históricos, porém, fundamentalmente, a violência é entendida como o "exercício da força física e da coação psíquica para obrigar alguém a fazer alguma coisa contrária a si, contrária aos seus interesses e desejos, contrária ao seu corpo e à sua consciência, causando-lhe danos profundos e irreparáveis" (Chauí, 2002, p.336). Na perspectiva ética somos pessoas e não meros objetos, argumento este que já fornece elementos para questionar os protocolos de pesquisa e os procedimentos meramente burocráticos que são justificados em nome de uma "ética".

Em termos éticos ou morais, a pessoa detentora de existência ética deve preencher as seguintes condições: (1) ser consciente de si e dos outros - alteridade; (2) ser dotado de vontade - a fim de ser consoante com a consciência, ter capacidade de controlar e orientar desejos, impulsos, tendências e sentimentos; (3) ser responsável - reconhecer-se com autor de suas ações, bem como avaliar efeitos e conseqüências; (4) ser livre - capacidade de autodeterminar-se, dando a si mesmo as regras de conduta (Chauí, 2002).

Nesta tensão entre a pesquisa ética - na qual o pesquisador é a todo o momento chamado para refletir, decidir e agir de forma ética - e a ética em pesquisa - que pode ser entendida de um modo exclusivamente regulador e normalizador de preceitos préestabelecidos de outras áreas, a exemplo das pesquisas médicas, biológicas e farmacêuticas para as quais foi criada -, Schmidt e Toniette (2008) apontam que:

A associação de diretrizes heterônomas à ética em pesquisa pode ser sinal de desconfiança na capacidade do pesquisador de refletir e agir de acordo com a sua consciência moral e com respeito à autonomia de um outro: grupo, comunidade, ou sociedade (p.106).

Nesta questão da ética na pesquisa em Ciências Humanas e Sociais na Saúde, cabe o constante debate para que este tema de suma importância não se transforme em algo meramente burocrático e legalista, mas um conjunto de princípios essenciais que norteiam a produção compartilhada do conhecimento. 
$\begin{array}{lllllllllllllllll}\text { C } & \text { A } & \mathbf{P} & \mathbf{I} & \mathbf{T} & \mathbf{U} & \mathbf{L} & \mathbf{O} & \mathbf{V}\end{array}$

\section{ESCUTANDO HISTÓRIAS, CONHECENDO EXPERIÊNCIAS}

\section{1. "A sociedade espera mais que um indivíduo seja mais um macho do que um homem": o depoimento de Jorge 16,17 $^{17}$}

Jorge tem 22 anos, nasceu em São Paulo, e é estudante universitário. Mora com o pai, a mãe e a irmã.

$\mathrm{Na}$ ocasião do encontro para a coleta do depoimento, lembro-me de Jorge, franzino, cabelos compridos, unhas bem tratadas, vestido de forma casual e elegante. Apesar de eu achar que sua introspecção não favorecia uma narrativa aprofundada, não foi o que aconteceu no depoimento de Jorge. A partir da questão disparadora "fale-me como foi desde a descoberta de sua sexualidade até chegar os dias atuais", senti Jorge um pouco embaraçado e até surpreso. Depois de algum tempo refletindo, iniciou seu depoimento. A lembrança imediata que ele relacionou à pergunta disparadora foram as conversas que teve com a mãe e os livros sobre sexualidade que ela lhe forneceu.

Ao longo da narrativa, Jorge apresenta quatro cenários principais constituídos por: família, escola fundamental, internet e faculdade. A linha narrativa, no geral, seguiu essa ordem de cenários, pelos quais passou ao longo da sua experiência.

\footnotetext{
${ }^{16}$ Os nomes utilizados nos depoimentos são fictícios e escolhidos pelos próprios participantes. Da mesma forma os demais nomes de pessoas e lugares citados também foram alterados.

17 A duração do depoimento foi de $2: 28 \mathrm{~h}$. Na ocasião da validação, Jorge apenas realizou a edição gramatical, sem alterar o sentido do conteúdo original.
} 


\subsection{Jorge na família: "se não fala, é melhor eu não falar também"}

No tocante à família, Jorge relata a abertura da mãe quando perguntou a ela como a sexualidade funcionava, e ela lhe explicou abertamente. Porém, mesmo sem abrir mão da vontade de conhecer, o foco principal no relato sobre a infância, num misto de apreensão e curiosidade, é lançado no modelo inspirado pelo pai baseado no: "se ele não fala, eu também não falo". A mãe forneceu-lhe um livro sobre o tema, mas Jorge não faz referências ao tipo de informações contidas e nem como as compreendeu. Chama a atenção seu cuidado em demarcar os limites da idade, considerando-se "precoce" e, por isso, "errado", não se sentindo autorizado a ter o acesso ao tema da sexualidade, mesmo que ela estivesse presente com seus pares na escola, pois "lá se comentava".

Jorge estabelece para si que somente a partir dos 15 anos poderia abordar esse universo no qual, sem se dar conta, já estava inserido. Essa mensagem foi reformulada a partir do contato com seu "amigo precoce", que tinha um contato aberto com a família sobre a sexualidade, além de já ter tido uma namorada aos 13 anos. Assim, Jorge passa a se autorizar a ter acesso a esse território, ou, ao menos naquele momento, o universo da sexualidade que se mostrava à sua frente ganhava novos sentidos. A sexualidade é aos poucos desvelada na experiência de Jorge, ganhando contornos.

Ao longo do depoimento, Jorge apresenta outras referências além daquelas provindas da sua mãe e do seu pai, sendo sempre a mãe "aberta e até sem-vergonha" - dada a sua abertura para falar sobre sexo -, e o pai "religioso, fechado e constrangido". A mãe, para ele, incentiva a descoberta, inclusive a sexual, e o pai é restritivo, mais no sentido de um embaraço, do que no de repreensão. Uma passagem que retrata esse embaraço é sua reação diante da pergunta feita por Jorge: "Tem a Virgem Maria. Por que ela é virgem? Aliás, o que é virgem?”. Como resposta, o pai disse: “Ah! É porque ela nunca namorou... ela não se casou... (...) porque ela teve um filho sem namorar, e que o filho dela não veio de um homem, veio de Deus". Jorge, mesmo reconhecendo a falta de sentido daquelas respostas, optou por encerrar o assunto com um "tá bom". Assim, por não se satisfazer com a resposta dada pelo pai, mas reconhecendo a temática do sexo e da sexualidade como algo delicado, ele estabeleceu para si que "quando eu for adulto, aí vou entender melhor". Nesse ponto vemos também a falta de preparo destes pais para lidar com a questão da sexualidade com seus filhos 
e, talvez, até com a própria sexualidade, em um contexto que não favorece o diálogo e a reflexão deste aspecto da vida humana.

Interessante notar que Jorge vê o sexo e a sexualidade como "coisa de adulto", mesmo a mãe "autorizando" o acesso a este território abrindo espaço para o diálogo e tendo fornecido livros sobre o tema. Além disso, ele se achou "velho", no sentido de estar atrasado para aquilo: “...eu perguntei para a minha mãe como funcionava e ela explicou abertamente, inclusive me deu uns livrinhos da coleção 'Vida sexual', (...) e acho que eu tinha 8 ou 9 anos. Já era um pouco velho. E aí eu li aquele livrinho, depois eu li o segundo, o próximo, acho que é pra, pra adolescente. Eu li um pouco cedo, se a gente for comparar...". Senti um tom na fala de Jorge que aqueles livros não tinham vindo em momento adequado para ele. Em um momento ele diz que era velho para aquilo, mas, em outro, afirma que leu aqueles livros cedo demais.

A religiosidade e o silêncio do pai com relação à sexualidade foram interpretados por Jorge como "se não fala é melhor eu não falar também. Eu sabia que era assim, fechado, então, foi ficando para depois". Por outro lado, a sua curiosidade e interesse eram sustentados pelos contatos com o "amigo precoce" e com outros colegas na escola.

O julgamento de valor quando o tema é sexualidade mostra-se presente, funcionando como limite para a curiosidade e o interesse, criando uma atmosfera de culpa pelo fato de "não dever" fazer aquilo, fazendo com que se retraísse ainda mais. A descoberta da sexualidade segue em uma perspectiva solitária e velada, com o obstinado juízo de valor no encalço da vazão da curiosidade emergente. O cenário que se apresenta é de uma mãe que sinaliza a possibilidade de diálogo e de um pai embaraçado que não fornece essa possibilidade. O "amigo precoce" e os livros tornam-se referências importantes naquele momento de descoberta da possibilidade do conhecer, do desvelar aquilo que acontecia com seu corpo, emoções, sentimentos, e na necessidade de relacionar-se, de estar-junto-com, vinculados ao que convencionamos chamar de sexualidade. 


\subsection{Jorge na escola: "tinha poucas pessoas para conversar sobre isso..."}

Em um momento do depoimento, Jorge distingue os eventos da escola dos eventos de casa: “...eram duas coisas completamente separadas", sendo que quando estava em casa não falava de escola e vice-e-versa. No cenário da escola, a partir do sentido da crença de que deveria ter acesso ao tema da sexualidade após os 15 anos, restringe este movimento a novas informações, escolhendo manter a sexualidade no âmbito do oculto, ao menos socialmente: "E aí eu soube depois, com os colegas na escola que comentavam, mas... pra mim ficava aquela coisa pra depois, de preferência quando eu fosse adulto, quando eu tivesse 15 ou 16 anos. Então não me interessava". Surpreenderia se houvesse interesse de sua parte, pois naquele momento não lhe fazia sentido compartilhar o interesse dos colegas, pois o modelo que tinha é que "se [o pai] não fala, é melhor eu não falar também".

Jorge indica uma realidade presente na nossa cultura, que é a deficiência, seja na família, seja na escola, de oferecer espaços de reflexão e diálogo sobre a sexualidade. Torna isso claro quando mostra que "tinha poucas pessoas para conversar sobre isso", mesmo os colegas falando nisso o tempo todo, a seu ver, chegando a ser "até uma coisa absurda". É importante ressaltar que em nome de espaços de reflexão e diálogo, não seja entendido como espaços para o controle, no sentido apontado por Foucault (2001) dos dispositivos da sexualidade, pois, neste caso, o silêncio, o segredo, o encobrimento podem ser entendido como forma de defesa e resistência ao controle.

Seguindo sua trajetória de permanecer oculto, a opção era falar pouco, ou mesmo não falar, por uma escolha própria. Vale pontuar que essa postura não era somente com relação à sexualidade, mas também a outros assuntos: "eu tinha um monte de assunto que eu não podia falar e esse era mais um desses...". Dessa forma, o impedimento de falar sobre a sexualidade ou outros assuntos limita sua interação com o grupo. No roteiro de ação de Jorge, a pauta era ficar à margem, ouvindo muito, a fim de absorver informações e outras referências, e falando pouco, para não se comprometer.

O trabalho com a sexualidade na escola não é apenas tratá-la de forma efusiva e direta, mas de um espaço de expressão, de escuta ativa e de acolhimento às dúvidas e incertezas inclusive dos educadores - surgidas e vivenciadas na especificidade daquela realidade escolar, 
sem ser algo imposto, ou espaço para "enquadrar" atitudes e comportamentos, assim como nos idos 1960, quando a educação sexual na escola dava os primeiros passos no Brasil com uma proposta normativa e moral no estilo "educação do moço e da moça de bem”, ou nos idos 1970, quando a proposta médico-biologista em uma base higienista e médico-profilática (Ribeiro, 2004; Nunes, 2006).

Quando Jorge transferiu-se de escola, o novo contexto não apresentou mudanças significativas, a não ser por ter se identificado com um grupo ao qual se refere como "meio 'nerds', todos envergonhados". Jorge expõe que: “...por algum motivo, que me colocava assim, era tido como o mais distante, o mais fechado, então nem falava nisso [sobre sexo]. (...) ...Quando eles falavam disso, eles sabiam que eu não ia comentar, então, nem me perguntavam, nem me colocavam na roda e... foi assim". Em seu perfil reservado, Jorge continua no lugar do isolamento, no lugar do espectador, do silêncio. O sentido que Jorge dá para não fazer parte dos grupos de colegas é, mais uma vez, inspirada na sua percepção do pai: "O fato de eu não fazer parte nas rodinhas, acho que provavelmente foi por influência do pai. Como já não falava sobre isso, o meu pai, então, eu também não vou falar". De acordo com o já exposto acima, deve-se considerar que essa escolha é feita dentro de um contexto em que Jorge passa a fazer parte de um grupo social, e que nesse contato com o grupo não se sentiu estimulado para o encontro de outras possibilidades de expressão, apesar de existir maior identificação do que com o grupos de amigos da outra escola.

Quando tinha por volta de 13 anos, a idealização do pai começa a ruir. O pai gostava de música sertaneja e Jorge ouvia apenas esse tipo de música, enquanto outros garotos da sua idade apreciavam Ozzy Osbourne, Jimi Hendrix, Iron Maiden: “Eles [os colegas] estavam errados por ouvir isso. Eles deviam ouvir alguma coisa melhor. Meu pai ouvia sertanejo! (...) O meu pai ouve sertanejo, tá certo, e o rock tá errado". Porém, para seu espanto, o pai chegou com um CD de Jimi Hendrix: "Aí, caiu meu mundo. Aí caiu o meu mundo. Poxa, o meu pai era o meu pilar... aquele que gostava... sertanejo tava certo, e o rock tava errado. Tudo por causa dele... tudo o que eu fazia era praticamente por causa dele... de não falar de sexo, por exemplo". Nesse instante Jorge se dá conta de sua individualidade: "Ele [o pai] não falava, continuava sempre fechado, mas quando eu perdi a referência, eu falei: 'Bom, não sou igual a ele"'. Em vez de se abrir depois do desencanto de saber que o pai também tinha suas contradições: “...me fechei mais ainda. Na parte sexual creio que aconteceu isso também". Com relação à música "não gosto de parar para escutar música, pois acho uma 
perda de tempo", servindo apenas para despertá-lo no rádio-relógio. Talvez a falta de norte, depois de ruído o pilar paterno, faz Jorge sentir-se sem nenhuma outra referência. Opta pelo retraimento ao lançar-se na busca ou descoberta de novas referências seja no aspecto sexual, seja no estilo musical que mais lhe agradasse.

Outro desencanto ocorreu quando Jorge e a sua mãe descobriram "revistas que não eram nenhuma 'Playboy', (...) era uma coisa bem mais explícita”. E continua: "Meu pai que nunca falava nada, que nunca conseguia me explicar o que que era virgem, e aí ele tem aquelas revistas ali dentro?". Com a idealização voltada para o pai em ruínas, Jorge passa a ter uma outra perspectiva do seu próprio conflito. O que outrora tinha hábito de regras a serem seguidas pela sua coerência com as atitudes e comportamentos do pai, agora ganha contornos de conflito. De certo modo, como Jorge pontua em momento posterior, o material pornográfico que encontrava na internet passou a ser cuidadosamente guardado em seu computador. O pai não teve o mesmo cuidado ao guardar as revistas na sua pasta de trabalho, em que o acesso era mais facilitado.

Com a revista pornográfica nas mãos, um recurso a mais, Jorge se masturba: "Eu lembro que foi bom, foi tanto que teve outras vezes que eu me masturbei. Eu lembro que me masturbava duas ou três vezes por semana, quando não tinha ninguém em casa, especialmente". Assim, Jorge adapta o seu roteiro para essa nova possibilidade, seguro de que conseguia obter prazer quando tinha certeza de que não teria ninguém em casa, utilizando de forma mais autorizada os materiais de conteúdo erótico que reuniu.

\subsection{Jorge no mundo virtual: "A internet abriu muito mais, tinha muito mais opções"}

O cenário da internet foi o mais referenciado ao longo do depoimento de Jorge. A partir do seu contato com o computador e a internet $^{18}$, por volta dos 11 anos de idade, Jorge toma conhecimento de materiais e conteúdos de cunho erótico. Por incentivo do seu já citado "amigo precoce", Jorge acessa esse material: "Nesse dia calhou de estar só eu e ele em casa, não sei por que, aí ele falou: 'Pega alguma coisa aî'. Aí eu peguei um arquivo aleatório, não

${ }^{18}$ Utilizarei o termo "internet" para me referir ao qualquer acesso à rede de computadores, suprimindo a distinção com a BBS - Bulletin Board System - antecessora do que conhecemos hoje por internet. 
lembro nem o que era. (...) Eu nunca tinha visto, não sei mesmo o que era o conteúdo". Jorge se autoriza a descobrir, junto com o amigo, aquilo que até então era tido como uma "coisa errada", proibida, mas que aguçava sua curiosidade. A sede de conhecer foi maior do que a interdição auto-imposta.

Familiarizando-se com os recursos da internet, Jorge seleciona algumas fotos eróticas para descarregar no computador. Visto que o contato com o material era feito de maneira solitária e secreta, o flagrante do pai, quando Jorge descarregava material da internet o desconcerta: "Quando meu pai viu isso, eu sai dali correndo, que ele nem comentou nada, acho que ele ficou mais constrangido do que eu". A atitude de conhecer, de satisfazer a curiosidade, foi abalada, mas não eliminada, e Jorge continuou suas buscas na descoberta do novo. O material que mais o marcou naquele momento foi um vídeo curto que mostrava uma relação sexual na qual um homem estava sobre uma mulher: "era um vídeo muito ruim, pegava uma perspectiva horrível, mas dava para ver o que tava acontecendo".

O que chama a atenção nesse processo de descoberta do material da internet, junto ao "amigo precoce", é que Jorge opta por manter uma postura neutra, sem demonstrar nenhum tipo de emoção, preferindo comentar sobre aos detalhes técnicos do vídeo e não ao conteúdo em si: “'Então, tá bom, vamos ver', mas eu me fechei. Eu olhava e assim: Ah! Ele veio aqui, tá a fim... Olhou: 'Ah! Tá bom, acontece isso'... Mas não demonstrava interesse, eu estava determinado a não mostrar emoção. Eu via, concordava: 'Ah! Interessante! É...', comentava os aspectos técnicos do vídeo: qualidade ruim, quadriculado, tá muito pequena a imagem, mas, o que tá acontecendo lá acho que eu nem comentava. Ele comentava porque ele gostava disso... gostava... quer dizer, tinha mais contato com isso. Para mim era... era um tabu, por assim dizer. Olhei, ele fez os comentários, viu que eu não demonstrei muito interesse e apaguei. E ficou por isso mesmo. Passou e foi só isso". Visto a sexualidade ser envolvida por uma aura de tabu, a distância entre a razão e a emoção deveria ser mantida, no sentido de a primeira estar no controle da segunda.

O mundo virtual torna-se uma possibilidade de experimentar o novo, em que Jorge aos poucos vai se soltando e se deixando guiar pela necessidade do conhecer, voltando para as áreas eróticas da internet: "eu confesso que eu voltei na área, apesar de não demonstrar curiosidade no momento, eu achei que mais por curiosidade do que por interesse". O material acessado torna-se central nesse processo, seja com imagens e vídeos, sejam com textos 
descritivos de cenas, personagens com suas emoções na interação sexual. Esse contexto todo acaba ganhando contornos, mesmo que nebulosos, e sentidos para a elaboração de roteiros sexuais com referência de toques, de gestos, de reações, de possibilidades dentro de um cenário erótico. Isso fica evidente quando se refere ao conteúdo dos textos eróticos. Num cenário de poucas referências, os textos dão sentido àquilo que até então era um assunto nãoautorizado. Além disso, Jorge poderia continuar na sua descoberta silenciosa sem ser flagrado, pois: “...um texto aberto na tela era muito menos problemático se passasse alguém atrás do que uma imagem aberta".

Jorge encontra na internet explicação para aquilo que havia compreendido nos livos e achava estranho: era apenas um homem e uma mulher se casar, deitar juntos e, a partir desta sequiência, gerar filho. Jorge não sabia o que acontecia entre eles para a concepção de um filho: “O pai e a mãe, na cama, e no dia seguinte normal. Mas como eu via aqueles vídeos, aconteciam coisas diferentes. Eu não sabia como aconteciam coisas diferentes: como é que eles fazem, o que que eles fazem de diferente do quê?...”. Aquilo que estava ocultado passa a ser desvelado a partir da sua busca por novas respostas, guiado pela indagação: “o que mais?”.

Depois das fotos, dos vídeos, Jorge descobre os textos eróticos: “Tem descrições boas de texto puro, não são só imagem. E achei até mais interessante o texto do que... porque o texto contava a história inteira, tudo o que acontecia, e tinha... tinha também a parte das emoções, não era só imagens. Tinha o que eles estavam pensando, o que eles diziam, durante, antes... Eu achei aquilo fantástico! Eu achei muito melhor do que uma imagem". Por meio dos textos, Jorge incrementa seu roteiro sexual, agora, com referência de emoções daquelas cenas e situações relatadas nos textos. Novas referências surgem e aquilo que era misterioso, passa a ganhar contornos e sentidos.

Impulsionado pelas novas fontes de informação, a língua inglesa não lhe oferece obstáculo, sendo que Jorge encontra sentido nos textos procurando outras referências pela internet, a exemplo de imagens com legenda, ou mesmo de termos encontrados ao longo do texto, reforçando sentidos e significados para a sua leitura. Mesmo assim, a apreensão e o medo continuam presentes diante do sentimento de ameaça, mesmo que não anunciada, do pai: "aquilo que eu baixava da internet eu armazenava por uma semana, e apagava, ficava 
com medo". Conseguiu driblá-los por meio da criptografia ${ }^{19}$, condizente com seu movimento de permanecer oculto nas suas descobertas. A sexualidade ainda continuava sendo algo proibido, um tabu, e com significativa restrição de diálogo com outras pessoas, inclusive de idade próxima à sua.

A vontade de saber era atendida pelo material erótico, mas também intercalada com o sentimento de não precisar mais daquilo, apagando todo o material coletado, mas que, posteriormente, seria novamente coletado a partir do questionamento do motivo daquilo ser proibido: “...é proibido porque não sei porque é proibido. Então, olhar aquilo pra mim... né, quer dizer, é normal, não é nada de grandioso aquilo, perdeu aquele impacto...". Esse questionamento parece sugerir um confronto moral entre o "querer conhecer" e o "não poder", ou a "não autorização" internalizada a partir do modelo exemplar do pai. A partir desta reflexão ele se apropria da idéia de que o acesso àquele material é possível e autorizado, porém, é algo que continua fazendo sozinho, sem poder partilhar com mais ninguém.

As fotografias, os vídeos e os textos não permitiam a interatividade, o que era possível com os jogos de luta que, caso vencesse as etapas do jogo, era premiado com a visualização de uma cena erótica baseada em desenhos "hentai",20, seus prediletos. Foi nessa fase que o que mais temia aconteceu. A sua mãe o surpreendeu. Nesse momento, ele faz uma distinção entre erótico e pornográfico de forma peculiar, tendo como referencial o grau de explicitação. Deste modo, o erótico consiste em uma "insinuação", e o pornográfico o "mais explícito". De acordo com as referências de dicionário, temos que o erótico se trata daquilo que "provoca amor ou desejo sexual", ou que "aborda ou descreve o amor sexual”; já o pornográfico é tratado com um tom mais depreciativo: "característica do que fere o pudor (numa publicação, num filme etc.); obscenidade, indecência, licenciosidade" (Houaiss, 2001). Em outras palavras, o que distingue o erótico do pornográfico é o juízo de quem vê.

Ele surpreendeu-se positivamente com a reação da mãe ao flagrá-lo visualizando a imagem hentai erótica como seu "prêmio" por ter vencido o jogo: “Aí apareceu aquilo, tudo bem, bônus! (riso), aí ela [a mãe] entrou. Ela não falou nada. Deu uma risada, achou

\footnotetext{
${ }^{19}$ O termo "criptografia" foi originado pelas palavras gregas "Kryptós" e "gráphein", que significam "oculto" e "escrever", respectivamente. O procedimento de criptografar tem como objetivo codificar uma informação de algum arquivo, ou outro dado, evitando que terceiros consigam interpretá-la.

${ }^{20}$ Desenhos inspirados na arte erótica japonesa, que no ocidente são conhecidos pelo nome de "Manga" ou "Anime".
} 
interessante que existisse aquilo...", condizente com sua postura diante do tema da sexualidade "bastante aberta, até sem-vergonha". Seu grande temor de ser flagrado perdeu o sentido diante da atitude positiva e aberta da mãe, reforçando seu próprio senso de autorização e liberdade para expressar-se.

Jorge percebeu que sensações surgiam com esse material da internet. A masturbação já fora tema das conversas na escola, ou seja, era algo incorporado em seu roteiro sexual: " $E u$ ouvia, então, tudo bem, eles fazem, e não é comigo. (...) Talvez, uma daquelas fotos, ou textos, eu tenha lido e descoberto ali. Aí só me complementou a informação da escola". Nesse momento de descoberta das sensações, os roteiros prévios são fundamentais para direcionar a ação. Mas, houve um porém: “deu certa culpa quando eu comecei a ejacular". Jorge teve de rever novamente as referências internalizadas para se localizar diante daquela nova situação em que passou a ejacular.

\subsection{Jorge e os jogos on-line: "era uma outra vida, quase que completa ali no jogo, e com um personagem feminino"}

Jorge conhece e tem acesso ao "Nexus", um jogo do tipo $\mathrm{RPG}^{21}$, onde pôde criar uma personagem masculina em um cenário próximo àquele que apreciava nos desenhos japoneses. Depois de a personagem ter morrido no jogo, resolveu criar uma personagem feminina, seguindo seu gosto de optar por esse gênero em outros jogos, e jogou até a manhã seguinte. $\mathrm{O}$ Nexus passou a ocupar parte considerável de sua vida: "Tinha a escola, tinha a minha vida. Eu fazia a lição de casa e começava a jogar. E era outra vida, quase que completa ali no jogo, e com personagem feminino".

Cabe aqui uma reflexão acerca do que é virtual e do que é real. Para Jorge, aquela personagem e aquele mundo ganharam ares de realidade. Até então, seus relacionamentos no plano real eram restritos, ele optava pelo isolamento, pela escuta, ou pelo lugar do espectador; agora, passa a se relacionar com outras pessoas: "E eu fiz amigos, no jogo, e amigas, inclusive". Sua rede social amplia-se no plano virtual, mas sabe que pode receber sanções dos

\footnotetext{
${ }^{21}$ RPG - Role Playing Game, que significa "Jogo de interpretação de papéis" em que os jogadores interpretam
} diferentes personagens em diferentes mundos. 
outros jogadores caso descubram que é um homem se passando por mulher, assim como testemunhou fazerem com outro membro da comunidade que foi descoberto e isolado.

A possibilidade de ser descoberto faz com que retome seu roteiro de manter-se oculto: "Se me descobrirem danou-se, especialmente porque nesses jogos as relações interpessoais ficam muito fortes, não sei por quê. (...) Tinha garotos que se apaixonavam pela minha personagem. Eu cheguei a receber (...) cartões de 'Valentine's Day', Dia dos Namorados. Tinha propostas de virem para cá, para me conhecer. Não posso aceitar. Então, tinha todo esse... toda essa situação". Com a identidade feminina assumida no jogo, sua rede social parecia aumentar. Com essa personagem não só amigos e amigas eram feitos, mas pretendentes também surgiam. Com isso, ao longo dos 6 meses de jogo, Jorge passou a incorporar em seu roteiro a experiência afetivo-relacional com outras pessoas, assumindo-se como uma menina.

Na sua singularidade, Jorge apresenta uma série de personagens que foi construindo ao longo do tempo com a finalidade de sentir-se integrado nos mais diferentes contextos. Essas personagens auxiliaram-no a tecer seu modo-de-ser singular, constituindo-se enquanto pessoa, e não enquanto um desviante. Assim, o modo-de-ser de Jorge organiza-se a partir de sua experiência vivida, a partir do contato, seja com o mundo virtual, seja com o mundo real, de forma mais complexa, de modo que sua subjetividade foi sendo constituída. No tocante aos roteiros sexuais, Jorge dá um exemplo do quão significativo eles são para a vivência de novas experiências: “...como eu tinha lido muito aqueles textos anteriormente, eu sabia como eram as relações escritas, descritivas, então, a gente fazia isso no jogo, nunca um ato sexual, no jogo... seria discrepante, mas sempre tinha um beijo, carinho...". O material coletado na internet funcionou não só como uma satisfação para a curiosidade, mas também com forma de inventar e criar novas possibilidades de roteiros sexuais, na interação com outras pessoas.

A vivência com outras pessoas, no plano real - apesar de o virtual passar a ser realidade para Jorge -, acaba ficando restrita, e o virtual acaba sendo tomado com mais ênfase, com mais realismo, reconhecendo as limitações para o seu trânsito, deixando claro, mais tarde, de que ali vive uma personagem: “Ficou tão... tão profundo o jogo na minha vida que era a parte principal, vida real é secundária. Eu ia na escola porque precisava. Eu dormia porque precisava, também, senão eu jogava o dia inteiro". 
Quando, no jogo, conheceu uma garota americana, a Rachel, a sobreposição do virtual sobre o real incomodou-o: "Poxa, a vida tão boa e eu fico aqui mentindo, e não tá certo eu mentir para ela, e também eu gostaria que ela me conhecesse de verdade', porque vai que acontece alguma coisa, vai que ela vira a minha namorada, porque eu nunca tive uma namorada. E ela morava lá num lugar longínquo dos Estados Unidos. Isso durou um tempo, por um ano".

A fantasia vai perdendo força diante de uma possibilidade real de relacionamento. Ao saber que Rachel havia sido traída pelo antigo namorado, o que culminou no rompimento da relação, Jorge, na identidade de Larissa, conta um episódio em que terminou o relacionamento virtual com outro rapaz e que afogou suas mágoas com vinho branco. Jorge conta para Rachel sua real identidade e a identidade fictícia. A reação dela foi de solidariedade: “Tenha um pouco mais de fé em mim'... 'Confie mais em mim'... ela aceitou numa boa”. Estreitando laços de relacionamento com Rachel, Larissa cede espaço para a nova personagem: Jean-Luc, com características mais próximas à realidade de Jorge.

Rachel, por motivos que ele não relata, desapareceu. Assumindo a nova identidade masculina como Jean-Luc, ele precisa desenvolver novos roteiros, para continuar no universo virtual. Com o tempo, faz novos amigos e novos afetos, dentre eles uma inglesa: "Jean-Luc se encontrou com uma pessoa, com uma garota, começaram a namorar. Como eu já tinha visto tudo aquilo, tinha visto nos jogos... Então eles namoravam lá, mas não acontecia nada, nem tinha mais interesse nas descrições, nas ações, aliás, eu não conseguia fazer muito bem o papel masculino nas discussões e... eu sabia que a dona daquela personagem era uma inglesa de trinta e tantos anos. Mas, tudo bem". Mais tarde, quando falavam sobre a questão do gênero do jogador diferente do gênero da personagem, ele soube que estava se relacionando com uma transexual quando ela diz: "I am female, but I was not born female".

No contato com a transexualidade da jogadora inglesa, Jorge identifica-se e experimenta novos contornos para a sua própria identidade enquanto um possível transexual. Rachel já havia levantado a questão de que Jorge poderia ser transexual e, a partir de contato com outras fontes na internet, ele conclui: “É, talvez eu seja”. Ele seleciona aquilo que lhe é significativo, a partir da sua subjetividade, o que caracteriza um transexual: “...o que eu li é que o transexual é... nasce homem biologicamente, mas tem a mentalidade de mulher. Eu pensei: 'Bom, não vai dar certo isso. Então tá bom, que se dane, se eu sou isso não vai fazer 
diferença, se tentar consertar piora, deixa pra lá'. Isso passou, até que eu encontrei essa inglesa que me falou que ela era. Aí que clicou: 'Puxa! Se ela é, então é possível, funciona, dá pra consertar. Será que eu sou também?".

Uma possibilidade identitária se abre para Jorge. O que até então era uma invenção virtual acaba por dar contorno a uma realidade. Ainda no tocante à identificação com a transexualidade, Jorge aponta características ao relembrar de uma cena da infância, quando estava na escola: "Aí quando eu olhei para trás, e grandes partes dos... dos... das características batiam, de pessoas tímidas, que não gostam de mostrar o corpo, não têm muito contato... claro que em grande parte eu associo ainda com o meu pai, mas uma coisa que me marcou, foi na pré-escola, quando eu tinha 7 anos... menos até, 6. Teve uma gincana, e uma das provas era quem conseguia... que sala conseguia fazer o representante vestir mais camisetas. Então todos os meninos tiveram que tirar a camisa, e eu não queria tirar, não queria e não queria. Até que tirei, pelo bem da classe, vá lá... eu tirei, mas naquela época a gente tinha que levar toalha para quando a gente fosse escovar os dentes, depois do recreio, então era uma toalha para enxugar. Eu tirei a camisa e automaticamente eu me enrolei na toalha. Eu me recusava a ficar sem a camisa. Tanto que sempre que tinha jogo de futebol, com camisa e sem camisa, se eu caía no sem camisa, eu dava uma desculpa e ia embora. Jamais eu jogava sem camisa. Para mim era coisa impensada. Eu deixava até de ir no clube por causa disso. Tava calor, mas eu não ia porque não queria aparecer. Às vezes, eu até ia, mas, na praia, sabe aquele garoto com maiô e com camiseta por cima? Era eu. Mas não tem sol, não tinha sol, mas mesmo assim, eu estava de camiseta. Até hoje eu não gosto de mostrar meu согрo".

A tensão continua presente: "Depois que entrou no transexualismo, tempos atrás, que fiquei revoltado com a minha condição, eu passei a criar um estereótipo exagerado do que eu não queria ser, que era o homem do tipo: vai no bar, toma cerveja, traí a mulher... que vê futebol... Tudo isso era o que eu não queria ser". Em lugar de transexualidade caberia aqui um questionamento se o modo-de-ser de Jorge não seria uma possibilidade a mais em serhomem. Outra possibilidade é uma identidade totalmente contrária ao modelo internalizado do pai, o qual foi fonte de ao menos duas decepções enquanto homem.

A partir da familiaridade no plano do virtual, nos jogos, na escrita e leitura de textos, desenvolveu um gosto pela editoração e resolveu ingressar em curso universitário na área, 
indicando que as marcas da experiência contribuíram para a elaboração de novos roteiros, a exemplo do profissional.

\subsection{Jorge na faculdade: “...pronto, eu sou uma garota”"}

Na faculdade, Jorge conhece Ângela, colega de sala, por quem se apaixona e passa a namorar. Jorge define o namoro como: “...desde o começo muito complicado, pois desde o início ela se dizia bissexual". Antes do namoro, Jorge partilhou com ela sua questão identitária, da possibilidade da transexualidade. Ele rompe com o paradigma do isolamento e da vida virtual paralela, para relacionar-se com alguém do plano real.

Ele faz questão de manter algumas características diferenciadas que ele próprio associa com a transexualidade, a exemplo de usar sempre camisa, por achar feia a maneira como os meninos se vestem normalmente, com o intuito de ser elegante, usar unhas compridas, assim como cabelos compridos.

Ângela interessa-se pelo tema, pesquisa muito e juntos concluem que Jorge é transexual. Com isso, Ângela passa a tratá-lo pelo gênero feminino: "Eu tinha vasta experiência de viver como uma garota. Então, bom... então, ela disse que por muito tempo... até hoje, ela me vê como uma garota. A gente tá conversando e ela se refere a mim no feminino... muitas vezes. E com o tempo eu aceitei, tudo bem... pronto, eu sou uma garota. Aqui na faculdade eu resolvo isso, sei lá... faço um tratamento depois". Até aqui não fica claro a qual "tratamento" se refere.

\subsection{Jorge e a busca de ajuda: a procura do $S A P^{22}$}

A questão da transexualidade, ou das pessoas que não conferem com um modelo hegemônico de vivência com o gênero do próprio corpo, apresentam diferentes queixas com relação à busca de ajuda: "Como é uma coisa que eu não falo com ninguém, não tenho com quem falar, porque só para explicar vai virar algo muito grande, vai ocupar muito tempo: 'O que que

\footnotetext{
${ }^{22}$ SAP - Serviço de Aconselhamento Psicológico - do Instituto de Psicologia da USP.
} 
é'..., 'Por que que é'... 'Como funciona', e 'Como que resolve'... Então eu nem falo, não vale a pena".

A sexualidade "normal", entendida aqui como heterossexual e monogâmica, já se mostra como um território complexo e delicado repleto de tabus e de mitos. Isso se intensifica quando se fala de diferença, que nem por isso se trata de "anormalidade". O preparo profissional deficitário no acolhimento de diferenças no que tange a sexualidade acaba sendo freqüente, até mesmo pela deficiência no conhecer a sexualidade, seja a própria, seja a sexualidade nas suas mais diferentes possibilidades. Jorge fornece um exemplo dessa complexidade no trecho a seguir, quando se refere à reação das pessoas frente ao seu modode-ser: “'Então você é gay?'. Não. 'Então você é uma menina?'. Não. 'Então o que você é? Você gosta de mulher?'. 'Sim, eu tenho uma namorada, gosto'. 'Então você é homem?'. Não sei, talvez eu seja mulher, talvez eu seja lésbica". Nesse contexto, somos convidados a abordar a questão da pluralidade de conceituações que, por um lado servem para a construção e manutenção identitárias e, por outro lado, para a criação de concepções das mais diversas, e até equivocadas, sobre a complexidade da sexualidade. Estas construções influenciam a constituição de subjetividades nos mais diferentes contextos culturalmente localizados e historicamente datados.

Jorge procurou a ajuda do SAP, incentivado por Ângela, em um momento de dúvida, por se sentir em alguns momentos Larissa aprisionada em um "corpo idiota" querendo mudar, e em outros momentos achando: "Que bobagem, a coisa funciona assim, não vamos tentar mudar que piora". A busca pela dialogia na compreensão do que acontece consigo acaba malograda: "O atendimento não deu em nada, porque acho que o assunto surpreendeu o psicólogo. Ele não esperava. Eu não esperava que alguém soubesse o que fazer". Jorge ressalta achar natural a surpresa do estagiário, ainda mais pelos contatos mantidos: "Eu tenho contato com outras transexuais, e todas elas falam que vão nos médicos, psicólogos, psiquiatras, endocrinologistas, qualquer coisa, e eles não sabem o que está acontecendo. Os médicos não sabem".

No tocante ao atendimento no plantão, o estagiário expressou sua surpresa e afirmou que pesquisaria sobre o tema. Mas, por motivos de "contratempos", quando um podia, o outro não, uma nova sessão acabou não sendo marcada e, de acordo com Jorge, não houve um 
fechamento do atendimento: "Não teve desenrolar, eu fiquei na dúvida". Optou por deixar a situação dessa mesma forma, em vez de procurar ser atendido por outro estagiário do serviço.

\subsection{Jorge se localiza: a assunção das dúvidas e do modo-de-ser singular}

A identidade assumida no momento do depoimento é ambígua, de forma que Jorge adota nem o gênero feminino nem o gênero masculino, a exemplo da substituição do "obrigado" por "grazie" e "thank you", a fim de não utilizar nenhum termo que implicasse na associação com o gênero, mantendo assim encoberta a possibilidade da identidade feminina: "Hoje, eu não me identifico, eu não conclui nada, tanto que eu uso meus cabelos compridos. E me perguntam: "Por que você tem as unhas compridas?", e eu falo que é tradição russa. No livro "Ana Karênina”, tinha uma passagem de um funcionário público que se encontrava com um caipirão... Um caipirão que encontra um funcionário público, e fala claramente que ele fica espantado com as unhas compridas do funcionário público e aí ele explicava que tinha isso para mostrar que fazia trabalho intelectual e não braçal. Porque não quebrava as unhas, não atrapalhava o trabalho dele. Que era um símbolo da profissão dele”. A cobrança pela assunção de um gênero de certa forma lhe é presente, mas Jorge mantém-se firme na androginia, apesar de não se identificar com essa classificação.

Jorge mostra que, apesar de ter mais delimitada para si sua forma de ser singular, o meio social ainda oferece resistência em reconhecê-lo como tal: "Eu me sinto cobrado, sem dúvida. Meus pais e alguns amigos me falam: 'Corta esse cabelo, corta essas unhas, vista-se como um homem'. Ah!... Sempre falaram isso. Desde bem antes de eu fazer qualquer coisa eles já falavam isso: 'Falem o que quiser, eu não tô ligando'. O cabelo comprido eu tenho há menos tempo, mas a unha, sim, eu sempre tive unha comprida. O cabelo foi bem depois, no colegial, a partir dos 18 anos, sei lá...”.

Quando aborda o território dos rótulos e definições - transexual, andrógino, homossexual... - acaba se confundindo e perdendo a linha do raciocínio. Talvez esse território não seja mais importante para o seu modo-de-ser e para o seu bem-estar: "Tem hora que bate uma coisa do tipo: 'Puxa... bem que eu poderia ser uma garota de verdade, bonitinha...'. Eu ando... se eu saio andando pela rua, eu me sinto mal, por estar na rua. Eu acho que eu estou 
andando torto, estou deselegante, que estou deselegante... que as pessoas estão reparando. Não gosto de me expor. Acho que talvez a coisa ficaria mais fácil, não mais fácil, mas seria mais confortável para mim".

Para ele, o que importa é aquilo com o que se encaixa, ou seja, é ser tratado como uma garota por sua namorada bissexual, fazer sexo, incluindo a penetração e o orgasmo. Sua relação com Ângela é uma forma possível, em que ambos sentem-se livres nas suas singularidades.

A lembrança de Larissa é trazida para a atualidade enquanto uma experiência vivida: “Apesar de ser virtual, para mim era tão real, o jogo, a Larissa, que... prá mim era como se fosse...". A apropriação dessa experiência abriu possibilidades de novas vivências para Jorge, ou da criação e invenção de novos roteiros. Jorge afirma sentir-se bem e satisfeito com as experiências: “...eu estou sossegado, como eu estou, porque eu já conheço, já vi, não faz tanta falta para mim, agora, não tenho desespero, assim...". Mas existe a auto-cobrança por uma assunção de um papel feminino, seja no seu jeito de andar, seja na sua aparência, seja na sua elegância. A auto-cobrança advém da sensação de que as pessoas reparam nele, e sua aparência é importante, mesmo que afirme não gostar de se expor.

\subsection{Jorge e a concepção de masculino e de feminino}

Ao longo do depoimento, Jorge traz algumas definições daquilo que foi aprendendo na sua trajetória sobre o papel de gênero, ou aquilo que seria típico de homem e o que seria típico de mulher, mas, além do pai e da mãe, não traz outras referências de gênero relacionadas a outras pessoas.

O gênero masculino durante muito tempo foi associado à função biológica, no encontro do genital masculino com o genital feminino. Essa concepção é ressignificada a partir do momento que descobre que a transexualidade subverte esse paradigma, pois a questão da identidade pode transcender a genitália, sendo que o significado e o sentido do modo-de-ser - ou dos modos-de-ser - homem ou mulher, ou indo além, em apenas "ser", como o próprio Jorge mostra em sua fala: "Hoje eu tenho isso claro para mim. Eu não tenho 
uma distinção certa. Não posso dizer que um homem tem isso ou aquilo. Eu tenho que um homem é um homem. Se a pessoa se diz homem, se sente homem, então é, e vice-versa".

A representação que Jorge tem de homem é daquela pessoa que: “...vai no bar, toma cerveja, trai a mulher, vê futebol, (...) aquilo que provavelmente me é cobrado, (...) aquele que trabalha, que ganha seu próprio dinheiro, que vai, que tenta ser independente... Não consigo formular... É aquele que tenta ser mais independente, que tenta ser mais dominante, e... tem uns hábitos mais definidos... não tão caricato como eu dizia antes... (...) Pelo o que eu vejo, a sociedade, entre aspas isso, espera mais que um indivíduo seja mais um macho do que um homem. (...) Para que os homens continuassem sempre a se manter: 'Eu sou garanhão, eu jogo bola". O modelo de pessoa pública que destaca para o padrão de masculinidade seria o ator Tarcísio Meira pela sua "cara quadrada, jeito de paizão, patriarca, é uma visão arcaica atê".

A representação do feminino é daquela pessoa: "bonitinha, não andar torto, ser elegante. (...) o futebol não é muito importante (...). Tem a opção de ser ativa, independente, mas também não ser cobrada, não ser colocada para fora por ser dependente, que é a opção de feminino. Não ter que manter a pose de dominante o tempo todo, como podem achar. É manter a sua própria coisa de status feminino. Tem que manter a sua própria pose (...), se definir como: 'Eu me visto bem, eu sou bonita, eu sou magra'. As mulheres seriam mais esse, não tem que ser como ativa, mas tem que ser elegante, bonita, se preocupar com ela mesma, em vez de tentar controlar o resto. Ela tem que ser boa. Boa em manter o padrão, o status dela, é... se manter, quer dizer... pode ser até dependente, mas tem que ser... (...) Tem que se manter apresentável, por assim dizer, na falta de uma palavra melhor. Tá muito superficial pelo jeito, né?!... Talvez seja esse o problema, eu confundo a sociedade com a minha opinião". O modelo destacado para mulher seria sua mãe, pela sua preocupação com a casa e com as pessoas próximas; além da atriz Nicole Kidman, pela beleza e da jornalista Ana Paula Padrão, por achá-la bonita e "parecer auto-suficiente, independente, bem ativa, mas ela tem ainda um quê de mulher". A antítese de mulher seria Miriam Leitão, por "não parecer mulher, mas uma economista falando".

O modelo de masculino e de feminino internalizado por Jorge é próximo daquele promovido por uma cultura machista e patriarcal no contraste do homem "ativo" e a mulher "passiva", na qual o homem deve dominar e a mulher ser dominada. Apesar de reconhecer em 
si a ineficácia dos rótulos e padrões, nos modelos de homem e mulher, destaca as características fechadas no gênero, a exemplo de Miriam Leitão, por considerá-la uma mulher apenas por ser, mas não reconhece que aquele modo-de-ser é mais uma possibilidade de ser feminino.

No tocante ao que contribuiria para que as pessoas vivessem sua sexualidade da forma mais plena possível, ele destaca: "que as próprias pessoas deviam deixar de se ver como o macho e a fêmea". Jorge mostra que tudo seria mais tranqüilo se a sexualidade não fosse tabu; a partir de um olhar para a sua trajetória, sugere que não falar em sexualidade e falar em excesso são coisas ruins. A questão que emerge é a falta de um espaço de escuta e de acolhimento em que pudesse compartilhar suas angústias ou mesmo suas descobertas, favorecendo um desenvolvimento como uma gama maior de possibilidades que não ficassem circunscritas ao plano do virtual.

A hipocrisia do não falar e do excesso de pudor também é referenciada por Jorge, e dos males que isso pode acarretar: "É meio hipócrita, pra que ficar escondendo tanto? Depois fica esse monte de gente vindo aos psicólogos discutir a sua sexualidade. Se fosse mais natural...”. A hipocrisia está associada àquilo que é dúbio, aquilo que é dissimulado dos sentimentos e intenções (Houaiss, 2001). O discurso não necessariamente confere com uma realidade. Um exemplo bem interessante é dado quando associa falar de sexo a falar de dirigir um carro: “...quando eu tinha 5 ou 6 anos eu queria dirigir o carro do meu pai, e ele me explicou, o carro dirige assim, o pai dirige assim, mas você é pequeno. Eu sei que é um exemplo bem forçado, mas sabia o que era o carro, como funcionava, por que era perigoso, como dirigir, não que eu soubesse dirigir, mas eu sabia tudo, as marchas, o que faziam... Mas sexo, não".

Jorge continua o depoimento apontando para uma realidade comum a muitas pessoas: “Até os 18 [o sexo] não existe, eu não posso nem olhar. Você fala assim: 'É assim, acontece assim, na hora que você vai querer fazer, que você estiver pronto, aí vem a pior parte, agüenta as pontas aí, mas com o tempo você faz, mas já que você insiste é assim, é perigoso assim, acontece isso'. Tinha que fazer parte. E um outro ponto é os pais deixarem de educar os filhos como macho e fêmea". Assim, o sexo é visto com algo naturalizado a partir de uma essência anterior, que vem de dentro e que, na hora certa, ele extravasará e tudo passará a 
funcionar. A partir desta "essência", em diversos momento de seu depoimento, Jorge remetese à questão do preconceito e do respeito às diferenças.

No final do depoimento ele faz referência a uma manifestação preconceituosa com relação às travestis e faz uma associação com a necessidade de a educação ser focada na formação de homens e mulheres, afastando-se do modelo "grotesco", próximo aos machos, e valorizando o modelo: "seja um homem, dê respeito, tenha respeito, respeite o próximo, o cara ali do lado, e não vai lá bater porque ele é diferente, porque está com uma roupa que você não gostou. Aceita e vai embora”. E finaliza lembrando que: “...não somos mais macacos, não estamos mais nas árvores, não tem mais que agir como um animal. Tem mais de 10 mil anos de civilização, é o suficiente para resolver alguns problemas. Deixa o mundo correr, não tem que tentar parar. É isso".

Significados e sentidos mudam ao longo da trajetória de uma pessoa, se atualizando a partir da experiência vivida em um contexto mais amplo, no relacionamento com outras pessoas e grupos (Gagnon, 2006). Na infância, o significado de Jorge para o sexo era o silêncio, sendo que, depois a partir do contato com o "amigo precoce", o falar de sexo é possível, porém, o que antes era dado como "falta de curiosidade", passou a ser dado como "medo".

Ao longo do depoimento de Jorge vislumbramos sua necessidade de espaços para expressar-se e compartilhar suas dúvidas e curiosidades, inclusive sexuais, apesar de ele ter optado pelo isolamento e pelo silêncio. A internet mostrou-se um espaço privilegiado para relacionamento com outras pessoas, sendo uma possibilidade a mais, mas que não substitui os o relacionamento com outras pessoas no plano do real, pois se tornaria algo limitante e limitado.

A singularidade do modo-de-ser de Jorge e sua vasta experiência diante do computador não impediram que estabelecesse relacionamento afetivo e sexual que atendesse às suas necessidades e interesses. Um ponto interessante é do quanto sua compreensão de identidade é mais forte do que a sua prática, ou seja, ele se vê, com certa dúvida, enquanto transexual, mas a prática sexual é com penetração e com orgasmo. Jorge não apresenta elementos que clarifiquem a forma de como pretende se "tratar" assim que concluir seu curso na faculdade. Um dos caminhos buscados pelos transexuais é a cirurgia de transgenitalização, 
que objetiva adequar a genitália à identidade sexual da pessoa. O acompanhamento psicológico, nesse caso, se torna fundamental para auxiliá-lo a elucidar dúvidas e compreender significados do "tratamento", a fim de que faça a escolha mais condizentes com seus objetivos.

Outro tema apresentado por Jorge é sobre o preconceito voltado para as sexualidades chamadas de "periféricas", ou seja, aquelas que não correspondem a uma hegemonia heterossexual, monogâmica, que tem o sexo como finalidade reprodutiva, a exemplo da transexualidade e do travestilidade ${ }^{23}$. Uma dificuldade na compreensão dessa possibilidade talvez seja decorrente de polifonia de definições de conceito. A transexualidade está relacionada com o estar em um corpo de um sexo, com a consciência de ser de outro sexo. $\mathrm{Na}$ travestilidade, a pessoa tem consciência do seu sexo corporal, mas, em dadas situações, pode assumir uma identidade do outro sexo (Costa, 1994).

A proposta do método dos relatos orais é justamente focar a experiência, os sentidos e os significados que a pessoa constrói ao longo da sua trajetória de vida. Motivo esse que chamo a atenção para não lançarmos um olhar nosológico seja para Jorge, seja para qualquer outra pessoa, como se ele este fosse um mero objeto de estudo, mas privilegiar um olhar para a pessoa de Jorge na sua singularidade e reconhecendo a sua forma de ser como uma alternativa válida e possível, privilegiando a fala de Jorge que, apesar da cobrança social: “...eu estou sossegado, como eu estou, porque eu já conheço, já vi, não faz tanta falta para mim, agora, não tenho desespero, assim...".

\footnotetext{
${ }^{23}$ Opto pelo uso do travestilidade considerando que o sufixo "-dade” significa "forma de expressão:”; sendo que no conceito travestismo", o sufixo "-ismo" pode ter uma conotação de doença ou desvio.
} 


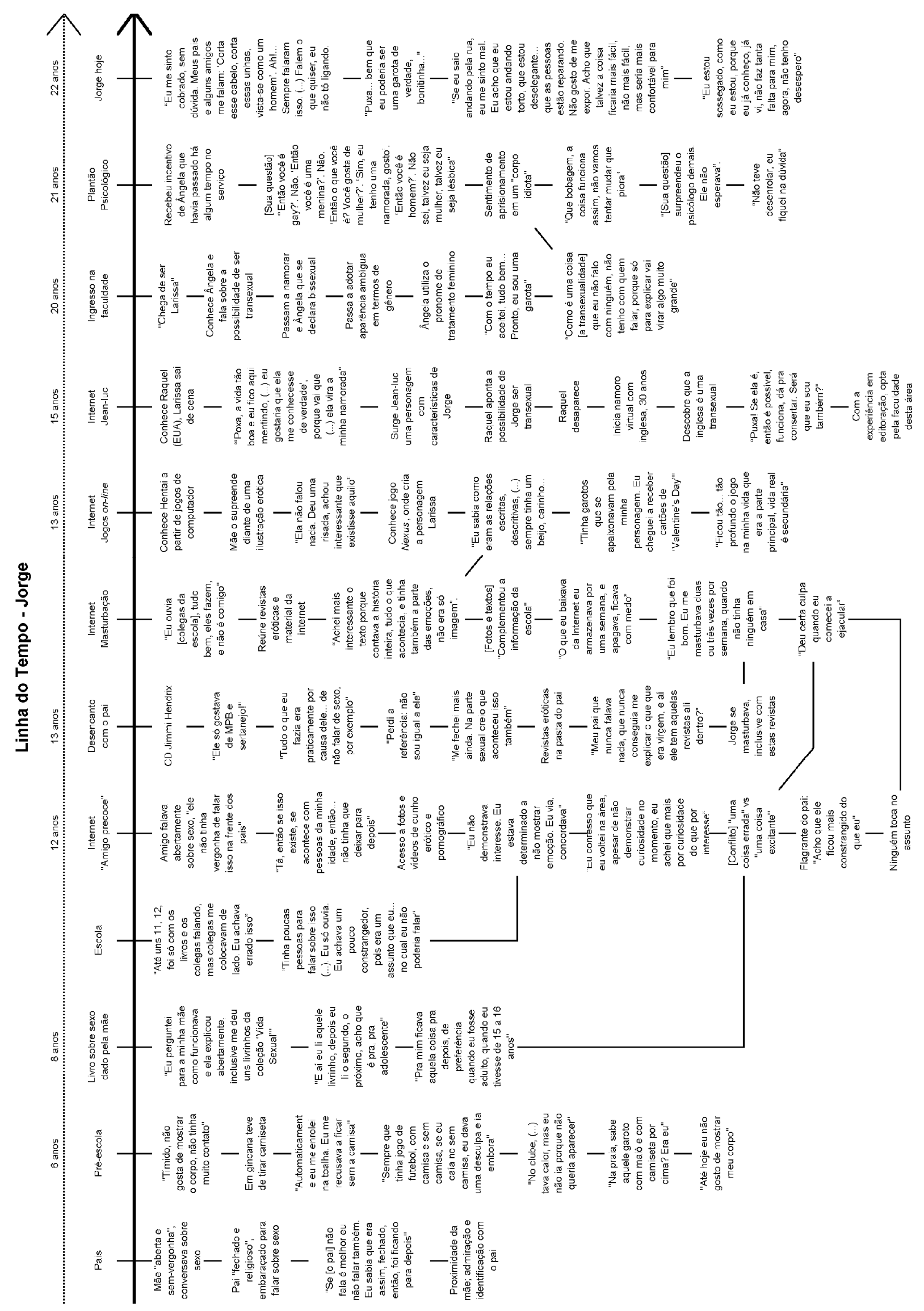

Figura 1 - Linha do tempo da trajetória de Jorge 


\section{2. "Hoje eu me considero homossexual passivo": o depoimento de Thiago ${ }^{24}$}

Thiago tem 23 anos, nasceu em São Paulo e atualmente mora com a mãe de 62 anos. Os pais são separados. Thiago concluiu recentemente o ensino superior.

Thiago iniciou o seu depoimento preferindo fazer o que chamou de "o contrário" da pergunta disparadora, optando por falar sobre como se percebe hoje, voltando então para o passado, até chegar à infância.

Visto que ao longo do depoimento as idas e vindas em episódios foram freqüentes, a fim de facilitar a compreensão dos momentos significativos da sua vivência, optei por organizar o material em ordem cronológica, partindo da percepção da sua sexualidade na infância.

O depoimento de Thiago tem como base a linha narrativa o ato de ter assumido publicamente sua sexualidade, perpassando todo o processo de constituição da sua identidade, que denominou de "homossexual passiva", apontando pessoas e lugares de referência neste processo.

A assunção da sua homossexualidade é um fato recente. Além de outros lugares que funcionaram como referência e apoio, Thiago mostra que a Parada do Orgulho Gay influenciou positivamente para que se identificasse enquanto homossexual num contexto em que a familiaridade e a identificação com semelhantes foram marcantes: “...a gente tem o dia da Parada, que eu fui lá, e a primeira vez que eu fui, sai assim, publicamente, e eu gostei muito de estar lá, tanto por que eu gosto da música, como pelo fato de me sentir bem ali. E eu tive uma visão de que eu estava meio que tipo numa família, meio que entre irmãos, uma coisa divertida, não muito consciente, mas tranqüila assim. E nesse dia, na Parada desse ano, eu resolvi assumir".

A partir do foco no desejo sexual como determinante da sua identidade sexual, logo no início do depoimento, Thiago apresenta a tensão entre o tênue desejo por mulheres e o intenso

\footnotetext{
${ }^{24}$ A duração do depoimento foi de 1:25h. Na ocasião da validação do texto, Thiago optou por suprimir diversos trechos e complementar outros.
} 
desejo por outros homens: “...hoje eu me considero um homossexual passivo, se bem que eu tenho um pouco de atração, se bem que bem fraco, por isso que eu nem considero por mulheres, e também por vontade de ser ativo, mas... como é usual por homens, que é bem mais forte, é que eu me considero sendo isso". Este cenário, em consonância com o contato e a interação com outras pessoas e espaços, favoreceu para os novos contornos da identidade de Thiago.

Depois de assumir sua homossexualidade na Parada, Thiago utilizou dois serviços da internet para encontrar amizades e relacionamentos: os grupos de discussão ${ }^{25}$ e o Orkut $^{26}$. A internet acentuou o sentimento de pertença e de familiaridade, mostrando ser um meio importante para a reunião de diversos segmentos que tenha semelhantes gostos, atitudes e comportamentos, fortalecendo a idéia de "sociedade em rede" proposta por Castells (1999), que será mais discutida em capítulo posterior.

No Orkut, Thiago passou a assumir a sua orientação do desejo sexual para quem o indagasse sobre isto. Até aquele momento, em seu círculo social mais restrito, com exceção dos pais, apenas a namorada ${ }^{27}$ e os amigos sabiam da sua homossexualidade. No e-groups ${ }^{28}$, passa a ter contato em busca de novas amizades, pois, até então, somente as tinha com pessoas que considerava heterossexuais, tornando restrito os temas de conversa. No e-groups, além de ter conhecido "pessoas com uma cabeça diferente", começou a namorar um rapaz de 19 anos, com quem se relacionava até o momento da entrevista.

\section{1. "Os outros garotos tinham um jeito mais... de garoto, (...) eu tinha uma delicadeza maior": Thiago na infância e o começo do enfrentamento do preconceito}

Thiago é filho único. Seus pais se separaram quando ele tinha 2 anos de idade. Ele não se aprofunda nas suas percepções sobre este fato, limitando-se a afirmar que "eles não se

\footnotetext{
${ }^{25}$ Serviço na Internet que permite troca de informações entre várias pessoas por meio de mensagens eletrônicas (e-mails), que estejam inscritas em grupos de interesse.

${ }^{26}$ Orkut é um site de relacionamento na Internet, criado por Orkut Buyukkokten, analista de sistemas turco, que trabalha na empresa Google, que está no ar desde janeiro de 2004.

${ }^{27}$ Mais adiante em seu discurso, Thiago fala sobre a participação de sua namorada neste processo de descoberta.

${ }^{28} \mathrm{O}$ e-group é um serviço da internet que consiste na troca de mensagens (e-mail's) entre os inscritos nas comunidades de interesse. Estas comunidades são criadas a partir dos mais diferentes temas e objetivos.
} 
relacionavam muito bem". O pai vive em outra casa, com sua atual esposa. Ele não teve outros filhos.

Após a separação, Thiago ficou com a mãe, a quem define como "superprotetora". O fato de ser filho único e de ter uma mãe super protetora contribuiu para que na escola ele fosse visto como "cuidado-que-a-mamãe-é-superprotetora", ainda mais por características físicas: "Eu tinha algumas coisas que os outros garotos não tinham: alguns cuidados a mais que acho que eram mais característicos de mulheres, de garotas, de meninas até... e talvez por isso que eles foram percebendo, essa voz fininha associada com essa delicadeza, por alguém que foi cuidado por uma mulher e que só vê o pai no final de semana, talvez daí pensavam isso e faziam essa zoeira no colégio. Os outros garotos tinham um jeito mais... de garoto, sabe, de menino, e acho um pouco que eu não tinha, pelo o que eu me lembre, eu tinha uma delicadeza maior".

Neste trecho do depoimento de Thiago fica evidenciada a rigidez que atribui aos papéis de gênero, sendo que as suas características pessoais - delicadeza, não violência -, corresponderiam ao ideal de papel feminino. Desta forma, a contraposição do papel masculino seria aquela associada à rudeza, violência e forte ligação com uma figura masculina, no caso, o pai.

Outro tema importante no que se refere à infância é com relação ao preconceito, no caso, a "zoeira" da qual era alvo pelo fato de não corresponder aos códigos de conduta masculino daquele universo.

Outro fato que se destaca é com relação à mãe superprotetora. Além de ser filho único, Thiago percebia a mãe como "superprotetora", o que pode indicar uma maneira de ela, mediante a diferença percebida, proteger o filho do preconceito, da discriminação ou de outras ameaças externas.

Thiago tem como marco para do início da sua vida sexual brincadeiras eróticas na infância: "Eu comecei a minha vida sexual aos 7 anos, com um amiguinho meu que tinha 6 anos. Ele me chamava para ir lá debaixo do sofá, fazer algumas coisas, no primeiro dia eu não queria, mas depois eu vi que era legal e fui. (...) Nisso foi evoluindo até que nós estávamos fazendo sexo nessa idade. Isso aconteceu na minha casa. Só que depois as nossas 
mães souberam, e com o passar do tempo, né, e depois outras pessoas também souberam e no meu bairro passei a ser chamado de 'gay', 'viado', 'sai daqui'... Então meus pais... Aí depois eu continuei os jogos eróticos com uma garota, quando eu era pequeno também, era brincadeira de médico, só que ela não queria tocar em mim e daí eu respeitei isso dela. Mas foi uma coisa rápida".

Ao longo do depoimento Thiago mostra uma outra visão daquilo que chamou de “início da vida sexual”: “...era como se a gente tivesse fazendo uma coisa que não era certa, era uma coisa errada. Não sei, mas acho que desde o começo tinha uma conotação de coisa errada, porque a gente fazia escondido, talvez pelo caráter sexual. Não sei, acho que... era gostoso, mas eu estava fazendo uma coisa da idade, mas também era uma coisa sexual, pois tinha a idéia do que eram os órgãos sexuais, não com a mesma visão que a gente tem hoje. (...) Tinha, sim, noção do caráter sexual, (...) mas não numa visão que o pessoal adulto teria”. $\mathrm{O}$ fato de a brincadeira acontecer de forma velada, escondida, mostra que eles tinham noção de aquilo de algum modo não seria aceito pelos pais. Por outro lado, conforme Thiago destaca, "era gostoso" e a visão do contato com outra pessoa, no caso o amigo, não tinha o mesmo significado do mundo adulto. A experiência era mais em um sentido de experimentação de sensações do que de um comportamento sexual desenvolvido, porém, o prazer sentido ficou registrado como algo errado ou indesejado para o universo adulto.

A discriminação, por ser considerado diferente dos outros garotos, acontecia não só na escola, como também na vizinhança da sua casa, pois a notícia de que praticava brincadeiras de caráter erótico com outro menino espalhou-se. Vale lembrar que Thiago tinha 7 anos e, de certo modo, o entorno já o determinava enquanto homossexual por "praticar sexo" com outro garoto.

No tocante à sexualidade infantil, é comum que os adultos percebam os comportamentos das crianças, a partir dos significados e dos sentidos daquilo que compreendem como sexualidade, em vez de reconhecer como forma de socialização e de experiência sensorial da criança (Gagnon, 2006; Nunes e Silva, 2006). O contato na forma de brincadeiras eróticas que Thiago teve com outro garoto, por se tratar de um tema que ainda gera discussões, a reação negativa é ainda mais presente. Isto é tão intenso que a mesma experiência que ele teve com outra garota não fica evidenciada, como será visto adiante. 
Thiago relata o quanto sofreu devido a esse tratamento hostil: "Desde o início, quando eu estava na $3^{a}$ série, eu enfrentava aquilo sozinho, é por isso que eu acho que tinha a depressão e isoladamente eu pensava em me matar. É porque é difícil por causa da idade. Além do mais, as pessoas não têm uma visão que o psicólogo tem de compreender a pessoa, de saber o que está acontecendo com a pessoa. Geralmente é uma coisa da mãe e do pai: 'Ah, isso é uma brincadeira de criança, e quando crescer um pouquinho, acho que isso vai resolver'... Os garotos caçoavam de mim, então eu vou lá falar com o orientador, 'eu tô sendo fraco', porque para ser homem eu vou ter que enfrentar eles, entendeu? Não contava nem com aquele amigo de infância que mudou [de residência] e a gente não teve mais o contato. Até hoje a gente não tem mais contato. Acho que ele ficou lá depois que as mães descobriram, a gente parou, e depois a gente ficou lá por uns dois anos e nunca mais a gente se falou. Eu nem sei como ele está hoje". Era esperada de Thiago uma atitude de tolerância à hostilidade sofrida, sendo que não podia contar com mais ninguém e, além disso, o fato de buscar ajuda seria compreendido como um sinal de fraqueza. O isolamento e a angústia se fizeram presentes num contexto de desamparo e incompreensão, em que o suicídio parecia ser uma saída. Bozon (2004) aponta a fragilidade da rede de pares de jovens homossexuais, dada a predominância de um ambiente predominantemente heterossexual, sendo que freqüentemente a depressão e o isolamento são experimentados por estes jovens.

Thiago continua o depoimento sobre o preconceito e o sofrimento emocional: “...muitas pessoas zoavam muito comigo. Então, qualquer brincadeira, eu via como uma coisa que queriam me ofender, por maldade, e eu acabei não aceitando as pessoas. Eu evitava que eu era, mas, mais do que isso, mais do que chamarem de gay, é a reação que as pessoas têm de você. Os meus amigos me chamam de gay e não tem problema nenhum. $O$ problema é a rejeição e a humilhação que você passa, por eles chamarem você disso em público, em uma fase que você precisa de amigos, mas você não tem jeito, você não consegue se relacionar muito bem, você é diferente dos outros".

Thiago aponta para dois contextos em que o termo gay tem conotações diferentes, sendo que num, gay torna-se ofensivo e, em outro contexto - agora atual -, em que os amigos identificam-no enquanto homossexual, porém, Thiago não percebe a associação com o preconceito e a discriminação, sendo algo positivo. Contudo, Thiago ressalta as marcas deixadas pelas ofensas na infância: "Faziam várias dessas brincadeiras que humilhavam e deixou marcas profundas no meu psicológico, infelizmente a depressão, e eu cheguei até 
pensar em suicídios. Pensava seriamente em suicídio. Mas na época eu era muito pequeno. Eu achava todo o tipo de relacionamento difícil. Não dava muito para eu me relacionar muito bem com as pessoas".

Thiago relata que sentia-se impedido de relacionar-se com o mundo hegemonicamente heterossexual, ficando no isolamento, fechado em seu próprio mundo, onde sentia-se integrado: "Devido a esses preconceitos que eu passei eu tenho um parâmetro para mim. Eu tinha uns animais de pelúcia, e eu assistia muito aos desenhos da TV Cultura, e passei a gostar daquele mundo, daqueles desenhos. Para mim aqueles animaizinhos, que eu tinha bichos, eles tinham vida, e eles eram os meus amigos, as almofadas que eu tinha no quarto eram as montanhas que eu tinha criado para o meu mundo. Eu era feliz naquele mundo. E isso me influencia muito no que eu sou hoje. Porque eu vejo, hoje, o mundo muito diferente daquele mundo de fantasia que eu tinha criado, porque lá tinha mais amor e amizade do que na realidade".

\section{2. "Em vez de ficar no meu quarto, sozinho, eu resolvi me converter": a experiência reliosa de Thiago}

Até a $7^{\mathrm{a}}$ série, foi ficando mais perceptível sua diferença com relação aos colegas: “...eu olhava, assim, eu olhava um colega, e eu desejava o cara, mas não disfarçava tanto, mas com cuidado, assim. Mas depois com a igreja, que eu comecei a freqüentar a igreja, foi uma coisa que: 'Olha, se você deseja homem, não entra no reino de Deus'. Tudo o que me tornava homem, eu acreditava, chegava ao desespero, seja o jeito de falar, qualquer coisa era pecado. Não dava para perceber quem eu era, porque eu me repreendia. Quando eu via que começava, quando eu adorava um menino, mas não olhava muito, não mexia. (...). Foi tanto que o meu foco era Deus".

O contato de Thiago com a espiritualidade, ou religiosidade, se deu no contato dele com a empregada do pai, que virou sua amiga: "Ela era do candomblé e achei superinteressante aquilo. Eu estava pensando em ir também. Eu não cheguei a ir, ela começou a se tornar evangélica, e aí ela foi me levando junto, porque ela me explicou porque que ela estava saindo. Eu perguntei: 'Você vai em igreja?'. 'Vou'. 'Então qual é?'... Meu pai não 
influenciou em nada, para ele, tudo bem. Eu acabei falando muito da minha mãe (riso)... o meu pai é católico não praticante".

Thiago encontrou amparo para lidar com a situação ao freqüentar uma religião, momento em que também namorou uma garota. De acordo com ele, isso fez com que se sentisse mais forte e integrado, aliviando o sofrimento: "Por eu me sentir amado pela garota, eu me tornei mais forte. Na igreja eu tinha aquela obrigação de ser amado por Deus, de você ter que superar os seus problemas. Aí, em vez de eu ficar no meu quarto chorando sozinho, eu resolvi me converter".

Thiago relata que o processo de envolvimento com a religião foi gradual: "Eu passei a ir mesmo com 17 anos, eu estava pisando na igreja, mas já com 16, com 15, eu estava meio que olhando a vida com outros olhos, com espiritualidade, e foi até os 23. Mas eu sempre tive uma espiritualidade, desde quando eu era criança. Até hoje o que eu não me lembro direito de onde vem essa espiritualidade: até onde eu me lembre, eu acreditava que Deus tinha super-poderes, quando eu era pequeno, que eu ia virar um anjo e daí.. eu sempre acreditei em Deus e, quando eu me converti na igreja. Eu achei que estava naquele caminho, e foi onde eu fui de cabeça... Foi gradualmente, mas depois eu fui de cabeça total, radical’.

Thiago passou por quatro igrejas evangélicas. Afirma que foi mudando de uma para outra por questão de fé, mas a vivência religiosa não impede o contato com a percepção negativa da homossexualidade: “... a que eu me converti foi na Renascer em Cristo, que é uma igreja mais aberta para os jovens, mas também nessa época não aceitava... As igrejas evangélicas, pelo menos o que eu conheço, mas elas estão mudando, elas não aceitam, é como se não fosse bom aos olhos de Deus um homem se interessar por outro homem. Seria algum desvio do que Deus teria criado igual à semelhança dele mesmo, mas que pela fé você poderia mudar. Na primeira igreja que fui, fiquei 3 anos, acabei me envolvendo, eu ia acabar ingressando no ministério. Saí por umas perturbações lá e acabamos saindo por um motivo de organização. Depois passei por mais duas igrejas, sendo que na última eu fiquei dois meses. Acredito em Deus, mas não freqüento mais igrejas hoje e isso não foi por causa de minha orientação sexual’.

Interessante este trecho do depoimento sobre a criação do homem à semelhança de Deus e sobre a "cura" da homossexualidade pela fé. De acordo com Thiago, por meio da fé, 
ele conseguiu estabelecer contatos com o mundo social, com grupos de pessoas que comungavam os mesmos objetivos e ideologia, mesmo que, na essência, continuassem a não aceitá-lo de forma integral, pois “...qualquer coisa era pecado. Não dava para perceber quem eu era". A motivação para fazer parte da comunidade evangélica, mais especificamente na Igreja Renascer em Cristo: “...o culto não é cansativo de se ouvir, tem outros jovens e possibilidades de se fazer amizades. Tem uma certa abertura para você participar. Você acaba aprendendo muito lá na busca de um equilíbrio. A linguagem que eles usam, é mais para falar para os jovens, não tem tanto aquele rigor cerimonial, não tem isso, que fica evidente no próximo trecho destacado a seguir". Neste contexto em que se reunia com outros jovens e existia uma abertura para participar, mostrar-se enquanto pessoa, era algo que Thiago ainda não havia experimentado de forma intensa. Esta vivência favoreceu um sentimento de pertença.

A religiosidade ganhou significado importante para Thiago após a sua passagem pelas religiões: "Depois de ter passado por essas igrejas, hoje, eu acredito que Deus seja um Deus de amor e que seria pecado seria você se ferir ou ferir uma outra pessoa, mas não é que você tenha amor por outra pessoa, seja mulher ou homem, que você esteja em sintonia com Deus. (...) .... a igreja me fez muito bem em algumas coisas, trabalhou muito lá... a visão psicológica é super forte, inclusive tem poucos estudos em relação a isso, acho que seria algo interessante para ser estudado. Mas também existiam outros conflitos, porque ao mesmo tempo eu era o homossexual e sentia atração por outros homens de dentro da igreja, no grupo de jovens, mas isso era errado, era um pecado, então eu me sentia mal, porque eu achava que eu estava magoando Deus e isso me deixava muito triste, às vezes, eu ficava... triste, às vezes, até com um pouco de depressão, mesmo, sabe aquela sensação de arrependimento, sentimento de culpa?". A percepção que passa a ter é de um Deus que se magoa. Por outro lado, ele se sentia inadequado por ter interesse em outros homens.

A culpa recai sobre seus prazeres a exemplo da masturbação, que ele praticou entre os 7 e os 20 anos, como única forma de expressão sexual, que percebia enquanto algo bom e prazeroso. Porém, quando se converteu, aos 13 anos: “....ah, era uma coisa mais ou menos assim... era bom, só depois que eu me converti é que passou a ser errado. Aí eu passei a querer evitar. Eu ficava uns 10 dias sem fazer e 'nooossa!...' e não agüentava. Fazia e me sentia na 'nóia'. Eu me sentia culpado, sujo, errado, assim... Fora que tudo você... por eu ser homossexual é como se eu valesse menos, entendeu?". Este sentimento indica o quanto sentia- 
se solitário na sua vivência. A culpa, enquanto internalização de formas de controle, exerce em Thiago o efeito de sentir-se menos do que os outros, por masturbar-se e por ser homossexual, uma dupla,condenação.

Não é de se estranhar que o suicídio tenha sido tema presente na sua vida, por sentir-se rejeitado e ter uma auto-estima abalada pelos impedimentos sociais e espirituais de ser quem se é. A percepção que tem de si aproxima-se de ser uma coisa, um pecador, alguém como ele mesmo diz "sujo, errado. Nesse trecho do depoimento Thiago revela a falta do respaldo social para constituir-se enquanto pessoa a partir da ampliação de possibilidades de contato compartilhado com o outro, numa situação em que exista o acolhimento, o respeito e a aceitação.

A fim de seguir os propósitos da sua fé, para se libertar do pecado de ser quem é, Thiago passou por programas de "cura" da homossexualidade: "Claro, eu queria mudar. Dentro da igreja eu falava para as pessoas que eu queria mudar. Eram duas pessoas próximas. Eu acreditava que eu poderia mudar. As orientações dadas eram para evitar masturbação, fotos, evitar esse tipo de pornografia, fazia jejuns, orava, enfrentava, reprimia, refletia sobre a culpa, sobre aquela luta contra o físico, muitas coisas nesse sentido. Seria um lado de oração, de enfrentar, mesmo". O fracasso em seguir estas diretrizes cede lugar à autocondenação e à culpa. O bem-sentir, ou o bem-estar, não é algo valorizado neste contexto, pois sempre se terá o que depurar na experiência humana.

A "cura" ou "conversão homossexual" tem caráter fundamentalmente moralnormativo. Não existem evidências da "conversão homossexual", de homossexuais "virarem" heterossexuais, ou mesmo o movimento contrário, em uma suposta "conversão heterossexual". Dada a atuação de alguns psicólogos que associam a prática profissional à religião que se propunham "curar" homossexuais, o Conselho Federal de Psicologia, em 1999, com a Resolução 01/99, proibiu que psicólogos desenvolvessem tais atividades, considerando que a homossexualidade não constitui doença, desvio ou perversão. Também não se fala em "cura" da homossexualidade, pois pressuporia a "doença". A homossexualidade, desde 1973, a partir do Diagnostic Statistical Medical - DSM -, deixou de fazer parte da lista de psicopatologias. 
Hoje, Thiago diz não acreditar na conversão de homossexual para heterossexual: “Olha, eu acredito que é algo difícil, é um trabalho penoso, mas nesse nível, agora sendo mais crítico, cético, eu não sei... É porque eu não tenho muito conhecimento, se tiver alguma coisa genética já seria bem mais complicado, ou mesmo se não tivesse, que fazem com a cabeça da pessoa, não só a igreja, mas pessoas que trabalham com isso, talvez seja impossível. Não que eles estivessem fazendo lavagem cerebral comigo, não é isso que eu quis dizer. Eu não acho que eles anulam a sexualidade. Eu nunca vi ninguém que tenha deixado de ser homossexual, mas pessoas que continuam numa repressão, em uma vigilância que continua... continua para a vida inteira. A vigilância é da pessoa sobre si mesma. Ela fica sabendo que está errado, e ao mesmo tempo ela mesma que vigia. A repressão é dela mesma". O mecanismo da culpa se faz presente no sentido de controlar a expressão sexual da pessoa. A pessoa continua tendo desejos homossexuais, porém, por meio da repressão, impede-se de sentir este desejo. Porém, vale ressaltar que desejo é um fenômeno subjetivo que não parte para um objeto de acordo com a razão. Deste modo, a repressão é dada diretamente ao desejo da pessoa como um todo, é a própria expressão sexual da pessoa que é reprimida.

Thiago percebe esta vivência religiosa não somente sob o prisma da opressão, mas também pela possibilidade de, naquele momento de sua vida, sentir-se pertencido a uma comunidade: "A minha avaliação disso, hoje, é que eu acho isso bem interessante porque isso me possibilitou ter uma vivência bem rica em algumas perspectivas de experiências, em contatos com pessoas diferentes, de classes sociais diferentes, com idéias diferentes, e todas as coisas que eu fui passando desde o mundinho que eu criei para mim, como são as coisas no mundo externo... como procurar entender, e foi aí que eu procurei a Psicologia, tudo aquilo que eu tive vontade de conhecer, de compreender, com pessoas da minha infância, tudo isso acho que influenciou muito a minha maneira de pensar e me ajudou a me liberar de alguns padrões que a sociedade não tem, então, eu comecei a pensar diferente, realidades diferentes, sei lá. Isso por quê? Porque eu continuo acreditando em Deus. Guardo essa coisa do carinho e consegui superar muitas das dificuldades que eu tive. Isso acaba sendo uma coisa mais positiva, eu estou falando no geral, no preconceito. Quanto ao processo de conversão, foi só perda de tempo, eu diria. Mas a minha passagem na igreja eu achava que era o certo aquilo. Eu não os culpo por agirem daquele jeito. Tem umas igrejas que já aceitam mais os homossexuais. Algumas coisas eu sei pelo contato com outros homossexuais, mas realmente era confuso. Era como uma família que eu tive. Mesmo porque minha 
concepção mesmo antes de entrar na igreja, eu achava que não era para ser daquele jeito, naquilo que eu recebia da sociedade, sei lá, dos estímulos... Eu não tinha para onde ir, eu não contava com mais nenhuma outra pessoa".

Thiago também ressignifica o episódio em que era alvo de chacotas na escola devido à sua forma de comportar-se: "A parte que foi ruim foi na escola que eu passei a me achar errado. Daí eu passei a afastar as pessoas. Eu ficava sozinho. Eu achava que tinha pessoas boas no mundo e pessoas más e era como se eu não conseguisse me proteger. O jeito que eu tinha era perdoar essas pessoas que tinham essa coisa de rejeição, que estavam fazendo de errado comigo, e eu tinha que ficar comigo, e não tinha muita esperança nisso". A resignação e a desesperança se fizeram presentes, favorecendo a a naturalização do preconceito direcionado para os diferentes. Thiago situava-se ao mesmo tempo que era situado na periferia das relações por ser homossexual.

Posteriormente, quando Thiago passou a ter outra percepção da sua experiência, o perdão continuou sendo mote para resignar-se: "Depois com o tempo eu passei a sentir raiva, quando eu fui ficando mais velho... com uns 15... eu acho 16... Quando eu, pelas coisas que eu aprendi na igreja, quando eu associei o preconceito que eu sofria, com as dificuldades que eu estava tendo com relação comigo mesmo, como a depressão, eu passei a sentir raiva daquelas pessoas. Só que como eu estava na igreja e tinha aquela coisa do perdão, assim, eu procurei, tentei perdoar essas pessoas... mas teve um momento que eu fiquei com muita raiva delas, tinha vontade de matar aquelas pessoas. "Nossa o que você fez comigo? Você destruiu a minha vida, agora você está vendo"... Mas devido às orientações da igreja eu resolvi perdoar aquelas pessoas e tentava superar aquilo não pela vingança". O perdão referido por Thiago pode ser uma forma de desprender-se das amarras do passado, de se colocar no alvo da intolerância alheia, e reassumir seu espaço no momento presente repleto de possibilidades de vivência.

Foi, porém, no espaço religioso, que Thiago encontrou o amparo de que precisava naquele momento: "A igreja mudou toda a minha vida, assim, pelo menos o que eu sou hoje está fortemente influenciado pela igreja. Não sei se estaria vivo sem a igreja. É aquele negócio: acredito que não seja errado o que a igreja manda, porque Deus é amor. Com relação aos movimentos religiosos frente à homossexualidade, eu acredito que... bom, o Brasil é um país laico. Eu acredito que as pessoas evangélicas poderiam agir de uma outra 
forma. Tem aí a lei que está para ser aprovada, a União Civil ${ }^{29}$, que está sendo combatida pelos homofóbicos. Conscientizar, tudo bem, é a crença deles, eu respeito, mas tem que procurar conversar com outras pessoas".

A postura atual de Thiago com relação à religião é mais flexível: “...hoje, eu me considero existencialista, mas não é tão rígido como os existencialistas materialistas são. Eu sou existencialista influenciado pela visão que eu tinha antes, de Deus. Daí que eu queria falar sobre os significados de fazer o bem para uma pessoa. Hoje estou tranqüilo com a religião, se bem que eu não tenho lido mais a Bíblia, às faço uma oração, às vezes, não faço, mas eu me sinto bem, me sinto tranqüilo com Deus. Ah! O meu namorado segue uma religião afro $^{30}$ (riso). É muito interessante, porque é uma nova religião, e eu não gosto, mas eu respeito e a gente até já conversou sobre isso, tal... Já cheguei a ir para conhecer, mas, não (riso)". Mesmo não se identificando com a religião do namorado, a flexibilidade permite que Thiago tenha uma postura de aceitação e respeito.

Thiago conclui que sua vivência religiosa permitindo-lhe compreender algumas facetas da sua vida: "Olhando para o que ficou depois que eu passei pelas igrejas, eu acredito que, primeiro, foi essa razão da homossexualidade, como não era coisa de Deus, era uma coisa mental e comportamental. E por eu ter passado por essa repressão, e por esse contato com homossexual com idade pequena, juntando com a ausência do meu pai, acho que por isso que eu era, que eu sentia atração por outros homens, porque eu tinha idade baixa, eu era pequeno, e tem essa repressão, que me fez eu me sentir desprotegido". Thiago procura explicações para compreender a sua condição marcada pelo isolamento, pelo silêncio, pelo desamparo.

\footnotetext{
${ }^{29}$ Esse projeto legaliza a união entre pessoas do mesmo sexo, assegurando direito à herança, plano de saúde, previdência e declaração de renda em conjunto. Esse projeto de lei, o Pacto de Solidariedade, é desdobramento de outro projeto apresentado em outubro de 1995, de autoria da então deputada federal Marta Suplicy (PT-SP), sob o nome de Parceria Civil Registrada, que ainda aguarda votação na Câmara dos Deputados.

${ }^{30}$ Thiago solicitou que o nome da religião fosse suprimido.
} 


\section{3. "Eu não me aceitava homossexual, eu não era, não era": o preconceito internalizado}

Ao longo da sua vivência, Thiago foi alvo de discriminação pelos colegas da escola, dos vizinhos, sendo que a alternativa encontrada foi se fechar em seu mundo de fantasia. $\mathrm{O}$ sentimento de solidão e de desamparo lhe faz criar alternativas para sentir-se parte de algo e defender-se daquilo que via como hostilidade do mundo.

Por mais que fossem rejeitadas as mensagens vindas do meio externo, do meio social, tais mensagens têm influência marcante em Thiago, nos sentido de ele se situar e ser situado na existência social. A internalização das mensagens negativas relacionadas ao seu modo-deser fortalece o conflito interno de "ser" e de "não ser", de "certo" e de "errado": "Quando eu passei a me dar conta da homossexualidade, acho interessante isso, eu não me aceitava homossexual, eu não era, não era. Eu notava apenas deslizes, era como se a minha cabeça não pensasse muito sobre nisso. Se alguém perguntava: 'Você é?', eu diria: 'Não'. Era como se a cabeça não pensasse muito sobre isso". Pensar na "homossexualidade" gerava aversão nele, afastando de si a idéia, até mesmo para não dar ainda mais margem para a intensificação do conflito interno. Thiago mostra a falta que teve de uma rede de apoio em que pudesse evitar ou atenuar parte do sofrimento vivenciado: "Mas na minha época eu não via espaço para falar sobre isso. Não tinha. Mas eu acredito que, hoje, esses grupos, assim, eles trabalham em escolas". Assim, Thiago apresenta no seu depoimento as negociações nas relações sociais para que, aos poucos, pudesse aceitar a sua homossexualidade.

\section{4. "Quando ela soube ficou, assim... nós nos conhecemos aqui na faculdade, e eu na época eu ainda não me aceitava como eu era": a experiência heterossexual}

A entrada na faculdade ofereceu um novo universo para Thiago. O isolamento já não era tão intenso como antes: "Na faculdade também foi assim, só que na faculdade é um mundo diferente, de pessoas diferentes. Eu não participei das coisas da faculdade, das festas... Mas não foi um problema. Eu me sentia cobrado pelos meus pais que cobravam uma namorada, mas algumas parentes, algumas amigas mais próximas já cobravam”. A pressão da família por um relacionamento heterossexual acabou fazendo com que Thiago se cobrasse ainda mais, 
pois já tinha internalizado a mensagem religiosa de que "se você deseja homem, não entra no reino de Deus".

De acordo com ele, foi na participação nos grupos da igreja que sentiu-se levado a iniciar um relacionamento com o sexo oposto. Quando entrou para a faculdade começou a namorar uma garota: “...nós nos conhecemos aqui na faculdade, e eu na época eu ainda não me aceitava como eu era, até no começo desse ano. Daí eu comecei a querer namorar ela, eu achava ela bonita, eu queria... sei lá, eu queria ficar junto com ela. E aí que a gente ficou um tempo. Eu falei que eu sentia por ela. Eu gostei muito dela, e ela correspondeu, e a gente começou a namorar". Thiago sentiu a necessidade de abrir-se com ela: "Mas eu percebi que havia uma certa falta de atração física por ela, e isso acabou prejudicando, na hora de se tocar, na hora de... então, eu contei para ela o que eu era, e ela ficou chocada, mas a gente continuou o nosso namoro. Não parou porque a gente volta e meia queria ficar junto". O sexo aconteceu entre eles, porém, não se sentia realizado, pois a vivência sexual com outro homem lhe tinha gerado mais prazer. Ele relata que a experiência sexual com a namorada: “...não era tão, não sentia tanta coisa como se fosse um homem. Eu já tinha experimentado com outro homem, e não com outras mulheres, ela foi a primeira. E... então, por isso eu percebi que ia ser difícil realmente, porque eu estava sufocado, sabe, nesse relacionamento com ela - era como se não estivesse sendo eu mesmo -, parece que tinha algo que faltava".

\section{5. "E nesse dia, na Parada desse ano, eu resolvi assumir": Thiago assume-se homossexual}

A participação de Thiago na Parada do Orgulho Gay foi importante para que se sentisse com suporte para conversar com sua namorada sobre sua homossexualidade: “...na Parada eu me senti bem e resolvi contar para ela". Mais uma vez a importância do encontro com semelhantes em que pode sentir-se pertencido, ou mesmo não precise dissimular o seu sentir: “...eu fui lá, e a primeira vez que eu fui, sai assim, publicamente, e eu gostei muito de estar lá, tanto por que eu gosto da música, como pelo fato de me sentir bem ali. E eu tive uma visão de que eu estava meio que tipo numa família, meio que entre irmãos, uma coisa divertida, não muito consciente, mas tranqüila assim. E nesse dia, na Parada desse ano, eu resolvi assumir". O sentimento de amparo e de familiaridade tornam-se presentes e ele sente-se livre 
para divertir-se de forma mais solta, "não muito consciente", experimentando uma possibilidade de modo-de-ser.

Com esta mudança de atitude, Thiago se recoloca no contexto social de uma forma mais positiva e auto-afirmativa: "Achei que eu me senti bem porque eu estava me olhando $e$ achei que não estava fazendo nada de errado pelo que eu sou mesmo, e sentindo muito bem. Aí esse sufocamento passou, e passei a contar a verdade para dadas pessoas do jeito que eu sou e não com uma imagem que eu tinha criado de mim mesmo, que eu vendia".

Para os pais, Thiago não comunicou abertamente, mas: "O meu pai sabe, eu não contei para ele, mas contaram. Ele perguntou para mim e eu falei. Ele falou que não esperava aquilo. Eu sabia que ia ser difícil, eu pensava que a reação dele fosse pior, mas... por isso foi... foi só aquele dia e hoje a gente não fala do assunto. Mas ele tende a aceitar". Já para a mãe: "A minha mãe ainda não sabe. Ela está viajando e ela vai saber quando voltar".

A idéia de família é presente no depoimento de Thiago e soluções alternativas para a sua escolha de vivência: "Então, daí eu acreditava que eu era homossexual, e por isso que eu acreditava no fato que eu poderia mudar isso, mas hoje, pelo fato de eu estar namorando e ter lido algumas pesquisas que falam que é uma questão genética também nisso. E como eu já falei, já saindo da igreja, mesmo que possa mudar, pelo o que eu tô vendo, não é fácil, porque não sei. Eu me sinto tão bem e eu posso ser feliz sendo o que eu estou sendo, pelo o que eu sou, da forma que eu sou. Daí abrem outros problemas de outra importância. $O$ problema é com filhos, né? Porque eu gostaria de ter filhos mesmo, mesmo sabendo que eles podem ser adotados. Eu não vou ter aquela coisa de tocar a barriga da mulher grávida, mas tudo bem". Assim, Thiago passa a ter uma nova consciência do seu lugar na existência social.

No campo social, Thiago passou a freqüentar lugares destinados ao público homossexual: “...eu estava indo em baladas. Eu nunca tinha ido e nesse ano eu comecei a ir em baladas $G L S^{31}$, para conhecer como é que é, e tal. E achei bem diferente do que eu conhecia, me impressionei com algumas coisas, as pessoas de lá realmente não queriam saber de namorar, era uma coisa mais para ficar e não era exatamente isso que eu estava querendo, assim... até para fazer amizades era um pouquinho mais complicado".

\footnotetext{
${ }^{31}$ GLS é uma sigla que significa Gays, Lésbicas e Simpatizantes.
} 
Outro ponto mencionado por Thiago é quanto ao preconceito que existe dentro do circuito GLS, voltado para aqueles que são "passivos": "Para mim não tem muita importância ser uma coisa ou outra, para o que que eu sou, o que eu... para mim, isso é o de menos, mas para algumas pessoas já dão mais importância para isso. Dentro do meio, dentro das pessoas que são gays, geralmente há também um preconceito contra quem é passivo, porque é visto como afeminado, coisa assim. Dentro de outros ambientes gays eu não sei. O passivo acaba se vinculando à figura do efeminado, e também ao mais fraco, coisa assim". Neste trecho do depoimento, Thiago aponta para a influência do preconceito quanto ao gênero, denunciando a influência de uma sociedade patriarcal e machista, onde a figura do feminino acaba sendo alvo de repressão.

\section{6. "Foi fácil encontrar o grupo, na internet tem alguns grupos": Thiago encontra um terreno fértil para ampliar sua rede social}

Como outro espaço de apoio e afirmação, e campo para a ampliar a sua rede social, Thiago encontrou na internet um grupo de homossexuais: "Foi fácil encontrar o grupo, na Internet tem alguns grupos. Esse grupo começou na internet, como grupo de discussão e tinha grupo de encontro aqui em São Paulo. Mas aí que eu comecei a me perguntar porque que eu não queria assumir, então, foi uma imagem que eu estava construído para mim mesmo que aquilo seria uma coisa meio que de fraqueza, ou alguma coisa assim, que eu tinha passado antes e também porque eu, antes disso, eu estava num grupo evangélico. (...) Eu conheci e entrei no e-groups de jovens de homossexuais para estar fazendo amizades, porque até então todos os meus amigos eram héteros, e algumas coisas não davam para conversar muito bem com eles. Aí, então, eu conheci pessoas com uma cabeça diferente, tal...".

No seu depoimento, Thiago disse ter ficado impressionado com o fato de as pessoas deste site e de outros ambientes GLS quererem apenas "ficar" e não namorar. O "ficar" está relacionado à idéia de relacionamentos passageiros, que implica certa intimidade corporal, sem envolvimento emocional ou sem firmar algum tipo de compromisso mais duradouro, mas que constitui um meio de familiarização de envolvimento amoroso entre duas pessoas (Castro, Abramovay \& Silva, 2004; Bozon \& Heilborn, 2006). Porém, foi neste espaço que conheceu 
o atual namorado: “...eu estou namorando, já, um garoto, que tem 19 anos, e tem sido bem legal estar com ele. A gente se conheceu há pouco tempo".

Em outro trecho do seu depoimento, Thiago mostra a importância da internet para jovens homossexuais, em uma idéia de sociedade em rede: “...eles vão em colégios, fazendo palestras - esses grupos de apoio a homossexuais. Hoje, os jovens têm a internet, e pode encontrar muitas pessoas como você, mas naquele período não tinha isso, acho que para hoje está um pouco mais ameno, assim, e a sociedade no Brasil, pelo menos em São Paulo, parece estar mais aberta. Teve até quase tendo beijo em novela. (...) Hoje, você não precisa sair de casa, você pode entrar em contato naquele momento com pessoas que estão distantes, com lugares, como grupos de discussão, com chat $^{32}$, você pode encontrar pessoas que tenham afinidade com você, amigos que você... você pode fazer amigos, e que você não conheceria se não fosse em um local virtual e depois você pode encontrar pessoalmente. Agora se você só fica virtualmente, pode ser ruim. É bom ter um diferencial, fazer alguma outra coisa junto, não ficar só no virtual. Tem um excesso de informação, danado, mas... acho isso legal na Internet, de ter contato com pessoas e também aprender muito. Para mim a Internet já foi melhor, porque... principalmente no primeiro ano de faculdade eu lia muito, eu estava descobrindo aquilo, via fotos de nudez que eu nunca tinha visto, que não tinha acesso fácil, e conversava com pessoas, mantinha contatos, e marcava encontros... Tem umas opções de amizade, sites, ou livros... O grupo da Internet e-jovem tem uma comunidade no Orkut. No site deles tem um lugar para chat. Mas eu torno a dizer, que quando eu falei dos sites, por que eu não me mostrava e aquilo era uma escapada". Naquilo que Thiago indica como uma "escapada", era uma maneira de acesso ao grupo com o qual se identificava, favorecedo a apreensão de novos referenciais para o seu roteiro, em contato com outras pessoas, mesmo que no plano virtual.

\section{7. "Ainda ficaram marcas disso, eu ainda não superei todas": Thiago hoje}

Thiago mostra as marcas deixadas pela trajetória trilhada até o momento: "Ainda ficaram marcas disso, eu ainda não superei todas, eu ainda tenho... ainda sou uma pessoa tímida, às

\footnotetext{
${ }^{32}$ Termo inglês, que significa "bate-papo", "conversação", que é utilizado para designar as conversas em tempo real que acontecem na internet.
} 
vezes, quero fazer tal coisa e eu me sinto um pouco inseguro, de falar... de repente... sei lá, de expressar de alguma coisa, de me vestir de uma forma, assim, coisa que eu tenho que superar. Mas todos aqueles problemas eu tive com as dificuldades, eu tive que enfrentar para superar aquilo, sem ser resignado. Mas eu sou introvertido, mas não sou tímido, então não conseguia falar em público. Depois que eu me assumi, foi como saísse uma carga, vários bloqueios psicológicos que eu tinha dificuldade foram caídos. Inclusive quando eu conversei aqui com a psicóloga daqui, com a psicóloga que eu conversei, foi muito positivo porque me fez pensar em algumas coisas que eu não pensava antes, e reconsiderar outras coisas". Ele mostra que o processo de auto-aceitação é lento, ainda mais quando ele é familiarizado a superar tudo sozinho, sem o partilhar com alguém as suas dificuldades, angústias e sofrimentos.

Na busca por ajuda psicológica, Thiago encontrou um espaço de escuta e de atenção que até então não havia experimentado. Ele deixa claro que a busca psicológica foi motivada pela então namorada na esperança de que Thiago passasse por alguma mudança: "Para mim não precisava, por mim não precisava, mas a minha ex-namorada estava insegura: 'Vai lá!...'. Daí: 'Tá, bom...”. Daquilo que ficou na sua ida para o SAP, Thiago destaca: "Não ficou marcada alguma coisa específica de quando eu passei aqui, não na forma de uma marca, assim... Foi uma coisa tranqüila, eu já estava mais... eu já tinha saído da igreja e tal... só me fez pensar melhor em algumas coisas e tal. Por que não sei, entendeu, ao conversar com alguém sobre aquelas coisas que você já tinha pensado, eu me perguntei: 'Por que não ser?', entendeu? E foi nesse período, em maio, no começo do ano, que eu efetivamente assumi para mim mesmo. Daí eu me dei alta, porque eu me sentia bem. Eu me dei alta, mas da orientação, que considero ter sido um tipo de catalisador para um processo que já tinha começado. Naquele momento rompeu algumas barreiras, sabe? Até mesmo na forma que você lida para com você mesmo". O plantão psicológico em sua proposta de acolhimento e de atenção funcionou como facilitador para que Thiago percebesse novos sentidos para a sua auto-aceitação. 


\section{8. "Ser masculino ou feminino é questão de comportamento, havendo influência de padrões culturais": a concepção de gênero na perspectiva de Thiago}

Na concepção de Thiago, o ser homem está relacionado com uma forma de apresentação contrária ao padrão feminino, porém, aponta para variações deste comportamento: "Você ser masculino é não ser efeminado; é você estar na busca daquela imagem típica do homem bronco. Isso mudou um pouquinho também. Mas o ser masculino é você não falar mole, é você usar roupas que fazem se sentir como homem. Você pode até ser aquele cara durão, mas não necessariamente isso é um padrão de masculino, mas você não vai andar rebolando, usar maquiagem, fazer algumas coisas... eu tô falando de atitudes, né?... É que é uma coisa que eu ainda não parei para pensar. E o que é ser homem? Ah, ser homem é uma questão de gênero, assim, você nasce homem e não importa se você gosta de homem ou se gosta de mulher, se você é efeminado, ou masculinizado, você vai ser homem e não mulher. Agora, falar de masculino é um pouco mais difícil de falar, porque é mais uma concepção da pessoa que tem de si mesmo... é a forma de você ver como um homem... Nossa! Você me colocou em xeque, agora (riso). Mas é isso: seria o não ser feminino. Não sei... Mesmo que você tenha uma certa delicadeza, não é uma delicadeza que você entende como uma mulher, senão queima a masculinidade, passa a não ser masculinidade. Se ele bate o pé na foto e fala: 'Ai!', daí é um cara que não tem masculinidade sendo homem. É um padrão dele. É que tem homens que se olham no espelho e se vêem como uma mulher. Aí fica difícil. Pelos mesmos motivos que eu não me vejo mulher. Não sei, acho que pela concepção que tenho de mim mesmo, vendo as coisas, hoje, tudo... Eu não acho que as pessoas sejam exclusivamente masculinas ou femininas, mas tem uma coisa, tem um comportamento nisso. Tem um misto de comportamento da pessoa, que acaba predominando na pessoa. Tem alguns homens que tem uma feminilidade e agem como se não tivessem, assim, talvez com 50 anos, uma... um dia ele falou: 'Aí!'. Talvez isso nunca tenha acontecido. Ele pode até ter se vestido de mulher, mas não significa que ele está sendo... ele pode, pode estar sendo só o lado feminino dele, mas depende do que ele entende como feminino.

Com relação ao ser mulher, na concepção de Thiago: “...eu acho que, ah, então, mulher também é uma questão de gênero, mas acho que ser feminino é aquele padrão que se estabeleceu na sociedade (riso). É louco, porque eu tenho tido contato com a quebra desses padrões. Eu tenho visto mulheres reclamar de feminilidade. É uma coisa que já não está tão 
certa para mim, por isso está um pouco, não está sendo tão fácil de responder. Há uma quebra nesses padrões e eu perdi um pouco dos meus referencias, nisso. Mas o que eu posso te falar é uma concepção de um padrão básico de uma pessoa que eu acho ser feminino. Eh... (riso) não sei. É uma coisa que eu não parei para pensar: o que é ser mulher?... Eu nunca refleti sobre isso... antes... Eu posso tentar pensar e depois eu te falo. Eu não posso falar agora, porque senão vou repetir o velho padrão da sociedade do que é ser feminino: é aquela que a mulher fica em casa, mas... mas eu nem concordo com isso, pois acho que isso é feminino também. Mas somar isso, somado com pessoas diferentes do padrão, que eu vejo, de bar, em balada... Então não dá para responder a essa pergunta".

Thiago fica perplexo diante da questão do ser homem e do ser mulher. A questão do gênero nem sempre é refletida, mas vivida. A partir da sua trajetória, Thiago apresenta um olhar mais abrangente que envolve o sexo biológico e a construção do gênero. No momento em que revisou o seu depoimento, ele acrescentou outros elementos nesta compreensão: "Ser masculino ou feminino é questão de comportamento, havendo influência de padrões culturais. A imagem ligada a esses termos é que másculo transmite força, segurança, firmeza nas decisões. Feminilidade transmite a idéia de sensibilidade, vaidade, inteligência emocional. Mas esses limites são cada vez mais questionados e tênues, desaparecendo em alguns casos. Por isso não importa a pessoa citada, que tal Brad Pitt e Angelina Jolie? Ambos têm características mistas, assim como ele, ela também passa a idéia de força e como ela, ele parece ser alguém mais sensível com as emoções de outras pessoas". Nesta nova compreensão, Thiago faz referência à constante mudança de concepção do ser homem e do ser mulher. Assim, ele passa a perceber que o ser homem também contempla o ser sensível, atributo tido como feminino, conferindo uma gama de possibilidades de ser em cada gênero.

No tocante a como as pessoas viveriam sua sexualidade de forma plena, Thiago aponta a importância do conhecimento e do diálogo, respeitando as diferenças e promovendo a compreensão entre as pessoas: "Eu entendo que as pessoas viveriam melhor sua sexualidade se houvesse maior conhecimento, maior abertura para que seja conversado sempre, sem malícia. É mais sobre isso, sobre os preconceitos, e fazer uma visão de análise sobre isso, e uma conversa que seja aberta, uma conversa com postura, sem a maldade, entendeu? Um entender o outro, uma visão crítica e com análise, de autoconhecimento e compreensão do outro, e sem ter o fundo da religião: eu quero isso para a minha vida, ou não quero? Você poder escolher o padrão, e não: 'Ah! É assim'. Não ter aquela consciência de que aquilo é 
um valor de que você pode escolher, ou não, sem que você tenha a passividade que aquilo acaba sendo um valor seu, porque assim que o humano sobrevive. Eu acredito que com essas coisas, com essas atitudes, as pessoas vão poder se entender melhor, viver melhor conversando sobre os seus medos, conhecendo, e procurar coisas que você não vive. Eu ia falar de uma coisa saudável, mas para mim uma forma de sexualidade saudável é uma que não vá te fazer um mal fisicamente ou psicologicamente para você ou outra pessoa".

O depoimento de Thiago sobre a sua trajetória mostra a carência de redes de apoio para que ele pudesse ter contato e dialogar, em um sentido compartilhado, sobre sua visão de mundo e seu modo de vivência. A percepção de si, ao longo do depoimento, é intensamente vinculada à constituição de sua identidade.

Desde a infância, passando pela escola, Thiago apresenta uma série de percalços para a vivência social plena. A brincadeira erótica na infância foi tida como algo negativo e indesejado pelos adultos que optaram pelo afastamento do amigo. Thiago traz aquela vivência como o início da sua vida sexual, mostrando o quanto foi marcante para ele.

O preconceito e o estigma foram elementos que acompanharam a sua trajetória até o início da fase adulta, sendo que, de acordo com os referenciais que tinha à sua mão, foi inevitável que este preconceito fosse internalizado promovendo uma imagem negativa e inferiorizado de si. O isolamento e o sentimento de não pertença são intensos na sua narrativa. A atitude defensiva é questão de sobrevivência em um mundo hostil.

A sua conversão religiosa foi um caminho adotado na tentativa de tornar-se "normal", entendido aqui como "ser heterossexual". Apesar de os preceitos contrários ao desejo por outros homens, inculcando a culpa e o mal naquele tipo de desejo, a Igreja foi um lugar onde sentiu-se amparado e cuidado. Mais tarde, pode constatar de que aquilo não servia mais para sustentar uma situação que ele próprio evitava.

Outro caminho adotado por Thiago foi o início de relacionamento com uma garota, porém o sentimento de sufocamento e incompletude o fez reconhecer que aquele caminho não era o melhor para si. 
A partir do contato e diálogo com semelhantes, Thiago encontra novas possibilidades de vivência, tendo uma nova concepção de si e do mundo, em uma perspectiva de autoaceitação e de pertença ao mundo. 


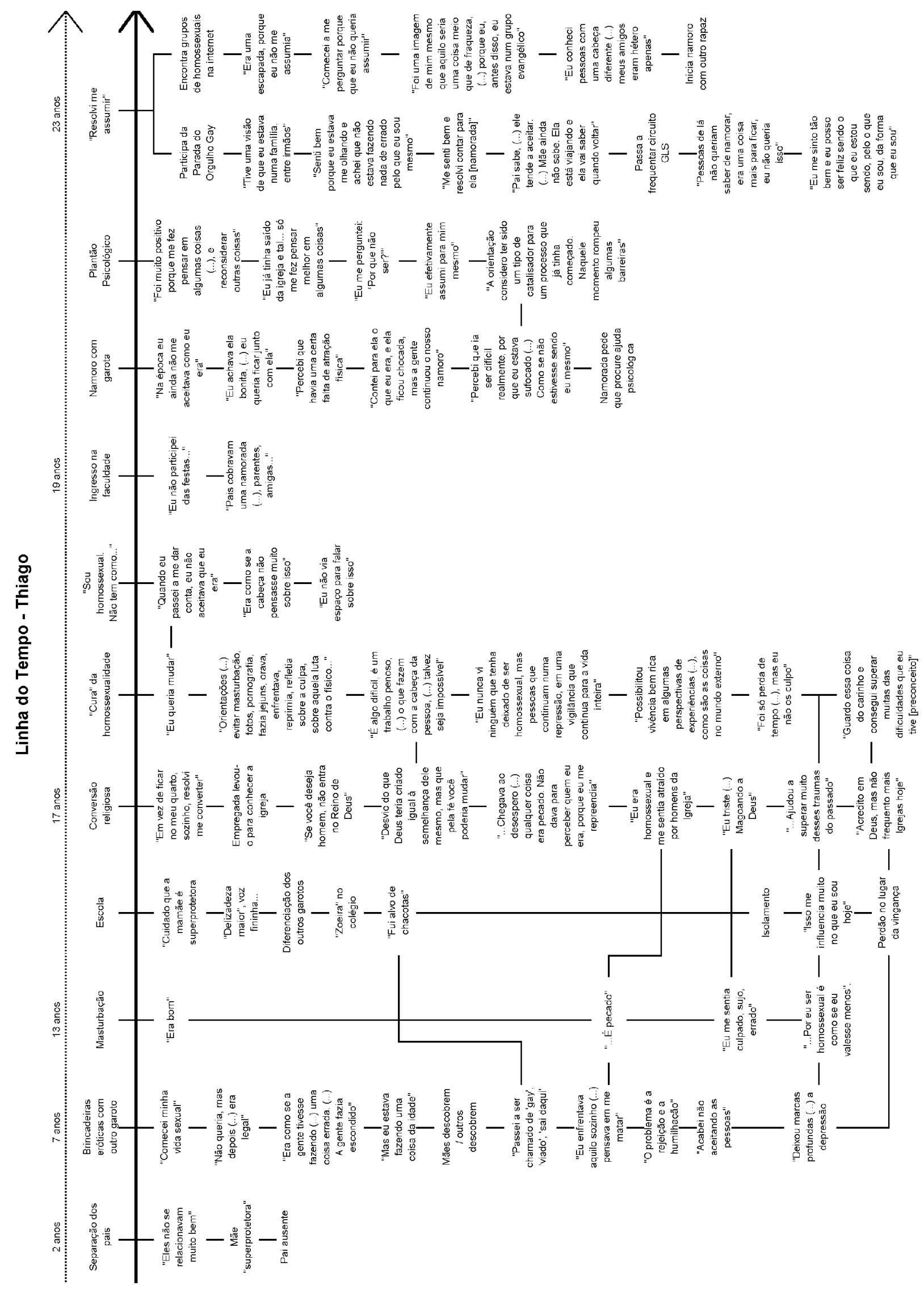

Figura 2 - Linha do tempo da trajetória de Thiago 


\section{3. "Eu realmente só estudava (...), eu não tinha vida no cursinho... não curtia as coisas, era uma máquina": o depoimento de André ${ }^{33}$}

André tem 21 anos, nasceu em uma cidade do interior de São Paulo, e cursa o nível superior. Mora em São Paulo, dividindo o apartamento, em regime de república, com outros 3 amigos que também são estudantes.

André é filho único por parte de mãe, e tem uma irmã proveniente de relacionamento anterior do pai. Ao longo do depoimento, André apresenta suas experiências e os caminhos trilhados tendo como pano de fundo sua emancipação e as novas descobertas que vem fazendo.

Diante da pergunta disparadora: "Fale-me desde como foi a descoberta da sua sexualidade até chegar nos dias de hoje", André remeteu-se ao seu estranhamento que, mais tarde, refletirá sobre o processo de descoberta da sua sexualidade: "Bom, na descoberta rolou muita incerteza(...). E... na... acho que 12 anos, 10, 11 anos, foi aí, com masturbação, normal. Achava isso... eu ficava... no começo tinha uma sensação meio de, assim, era estranho, mas... depois passou, ficou normal, e eu tive minha primeira namorada. E talvez, com ela foi o mesmo problema que eu tive, que eu acabei... acho que eu ainda tava um pouco confuso na cabeça. Com a minha primeira namorada não foi realmente uma experiência. Mas, agora, tipo, já tá bem antigo, já meio confuso. (...) Talvez isso...". Mais adiante, André retoma o tema da sua iniciação sexual, dizendo que a sua primeira relação sexual completa não foi com a namorada, mas com uma prostituta. Porém, ele não considera a experiência com a prostituta como um marco na sua iniciação sexual.

André relata que descobriu a masturbação por "instinto", mas que tinha ouvido amigos e primos falarem sobre esta prática: "Acho que eu fiz primeiro, depois que eu tive mais informação. Depois disso, sei lá, ver com meus primos, tipo, ver filme pornô, que a gente, né... ficava um rolo, e tudo, todo mundo via, e tal... daí sei lá, a gente já era mais velho um pouco, e tal'. A troca de experiências e de informações em grupo, além dos filmes pornográficos, foi importante para que André incorporasse sentidos para aquilo que despertava sua curiosidade em termos de sensações.

\footnotetext{
${ }^{33} \mathrm{O}$ depoimento de André foi coletado duas vezes. Na primeira vez, dado o seu estado gripal, e problemas na captação do áudio, a gravação ficou inaudível, inviabilizando a sua transcrição. O segundo depoimento teve a duração de 1:46h. Na ocasião da validação do texto, André manteve o texto na íntegra.
} 
Guiado pela vontade de saber, André utilizou das mais diferentes referências no exercício da sexualidade, dentre elas, os filmes pornográficos: “...uma coisa engraçada... a informação que a gente tem quando a gente é jovem, homem, é sempre assistindo filme pornô, então você acha que é igual (risos). (...) Era meio estranho. Era, assim... Não, não é estranho... estranho é você tentar fazer isso com a sua namorada, sabe? Não é estranho. Acontece mesmo, às vezes, acontecem algumas coisas, sabe? Nunca assisti filme pornô com a minha namorada. Comigo não, ela não assistiu. Mas... mas, entendeu, as informações que vinham, de onde vinham? Tipo: 'Como faz isso?', tipo: 'O que é...". "Como é” e "como se faz isso", eram questionamentos presentes nos seus primeiros contatos sobre a sexualidade, que foi ganhando sentidos e significados, a partir do contato social, com amigos e primos, além de filmes pornôs, para aquilo que ele anteriormente chamou de "instinto".

Outro referencial importante para estes significados e sentidos foi a internet onde André coletava fotos e vídeos com conteúdo pornográfico: "Vídeo pornô vem da internet. Antes eu pegava mais, sei lá, era adolescente, 14 anos... Tinha mais foto, naquela época, acho... nem tinha vídeo. Não... devia ter, sim... tinha um pouco. Bom... era isso e, sei lá... era essa informação sexual, mesmo, que eu tinha, sem ser a... que... com... sexo, mesmo. Não de camisinha, essas coisas que envolve... isso tudo bem, tinha em escola, tinha a minha mãe". Ao falar sobre o diálogo em casa, André lembra que: "Minha mãe que falava, meu pai falava pouco, mas falava. Era um papo meio informal, sossegado, mas... não era muito profundo. Hoje eles me enchem o saco um pouco quando a minha mãe tenta ter abertura comigo, pra falar coisas... assim, sei lá, que minha mãe intromete muito na minha vida, então... me... deixa nervoso. Se... se ela faz muita pergunta, eu estresso um pouco. Mas ela não tá nem aí mais... sobre a minha vida sexual. Às vezes, ela perde um pouco isso, ela é meio... sei lá, ela é meio superprotetora e acha que ainda é o filhinho... então, meio deslocado, assim". André indica que a "superproteção" da mãe tem um sentido de falta de noção dos limites sobre a sua intimidade, ainda mais no momento de vida que ele se encontra, aos 21 anos de idade. Interessante observar que o cenário do lar e o cenário da escola são espaços em que o sexo é relacionado à prevenção, sendo que o sexo relacionado ao prazer tem vazão em outros espaços, a exemplos dos "amigos-amigos", referidos por André, com os quais tem mais intimidade. 
André encontrou no contato com os amigos da mesma idade e na psicoterapia um espaço importante para falar sobre a sexualidade: "Além da minha terapeuta, eu conversava sobre esses assuntos de sexo com meus amigos... não aqueles de escola, amigo-amigo, mesmo... (...) Tenho alguns amigos que são bem próximos. Conversas assim, não como um problema, com um sei lá, falar que eu não dei... nenhum deles sabe... ou que eu saiba, não... da falha, assim, sabe?". André indica de forma mais clara, quando o assunto é desempenho sexual, a tensão é presente quando esse desempenho não é o esperado: "Quando aconteceu com a Mônica, que eu tava muito mais aberto, sei lá, eu... eu falei um pouco assim: 'Ah, foi tão bom com ela", porém, o encontro sexual com Mônica não fora "tão bom assim”: “Foi estranho a primeira vez', eu não falei. (...) A gente transou, tal, acabou, ela ia embora aquele dia... (...) eu fiquei meio... 'Pô, foda isso, né?'.(...) Depois passou’. Falar do próprio desempenho sexual o qual, por ser homem, se espera o sucesso da experiência, André opta por dizer que a relação fora boa, mesmo não sentindo isso. Deste modo, não se fala das dificuldades experimentadas, mas sim do fortalecimento de uma imagem viril. A descoberta do novo é permeada pelo embaraço e pela incerteza, nem sempre sendo este momento reconhecido como possibilidade positiva da experimentação, ou mesmo de aprendizagem, desta nova situação, mesmo tendo uma série de informações previamente coletadas a respeito do sexo e da sexualidade nas mais variadas fontes. Gagnon (2006) sintetiza a questão das dificuldades sexuais remetendo-se aos roteiros das moças e dos rapazes:

O problema das moças não é tanto a repressão direta, mas de falta de circunstâncias, na socialização convencional, que proporciona conteúdo e ligação entre os roteiros mentais e a ação concreta. Nos homens de todas as idades, o problema talvez seja a relação sobredeterminada entre os roteiros e as atividades concretas (p.144).

A sexualidade é compreendida por André como algo difícil de ser definido: “...não sei, a palavra, assim, sexualidade, parece... ah, sei lá, parece... lembrar, masculino e feminino... é... pode ser, tipo, como se trata isso, como se trata o sexo". (...) Sexo, acho que... teve lá, o ato que a gente faz, sexual... não... tem muito... mais ou menos, lembra... lembrar lembra isso... e... pra mim, lembra muito isso, só, sem, tipo, as sensações em torno, sabe? Há um meio... fisicamente aquilo, é aquilo, sexo fisicamente é isso. O que lembra é isso, o ato sexual. É fisicamente, sabe, sexo... O que é sexo?... É duas pessoas, juntas, fazendo sexo! Não é a sensação, não é tipo o que elas dizem... 'Sexo é duas pessoas se amando, fazendo o ápice'. 
(...) Vamos supor, com uma menina que você goste, que você quer... então, você vai falar, sentir a pele dela, sentir isso, ou aquilo, beijar ela... é sexo? A primeira idéia que vem na minha cabeça: não, não é sexo, é mais que sexo! É, tipo, sexo mais... sei lá, algum... dá algum nome pra... pra essas coisas, sabe? Tá? Tipo, sentir a pele dela, o cabelo dela, sentir bem por causa disso, e aí sexo, falar que sexo tem o prazer, sexo que é tipo... aquela hora que você chega no máximo e aí tem aquele prazer. Só que o... por que a gente tá falando? Pode ser mais... gosto dela... se sente bem tocando a pele dela, e isso pode dar mais prazer sentindo, tocando a pele dela. Mas a primeira idéia que vem de sexo é uma coisa... física”. Nesta fala de André é mostrada a tensão entre o sentimento que vivencia no encontro afetivo-sexual e aquilo que idealiza deste encontro no encontro dos corpos, na presença dos sentidos e do prazer compartilhado.

\section{1. “Acho que eles não entendem o problema psicológico que eu tenho...": o relacionamento de André com os pais}

Ao longo da infância, André apresentou enurese noturna. Os pais o levaram a diversos médicos em busca de uma solução, mas sem sucesso. Mais tarde, por volta de 12 anos, iniciou psicoterapia: "Daí eu fui pra psicóloga e resolveu a enurese noturna, mas eu larguei a terapia depois de um, quase dois, um ano e meio, e foi por conta própria porque, sabe, tinha resolvido o que parecia ser o problema. Nesta época eu estava com uns 14, 15 anos". Interessante ressaltar na sua fala o termo de que "parecia ser o problema", sugerindo que a enurese era apenas uma manifestação de uma dificuldade que, nesta época, não era possível ser delineada.

André acredita que a enurese estava relacionada à dificuldade no relacionamento com os pais: “...até hoje acho que eles não entendem realmente o problema psicológico que eu tenho". Ele sempre se opôs ao fato de a mãe sempre ter tentado mimá-lo, atrelado ao distanciamento do pai: "Vir pra São Paulo foi livre opção, eu poderia ter ficado no interior... Eu quero me desligar, entende, e isso que gera o conflito, e ela sempre fazendo isso, um jeito, mas alguma coisa ficava do jeito dela. E meu pai é alcoólatra, não sei se isso tinha a ver. Eu acho que tem, porque eu sinto uma ausência dele e hoje o que mais dá rolo, assim, minha terapia é tentar arrumar essa ausência, tentar me aproximar dele, e é o que eu menos 
consegui até agora, porque... tudo bem, ele é... ele é super bom em certos momentos, ele... me... ele... mas ele... o problema é que ele me enche de dinheiro e acha que isso resolve, e... sabe, num... e eu consigo fazer enxergar os problemas, às vezes, e tipo, às vezes eu tenho que ficar sozinho com ele e conversar, e é sempre um negócio seco, assim, quer dizer... ê".

Quando ingressou na faculdade, André retomou a psicoterapia com a mesma psicóloga que o atendeu quando apresentava enurese noturna. Dois fatos contribuíram para que ele voltasse para a terapia: a insatisfação com a qualidade do sexo com a namorada; e o fato de ter entrado na Faculdade de Engenharia. No seu ingresso no curso, os problemas se intensificaram e foi quando procurou o Plantão Psicológico, pois a sua psicoterapeuta atendia em sua cidade natal. André aponta os ganhos com o atendimento psicológico: “...abriu muito minha cabeça, e mudou muitas coisas, então, tipo, às vezes... eu acho que agora eu tô mais correto, não sei, mas tá diferente, pelo menos".

\section{2. "Passou, e aí? O que a gente faz agora?": o ingresso na faculdade}

Foi impactante para André a diferença entre o ritmo do cursinho e o ritmo da faculdade. Nesse momento percebeu suas dúvidas: “...agora eu sei que era o que eu queria, na época acho que eu fiz a outra entrevista ${ }^{34}$, eu tava em dúvida, tinha muita raiva da [faculdade] quando eu entrei, porque eu tava acostumado com faculdade do interior, e não sei... Meus amigos todos ficavam lá e é uma festa, toda hora, uma bagunça. A [faculdade] é bem diferente disso, acho que eu sofri muito quando eu entrei. (...) ...Não enxergava o que realmente era, não enxergava que isso realmente aconteceu mesmo porque eu também não conhecia. (...) Eu entrei na [faculdade], fiquei... fui ficando decepcionado, tipo, no dia mesmo eu já fiquei decepcionado porque no dia que eu fiz a matrícula, sabe, eu fiquei muito nervoso".

Fora a mudança do contexto, o outro choque de André no seu ingresso na faculdade foi quanto ao seu desempenho nos estudos nesta nova realidade: “...foi desastroso, o primeiro semestre... sabe uma pessoa que estava acostumada, que passou super-bem na faculdade?... Realmente eu passei extremamente bem, muito, muito bem, e... ia muito, muito bem no cursinho e, no interior, então, era mais simples ainda. E aí chega ali e se ferra em tudo!

\footnotetext{
${ }^{34}$ Referindo-se à primeira entrevista para esta pesquisa.
} 
Hoje, por exemplo, eu tenho $3 \mathrm{DPs}$, eu que nunca... sempre passei logo nas provas do $3^{\circ}$ bimestre. Ou, mesmo na FUVEST, tipo, poderia ter deixado de fazer, acho, duas provas de $2^{a}$ fase que eu passava".

André percebe que este sofrimento vivido esteja relacionado com a precariedade nas condições daquele momento quando diz que: “...foi um ano que eu fiquei muito angustiado no cursinho, eu realmente só estudava. Talvez esse tenha sido um grande problema, carga local. Ainda mais tinha tudo isso. Na [faculdade] eu não consegui manter isso, porque eu não tinha vida no cursinho, era... não curtia as coisas, era uma máquina... E, um problema que eu tinha, que a gente... sei lá, estudou na terapia que eu até hoje... fechava os sentimentos ou... eu vivia pra, tipo, pras pessoas acharem isso ou aquilo, sabe, muito... na cabeça era muito racional, e era: 'Eles vão achar isso ou aquilo', sabe? E aí com todo esse bolo de problemas, a [faculdade] ferrando, uma coisa que eu não sonhava... sei lá’. Assim, André indica que o seu ritmo nos estudos sempre foi intenso.

\section{3. "Foi uma sensação... estranha, não parecia que eu tinha transado": a primeira relação sexual com uma prostituta}

Seis meses antes da sua relação sexual com Beatriz, sua namorada, André teve uma relação sexual com uma garota de programa que encontrou pela internet: "Quando eu tava (...) bem próximo de 17, 18, eu tive minha primeira transa. Foi com uma prostituta. Quando eu fui transar com a prostituta foi por curiosidade, acho, puramente, assim. (...) Era um anúncio que tinha na Internet tinha uns negócios e pronto. Eu liguei e ela veio no meu apartamento". André descreve como percebeu a experiência, naquele momento de vida: "Foi uma sensação... estranha, não parecia que eu tinha transado... uhn... não sei. Continuou minha vida normal. É o que eu falo, aquela época eu já tava bem no limite, assim, sem saber. Então eu acho que eu já tava fechado, e tudo, assim, então acho que eu não senti nada... quase. Eu não sentia muita coisa, sabe? (...) Agora o que eu acho é que, tipo, foi um negócio, sabe, eu nem lembro... Quando eu lembro, assim, quando foi minha primeira transa eu não penso que foi com ela, sabe? Não sei, porque foi algo rápido, foi estranho, foi, tipo... é... seco... e... foi engraçado, porque depois eu fiquei conversando, eu queria descobrir, sabe, tipo, coisas dela, e isso foi engraçado... Depois de conversar um pouco, ficamos juntos, e ela foi embora. Era 
meu apartamento aqui em São Paulo, eu morava sozinho". Este cenário apontado por André pode remeter ao que já foi citado antes quanto ao sexo idealizado e ao sexo real. A expectativa pelo primeiro encontro sexual foi tamanha que teve dificuldade de usufruir das sensações proporcionadas naquele momento.

Com relação a esta experiência com a garota de programa, André enfatiza: "A minha primeira vez foi num lugar longe, num hotel, até, num hotel... E.. sei lá, a primeira vez... esquece a primeira vez, a primeira vez com a minha namorada". O registro para si da sua primeira experiência sexual associa-se à sua namorada, talvez por ter sido atrelado ao aspecto afetivo, e não apenas à contratação de um serviço.

André acredita que naquele ano de cursinho pré-vestibular isolou-se muito devido à sua dedicação aos estudos: “...eu preferia não... não resolver com minha namorada, e a gente ia transar, eu preferia pagar e transar ali, entendeu? Queria conhecer também, legal, tal, como não, mas outras coisas, tipo eu tava muito... estudando demais, me fechando cada vez mais, e ficando meio... meio fora do ar".

\section{4. "A gente estava os dois descobrindo juntos": o primeiro namoro e o início da sua vida sexual com sua namorada}

Por volta dos 15 anos, André e Beatriz começaram a namorar. Beatriz era 1 ano mais nova do que ele: “... a gente começou a namorar, ela tinha um ano a menos que eu, né? E a gente fazia sexo oral e... brincava, aí, tudo, desde essa época, desde, assim... passou aí um ano de namoro, a gente já fazia de tudo isso e... com uma certa constância. (...) A gente estava os dois descobrindo juntos. Não foi só... só uma coisa... E era o único meio, porque não rolava transa por... pela parte dela".

A época em que André ensaiava experimentar uma relação sexual completa acontecia de ele ter entrado na faculdade, uma época delicada de mudanças e de novos rumos na sua trajetória. André apresenta a sua percepção de como foi esta época quando se relacionava com Beatriz: "Na época era... parecia que tudo dava errado. Eu tava namorando, ainda, e tava uma coisa extremamente... na época acho que não tava uma coisa extremamente fria, mas 
tava mais ou menos. E com essa racionalidade, acho que o grande erro foi que a gente decidiu quando a gente ia transar a primeira vez, sabe? Algo quase de robô (riso). Nesse dia, assim, quando a gente foi transar pela primeira vez... E foi horrível, foi tudo planejado e não deu certo, e não transou. Porque chegou na hora, e foi estranho e, tipo... uma coisa que até hoje é assim, é estranho, é ir pro motel. Isso já é horrível. E... não que talvez seja a lembrança disso, porque é uma coisa estranha". A idéia de sua primeira relação sexual em um relacionamento mais-ou-menos, atrelada ao contexto impessoal de um motel mobilizou um estado de estranhamento em André, dificultando que ele se lançasse à experiência do encontro sexual, despertando a sensação fria de quase-de-robô.

Em outro momento, André retoma o relato sobre o início das relações sexuais com Beatriz, comparando-o com a experiência que teve com a prostituta: "Antes da primeira vez com a minha namorada, eu tinha transado com uma prostituta na minha casa em São Paulo. (...) É que essa que eu considero a primeira vez. Eu acho a outra uma coisa... 'xis'... e... bom, aí a gente foi, não deu certo, eu... acho... tive ejaculação precoce, não sei, meio, e depois eu não consegui mais. A gente ficou tenso, o negócio, e enrolava. André descreve a relação com a prostituta com a obscuridade de um "xis", manifestando o quanto aquela experiência não ficou clara para si, tornando até mesmo difícil a sua explicação, a não ser descrevê-la. A não familiaridade com a situação sexual não favorece que ela seja prazerosa como André gostaria que fosse, porém, dada a ansiedade também não é favorecida a apreensão da experiência como um processo de aprendizado do encontro sexual (Gagnon, 2006). Vale também destacar que numa sociedade ocidental patriarcal, a "primeira vez" masculina, tem um peso significativo tendo em vista seu caráter probatório da virilidade (Castro, Abromovay \& Silva, 2004). Todo este cenário, atrelado a uma cobrança interna já presente, o super-desempenho era algo mais valorizado do que a possibilidade da experiência de novas sensações.

Quando foi ter a sua primeira relação sexual com Beatriz, cerca de 2 anos depois que teve a experiência com garota de programa, de certo modo, existia um planejamento dele e da sua namorada para esta experiência. Eles estavam a sós na fazenda dos pais de André. Esta experiência, em outra proporção, tornou-se tão obscurecida quanto a experiência que teve com a prostituta: "Eu nem lembro direito, parece que a memória apaga, um pouco e depois, o que aconteceu. Qual foi a nossa reação? Só sei que foi horrível. Eu fiquei com raiva na hora". Na fala de André, vê-se que aquilo não poderia ter sido daquela forma que o esquecimento é considerado bem-vindo, uma forma de "xis" que não favorece a compreensão 
daquela experiência na sua integridade, reduzindo-a a algo "horrível". A raiva surge como reação quando sua expectativa foi por terra. Neste cenário de tensão, a percepção da experiência em termos sensoriais restringia-se de forma a não favorecer o sexo.

André descreve o desdobramento desta noite: "Depois, no outro dia, eu lembro que pouco tempo depois a gente tava em outro lugar e... sabe, tipo, rolou, assim, aquela coisa assim, a gente começou a se beijar e tal, tal... aí que era um lugar que não era pra gente transar... não era assim, era sozinho, a gente podia transar mas não era combinado: 'O lugar 'xis', na cama tal, do jeito tal'. Poderia ter rolado, mas sei lá, ela não topou. Isso eu tenho raiva, de novo. Isso aconteceu quando estávamos na fazenda que meus pais têm, uma fazenda no interior (...). A gente tava na piscina e tal. Aí depois foi se trocar, pra ir no banheiro. Nós dois só, na fazenda inteira... e em qualquer lugar (riso). Mas não rolou porque ela não queria que fosse assim, sabe, naquele lugar, que a gente tava no banheiro e tal. E... bom, com certeza eu tava só querendo provar que eu conseguia, tipo, foi uma coisa que eu fiquei fazendo... depois... acho que... meu namoro, hoje eu tenho certeza que ela não era a pessoa certa, a gente era muito estranho, muito diferente, mas talvez isso ajudou a destruir, a chegar no fim do namoro, eu sempre tentava transar com ela provando que eu tava... que eu conseguia, sabe?". Neste momento André aponta para outra situação da experiência: de um lado a descontração e o relaxamento facilitadores para a expressão do seu desejo, sem o peso de uma situação-xis; do outro lado, a vontade de Beatriz para que este momento fosse especial e que, certo modo, acabava se tornando a tão temida situação-xis para André. A necessidade de André acaba sendo a de provar para si mesmo que poderia ter uma relação sexual, pois sentia que todo o cenário favorecia. Nesta prova-de-fogo a tensão era companheira certa, o que diminuía ainda mais as chances de usufruir das sensações eróticas da experiência, acontecendo o reverso, tornava-se um fardo para si.

\section{5. “Pô, vai falhar de novo?”: o padrão de qualidade no sexo}

As relações sexuais com Beatriz aconteceram posteriormente, mas quase nunca eram gratificantes para ele. $\mathrm{O}$ trabalho da psicóloga que o tinha atendido no passado surgiu para auxiliá-lo a compreender a obscuridade da experiência: "Foi o que aconteceu depois... que eu não consegui tran..., não foi bom transar com ela depois, eu não me lembro ao certo se eu 
transei com ela só depois de ir na psicóloga ou antes, mas sei que aconteceu outras vezes de... de não dar certo, de eu broxar, e todas as vezes depois eram tipo... ruins, sabe? Era rápido, às vezes, era estranho, não era bom". Quando não tinha problema de ereção, a ejaculação rápida se fazia presente restringido, seu prazer. A qualidade do contato com a experiência não era das melhores e o auxílio psicoterapêutico foi buscado.

Começou a ficar mais claro para André que a tensão, proveniente da sua autocobrança, era um obstáculo importante na limitação do seu prazer: "Eu acho que o que influenciava nesse problema, eu acho que a tensão, assim. Por que que eu tenho a tensão? Foi porque, acho, que eu broxei uma vez e porque... sabe, na primeira vez, com a minha namorada (...) Eu era muito, antes, que eu falei já... preocupado com o que as pessoas pensavam, sabe? Tinha que ser aquele estereótipo. Fechava tudo que eu sentia para mostrar que era alguém que eu queria ser. E isso com uma prostituta eu era muito.... 'Foda-se o que ela vai pensar de mim, ela está sendo paga. Ela tem que pensar no dinheiro'. Agora, com a minha namorada, e com as outras meninas depois, não, então talvez esse era um problema que eu tinha e que talvez ainda tenho, uma preocupação minha... é... aí minha psicóloga brinca de... tipo, de padrão de qualidade, sabe, pra eu deixar de lado esse padrão de qualidade. Porque fica correndo atrás disso e o negócio perde a... sei lá, a sensação. E o pior de tudo: na primeira vez que esse padrão de qualidade tinha que ser seguido ele falhou, entendeu, que era com a minha namorada, então... ferrou tudo, eu tinha medo, depois, sabe...: 'Pô vai falhar de novo?'. Ainda mais isso, uma coisa que não tem jeito, sabe? É foda!"'.

A necessidade de provar que podia relacionar-se sexualmente e, assim, fortalecer sua virilidade, formava uma rede complexa de pensamentos que prejudicavam perceber aquilo que fazia sentido para ele naquela situação. A obrigação de transar, de valorizar a performance tornou-se mais importante do que o contato com experiência atribuindo sentidos. Isto vai ao encontro da sua auto-percepção nesta época citado anteriormente de que: “...Eu realmente só estudava (...), eu não tinha vida no cursinho, era... não curtia as coisas, era uma máquina". O fato de estar com uma prostituta, de certo modo, quebrava esta obrigatoriedade da relação sexual, pois estava adquirindo um serviço. Deste modo, cabia a ele usufruir ou não daquele momento com uma parceira que certamente não o cobraria futuramente diante de uma "falha". Depois de paga, a parceira iria embora com as marcas e registros deixados pelo encontro. 
André segue falando sobre a namorada: "Então, continuava me cobrando com minha namorada, por isso era horrível, transar com ela. Não tenho recordação nenhuma de transa maravilhosa com ela. Depois disso, bom... eu e a Beatriz transava, certo, e aí eu comecei a ir na psicóloga e a gente começou... comecei a melhorar e transar com a minha namorada, assim, eu conseguia, e tal, mas não era bom, não era...". Nas suas palavras, a sua relação com Beatriz foi ficando cada vez mais fria. Depois de 4 anos e 2 meses de namoro, André e Beatriz se separam: "Tava muito frio nessa época, já, o namoro, e eu acabei largando da Beatriz. Num... eu notei que não teve problema nenhum eu largar, foi a coisa mais simples que eu fiz. Eu notava que já tava terminado fazia tempo". No trabalho psicoterapêutico André foi incentivado a ter contato com os significados que atribuía à sua experiência, dando contornos e cores aos fatos vividos. Num padrão-máquina que regia seu modo-de-ser, em que a produtividade e a performance são essenciais, a psicoterapeuta auxiliou-o a compreender a necessidade de um padrão de qualidade cuja premissa é de que os produtos e serviços sejam o mais primorosos possível, beirando a perfeição, algo incompatível com a condição humana, resvalando para o desumano. André demonstrou nesse momento o preço que muitos homens pagam para manter o ideal masculino de desempenho sexual. A dificuldade torna-se ainda maior quando na aflição da dificuldade sexual o homem não percebe aquilo como o desdobramento de um modo-de-ser e não necessariamente algo próprio do funcionamento peniano (Toniette \& Lilienthal, 2005). No caso de André, quando ele percebe sua autocobrança de atender a um padrão de qualidade gera tensão, as condições se tornam mais favoráveis.

Além da dificuldade afetiva com Beatriz, André lembra que nessa época o fato de ter entrado na faculdade também gerava tensão, indicando que o desempenho sexual está vinculado ao seu grau de bem-estar geral: "Esse ano que a gente ficou transando, foi o ano... de $1^{o}$ ano de [faculdade]. Além de tudo, eu tinha [faculdade] na cabeça, que ferrava tudo e enchia o saco, eu não conseguia nem sair direito de tanto cansaço... e eu ainda tava com... eu fiquei meio em estado depressivo. Eu tomei remédio, pra ir... quando eu via que tava num ponto de pico, pico assim... quase, nossa, agora eu lembro, eu sei que era muito foda, muito estranho. Foi muito horrível assim, sabe?". A tensão vivida por André era tamanha que a medicação e a psicoterapia foram as alternativas buscadas para encontrar uma forma de alívio: "No final a gente [ele e a psicóloga] chegou à conclusão de que tudo isso era um problema que tinha em mim, já... psicológico, acho, não sei, um problema de toda essa criação. Alguma 
coisa faltou. Não sei se foi meu pai, se foi minha mãe que me mimou demais, os dois juntos... A minha cobrança que sempre existiu, eu sempre me cobrando porque ninguém me cobra, mas eu me cobro. Então tudo isso precisava ser arrumado. A enurese noturna era um escape, que era verdade, que tipo quando tinha prova, essas coisas, um momento de tensão, acontecia com mais freqüência. Depois... veio todo esse estado depressivo que além de... de não ter ereção era... sei lá, tava estressado, tava... uma pessoa incomum, sei lá, não era eu, assim, não conversava direito, tava... altamente fechado. Tava muito, muito mal, muito mal. Nesta época eu estava com 19 anos... 18 pra 19 anos".

Mais adiante no seu depoimento, André revela que o que mais marcou a sua vida sexual foi justamente a dificuldade ocorrida no relacionamento com Beatriz: "Na minha vida sexual o que mais me marcou... uhm... não ter transado com a minha namorada, a Beatriz, acho que... sei lá, aquela vez que a gente foi pra transar. Mas já esqueci um pouco, já. É estranho, parece um ponto lá atrás, que já não... não é mais tão marcante, mas talvez tenha marcado negativamente. Por outro lado, agora, sei lá, as últimas vezes foram boas, assim, acho que... com a... com a Mônica, várias coisas aconteceram positivamente como ter falhado, depois ter conseguido, foi bom".

\section{6. "Existe uma ciência por trás disso, então eu confio mais": André procura o Plantão Psicológico}

André ressalta no seu relato a presença constante da auto-cobrança para que corresponda às expectativas, o que culminou na depressão, aumentando significativamente os conflitos vivenciados: "Não era estresse, era... depressivo, mesmo, sabe? Tava mal, não tava no lugar certo... Era horrível. Tipo, às vezes, eu pensei: 'Pô, fui fraco, devia ter agüentado, sei lá, o que aconteceu’. As poucas vezes que voltou, que foram coisas diárias, às vezes pontuais, assim, um momento que me dá um negócio doido... sei lá, que eu fico mal no lugar que eu tô, que eu quero fugir, que me dá uma coisa, assim, estranha... (...) Depois teve um momento desses que eu vi que tinha alguma coisa errada, que eu vim aqui no Plantão". A angústia e o estranhamento daquele momento de vida de André foram base para que procurasse ajuda, a fim de que tivesse algum senso de pertença àquele contexto que considerava hostil que lhe exigia fazer escolhas que não meramente a fuga. A cobrança interna também foi um fator 
importante e continua presente de forma pré-reflexiva quando diz ter sido fraco - ou seja, não viril - e que deveria ter suportado aquela situação que o estava deixando confuso.

No Plantão Psicológico André sentiu-se acolhido, amparado e compreendido, a ponto de ele fazer um paralelo: "Acho que é uma solução racional, que tá dentro do meu padrão do que eu acho racional, acho que... tem que ser uma coisa racional, não entro numa igreja pra ficar rezando, assim, sabe, então... a igreja não é racional, então, não... existe uma ciência atrás disso, então eu confio mais. Não sei, às vezes, a pessoa tá se sentindo bem... e eu me sinto bem indo na terapia. Porque é racional, mesmo, né? Então... eu vim pra cá. (...) ...Eu lembro que realmente foi difícil, assim, aquela época, que não dava pra ter saído sozinho. As poucas vezes que aconteceu isso, às vezes de madrugada, de eu ligar pra minha psicóloga e conversar um pouco com ela... É muito ruim. Mas não é sempre que acontece. Esta psicóloga é a mesma que curou da enurese noturna". Enquanto o Plantão Psicológico é associado ao aspecto racional da ciência, o que desperta maior confiança do que a igreja que é percebida como não racional e que é lugar onde se reza. André necessitava de medidas mais práticas, como foi a sua busca pelo Plantão Psicológico, ou mesmo de psicoterapia, a ponto de fazer contato telefônico com sua psicóloga quando sente-se muito mal.

\section{7. “A saída: eu falei 'Foda-se!"” novos significados e sentidos para sua sexualidade}

Depois de ter rompido com Beatriz, André passou por um período sem relacionar-se sexualmente: "Eu tava sossegado, eu queria curtir com meus amigos, e tudo, tá, acabei ficando com várias meninas diferentes, fazendo várias coisas, mas não transei com elas. Chegou até perto, mas não transei, e tal. Depois comecei a ficar meio de rolo, não namoro, com uma menina que era mais nova... um ano mais nova, só que ela era bem fechada, assim, e também não rolou nada". As festas e os encontros com os amigos do interior eram constantes. André passa a investir mais intensamente no âmbito dos seus relacionamentos sociais, desfocando de forma sutil do âmbito sexual: "essa época foi muito forte pros meus amigos, assim, pra minha turma, não só amigos, tinha amigas também, tipo, da minha turma lá do interior, a gente fazia muita bagunça, muita festa, curtia muito". 
Foi em um destes encontros que surgiu uma nova possibilidade de relacionamento com uma antiga amiga de infância: "Tinha uma amiga minha, muito amiga, a Mônica, que quando eu era criança eu gostava dela, tal, mas era muito amiga mesmo... Eu gostava assim, eu lembrei dias depois, era bobeira de criança, mas eu tava agora... e aí a gente ficou, e já tava meio próximo da gente ficar, assim, já tava segurando porque achava que ia dar rolo, porque era amiga, e tal... Deu (risos). Tô contando o final da história, já: deu. Cortou um pouco a amizade, assim, bastante assim... foi estranho. A gente transou na boa, mas... foi estranho. Mas com ela foi... mas também não deu certo a primeira vez, tipo, não rolou ereção, assim... teoricamente. Na hora que eu quis não deu certo, mas meia hora depois deu. Então... mas com ela foi ótimo, assim tipo, teve várias vezes muito bom, maravilhoso. E... com ela foi estranho, sei lá, a gente logo que a gente ficou, como a gente era muito amigo, a gente já dormiu junto, mas enrolei de não fazer nada porque a gente tava meio bêbado, e a gente tava zuado, e era na chácara, todo mundo da turma dormindo lá. (...) ...Isso foi pouco tempo, foi uma semana, acho, foi uma semana e... a gente ficou". A amizade e o relacionamento íntimo nos dizeres de André não eram incompatíveis, embora lhe causassem estranheza quando aconteciam. Mais tarde ele reconhece o quão foi prazeroso aquele encontro.

André aponta o auxílio psicoterapêutico como importante recurso para compreender novos significados e sentidos para sua vida, inclusive no aspecto sexual, e abrir-se para os relacionamentos: "Eu já tinha conversado com a minha psicóloga várias vezes, duas vezes antes, e eu tava tenso, sabia que, tipo, tava ali para acontecer, e era com uma grande amiga minha. Se desse errado ia ser muito estranho". Porém, diante da situação do encontro com Mônica, o embaraço frente ao desconhecido se fez presente, mas, agora, a tensão cedeu lugar para o humor: "E foi engraçado, porque dessa vez, sei lá, eu tava mais preparado, assim, não sei, era uma pessoa que eu confiava muito, que tipo, que ia dar, eu ia ficar sossegado, e na hora que eu fui transar com ela não deu certo. Eu tava tudo beleza, mas é incrível, tipo assim, uma coisa que eu notava, que eu notei, na hora que eu pegava a camisinha, que eu ia por, sabe? Acontecia alguma coisa, não dava certo. Só isso. Se eu parasse e voltasse a fazer tudo normal, beleza. Se eu ficasse ali junto, né, sexo oral, beijar, só, aí.. bom, não. Quase que da primeira vez isso aconteceu com ela, daí eu fiquei um tempo tenso, daí, na mesma hora, voltou normal nesta primeira vez que eu transava com ela. E... mas sei lá, na hora eu fiquei meio tenso, assim, primeiro eu parei, e falei pra ela que, sei lá, era muito amiga, que tava estranho, sei lá. Mentira, eu não sabia por quê. E... aí eu fiquei quieto um pouco, parado. Eu 
não sentia raiva nem, tipo, eu precisava fazer isso... Eu falei: 'Ah!...', e foi a grande saída, mas eu já tinha conversado muito disso, com a psicóloga, então já (riso) tava encaminhada a saída: eu falei 'foda-se!', e fiquei deitado, pensando na vida, até. Tipo... rolou. Depois, de novo. Isso, vai, passou, meia hora, enfim. Aí sei lá, rolou sem camisinha e foda-se, depois no meio a gente parou e pôs a camisinha. E... aí, depois disso, todas as vezes aconteceu na boa".

Esta parte do depoimento de André aponta para algumas sutilezas que envolvem o prazer e o sexo protegido. Diante da tensão, do embaraço, foram deixados de lado recursos importantes para a prevenção de doenças sexualmente transmissíveis e da gravidez não planejada. A prioridade para André era concretizar o ato sexual com alguém por quem tinha afeição e ternura. André percebeu a importância de despojar-se daquilo que considerava ideal em uma relação sexual e utilizou o recurso do "foda-se", no sentido de abrir mão de referenciais pré-concebidos e abrir-se para a nova experiência que se apresentava, sem se importar com o "controle de qualidade". Com a maior flexibilidade, o prazer tornou-se possível, sendo que todo o seu organismo correspondeu àquele momento. Um mês depois, André foi para Florianópolis, onde Mônica estudava. Ele ressalta: "A gente não namorava, a gente era só amigo, mas aí... e... a gente se falava bastante”. (...) Também fiquei meio tenso, e tal, mas não, foi sossegado, foi tudo bem. E aí meio que acabou o problema...”.

Depois de um tempo conheceu outra garota, Cínthia, 13 anos mais velha que ele, com quem também teve experiência sexual. Novamente ele aponta a camisinha com um empecilho na relação sexual: “...Transei com outra garota. Muito estranho, ela tem 34 anos, bem mais velha que eu. Só que... também, sei lá, foi a mesma coisa, assim, na hora de pôr a camisinha ficou meio estranho e tal, não rolou muito, mas... essa não levou 5 minutos, assim, então, sei lá, voltou ao normal. É... é algo estranho, tipo, sei lá, na hora que eu ponho a camisinha, uma coisa que eu notei da última vez, eu... com certeza, não tem mais a preocupação de fazer a pessoa... tipo, 'não, ela tem que achar maravilhoso, a melhor da vida dela', mas, claro, eu continuo com a preocupação, um pouco, com o padrão de qualidade... tipo querendo, dar uma coisa boa, assim, mas na primeira vez eu não penso isso, sabe? E tipo, eu notei que foi muito melhor com a antiga, a Mônica". Ao longo da experiência vivida, consolida-se aos poucos uma percepção mais positiva e tranqüila do sexo. A camisinha, aos poucos, integra-se ao jogo erótico, tornando possível a excitação. O roteiro sexual de André, a partir das novas experiências, é aos poucos aprimorado, e o "padrão de qualidade", marcado pela autocobrança e pela idealização, cede espaço para o prazer compartilhado. 


\section{8. "O que mudou comigo não é só com o sexo": apropriando-se da sexualidade enquanto parte de si}

A descoberta da sexualidade e da vivência sexual quase sempre é cercada por tensão, embaraço, incerteza, carência de referenciais (Gagnon, 2006). O sexo, assim como a sexualidade como um todo, torna-se uma ficção, algo que muitas vezes parece estar apartado da realidade humana fortalecendo, assim, uma série de idéias e valores que funcionam como base para a idealização desta vivência

A partir da experiência de André vê-se que o sexo ganha contornos de uma possibilidade a mais de expressão e vivência do afeto e do prazer. A experiência do sexo repleta de tensão e de embaraço pode ser compreendida como um modo como ele a si mesmo e ao mundo: "O que mudou comigo não é só com o sexo. Teve uma... com tudo, né, teve uma liberação, total, assim, tipo, apertei um 'foda-se', um pouco. Foi uma coisa... foi um momento de... naquela hora da depressão foi um momento de desregular tudo, assim... tava... talvez até estabilizasse, mas vamos supor, uma cobrança... lá em cima, não sei se crescendo ou tava estabilizado, mas tava lá em cima. Talvez acho que até crescendo, porque as coisas começaram a dar errado, [faculdade] dava errado, uma coisa que eu sempre me dei bem, com a escola, tava dando errado. Eu... coisas que eu normalmente falava... eu, tipo, no interior, sabe, de uma cidade que tem 7 mil habitantes agora, então eu conheço todo mundo e você não é mais um, sei lá, em São Paulo você é mais um. Então, você não se sente no seu lugar, cê... cê tudo tava dando errado, então talvez eu me cobrava mais, sexo dava errado, com minha namorada, algo, tipo, três anos programando, aí na hora, no momento, que eu fiquei mesmo muito mal. E aí quando eu procurei ajuda foi quando deu... deu uma desregulada forte, assim, tipo... fiquei um bom tempo, talvez um ano ou mais um pouco, desregulado, assim, de alta cobrança e caia num zero, assim, fazia tudo o que me dava na cabeça, fazia uma pá de coisa errada, nada extraordinário, assim um... não fiz nada fora do comum". André não só se apropria da sua sexualidade, mas se apropria de si, das suas angústias, do seu modo de compreender a si mesmo e do seu modo de compreender o mundo, "nada fora do comum", mas justamente tomando posse da sua experiência.

A abertura e o senso de liberdade possibilitados pela flexibilidade deste momento levaram André a vivenciar novas experiências, diferentes daquele modelo ideal do "bom moço": "Bom, tipo, a [faculdade] ferre-se. A minha namorada não dava certo mesmo, não 
tava mais com problema de não ter ereção, mas não tava curtindo e larguei, sem o menor problema (...). Eu lembro que teve a mãe de um amigo meu, que hoje mora comigo, que, sabe, tudo se espelhava em mim (...) Depois... ela proibiu ele de sair comigo (...). Nessa época eu ia pra balada e sempre, sexta e sábado, e bebia muito, eи e o amigo meu, que também, até hoje ele bebe muito, mas eu parei, sabe? Aquela curtição. Foram, assim, 6 meses, acho, por exemplo, de balada e tem... tudo pra contar, e todas, sabe, liberadas, tipo de voltar de madrugada bêbado dirigindo o carro, de nem lembrar pra onde ia. E isso é perigoso. Depois, racionalmente, tá errado, mas aconteceu. Uma coisa que eu não faria. Essa preocupação com as pessoas na [faculdade], temia a minha DP e não tava nem aí... é... foi degradando tudo, sabe?".

André vai de um extremo a outro. Num um extremo, está o "bom moço", que estuda, tira boas notas e preocupa-se em passar uma boa impressão a outras pessoas. No outro extremo, o rapaz rebelde, enfrentando limites que colocavam sua própria vida em risco. A conclusão que André faz deste momento é de que: "Então, sei lá, é bom errar, ser humano, e era isso que eu apertava um pouco pra não acontecer: não errar. Então tudo isso foi mudando, foi ficando bom, deu tudo certo, tipo eu errava, e... igual, aconteceu com a Mônica. Errei sério... errei... inclusive foi uma coisa muito engraçada, quando aconteceu isso com ela na hora, depois que eu fui conversar com a minha psicóloga, falado o que tinha acontecido, parecia que eu tinha que dizer: 'Eu erro', sabe? Aí eu falei: 'Eu errei... tá vendo?' Aí: 'Tô vendo'. Aí: 'Beleza, agora vai!'”. André apropria-se do erro, daquilo que era considerado inadmissível por aquela identidade que acreditava ser a sua, enquanto parte da sua realidade. Com novas experiências, passa a ter uma nova dimensão de si e do mundo.

André reavalia sua experiência de relacionamento com Beatriz, Mônica e Cínthia. Com Mônica não existia namoro, mas uma relação de amizade em que desde a infância de ambos o afeto sempre foi presente. Interessante notar que Mônica torna-se referência quando ele fala das outras namoradas: "Com a Mônica, tipo, um momento de curtir, assim, de achar legal, coisa que nunca existiu com a Beatriz, assim, bem longe de existir com ela. A diferença que existia era de curtir, sabe? De ficar... sei lá, era bom o sexo com a Mônica, com a Cínthia, agora, com a Beatriz, não. Não era um negócio... não... sabe? Na época eu podia achar... bem claro, acho, com a Beatriz era, sei lá, aquela sensação do momento, e aí quando você chegava no final, aí pronto, acabou. Com as outras duas, não, era um negócio, tipo legal, assim, bom, tinha mais do que só transar e sentir aquela sensação na hora que acabou, 
sabe? Tipo, com duas teve um negócio, assim, tipo, na hora você está se sentindo bem, você tá... mais sensações, assim, não sei”. A vivência sexual associada à vivência afetiva torna-se mais gratificante para André do que a vivência sexual como algo executado de forma mecânica.

André reconhece a importância de Mônica para perceber o prazer que os relacionamentos podem trazer: "A Mônica foi ótima pra ajudar nisso, porque ela também, tipo, sossegado. (...) A gente não namorava. Eu fiquei com outras meninas daqui, ela podia ficar com outro lá. Não sei se ficou ou não. Era algo altamente liberal, assim. Por isso eu acho que a gente tinha um compromisso, sim, e, tipo, a gente se falava sempre... Rolava um compromisso, mas era algo bem... sossegado, assim, bem liberal. E isso mostra quanto que essa cobrança, tipo, sei lá, diminuiu. Não cobrava, sei lá, altas cobranças, não noto muito isso, mas o jeito de ver as coisas, mais... menos conservadoras, assim, acho". A flexibilidade ganha espaço que até então era ocupado pela rigidez, assim como a afetividade ganha mais espaço que até então era ocupado pela racionalidade.

Depois de uma viagem que André fez para os Estados Unidos, o contato com Mônica foi se tornando menos freqüente e, quando André voltou, notou um distanciamento por parte dela: "Eu fiquei bem mal depois que terminei com ela, sei lá, não tava a fim de menina nenhuma. Rolou de ficar com uma menina, mas... com outras duas, eu acho, ou três, mas não... não dava muito certo. E a gente, sei lá, na terapia eu gastei várias sessões falando da Mônica. (...) Com a Mônica eu tentei o negócio do sentimento, assim, tipo, foi muito... foi muito travado pra eu ficar com ela, eu era muito travado com ela. Eu conheci ela como amiga, como amiga ela nunca namorou outro cara, ela nunca, tipo, ficou nem o tanto que ficou comigo. Ela era uma menina diferente do que foi comigo, talvez por isso acho que acabou. (...) Na época eu não tava a fim de terminar com a Mônica, mas ela estava diferente. Agora, pensando... não... tanto que era assim, no começo eu não queria, tipo, que acontecesse, que a gente ficasse junto, porque eu sabia que... sabe, tava estranho, foi muito estranho, porque, tipo, não era a Mônica que eu conhecia, porque a Mônica que eu conhecia como amiga não queria ficar junto com ela, namorando. Essa era diferente. Foi dando certo foi deixando acontecer... foi... no começo, eu travava, travava, muito simples, não rolou com ela, depois me envolvi. Daí, beleza, acabou, ficou mal, assim, e... sei lá, eu tinha opções de sair com outras garotas, eu tava até de rolo, mas achava muito chato sair com ela, achava muito seca, assim... A Mônica era muito foda, assim, muito carinhosa, tipo, era minha amiga, 
sabe, desde que eu nasci". O estranhamento de André se deu pela falta de clareza dos limites de até onde ia o relacionamento de amizade e de até onde ia o relacionamento de "ficantes" com Mônica, como se um fosse incompatível com o outro. Independente de qual fosse o tipo de relacionamento, André parece reconhecer, pelo sofrimento gerado pelo término do relacionamento, de que o afeto existia. A vivência deste afeto, naquele momento, pode ter sido angustiante dada a pouca familiaridade com esta situação.

Depois que terminou o relacionamento com Mônica, André passou a sentir-se só: “Depois que eu larguei da Mônica, eu tava nesse negócio de... tipo, me sentindo, sei lá, meio muito sozinho, porque ela era muito próxima de mim. Era muito bom ter ela". Foi então que começou a ficar com Cristina, que também fazia parte do grupo de amigos. André não se aprofunda ao falar sobre este relacionamento, mas define Cristina como "bonita" e também "seca": "Liguei pra ela e foi, sabe? Levei ela pra minha casa e tudo, sabe, planejei uma noite pra gente, pra gente ficar junto bem, e é incrível como tudo deu errado, com ela, por isso eu nem quis... Tudo errado, assim, ela não era aquela pessoa, ela não sabia, tipo, admirar aquelas coisas... ela não curtiu. Não sei, ela pode ter curtido pra caramba, mas foi tudo estranho, ela não era... eu acho... Tinha até rolado um clima... até rápido... mas, tipo, acho que ela era estranha, mas, tipo, acho que ela não era não. Sei lá, ela era meio seca, não era uma pessoa muito carinhosa ou... coisa que eu prestei atenção depois... falei um monte de coisa de mim pra ela e ela não falou quase nada. E... isso acho que, tipo, sabe, foi horrível ter ficado com ela. Se eu tivesse ficado mais uma vez, coisa que era altamente possível, porque tava ali fácil, talvez teria transado, com certeza...". O estranhamento e, agora, a incompatibilidade nas atitudes e posturas não permitiu que a relação se fortalecesse. Na sua fala, André mostra que foi marcante o fato de ele expressar-se para Cristina e ela não ter também se expressado. De certo modo, parece que Cristina foge do roteiro da mulher que gosta do "clima". Parece também que não existiu um tempo maior para que a expressão de ambos acontecesse de forma mais plena, porém, uma das características do "ficar" é justamente permanecer na superficialidade da relação, em um curto espaço de tempo.

Na trajetória de André, a noção de parceria ganha limites mais significativos. Em termos de prática sexual e preocupação com seu desempenho, André mostra que o fato de não conhecer a parceira influencia para que não tenha dificuldade sexual, sendo que o contrário acontece quando conhece a parceira há mais tempo: "É possível eu ir pra cama e transar, sei lá, com outra... uma menina que eu não tô nem aí, assim. (...) Esse algo seco, sei lá, tipo, eu... 
sei lá, algo sem sentimento. Será que eu iria me preocupar de acontecer e iria acontecer? Talvez eu não me preocupe e não aconteça, talvez eu me preocupe e aconteça. E acho que ia ser muito mais difícil com uma menina assim, que eu não queria, que eu tava ali só pra transar, assim, por puro... acho que prazer, simplesmente, assim. Mas não assim, prazer... é o

que eu falei da Beatriz, lá, no começo, ou da prostituta, sabe? É aquele negócio, assim, rápido, sabe, você tá ali, cê tá com vontade naquela hora, mas é um negócio meio... mó por... instinto, no fundo, que vou transar. Mas na hora que acaba, quando vê, você... sabe, não é a sensação que você sente com uma menina que você conhece, e gosta, igual foi o último, e você se sente bem e depois... sei lá, é diferente, tem mais sentimento". Torna-se mais significativa para André a relação sexual com uma parceira com quem estabelece vínculos afetivos, mas ele aponta o risco de frustrar-se o próprio desempenho sexual pelo fato de querer agradar muito quando a parceira é conhecida, ou seja, quando estabelece vínculo afetivo. Isto já não acontece quando se propõe apenas à atividade sexual, sem estar motivado para a troca afetiva, num ato que ele próprio definiu como "seco", ou "mecânico". É peculiar o grau de prazer obtido em ambas as situações.

Nos últimos relacionamentos de André, com Mônica e com Cínthia, fica evidente o grau de afeto investido na relação, não na perspectiva da idealização da parceira, mas pelo gosto da abertura para a relação e da descoberta: "Com a Mônica foi uma história, assim, de descoberta, tipo, eu querer saber". E mais adiante reforça a idéia de parceria: "Não, sei lá, o prazer das outras, que parece que é tipo da companhia, tipo de tá junto, sabe, um negócio de sentir a menina, que você quer... sabe, ter ela inteira não só... assim, como foi aquela primeira da prostituta". Ou seja, espera-se que os parceiros estejam não só disponíveis sexualmente, mas também afetivamente.

\section{9. "A camisinha é o tempo de pensar, dá prá quebrar o clima": a percepção do sexo protegido e da resposta sexual}

Ao longo da sua experiência André percebe que o relacionamento é uma via de mão dupla e que a disponibilidade e postura da parceira, portanto, também são fundamentais: "A última que eu fiquei foi bom de novo, foi com a Cínthia. Ela é uma pessoa, sei lá, carinhosa, atenciosa... foi... foi... na hora que falhou ali com ela, tipo, sei lá, quase não falhou, foi 10, 5 
minutos, sabe, a gente... 'Faça direito senão eu erro"'. Nessa relação com Cínthia, a camisinha, mais uma vez, é tida como algo que atrapalha a relação: "Então... na verdade, eu nem falhei direito, foi só... Incrível como é sempre na hora de pôr a camisinha, assim. Não sei se tem mais alguma coisa, só sei que corta. De certa maneira parece que eu me prendo muito, não presto atenção, sei lá, o negócio parece que corta, assim, ainda que eu consiga, com muito custo, não racionalizar aquele momento. Quando eu vejo, tudo pára, e, tipo... aquele negócio, sabe? Pára, assim, pra eu abrir aquilo e tal, aí eu consigo pensar e eu consigo pensar no falhar, tal... O momento que eu abro a camisinha é uma brecha para isso acontecer. E isso é ruim". Mas, nas relações com Cínthia, ambos não abriram mão do uso da camisinha, encontrando meio para a integrá-la ao jogo erótico, diferentemente do que havia acontecido com Mônica.

André retoma o relacionamento com Mônica, tentando justificar o não uso da camisinha com elementos que podem estar presentes na vida de muitas pessoas colocando-as em situações de risco: "Aí tem umas vezes que... igual a da Mônica, eu peguei, larguei mão da camisinha, fui sem, e depois eu pus. Mas ela não percebeu... mas depois a gente pôs, e tal. Nenhum problema, porque ela não tem doença... acho... com certeza. Seria só de engravidar. Mas a camisinha só quebra quando é a primeira vez, com uma menina diferente. Nas outras vezes a camisinha não quebra o clima. Com a Cínthia a gente passou um fim de semana prolongado junto. A gente transou todos os dias, três dias, e... quer dizer, três noites. E, tipo, foi só na primeira que rolou esse problema, nas outras vezes, não. Agora não sei... na hora de pôr a camisinha e não deu certo, mostrei que eu erro, e aí pode funcionar, ou... dei aquela erradinha, mas acertei, transei com a pessoa e, na segunda, já acertei, não tem nenhum problema. Acho que é um pouco isso. Acho que de... já foi, sabe, já fez... já fez a obrigação, agora pode curtir. A camisinha é o tempo de pensar, dá pra quebrar o clima. Ou... é óbvio que, sei lá, se ela pegasse a camisinha, abrisse e pusesse em mim, acho que não ia dar tempo de quebrar o clima, sabe, sensualmente, não sei... Mas eu não testei isso, ainda. Elas não testaram, elas não testaram. (...) O que aconteceu foi que eu fiquei parado. Ela, tipo, perguntou algumas coisas, eu respondi, enrolei. Ela ficou meio, sei lá, com dó. Isso que dá raiva. Aí a gente ficou junto, parado um tempo, começou a se beijar e rolou. (...) Talvez ela nem tenha notado direito isso... e... aí ficamos juntos, de novo, sabe? Na hora construí o clima e aí foi sem camisinha. E depois eu parei e pus". André aponta o risco da gravidez não planejada como justificativa principal para o uso da camisinha, porém, não queria abrir mão da sua excitação. Por outro lado, André traz elementos que mostram que a camisinha pode 
fazer parte do jogo erótico, sem "quebrar" o clima da relação. De acordo com a experiência dele, tanto a relação sexual, quanto o uso da camisinha, são situações aprendidas.

\subsection{0. "Ser homem, eu acho que... é... sei lá... homem é difícil, pô! Eu que sou homem, então falar isso...": a percepção do ser homem}

Para André, ser homem está significativamente vinculado à capacidade de provocar prazer na parceira, no sentido do "padrão de qualidade", a qual já havia se referido. Esse padrão de qualidade está intrinsecamente relacionado com a forma peculiar com que ele compreende o sexo e a sexualidade: “Com relação ao ser homem, é uma coisa engraçada, a última menina que eu fiquei, que era dessas que eu tava muito bêbado... só fiquei com ela mesmo pra transar, que eu achei que ela era uma que ia transar, não transei... e... ela não transou, a minha saída pra uma menina dessas, que não transa na primeira vez, é, tipo, é a saída que eu sempre faço... não é a saída, eu volto a ser normal. E, no normal é, sei lá, tipo... ser carinhoso, é... querer bem com a pessoa que tá ali comigo e tal. Sei lá, ela falou que isso era ser homem, da última vez, por isso eu dei risada, eu lembrei. Mas, é legal, mas eu não transei com ela, tipo... era o que eu queria na hora, sabe?".

A alternativa encontrada por André contrasta com a expectativa de que a relação sexual é certa quando o homem está com uma mulher, porém, ao quebrar esse estereótipo, a situação fica mais confortável. De certo modo, a parceira citada por André também traz esta expectativa, mas, diante da atitude carinhosa e valorativa dele, surge a aprovação da parceira e o reforço do seu "papel de homem" de não forçar uma situação para que o sexo aconteça. Deste modo, André continua: “...ser homem não é tipo... transar, não é, eu tenho certeza disso, só transar, entendeu, só enfiar sem sentir nada, então, não é... Então, ela falou isso e... tipo, eu tenho certeza que eu me sinto homem, sim, (...) sei lá, meio que abraçar uma mulher assim... não abraçar simplesmente, mas... sei lá, querer ela bem... tipo... não precisa amar, mas cê tá preocupado com ela se sentir bem, meio que preocupado, com outro, meio que aquela história do padrão de qualidade, também, mesmo. (...) ...Isso parece ser homem, sim, você fazer ela se sentir bem, sei lá. (...) Você precisa só sexualmente satisfazer ela, entendeu? Claro que é bom, também, mas... acho que me sinto homem quando eu... tipo... sei lá, quando eu tenho ela por inteiro, assim". A atitude de satisfazer a parceira sexualmente, que está de 
acordo com a expectativa do homem que precisa transar diante da mulher pode trazer para André elementos para a auto-cobrança, funcionando como um obstáculo para a vivência prazerosa com a parceria.

No âmbito identitário, André aponta que: "De uma forma mais ampla, racionalmente, ser homem é ter 'masculino' no RG (riso). Essa é situação mais simples que você vai achar. Ou então... por opção, às vezes, o cara não quer ser homem, mas tem 'masculino'. Se comparar com homossexuais, eu considero eles, ou não? A maioria não... Também é homem... não sei. Sei lá, essa questão é muito ampla. Pode ser aquela idéia geral de... ser homem é, não sei... ter alguns valores, por exemplo, eu não acho que isso é ser homem, não, isso é ser uma pessoa boa, mas é você ter valores de... sei lá, vamos supor, o cara ser bem sucedido, o cara é... não precisa ser bem sucedido, mas sei lá... não sei, o cara é um pouco mais formal, entende? É... rigoroso... não sei, tem valores bons... não, isso não é ser homem, acho, parece até isso que indica, parece que... a pergunta: 'O que é ser homem?', ah, é ter valores bons, mas não acho que não é ter valores bons". André mostra nesta fala elementos que vão ao encontro daquilo que está dentro da categoria do gênero masculino, como os valores, a exemplo de ser uma pessoa boa e bem sucedida. No caso dos homens homossexuais, André fica em dúvida quanto à categoria a que pertencem, mesmo tendo "masculino" no documento do RG. Mais adiante, ele aponta outras características relacionadas ao ser homem: “...A aparência, tipo, uma seriedade, assim... mas não é verdade assim, a gente é como qualquer outro, aberto, sei lá... aquela idéia de que a gente também pode ser aberto, vamos supor, tipo, chorar, tá triste numa hora, ou tá feliz em outra. A gente pode ser igual a elas. Elas também podem ser sérias, mas, tipo, acho que aí acho que foge de ser mulher, porque elas não são muito sérias, parece, sério de sério... (...). ...O homem tem uma visão, ampla, pra falar... tipo, focada, e isso e aquilo, e mulher consegue entender várias coisas, assim, fazer várias coisas ao mesmo tempo. As mulheres eu acho, eu acho que consegue. Comigo, acontece muito, tipo, eu sou focado numa coisa e... não consigo escutar outra ao mesmo tempo. E... sei lá, é muito diferente, realmente, homem e mulher. Mas eu... eu não sei qual é o estereótipo de homem, assim, o que ele aparenta. Sei lá, aparenta seriedade, aparenta... não sei o que mais. Talvez algo meio rústico, mas não muito. Não é verdade, sabe, pensando... Por isso que eu tô confuso". A expressão verbal exige de André a percepção de como distingue os gêneros. Esta distinção existe, porém, em diversos momentos ela se confunde. A flexibilidade e a rigidez se alternam no que diz respeito ao ser masculino e o ser feminino. 
Esta perplexidade com relação aos gêneros, no sentido identitário, também é apontado por André quando percebe suas poucas colegas de turma na faculdade: “ $N a$ [faculdade], por exemplo, a gente tava analisando, eu e meus amigos, que têm poucas mulheres, umas duas por sala. Mas o maior problema lá nem é esse. As mulheres que tem lá... algumas até são bonitas, mas... é incrível como elas não se vestem como mulheres, sabe, tipo, a maioria, assim. São mulheres, namoram e tal, mas... é isso... é... vai só até esse ponto. Isso é... vai lá tirar uma foto pra você ver. Usam, sabe, camisa, igual homem, assim, larga, e às vezes, rasgadas, assim, não pintam a unha, tipo... sei lá, todas as amigas que eu tenho, de classe... nem falo nada, assim, né, pra... eu acho isso muito importante, e faz muita diferença. Todos acham, não sou só eu, lá, que conversa, a gente... falou, sabe, que... é muito diferente. Em mulheres isso é muito bom, acho, né... eu acho maravilhoso, assim, tipo, você sentir que ela é mulher, sabe, que, tipo, tem um charme, ali, sabe, se cuida diferente e tem aquele cheiro bom, tipo, usa perfume, sabe, tá preocupada com isso, com aquilo, a aparência... Acho aquilo interessante, muito interessante. E isso, pra mim, é uma mulher, nessa... nesse aspecto de visão". Para André, cuidados com a aparência e a forma de apresentação são fundamentais numa mulher. As colegas dele são mulheres que seria possível comprovar por fotos, embora não tenham estes cuidados e apresentação que ele considera essenciais. Isto aponta para um padrão relacionado ao gênero feminino. Ainda no tocante à sua perplexidade com relação aos gêneros, André observa que muitas das convenções estão em mudança. Embora ainda seja difícil estabelecer algumas mudanças para o homem, ele que "a mulherada pode tudo", o que indica as transformações da últimas décadas.

Mais adiante em seu depoimento, André retoma os atributos relacionados ao gênero masculino reforçando, de certo modo, o homem com o papel de dominador. Estes atributos relacionados ao ser-homem estão intrinsecamente relacionados com seu padrão de atitudes e comportamentos durante a relação sexual: “...o homem tá, assim, sério, ou sempre... sei lá, é meio que é o dono do negócio, a mulher tá mais pra aconchegar, tá... tá ali de braços abertos pra... E isso na hora do sexo aparece muito, acho. E... isso é... é antigo, é... estranho, não é a verdade, não, o mundo como é hoje, mas na hora... de... sei lá, sexualmente, assim. (...) Ah, não sei, sexualmente, também... mas algo estranho, assim, sei lá, eu me sinto, tipo, como o dono da relação sexual, mas lá... lá, se a mulher tentasse tomar esse posto eu acharia estranho isso, pra fazer um paralelo". Este padrão de comportamento do homem está relacionado ao instinto: "Porque não deu certo, sabe, não tem que ter dó [referindo-se à 
Mônica quando transaram], ela não tá no posto de ter dó, ela não... entendeu? E isso me deixava mal, assim, tipo, é... talvez seja um pouco... antiga essa idéia conservadora. Mas... não sei, é... é como eu falei, é um negócio instintivo, na hora. Então... é a verdade, é o instinto, entendeu? A gente pode mudar aos poucos". André indica a sua percepção do estereótipo quando se refere ao alto preço pago pelo homem para permanecer no papel que considera instintivo do dominador sendo que a mulher não precisa ter piedade, pois é intrínseco ao homem ser "dono do negócio", cabendo à mulher a doce passividade transmitida pela imagem dos "braços abertos".

\subsection{1. “A mulher tá mais pra aconchegar, tá... tá ali de braços abertos": a percepção do ser mulher}

André mostra que percebe a existência de um caráter cultural, porém, não consegue discernir aquilo que propulsiona o comportamento dos gêneros: “...Eu não lembro se eu já vi isso em algum lugar ou... mas é verdade, é... tem no meu pensamento, veio de algum lugar, teve alguma informação assim, mas eu.. tipo, aceito isso, eu acredito nisso, eu acho que eu vejo isso, sei lá, que na hora que, esse negócio que a gente tá falando de homem rústico e mulheres, sei lá, tá com, por exemplo, o homem tá, assim, sério, ou sempre... sei lá, é meio que é o dono do negócio, a mulher tá mais pra aconchegar, tá... tá ali de braços abertos pra... E isso na hora do sexo aparece muito, acho. E... isso é... é antigo, é... estranho, não é a verdade, não, o mundo como é hoje, mas na hora... de... sei lá, sexualmente, assim". Porém, André mostra mais adiante que existem exceções para estes papéis: "Tirando isso, os padrões, assim... os padrões, e os estereótipos, eu acho, tipo do... jeito de ser... a pessoa (...) eu tinha pensado nisso antes, menina chegar em menino, uma coisa que não acontecia antes, sabe, tipo, normal. Aquela Cris, que eu te falei, ela que chegou em mim. Tipo... claro que continua tendo história do homem ter que fazer, sabe, mas eu odeio. Adoro menina que chega".

As mudanças no estereótipo do gênero feminino são mais fáceis de compreender do que as mudanças no estereótipo do gênero masculino. A questão da atividade e da passividade acaba sendo colocada em jogo e André percebe que aprecia ser conquistado a conquistar. Diferentemente do homem que pinta as unhas e compromete a sua identidade masculina, as mulheres que assumem uma postura mais ativa não comprometem a sua feminilidade: “...A 
Cris veio conversar comigo, por exemplo, entendeu? Eu tava sossegado, na minha. E a outra, que aconteceu isso também no Estados Unidos, tipo, sem mais nem menos ela me beijou. Eu devia estar bêbado, coisa e tal, mas tava dançando, daí ela apareceu, a gente dançou junto... Então... Eu acho isso legal, acho interessante, essa parte, as azarações, assim. Acho que isso não torna ela menos mulher". Por outro lado, o fato de ele desempenhar um papel de dominado, de certo modo, o frustra: "Sobre a Cris, de novo, ela não é muito... ela é muito... muita coisa pra fazer, muito, sabe, tipo, ela não se abriu como mulher pra mim. Ela não... não deixou eu abraçar ela e eu comandar, sabe? Comandar não ela, de mandar, vai fazer isso... comandar a relação, deixar eu... coisas boas que eu queria fazer e ela não se abriu pra isso. Então eu acho que esse foi um dos principais motivos que eu não quero transar com ela. Não quero ficar por ficar". Mais adiante na sua fala, André clarifica o que espera da mulher: "Eu acho que... eu... mais ainda é... deixo aflorar esse instinto de, tipo: 'Eu sou o homem da relação, ela é a mulher e eu sou...', sabe? (...) Eu saio, eu quero pagar pra menina, tipo, eu não quero que ela pague. (...) Eu quero, tipo... sei lá, um pouco, assim, de eu sou homem, eu tô, tipo, comandando isso, a gente vai no lugar que eu escolhi porque eu pensei antes esse lugar, eu pensei muito, e é um lugar em que você vai se sentir bem, e você vai relaxar, entendeu? E eu quero comandar, eu quero... 'Agora vai ser assim, assado, a gente... você vai fazer isso'. Tudo bem que é maravilhoso quando é junto, também, igual, mas... mas a mulher tomar a decisão, assim, não. (...) ...É o que eu vejo agora, que é um pouco, assim, eu gosto eu de comandar um pouco. Nada da mulher, assim, ser escravizada. Não é isso... Você entendeu, né?". A idéia do poder se faz presente, André sente-se mais confortável quando está no comando, na justificativa de que ele, sendo o "homem da relação", tem o conhecimento, ou o "instinto" necessário para saber o que é bom para os dois. Deste modo, a mulher fica representada pela passividade e disponibilidade perante o homem. Este cenário em que a atividade e da passividade se inter-relacionam vai ao encontro de Scott (1995), quando afirma que a construção do gênero além de ser um elemento constitutivo de relações sociais baseadas nas diferenças percebidas entre os sexos, ela também é uma forma primária de dar significado à relações de poder.

O relacionamento entre os gêneros é complexo e faz André apontar novas perspectivas: "O que eu espero da mulher é, sei lá, uma postura ótima, que, tipo... uma postura de... no sentido não sei de... sei lá: 'Hoje ela não paga' ou, 'Oh! Ela pagou a conta hoje! Oh! Vou morrer!', não, nada disso. São fatos que mostram isso, mas não são fatos que formam isso, entendeu? Acho que um pouco a sexualidade é uma forma não de... do ato 
sexual, mas de tá junto e tal, se ela... sei lá, se ela quer comandar aquilo, ali, da gente tá junto, ela quer... não sei, estranho, não tinha pensado. É que é muito confuso deixar isso claro. Por exemplo, assim... não sei, é estranho, mas se ela não é receptiva, assim, ah, você ser o homem da relação, sabe? Mulher é, tipo, é o jeito, não sei... é afetuosa, carinhosa, sabe, você se sente bem, ali. E isso, é... eu acho, se ela não é assim é estranho, entendeu? Só".

\subsection{2. "Ele homem e ela mulher'. Quem vai ser o presidente?": o gênero e papel de gênero}

André clarifica as distinções entre os gêneros trazendo referências que contribuíram para esta construção. Mesmo reconhecendo o caráter conservador de sua linha de pensamento, André justifica o lugar do homem a partir da sua capacidade instintiva de comando: "Para mim, essa é a característica de homem, acho que sim, de como... é o que eu falei antes, de comandar, assim, é que... não queria que fosse assim. Vamos supor, na cabeça, hoje, vamos supor, você tá numa empresa e fala: 'Ele homem e ela mulher. Quem vai ser o presidente?' Quem for melhor, entendeu? Mas o homem, instintivamente, ele comanda. Agora, coisa de teste... ele aparenta seriedade, ou quer ter a coisas sob o controle dele. As mulheres, vamos supor, numa relação a dois, tipo, a mulher e... e... tipo a mulher parece que quer... abraçar ele, servir ele. Essa é uma idéia que, racionalmente falando, é horrível até, de conservadora. Eu pus agora a mulher servindo ele, eu já lembrei de, sei lá, uma serva, mas, sei lá, não é isso, entendeu? A minha idéia não é essa na vida cotidiana, uma mulher numa empresa, por exemplo. Mas no sexo, na relação, parece. Eu acho bom". Por mais que publicamente acabe se tornando mais flexível os papéis de gênero, no relacionamento íntimo espera-se que a mulher torne-se receptiva, porém, nem "escrava", e nem "serva", mas "de braços abertos" para o homem.

Esta polarização de percepção entre os gêneros, acaba sendo abalada quando lembra do modelo de relação de gênero que assiste dentro do próprio lar, a partir do relacionamento dos pais: "Uma coisa engraçada sobre o que a gente tava falando, deixa eu falar, só pra acabar: a minha mãe é muito mais comandante do que o meu pai na minha casa, muito, muito, muito mais. E ela é assim, ela é... minha mãe que... que paga as contas. Não, não com o dinheiro, o dinheiro vem do meu pai, a maioria, mas quem comanda é ela. Minha mãe fala isso, fala aquilo, sabe? Meu pai é muito servo da minha mãe. É muito invertida as coisas lá. 
Isso, racionalmente, dá uma raiva porque o meu pai... realmente, assim... perdeu a hombridade, dele, eu acho. Aí... na minha casa pode se dizer, se perguntando se ele é homem, ele não é homem na minha casa, isso... entendeu? (pausa) Ele perdeu... Tem sempre o que falta, sabe, ele tem agenda, tem tudo, onde ele trabalha. Onde ele trabalha é que ele é homem... na minha casa, se você perguntar pra ele: 'Ah, pega o telefone do André, quero falar agora', ele não sabe, não sabe achar a agenda, não sabe achar nada, sabe? Não sabe nada da minha casa, ele não vive na minha casa, ele... ele nunca, de jeito nenhum é o chefe da minha casa. Se fosse uma igualdade de decisões e a mulher não fosse claramente o servo, nem o homem, sei lá, o comandante seria até aceito... altamente aceitável porque ela... é o mundo como é hoje, não existe mais esse negócio, mais, patriarcal, assim, de ele mandando. Mas é o que eu falei, é o instinto. E, tipo, se igualar as coisas é uma coisa, agora, inverter isso, sabe... tipo... é muito mais forte... sabe, o que aconteceu ali, é muito forte, acho. Ali não é uma igualdade, é uma inversão, entendeu? A mulher faz o papel de homem e o... é horrível falar isso, mas... 'Ah, ela não pode mandar na casa?', sabe, 'Você quer que ele mande?'. 'Não, não quero que ele mande. Eu o...'. Não gostaria também que meu pai fosse como minha mãe é, entendeu? Ao contrário. Adoraria que fosse igual, mas... ela com o papel assim, de homem, de decisões, de... sabe, muito mais de comando... Acho estranho, acho muito estranho. Acho muito ela mais forte do que marido que... fugiu ao normal".

Diante do padrão de papel de gênero e do relacionamento de gênero de André, o pai, dentro do espaço da intimidade, deixa de ser o homem da casa pelo fato de depender da mulher e não ter tanto domínio. Porém, publicamente, no escritório, ele continua sendo o homem que instintivamente tem o poder de comando. É importante lembrar que a casa por muito tempo- e talvez ainda seja - espaço do feminino, da "rainha do lar", o complemento doméstico do marido (Del Priori, 2006). Na fala de André nota-se o apelo ao instinto, à natureza das relações de gênero. O conflito se mostra quando André experimenta nos próprios relacionamentos esta desigualdade entre os gêneros, ao menos percebidas deste modo. Quando Cris passa a conquistá-lo, ou seja, a não agir como o esperado de uma mulher, André deixa de interessar-se por ela.

No tocante à esfera pública, ao ser solicitado a fornecer exemplos de homem e de mulher que representassem, de certo modo o seu modo de perceber os gêneros, André mostra a complexidade destas construções: "Pensar em alguém da esfera pública que pode ser apontado como modelo de homem ou mulher... nossa... é difícil, hein? Desse jeito que eu 
acho, assim... Ah, não sei bem te falar um nome assim, que eu possa falar. Precisaria, sei lá, conhecer a pessoa. Não sei. É muito complicado... tipo, é resumir tudo que te falei em uma única pessoa". Deste modo, André optou por apontar os cargos ou funções dos gêneros. $\mathrm{O}$ ser-homem "...remete a alguém sério, assim... vamos supor... um governador, um cara, assim...”. Já a mulher: “...não sei... (pausa) alguém... ou uma mulher assim... não sei... não lembro muito cara de mulher moderna, assim, que nem mulher... parece mais... não sei, bondosa, assim, tipo, carinhosa... mesmo assim... não sei, não acho que seja publicamente... conhecida do publico, não sei, talvez, Gisele Bündchen. Falei, porque foi simplesmente porque pintou... porque é... porque eu não conheço ela, não sei se ela é... Se eu conhecesse eu poderia dizer. Agora, outras mulheres, não, mas é pelo seguinte, tipo... porque eu não conheço nenhuma, então... sabe? Ela é bonita, é o que você vê, e o que você vê numa mulher dessa é, tipo, beleza, só. A televisão só passa beleza, então, mais bonita, mais mulher". Retomando o modelo de ser-homem na esfera pública, André aponta: “....me veio, tipo, sei lá... odeio, mas, Bush, Lula, sabe, Serra... assim, um cara tipo... pela idéia de que tem poder. Mas isso é por causa do que a gente falou antes, que é a minha visão de homem. Mas... não quero que isso resuma o que eu falei". A intenção de elencar pessoas da esfera pública é de justamente trazer figuras que surgem de imediato com relação ao tema sobre construção de gênero. Assim, as pessoas elencadas tornam-se significativas sem resumir a representação dos gêneros explanadas ao longo do depoimento. Torna-se significativo, na percepção de André o homem como aquele em que o poder é eleito, o governador, aquele que comanda, é algo que já faz parte do ser-homem. Por sua vez, à mulher é dado um papel que não chega a ser o extremo oposto com relação ao homem, mas daquela que esteja em um nível de igualdade perante o homem, sem nunca ultrapassar o âmbito do que é tido como masculino. A representação da mulher se dá por aquela que tem "braços abertos" e pela "beleza", algo que é mais externo, mais performático, sendo "mais bonita, mais mulher".

\subsection{3. "Acho que a liberação ajudaria as pessoas na sua sexualidade": a sugestão de André para a vivência mais gratificante da sexualidade}

André reconhece o quanto supervalorizou o sexo e o quanto isso serviu para norteá-lo na vivência afetivo-sexual: "Acho que a liberação ajudaria as pessoas na sua sexualidade, entendeu? Isso era o que eu não tinha... é, tipo, a trava que... pra mim aquilo era um... mais 
um vestibular, mais uma coisa foda que eu tinha que passar. Se fosse... se fosse só sexo, sabe, igual ao que é hoje, pô, seria maravilhoso. (...) Sei lá, do nome sexo ser: 'Oh! É sexo!', sabe, não é... não é assim, tipo, é ótimo, todo mundo faz, todo mundo vai fazer. Não é escabroso, tipo, sabe? Não precisa... se você não tiver um medo, se você não ficar preocupado com o que a outra pessoa vai sentir, ou o que você vai fazer ou não, aí é bom. Tipo, não é racional. Tipo, se eu pudesse não ter pensado desse jeito seria bom, também”. André mostra na sua fala o quanto o sexo e a sexualidade acabam se tornando uma ficção: “Oh! É sexo!”, o quanto isso pode funcionar como um entrave para a vivência afetivo-sexual de uma pessoa criando idéias e valores que reforçam o âmbito racional e não o vivencial. Deste modo, parece que André passa a perceber o sexo e a sexualidade de uma outra forma, de uma forma mais humana e não daquela forma "máquina" com se via anteriormente programada para corresponder àquilo que era esperado, na ausência de afeto ou de sentido.

André continua falando sobre a sua percepção e vivência: "Acho que ficar... fechando a coisa, assim... tipo, parecendo que é um negócio grande, sei lá, mesmo que seja, tudo bem, mas que é algo inatingível, algo foda no acesso... é... isso é praticamente uma lavagem cerebral. Por 14 anos, ou 10, ou 12... crianças, só há mente ali... É um problema, é um grande problema porque, sei lá, foi criando esse... negócio de achar que sexo é 'Oh!...', sabe, uma coisa... Mas, e como... como você vai fazer isso? E aí? Tipo, você vai falar: 'Ah, minha filha tem doze anos e vai começar a transar?' Então se ela tomar a atitude e ela quiser... Mas é difícil... é difícil. Eu não faço idéia de como seria isso (riso). Na minha vida eu acho que... eu não sei como eu poderia ter mudado isso, sabe? É algo cultural, assim, essa idéia de... sexo é... é uma coisa que, sei lá, um ponto que você, às vezes, espera vários anos pra chegar. Bem, a idéia do vestibular num ponto que... a pessoa pegar como.... demora pra passar, e até chegar lá. É da cultura, tipo, pegar tudo que a gente fez até hoje, tudo tem sexo misturado no meio. Mas se fosse mais tranqüilo, até quanto a gente teria que se preparar pra isso? $O$ problema é se preparar muito e se cobrar muito, igual eu fiz e... se ferrar. É isso (riso)".

No depoimento de André são revelados a frustração, o estranhamento e os percalços para descobrir e saber mais sobre o sexo e a sexualidade. Ele faz uma interessante comparação do sexo com o vestibular em que muito se espera para chegar e, quando chega, vem a frustração. A realidade se mostra de forma dura e crua, sendo que todos os sentidos e significados assimilados até então são colocados em jogo, triturados, montados, remontados, na perspectivas de dar contornos e, com isso, novos sentidos para possibilidades de vivência. 
André atenua o "jeito máquina de ser", porém ainda é presente a tensão entre a vivência afetivo-sexual mais humanizada e os rígidos padrões de gênero internalizados. 


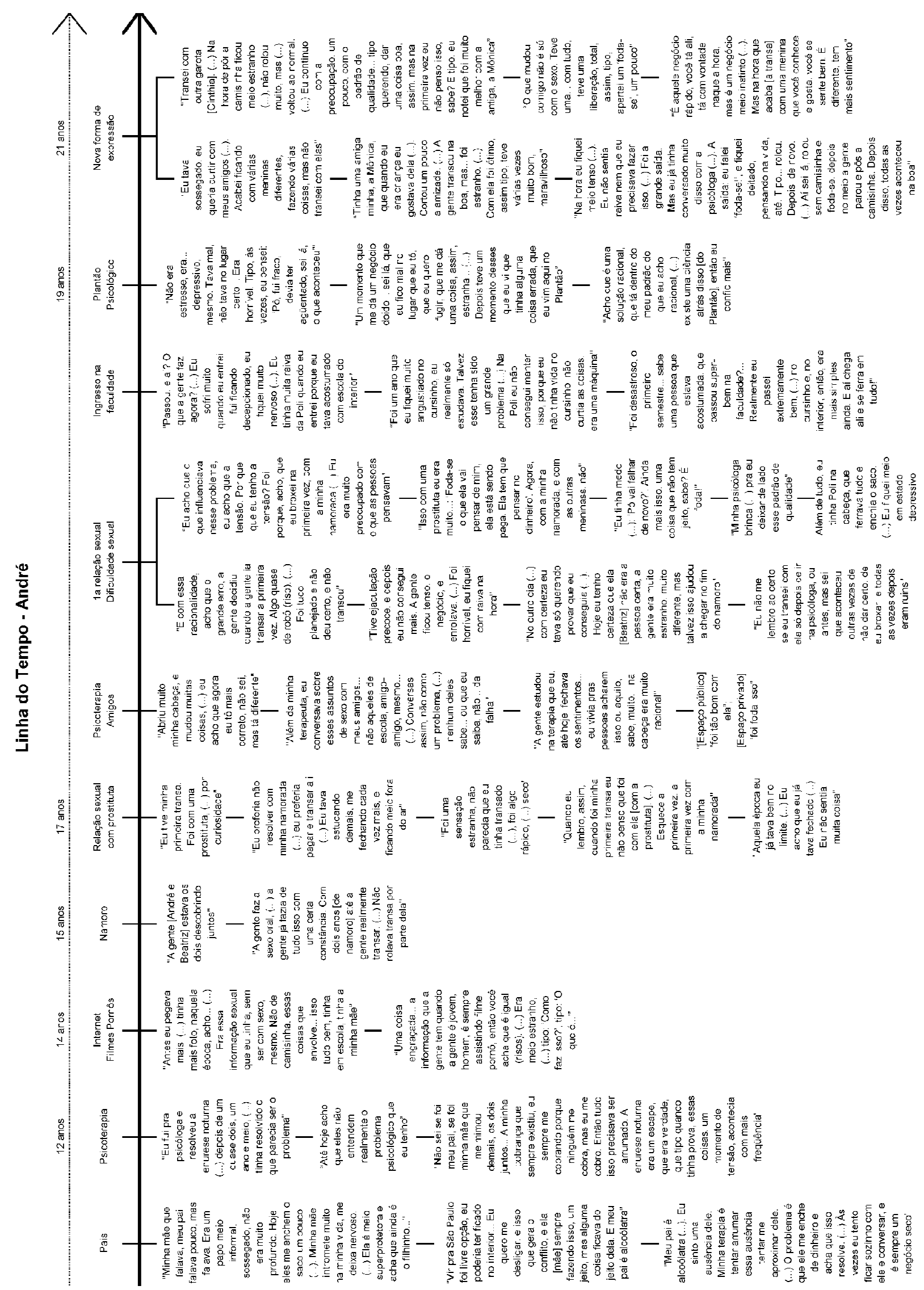

Figura 3 - Linha do tempo da trajetória de André 


\section{4. "Você tem que ser maduro, vai ter que ter responsabilidade e coragem de assumir": o depoimento de Melina ${ }^{35}$}

Melina tem 21 anos, nasceu em São Paulo, e é estudante universitária. Mora com a mãe.

No dia combinado para a coleta do depoimento, Melina atrasou-se mais de uma hora do horário combinado.

Foram realizados dois encontros devido a falha mecânica do gravador. Melina aceitou de imediato o convite para um segundo encontro. Por questão de agenda, esse segundo encontro deu-se por volta de um mês após o primeiro. Interessante observar a fluência das idéias de Melina do primeiro para o segundo depoimento, sendo que diversas questões foram reformuladas, a exemplo da sua percepção sobre os gêneros masculino e feminino. As entrevistas, mesmo que destinado à coleta de depoimento, torna-se um espaço privilegiado para a reflexão e a ressignificação de eventos significativos da própria trajetória de vida.

Em seu depoimento, Melina privilegia seu projeto de vida, os relacionamentos e as representações do gênero masculino e feminino. Depois de sua resposta imediata: "Ai... é meio complicado", o episódio do abuso sexual é o primeiro tema que surge diante da pergunta disparadora para falar sobre a descoberta da sua sexualidade. Os cenários principais os quais o depoimento de Melina apresenta são constituídos pelo ambiente familiar; pelo ambiente escolar; pelos namoros - com ênfase ao relacionamento com Pedro, seu noivo -; e pelo movimento negro. Esses cenários perpassam a reflexão dos modelos sociais, com destaque para as diferenças entre classes sociais, além do próprio projeto de vida e as escolhas ao longo desse processo.

\footnotetext{
${ }^{35} \mathrm{O}$ depoimento foi gravado em duas vezes, tendo a duração de $0: 45 \mathrm{~h}$, no primeiro encontro, e 1:10h, no segundo. Na ocasião da validação do texto, Melina acrescentou dados, sem suprimir nenhum outro.
} 


\section{1. "Talvez até por isso é que eu tenha passado durante vários anos por abuso e não falava para ninguém, porque sexo é uma coisa que não se comenta": Melina e o abuso sexual na infância}

A infância de Melina foi vivida num contexto de dificuldades econômicas, numa casa de quarto e cozinha: "Eu vim de uma família pobre e eu fui criada só pela minha mãe até uma certa época, e a mãe que tem a obrigação de ser mãe e pai é complicado, nem dá para tocar nisso porque a educação dela foi super-conservadora, né? Então o sexo na minha família não foi falado, entendeu? (...) É como se fosse realmente um tabu, essa coisa não existe, daí complicada".

Os pais de Melina se separaram quando ela ainda era muito pequena ${ }^{36}$. Nesta época, o pai já conhecia outra mulher, e a mãe de Melina estava acamada, depois de ter sofrido um grave acidente de carro. Na separação, o pai de Melina levou consigo as duas filhas mais velhas. Melina, a caçula, não traz referências sobre os motivos dessa escolha. Sobre o pai, ela diz que: "meu pai não deixava minha mãe ver as minhas irmãs e também não foi atrás de mim...", mostrando o quanto as relações intrafamiliares eram conflituosas. O contato de Melina com o pai se deu aos 15 anos, quando ela o procurou, mas não sentiu receptividade por parte dele.

Geraldo, o padrasto, entra em cena num momento em que a mãe de Melina atravessava por um momento de extrema dificuldade, em que tinha de lidar, ao mesmo tempo, com convalescença e com abandono. O padrasto oferece amparo e diz gostar muito da mãe. Mais tarde, ele foi morar junto com Melina e a sua mãe. Ele cuidava do seu bar, e a mãe de Melina trabalhava fora.

A descoberta da sexualidade de Melina não foi algo refletido ou planejado, ou mesmo acordado de forma madura com outra pessoa no seu mesmo estágio de desenvolvimento. Melina passou por um período de 9 anos em situação de abuso sexual pelo padrasto. "Porque conheci o sexo muito cedo, aos 7 anos. (...) ...Eu vim descobrir o que estava acontecendo, perceber a gravidade do que eu estava vivendo, aos 16 anos. Então, tirando essa parte do abuso sexual, eu digo aos 16, onde as coisas podem ter existido realmente... as diferenças... e

\footnotetext{
${ }^{36}$ Melina não cita a idade que tinha quando os pais se separaram.
} 
tudo o mais. Acho que é isso...". A apropriação sua vivência sexual se dá mais tarde, quando inicia contatos e namoros com outros rapazes.

Melina relata que o abuso sexual começou quando ela tinha entre 6 e 7 anos. Nessa época, a rotina de Melina era voltar da escola, à tarde, almoçar assistindo à TV, e passar a tarde fazendo as tarefas de casa. $\mathrm{O}$ abuso sexual foi incorporado à rotina cotidiana: "A gente ficava em casa, juntos, uma boa parte do dia, aí ele fez isso a primeira vez, me catou pela primeira vez e falou que não era para eu contar para ninguém. Foram se passando os anos e eu sempre calada, sempre agüentando, sempre calada. Aí chegou um momento que eu não agüentava mais aquela situação, aí eu falei para ele, eu falava para ele assim: 'Vai embora porque eu não vou falar para a minha mãe', porque a minha mãe gostou muito dele, até hoje ela gosta dele, então eu não contava para ela para poupar de todo esse sofrimento, e ele não ia. E foi piorando a situação, piorando a situação, até que um dia, em discussão, uma vez ele brigando com a minha mãe, eu aproveitei a situação e contei. Aí ele falou que ia me matar, ele tinha arma, ele falou que ia me matar, ia matar a minha mãe, como sempre ele me ameaçava, depois ele falava que ia se matar, fugiu, e eu fui na delegacia, tudo, e eu fiz o boletim... Ai fiz o exame no $I M L^{37,}$.

Nesse cenário, o papel de Melina parece ter sido o de ficar calada, submissa ao desejo do padrasto, enquanto teria sido aquela que supostamente nada sabe, ou que de nada quer saber. Melina descreve que nessa situação se sentia: “...como se eu tivesse sido destinada para aquilo, era... era... como eu posso dizer, não tinha como mudar, era daquele jeito ali e ia ser aquilo sempre. Só ia ter fim quando eu tivesse 18 anos, que eu começasse a trabalhar, e que eu fosse embora de casa". Dado o distanciamento do pai biológico, o padrasto passou a representar para Melina uma figura importante de paternidade. Melina determina para si que somente seria livre com sua maioridade, o que de fato aconteceu um pouco antes, aos 16 anos, quando denunciou a situação vivenciada. O modo-de-ser de Melina paulatinamente foi se voltando para o questionamento dos seus valores e do mundo diante daquilo que vinha vivenciando, tendo o âmbito escolar como novo cenário onde pode aplicar-se nos estudos e sair das restrições do lar em que vivia.

\footnotetext{
${ }^{37}$ IML - Instituto Médico Legal.
} 
Melina aponta a mãe como uma pessoa conservadora, nervosa, distante, que batia, que não lhe dava carinho e a quem não podia confiar segredos: "Eu não tinha identificação com a minha mãe. O pouco de sentimento que a gente tinha junto era brigando, era reclamando, e era batendo. (...) A minha mãe não era de chegar, de abraçar, de fazer carinho. Era uma coisa bem distante, mesmo. (...) Era direto eu levando surra, levando surra, mesmo, que você perde a confiança, porque eu acredito muito que a criança, quando na infância principalmente você tem confiança naquelas pessoas que demonstram afeto, que demonstram um sentimento, e um entendimento com o que você...". Era tamanho o sentimento negativo diante da mãe que quando ela saía para trabalhar, Melina desejava que ela não voltasse para casa: "Não quero que ela volte, não, porque para voltar e me bater eu prefiro que não volte". Por outro lado, o padrasto, além de protegê-la das agressões da mãe, era um interlocutor importante para Melina: “...quando discutia alguma coisa de escola era sempre muito compreensivo, ele dava ouvidos. E com a minha mãe eu nunca tinha isso". A mãe inspirava pouca confiança e a reprimia, e o padrasto aquele que acolhia e protegia. Esse cenário e essas formas de compreender os papéis de mãe e do padrasto, na trajetória de Melina, contribuíram para o silêncio do abuso sexual, restando pouco a fazer ainda mais pela restrita rede social: "Eu não gostava do que ele fazia comigo, de ele querer que eu praticasse o ato sexual com ele, mas eu tinha um sentimento forte por ele como se fosse realmente um pai". Nesse período, Melina diz que nem mesmo falava para as irmãs, por não ter contato com elas, devido ao fato de morarem distante. A leitura que faz da situação é de que aquilo era imposto pelo destino. Desse modo, a situação permaneceu ocultada por longos anos.

$\mathrm{Na}$ escola, nos contatos com as amigas, Melina teve conhecimento da masturbação como "um meio de você se conhecer mais, até porque é uma fase legal da vida". Ela passou a ter contato com revistas para saber sobre sexualidade: "Então eu li bastante revistas quando eu era adolescente e tinha vontade de falar com as pessoas em casa, mas não podia de jeito nenhum, porque era tabu. Mas na escola com as amiguinhas, poderia ser uma coisa 'light', mas não foi, né, conversei, perguntei para as minhas amigas se elas faziam, mas elas falaram que não faziam. Teve uma que ficou horrorizada (riso), que até hoje eu penso: 'Como será a vida sexual da Camila', né, 'Se naquela época pensava assim, imagina hoje!'”. Melina fornece uma amostra de algumas fontes para seu roteiro sexual. Ela se posiciona como mais experiente do que a amiga que ficou constrangida ao saber sobre masturbação, pois era algo comum entre as demais. Os relatos de outra amiga que já tinha contato sexual eram atentamente ouvidos por Melina, porém, com certa discrição: “a gente conversava um pouco, 
mas também era bastante complicado, porque se você é adolescente e você é só uma menina que já teve relação sexual e você começa a falar, falar, falar, aí ela fala para as outras que você já deve ter tido. (...) É meio assim, não sei o que acontece, mas é encobrido na cabeça das pessoas não sei que em fase da vida, que se você comenta muito de sexo, ou é porque você está a fim, ou porque já fez, então, você não pode falar de sexo porque você está com vontade e tudo mais".

A vivência de forma consciente e plena da sexualidade se deu mais tarde, aos 16 anos, quando inicia namoro com um rapaz na escola, de uma maneira que, na sua concepção, é a mais adequada: “...Depois dos 16, aí a coisa começou a ir normalmente, normalmente de acordo com a minha juventude. Normalmente, porque, ah, você conhece a pessoa, e... tem a amizade, rola o interesse... Aí você beija, rola o beijo durante um tempo, e depois acontece o ato sexual". Para Melina, a normalidade se dá pelo respeito a um processo de aproximação e construção, de forma negociada, de um espaço de intimidade que permita a troca afetiva.

O abuso sexual e o silêncio são temas privilegiados no início do depoimento, seguindo a perspectiva de que "sexo é uma coisa que não se comenta". Cabe aqui a observação sobre a importância do diálogo no processo de socialização, pois favorece a apreensão de significados e sentidos da experiência, fornecendo elementos para a constituição da subjetividade. $\mathrm{O}$ conhecimento dessa subjetividade somente é possível a partir do mergulho na narrativa, no compreender, junto a Melina, os elementos e a trama de significados e sentidos da sua experiência. Assim, o cuidado nessa compreensão da narrativa de Melina é o não focar demasiadamente na situação do abuso sexual procurando por fatores facilitadores, responsabilidades, causas, ou seqüelas deixadas em Melina. Mesmo que o assunto seja delicado e tenda a despertar sentimentos de indignação e o desejo de punição - esse é o meu caso -, torna-se necessária a suspensão desse juízo a fim de não obliterar o relato de uma experiência e de seus significados e sentidos. Essa suspensão do juízo também resguarda de olharmos para Melina a partir do estigma da vítima de abuso, o que fatalmente anularia o olhar para a pessoa que se mostra, restringindo a compreensão da experiência de Melina a partir de lente estigmatizante e estigmatizadora, que limitaria a um recorte da sua trajetória.

Atrelado ao silêncio imposto sobre a sexualidade, Melina faz referência ao contexto machista, sendo que: “...por mais que tenha existido o movimento feminista, as mulheres tendo cada vez mais se impor, ou se destacar em determinadas profissões, mas o machismo 
ainda vigora". Assim, ao longo do depoimento nos deparamos com uma situação de impunidade com relação ao padrasto, fortalecendo ainda mais o silêncio das mulheres submetidas à situação de abuso sexual: “...se nós mulheres, adolescentes, ou não, tocar no assunto é porque está querendo ser safada, que é assim que eles falam, né, 'está querendo ser safada'... não sei o quê, então muitas vezes fico até intimidada pelos homens. (...) É difícil encontrar um homem que discuta e não leva para segundas intenções". Na ocasião da revisão do depoimento, para fins de legitimação, Melina reforça esta idéia dizendo que se a mulher se mostra delicada, frágil, é carta branca para a "farra", pois faz o tipo do "saiu-e-transou-com-oprimeiro-que-olhou-e-gostou". Interessante notar a questão do gênero aqui presente em que o homem tem essa liberdade de relacionar-se sexualmente com a primeira pessoa que encontra e gosta, sendo que isso não é o esperado para a mulher. De acordo com o contexto machista referido por Melina, a mulher precisa manter uma postura, caso contrário, pode ser desvalorizada e até vista como desviante de acordo com modelos rígidos de masculinidade e de feminilidade pré-estabelecidos. Esses modelos serão mais aprofundados no momento do depoimento a seguir.

\section{2. "O Brasil começou com um patriarcalismo muito grande e essa questão do homem como senhor vem desde sempre, e até hoje, ainda": olhares sobre a diferença de gênero}

Melina refere-se ao machismo como algo proveniente do sistema patriarcal, no qual o homem é o senhor e a mulher, submissa a ele. De acordo com Melina, esse sistema é mantido pela própria sociedade, onde as mulheres ficam caladas, permitindo a manutenção da postura machista que impera até os dias de hoje. Para ela, esse sistema: “...de certa forma ainda é culpa das mulheres, porque algumas, ou muitas, ainda se deixam levar por isso, obedecem as ordens. Não que tenha que se rebelar, não é isso, mas aceitam tudo o que o homem fala, tem que colocar o seu ponto de vista naquilo, tem que mostrar, se apresentar a favor ou contra aquela opinião. Eu acho que a sociedade tem culpa nesse sentido. As pessoas aceitam, simplesmente, não interagem, você fala as coisas comigo e não falo para você se foram boas, ou ruins, eu simplesmente aceito, entendeu?".

Melina faz referência à incorporação de um modelo vivido e reproduzido no cotidiano sem a devida reflexão. Em sua trajetória, ela descobriu que, se pontuar que não aceita 
determinadas coisas, o próprio homem - no caso o atual noivo - aceita o posicionamento dela, mostrando que o relacionamento entre os gêneros é algo que perpassa por uma negociação entre partes: "O meu namorado vai comigo até onde eu deixo ele ir. Chegar numa hora que ele fizer alguma coisa que eu não gostei, e eu falar para ele que não gostei disso, da próxima vez que ele fizer e eu falar, vai ter uma hora que ele vai parar. Se ele fizer uma vez e eu não falo nada, aí ele vai continuar fazendo, entendeu? Então eu acho que é bem isso. Se o marido pede para a mulher largar o serviço para ficar em casa, porque ele quer que ela cuide dos filhos, e ela aceita, às vezes, o coitado está querendo ajudar porque pensa que ela realmente gosta daquilo, claro que é por puro machismo dele. Agora, se ela não diz, se ela não se pronuncia diante daquilo, não tem como mudar, vai ser sempre daquela mesma forma, isso aí a coisa não muda, vamos supor, se ela não ensinar para os filhos dela que tem que mudar, isso vai continuar e o ciclo vai continuar sendo o mesmo. Por isso o machismo na nossa sociedade".

Ainda na perspectiva da relação entre gêneros, em um momento do depoimento, Melina faz referência ao modo como a educação leva à formatação das diferenças entre gêneros, determinando aquilo que é típico de homem e aquilo que é tipico de mulher: " $E u$ acredito no núcleo familiar, a mãe, o pai, as tias, os irmãos... Todo mundo já educa a menina, ou a mulher, tanto que a menina sempre brinca de boneca, quando entra na adolescência não pode, no meu caso, eu não podia brincar com os meninos, porque menina que brincavam com meninos era menina dada, entende? Então a mãe falando, o tio falando, o filhinho falando, todo mundo falando a mesma coisa, te afasta, por quê? Porque acha que aquela brincadeira é você brinca de ser doméstica, você tem que limpar a casa, se você tiver irmão, no meu caso eu era a caçula, mas se tiver que cuidar dos irmãos para você se formar uma dona-de-casa, para depois ficar com o papaizinho. Esse modelo é forte na minha educação, eu não sei na classe média e na alta, mas na classe baixa, sim, é, porque eu vejo as minhas vizinhas, as crianças, as adolescentes, as mães quando sentam em grupo para conversar, ao invés de falarem que a criança estuda, que a criança tem algum dom especial para alguma coisa, elas falam que elas limpam bem panela. Então tem essa coisa dos afazeres. Não seu se na classe média tem, porque geralmente as crianças de classe média não fazem o serviço de casa, mas na pobre, tem. Então, se você senta com elas para conversar, por exemplo, domingo, eu fui para a casa da minha tia, e a minha tia falou: 'Olha a sua prima Raquel, de 10 anos, limpa uma casa do jeito que tem muita dona-de-casa que não limpa'”. 
Desse modo, a mulher acaba sendo educada de forma a focar no cuidado com a casa e com o marido, sendo um apêndice desse. Essa educação se dá logo nas primeiras brincadeiras na infância, a exemplo do brincar de boneca, que treina para o cuidado com um bebê na fase adulta, ou mesmo o brincar de casinha, que treina para o trabalho doméstico futuro. A repetição que os membros da família, ou mesmo a sociedade emite essas mensagens e apropria vivência delas, de certo modo, passam a ser incorporadas e automaticamente reproduzidas, sendo que não necessariamente passam por uma reflexão sobre a influência dessas mensagens nos roteiros sexuais. Melina destaca o fator de classe social, dando um exemplo sobre essa formatação do gênero feminino, quando lembra de uma reunião entre familiares em que a prima, de 10 anos, foi valorizada diante do grupo por limpar a casa de forma que "nem toda dona-de-casa limpa". Assim, na perspectiva da idéia de roteiros sociais proposta por Gagnon (2006), a mulher é submetida a uma maciça carga de mensagens que formatam o roteiro intrapsíquico para que sejam treinadas a serem boas donas-de-casa; já os homens são treinados para serem provedores do lar e que podem contar com a possibilidade de serem cuidados pelas mulheres. Vale a ressalta de que a constituição do gênero sempre se ancora na existência social, conferindo um ampla gama de possibilidades de ser homem e de ser mulher, as masculinidades e as feminilidades.

Nessa formatação de roteiros, Melina também traz uma outra situação exemplar envolvendo a construção do modelo do amor romântico quando os pais e mães valorizam o amor, o casamento, na formação dos seus filhos: "Eu acho que quando a menina tenta assumir essa coisa do amor, não sei como chamar isso, mas assim, às vezes, o pai ou a mãe ensina a filha, para a menina, que o amor é tudo, casar por amor, fazer o sexo por amor, tudo por amor. Então ela coloca naquela idéia de que o marido dela é perfeito, motivada pelo amor, se não houver o amor, então não há nada. Então ela casa, tem os filhinhos dela, e ela segue como dona-de-casa. Agora, se na educação for colocado para a menina que ela também serve para pensar, para agir racionalmente, vai ser a mesma coisa que o rapaz, vai conseguir fazer as mesmas coisas que o rapaz tem... Eu acho que por isso eu acho que até que tem mulheres hoje em acumulando outras profissões que antes era só o masculino, talvez seja passado seja passado para elas que elas também podem fazer e não simplesmente ficar ajudando". Assim, apesar da presença forte de um contexto machista em que a mulher deve ter total abnegação ao homem, em nome do amor romântico, Melina aponta conquistas da 
mulher no âmbito social a partir do questionamento do amor romântico e do exercício de novas práticas antes destinadas apenas aos homens, em uma atualização dos roteiros sexuais.

O questionamento dos papéis esperados de uma mulher tem um preço quando Melina cita: “...na minha família, eu não tenho valor, primeiro porque eu suportei um abuso durante vários anos e não contei para ninguém, e segundo porque eu escolhi pensar e não simplesmente amar (riso). Para mim o amor não é o fundamento da vida e... então assim, a vida é muito mais do que amar e namorar o meu noivo e para ela, para a minha mãe e pra minha tia, não é bem assim, então é tanto que eu sou a largada, ninguém me respeita, ninguém me ouve, como se eu fosse uma ovelha-negra, porque eu não escolhi o mesmo caminho. (...) Eu tenho duas irmãs, uma de 25 e uma de 26, casaram, largaram o serviço, e cuidam de casa. Uma deixou de cuidar de casa, até porque acho que o casamento dela não estava indo tão bem, e resolveu trabalhar. (...) A outra trabalhou dois meses e preferiu ficar em casa, viraram donas-de-casa. (...) Eu gosto muito de cozinhar, eu gosto da arte de cozinhar, a arte, e não cozinhar por obrigação. E minha irmã acha um absurdo eu achar um absurdo que elas fiquem em casa, limpando, ficando lá cuidando de criança, fazendo o dia inteiro isso, porque eu acho que isso atrapalha a vida da pessoa, inclusive o desenvolvimento sexual. E ela acha isso um absurdo". Melina apropria-se de sua vida enquanto pessoa e enquanto mulher para fazer as escolhas mais pertinentes com aquilo que faz mais sentido para si. O ingresso na faculdade também funciona como um catalisador para esta auto-afirmação, rompendo com modelos recorrentes de mulher testemunhados na sua família e do contexto que vivia, a exemplo da mãe submissa e abandonada, e das irmãs que se apropriaram da idéia de cuidar de casa e dos seus respectivos maridos e filhos abrindo mão do trabalho fora de cada. Não que a escolha de suas irmãs seja uma de menor valor, mas é mais uma dentre tantas outras escolhas que Melina não compartilha. Para o contexto em que vive, Melina transpassa uma sensação de deslocamento que beira o desvio daqueles modelos testemunhados, indo estudar e trabalhar fora, rompendo com as expectativas do grupo, com os roteiros previamente delimitados, ou dos modos-de-ser de uma mulher que é parte daquele contexto social datado e localizado.

No tocante à relação de gênero em um contexto machista, Melina faz mais uma vez referência sobre a administração das diferenças. Apesar do modelo dado ser do homem racional, forte, ativo; e o modelo da mulher ser emocional, frágil, e passiva, na prática, a vivência dessas diferenças se dá de outra forma: “...na realidade, desculpa, mas o homem, por 
isso é que eu digo, porque a mulher quando quer, a mulher consegue levar, o homem é muito bobo por ser enganado. Você finge que ele está mandando, você finge que ele manda, que aceita, e ele também finge que está mandando. E meio que recíproco, né? Dois fingidos (riso)". Assim, Melina sugere que apesar da aparência rígida dos papéis, o que impera é a forma do relacionar-se, é a singularidade de cada um quando em relação com outra singularidade. O relacionamento só é possível, de acordo com Melina, se existe uma flexibilidade entre as partes: "você cede e a pessoa também cede, e você vai se ajustando, uma vai se ajustando a outra, senão não tem como". Desse modo, abre-se a possibilidade para os mais diversos arranjos de pares, indicando que o estar em relação torna-se fundamental para a negociação de papéis e lugares.

Chama a atenção no depoimento de Melina questionamento e a negociação sobre os roteiros sexuais e suas escolhas condizentes com a quebra de paradigmas e os roteiros impostos. Dentre essas escolhas está, além do investimento nos estudos, apostar no sonho de ir para a França com o objetivo de estudar gastronomia. No momento em que ela revisou seu depoimento, declarou estar confusa quanto à realização deste sonho. Abre-se aqui uma reflexão daquilo que conscientemente apreendermos como roteiro, e aquilo que é incorporado nos roteiros intrapsíquicos, de forma velada, do que é esperado de uma mulher, no caso, de uma mulher que tem um noivo, com vistas a um casamento. $\mathrm{O}$ conflito se instala quando lembra dos modelos das mulheres de sua família, e daquilo que deseja para si: "Eu gosto muito do Pedro, eu só não quero... (...) ...é medo de, por medo, eu tenha que abrir mão de certas coisas, porque como eu vi a minha mãe, as minhas tias, as minhas irmãs, abrindo mão das coisas que elas queriam pelo casamento, pelo amor, ou não, se é amor verdadeiro, ou não, aí não dá prá discutir, eu não quero perder aquelas coisas que eu sempre cultivei, aqueles sonhos que eu sempre tive, por causa de um relacionamento". Melina sente na pele o preço do amor romântico abnegado, abrindo espaço para a dúvida de como direcionar seu projeto de vida: casar-se e se apaziguar com as expectativas sociais e viver compromissadamente com seu atual noivo; ou romper com os esquemas e aventurar-se na realização dos seus sonhos. 


\section{3. "Vou seguir a minha vida porque não dá pra ficar a vida inteira parada, foi algo que aconteceu, mas acabou": lançando novos olhares sobre o abuso sexual}

A culpa foi um sentimento de presença marcante na trajetória de Melina, seja direcionada a si mesma, à sua mãe, ao padrasto, e ao pai biológico. Esse sentimento foi amenizado a partir do momento que se apropriou da sua experiência e ressignificou-a: "Hoje eu aceito assim, foi uma coisa ruim, muito ruim que eu passei, mas sem ela também eu não seria a mesma pessoa que eu sou hoje. Não que tenha sido bom, não, mas boa ou ruim, trouxe alguma coisa para mim. Talvez se eu não tivesse passado por essa experiência ruim, talvez eu não teria o mesmo pensamento que eu tive".

No passado, Melina denunciou o abuso sexual num momento de desentendimento entre a mãe e o padrasto. A atitude deste foi de ameaçar de morte tanto Melina quanto sua mãe. Aquilo que era até então mantido sob o silêncio, desvelado e transformado em ameaça, gera mudanças no arranjo familiar. Geraldo fugiu de casa e a relação de Melina com a mãe foi se complicando cada vez mais. Melina teve de se mudar de sua casa, pois recebia ameaças por parte do padrasto. O exame de corpo de delito, comprovando o abuso sexual, demorou meses para sair. Com persistência, Melina foi ao Fórum e soube que o exame "desapareceu", e não foi por acaso, de acordo com o promotor de justiça do Fórum: "O promotor de justiça do Fórum, ele me falou para mim assim: 'O seu exame, ele desapareceu, e ele não desapareceu por acaso. Então assim, alguém fez com que ele sumisse. Se alguém fez com que ele sumisse, acho que alguém não queria que ninguém soubesse o que estava escrito nele, o que ele dizia. Então assim, então você escolhe, ou você reabre o processo tudo de novo, e você arca com as conseqüências, ou então você deixa como está. Isso porque assim, esse marido da minha mãe, ele já mexia com drogas e um monte de coisa errada, então, ele falou assim que, pelo menos que o promotor falou para mim, que a qualquer momento ele poderia fazer algo comigo ou com qualquer pessoa da minha família, até porque nesse meio tempo, até meus 18, 19 anos, ele ligava para a minha casa para me ameaçar, entendeu?". Melina, assim, foi orientada para que deixasse a situação do jeito que estava, o que ela consentiu a fim de evitar novas ameaças. Melina não teve como contar com outros suportes para lidar com a nova situação a partir do desvelamento do abuso, caindo novamente no silêncio. Neste ambiente desfavorável, imperava a impunidade, a carência, até mesmo por parte da mãe ou de familiares de quem não obteve o suporte de que necessitava: "Aí eu coloquei os pesos na balança e realmente é uma coisa que já passou, já acabou, teve fim, então eu deixei por aí, 
tentei conformar, e fui levar a minha vida a partir daí como... da melhor maneira possível, mas foi indo".

O sentimento de culpa direcionado à mãe é pelo fato de ela talvez tivesse conhecimento sobre o abuso sexual: "Eu era muito pequena... muito pequena, então assim, eu nunca fui de amigos, nunca fui de amizades, eu sempre fui muito quieta, muito na minha. Por isso que, às vezes, eu achava que a minha mãe sabia, porque não é normal uma criança muito quieta". Castro, Abramovay e Silva (2004) destacam o silenciamento das mães diante do abuso sexual, mesmo diante de queixas concretas das filhas, apontando para dois motivos principais: a dependência financeira do criminoso que sustenta o lar; e a dependência afetiva da mãe em relação ao agressor que representa um complicador para a defesa dos direitos dos filhos. Hoje, Melina acredita que o fato de ter tido uma infância isolada e até rebelde era indício de que algo não ia bem, mas, mesmo assim, a mãe não tomou nenhuma providência: “Com relação ao abuso, hoje eu não tenho, assim... durante muito tempo eu me culpei, durante um tempo eu me culpei, durante um tempo eu culpei a minha mãe, durante um tempo eu culpei a pessoa (riso) que fez isso comigo, depois eu voltei a me culpar, e depois eu compreendi”. O silêncio da criança é o desdobramento da submissão à autoridade do adulto, que gera o temor da punição ou da incapacidade dos adultos em protegê-la, sendo que, o fato de não falar indica a perda da confiança no adulto (Lamour, 1997; Castro, Abramovay \& Silva, 2004; Ribeiro, Ferriani \& Reis, 2004). A alternativa encontrada por Melina foi dedicarse principalmente aos estudos e ao questionamento do mundo. Melina afirma que: "eu acho que se isso não tivesse ocorrido [o abuso], eu num... num teria criado esse hábito de estudar, de questionar mais as coisas, de ouvir o outro, entendeu? Que são coisas que... são características minhas que eu não acho que vieram comigo, eu acho que foi algo que a vida me trouxe, que eu não acho que sejam ruins, pra mim é muito bom, entendeu?". Assim, Melina ressignifica a situação que passou sem assumir uma posição de vítima, mas encontrando respaldo e se fortalecendo de alguma forma nos estudos, reforçando seu desejo por independência e maturidade.

Essa postura a partir da ressignificação do abuso não é admitida pela mãe quando diz a Melina: "Você não tem trauma, pois se você tivesse trauma, hoje você não teria relação com o seu noivo". Assim, fica revelado um modo de como o social reforça o estigma do abusado, lançando um olhar na pessoa de forma a limitá-la até mesmo nas suas relações. Melina relata que antes de conquistar uma vida sexual ativa e prazerosa com Pedro, seu noivo, ela teve de 
enfrentar dificuldade sexuais: "Foi um pouco complicado a relação em si, e principalmente o ato sexual, e nо теи [relacionamento] atual foi muito complicado, (...) já rolava aquela coisa, rolava mesmo o tesão, mas não tinha... não tinha... o ato sexual não rolava. Toda a vez, é... eu chorava, ou, às vezes, uma forma, ou um toque, era o mesmo toque que a pessoa fazia, entendeu? Então, assim, estava o maior clima legal, mas quando eu me sentia tocada de uma certa forma e já vem tudo aquilo na cabeça".

O início da vida sexual consiste em um rito de passagem e nem sempre é tranqüilo, por acontecer em um cenário de cultural delimitado por preconceitos e rituais, marcado por exigência de performance, formas de ser, padrões socioculturais e ditames da sociedade de consumo (Giddens, 1993; Castro, Abramovay \& Silva, 2004; Gagnon, 2006). O contrário acontece com os homens que são estimulados a exercerem a sua sexualidade com o gênero oposto. Para Melina, que passou por 7 anos sob pressão do padrasto, as mensagens que ficaram atreladas ao ato sexual foram: "Se você falar para alguém, eu te mato"; "Se você for embora e não falar para ninguém, e eu descobrir que você está com outra pessoa, eu vou lá e mato você e a pessoa". Melina de certa forma assimilou o roteiro da situação de abuso sexual, e conseguiu ressignificar esse roteiro em uma nova situação com o atual noivo, encontrando no sexo uma possibilidade positiva e prazerosa.

O medo foi outra marca deixada por este episódio do abuso sexual. Ela mudou seu horário no colégio dado que o medo de ser atacada era intenso: "Eu ia dormir, escutava algum barulho na rua, eu ficava com medo. Eu parei de estudar aqui [na USP] à noite porque eu ia embora com medo de que alguém viesse... porque o meu medo não era vir ele e fazer alguma coisa comigo, mas ele mandar alguém fazer algo comigo. Toda a pessoa que se aproximava de mim e ficava com aquela desconfiança, 'Será que ela não foi mandada por ele, para vir atrás de mim me matar?'... Mas hoje eu vivo bem, não tenho mais essas coisas, mas até um ano e meio atrás, um ano atrás eu ainda tinha". Foi nesse período que Melina buscou os serviços do Plantão Psicológico.

Atualmente, a mãe não mais se relaciona com o padrasto, apesar de Melina acreditar que ela ainda nutre sentimento por ele. Em situações de briga, quando Melina diz querer ir embora, a mãe diz que: "se você for embora talvez a minha vida fosse melhor", reforçando a suspeita de Melina de que pode ser um empecilho para a mãe reatar o relacionamento com o padrasto: "Ela não fala comigo, porque ela nunca vai falar, e outra que se ela for falar a 
família inteira vai discriminar, querendo ou não, a família não vai aceitar que ela fique com uma pessoa que fez isso com a filha dela, então, talvez venha da família, ou mesmo da sociedade, não sei, mas às vezes, eu chego a pensar que ela ainda gosta dele".

Com relação ao pai, no primeiro encontro para o registro do seu depoimento, Melina diz ser rancorosa com relação ao abandono dele, principalmente ao longo da infância. Procurou-o quando tinha 15 e 16 anos, incentivada pelo noivo, mas "não foi 'aquela' recepção". Melina queria este contato para saber o motivo de ele não procurá-la. Tentou uma segunda vez o contato com o pai, ficando uma semana na casa dele e de sua família, pois passava por um período em que era ameaçada pelo padrasto: "E aí o contato com a família dele não foi essas coisas. (...) Eu sou muito rancorosa, eu tenho esse defeito, muito rancorosa. Eu nunca consegui perdoar, nem sei se perdoar, mas esquecer que meu pai me abandonou durante toda a minha infância". De uma forma resignada diz que o pai tem o comportamento de casar-se, ter filhos, separar-se e contrair novo casamento: " $E$ da mesma forma que ele fez comigo, ele fez com a outra mulher que ele teve crianças, ele também se separou, e agora com essa que ele está agora talvez faça a mesma coisa". O rancor tornou-se maior quando Melina soube que o pai, mesmo sabendo da história do abuso sexual, convidou o padrasto para um churrasco na casa em que Melina estava morando com a mãe: "Como que aceita que um cara que fez isso com a minha filha, e eu marco um churrasco com a pessoa na minha casa? (...) ...mesmo que não tenha um contato, é filho, é sangue, entendeu? E assim, uma coisa é... é, vamos supor, eu ter me oferecido para ele, eu falar 'Eu quero você, e... vem'. E outra coisa é você corromper uma criança de 7 anos, entendeu? Para mim é uma coisa muito grave, é muito monstruoso de se fazer para depois eu chamar, e saber que voc... e depois vem aqui na minha casa...". Fica destacado na fala de Melina o sentimento de falta de proteção, reforçando o silêncio e o isolamento vivido desde a infância.

Melina entende a atitude do pai como uma traição ao próprio sangue, sendo condescendente com o abusador. Na segunda entrevista, Melina disse tê-lo perdoado, e reforçou isso na revisão do seu depoimento, dizendo ter aprendido o valor do perdão. Não fica claro se é um perdão que lança uma cortina de fumaça em fatos passados, ou que absolve as atitudes do pai. Independentemente de qual for o sentido do perdão, Critelli (2006) aponta que o velamento - aquilo que é esquecido, ignorado, desentendido - é essencial, pois caso não existisse, a existência seria insuportável diante de inúmeros fatos e eventos vivenciados ao longo da trajetória de vida. 
O incidente da falha do gravador na ocasião da coleta do primeiro depoimento deu espaço a um ponto importante no que diz respeito pesquisa por meio dos relatos orais. $\mathrm{Na}$ segunda entrevista, alguns pontos foram retomados com um novo enfoque, o que aponta para a constante ressignificação e para o lançar de novos olhares para a experiência: "Aquele dia da entrevista ${ }^{38}$ foi muito chato, não queria mais falar com ninguém, foi bem chato e... e depois eu comecei a refletir sobre o assunto, e um pouco sobre a minha vida, sobre a questão do meu pai, da família, de tudo o que aconteceu"; em outro momento do depoimento reforça que: “...eu prefiro fazer de conta que nada daquilo existiu e fique sabendo que talvez por isso que quando eu saí daqui naquele dia eu fiquei ruim, né, pelo fato de eu ter que lembrar desse período da minha vida e despertar sentimentos, mas tudo bem, são etapas que a gente tem que passar, numa boa". Fica aqui a questão de como ela lida com essa questão no âmbito afetivo, pois simplesmente "esquecer" não parece ser um caminho mais indicado visto que a todo o momento algo trará à tona o ocorrido, porém, é uma alternativa para conseguir algum alívio diante da sensação permanente de algo que não foi resolvido.

O fato de ter rompido o silêncio e falado para a mãe sobre o que estava passando funcionou como um marco na vida de Melina: “...quando eu contei para a minha mãe, assim, pra mim foi um alívio, mas não, porque eu ficava pensando no passado, porque era daqui pra frente. Eu esqueci tudo, o que aconteceu comigo, todos os momentos ruins que aconteceu, e passei a pensar assim: o ruim já passou e agora só tem a vir coisas boas e passei a correr atrás dessas coisas". Melina opta por lançar um véu sobre o passado, e lançar-se para conquista de novas possibilidades na vida, apesar de ainda existir uma pressão das pessoas de convivência que destacam o fato de ela ter sido abusada sexualmente, reforçando a idéia de estigma: “...o meu comportamento foi uma das coisas que mais dificultou as pessoas acreditarem em mim, porque eu vivia feliz, eu vivia alegre e, assim, eu já tinha parado de ser aquela menina excluída, quieta, caseira e comecei a viver um pouco a minha juventude, e isso a minha mãe não aceitava, porque ela falava assim: 'Como você passou por abuso sexual e se comporta desse jeito?"'. Isto indica que o abuso sexual, além de ter desdobramentos em termos emocionais e sexuais, também existe os desdobramentos sociais, reforçando o sentimento de culpa, mesmo diante do fato de ter conseguido administrar o ocorrido.

\footnotetext{
${ }^{38}$ Referindo-se a primeira entrevista de coleta de depoimento.
} 
O estigma repousa justamente nessa idéia do "como você se comporta desse jeito?", que a mãe e os vizinhos lembravam a todo o instante, como se existisse uma maneira prédeterminada de uma pessoa comportar-se por ter sido abusada sexualmente. Melina refere-se às pessoas de seu meio como aquelas que: "durante alguns anos eu tive que conviver muito com os olhos das pessoas de onde eu moro, todo mundo ficou sabendo, com os olhos das pessoas que incriminavam e incriminam até hoje... não sei se até hoje incriminam, mas quando hoje elas olham para mim eu ainda vejo isso nos olhos delas". O verbo "incriminar" diz respeito a atribuir um crime, como se Melina fosse o pivô da situação de violência e, de certo modo, tivesse favorecido ou buscado aquilo. Braum (2002) aponta o quanto é lamentável que o agressor, quanto a própria família, diante de uma situação de abuso acusam a criança de "sedução", o que revela que a violência doméstica não deve ser entendida apenas na relação agressor-vítima. Em um contexto em que o machismo impera, é associado à mulher a idéia daquela que pode "desvirtuar" o homem do seu "bom caminho", mesmo que essa mulher seja uma criança. Esse modelo é conferido na idéia equivocada de que se a mulher não facilitar, o homem não abusa. Assim, em uma situação de abuso sexual parece existir uma tendência de as pessoas incriminarem a mulher, como aquela que seduz o homem, e este é visto como alguém facilmente seduzível. Melina quebra essa vitimização começando pela mãe quando estabelece limites e deixa de dar espaço para o compartilhar sua intimidade com ela. Assim, o distanciamento entre mãe e filha é reforçado, diminuindo possibilidades de apoio mútuo.

Melina retoma a sua fala sobre o relacionamento da mãe com o padrasto, dizendo que a mãe se "entregou de corpo e alma", e "abdicou a vida dela para ele, renunciou a tudo o que era dela em prol dele...", que o erro da mãe foi "agir mais pela emoção do que pela razão", afastando-se dos familiares e não dando ouvidos para o que vizinhos diziam sobre o comportamento de Geraldo. Fica destacado aqui um modo próprio de olhar para as relações, devendo predominar o racional, o controle, cuidando para não se entregar demais nos relacionamentos, até mesmo para não colocar tudo a perder, e nem ficar numa situação de dependência do parceiro, assim como fizera a mãe e outras mulheres do seu entorno. 


\section{4. "Agora já passou o período tenebroso, agora vou viver a minha vida": libertando-se das amarras}

Melina retoma a descoberta da sua sexualidade que se deu na adolescência, por volta dos 14 anos, a partir de revistas e de amigas na escola, por quem soube da masturbação como um meio de auto-conhecimento. $\mathrm{O}$ tabu sobre o sexo que a levava ao silêncio ganha um novo significado: “...se você comenta muito de sexo, ou é porque você está a fim, ou porque já fez, então, você não pode falar de sexo porque você está com vontade e tudo o mais". Esse significado tinha um impacto importante em um contexto de valorização da virgindade. Dessa forma, seguindo as palavras de Melina: “...para evitar maiores conflitos, você prefere ficar mais reservada".

Por volta dos 17 anos, Melina amplia o círculo de amizades e, durante alguns meses, teve um namorado, com quem pôde iniciar-se sexualmente de forma consentida. Não sentia prazer sexual nesse relacionamento, mas nem por isso deixava de ser gratificante: “...porque se meu psicológico já estava liberado nessa época e eu já tinha também passado um tempo considerável, e eu também estava disposta mais a curtir, a viver, então assim, com o fato de você estar bem, estar bem com a vida, aí as coisas fluíram, foi mais fácil e foi mais prazeroso".

Melina passa a escolher conscientemente sua parceria, a exemplo do relacionamento que teve de duas semanas com outro rapaz cuja intenção explícita era ter relações sexuais com ela. Melina deixou claro para o rapaz que queria ficar somente nos beijos, reforçado pelo fato de não ter um "sentimento forte" por ele. Depois da insistência do rapaz, Melina se aborreceu e o dispensou. Para a surpresa dela, ele gostou de sua atitude e propôs insistentemente querer namorá-la: "homem gosta de mulher que se impõe e ponto". Fica claro nessa passagem um exemplo claro de roteiro sexual em que o homem assume a postura do "ativo" e daquele que autorizado a conquistar e a ter quantas relações sexuais desejar, porém, Melina não corresponde à postura da conquistada, o que parece ter encantado o rapaz, por não conferir com a imagem de "mulher fácil" instigando ainda mais a conquista: “...na periferia as meninas que ficam tem uma imagem muito feia para as pessoas, principalmente das mães das amigas, principalmente o pessoal que tem mais idade, que teve outra situação". Nessa passagem se revela a desigualdade que existe nos roteiros dos gêneros, ainda mais com 
relação às diferentes classes sociais, revelando conflitos com a permanência de valores relacionados aos gêneros (Heilborn, 2006; Heilborn, Cabral \& Bozon, 2006; Knuth, 2006).

Melina diz que as pessoas da periferia são mais conservadoras do que as pessoas de classe média e alta, sendo essas últimas mais permissivas no que diz respeito à sexualidade e cita a traição, como exemplo. A questão que se apresenta é quanto ao acesso e ao tipo de informação e vivências que pessoas de diferentes classes sociais no que diz respeito à sexualidade, ou mesmo com relação à estrutura dos arranjos familiares em que os relacionamentos extra-conjugais são mais ou menos tolerados, o que confere a diversidade de roteiros sexuais. No caso, os significados e sentidos de sexualidade parecem diferir de acordo com o poder sócio-econômico. A perspectiva de Melina é de que: “...pelo menos assim, para elas [mulheres de classe média e alta] está bem mais resolvido no psicológico essa coisa de você ter um relacionamento e sair com outra pessoa, do que para o pessoal da periferia, talvez por causa desse lado conservador que tem".

Ainda na questão do "ficar", Melina mostra que é uma forma de relacionar-se não bem vista no contexto em que vive: “...o fato de eu estar ficando com uma pessoa é algo pejorativo... (...) ...ficar é uma coisa que você beija, se tiver a fim, você transa, e se tiver a fim, você transa de novo, e assim vai... E daí você vai ficando com a pessoa. E para eles, não, para eles você ficar é você beijar e já ir para a cama. (...) Não tem a coisa do ato sexual. É uma coisa que às vezes acontece e, às vezes, não, depende das duas pessoas". A mulher "ficante" não é bem vista quanto acontece com o homem "ficante". A mulher nesse caso é vista como a "dada", a vulgar; sendo o homem nessa situação o viril (Castro, Abramovay \& Silva, 2004).

4.5. "Vem cá, se você me beijar a gente namora, porque eu não vou ficar, não'. Aí ele beijou e a gente começou a namorar e está bem até hoje": o início do relacionamento com o noivo

Depois de 2 anos sem relacionar-se com outro rapaz, Melina conheceu Pedro. A princípio ela achou que ele era casado, mas sentiu-se atraída por ele e foi correspondida: “...a gente se conheceu, fez amizade, depois de 3 meses juntos, a gente passou a ter relações e, hoje, rola 
normalmente". Chamou a atenção de Melina o corpo sarado e o jeito maduro. O primeiro contato foi de forma ríspida quando ele foi a casa de Melina com a justificativa de arrumar a antena da TV. O segundo contato também foi de forma rude quando Melina saía do prédio e Pedro fechou o portão. Melina diz que o fato de falar bem o português influenciou positivamente para o início do namoro com Pedro, ex-professor de Português e atual soldado da Polícia Militar - PM.

Foi nessa época que Melina desenvolveu vitiligo ${ }^{39}$, que percebeu como uma ameaça para a sua negritude. Melina fazia parte do movimento negro e as manchas brancas deixaramna transtornada: “...eu era militante do movimento negro, então assim, ser negro para mim era tudo, de repente, aparece um monte de mancha branca no meu corpo, aí assim, eu fui lá no fundo do poço e fiquei muito mais nervosa...". Melina diz que na época iniciou tratamento dermatológico e foi se controlando emocionalmente, tornando-se uma pessoa mais calma. A negritude é uma referência importante para Melina no que diz respeito à sua identidade, sendo as manchas brancas do vitiligo uma ameaça para essa identidade. Vê-se nesse posicionamento a valorização da perspectiva do corpo na construção da identidade (Heilborn, 2006).

\section{6. "Ser homem, ou ser mulher, é o ápice de um amadurecimento": a concepção de masculinidade e de feminilidade}

Ao ser perguntada sobre como percebe o ser-mulher, Melina diz que pensou, sem chegar a uma conclusão, naquilo que disse no primeiro encontro sobre a masculinidade e a feminilidade ser mais uma questão de genitália, ou desenvolvimento do corpo. No segundo encontro, ela complementa, mesmo dizendo não saber ao certo, se é algo relacionado ao um "modo de ser". Para ela, "o que difere mesmo, assim, é além do comportamento, daquela coisa que já vem, que a gente já nasce com isso, que a sociedade já impõe isso, da delicadeza, da compreensão". Para Melina, a pessoa nasce com uma certa tendência, mas que a sociedade tem papel fundamental no desenvolvimento, ou não, dessa tendência. No caso da mulher, Melina destaca a delicadeza, a compreensão, fragilidade, poder chorar, de ter um olhar mais brando para as coisas. A idealização do ser mulher é de tal modo que ela própria não se sente enquanto mulher: "Eu não sou mulher. Porque assim, para mim, a mulher é o

\footnotetext{
${ }^{39}$ Afecção de pele caracterizada pela despigmentação da pele, e que forma manchas de bordas bem delimitadas.
} 
ápice do desenvolvimento. É tudo o que eles dizem de desenvolvimento, de ter toda aquela maturidade psicológica, para o corpo, e quando você atingir o ápice, aí você é mulher". Para ela, seu modo-de-ser equipara-se a uma menina, de ter um lado infantil, ficando confusa na hora de resolver alguns assuntos a exemplo do casar-se ou não se casar.

Interessante notar aqui o impacto que existe quando Melina se depara com a instituição do casamento, pois, para ela, um indício de que a mulher atingiu o ápice do desenvolvimento é de não ter medo de se casar. A maturidade fica desse modo atrelada à aceitação da instituição do casamento, sendo que a dúvida com relação aos seus interesses pessoais abala esse valor. O modelo construído socialmente de um ideal de relacionamento, ou mesmo um ritual de confirmação de um relacionamento, fica entranhado no roteiro intrapsíquico, sendo que fugir desse modelo, ou mesmo questioná-lo, acaba por abalar até a própria identidade, no caso de Melina, a sua identidade enquanto mulher. Vê-se o peso que representa o casamento para Melina, sendo que até imagina o que poderia acontecer caso escolhesse não casar-se: “... a sociedade cobra a gente a toda a hora”, sendo que a mulher que não se casa tem de lidar com um mundo que "a todo momento terá pessoas que vão falar para você e vão te cobrar isso", conferindo-lhe a indesejada situação de ter "ficado para tia".

Melina expressa uma insegurança que é inerente até ao próprio humano, de um dia ter convicção de algo e no outro dia, não. Ela sabe que a escolha do casamento implica em sustentar as expectativas do papel de esposa advindo, o que fica incompatível com seu sonho de ir para a França estudar e deixar o parceiro no Brasil.

Já o homem, Melina percebe que tem "aquela coisa bruta", não pode chorar, tem que ter atitude, ter maturidade de homem, sabendo diferenciar as coisas no sentido de fazer algo errado, voltar atrás e assumir. Pedro tem o estereótipo desse homem maduro até mesmo pelo seu trabalho como soldado da PM, conferindo-lhe um modo-de-ser responsável e ponderado. Mesmo assim, Melina reconhece que ocorre com o noivo o mesmo que nota em si, a presença de um lado infantil que se expressa no modo de vestir, no andar, de gostar de surf, de videogame. Isso aponta para o fato de que os próprios gêneros são flexíveis e negociados, o que vai depender do contexto, como será visto adiante.

Melina mostra que não é possível ser mulher ou ser homem seguindo roteiros sexuais tão rígidos o tempo todo. Assim, Melina sente-se segura com o lado homem-pessoa-exemplar, 
de Pedro; e não com o homem-moleque, que inspira indecisão e imaturidade. Melina retoma que ser homem ou ser mulher é o ápice de um amadurecimento, onde cada um pára para questionar o por que das coisas, de decidir e assumir escolhas. Nessa perspectiva de Melina, as pessoas não nascem homens, ou mulheres, mas tornam-se homens e mulheres.

Melina elegeu a senadora Heloísa Helena como representante do modelo de mulher, não só pela questão política, mas pela sua maturidade e atitude, por querer e defender esse querer. Outra figura pública que representa a mulher para Melina é a atriz Maria Fernanda Cândido, por demonstrar ser uma pessoa madura e não explorar sua beleza de maneira fútil. Outra atriz citada é Malu Mader, que Melina diz que desde pequena inspirava o senso de "parece mulher", pelo jeito de se vestir e por não ter um jeito devasso quando se fala. Nesses modelos de mulher fica evidenciada a valorização da mulher que não se corrompe, que defende o que quer, que não se entrega de forma fútil, ou mesmo seja uma devassa, sendo valorizado o resguardar-se sexualmente.

Para os homens, de início, Melina disse que não tinha nenhuma figura em mente que os representasse, mas depois lembrou de José Dirceu, pela sua história no Partido dos Trabalhadores - mesmo considerando os escândalos de corrupção nos quais está sendo acusado de envolvimento -, e também pela sua garra na juventude, de eleger um sonho e correr atrás.

As características de mulheres e homens citados por Melina vão ao encontro da sua própria trajetória de defender e ir atrás dos seus sonhos. Melina retoma a representação que tem de homem e de mulher valorizando a flexibilidade quando diz que aprecia um homem que não segue à risca o estereótipo de homem, a exemplo de saber conversar, de ter educação, de compreender, além de saber cozinhar, pois isso é mostra de que o machismo não é forte nele.

Para Melina, a vivência plena da sexualidade entre homens e mulheres se daria pelo respeito e pela compreensão, sendo o respeito premissa para existir uma aproximação entre duas pessoas. O equilíbrio se faz necessário no relacionamento: "Mas se os dois souberem dosar, a partir do momento que a mulher que, não, a partir do momento que é realmente é mulher, e é madura, sabe dosar o seu feminino, e o homem também sabe dosar o seu machismo, eu acho que aí a gente encontra um bom desenvolvimento e um bom 
relacionamento em si". Assim, Melina coloca em questão a educação que leva as mulheres a serem donas-de-casa, como única possibilidade; e os homens como machistas, sendo que, na relação, existe uma alternância desses papéis, dependendo do contexto. Diante das amigas, esse modelo pode ser exposto, sendo que o mesmo não acontece diante dos amigos de Pedro, aos quais deve passar a imagem de que a mulher obedece o homem. Melina acredita que o homem não consegue realizar sozinho o papel que a sociedade lhe confere, sendo a ajuda da mulher fundamental, concedendo às mulheres uma força maior que a dos homens. De acordo com Melina, essa força feminina é conquistada pela trajetória de vida repleta de sofrimentos, contrária à trajetória dos homens que, por sua vez, não passam por tantos percalços. Desse modo, “o 'não' para o homem é uma coisa muito mais complicada, ser recusado, ou não ter aquilo que quer, é muito mais complicado. Apesar da mulher ter toda essa fragilidade que as pessoas falam, o homem é bem mais frágil do que ela", sendo que a mulher "sofre por um olhar negado, ela sofre por um sorriso negado".

Ao final do depoimento, Melina retoma a questão do casamento de uma forma polarizada entre o "sim" e o "não" no sentido de que corresponder à expectativa social é algo importante, mesmo estando confusa e insegura com relação ao casar-se ou não casar-se. $\mathrm{O}$ "sim" seria o firmar compromisso casando-se com Pedro e se apaziguando com a expectativa social; sendo que o "não" seria o "ficar para tia", rompendo com essa expectativa social de casamento compulsório: Hoje tenho medo de chegar a esta idade e não encontrar alguém pra casar. Sabe, é difícil na casa dos 30 arrumar marido. Às vezes, penso em ficar só, às vezes, penso em casar com o Pedro mesmo. Mas, às vezes, também penso que encontrarei alguém um dia que cultive as mesmas idéias e valores que eu! Sei lá, tô muito confusa em relação a casamento! Mas tô achando que ficarei sozinha, embora ache que isso não seja o ideal..."40.

O fato de não se sentir segura com relação ao casamento reforça para si a idéia de imaturidade e depreciação, pois: "para ser maduro você vai ter que ter a responsabilidade e coragem de assumir". Um mundo se apresenta para Melina, sendo o casamento uma possibilidade dentre tantas. Mas ao longo da sua trajetória e do contexto em que vive atualmente, o casamento torna-se algo quase compulsório, algo que "parece que nasceu para aquilo".

\footnotetext{
${ }^{40}$ Trecho acrescentado em momento posterior à entrevista, na fase de validação do depoimento.
} 
O sonho de estudar na França por algum tempo talvez represente a possibilidade de conceder a si mesma um período de distanciamento da situação e dos conflitos que ora vive, assim como uma maneira de quebrar o modelo de gênero feminino vinculado ou dependente do gênero masculino. 


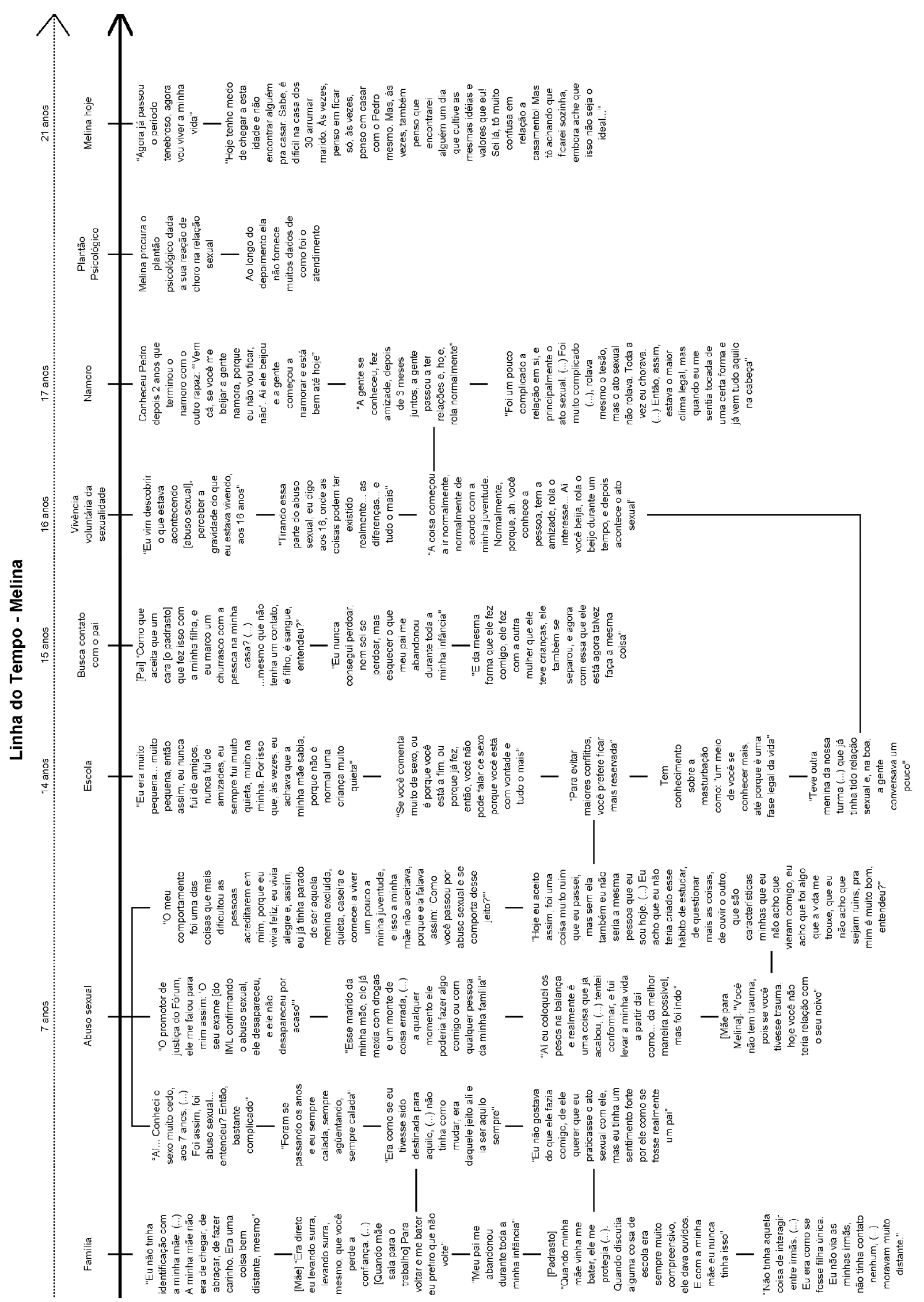

Figura 5 - Linha do tempo da trajetória de Melina 


\section{5. "Uma coisa que, tudo bem, foi tardia (...), pensando socialmente, mas para mim acho que foi meu momento": o depoimento de Sofia ${ }^{41}$}

Sofia tem 20 anos, nasceu em Cotia, SP, é solteira, estudante do $1^{\circ}$ ano da faculdade de uma instituição de ensino particular. Seus pais são separados. Mora com a mãe, a irmã, 15, e o irmão, 12.

Na primeira parte do depoimento, Sofia fala de algumas aventuras afetivo-sexuais, sendo que, na segunda parte, adentra em questões existenciais relacionadas à sua sexualidade.

Diante da questão disparadora: "fale-me sobre como foi desde a descoberta da sua sexualidade até chegar nos dias de hoje", Sofia reporta-se à sua primeira experiência sexual com penetração: "Acho que foi um pouco tarde... mas acho que foi um pouco tarde... É, porque as pessoas falavam muito, a minha mãe falava muito desde o meu primeiro beijo, sabe, a minha relação sexual eu tive a primeira com 18 anos, só, a primeira vez. E... o primeiro beijo acho que foi com 13...". Sofia mostra que se sentia cobrada, pois "foi uma coisa que todas as minhas amigas já tinham feito, sabe? O meu primeiro beijo, ah, as minhas amigas já tinham feito, e eu ainda, não; aí a primeira relação sexual, já tinham feito também, e já comentavam, assim, e eu ainda não, sabe? Uma coisa que, tudo bem, foi tardia. Tardia, assim, pensando socialmente, mas para mim acho que foi meu momento, e... acho que foi isso (riso)".

Sofia fala do seu primeiro beijo, que foi com seu primo, em uma festa familiar. Para ela, "o mais legal ainda não foi nem o primeiro beijo, foi a expectativa”, revelando a espera por aquele momento. Ela relata que nesta experiência sentiu-se pressionada por beijar, mas, por outro lado, ela transmite a idéia da magia do beijo roubado, do beijo dado em um clima de descoberta e de cumplicidade: “O meu primeiro beijo foi com um primo meu. (...) Já estava tudo programado que eu ia ficar com o Rogério. (...) A gente foi lá para o quarto. (...) Eu me senti muito mal, porque eu tenho muita vergonha de mim, eu me culpo por ser meio covarde, eu acho. (...) Ele ficou mudo, e eu fiquei muda. (...) Aí de repente ele me beijou, sabe, foi meio impulsivo (riso)". A marca deixada pelo primeiro beijo não foi das melhores, que ela vai

\footnotetext{
${ }^{41}$ A duração do depoimento foi de 2:00h. Na ocasião da validação do texto, Sofia manteve o conteúdo original.
} 
depor a seguir indicando que ela o fez sentindo-se pressionada pelo fato de, aos 15 anos, nunca ter beijado: "a primeira sensação que eu tive foi ruim, porque eu não gostei daquilo, eu fiquei meio pressionada, assim, sem saber para onde ir, sabe, porque foi numa situação constrangedora. Mas depois que eu beijei, eu gostei de beijar (riso). Aí eu fiquei beijando, assim, acho que ele, sei lá, acho que nossos beijos combinaram e aí (riso)... por isso, eu gostei assim". Após ter dado o primeiro beijo, Sofia diz que sentiu-se aliviada da cobrança velada das pessoas pelo fato de não ter beijado: "A situação que eu convivia, sabe, as pessoas perguntavam e as pessoas comentavam como era, e eu não comentava porque eu nunca tinha beijado, sabe? Mas é que também eu nunca tinha pensava nisso, isso que era engraçado, atê".

Neste início do depoimento de Sofia confere-se a influência do contexto social, das pessoas, das cobranças, mesmo que veladas, para que desenvolvesse um roteiro sexual entendido como norma da idade que tinha na época. Visto que ela estava com 15 anos, e ainda não tinha beijado, tornou-se foco da atenção de primos, primas, e colegas que talvez também não tivessem vivenciado efetivamente esta experiência. Contudo, o discurso era de que “todos" já tinham beijado, menos Sofia. O interesse afetivo pelo primo existia e Sofia tinha uma forma própria de se aproximar dele por meio de pequenos golpes físicos. O incentivo dos primos, primas e colegas, pode ter funcionado como o incentivo de ela precisava para intensificar esta aproximação e, com isso, ter uma forma de dar início à vivência de seu roteiro sexual, assim como ser uma referência para os próprios primos, primas e colegas. A experiência do beijo gerou um estranhamento que foi, aos poucos, dando lugar para o prazer e para a vontade de beijar mais.

Ao relatar a experiência do beijo, Sofia remete-se a atração por um colega, quando estudava no nível fundamental e, segundo ela, o sentimento era recíproco: “Eu... eu não pensava nisso [no beijo], sabe? Eu... eu lembro que até gostava de um garoto na escola, o Marcos Aurélio, e ele gostava de mim, mas ele não sabia que eu gostava dele. Ele me dava ovo de Páscoa, ele ia na minha casa todos os dias. E eu adorava isso, sabe, ele era o cara perfeito, assim, eu achava tudo perfeito nele. Mas eu não ficava com ele, assim, não sei, eu não queria ficar, sabe, eu queria dar uma de difícil. (...) Eu só queria que ele só ficasse gostando de mim, mas eu não ficava com ele. (...) Uns dois anos depois, assim, eu encontrei com ele, aí eu fiquei olhando para ele, para a cara dele, atraente, bonito, uma pessoa bacana... aí eu falei: 'Por que que eu não beijei ele, sabe? Não tinha porque não fazer isso'. 
(...) Aí eu comecei a pensar nisso, sabe, depois de um tempo, assim, comecei a falar: 'Por que não?', sabe, 'por que não ficar com as pessoas, sair de casa e não beijar?...'. Aí eu beijei! Aí depois que eu dei o meu primeiro beijo, eu fui ficar com um outro cara, tipo, 8 meses depois, só, assim". Os novos sentidos funcionam como referências significativas para o roteiro sexual que favoreceram para que Sofia passasse a desenvolver a sua expressão afetiva e sexual. Tais expressões são aprendidas das mais diferentes formas a partir da vivência e da interlocução da pessoa com no contexto do qual faz parte (Bozon \& Heilborn, 2006; Gagnon, 2006).

A questão da expectativa social com relação ao estágio de desenvolvimento da infância e adolescência é marcante para Sofia enquanto referência para as suas atitudes e comportamentos. A expectativa do social amplifica o próprio desejo em experimentar o contato com o outro. Neste mesmo sentido em ter outras pessoas como referências para seus comportamentos e atitudes, Sofia refere-se à irmã: “...eu gostava muito de brincar. Eu não sei se era eu que era muito criança, ou se... se as pessoas ficam maduras rápido demais (riso), ou se eu fiquei criança muito tempo, sabe, porque eu com 12 anos eu gostava de brincar, sabe? Eu vejo agora meu irmão de 12 anos, assim, tudo, já homens lindos... Eu não sei, os tempos são outros, também. (...) A minha irmã eu sempre digo assim, que ela tem 17 anos, mas parece ser mais velha do que eu até. Eu não sei se porque... se é uma troca assim, entendeu, eu fiquei acho que um pouco mais, um pouco criança, porque ela é mais nova e eu sou um pouco mais velha, entendeu? Não sei. Eu acho que isso aconteceu. Eu demorei um pouco e ela foi um pouco rápido demais. Aí... então, aí, só que aí depois, quando eu fiz 14 anos, 15 anos, comecei a beijar, assim, sair com os caras... (riso)".

\section{1. “Eu queria, mas não conseguia namorar": o início dos relacionamentos}

Quando tinha por volta dos seus 15 anos de idade, Sofia revela que não conseguia dizer "não" para um rapaz, por outro lado, isso não significa que o "sim" acontecia de forma tranqüila. Era presente a tensão entre o querer e o realizar: “...eu nunca fui de namorar, sabe, eu nunca gostei muito disso, assim. Eu queria, mas eu não conseguia namorar". Contudo, esta tensão não impediu que Sofia se relacionasse com outras pessoas, mas reconhece a ausência de uma implicação afetiva, ou a falta de um reconhecimento desta implicação: “...eu podia ficar com o cara, ele me tocar, assim, eu nunca conseguia (...) parar (...); uma coisa estranha que 
depois eu me arrependia, depois eu falava: 'Nossa!...', eu deixei o cara fazer essas coisas em mim que eu nem queria, sabe, às vezes, eu saia com um cara, ficava com umas pessoas que eu não queria ficar, sabe? Eu saía para as festas e eu ficava com várias pessoas. Teve uma época que eu despiroquei, mesmo, eu surtei. (...) Mas, então, sempre foi uma coisa meio assim, meio distante, nunca foi uma coisa efetivamente, assim, é... próxima. Nunca tive muito proximidade, assim, sentimentalmente falando".

Ainda na época em que tinha 15 anos, Sofia teve seu primeiro namorado, Diego, num relacionamento que durou 3 dias: "Nosso namoro começou quando ele me pediu em namoro, só que aí eu falei 'sim', porque tipo eu não tinha como dizer 'não', sabe? Então, ter até tinha, né, como dizer 'não', mas eu não sei, eu fiquei... sei lá... Ah! Acho que eu não sabia como falar 'não', aí... Então, tá. Na verdade eu não sabia nem como falar 'sim', porque eu achava ridículo eu falar: 'Sim, estamos namorando'. (risos)".

O relacionamento com Diego lhe conferia a ela certo status junto a sua rede de amizades na academia: "Ele era um garoto, assim, que todo mundo na academia queria namorar com ele, sabe, não sei o que eles vêem em mim. Acho que é porque eu meio que afastava eles de mim e eles se atraíam, sabe? (...) [Na academia] tinha várias garotas bonitas, e eu era tipo meio louca, sabe, sei lá, eu ficava fazendo... eu fugia um pouco dos padrões de beleza (riso)". O seu "tipo meio louca", o não se achar dentro de um padrão de beleza, e suas atitudes de não envolvimento eram percebidos por Sofia como fatores atrativos para os rapazes.

O namoro com Diego começou quando um dia chegou em casa, depois da escola, e, exausta, foi para o quarto. Depois de algum tempo, ouviu a voz de Diego e até achou que imaginava coisas: “...eu ouvi a voz dele e eu falei: 'Nossa! Estou até ouvindo a voz do Diego'. Que eu nem imaginei que ele ia estar na minha casa, tipo uma hora da tarde, sabe, em plena terça-feira. Porque eu sempre gostei muito de sair com o cara no final de semana, à noite, sabe? (...) Acho que tô surtando, né? (riso)". Desceu e viu a sua irmã conversando com Diego.

O fato de Diego estar na sua casa a fez sentir-se invadida e irritada: "Aí eu fiquei com muita raiva, sabe, e eu falei: 'Oi!... O que você está fazendo aqui na minha casa, tipo, agora, sabe?’. (...) Eu falei: 'O que você tá fazendo aqui?’. Só que eu não falei para ele, assim: 
'Meu, o que você está fazendo aqui?!', grossa, sabe?... '...Se toca, vai embora, eu não quero que você venha aqui nesse horário, agora, tipo...' (riso). Aí ele ficou lá, aí me beijou... (...) Eu já falei para a moça que trabalhava em casa: 'Ah, Maria, esse aqui é o Diego'. Ela: 'Ooooi!'. Tipo, que um dia antes, ele tinha ido na minha casa à tarde, e eu não estava, aí ele deixou uma flor lá para mim, sabe, ele deixou para a Maria. Aí ela: 'Você que deu a flor para a Sofia, né?'. Ele: 'Foooi, foooi...' (...) Aí eu falei: 'Então, tá, Diego, não sei quê...', e já dei um jeito de ele ir embora (riso)".

Durante o curto período de relacionamento, Sofia descreve a sua rispidez e a frágil intimidade do casal: "Porque eu gostava de ficar com ele, eu gostava do jeito dele, só que eu não gostava de namorar com ele. Aí... eu acho que eu sou agressiva, olha que isso é uma característica minha, que aí a gente vivia nos mesmos lugares, porque a gente brigava muito, assim, sabe, não como namorados, como amigos. A gente ficava, sempre que a gente saía, a gente ficava, tipo, a gente se beijava, tal, só que a gente nunca ficava assim tipo de mãozinhas dadas, nunca gostava de ficar assim, gostava de, meu, beijava e: 'Vou ali e já volto' (riso). Nunca teve essa coisa assim sabe, essa troca... essa troca de carinho, eu acho. Aí ele pegou, aí tanto é que teve um dia, que a gente vivia brigando, e uma vez eu dei um soco nele".

Sofia reconhece que apesar de sentir-se atraída por Diego, e talvez até apreciando a tentativa de Diego de se aproximar dela, ela não tinha disponibilidade para o envolvimento afetivo, talvez mesmo pela falta de contornos na vivência do roteiro sexual: "Porque eu acho que, na verdade, tipo, eu gostava de ficar com ele, até gostava de beijar ele, de ficar com ele de alguma maneira, mas eu não queria intimidade com ele, eu acho que ele tava meio que... sabe, o que as pessoas quando namoram fazem, né (riso), dividem a sua intimidade. E eu não queria isso. Eu nem me toquei sobre isso na época, eu fiquei.. eu percebi que era isso posteriormente (riso)".

A dificuldade afetiva referida por Sofia, pode ter influenciado na duração do relacionamento: “...no começo eu me sentia atraída por ele, porque ele era bonito, assim, todas as garotas tinham atração por ele. Aí quando ele ficou muito interessado em mim eu meio que peguei uma repugnância dele". Sofia diz que o namoro terminou pelos diversos encontros "casuais" que tinha com Diego. O último foi quando ela ia para a farmácia e fingiu 
não vê-lo, mas este a abordou: “...foi péssimo, sabe? Aí... Aí eu falei para ele: 'Ah, Diego, acho melhor a gente nem namorar mais'. Aí a gente terminou. Aí durou 3 dias".

No término do relacionamento com Diego, Sofia acredita que foi a garota que Diego mais gostou, mas tem dúvida que ele saiba que o sentimento era recíproco. Ela justifica a brevidade e a incerteza do relacionamento à sua dificuldade: “...eu tenho fortes problemas de relacionamento (riso). Eu tenho muitos problemas, assim, tanto é que meus namoros sempre foram todos assim, sabe... 'todos', não, porque eu namorei ele, e mais um outro cara... que chama Kadu".

Aos 16 anos Sofia conheceu Kadu. Ela se refere ao relacionamento com Kadu Ricardo - de forma que não houve uma definição explícita de namoro: “...a gente namorou mas não usou esse termo: 'estamos namorando', e foi um relacionamento que deu certo, assim, a gente ficou 2 meses juntos, só, assim, mas deu certo, tipo... a gente teve relação de namorado, sabe?... (...) ...A gente namorou, e eu namorei com ele meio que por esse lado, ele queria me buscar no colégio, sabe, e eu não queria. Eu meio que repugnava ele, sabe, eu desprezava ele muito, assim". Kadu trabalhava o dia todo e, nesta época, Sofia tinha ganhado de presente uma moto Biz: “...ele trabalhava o dia inteiro, e eu o dia inteiro andando de moto... (...) ... olha como eu era louca, ele trabalhava... eu passava onde ele trabalhava, assim, passava eu e os meninos, e eu ainda buzinava, sabe: 'Olha o Du!', não-sei-lá-não-seiquê, e ele fazia assim para mim ainda [faz balanço negativo com a cabeça], só na cabeça. Aí a noite ele chagava em casa e ficava lá me xingando, me xingando... e aí eu nem argumentava quando ele me xingava. Ele me xingava e eu só ficava ouvindo. E eu: 'É...'. 'Sofia, você tem que mudar o seu jeito, não pode ser assim'. E eu: 'Kadu, não tem nada a ver uma coisa com a outra. Eu estou lá com meus amigos, não-sei-o-quê-não-sei-o-quê'. (...) Só que foi um namoro meio... meio que assim... assim... que não deu certo. Só ele namorava comigo, acho que eu não namorava com ele, sabe?".

No tocante às amizades, Sofia diz que sempre teve amigos homens. No seu grupo de amizades também existiam mulheres, mas “...meninas gostam de ficar com meninas $e$ meninos, né, porque é onde pode acontecer alguma coisa...", indicando que os rapazes geralmente formam grupos de rapazes. Sofia não apreciava ficar nos grupos de garotas, preferindo o grupo de rapazes. 
Quando tinha 18 anos, Sofia passa a relacionar-se com outro rapaz, também apelidado de Kadu. Ela descreve este relacionamento como: “...foi muito legal, sabe, eu adorava ficar com ele. Eu já tinha sido meio apaixonadinha pelo irmão dele. Aí foi legal, assim, eu vivi umas coisas meio emocionantes com ele, assim, sabe, é que eu nunca tive emoções muito fortes com os caras. Aí ele fazia umas coisas legais comigo". Geralmente eles iam para o sítio dele e ficavam em cima de uma pedra. Sofia descreve que sentia liberdade de conversar com ele, porém, evitavam falar de si: “.... a gente não conversava muito sobre mim e nem sobre ele, tipo, a gente conversava assim, ele falava uma coisa e eu continuava aquilo...”.

Sofia não fala como foi o término deste relacionamento com Kadu, mas aponta para um padrão que reconhece em si e que já havia citado, mas ela demonstra nas entrelinhas seu sentimento de não envolver-se de forma intensa nos relacionamentos: “...engraçado que meus relacionamentos sempre foram assim, bom, o garoto que eu ficava, ficava apaixonado assim por mim, não sei porque que isso acontece (riso), ele meio que se interessava bastante por mim, assim, até que eu não queria nada com ele, eu falava: 'Não, até parece!'. Aí depois que eles me desprezavam... (...) Aí eu sempre faço isso. Depois que passa, eu sempre ligo para as pessoas e tal, não-sei-quê, e já não é a mesma coisa, né?".

Passado alguns anos, Diego, que foi o seu primeiro namorado, foi procurá-la. Diego há muito tempo estava morando em Poços de Caldas e retornou a São Paulo. Sofia não conteve a sua emoção ao vê-lo: "Ele mudou, estava bonitão, assim... Ele não mudou, ele cresceu, ficou maior, assim”. Só que havia um problema: Diego estava com Kauan, rapaz este que era amigo em comum e que Sofia “...pagava o maior pau para ele”. Isto acabou sendo embaraçoso para Sofia, pois Diego voltou demonstrando interesse por ela. Os dois rapazes, mais Sofia e a irmã dela foram fazer um passeio pelas trilhas de um sítio, e depois foram nadar em um rio. Kauan aproximou-se de Sofia e lhe disse que “...tem um amigo, tal, que veio de Minas só para te ver, não-sei-que-não-sei-que'. E eu falei: 'Ah, é?! Que amigo que é, hein?' (riso). Aí ele falou: 'E aí? Rola alguma coisa?'. Eu falei: 'Ah, cala a boca, Kauan, não sei, né, vou falar que não rola?". Sofia depois deste clima: "Eu sei que a gente ficou, a gente se beijou, tal, não-sei-quê, ficou...". 


\section{2. “Eu acho que tem um problema porque não é bom, e as pessoas acham bom": a primeira relação sexual de Sofia}

Na noite daquele mesmo dia do passeio os amigos voltaram a se encontrar no condomínio onde Sofia mora, só que, agora, Kauan com sua namorada, e Diego e Sofia, além de outros amigos. O lugar predileto de ficarem era sentados em um balão na rua deste condomínio. Tarde da noite, os demais amigos foram embora e os dois casais foram para a casa de Kauan. Foi quando Sofia teve a primeira relação sexual, que aconteceu com Diego. Sofia descreve a experiência como: "Aí a gente ficou lá na casa do Kauan, aí a gente ficou lá, tal, e a gente transou, sabe, eu e o Diego, só que foi uma coisa meio estranha, assim... tipo, não foi estranho, mas... foi estranho, não sei se foi estranho, mas foi estranho".

O estranhamento descrito por Sofia está relacionado ao fato de ela perceber que "viaja" na relação sexual: "na hora que estou tendo uma relação sexual, assim, eu não tenho... não é que eu não tenho prazer, assim, mas eu não tenho uma coisa a mais, assim, sabe, que eu acho que todo mundo sente e eu não tenho, uma coisa meio... eu fico meio viajando". De acordo com aquilo que apreendeu sobre prazer sexual, Sofia sente-se estranhamente diferenciada da maioria, daquilo que "todo mundo sente" na relação sexual. Durante a relação sexual, Sofia pensa em outras coisas, distanciando-se do contato entre os corpos: "Eu fico pensando em delta, sabe delta de matemática? (riso) Eu fico pensando em delta! (riso)... Estranho, né? Aí eu fico pensando, tipo: 'Nossa!', eu tô lá: 'Nossa! Amanhã tenho que fazer isso, isso, e aquilo...', uma coisa que eu viajo".

Ela esclarece melhor esta "viagem", este sentir-se diferente: "E o pior que é assim, eu tenho mais prazer desejando, do que, assim, desejando o desejo do que na parte prática, sabe, então, eu fico surtando, assim, sabe? ...Eu fico surtando pensando no desejo, imaginando, e imaginando eu fico acho que mais excitada do que... no ato excitada em si. Estranho isso, né? (riso) Uma amiga falou que tenho passar por um médico. Aí eu falo: 'O médico não vai me... sei lá... uma hora melhora'. Então, eu deixo as coisas irem, aí eu vou praticando até as coisas mudarem. Então, só que aí agora estou numa fase meio de surto". $\mathrm{O}$ diálogo que ela estabelece com a amiga desperta o estranhamento, um estado que não corresponde àquilo que é esperado de uma norma de conduta sexual, sendo o especialista recomendado para auxiliá-la a incluir-se na normalidade. A visão de sua forma singular de prazer não tem um viés patológico, sendo a escolha de Sofia o continuar no processo de 
experimentação deste modo de ter contato com o prazer, permitindo-se o novo. Apesar de ela referir-se a este modo de ter prazer como "estranho", não fica evidente na sua fala de que existe um sofrimento ou um impedimento à sua forma de prazer singular, a não ser pela perplexidade de que percebe que as pessoas acham o sexo bom: "Porque eu considero uma anormalidade, é uma coisa que as pessoas consideram bom e prá mim não é muito bom (riso), entendeu?". A questão trazida por Sofia é sobre o sentimento de não seguir os sentimentos e sensações que usualmente são experimentados pelas amigas, inclusive o de perceber o sexo como algo bom.

\subsection{Sofia e a relação com o(s) pai(s): “...eu não sou filha dele, eu sou filha de uma outra pessoa..."}

Sofia acredita que a sua dificuldade nos relacionamentos devido aos problemas que tem com o pai: "Esse meu pai que é separado da minha mãe, na verdade, eu não sou filha dele, eu sou filha de uma outra pessoa que eu conheci no ano passado e, assim, eu, tipo, foi uma coisa meio ruim, assim, para mim". Sempre existiu a desconfiança por parte de Sofia de que aquele que chamava de pai, na realidade, não era o seu pai. A situação foi esclarecida por volta dos 12 anos, quando sua mãe lhe contou que seu pai biológico era outra pessoa: “...olha que engraçado, eu sabia indiretamente disso, mas eu achava que era... antes da minha mãe me contar que eu não era filha dele, mas eu achava que era um pesadelo que eu tinha tido. Olha que 'nóia' (riso)". Desde os 3 anos de idade ela morava com o padrasto.

Quando sua mãe lhe contou sobre seu pai biológico, Sofia disse que "aquilo não significava nada". Mesmo assim, sua mãe disse que a levaria para conhecer o pai assim que quisesse. Sofia mostra que a mãe era até insistente para que conhecesse o pai, mas Sofia nunca mais tocou no assunto. Ela mostra seu desconforto com a forma de a mãe em lidar com o assunto, mas, por outro, reconhece alguns ganhos desse seu lugar na família: "E minha mãe sempre ficava insistindo em tocar, sabe, e eu não gostava muito de falar. Aí qualquer probleminha que eu tinha, assim, qualquer coisa que acontecia ela já achava que era por causa disso. E aí eu fiquei meio que super-protegida em casa, assim, sabe? Minha irmã briga muito com a minha mãe, ela fica jogando isso na cara da minha mãe: 'Ah! Tudo é para a Sofia!'. Porque acho que meio que é culpa da minha mãe, sabe, um pouco, minha mãe me 
teve com 18 anos, aí eu acho que ele era casado, não sei, eu não pergunto muito, sabe, eu não questiono isso. É até estranho, mas eu não fico questionando, devia questionar, mas eu não questiono. Aí ela pegou, e deu a maior briga na minha casa que minha mãe fica mais comigo, de fato, minha mãe realmente, assim, se dá muito melhor comigo, meio que, faz mais por mim do que a minha irmã, assim".

Interessante a forma com que Sofia descreve a mãe, que, de certo modo, é bem próximo à sua própria apresentação: “...minha mãe é meio assim... fala muito, não-sei-quenão-sei-que, a minha mãe é meio doida, assim, meio... aí... minha mãe é meio espontânea demais, às vezes, eu acho, ela fala umas coisas que ela não devia falar, até. Ela briga mesmo, sabe, se tem que brigar, ela briga. Minha mãe fala umas coisas que vai lá no cérebro, sabe? (riso)".

No ano passado, aos 19 anos, Sofia resolveu conhecer o pai: “...cheguei num estágio, assim, psicológico acho que muito ruim, eu não conseguia me envolver com ninguém, assim, eu não tinha amigos, assim, eu não tinha... eu não conseguia arrumar um namorado, estava me fazendo mal, sabe? Eu não conseguia mudar isso, reverter isso. Aí eu falei: 'Ah! Eu vou conhecer ele...". A experiência não foi muito boa, pois o achou "arrogante" e "meio mentiroso": “...minha mãe falava que ele era uma pessoa intelectual, assim, ele era mesmo, sabe, ele era uma pessoa muito bem entendida, tal, mas ele tinha umas idéias diferentes da minha, ele é meio capitalistazinho, assim, sabe? (riso)". Tamanha foi a aversão ao pai que chegou a lhe provocar ânsia de vômito. Isso foi agravado quando notou que o pai tinha uma postura negativa com relação a sua mãe: “...eu acho que ele não gosta desse jeito da minha mãe, muito, porque ele falou assim, a gente chegou, aí ele: 'Ainda bem que a sua mãe não veio, porque se a sua mãe viesse eu já ia mandar ela ir, meu, passear, porque eu não ia querer ela aqui com a gente'. Aí eu não gostei do jeito que ele falou, assim, sabe, porque, tipo, cala a boca, aí eu peguei e falei assim: 'Não, a minha mãe que não quis vir, eu até queria que ela viesse, mas ela falou que não queria vir'. Tipo, eu falei que minha mãe não ia vir, sabe?".

Atualmente, com os outros encontros com o pai, Sofia está se familiarizando com o jeito dele e diz passar a gostar: “...eu tô vendo que no fundo ele é uma boa pessoa”, apesar de "ele gosta meio que de impressionar", e "não é muito humilde", coisas que não a agradam. 


\section{4. “Eu estava preocupada com essa questão de que eu queria arrumar namorado (...) mas eu não conseguia fazer essa aproximação": Sofia procura o Plantão Psicológico}

Sofia relata que fez terapia diversas vezes, mas que o tema da sexualidade nem sempre foi tocado, pois não pensava sobre isso. Desde os 3 anos de idade a mãe de Sofia - que é psicóloga - insiste que ela faça psicoterapia. Alegando que o atendimento psicoterapeutico nunca mudou nada em sua vida, Sofia deixou-o. Ela aponta o motivo da insistência da mãe para o trabalho psicoterapêutico: "Porque eu sou uma pessoa fechada, nunca fui de falar nada de mim, assim, pra minha mãe nunca fui de falar nada, nunca fui de chorar, eu era muito agressiva, sabe, gritava muito não-sei-quê, batia no meu irmão (riso)... Aí eu sou meio agressiva e a minha mãe, né... A minha mãe é psicóloga também... Aí a minha mãe ficava numas neuras, lá... Eu até gostava de ir, sabe, mas eu não sentia diferença nenhuma, não mudava muito a minha vida".

Mais adiante no seu depoimento, Sofia mostra sua preocupação com o fato de não conseguir um namorado: "Quando eu vim procurar o serviço eu estava preocupada com essa questão de que eu queria arrumar namorado, sabe? Porque eu me sentia sozinha... eu me sentia, assim, sabe, eu sentia que eu precisava de alguém, mas eu não conseguia fazer essa aproximação, e aí eu fiquei... e aí surgiu uma série de questões, eu fiquei pensando: 'Será que o problema é comigo?' (...). ...Porque eu sempre fico reclamando para a minha mãe: 'Eu quero namorado!' (riso), 'Ah! Eu não arrumo namorado, não-sei-quê...'. E aí eu fico: 'Ah! Você vai casar primeiro que eu', pra minha irmã, sabe?... Ela namora há muito tempo... há 3 anos. (...) ...A minha mãe falou: 'Claro, todo mundo que aparece você encontra um defeito, você afasta as pessoas que gostam de você', e aí eu fico pensando nisso, sabe, eu nunca paro para pensar nisso, mas aí eu fiquei pensando, eu falei: 'É verdade', sabe?'.

A cobrança interna é intensa, ainda mais quando compara-se com as pessoas no contexto em que vive. Mas Sofia vai, aos poucos, direcionando seu depoimento não mais para as aventuras, mas como sente-se nelas e o significado que estas experiências têm para si. O sentimento de estar só é presente, assim como é presente uma perplexidade sobre o fato de não conseguir aproximar-se de forma mais íntima e duradoura de alguém.

Reconhece que a idealização do parceiro é presente e que não está preparada para uma relação a dois: “...Eu fico esperando um príncipe encantado, eu falei... e a minha mãe: 'Não 
existe um príncipe encantado', sabe, 'não vai existir alguém que não tenha defeito, você vai ficar aí esperando a sua vida inteira'. E é verdade. Os defeitos das pessoas me incomodam, assim, não me incomodam pelo fato de serem minhas amigas, sabe, eu não me importo com defeitos de amigos, assim, sabe, eu me importo para ter uma relação de casal já...".

A idealização de um parceiro é presente para Sofia, e ela acredita que isto contribui para sua dificuldade nos relacionamentos. Esta idealização perpassa também o relacionamento com os psicólogos que passou ao longo da vida: "É muito engraçado, (...) ...eu gosto que fiquem atrás de atrás de mim, assim, eu gosto de falar 'não', e ficar insistindo... E acho que a minha relação com os psicólogos foi mais ou menos assim, também. No fundo eu queria que eles... o que eu ficava pensando: quero que, meu, que o fulano se determine, assim: 'eu vou mudar a vida da Sofia', e fique insistindo em mim, sabe, eu digo que... sabe aquelas pessoas rebeldes, assim (...): 'Vou continuar do jeito que eu sou', e a pessoa fica insistindo até fazer você mudar, porque eu precisava de uma mudança assim, eu acho, eu preciso de uma mudança na minha vida, eu acho, só que eu espero que a mudança vir do outro, entendeu, tipo, não de mim. Isso é ruim".

Quando soube que o serviço oferecido pelo SAP era gratuito, resolveu vir, pois não dependeria da mãe para pagá-lo. Viria por sua própria vontade. Chegando ao SAP foi atendida por Alex: "O psicólogo que estava falando comigo, eu achei ele meio desafiador, assim, sabe? Aí eu gostava do jeito dele, e eu acho que ele era homossexual (riso), e aí eu começava a falar muito sobre esse assunto, comecei a falar sobre esse assunto por causa dele, sabe, eu não perguntei para ele, mas eu ficava me perguntando... porque eu gostava do jeito dele, assim, sabe, aí eu ficava questionando ele, e ele não gostava de falar quando eu questionava ele. (...) ...Ele não falava nada, sabe, acho que ele gostava meio que de Lacan, porque os lacanianos não falam muito, né? (...) Aí eu ficava perguntando, porque eu queria ver ele falando, eu perguntava as coisas para ele (...) tipo, ele começava a responder às minhas perguntas, aí só que eu perguntava a coisas dele, entendeu, sobre ele. Aí acho que ele pensava: 'Caracas! Cala boca! Eu falar de mim para ela?!', aí ele: 'Sofia, não estamos aqui para falar de mim, estamos aqui para falar de você, tá bom?, não-sei-quê-não-sei-quê'... Aí eu ficava, só perguntando... Ele era meio grosso, assim, só que eu gostava do jeito dele... Acho que é o psicólogo que mais gostei de conversar". Neste trecho do depoimento em que Sofia fala das suas primeiras impressões sobre o atendimento no Plantão Psicológico, e de como percebeu o estagiário-conselheiro. Sofia percebia algo em Alex que a remetia à questão 
da homossexualidade. Mesmo no atendimento, Sofia mantém a sua atitude de preservar-se e passou a explorar de alguma forma Alex a fim de que este se abrisse com ela, principalmente no que dizia respeito à homossexualidade dele, porém, mais adiante, Sofia traz a questão da homossexualidade como um dos motivadores para a busca de atendimento no SAP. No que tange ao atendimento, foi interessante a postura do estagiário, de fornecer limites no encontro. Os elementos são escassos para a afirmativa de que isso pode ter favorecido a empatia de Sofia, mas, por ter passado por vários profissionais, nas palavras dela, Alex foi o "psicólogo que mais gostei de conversar”. Em outro momento do depoimento, Sofia retoma a sua opinião positiva sobre Alex: “...Eu gostei muito, assim, do psicólogo que eu vim aqui, do Alex, que eu gostava do jeito dele, assim, que ele não se manifestava. Quando foi a nossa última consulta, que ele falou que era para a gente concluir alguma coisa, eu não vim. Aí eu nunca mais falei com ele (riso). Não sei qual for o motivo de eu não ter vindo, eu fiquei pensando se era alguma coisa inconsciente, ou se foi... sei lá... é que não sei... nenhum motivo".

Ao longo do atendimento, diante de vários indícios, a exemplo dos relacionamentos rápidos provenientes da sua dificuldade neste aspecto, Sofia passa a questionar sua própria orientação do desejo sexual: “...eu comecei nesse período, eu pensei nisso, eu falei isso: 'Será que eu gosto de mulher?' (riso), porque era possível, sabe?, é... 'por que não?'... mas eu tenho um desejo por homem, quando eu tenho um desejo, assim, um pensamento, é com homem que eu tenho esse desejo, sabe, aí eu fiquei pensando assim: 'Vou fixar o meu pensamento. Vou ficar pensando em mulher'. Aí eu achava meio nojento, assim... não vou dizer nojento, mas... sei lá, sabe, não é uma coisa que eu... que eu pensava (riso). E já beijei, assim, mulheres... (riso) assim, não beijei mulheres, beijei amigas, assim, vai, tipo numa festa, agora. Eu fui em uma festa sexta-feira, na minha cidade, e... aí, meu, aí eu fiquei muito louca e tomei bala, sabe, eu nunca tinha tomado isso, e eu tomei (riso)". Sofia relata as suas experiências afetivas, uso de substâncias, e dúvidas provenientes do seus conflitos e comportamentos. A conclusão a que chegou era de que seria possível ser homossexual, mesmo que não identificasse em si o desejo afetivo-sexual por "mulheres". Interessante a diferença que faz de "mulheres" e "amigas", sendo que, nesta última categoria, o beijo é mais permitido em um contexto de experimentação. 


\section{5. “...Meus desejos ficaram incontroláveis, mas eu achava que tava controlando...”: a experiência com drogas e expressão afetivo-sexual}

$\mathrm{Na}$ festa citada, ela e a amiga consumiram ecstasy, o que parece ter motivado ainda mais o beijo: “...Aí deu uma coisa, sabe? Fiquei, fiquei viajando... eu viajei lindo nessa festa. Aí tipo a gente se beijou, eu e ela. Eu já tinha beijado ela, assim, meio que a gente se beija em festa, aí a gente beijou, assim, e eu tinha ficado com um cara, que eu já tinha ficado antes, aí eu fiquei com ele, tal, não-sei-o-quê, e aí eu comecei a beijar ela na frente dele, sabe, ele surtou e: 'O que é isso!'. E aí começou a me beijar, sabe?... Eu beijava ela, eu beijava ele. Eu viajei, viajei, eu viajei muito nessa festa, pior é que essa pessoa é da minha cidade, ainda, deve ter vários comentários, agora, aí depois eu beijei um outro cara, que minha irmã tinha ficado, assim, todo mundo conhecido".

O uso da droga gerou um estado em Sofia em que sentiu-se mais solta: "Nessa festa que eu tomei bala, eu estava bem consciente, só que eu estava muito energética. (...) ...O ecstasy (...) eu acho que mudou o meu estado, mas eu achei que no fundo eu estava me controlando, mas no fundo eu acho que não estava me controlando, entendeu, tipo os meus desejos ficaram, incontroláveis, mas eu achava que eu tava controlando, não que eu achava que tava controlando, é que eu acho que eu perdi a censura (...), não tinha controle, não tinha porque eu pensar que eu não estava controlando, porque eu não queria controlar nada, então, não tinha o que pensar que eu estava controlando, por isso que eu achava que eu estava controlando". Deste modo, Sofia experimenta a "perda da censura" para lançar-se na festa.

Bebeto, 25 anos, o rapaz citado por Sofia, nesta festa, estava embriagado. Ela discorre uma série de adjetivos para Bebeto: "o troço mais lindo da minha cidade", "uma pessoa inteligente", "cara educado", "gente fina", "um exemplo de homem", "meio político", "muito meu irmão". Ele e a irmã de Sofia já tinham ficado juntos. Sempre que Bebeto passa por algum problema vai a casa de Sofia conversar. Foi quando Sofia sentiu que algo acontecia entre eles: “... a gente conversa bastante, aí eu senti que rolou uma coisa estranha entre eu e ele, assim, sabe, porque geralmente, fica conversando eu, ele, a minha mãe e a minha irmã. Aí a minha mãe subiu, foi dormir (...),ficou eu e minha irmã. Aí geralmente ele e a minha irmã fica meio que com gracinha, só que eu senti que ele não tava com gracinha para a 
minha irmã, achei que ele estava meio estranho prô meu lado, sabe? Eu falei: 'Não, é coisa da minha cabeça...".

Voltando para a festa, Bebeto estava com Sandra, sua namorada. Sofia relata que: “...ele me cumprimentou: 'E aí, Sofia!... não-sei-quê'. Ele estava louco também, só que não de droga, ele nunca usou nada, ele estava bêbado, só. (...) Ele me pegou e falou assim: 'Sofia, se a minha namorada não estivesse aqui e ia agarrar você e beijar a sua boca agora'. Só que eu fiquei pensando: 'Gente, por que será que ele falou isso?... Porque eu devo ter falado alguma coisa para ele, será que eu me insinuei para ele, ou será que... ele falou isso... porque ele tava louco e resolveu falar?' Aí eu fiquei maior na neura". Bebeto abraçado com a Sofia, diz que Billy, o rapaz com quem ela já tinha ficado, estava olhando para os dois.

No final da festa foram para o carro dele aonde aconteceu o beijo: “...sei que aconteceu alguma coisa a mais entre eu e ele, só que eu não lembro. Aí eu sei que na hora de ir embora, ele pegou e falou assim para mim: 'Sofia, vem aqui, vem aqui, vem aqui!...'. Ele estava no carro dele, eu estava saindo, já indo embora. Aí ele pegou e: 'Vem aqui! Vem aqui! (...) Entra aqui, e vamos embora comigo'. Eu falei: 'Claro que não! Não surta!'. Ele falou: 'Entra aqui, por favor, Sofia, vamos embora comigo'. (...) Aí eu entrei no carro e a gente ficou parado, ficou parado na porta da festa, todo mundo tava saindo e vendo eu e ele dentro do carro, mas só que aí não tinha nada a ver, até então, né, porque eu estava só sentada no carro... A namorada dele estava lá [na festa], mas só que por isso mesmo, estava parado na porta... (...) Daqui a pouco só vejo o Billy, que era o garoto que eu estava ficando, e os amigos dele vindo correndo. Ai ele [Bebeto] e saiu correndo, (...) foi para a porta da minha casa. (...) Eu estou te contando essa história toda para chegar numa parte interessante. Aí ele pegou, me beijou, assim, e, aí, ele beija muito bem, bem que a minha irmã já tinha falado que ele beija bem (riso). Aí ele pegou e estava tendo o maior pega forte, assim, sabe, vem pra lá, vem pra cá... (...), tava bom, era para ser bom, porque eu sempre fui atraída por ele, assim, tal, era para ser uma coisa muito boa, mas aí, mas aí... é que teve um pouco de penetração, sabe... mas teve muito (riso), aí sei que tava bom, mas eu falei: 'Pára, pára, vamos parar, vamos parar', aí porque, tipo, eu até podia continuar, sabe, só que eu falei assim: 'Eu não vou estragar porque, meu, eи vou estragar o que existe entre eu e ele, e eu não quero estragar'. (...) ...E a gente ficou lá não-sei-quê, até teve umas coisas, sabe, isso já era umas 7 da manhã, a minha vizinha (riso) já estava na sacada dela, e eu falei: 'Meu Deus do céu!...'. (...) Aí de repente eu olhei para ele e falei assim: 'O que eu tô fazendo no banco do 
motorista e você está fazendo aî?' (riso). Ele: 'Nossa! Não sei! Vamos trocar!'. 'Que vamos trocar! Eu vou descer, eu vou embora!'. (...) E ele: 'Então, tá'. Aí a gente se beijou, assim, e aí eu saí toda descabelada do carro (riso), abri o portão e entrei. Aí eu fiquei pensando... Então, foi uma coisa estranha, tanto é que eu fiquei pensando nele o dia inteiro, depois, sabe, eu falei: 'Nossa! Eu queria achar ele'...”.

Mais no final da tarde, Sofia reencontra Bebeto: “...eu passei em frente a casa dele, de carro (...).Aí eu peguei e fingi que não vi ele, e ele: 'Sofia!'. Aí eu não olhei de novo, aí ele pegou, aí, não, ele assobiou, assim, aí eu olhei, aí ele pegou e falou assim (...): 'Desculpa por ontem'. Aí eu peguei e falei assim: 'É recíproco' (risos). Eu peguei e falei tchau, e fui embora, né? Aí eu liguei para ele depois (...): 'E aí? Tudo bem?'. Ele falou: 'Tudo bem, e você??'. 'Tudo bem?'. 'Tudo bem'. Ficou uma coisa meio assim, sabe? Aí, eu liguei para ele porque eu tava com muita vontade de ligar para ele, porque... porque foi engraçado, eu até ria até, foi uma coisa desajeitada no carro, foi uma coisa meio nojenta. Eu gosto dele, sabe? Eu queria ele de novo, eu queria que aquilo tivesse sido melhor, sabe? Não sei porque foi uma coisa nojenta... Sempre que eu tenho uma relação sexual com alguém, depois eu... alguma coisa, assim, eu me atraio por ela, mas ao mesmo tempo tem uma coisa paralela, sabe, porque eu continuo atraída por ela, assim, alguma coisa... assim, tipo, uma atração fortalece e uma coisa... uma repugnância, também, assim, sabe, são duas coisas distintas que estão juntas, assim, acontecem simultaneamente. Toda a vida foi assim".

\section{6. “Eu não lembro se tive uma experiência sexual boa...”: Sofia e a vivência sexual}

No envolvimento sexual com Bebeto, Sofia reconhece as marcas deixadas, não muito claras para si, mas marcas com um sentido de atração e repugnância, prazer e repulsa, como ela explicita dizendo que são coisas paralelas mas que acontecem ao mesmo tempo. Esta explosão de sensações e os conflitos que a acompanham seguem a sua vivência nos relacionamentos rápidos.

Um aspecto significativo trazido por Sofia é de que ela não se relaciona pelo sexo em si, mas com a parceria. Ela relata outra experiência vivenciada com um professor da sua faculdade a fim de comparar com a que teve com Bebeto: "Eu não lembro se tive uma 
experiência sexual boa... teve, assim, porque eu nunca tive muitas vezes, tipo, relação sexual, muitas vezes com uma só pessoa, entende, tipo, sempre com caras diferentes, assim. Aí só que assim, eu saí com um professor da minha faculdade, aí... (riso), aí, a gente saiu algumas várias vezes, assim, então, também... nada nojento, assim, foi a relação sexual mais confortável que eu tive, assim, e mais, com eu posso dizer, não foi maravilhosa, assim, porque eu não sentia aquela coisa que todo mundo sente, mas foi boa, eu gostava de ficar deitada lá, e ficar com ele, entendeu? Eu não pensei muito sobre isso. Eu não sei, justamente, mas todo mundo tem coisas boas para falar e eu não tenho coisas boas para falar, entendeu? Essa é a questão. Então, mas o bom, não era, não foi, por exemplo, o ato, por exemplo, de sexta-feira, não foi o ato sexual, no caso, assim, o bom foi a pessoa que estava do meu lado, entendeu, foi... era ele, o fato de ter sido o fulano que foi legal, ou melhor, ter sido com o fulano. Mas é nisso que a coisa complicada, porque eu tenho essa relação negativa com a relação sexual, tipo, estranho, né, porque... é, então".

Nota-se que com Bebeto o que aconteceu foi um relacionamento carregado de afeto e, com seu professor, um relacionamento visando o prazer do momento, sem tanta ênfase no aspecto afetivo. $\mathrm{O}$ ato sexual acaba sendo prazeroso, porém, de pouca intensidade. $\mathrm{O}$ não envolvimento afetivo pode prejudicar a abertura para a intimidade, o deixar-se levar pela relação, tornando o prazer não tão maravilhoso como gostaria. Sofia aponta alguns aspectos que acredita influenciarem no seu prazer: "Eu acho que eu sou muito dura comigo em vários aspectos, assim, eu... então, com certeza, eu sou sempre assim comigo mesma (...). Eu não sou otimista nem um pouco com a vida, sabe, eu sou completamente pessimista com a vida, sabe, eu fico o dia inteiro assim: 'A vida é uma bosta... Por que que eu nasci assim?... Por que que tinha que acontecer comigo, sabe?... Porque que eu tô tão infeliz?... Por que que isso não dá certo?'. (...) E aí eu tô optando por isso, agora (riso)... Estou num processo de aprendizagem, de compreender isso. E, agora, voltando a questão sexual, eu, eu fiquei pensando muito, assim, nessa questão, por exemplo, na sexta-feira, a minha amiga falou assim para mim: 'Às vezes você fica fugindo das coisas mais profundas e fica se apegando a coisas muito superficiais'. (...) ...Cheguei a conclusão de que (...) podia ser bom, podia ter continuado, já tava ali mesmo, já tá na chuva é para se molhar, né? Só que aí eu parei no meio, assim, sabe, por que eu parei, né? Aí eu fiquei pensando comigo, eu falei: 'eu parei porque eu me culpo, eu estava me sentindo culpada por aquilo', eu pensei, 'eu concluir isso, sabe, por que que eu estava me sentindo culpada?'. Não sei responder porque eu estava me sentindo, sabe, eu tava achando que aquilo era errado, eu acho, não sei por quê. Acho que 
não era momento... também tem isso, né? É, eu pensei muito nisso, eu falei que eu queria... é isso que eu tinha falado antes, né, eu não falo 'não' e aí eu não falo as coisas no momento, eu falo por impulso, assim, pela situação, né?’.

Apesar dos conflitos, Sofia reconhece a importância do aprendizado e se autoriza parcialmente, a mergulhar na experiência sexual. A autorização somente não é total pelo fato de evitar - ou não ter tido oportunidade de - envolver-se afetivamente de uma forma mais intensa; e pelo fato de associar o sexo àquilo que pode abalar uma amizade, a exemplo da experiência com Bebeto, ou mesmo associar o sexo a algo repugnante, a exemplo da experiência com seu professor. A culpa acaba ganhando lugar significativo na sua experiência, dificultando ainda mais a sua expressão afetivo-sexual, permanecendo na tensão entre o certo e o errado, o ter o prazer intenso ou não ter nenhum prazer. $\mathrm{O}$ uso do ecstasy, como relatado por ela, favoreceu que se libertasse momentaneamente do crivo da crítica, lançando-se nas experimentações. A idéia do "estar na chuva é para se molhar", pode ser uma possibilidade para que apreenda a experiência sem idealizá-la, mas reconhecendo como possibilidade de vivência e obtenção de prazer.

\section{7. “O trabalho aqui (...) foi o que eu fiz por menos tempo, mas o que mudou mais alguma coisa": Sofia avalia o atendimento no Plantão Psicológico}

Sofia reconhece que sua disponibilidade é fundamental para que algum tipo de melhoria aconteça na sua vida. Para ela, o Plantão ajudou-a a ficar mais consciente das suas necessidades: “...eu acho que praticamente ainda não mudou muito, assim, sabe, mudou alguma coisa, mas, teoricamente, eu já me tornei mais consciente de algumas coisas que eu precisava me tornar, (...) por exemplo, de que eu preciso aceitar as pessoas do jeito que elas são, e eu preciso me propor a isso para arrumar um namorado... entendeu? Eu preciso (...) me sentir mais envolvida, me permitir me sentir mais envolvida, né, eu acho que essas coisas, assim, mudaram, mudou um pouco no meu pensamento. Acho que é isso".

Ela retoma a questão da idealização dos relacionamentos referindo-se ao Bebeto: “ $E u$ fico muito viajando, (...) ...eu pego uma pessoa, por exemplo, esse Alberto, o Bebeto, que eu fiquei o final de semana inteiro, tipo, namorando com ele em pensamento... namorando com 
ele em pensamento, sabe (riso), tipo, analisando o que a gente ia fazer, porque eu conheço o jeito dele, aí eu fiquei pensando: 'Se a gente namorasse, ia ser assim-assim-assim-assimassim'... e aí eu vou viajando, viajando, eu quando eu vejo eu já tô namorando com ele na minha cabeça, sabe? E a gente já tá indo pros lugares, eu fico imaginando a gente fazendo as coisas, eu fico imaginando as nossas brigas, sabe? (riso). Todos os meus amores são platônicos. Aí eu fico imaginando... sabe, eu fico imaginando as nossas brigas, assim, eu fico falando sozinha. Todo mundo fala que eu falo sozinha. (...) ...Olha só a minha viajem, eu fico imaginando a ex-namorada dele chegando, e querendo brigar comigo, (...) porque a gente vai chegar uma hora em que a gente vai estar no mesmo lugar, eu, ela e ele, e aí eu fico pensando o que eu ia fazer. Se tivesse eu, ela e ele, não sei, assim, já queria, tipo, de fazer de namorada, supervalorizar, aí eu fico surtando, aí fico imaginando uma cena, a gente num restaurante, ela chegando, eu fico até imaginando em qual restaurante. Imagino tudo, o garçom, quem vai ser o garçom, tudo, e parece que tudo fica real, assim, na minha cabeça... aí eu fico lá, aí a namorada dele brigando, aí eu falo assim, ó: 'Eu tô indo embora' (riso)... Que viagem!... 'Eu tô indo embora porque eu não quero participar dessa palhaçada' (riso), tipo coisas assim, sabe, na minha cabeça... E aí a batata assa, e aí, meu...”.

O sentido que Sofia dá para a sua "viagem" é que se sente, de certo modo, relacionando-se com alguém, sentindo-se amada. Mas Sofia percebe que isso lhe gera sofrimento: “...eu penso assim, é um vício, sabe, porque eu penso assim: 'é tão gostoso viajar, é tão bom, sabe'... é, então, é uma droga, eu preciso, a sensação que aquilo me causa, eu preciso, sabe, assim, é tão bom, assim, e, às vezes, as minhas emoções são tão ruins, sabe, eu falo... e aí eu fico viajando parece que é real, sabe, parece... eu chego a acreditar que é real e é tão bom aquela sensação, como se aquilo... é como se eu já tivesse: 'Pronto, eu já namorei o Bebeto', sabe? Eu não preciso mais namorar com ele, porque eu já namorei com ele na minha mente (riso)... e aí... fica nisso... só que aí... é porque eu não paro para me dar conta, geralmente, mas agora estou começando a falar: 'Meu... Sofia, acorda para a vida, porque...', esses dias eu comecei a entrar numa frustração meio de idade, assim, sabe, eu estou com 20 anos, sabe? E a minha vida? E o que que eu fiz? Sabe? E o que que eu quero? Pra onde eu vou? O que que está acontecendo?... Eu tô só na minha mente e tudo o que eu fiz. de prático na minha mente, não tá aqui, sabe, não existiu...”. 


\section{8. "Uma fragilidade que esconde uma coisa determinada": a representação de mulher para Sofia}

Sofia diante da pergunta do que é ser mulher procura significados para si, mas, antes, leva algum tempo para formular a sua resposta revelando que nunca parou para pensar nisso. “...Feminino acho que é... deixa eu ver... (pausa) ah, não sei, talvez seja aquilo que seja diferente do que o... seja... que o homem e a mulher são coisas... têm suas semelhanças enquanto humano, e têm as diferenças que os distinguem enquanto homem e mulher, e aí, coisas como, por exemplo, é... não sei que coisas diferenciam um homem de uma mulher (riso). Ah... não sei, nunca parei para pensar nisso, deixa eu ver, será que é?... (...) Uma coisa mais terna, assim... não sei se é isso... uhm... um eufemismo, assim, do masculino é a mulher, sabe (riso), uma coisa mais... (riso) uma coisa mais frágil, eu acho... Então, não que seja isso, ou então o que eu acho que as pessoas acham que é, não que as pessoas acham que é, mas é uma coisa que é um modelo que está, que está teoricamente colocado, entendeu, que é uma coisa frágil... é, mas ao mesmo tempo que é frágil, é assim, uma fragilidade que esconde uma coisa determinada, sabe? A mulher, o que é a mulher para mim, assim, mulher para mim, é melhor, ah, então, mulher eu acho que é isso que eu tava falando é aquela coisa assim, aquela figura frágil, ali, tipo... delicada... delicada, não, essa coisa frágil, mesmo, que esconde... não que esconde, mas que... tipo, cobre uma coisa determinada, uma pessoa... sabe, é uma pessoa... enrustida, eu acho, a mulher. Não sei definir mulher, francamente (riso). Então, eu não percebo, pelo visto. Eu percebo assim, mas eu não sei se é assim, entendeu? Eu percebo, assim, eu percebo a mulher de uma forma meio enrustida, assim, sabe?".

Quanto ao como Sofia sente-se mulher, mais uma vez, ela diz nunca ter pensado sobre esta questão e revela a sua angústia de ser: “...eu me incomodo muito, eu sempre fui muito incomodada, eu não sei, agora, é que eu nunca parei para pensar nessa questão, mas, eu sempre me incomodei muito com o fato de ser, assim, humana, sabe, eu desejei já morrer várias vezes, sabe, eu achei a vida um desperdício, assim, comigo, sabe, eu sempre pensei, assim, tipo... é... sabe... não que eu quis morrer, mas eu sempre me senti pronta para morrer a qualquer momento, assim, sabe, porque a vida não... não... sabe, não significava nada, mas isso dá para simplificar como mulher (...). ...Nunca diferenciei, sabe, o que eu te falei, eu nunca me senti angustiada pelo fato de ser mulher, eu nunca parei para pensar: 'Uhm... se eu eu fosse homem, talvez as coisas pudessem ser melhores', então, eu nunca pensei por esse 
lado, mas... (pausa) deixa eu ver... eu não sei, mas eu acho que deve ser mais vantajoso ser mulher do que homem... Não sei, não sei, como que eu... como que eu me sinto mulher, né?”.

A sexualidade não está restrita à categoria sexual de uma pessoa, mas a condição dada por uma dada cultura (Paiva, 2000; Gagnon, 2006; Heilborn, 2006). A angústia mostrada por Sofia revela um estado de incerteza de seu lugar, mas, mesmo na sua percepção dos homens em uma categoria hierarquicamente superior, existe um sentido de que ser mulher é melhor do que ser homem. Sofia aponta as vantagens do ser mulher: “...eu acho que aprendemos a ser estrategistas, não estrategistas, porque estrategista é muito assim... (...) a mulher passou por mais experiências do que homem, (...) porque eu acho que você aprende muito sobre a vida passando por ela (...), ...enfim, isso que eu te falei que a mulher aprendeu com o tempo a ser mais forjada... o que faz com que ela seja mais experiente. (...) O que que forja a mulher acho que ela é meio privada da liberdade. (...) ... (pausa) quando você não é uma pessoa livre, completamente, eu acho, ou que alguém seja, mas você precisa aprender a viver naquelas circunstâncias (...). Por exemplo, (...) ...eu tenho certeza que, assim, um escravo poderia falar muito melhor, muito mais sobre liberdade do que um senhor de engenho, né, é mais ou menos isso, assim, é meio radical isso, (...) ...quando você vivencia uma coisa, você sabe mais sobre ela, acho que você entende mais, você se torna mais capaz diante dela (...). ...Estrategista é isso, não estrategista num sentido negativo, assim, mas nesse sentido, assim, de você... então, mas o que eu acho ruim nisso, pelo menos para mim, assim, enquanto mulher, isso acontece comigo, entendeu, eu penso assim porque isso acontece comigo, eu não sei se isso acontece com todas as mulheres, mas assim, o que eu acho ruim disso é que eu me sinto prisioneira disso, sabe, prisioneira disso que talvez se chama de regras".

Dentre os modelos da categoria mulher, Sofia diz que durante muito tempo sua mãe ocupou este lugar, pois hoje acha a mãe "uma pessoa completamente prisioneira de... de regras que ela impôs a ela...", e assinala a sua postura diante das regras: “...eu odeio isso. Isso é o que eu menos gosto na vida, sabe, é o que eu menos gosto...”. A sua tia acaba ganhando o lugar de modelo de mulher para Sofia, pois identifica nela uma forma de existir e em não negar aquilo que considera uma realidade humana: “...está desempregada, está sofrendo, está (riso) muito mal, mas que ela está assim, sabe, porque ela está sentindo isso. Não sei se ela é um exemplo de mulher também, porque ela tinha que ter sobressaído... (...) ...ela tá mal, ela não faz nada, ela toma antidepressivo, ela tá acabada, sabe, e... todo mundo tenta ajudar ela, mas ela não quer ajuda, sabe? Aí eu fico pensando: 'Poxa, a minha mãe não ficaria assim 
nunca', sabe, a minha mãe não se permitiria sofrer, ela não se permitiria sofrer o suficiente, sabe, e ela, não, ela está se permitindo sofrer, assim, sabe, e isso faz parte, porque eu fico pensando: 'Caraca!', sabe, a gente sofre, a gente sente dor, por que não sentir, então? Por que eu tenho que falar: 'não, não vou sentir isso, vou... vou... vou me superar isso?', não, não tem isso, tem que sentir, sabe, fazer parte de mim. E isso ao mesmo tempo que é dolorido, eu acho isso bonito, sabe, aí eu acho isso bom, assim, isso é autenticidade humana, sabe, não é autenticidade de personalidade, isso é autenticidade humana, eu acho... eu acho que é isso".

Ainda no tocante a exemplo de mulher, Sofia aponta as mulheres da esfera pública que se aproximam da sua representação e revela um retrato do momento atual em que, na faculdade, estuda o existencialismo: “A Ana Paula Arósio... (...), ...eu gosto do jeito dela, (...) ...é que eu gosto do sofrimento, assim, sabe (riso)... eu acho o sofrimento bonito. Meu professor de fenomenologia estava falando ontem de Sartre que... nunca vi nada... eu quero ler o 'O ser e o nada'. Eu até peguei na biblioteca da minha faculdade, fiquei lendo outras coisas, e depois tive que devolver, mas não li... Eu gosto do sofrimento porque eu acho que o sofrimento é mais verdadeiro, sabe? Pode ser mais verdadeiro do que... do que a felicidade, do que o bem-estar, assim, sabe, porque é bonito, assim, dentro dos padrões, assim, que a gente vive, é bonito você ser feliz, né, porque as pessoas saudáveis têm que serem felizes, uma pessoa que sofre, ela está fugindo dos padrões, né, ela tá... por que que ela está sofrendo? (...) Então, aí a Ana Paula Arósio eu já li umas coisas dela assim, eu acho ela uma mulher meio sofrida, assim, sabe, eu li uma entrevista dela falando que ela era muito bonita, que ela sofria muito porque ela era muito bonita, não-sei-o-quê... e aí uma vez eu vi uma entrevista dela, que ela começou a dar um show, sabe, deu um surto nela, assim, ela saiu, sabe, ela não queria falar, começou a xingar os repórteres. (...) Eu achei ela meio desequilibrada, assim, sabe, eu acho ela meio desequilibrada, e eu acho legal isso, assim, porque eu não consigo, assim, achar só horrível, não horrível, mas eu não consigo... pessoas muito equilibradas, assim, eu acho que não são pessoas, eu acho que eu não consigo aceitar que uma pessoa seja equilibrada, assim, sabe, eu acho que a gente vive em um... um estágio de vida, assim, que não dá para chegar nesse equilíbrio, sabe, que umas pessoas demonstram, assim... acho que a gente, todo mundo é um pouquinho louco, assim, e eu gosto quando as pessoas mostram um роисо a sua loucura (riso)".

Continua enumerando outros exemplos de mulher, que se contradizem com o fato de não aceitar pessoa equilibradas: “...eu gosto muito da Vanessa da Mata. Eu gosto do jeito 
dela, assim, do jeito da Adriana Calcanhoto... eu acho tão... são exemplos de equilíbrio, assim, que eu... equilíbrio, eu, eu, porque, assim, eu gosto do jeito dela, assim, porque eu acho que elas são, assim, é... elas entenderam o desequilíbrio delas, sabe, elas entenderam... o desequilíbrio delas e aprenderam a viver com esse desequilíbrio, sabe... então, assim, são pessoas que são calmas, eu gosto também de pessoas assim, sabe?... (...) Então, elas falam muito de... de... assim, a Vanessa da Mata, nas músicas dela falam muito de, assim, de sofrimento nas músicas, sabe, e aí eu fico pensando: 'Como é que ela fala, assim, de sofrimento na música assim?', ela fala porque ela conhece, né? (...) Já a Adriana Calcanhoto... (...) ...eu a acho muito linda, sabe, eu gosto do jeitinho dela, assim... eu queria até ser uma pessoa assim, sabe, uma pessoa doce, calma... A Vanessa da Mata também é doce, assim, tal... fala devagar, assim, sabe, e eu, não (risos), eu sou toda assim...". Sofia continua apontando em seu depoimento o modelo que associa mulher ao sofrimento com certa severidade diante do próprio desequilíbrio.

\section{9. “...Uma coisa mais autêntica do que a mulher": a representação de homem para Sofia}

Já diante da pergunta sobre o que é ser homem, Sofia, com mais fluidez, apresenta a sua definição: "Eu acho o homem uma coisa mais autêntica do que a mulher (...), ...se preocupa menos, eu acho, com determinadas coisas, por exemplo, com tudo, eu acho. (...) É meio complicado generalizar, (...) não é uma preocupação, o homem é mais sincero, assim, eu acho, em algumas coisas, mas ele é mais sincero por espontaneamente, sabe? Mulher, quando a mulher é sincera, eu acho que ela sincera premeditante [sic] de sinceridade, entendeu, sabendo o que é a sinceridade, sinceridade é isso, isso e aquilo, e aí ela se determina a ser sincera, entendeu? Homem, não, homem, eu acho, por exemplo, que ele é sincero espontaneamente, ele não sabe o que é sinceridade, mas ele está sendo sincero, sabe? (...) Por exemplo, (...) o homem mente para uma mulher... mas eu acho que ele mente sinceramente, dá para entender isso? (...) ...deixa eu falar melhor: eu acho que o homem é mais puro do que a mulher. (...) Eu não sei se é porque ele é, ou se é porque o mundo é assim, a sociedade deu essas possibilidades para ele, entendeu, e tirou essas possibilidades da mulher. (...) Por mais natural que seja uma mulher, ela ainda esconde alguma coisa, sabe, eu 
acho que esconde alguma coisa, sabe, eu acho que ela é forjada para responder alguma coisa, ainda. Mas eu acho que não é culpa dela, é culpa do mundo, assim, da sociedade, vai”.

A definição do ser homem e do ser mulher nem sempre é algo claro no sentido de uma definição, por se tratar de uma questão de gênero que é socialmente construído a partir das relações entre as pessoas de uma dada cultura (Paiva, 2000; Bozon, 2004; Gagnon, 2006). A categoria homem e mulher são dadas e vividas desde antes do nascimento quando surgem as expectativas da criança ainda no ventre da mãe.

As definições de Sofia mostram a mulher detrás de uma fragilidade forjada, mas que esconde uma determinação. Por outro lado, o homem, aquele que é puro, que "mente sinceramente", que se mostra mais do que as mulheres. No relato, considera o papel da cultura que confere ao homem o espaço para a "pureza", espaço este de que as mulheres são destituídas, por uma condição dada pela cultura machista e patriarcal diante da construção dos gêneros masculinos e femininos.

Com relação aos modelos de homens presentes na esfera pública, Sofia aponta algumas estrelas do rock, pessoas que buscam aquilo que somente eles próprios entendem, em um sentido de rebeldia às regras sociais rígidas: “...Jim Morrison, (...) Mick Jagger, (...) Kurt Cob [Cobain]... (...) ...Eu gosto, assim, deles (...), eu acho que eles sofrem pelos méritos... pelos jeitos com que eles optaram viver, (...) ...eles abriram mão, sabe, de muitas coisas assim, então de... sabe, de uma busca, assim, que só eles entendem (riso), eles, sabe, eles querem cantar, eles querem pular, eles querem se drogar, sabe, eles querem... tipo, o Cazuza, assim, sabe, o Cazuza é meio... (...) acho que ele era meio... publicidade, eu acho, um pouco, assim. Mas esses caras que eu falei, sabe, eles não queriam saber de nada, sabe, eles queriam, meu, não é, sei lá, gritar na rua, eles queriam... e eu acho que todo mundo tem essa necessidade, né, mas nem todo mundo tem coragem suficiente para fazer". 


\subsection{0. "[O homem] sempre teve mais liberdade do que a mulher, em vários sentidos": as diferenças entre os gêneros}

Sofia continua sua resposta lançando sua reflexão sobre onde está embasada a diferenciação entre homens e mulheres. Para ela, o fato de a mulher ser mais "forjada" é pelo fato de que ao longo da história a liberdade sempre foi dada ao homem: “...ele sempre teve mais liberdade do que a mulher, em vários sentidos, sabe, de expressão, dos seus atos, é... de fazer aquilo que ele quisesse e não ser questionado (...). E a mulher, não, a mulher teve sempre que... por muito tempo, e por hoje também, (...) ...teve que se preocupar com as suas ações... do que ela faz, do que ele quer, do que ela deixa de querer... E o homem, não, ele sempre teve a liberdade, eu acho, de... de... de, sabe, de falar: 'Eu quero isso', sabe, e se preocupar menos com o social, a mulher se preocupa mais com o social". O sentido do social para Sofia relaciona-se com a forma que homens e mulheres se expressam socialmente, sendo dado aos homens maior liberdade de escolha de possibilidades, sendo restritas essas possibilidades para as mulheres.

As diferenças entre homens e mulheres, de acordo com Sofia vêm desde o período préhistórico, marcando hierarquicamente os espaços: “...Desde o homem de Neanderthal, desde o homem da caverna, existiu essa diferença, né, essa superioridade do homem e da mulher, do homem assim... não sei se superioridade, porque eu não sei definir o que é superior, entendeu, mas essa diferença existiu sempre e vai existir sempre, por mais que tenha vários movimentos aí querendo igualdade dos gêneros, eu acho que vai ter sempre porque somos seres diferentes".

\subsection{1. "Não tem nada de marcante, nem quando eu perdi a virgindade": Sofia fala de sua vida sexual}

Sofia remete-se à sua primeira relação sexual, porém, o significado fica esparso. Ela associa a algo estranho que acontece consigo quando perguntada sobe algo marcante na sua vida sexual: “...na hora, uma coisa meio quadrada, meio redonda, não sei (riso), é um surto que eu tenho, eu acho, na hora eu fico surtada, aí fica uma coisa assim, ó, é... como uma coisa que 
cria, tipo uma venda, como se tivesse um cortinho, assim, uma coisa quadrada, assim, na minha mente, sabe, aí eu fico imaginando nós dois, assim, eu e a pessoa, pequeninhos, assim, na minha mente. (...) ...Às vezes, os meus sonhos se misturam com a minha realidade... É pra você ver como eu sou meio esquizofrênica, (riso) daqui a pouco eu estou vendo as coisas, mesmo (...) Coisa estranha, né? É, sei lá... mais marcante... não, nunca tive alguma coisa marcante, assim... Todas as minhas relações sexuais parecem que foram uma única (riso), porque são todas iguais, entendeu, são todas... nenhuma parece que se difere uma da outra, assim... Porque parece que na hora eu fecho os olhos, assim, eu fico pensando na sensação, sabe, e essa sensação parece que é sempre a mesma, uma coisa insignificante a propósito, até, aí... Engraçado, né, não tem nada marcante, nem quando eu perdi a minha virgindade... Foi dentro de um carro, com meu amigo... foi uma coisa, assim, estranha, foi aos 18 anos".

A masturbação sempre fez parte da vida sexual de Sofia. Misturando a fantasia com a realidade, ela diz que desde a infância acreditava que tinha "poder mágico" quando provocava sensações ao colocar uma almofada entre as pernas: "eu sentia umas coisas, assim, aí eu achava que tinha poderes, sabe, eu falava, juro, eu achava que era uma... não sei, uma coisa de bruxa, assim, sabe, que eu ia ser bruxa, aí eu achava que eu tinha o dom para despertar aquilo (risos), aí um dia eu estava lendo uma revista, dessas de adolescentes, sabe, ‘Capricho'... sei lá que revista que era, aí eu vi que chamava 'masturbação' (riso)”. Quando aquelas sensações mágicas ganham um nome, uma definição, elas deixam de serem mágicas: "Aí eu até fiquei meio frustrada, assim, falei: 'Que pena, né?"'. Por outro lado, o contato de Sofia com o próprio corpo não é tão apreciado: “...que merda, mas aí eu nunca... eu nunca gostei de me tocar com as mãos, assim, sabe, sempre colocava, apertava o travesseiro, assim, isso quando era menor. Aí, depois de grande, também, assim, eu tentei me tocar algumas vezes, assim, mas eu não sentia nada, sabe, eu achava uma coisa meio-nada-a-ver. Aí de uns tempos para cá eu estou me tocado mais, assim... tenho sentido prazer, mas não orgasmo... mas está bem melhor (riso). Está sendo bem melhor do que as minhas relações sexuais (riso), estou me virando melhor com a minha (riso). Eu acho que eu estou no caminho certo". 


\subsection{2. “...As pessoas entendendo que elas são diferentes umas das outras": possibilidades de as pessoas viverem a sua sexualidade pela autoconhecimento}

No final do depoimento, Sofia expressa aquilo que contribuiria para homens e mulheres viverem a sua sexualidade da forma mais plena possível, apontando que o autoconhecimento é algo importante nesta questão: "Eu acho que (...) é com as pessoas entendendo que elas são diferentes umas das outras, e... tanto acho que as pessoas criam expectativas, e elas tinham que entender as suas diferenças em todos os sentidos (...). Para que isso pudesse se tornar prático, concreto, acho que tinha que ser através do autoconhecimento de cada um, assim, que tinha que se autoconhecer, para depois... porque eu acho que as pessoas são mais conturbadas, quer dizer, homem, mulher, ou qualquer outra coisa, são aquelas situações em que as pessoas têm... quanto menos autoconhecimento, mais conturbadora é... eu acho que tem que ter mais autoconhecimento, assim... se autoconhecer melhor".

No final do depoimento, Sofia pede para acrescentar a dúvida e curiosidade que se acerca da homossexualidade e de como a compreende teoricamente, a partir das suas referências esse fenômeno: "O que que faz, por exemplo, um homem se interessar por um outro homem? E não todos os homens se interessarem por homens e mulheres? E o que faz uma mulher se interessar por outra mulher, e não por homem, ou pelos dois? Ou só por homem e não por mulher? (...) Na minha opinião, eu li uma vez, uns papéis e não sei nem de quem que era ou o que que era direito, mas eu comecei a ler, assim, e tava falando sobre Complexo de Édipo, né, aí... pode ser alguma coisa nisso, né, tipo, algum conflito que aí, por exemplo, pode ser, por se apaixonar pela sua mãe, e ser rejeitado pela própria mãe, e você se volta para o pai. Você criou uma relação, né, sua paixão fica... você vê que você fica... você desgosta, assim, por exemplo, disso, e parte para outra... ah, não sei... ainda vou estudar isso, eu acho". Sofia indica um sentido de falta de esperança no âmbito afetivo-sexual, que denuncia a contestação de regras sociais para a vivência sexual desde o primeiro beijo, até o sentir prazer nas relações sexuais, revelando a tensão entre uma maneira singular de ser e as normas e condutas sexuais vigentes. 


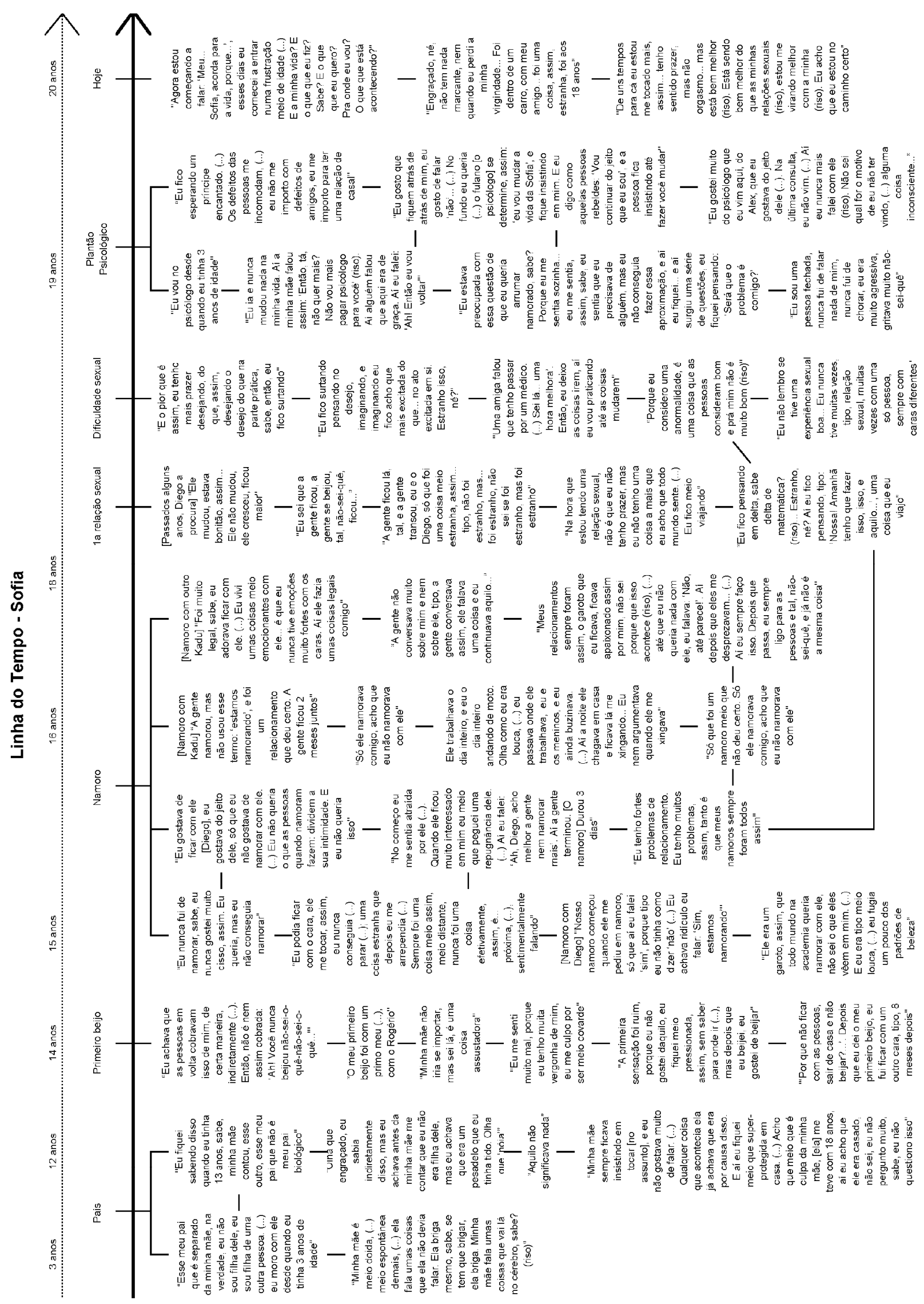

Figura 5 - Linha do tempo da trajetória de Sofia 


\section{6. "Eu acho que a minha vida sexual foi muito complicada. Eu acho que ainda é...": o depoimento de Mariana ${ }^{42}$}

Mariana tem 27 anos, nasceu em São Paulo, é casada há 10 anos e tem um filho de 8 anos. Está finalizando o bacharelado e, atualmente, realiza estágio de iniciação científica.

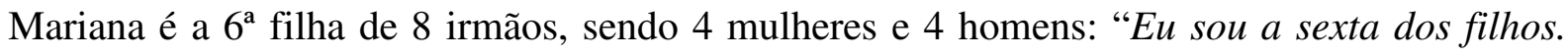
Antes de mim já tinha duas". Ao longo do seu depoimento Mariana mostra-se consciente e segura quando refere-se ao desenvolvimento da sexualidade que se deu de forma gradual e sem referências importantes dentro de sua família de forte tradição católica. Na ocasião da validação do depoimento, ela desculpou-se por aquilo que tinha dito na sua entrevista optando, em um primeiro momento, de suprimir diversas partes do seu depoimento: "Percebi neste depoimento que quando estou falando sobre sexo fico nervosa e me expresso muito mal, de repente deva ser pela forma que este assunto foi tratado em minha vida". Ela se mostrou surpresa quando the falei sobre a riqueza do material. Mariana disse não discordar do conteúdo do depoimento literalizado apresentado, sendo que seu intuito em suprimir os trechos da entrevista era de auxiliar no trabalho de pesquisa, intuindo que aqueles trechos não seriam importantes. Mariana informou que gostaria de apreciar o depoimento literalizado novamente. Nesta segunda etapa, ela o validou, mantendo o conteúdo original na íntegra.

Diante da pergunta disparadora: "Fale-me desde como foi a descoberta da sua sexualidade até chegar nos dias de hoje", Mariana responde que: "A minha sexualidade, assim, foi muito com que tinha que ver com outros colegas, de comentários, de tudo o mais...

de televisão. É... E como eu venho de uma família religiosa de Minas Gerais, então, a minha mãe tem muito de... tem muito disso, assim, de mulher casar virgem e enfim... É claro que eu não casei virgem, né, mas... eu comecei a sexualidade com meu marido mesmo... é... não... não com meu marido, mas eu tive o... o meu primeiro contato mais íntimo com ele. Mas eu tive um namorado que sempre tinha carícias diferenciadas. Eu acho que já seja dessa fórmula parte a sexualidade em si, né?". A sexualidade para Mariana tem ligação com a idéia de virgindade e do contato íntimo com um ex-namorado e com o marido atual. Ao longo do

\footnotetext{
${ }^{42}$ A duração do depoimento foi de $1: 18 \mathrm{~h}$.
} 
seu depoimento é quase sempre presente a tensão entre os valores morais e as descobertas que foi se autorizando e se dispondo com relação à sua sexualidade.

Na primeira parte do depoimento, Mariana privilegia o namoro com seu atual marido e a gravidez que levou ao casamento, passando pela identificação de sua falta de desejo sexual e a busca de especialistas na procura de solução para este quadro: "Meu marido foi... é... que eu tive no namoro um contato mais íntimo, e foi muito rápido, em questão de um ano, eu logo fiquei grávida. Nesta época eu tinha 16 anos. Eu tinha, na verdade, quando comecei a namorar com ele, 15 anos. Então eu engravidei muito rápido. A gente resolveu casar, né, dois adolescentes, dois adolescentes, mesmo, né? Nesta época meu marido estava com 19 anos. (...) A primeira gravidez eu perdi, nasceu morto, tinha 7 meses. Hoje eu falo com maior tranqüilidade porque, enfim, se passaram 10 anos, já consigo... E... aí a gente casou, né?".

A gravidez foi o principal motivo para a sua união com Carlos. Mais adiante no depoimento Mariana revela que: "Tudo teria sido diferente se tivesse tido um planejamento melhor pra marcar o casamento. Porque, antes, a gente não casou porque se gostava. Isso sem dúvida. Mas foi meio uma obrigação, entende? Porque eu engravidei e dificultou tudo... e eu era muito jovem. Mas eu acho que se de repente a gente tivesse tido um tempo maior, é... um namoro até decidir que: 'Vamos casar e depoooois vamos pensar em ter um filho', enfim. Eu acho que esse tempo é bom pra se descobrir, né? E... Ah, eu acho que isso afeta a autoestima, também. (...) Eu acho que... eu acho que é o fato da mãe, dos pais não conversarem sobre esse assunto... e você ouvir muito isso de colegas, ou sobre sexualidade com amigos, com colegas, mas você não saber diferenciar o meio do promíscuo, sabe?”. Diante de uma gravidez não planejada, o casamento acabou sendo um desdobramento de um compromisso intrínseco a este fato. A obrigatoriedade do compromisso limitou o tempo para que ambos se conhecessem melhor e elaborassem e se familiarizassem com um projeto de vida em comum. O fato de a família ter forte tradição conservadora, em que a virgindade é valorizada, impediu de que lhe fornecesse referenciais, ao menos claros e objetivos, sobre a possibilidade de a filha ter uma vida sexual ativa. Os referenciais de Mariana eram principalmente provenientes de amigos e outros colegas. 


\section{1. "Nas aulas você aprende sobre o que é, pra o que que serve, (...) não se fala do que é um ato de amor": as primeiras informações sobre sexo}

A escola também foi uma referência importante para Mariana, ao menos no que diz respeito à parte formal sobre a fisiologia e sobre métodos contraceptivos: "As minhas primeiras informações sobre sexo eu, de fato, aprendi na escola, eu acho que na aula de ciências. Nas aulas você aprende sobre o que é, pra o que que serve, né, o uso de camisinha, quais são os outros contraceptivos. Não se fala... (riso) do que é um ato de amor, né, não se fala assim. Fala como se fosse um ato mecânico, né, como se fosse um ato animal, né, todos os animais fazem. Como eu sou um animal, eu vou fazendo também. Mas pra que a gente não tenha um monte de filhos como os animais, então use esta... (riso) pílula. É algo assim, mecânico, que eles vão passar, né? Mas foi assim, assim que a gente aprende. E agora que eu descobri que tem muita coisa na sexualidade, o que acontecia... dos coleguinhas da escola, sabe, os colegas, amigos da escola, ou primos, também. Tenho um montão de primos de... é... de querer abraçar, e você também sentia alguma coisa e achava legal, aquilo, né? Eu percebia que isso acontecia também. E eu acho que também, alguns primos mais velhos acabam... acabavam é... querendo dar um abraço na prima mais nova, né... e eu acabei descobrindo que eu sentia prazer naquele abraço. Aconteceu isso comigo. Eu comecei a sentir que isto era diferente quando eu tinha uns doze pra treze anos... Na adolescência, mesmo. Eu percebia assim. Você percebe, você não entende... você percebe que: 'Puxa, isso que é bom', né? Não é o sexo que você aprende na escola, né, mas você vê que: 'Não, eu não posso fazer', né, 'Eu não posso...', não é assim, né? Você começa a tentar achar algumas respostas, mas em certa medida você busca em qualquer lugar, eu... eu acho que é algum meio de começar a orientar...". Mariana começa a perceber que as aulas de biologia tinham suas limitações, principalmente por enfocar sobre "o que é", e enfocar o "para que serve", mas não contemplando a forma pela qual, ou o como, integrar aquelas informações à sua vida. $\mathrm{Na}$ prática, a partir do afeto despertado nas relações sociais, o desejo, as sensações provocadas pelo abraço com os primos ganhava sentidos de prazer, ou, nas palavras de Mariana: "achava legal", ou "isso que é bom". Vale ressaltar a necessidade de saber, a necessidade de orientarse nestes novos sentidos que, até o momento, tinham como referência o não-poder-fazer, abrindo até possibilidades para o não-poder-sentir. O sexo ganha status de "coisa animal”, que é muito compatível com a idéia difundida socialmente de que a sexualidade é proveniente de uma força interna ligada ao "instinto" animal que habita cada um dos seres humanos, em uma 
perspectiva biologista que é uma vertente que Duarte (2004) mostra que faz parte da linhagem mais imediata dos saberes biomédicos contemporâneos, que preconiza a condição "natural" dos aspectos da reprodução e da sexualidade. Esta perspectiva funciona como base para o discurso de que a sexualidade necessita ser vigiada e controlada.

Este movimento vinculado à tensão entre o não-poder e a vontade-de-saber talvez tenha contribuído para que Mariana fosse ao encontro de outras referências a respeito da sexualidade. As revistas voltadas para o público adolescente fazem parte destas referências: "Eu também procurava informação em revista. Adolescente lê revista. Essas revistas de adolescente, revista que a irmã comprou... (...). Você passa a revista, e você vê alguma coisa sobre sexo... você lê. Lembro que eu lia... acho que é Criativa... ah, eu não lembro mais os nomes, mas são revistas femininas, essas revistas que você... tratam desses assuntos, também, entrevistas, com... tipo mulheres que te ensinam a fazer, enfim... Com isso você acaba vendo, né, e fala... A curiosidade aumenta, né? (...) Na minha experiência essas informações não sei que influência que teve, não sei se foi... eu não consigo explicar (riso). Eu... é... bem... eu lia, né, mas eu não... eu ainda tinha esse pensamento de que: 'Não, não posso fazer', entende? Ou: 'Não, é... tenho que esperar casar', ou... igual minha mãe faz... eu não falava nada, eu fazia isso: 'Cuidado, não sei que...', é... 'Sexo só quando casar', enfim, só isso que se falava. A gente via tudo, mas só em revista a gente tinha que esconder pra não verem que a gente tava lendo sobre aquilo. Elas foram proibidas, as sobre sexo eram proibidas. Então, na verdade, é que não deve ser tratado assim, né, não é uma coisa proibida, é uma coisa de consciência, ser feito por consciência". Mediante o contato com as informações e as identificações relacionadas a estas informações, a sexualidade passa a ganhar novos sentidos e significados, aumentando a curiosidade por uma fonte de referência que corresponde às necessidades vividas naquele momento. Estes sentidos e significados não são traduzidos racionalmente na experiência, mas são apreendidos e incorporados de forma subjetiva ao seu roteiro sexual (Gagnon, 2006).

Os valores e referências internas de Mariana eram mobilizados no contato com as novas informações gerando tensão: não-não-posso-fazer, não-eu-tenho-que-esperar-casar, cuidado-não-sei-quê, sexo-só-quando-casar. Mariana reconhece que a negativa, o não falar sobre, ou mesmo o reprimir, não garante a vivência responsável da sexualidade, mas, sim, a instalar do conflito em que a sexualidade instintiva deve ser domada e controlada, sendo "adequado" a sua vazão somente após o casamento. 
Sobre a proibição da sexualidade, Mariana continua: "Eu saber que aquelas informações eram proibidas, eram vistas como uma coisa errada, né... gerava um conflito, né, porque... você fala assim: 'Não, as pessoas preferem desse jeito, mas as pessoas não têm opinião, entendeu, não têm...', né, essa... ah, você já vive como, sei lá, como uma moça que não tem família, como uma pessoa que não tem um... sei lá, não tem... vamos dizer, moral, né: 'Você pensa nisso'. É essa a visão que a gente tinha. Então quando você sente alguma coisa, quando você faz alguma coisa, tem que fazer escondido. Até, até... o ato de se masturbar, mesmo". Neste trecho do depoimento fica ainda mais explícito o conflito entre o permitir-se ter contato com novas informações com as referências morais até então internalizadas. Deste modo, uma moça de família não pode pensar em sexo, nem ao menos se tocar. O máximo seria o descobrir novas sensações às escondidas, revelando a cisão entre discurso e prática. Ao mesmo tempo que descobre possibilidades, a pressão moral também vai sendo fortalecida na forma de uma "pureza" garantida pela virgindade. Castro, Abramovay e Silva (2004) apontam que a virgindade ainda é um fator que diferencia os gêneros na cultura, vigorando dispositivos de controle que norteia comportamentos e delimita atitudes, agindo no plano simbólico criando espaços de tensão na decisão dos jovens em iniciar a vida sexual. Heilborn (2006) mostra que a virgindade deixou de ser atributo passível de estigmatização das mulheres, mas ainda perdura a idéia de uma virgindade moral.

Mediante este contexto, a descoberta das sensações a partir do contato com o próprio corpo era permeada pela culpa, que fica evidenciada quando Mariana refere-se à masturbação: “Eu fiz isso algumas vezes quando eu era menina, quando era adolescente, eu fazia, né, eu ia tomar banho, né, mas: 'Imagina, isso é um absurdo, ninguém pode saber!'. Claro que eu tinha isto na cabeça! Aí tinha horas que eu passava a noite inteira de terror, eu falava: 'Eu não posso fazer isso, porque tá errado!', né? Mas acho que é por conta disso, de viver numa família muito conservadora. E você não ter contato... eu acho que... que falta mesmo é o contato da família com você em relação ao sexo". Prazer e culpa são combinações que há muito se fazem presentes na esfera da sexualidade humana. Mariana se remete à falta de contato da família com os filhos sobre a esfera da sexualidade, mas fica a questão sobre quais seriam estes referenciais para os próprios pais em falarem sobre sexualidade com os filhos.

Mariana fornece outro exemplo sobre este contato dos pais com os filhos a respeito da sexualidade com relação à sua menarca: "Sobre a primeira menstruação, ai... olha, eu tinha 
informação daquela forma ahn... superficial, nada do que acontece com o corpo, enfim... Nessa época eu tinha acho que treze anos, mais ou menos. Eu não sabia, assim... sabia. Quem me deu algumas informações foi a minha mãe, mesmo. Mas não porque ela sentasse comigo e conversasse sobre, mas o que aconteceu com ela, com a minha irmã mais velha, daí ela... ela comentou alguma coisa, ou porque você mesmo viu, enfim... na escola. Mas, assim, eu acho que eu não tinha tanto exemplos de por que que aquilo acontecia... enfim. Então eu achava que era uma coisa assim: 'Ah, teve a menstruação, então ela vai ser moça!'. Então... era algo: 'Oh, eu quero ser moça!', né? Então você via como algo legal, né? 'Ah, eu sou moça!'. Falava no colégio: 'Ah, eu sou mocinha, já!'. Eu lembro que foi assim. Era muito inocente, eu acho, falta de informação de saber o por quê. Eu achei legal (risos)". Diante da sua nova identidade de "moça", Mariana passa a se situar de uma outra maneira no meio social, pois, de certo modo, este novo status lhe gerava uma satisfação. Mesmo com a falta de referências, a não ser pelo fato de se perceber enquanto moça, a menstruação foi uma experiência positiva para Mariana no seu contato com o ser-mulher. A referência por parte da mãe de Mariana sobre menstruação foi superficial, porém, de uma forma possível a partir da sua própria experiência enquanto mulher. Mariana acolhe a experiência da menarca de forma positiva indo ao encontro do seu desejo de ser moça.

Ainda sobre a menstruação, e sobre o constrangimento em se lidar com a intimidade, Mariana fala do seu relacionamento com as irmãs: “...A gente brincava muito, a gente se gostava bastante (riso). Mas não tinha muita conversa... (...) Engraçado, eu não tive muito esse tempo de conversar... de irmã... porque eu casei tão nova, né, saí de casa tão rápido... Comecei a trabalhar cedo, também, e as minhas irmãs também trabalhavam, sabe? (...) A gente conversava, tudo, mas não era nada muito... assim... de tanto que uma das minhas irmãs escondeu que tinha ficado menstruada, que tinha ficado mocinha, de falar, que ela tinha vergonha... Engraçado, que eu já não tinha, já era bem mais... ahn... mais pra frente, né?". Mariana passa a identificar-se como alguém diferente em relação às irmãs. Por ser mais nova, talvez não existisse abertura para estabelecer diálogo, ainda mais pelo pouco tempo que passavam juntas, pois todas trabalhavam. O pai também não era uma referência significativa: "Meu pai não sabia de nada, de menstruação. Hoje eu sei que ele sabia das coisas porque minha mãe contava pra ele. Mas ele nunca falou nada, nunca conversou com a gente. Então também trabalhava muito, então a gente também não tinha muito tempo com ele, entendeu?". Neste cenário, o papel de educar e lidar com estes aspectos ligados ao desenvolvimento e à socialização dos filhos parece recair sobre a mulher, sendo o papel do homem o trazer o 
sustento para casa. Mas, existiu outra pessoa que abria espaço para assuntos relacionados ao sexo e à intimidade: "Nesta época tinha amiga, tinha uma amiga que conversava sobre essas coisas, entendeu? (...) ...Até a mãe dela falava... de coisas parecidas... Mas eu ouvia conversar, ela almoçava com a gente, ela falava algumas coisas. Era legal, até... era interessante".

Atualmente, Mariana diz que conversa com a mãe sobre sexualidade: “...Hoje eu consigo conversar algumas coisas com a minha mãe. Engraçado, depois de casada, depois de quanto tempo!... Eu consigo puxar algumas coisas dela... dela, né, mas também, hoje, eu percebo mais liberdade em conversar, eu acho, com ela, enfim, do que antes. Mas isso não é muito específico". Chama a atenção de Mariana o fato de falar de sexo com a mãe agora que está casada. Ou seja, aquilo que até então não era permitido com sua condição de "moça", agora é, mesmo que a conversa sobre sexo seja de forma superficial.

\section{2. "O que mudou, eu acho, que eu, eu ir atrás de algumas informações", a religião e a especialidade}

Além do fato de que buscar informações sobre sexo auxiliou-a expressar-se mais sobre esta temática, Mariana revela que a concepção que a sua religião tem a respeito do sexo também contribui para esta expressão e vivência de forma positiva: "O que mudou, eu acho, que eu, eu ir atrás de algumas informações, de buscar informação. E também esse... essa busca de exemplo, de... saber que é bom, de saber o que é o sexo mesmo, o que é isso, o que representa o sexo pra Deus, por exemplo, e você achar que realmente que isso não... não é ruim, né, então... isso eu tenho muito, eu leio muito. Eu gosto de ler livros, partes da Bíblia, pra entender o lugar do masculino e feminino, porque há muita diferença. Assisto muito... alguns programas que falam sobre isso. Então eu tento de alguma forma... entender algumas coisas". Mariana continua buscando formas alternativas para compreender a sexualidade. A religião, ou mesmo a Bíblia, em sua percepção, forneceram subsídios para compreender o gênero e o sexo de uma forma positiva. Os programas de TV também são buscados por Mariana enquanto referência para compreender aspectos relacionados à sexualidade. 
Dentre os livros lidos por Mariana, um ressaltou a diferença entre gêneros: "Um livro que eu li também e achei muito bom... ahn... deixa eu ver... acho que é: "Porque os homens fazem sexo e as mulheres fazem amor”. Fala muito da diferença, né, do masculino e feminino, pelo menos pra grande maioria, né? (...) Às vezes, esse pensamento que a gente acabava tendo [de sexo]... pelo menos eu tinha, porque eu não queria, mas ele queria a toda hora, todo dia, enfim... né? Então sexo acabava sendo uma coisa mecânica". Uma das características do masculino, portanto, é sempre procurar por sexo, o que já nem sempre ocorre com o feminino. Esta percepção vai ao encontro de Castro, Abramovay e Castro (2004) para quem a vida sexual dos rapazes sobre forte pressão social para que aconteça o mais cedo possível, sendo que, com relação às moças o movimento é contrário. Assim, os roteiros do gênero masculino têm mais incentivo para se desenvolverem a vida sexual no cenário sociocultural (Gagnon, 2006).

Ainda no tocante às referências, a especialidade no campo da sexualidade também tornou-se importante, tanto para Mariana, quanto para Carlos: "Tem um programa: 'Tudo sobre sexo com Dr. Drew', na TV à cabo, no canal 54, o Home \& Health, que eu descobri agora, que fala só sobre sexo. Mas ele passa às dez e meia da noite, e é muito legal porque ele fala, eles batem papo mesmo, e eu acho que isso falta hoje em dia. Então eles batem papo mesmo, é uma conversa como se eles estivessem conversando sobre o bolo que eu fiz ontem, né? Eles conversam assim. Então, assim é legal, eles conversam muito, ouvem relatos... relatos de casais, e deixam que eles falem também, e tentam falar em cima... então você acaba se encaixando em alguma história. É muito legal, eu acho legal". Mariana mostra que o exemplo de outras pessoas e outros casais podem ser referências para compreender a própria vida sexual, tornando o assunto mais palatável, permitindo a identificação com alguns casos apresentados.

O fato de Carlos assistir ao programa junto a ela funciona como um estímulo para que os dois conversem mais sobre o tema: "Os programas de TV, que eu falei, que tratam sobre sexo, às vezes ele assiste comigo, mas normalmente é só eu. Ah, mas a gente conversa sobre, né, e tal... Isso é bom, eu acho bom porque a impressão que... tanto eu quanto ele tinha é que só acontecia com a gente, né? Que a gente tinha dificuldade no sexo mas porque acontece com a gente, com os outros casais não acontece assim. Tanto que hoje diminuiu um pouco, assim, de conversa, mas antes a gente falava muito: 'Ah, vê os outros casais como todo mundo se dá bem, e não sei o quê', né, 'Conversa com as outras pessoas pra ver que não é 
assim', então, quando a gente começa a assistir esse tipo de... de programa... você começa a perceber que não, que os casais... que outros casais passam por outras... eles passam pela mesma situação, ou parecida, enfim... também têm dificuldades, né, então isso ajuda bastante... também". A escuta de outras experiências, atrelada ao fato de Mariana e Carlos conversarem sobre a própria vida sexual, permite que se apropriem da experiência e compartilhem entre si suas dificuldades e até facilidades, diminuindo a auto-cobrança e, assim, a cobrança mútua. A vida do casal deixa de ter uma dimensão problemática, à parte da realidade de outros casais, para ganhar status de experiência vivida e compartilhada. Neste sentido, o sexo vai sendo aos poucos desmistificado, o plano ideal - a suposta vida sexual de outros casais - cede espaço para o plano mais real, próprio do casal, em um sentido de uma descoberta gratificante, prazerosa e positiva.

\section{3. "Não percebo que a necessidade que eu tenho de sexo, $e$ [a necessidade de sexo] que meu marido tem, seja a mesma": a dificuldade do casal}

A percepção de Mariana quanto a reduzida intensidade de desejo para atividades sexuais vem de longo tempo. Mariana relata que: "Quando eu namorava o desejo era... sempre... sempre assim, sempre bem atenuado. Eu acho que a falta de diálogo comigo e com ele de... de, assim, de eu sentir liberdade para falar para ele: 'Olha, eu não estou gostando assim', ou: 'Hoje eu não quero', né, ou: 'Vamos fazer diferente'. A vergonha que você sente de colocar uma lingerie diferente. Hoje não, hoje eu compro uma lingerie, tento fazer uma coisa diferente. Hoje melhorou muito em questão de... do... de um tempo atrás, né? Hoje melhorou muito. É claro, eu tenho certeza que ainda falta muito, porque eu tenho algumas dificuldades, mesmo que seja... de repente até... não manter tão atrelado ao sexo em si. Mais a minha atitude um pouco depressiva, enfim, um pouco isso... sei lá, não tô bem com a vida e acaba influenciando, né?". Mariana refere-se à falta de diálogo entre ela e o marido. O conflito referido em outro momento do depoimento em que Mariana revela o conflito entre o prazer e a culpa, aqui ganha contornos da opressora "vergonha". Este conflito certamente contribuiu para que ao longo do seu desenvolvimento existisse uma certa inibição na percepção de sensações prazerosas provocadas por estímulos eróticos. Antes não podia, pelo fato de ser solteira; depois, já casada, ela socialmente estaria autorizada a experimentar estas sensações, mas teria dificuldades para isso devido ao aprendizado precário sobre como vivenciar 
positivamente esta nova realidade. Mais uma vez, o conflito se faz presente. Associado a este conflito, a tendência ao estado que Mariana chamou de "depressivo", acaba por inibir ainda mais a percepção de estímulos no contexto em que vive. Neste sentido, Mariana nos revela que o estado emocional influencia de forma significativa a disponibilidade para a vivência sexual. Outro aspecto a ser destacado, é quanto a forma com que Mariana percebe a pouca disponibilidade para o sexo, porém, procura maneiras para que este "desejo" e "interesse" surjam em algum momento.

O conflito entre a vivência ou não do prazer ao longo do desenvolvimento de Mariana fica evidenciado quando ela diz que: "Antes eu não tinha essa liberdade, eu tinha vergonha, na verdade. Eu não entendo por quê. Eu acho... Eu era muito menina. Com 15, eu não queria conversar com outras pessoas, enfim, não tinha uma... um... eu não tinha essa... eu não sentia liberdade pra conversar com outra pessoa sobre o assunto. Eu acho que por conta disso, né, assim, do que eu acho, de pecado, assim. Depois fui entender que não é. Eu acho que até meio que, não sei, não diretamente, mas isso ficou na mente, eu acho". Dois elementos são apontados por Mariana como supostas bases para a sua dificuldade. O primeiro seria a falta de diálogo com outras pessoas. Outro ponto levantado é quanto à interdição, o "pecado", que acabava por privá-la ainda mais de possibilidades de descobrir ou conhecer aspectos relacionados à sexualidade e ao prazer.

A concepção da diferença entre os gêneros é algo marcante na dificuldade vivenciada pelo casal que tem relação com a disponibilidade em terem atividade sexual. Assim, na percepção de Mariana, ela tem menos desejo sexual do que o marido algo que, segundo ela, está vinculado às diferenças entre os gêneros: "Não percebo que a necessidade que eu tenho de sexo, e que meu marido tem, seja a mesma. Então eu percebia, eu falo isso pra ele, e hoje ele consegue perceber isso. Eu falo: 'Carlos, o que me excita não é você se despir e falar: oh, agora tô pronto pra fazer sexo'. É você... como você ficou comigo no dia, né, como você falou comigo naquele dia, como você me trata, um carinho que você faz...'. Tem carinho que ele faz que eu falo: 'Olha, não gosto que faz assim', né? Então, assim, hoje a gente consegue conversar mais e eu consigo falar, né, do que eu gosto e do que não gosto. Então... A paixão a partir da leitura desse livro ['Porque os homens fazem sexo e as mulheres fazem amor'] influenciou bastante. Consegui entender algumas coisas que antes eu não entendia”. A busca de leituras específicas a exemplo da citada por Mariana influenciou no seu roteiro sexual, contribuindo significativamente para que ela compreendesse e desse sentidos para a sua 
necessidade de pontuar para o marido aquilo que aprecia e aquilo que não aprecia para sentirse estimulada. O diálogo do casal, portanto, foi crucial para esta encontrar uma melhoria na vida sexual.

Mariana afirma que a sexualidade até nos dias de hoje é complicada, mas aponta fatores significativos que podem influenciar para a pouca disponibilidade para a atividade sexual: "Eu acho que minha vida sexual foi muito complicada... Acho que até hoje ainda é por conta de trabalhar, estudar, eu acho que isso interfere muito. É um cansaço, às vezes, você quer um... momento mais íntimo com o marido e, às vezes, não consegue porque tá cansada, enfim... A diferença entre personalidades masculina e feminina, pelo menos de um ponto de vista, o homem, fisiologicamente, (riso) não consegue ficar muito tempo sem sexo, e a mulher já consegue ficar um tempo sem o sexo". Retomando a idéia das diferenças entre os gêneros, o homem se predispõe mais para o sexo do que a mulher, na concepção de Mariana, sendo que ela espera mais carinho e, o marido, espera mais diretamente o sexo.

Não se pode descartar que o estresse gerado pela vida profissional e a expectativa do papel da mulher no casamento influencia na diminuição do desejo sexual; por outro lado, parece que o marido não apresenta tal indisponibilidade e tem dificuldades para compreender o que acontece com sua parceira. Isto se tornará mais claro quando Mariana revela que: “...No namoro tudo era novidade e tudo... deixa a gente atraída, né, tudo dá tesão, enfim, tudo fica fácil. Depois de casado, eu já acho que fica um pouco mais complicado. Você tem... você tem que se espelhar na mulher, que se sente um pouco na obrigação de estar sempre com o parceiro como mulher, como esposa, eu acho que isso afeta por dar conta disso, da sociedade, mesmo, acho que é uma pressão social... e... ah, às vezes... se sentir na obrigação de estar sempre fazendo sexo com o marido, por mais que ela não tenha vontade. E eu passei por essa situação, né? Pra não falar pro marido que você realmente não tá com vontade naquele dia: 'Não tô, não quero, só quero conversar'... enfim". No namoro tudo é novidade, tudo é descoberta em um clima de confidência, de segredo, e, no casamento, entra em cena a pressão para corresponder a um papel social preestabelecido em que a mulher, em uma perspectiva machista e patriarcal, deve dar o suporte necessário para o marido. Dentre estas obrigações do matrimônio está o de satisfazer as necessidades sexuais do homem. A atividade sexual prazerosa, na perspectiva de Mariana, é incompatível com a obrigatoriedade, sendo que o desejo é algo espontâneo, que necessita de estímulo para intensificar-se, na obrigação, no 
ter-que-sentir, o que surge é a mera mecanicidade a qual Mariana se referiu quando, na escola, teve aulas de sexo na matéria de Biologia.

Ao longo do tempo a situação entre ela e seu marido vem se modificando. O comportamento assertivo de expressar aquilo que sente e deseja, aliado ao fato de Carlos escutá-la e compreendê-la, constituem elementos importantes neste processo de melhoria da vida do casal: "Hoje eu consigo entender umas coisas, e, enfim... ele também. A gente conversa bastante. Então, quando eu não quero: 'Ah, não dá'. Mas por entender, isso também, quando... e também fazer um pouco mais de esforço, é... me estimular mais pra... pra que os dois se sintam satisfeitos, os dois se sintam... Antes era mó foda, ele queria namorar e eu não queria, só que pra ele não sair chateado, eu não falava, e ficava uma situação meio chata. Eu passei por muitas situações desse tipo. Antes isso acontecia. Hoje já não... hoje a gente já conversa bem mais... bem mais... é menos forte... e, se eu não tô com vontade, de repente, a gente namora, a gente namora de outro jeito". Compartilhando as próprias necessidades, sem a pressão de corresponder a uma idealização de uma vida sexual perfeita, Mariana e Carlos vão construindo a singularidade de sua relação de forma prazerosa e gratificante para ambos.

Idealização e realidade da vida sexual seguem em paralelo. A questão da especialidade por um lado, pode contribuir para o encontro de novas alternativas mais positivas e gratificantes com relação ao exercício da sexualidade. Como pontua Gagnon (2006), a maior parte da aprendizagem dos roteiros acontece nos relacionamentos em que os casais elaboram aquilo que lhes é mais conveniente, e faz uma crítica:

A maioria dessas relações fica aquém das metas absolutas estipuladas por livros como A alegria do sexo, mas apenas algumas pessoas acham que as dificuldades experimentadas em suas relações precisam de terapia sexual. (...) A distribuição das dificuldades observadas na terapia não pode ser generalizada para os índices ou distribuições das dificuldades encontradas na população em geral. A importância desta observação está no fato de que o grau de satisfação sexual na sociedade depende tanto do nível de insatisfação dos indivíduos e casais com sua vida quanto no das práticas sexuais efetivas a que eles se entregam (p.263-4, grifo meu). 
Deste modo, deve-se atentar para posturas "absolutistas" que fixam padrões e modelos do que se chamaria de um "bom" desempenho sexual, sem levar em consideração as particularidades do casal.

Mariana incorpora no seu roteiro a necessidade de um especialista para suprir o que percebe como lacunas ao longo da sua trajetória: "Na verdade eu ainda acho que falta, pelo menos pra mim, de repente, continuar conversando com alguma pessoa, especialista mesmo, pra falar algumas coisas que ainda falta. Acho que por esse muito tempo, eu ainda ser jovem, e não entender muito sobre o assunto... enfim... eu acho que atrapalhou um pouco... ahn... não tive muitos outros namorados, não tive nenhum outro contato sexual, enfim. Tinha carícias íntimas, mas não passou disso. Quando eu falo de conversar com um especialista não acho que é uma coisa que parte só de mim. Eu acho o casal, mesmo... (...) Acho que por a gente ser muito jovem, eu não sei, crescer... por a gente ser muito jovem, enfim... a gente não tinha essa liberdade. E também no começo do casamento a gente passou pela situação de perder um filho. Então foi uma coisa, assim, muito conturbadora e.. perder um filho, também... interferiu um pouco, né... interferiu também”. A questão vivida pelo casal é singular e carece ser compreendida e apropriada pelo próprio casal, seja com o auxílio especializado, seja na vivência compartilhada de experimentações na vida afetivo-sexual, elaborando aquilo que lhe é conveniente. No discurso de Mariana a pressão que até então era da expectativa social da esposa em garantir a satisfação sexual do marido, parece deslocar-se para o especialista que supostamente saberá apontar o que é melhor para o casal em termos sexuais.

Mariana relata que hoje ousa fazer coisas que antes seriam impensadas. A partir da experiência vivida em contato com o mundo, incluindo referências já citadas como livros, TV, revistas, igreja, amigos, entre outros, ela se autoriza experimentar novas possibilidades de conhecer o próprio corpo e de experimentar o prazer sexual: "Com certeza eu sinto que passou a existir um antes e um depois. E, hoje, hoje, depois de muito tempo, eu comecei a estimular eu mesma, sozinha, sabe, masturbar, enfim, pra ver esse desejo. Começar testar outras coisas, pra ver se realmente eu tinha algum problema hormonal, ou qualquer coisa assim, porque eu não sinto desejo, enfim, às vezes, eu não sentia mesmo e eu percebo que com ele, quando estou com ele, as coisas são diferentes, entendeu?". 
Ainda sobre a masturbação, ela afirma que: “Antes eu não me masturbava. Quando eu era menina, às vezes, acontecia uma vez ou outra, mas não era comum. Era uma coisa de descobrir, mas não de... Acho que por conta da religião achar que... A minha mãe era católica, e eu também era. Hoje eu sou cristã... é... sou evangélica. Mas a gente tem uma visão diferente. Não que seja uma visão diferente, mas vem cá, a gente entende que o casamento realmente é... que o sexo realmente é melhor que seja com uma pessoa com quem seja casado, e que o sexo é uma benção, e isso é bíblico, pelo menos isso é bíblico. Legal, né? Não é religião, é Bíblia. Você pode procurar que isso você encontra, que o sexo é realmente uma benção, é visto como uma benção, mas dentro do casamento. E isso é bom a gente entender, e tirar isso como um conceito ruim. Até então sempre aparecia como: 'Não faça, não faça, não faça', e quando você tá fazendo já fica com aquele conceito de: 'É pecado', né?". Mariana clarifica que o sexo, de acordo com sua religião, deixa de estabelecer impedimentos para o sexo, fornecendo status de bênção, com uma condição: que seja praticado dentro do casamento. Esta perspectiva segue a instituição, a partir dos séculos XII e XIII, do casamento cristão, monogâmico e indissolúvel. O foco principal da Igreja Católica e seus clérigos que se voltavam para o controle da vida moral dos fieis para que não tivessem atividade sexual fora do casamento e que se limitassem à prática com inseminação (Bozon, 2004).

\section{4. "A minha sexualidade eu venho descobrindo agora... agora mesmo, é coisa bem recente": Mariana chega ao SAP}

De forma serena e contundente, Mariana fala que somente agora vem descobrindo a sexualidade. Percebe que neste momento se permite experimentar sensações com o próprio corpo, e de expressar para o marido aquilo que gosta e aquilo que aborrece no momento do encontro sexual, favorecendo o encontro formas mais prazerosas de contato: “...A minha sexualidade eu venho descobrindo agora... agora mesmo, é coisa bem recente".

Mariana diz que o atendimento do Serviço de Aconselhamento Psicológico - SAP contribuiu sobremaneira para este processo de descoberta da sua sexualidade: "Hoje, hoje, depois de 10 anos, eu consigo compreender isso. Eu acho que faz muito... acho que faz um 
ano, depois de ler muitos livros, conversar com a... a psicóloga do $C A P^{43}$, não lembro o nome dela, da psicóloga daqui... (...) Ela foi maravilhosa. Eu não fiquei muito tempo em atendimento, ela me encaminhou para outra pessoa. Eu fiquei muito triste, né, porque me ajudou a pôr pra fora. Eu não lembro o nome dela, agora. Foi bom. E... e hoje eu percebo essas coisas". O fato de ter alguém para compartilhar suas dúvidas e necessidades trouxe o alívio de que precisava para sentir-se mais confortável com sua singularidade. Pela tristeza de Mariana diante do encaminhamento para outro profissional, nota-se que o trabalho foi significativo para a sua experiência no sentido de contribuir para que compreendesse o momento de vida que atravessa, fornecendo-lhe alguns subsídios para a melhoria de sua qualidade de vida.

Mariana continua sua fala referindo-se ao SAP: "Essa descoberta da minha sexualidade aconteceu a partir de quando eu comecei a conversar com essa moça do SAP. Eu comecei a descobrir algumas coisas... descobrir algumas coisas, não, mas é... consegui ter uma atividade melhor com meu marido, conversar mais com ele, ver como... porque eu... até dentro da crítica, mas não um... falo... do que prejudicou minha vida íntima, assim, por conta dessa pedra psíquica, né, a gente descobriu isso, também, na conversa, né? E... eu não associava tudo isso com a sexualidade, essas coisas. Ahn... mas assim, eu tento... tento me descobrir, tento ver de outras formas pra melhorar. Vejo que ainda não está bom. Não tá bom. Ele tem desejo, ele é homem, ele tem que ter desejo (riso), senão tem problema, mas não sei... Talvez eu esteja, né?... Então, acho que falta na mulher, né? Enfim... Mas eu acho que eu ainda... é... eu tenho dificuldade em sentir desejo, mesmo, com o meu marido, né? Na hora do deita e rola já cai nisso". Interessante observar o significado do atendimento no SAP em catalisar o processo da descoberta de novas coisas que a própria Mariana se predispunha, melhorando a qualidade do diálogo e do contato com marido. Além disto, de acordo com Mariana, o atendimento no SAP auxiliou-a em compreender que diversos outros fatores influenciam na vida do casal a partir da sua trajetória de vida. Atrelada à sua representação de gênero, parece que Mariana entrega-se à idéia de que o desejo é algo inerente à "natureza" do homem, caso contrário, existe algum problema; porém, na sua condição de mulher, ao contrário do homem, talvez a falta de desejo seja inerente à sua "natureza". O processo de descoberta é dinâmico e se atualiza a cada instante.

\footnotetext{
${ }^{43}$ Centro de Atendimento Psicológico.
} 
Em um encontro em que a sua singularidade foi reconhecida e acolhida como tal, novos sentidos foram sendo revelados para Mariana: "Então eu tive vontade de mudar, quando eu tentava conversar com ele, falava: 'Não gosto assim, ou gosto assim, vamos fazer assim', né? A gente brigava muito, também, então... daí chegava a hora de dormir e, em vez de se amar, briga. Aí ia pro sexo, então isso foi atrapalhando muito, enfim, eu percebi que isso atrapalhou muito durante um tempo. Aí foi se tornando como uma obrigação, era essa a impressão que eu tinha: ter que fazer pra gente não se separar. Não era pra dar prazer. Hoje eu consigo sentir um pouco mais de liberdade de, de repente, conversar com ele, mesmo. E a gente... e ele pergunta, né, coisa que não fazia antes. Porque quando eu procurei aqui, pra o tratamento aqui, eu conversei com ele, falava das minhas dificuldades, a gente tava a ponto de se separar, mesmo, porque isso foi um grande agravante, mesmo, pra gente se separar. Enfim, porque a gente não conseguia ter intimidade... aí quando eu saí a gente começou a falar sobre, aí ele falou: 'Ah, tá bom!'. Aí quando a gente foi que eu percebi que: 'Puxa vida, ele quer que as coisas melhorem. Então vamos conversar mais!'. Eu não podia falar. Hoje eu falo: 'Olha, eu gosto assim, eu gosto assado, ou faz assim...'. Antes eu morria de vergonha, imagine! Eu tinha vergonha de falar: 'Olha, me toca, coloca a camisinha, me masturba', por exemplo, né? Eu achava muito estranho, eu achava que era uma coisa individual, não sei... daí.. Eu me colocava assim". Neste momento do depoimento Mariana aponta para fatores cruciais que influenciavam negativamente a relação do casal. Tais fatores não estavam circunscritos apenas na individualidade de Mariana, nem na individualidade de Carlos, mas em um terceiro lugar, na singularidade da relação que se estabelecia. Até então, na concepção de Mariana, a questão era individualizada, por mais estranha e vergonhosa que a situação despertasse. Esse retraimento vivenciado por cada um dos parceiros inevitavelmente prejudicava a qualidade da comunicação que seria canal para a expressão daquilo que agradava, ou não, a cada um, a fim de contribuir para um lugar compartilhado do casal. $\mathrm{O}$ diálogo, portanto, se tornava inviável, e, qualquer possibilidade de contato era descartada, cedendo espaço para brigas e desentendimentos que se refletiam na vivência afetivo-sexual. $\mathrm{O}$ contato sexual tornou-se palco do "sexo mecânico" - "não era por prazer" - apreendido na escola, e do "sexo-serviçal" - "se não, se separa" - apreendido no âmbito do social em que a mulher deve satisfazer ao homem. A ida para o SAP potencializou em Mariana a sua percepção de si, a sua percepção de Carlos, a seu a percepção do casal como um todo, gerando um movimento que Carlos passou a corresponder positivamente para o que agora pode-se chamar de diálogo. 


\section{5. 'Essa melhora da nossa vida sexual, olha, eu comecei a perceber a partir desses testes que a gente costuma conversar e fazer, eu e meu marido...": Mariana e Carlos experimentam novas possibilidades na relação}

O estado da relação afetivo-sexual do casal era precário em diversos sentidos. Mariana tem consciência de sua limitação no que diz respeito à intimidade, inclusive com o próprio corpo e sensações geradas a partir dele. Não é possível referirmo-nos à realidade vivida por Carlos, que fugiria à proposta desta pesquisa. $O$ que se pode afirmar é que Mariana e o relacionamento estavam em severa crise: "A situação que a gente tava passando não era simples. Então vamos separar ali. E, praticamente, era por causa disso, né? Hoje a gente consegue transar um pouco melhor. É claro que eu ainda acho que com um pouco de dificuldade. Essa melhora da nossa vida sexual, olha, eu comecei a perceber a partir desses testes que a gente costuma conversar e fazer, eu e meu marido... teste de fazer coisas diferentes, de colocar uma lingerie, de pôr uma música... né, de ir pra um motel, né, que antes eu nem ia, 'Deus do céu!'. E ir pra motel pra quê? A gente é casado, né! Então a gente já achava que não vale... entende? Pra que pagar motel? Já tem uma cama dentro de casa! Não, motel tem de monte. Tem muita coisa porque... e... eu percebo que eu, quando eu me sinto é... mais bonita, quando eu me sinto atraente, eu percebo que eu fico com mais desejo. Então, assim, eu tenho que, realmente, sempre todo esse preparo, sabe, de colocar uma lingerie, de repente... é... de me sentir sensual, mesmo. E, é claro, tem que tá fora da época da $T P M^{44}$, que eu fico extremamente... depressiva. É um momento muito ruim (riso)". A melhoria da relação afetivo-sexual do casal a partir do diálogo abre espaço para experimentam novas situações, inclusive aquelas que não eram admitidas no passado como ir ao motel, considerando o estado civil de ambos, como se aquele espaço fosse restrito aos namorados e amantes. A lingerie deixa de ser algo que desperta o sentimento de vergonha para ganhar um sentido de erotismo na relação. Mariana e Carlos mostram que, mais uma vez, autorizam-se a novas experiências, a novas sensações, inclusive àquelas relacionadas à transgressão. Mariana começa a tocar em um outro assunto que está intimamente associado à sua disponibilidade na relação: a auto-estima. Ela começa a perceber que a sua disponibilidade ao prazer e a sua confiança aumenta quando sente-se valorizada no seu modo-de-ser, na sua singularidade, incluindo a sua percepção de sentir pouca disponibilidade no período da TPM.

\footnotetext{
${ }^{44}$ Tensão pré-menstrual.
} 
Mariana revela também que Carlos carecia de algumas referências sobre o universo feminino com que o diálogo com ela contribuiu significativamente para que ele tivesse contato: "Meu marido sabe sobre essa questão da TPM. Agora ele tá começando a perceber isso, sabe? Antes não tinha... me chamava de chata, não sei que... e eu também não conseguia entender, e achava que aquilo enchia, eu achava que era frescura, e enfim... Depois eu comecei a perceber: 'Pô, dá todo o mês!'. Você oscila muito na época da TPM, eu tô muito... depressiva mesmo, sabe, de não... de jogar tudo e não querer fazer nada, realmente nada. E depois que passa fico animada, sabe, quero fazer coisas, quero... é... fico animada pra fazer um monte de coisas... enfim. Tanto até que meu desejo sexual vem dessa... desse estado de me sentir sensual mesmo, de quando me arrumo, quando me sinto bonita. (...) A gente fica preocupado com algumas coisas, filho doente... e eu fico muito preocupada e acho que acaba... acabo me achando... sabe, se olha no espelho e se acha feia. Enfim... e pra... pra... eu percebo que atrapalha". De certo modo, Mariana também não identificava no corpo os sinais característicos da TPM, dentre eles, no seu caso, de sentir-se pouco disponível para fazer coisas, inclusive o sexo. Porém, quando este período termina, o ânimo retorna e, junto com ele, a auto-estima.

Mariana encontrou alternativas para lidar nos períodos de TPM: "Sexo é algo que eu não tenho feito quando me acho feia. Nestes momentos dou uma caminhada, por exemplo". E revela o que faz para sentir-se bem, sem deixar de reconhecer e aceitar quando não se sente tão bem: "Eu gosto, eu acho que me sinto... me sinto, enfim, animada... Ah, me arrumar, escovar... escovar o cabelo, pôr uma maquiagem, né, me depilar, principalmente... eu nem gosto disso, eu falo (riso), eu não gosto... Então são essas coisas... E assim, às vezes, até por conta da... da condição financeira eu... 'Poxa vida, não posso me arrumar...'. Eu acho que isso atrapalhava bastante. (...) Inclusive eu demorei muito pra entender isso, né? Porque eu falo... tava me sentindo feia, muito feia e falo: 'Não, você tá linda', né? Antes não falava isso de jeito nenhum, e hoje, né, hoje é uma dificuldade que a gente passou a... a entender isso, sabe, de falar: 'Gosto assim, você fica bonita', né? Mas, nesse momento, agora, por exemplo, de ele falar: 'Vamos sair', se eu tô me achando feia, não adianta ele falar que eu tô bonita, se eu tô me achando feia. Que é como se fosse... mesmo, se fosse uma palavra neutra, não tivesse efeito algum. Se eu tô me sentindo bonita, se eu falo que eu tô bonita é um... mas eu não tô, não tô me achando bonita. Eu tô me achando... não me dou bem comigo mesma. Sei lá, prejudica um pouco, eu percebo isso no corpo inteiro e até na satisfação sexual. É o que eu percebi durante esses dias". A dificuldade que antes era restrita ao desejo sexual começa a 
ganhar uma dimensão em que engloba a dimensão do seu modo-de-ser, onde percebeu que sua auto-estima estava prejudicada. O fato de sentir-se bonita - que é diferente de alguém lhe dizer isto - é algo que favorece a sua expressão para o mundo.

\section{6. "Mas eu acho que é essa falta de conversa, de repente, de mostrar que a sexualidade é algo bom, enfim, não tem nada de ruim no sexo": o sexo no contexto social}

Mariana revela em sua fala que o discurso sobre o sexo mostra-se ambíguo no âmbito social. Por um lado, é algo positivo para falar sobre sexo, mas, por outro lado, em uma perspectiva moral, isto ganha ares de promiscuidade, ainda mais no caso da mulher: "Normalmente as pessoas que falam de sexo, assim, abertamente, numa conversa de amigos, ou porque é um galinha ou porque a moça é vai com todos. Normalmente essa visão, infelizmente, que a gente tem. Não sei, infelizmente, não sei, pelo menos acho que não deve. Isso faz muita gente parecer promíscuas, do ponto de vista deles. Mas eu acho que é essa falta de conversa, de repente, de mostrar que a sexualidade é algo bom, enfim, não tem nada de ruim no sexo, né? Eu acho que tem que ser conversado e ser explicado que tem que ser feito de forma consciente. No meu ponto de vista eu hoje penso que sexo tem que ser com casamento. É isso que eu penso. Mas não precisa ser... não precisa deixar de falar sobre sexo... Mesmo antes que não... mesmo que não faça sexo, eu acho que tem que ser conversado sobre isso, né, tem que ser falado sobre isso, como funciona, o que é que é... sabe?". É presente aqui a tensão entre o falar sobre o sexo e o não falar. O status de quem se atreve a falar sobre sexo pode ser abalado, mesmo sabendo que muitos gostariam de ouvir ou, quem sabe, também falar sobre sexo. A partir da trajetória de Mariana vê-se que o sexo sempre foi tratado de forma oculta, marginal, porém, isto não bastou para que ela se mobilizasse para conhecer mais. A questão, mais uma vez, reside no fato de que não existe um fim para a descoberta, ou mesmo um fim para o prazer, que se atualiza com o tempo, na cultura circundante (Gagnon. 2006). Na fala de Mariana, existem indícios de que esta busca não se encerrará tão cedo, o que não quer dizer que ela encontra aquilo que busca de forma arriscadamente idealizada. No seu universo, o sexo deve principalmente estar vinculado ao casamento, mas também admite que o sexo pode estar presente em outros tipos de relacionamento. 
O universo de possibilidades no campo da sexualidade se torna possível a partir da convivência social, na apreensão de nuances possíveis, ou até necessárias no sentido de reconhecer diferenças e diferentes formas de expressão e vivência da sexualidade. Mariana aponta que este reconhecimento poderia se dar desde a infância, reforçando a idéia da necessidade de as pessoas terem acesso a esta temática: "Eu acho que deve-se falar de sexualidade desde a adolescência, que é a hora que vem. É porque, como os adolescentes estão descobrindo coisas bem mais rápido que antes, é... acho que há... é difícil, mas os pais dá pra perceber isso, né, de virar pro filho e achar: 'Olha, agora que ele já tá arrumando outra namoradinha'... enfim... Mas na adolescência, eu acho que a adolescência... não preciso dizer a idade, pois eu acho que os adolescentes... que as crianças já tão muito em foco, né? Eu acho... de repente até você falar não sobre o sexo propriamente dito com a criança, mas... porque quando ela começa a descobrir, também, né? Elas vêem televisão. Eu acho a televisão um veículo... bom... ao mesmo tempo que é bom é extremamente ruim, porque acaba... preconizando muita coisa pro... pra criança, eu acho. E a gente tem que se garantir. É... você se predispor... pelo menos com meu filho". O canal que se apresenta para lidar com a sexualidade acaba recaindo nos programas de TV. Mariana já havia citado o seu programa de referência na TV sobre assuntos relacionados ao sexo. A tensão, mais uma vez se instala no tipo de comunicação voltado para as massas da TV, e a comunicação das diferentes realidades dos lares no cotidiano. Se a tensão existe entre o público e o privado, a tensão estará presente quando os próprios pais tratarem do tema com seus filhos, dependendo de como foi a própria trajetória destes pais.

Mariana clarifica esta tensão envolvendo a TV a qual refere-se como o lado bom e o lado ruim deste meio de comunicação e de formação de opinião e de costumes: “A televisão passa mensagem de que sexo ainda é pecado, eu acho. Não passa que... como sexo é uma coisa boa, sabe? (...) ... O sexo também é uma conquista pessoal, individualmente... eu acho, e isso não é passado na TV, né? Você vê acontecendo um... uma pessoa traindo a outra, né, enfim... você não vê como... você não vê como algo mais interessado, mais como... como amor, mesmo, como se fosse parte do carinho, como se fosse um... uma conseqüência do carinho no casal, enfim. É difícil você ver isso e compreender. Normalmente passa ou porque alguém tá traindo alguém, ou porque... ou você vê um sexo muito selvagem, enfim... (...) As pessoas estão sendo educadas dessa forma (...): 'É gostoso, é prazeroso'... como se fosse drogas: 'Dá prazer, vamos fazer', né? (...) E não é bem assim, né, eu acho que pra você ter realmente um sexo bom é preciso ter uma relação boa, cara. Eu acho que tem que fazer parte 
da vida da pessoa, não só simplesmente... é... só o prazer em si, usar esse prazer como se fosse uma droga. Eu uso maconha, ela me dá... me dá prazer naquele momento, mas agora... depois de um tempo não te dá mais, daí você muda... né, de droga, enfim. Eu acho que isso não é legal, e é essa visão que eu acho que as pessoas estão tendo hoje de: 'Ah, não é bom com esse, então vou pro outro', 'Ah não gostei com esse então vou procurar outro'... 'Vou namorar com vários'... Eu acho que isso deixa o sexo como uma coisa muito banal, como só é... sensação, prazer e ponto em relação... eu acho". Neste ponto do depoimento, Mariana associa a mensagem transmitida pela TV como o sexo vinculado ao pecado e às drogas, defendendo que o sexo é uma coisa boa desde que seja vinculado a uma relação estável e monogâmica. Na perspectiva de Mariana, a TV transmite a mensagem de que o sexo é desvinculado do afeto, assim como o viciado sempre busca uma nova droga ara reproduzir os efeitos experimentados com um tipo de droga usado. Deste modo, Mariana percebe que não existe disponibilidade significativa para investimento na parte afetiva da relação a dois, que poderia, por sua vez, favorecer um melhor entrosamento no âmbito sexual do casal. De uma forma crítica, Mariana aponta os programas de TV carecem do incentivo de mensagens do sexo vinculado a uma conquista pessoal, como desdobramento do envolvimento afetivo, e carece do incentivo à promoção de relacionamentos monogâmicos.

\section{7. "Ter o poder maravilhoso de ter filhos": o ser mulher para Mariana}

O sentimento de ser mulher, para Mariana, está fortemente vinculado à maternidade, à beleza, e ser suficiente para lidar com diversas frentes de trabalho, seja no trabalho doméstico, seja no trabalho fora de casa: "Ser mulher é... sabe, de ter o poder maravilhoso de ter filhos, eu acho que é lindo, maravilhoso, excepcional. Ah, é essa... é ser vaidosa (riso), apesar de eu não ser. (...) Acho que transmitir, expressar mais amor do que... diferentemente do homem, né, o amor de formas diferentes. (...) Eu acho que a mulher tem mais afeto. Assim, mulher é ser guerreira, né, poder fazer muitas coisas ao mesmo tempo, poder trabalhar, ter filho, ahn... ser mulher... ter a... questão conjugal como, né?... Eu acho que é ser o multiuso (risos) Ou ser multiuso ou... é fazer... fazer tudo mesmo, né, você acaba virando em mil, eu acho".

Esta concepção do ser mulher repercute em como Mariana se sente sendo mulher no sentido de ficar em um estado de alerta e de tensão diante de tarefas do cotidiano: "Por ser 
mulher, eu me sinto um pouco mais cobrada. Ah, cobrada pra ser dona de casa, cuidar do filho... Marido se sente, também, que tem que ser cuidado, sabe? Tem que estudar, tem que trabalhar, tem que ajudar, enfim, eu acho... Eu fiquei com a cobrança um pouco maior pra atender a família. E eu acho que essa cobrança vem de mim mesma, de mim pra comigo mesma, de me sentir bem dos outros dias, de fazer alguma coisa que me sinta bem, é... de tentar achar alguma coisa pra minha auto-estima. Aí... Você se sente horrivel. É péssimo, péssimo, péssimo, péssimo mesmo. Ah, e tem os momentos gostosos, né, ter filho, né, filho com o pai que eu amo, que te abraça, ou quando faz algum desenho pra você na aula de desenho, ou quando traz alguma informação da escola: 'Ai, mãe, eu fui bem, mãe, recebi um parabéns, ou fui muito bem na prova'. Isso me deixa muito feliz. Ah, também quando o marido, quando tá mais atencioso, tá mais afetivo, enfim, sabe?". Mariana aponta aquilo que a motiva para manter-se disponível para suas atividades no lar e fora dele, como o carinho do marido e as conquistas do filho. Esta cobrança maior por atender à família reproduz, de certo modo, a referência que tem de sua família de origem. Porém, pelo fato de estudar e de trabalhar, acaba sobrecarregando a si em corresponder às expectativas sociais. Uma destas expectativas é o cuidar do marido que, enquanto homem, coloca-se e é colocado no lugar daquele que é cuidado. Torna gratificante quando Mariana sente-se minimamente cuidada e atendida pelo marido.

Como representante do gênero feminino, Mariana diz nunca ter pensado num modelo nesse sentido, e prefere eleger sua própria mãe como modelo de mulher: “...porque ela é muito, é... esse de cuidar de todo mundo, quer fazer tudo, e também puxa muita... muita... responsabilidade pra si sem necessidade, né? (...) Agora, uma mulher que represente, eu acho... gostaria que tem que ser, né, assim, uma mulher sensual, uma mulher sensual, uma mãezona, não consigo perceber uma... sei lá, eu acho a Cláudia Raia. (...) [Ela] é uma mulher que trabalha muito, lutadora, tem os seus filhos, consegue ser uma mãezona, e por ser uma mulher sensual... pelo menos não trocou de marido (riso). Que eи acho que eu nunca vou me sentir sensual e ter uma vida feliz sexualmente se eu ficar trocando de marido. Eu... você mudando muito de marido você não percebe quais são os seus problemas. É assim que eu penso. Eu acho que não é bom uma mulher fazer isso". Mariana faz uma distinção de um modelo real, a sua própria mãe, que acaba se sobrecarregando de tarefas que nem sempre lhe caberiam; e de um modelo ideal, Claudia Raia, que mantém a sensualidade e ainda consegue corresponder às expectativas atreladas ao papel de mãe. Na sua perspectiva a mulher se torna mais valorativa e feliz quando não se separa do marido e inicia novo relacionamento. 


\section{8. "Ser o forte de casa (...), ser o forte da família": o ser homem para Mariana}

A representação que Mariana tem de homem está relacionada à idéia do homem provedor, que traz o sustento para a casa e tem disponibilidade e interesse pelo sexo: "Pensa em sexo a toda hora... (risos) homem só pensa em sexo. Não é?... Eu acho que é essa coisa do animal, de trazer o mantimento pra casa. Por mais que a mulher trabalhe, mas eu ainda consigo ainda ter essa visão de que a responsabilidade maior da casa é o homem de trazer, teoricamente, suprimento da família... aí, eu acho que ser... ser a força da casa, né, do carinho, do apoio, na responsabilidade, enfim, ser o forte da família, é o forte”. A perspectiva de Mariana também vai ao encontro do modelo do homem patriarcal em que a mulher ocupa um papel secundário. Este modelo acaba se evidenciando, mesmo Mariana tendo uma vida ativa e atribulada, com exceção do sexo, em que queixa experimentar baixo desejo sexual. Mariana coloca-se no lugar de obrigatoriedade em se dispor para o sexo com o marido, com uma percepção limitada do seu próprio prazer.

Para Mariana, o ator Reynaldo Gianechini ocupa o lugar de representante da esfera pública de homem: "Um modelo de homem?... Ah, me veio o Gianechini, né? (riso) Oh, homem lindo, meu Deus! Alto, sensual, forte... Bem, mas... bom, não é só isso, né? Ai, que difícil essa pergunta... (...) É difícil responder, eu não consigo achar ninguém que seja... (pausa) o homem completo (riso). Acho que tem personagem. Eu não lembro o nome dele (riso), mas foi do filme é... meu Deus, qual o nome do filme?... (...) Ele é um advogado, um advogado que... enfim, que... que ajuda um rapaz que matou, um cara que atirou num... num cara que estuprava a filha criança. Não lembro o nome dele. Mas era um advogado que tinha, sabe, esse objetivo dele de ajudar o outro? E é casado, tem uma... uma esposa maravilhosa, tem uma filha, muito carinhoso com a filha, muito carinhoso com a esposa, e tem esse jeito de cuidar, ali, da família, né, e... e mesmo quando ele se encontra no momento difícil, ele teve contato com uma outra mulher e mesmo assim não traiu a esposa, né? (...) Da esfera pública... Da política nem pensar. Com os políticos que a gente tem? Aí não dá... (risos) Não consigo achar... (pausa). Agora, filme... sei lá, a gente não assiste muito. Esses homens trocam muito de esposa, não consigo pensar em um que seja fiel. Eu acho que... isso é importante". A beleza e a sensualidade são marcas que Mariana confere ao ator Gianechini, mas, ressalta, na figura do personagem de um filme que é casado, altruísta, carinhoso e cuidadoso com esposa e filha, e não sucumbe diante de uma situação que envolve sedução por parte de outra mulher, optando por manter-se fiel à esposa. 


\section{9. "O que mais marcou minha sexualidade, na verdade, foi o namoro": o olhar para os caminhos trilhados}

Ao longo da sua trajetória, Mariana destaca o momento em que iniciou o namoro com seu atual marido, revelando a tensão entre o permitido e o proibido: "Hoje eu posso dizer que o que mais marcou minha sexualidade, na verdade, foi o namoro. Porque é algo muito horroroso, né, porque era meio proibido, meio gostoso... então era... era legal (riso). Estou me referindo ao meu marido. Ah, eu segurava a mão dele. Era legal ir pra Igreja... e tava só nós dois... Ah, era tudo muito conturbado. (riso) (...) De repente acho que isso que foi até que... não sei... e era... mas era bom, porque, enfim... antes de você... antes de chegar o momento de transar ali, em algum lugar da casa, porque não tem ninguém... enfim, é... você já tava com vontade antes, né... porque namorava, mas não tinha o ato em si, porque também não dava... então, era gostoso, mas não tinha essa parte, né, essas... essas carícias que tem que ter antes, e hoje a gente percebe (riso) que acha que é bom... enfim, algo engraçado". Esta tensão entre o permitido e o não permitido, o prazer e a aflição de não ter um contexto favorável para avançar nas carícias, é visto por Mariana como algo ao mesmo tempo "horroroso" e "legal". Porém, esta percepção tornou-se mais clara nos dias atuais, encontrando até um senso cômico.

Antes de iniciar o namoro com seu atual marido, com quem teve sua primeira relação sexual, ela namorou outro rapaz, aos 14 anos, com quem experimentou carícias íntimas mais intensas: "Me lembro que foi na casa dele, (...) um apartamento, e tinha até cama de casal, e a gente ficava namorando no quarto. (...) Eu lembro que tava morrendo de medo, tava apavorada. (...) E você nem pensa. E isso é ruim, até, acho que essa falta de informação atrapalha tanto que... que a menina no momento tá tão apavorada que não pensa esses detalhes... enfim. (...) E eu falei: 'Não, não quero, não quero, não quero'. Ele ficou nervoso, apavorado. (...) E aí, não aconteceu, não aconteceu". Neste olhar para a sua trajetória pregressa, no início da descoberta do relacionamento a dois, Mariana considera que a falta de informação é um impeditivo para o início da vida sexual de jovens. De certo modo, como dito em momento anterior, a informação até existia, porém, fica evidenciada a carência de orientação sobre como lidar com estas informações.

O desdobramento desta recusa em prosseguir na relação sexual apresenta outro ponto valorizado na construção do gênero, que é a virgindade: "Ele nem quis mais namorar 
comigo... 'Uma menina que não quer (riso), que me deixou na mão...' (riso). Mas depois de um tempo, depois de um ano, eu ainda era menina. (...) A gente voltou a namorar. Eu lembro que... mesmo assim eu não transei com ele, porque eu tinha percebido que a impressão que (...) só queria aquilo comigo, que eu não queria... Até namorou com uma garota, mas ele sabia que eu gostava dele ainda. Daí terminou com essa garota pra poder ficar comigo... enfim... e só queria avançar o sinal de novo em pouco tempo. E isso pra mim, aquilo pra mim era uma ofensa, achava que era uma ofensa: 'Peraí, não é assim, esse cara só quer transar comigo, né? Aí não quero mais também'. Aí quem deu o pé na bunda dele fui eu. Então foi esse aos 15 anos. Tive ainda os namorinhos, né? Mas depois conheci o meu marido, começamos a namorar, enfim". De acordo com os valores de Mariana não se é aceitável a relação sexual desvinculada da relação afetiva. Este movimento de preservar-se das investidas do namorado lhe deu um lugar em que sentiu-se em condições de dispensá-lo sem ter atendido às expectativas dele.

A iniciação sexual quando namorava o seu atual marido ocupa lugar de destaque na trajetória de Mariana: "A minha primeira relação sexual foi com meu marido. A gente tinha viajado pra praia, estávamos todos em família... Tava toda a minha família e ele foi junto, né? E engraçado que a gente tava, eu tava numa casa, então tava separadinho, cada um tava num lugar, tudo, e eu lembro que tava todo mundo dormindo. (...) Já tinha tido várias carícias, já tava bem íntimo, assim, juntos, já tava a algum tempo juntos... aí eu disse... ele inventou de tomar banho. Todo mundo dormindo, né? E eu tava acordada, acordei e fui pro banho! Eu entrei lá. É agora, é agora, né?". A temática da virgindade fica mais evidente aqui quando Mariana se refere às marcas trazidas pelo marido desta experiência: "Até hoje ele fala: 'Você não casou comigo virgem', mas não... E eu falo: 'Você não foi o meu primeiro namorado!'. Ah... eu tentei explicar pra ele como é que foi essa... esse namoro, daquele outro namorado... Ele fica bravo, não quer que fala... (riso) E eu acho que eu fui muito atrevida pra... pra uma pessoa que nunca tive... que nunca teve uma decisão para aquilo... Quando eu fui tomar banho com ele foi muito bom... Eu acho que ele me... mas aí foi decisão minha, né, a gente tava namorando muito e já tava em outro estágio. Foi bom por isso, né, eu acho... eu acho". Duas questões são apontadas aqui que se referem à virgindade enquanto garantia da exclusividade da mulher para o homem; e a outra questão é sobre o grau de envolvimento que Mariana tinha com seu namorado quando resolveu iniciar a sua vida sexual, ou seja, ela estava, nas palavras dela, "em outro estágio", em que se era permitido, e se permitia, o contato mais íntimo de uma relação sexual completa. 


\subsection{0. "Minha vida toda foi muito precoce (...), eu poderia ter brincado mais": os contraceptivos e a gravidez não planejada}

Aos 15 anos, idade em que conheceu o atual marido, Mariana teve seus primeiros contatos com os métodos contraceptivos: "Essa informação de que... tem que usar camisinha por conta de doenças, enfim... você tinha, eu tinha essa informação, mas não era uma coisa tão... íntima, como hoje, como as pessoas falam, né, essa coisa da conscientização... da doença, enfim. Essas coisas de camisinha e pílula eu tive a partir da ginecologista. Eu comecei a ir na ginecologista com essa idade, 15 anos, por aí... Isso há muito tempo atrás...”. A ginecologista apresenta as primeiras orientações sobre como lidar com as informações sobre temas relacionados à sexualidade que até então tinha tido na escola.

A ida à ginecologista foi por iniciativa própria, sem conhecimento da família. Mariana aponta este fato ser devido ao ter começado trabalhar muito jovem: "Nessa época eu já trabalhava! Eu comecei trabalhar jovem! Comecei trabalhar numa loja de sapatos eu tinha 14 anos. E antes disso, a minha mãe trabalhava com costura e eu ajudava muito ela, ela sempre me chamava pra ajudar, pra tirar linha de... costura, essas coisas, então sempre dava uns troquinhos. (...) Minha vida toda foi muito precoce (riso), outra coisa que é ruim, assim, eu poderia ter brincado mais! (riso)". Ter começado a trabalhar conferiu a Mariana a autonomia para tomar decisões sobre os caminhos que desejava trilhar. O custo foi o de ter aberto mão de alguns momentos da sua infância.

Com a autonomia e a liberdade desta nova etapa de sua vida, Mariana não esperava que se deparasse com o obstáculo da gravidez não planejada: "Engraçado que quando eu fiquei grávida foi... então... muita besteira, eu acho, muita bobeira... porque eu lembro que... é... eu tomava pílula e, uma vez, a gente vinha, eu e minha mãe, (...) [e] com meu namorado, e a gente ficou. E lá eu tinha que continuar tomando. Então eu tinha que comprar na farmácia a pílula, e aí, como é que eu compro? Mas assim, foi muito no início da sexualidade, do nosso ato sexual, mesmo. Então eu tomava e... Ninguém sabia que eu tomava pílula, e eu tinha que comprar a cartela, pô, pra continuar, depois da... do período de descanso, como a gente fala. Aí eu não tinha como comprar, né, porque tava a família toda, era uma cidadezinha pequena, do interior, não tinha o que fazer, aí eu voltei sem tomar, né? Aí... pensa: 'Tem camisinha?'. 'Não, não tem'... Aí dá a vontade, né? Vai, vai assim mesmo...". Não cabe aqui apontar a falta de suporte da família com quem Mariana não sentia liberdade para conversar sobre assuntos 
relacionados à sexualidade, mas também é inevitável apontar a importância de existir dentro da família um contexto mais favorável para a exposição de necessidades e dificuldades relacionadas ao tema da sexualidade. Atrelado a isto, o fato de estar em uma cidade pequena do interior de Minas onde supõe-se que seja tênue a barreira entre o público e o privado, inibe Mariana de adquirir suas pílulas anticoncepcionais ou mesmo a camisinha. Mas este momento do depoimento não fica claro sobre disponibilidade do casal em encontrar alternativas contraceptivas diante do desejo crescente entre eles para o encontro sexual.

A alternativa de método contraceptivo encontrada por Mariana e pelo namorado foi a partir da memória de certa vez, às escondidas, ouviu sua mãe falando sobre o coito interrompido e sobre a ducha íntima ${ }^{45}$ : "E... eu acho que também eu acho que uma situação muito chata que aconteceu, que hoje eu dou muita risada, que eu lembro que minha mãe, eu não sei, de conversa que ela teve com alguém, eu não lembro como foi essa conversa, mas eu me lembro dela comentar de coito interrompido, sabe? (...) E eu lembro que ela falava que tinha... que tinha gente lá no interior que fazia sexo e depois pegava a mangueirinha do chuveiro e se lavava, o chuveirinho. E eu fui um dia, que tava... tava sem tomar pílula, sem camisinha e inventei de fazer isso. Aí foi quando... engravidei (riso). Eu tinha 16 anos. (...) Mas só pra você ver, eu acho, como a informação da mãe é tão marcante pra menina. (...) Se tivesse me orientado de forma mais correta, de repente eu não teria um filho... eu não teria ficado grávida antes, enfim. Ou ter... tem isso, também... me prevenido de doenças possíveis que eu poderia ter, né?". Mariana aponta a importância do diálogo com a mãe e que em um plano ideal seria ela a fonte para orientá-la sobre o que melhor fazer na sua vida, inclusive a sexual.

É importante aqui ressaltar que quando em um contexto a sexualidade não é discutida não se quer dizer que não existam mensagens não-verbais com relação ao tema. Parece não ser este o caso, mas sim, de pura carência de subsídios para se discutir o tema: "Mas eu era muito... eи era muito... é... me esforçava muito, né? Tentei puxar conversa, muito e, às vezes, eu falava, também, né? (...) Eu lembro que falava muito... eu era muito rebelde. Eu falava que ia embora assim que tivesse 18 anos, eи ia embora daquela casa. (...) O meu irmão namorava com uma moça, e... a gente ia passear, não sei, e a minha irmã comentando com a minha tia,

\footnotetext{
${ }^{45}$ De acordo com Peres et al. (1999), a prática do coito interrompido é um método pouco eficaz na margem de segurança para evitar a gravidez. Já a ducha íntima, ou lavagens, não apresenta nenhuma eficácia anticoncepcional.
} 
mas eu tava junto, e tava comentando que achava que os dois já tavam é... no ato sexual, né? Aí eu falava: 'Mas, mãe... Ela não...' eu lembro a menina, até comentei com ela: (...) 'Mas não pode, mãe, que ela tá menstruada'. Aí minha mãe olhou, e deu risada, mas... do tipo: 'Se tiver menstruada, ou não, se quiser fazer, faz, minha filha!'. (...) ...Se tivesse que chegar e conversar com ela, eu tivesse puxado o assunto ela conversaria, a minha mãe, mas a minha mãe não era... Eu acho que aquele medo... aquele medo da mãe falar, ela falar sobre assunto estar incentivando. Eu acho que essa... essa era a idéia que a minha mãe tem, eu acho. Eu não acho que influenciaria, não... (riso) eu acho que o incentivo já vem natural. Alguma coisa assim... E acho que incentivando, ou não, a criança ou adolescente vai ter esse momento de sentir desejo a qualquer momento da vida. É por isso que eu acho que é importante estar atento, que a criança deve saber o que está acontecendo com ela. Eu acho que tem que ter consciência". A partir de um comentário da irmã com a tia, existe um espaço para Mariana participar da conversa envolvendo relacionamento íntimo. Mas a tensão parece sempre estar presente quando o assunto é sexualidade. Neste sentido, é encontrado um ponto interessante que, dentre outros, alimenta um sentido de o assunto da sexualidade continuar não sendo tocado, pois, se fala corre-se o risco de incentivar os filhos à vivência sexual, ou, conforme a história de Mariana, corre-se o risco de faltar subsídios para lidar com a própria vivência sexual quando ela deixou de tomar a pílula e não fez uso do preservativo.

Um elemento importante neste ponto da trajetória de Mariana que se refere à gravidez não planejada é que pouco ela se refere à responsabilidade do namorado neste episódio, refletindo que, quase sempre, recai na mulher a responsabilidade deste tipo de acontecimento, como se o próprio homem não tivesse condições de escolher alternativas preventivas. Porém, a postura de Mariana segue na perspectiva da sua concepção do homem como aquele que transpira a sexo. Esta postura vai ao encontro da representação comum de que o desejo sexual é marca do signo masculino,e as necessidades femininas mais moderadas com relação ao sexo (Heilborn, Cabral \& Bozon, 2006). 


\subsection{1. "As pessoas deveriam ter um acesso mais facilitado com um especialista": Mariana aponta aquilo que acredita contribuir para a vivência sexual das pessoas}

Para Mariana, é imperativo que se promova uma visão mais positiva com relação à sexualidade, dissociando-a de uma perspectiva baseada no pecado ou promiscuidade: " $E u$ acho que ajudaria muita às pessoas ter uma visão de sexualidade como a... algo bom e... até mesmo sentir, do fato fisiológico, do ser humano, né, com momentos de felicidade que a gente pode ter durante a nossa vida (...), que não é algo... que é pecado, ou promíscuo, enfim... não que eu ache, também, que a pessoas tenham que ter essa troca de... sabe, ter que experimentar outras coisas pra poder ter uma consciência: 'Ah, de fato isso é bom'. Não acho que seja assim, também, não. Eu acho que é mais algo pessoal, individual, do que experimentar um monte de pessoas e depois ver qual que é melhor. Eu acho que com uma pessoa só dá pra sentir tudo isso, com diálogo, com muito diálogo, eu acho, mesmo, e com muito afeto, né?".

Quando Mariana se refere à importância do diálogo sobre sexualidade com algo que não necessariamente interfira no limite entre o público e o privado: " $E$ as pessoas têm a aquela visão: 'Vida íntima não é pra se conversar, não pode conversar com o outro'. Não precisa conversar sobre o que o marido faz ou deixa de fazer. É só se conversar sobre o assunto, não é? A intimidade tem que ser preservada, é óbvio. Mas acho que deveria ser um assunto mais... mais, assim, mais conversado, algo como: 'Ah, hoje eu fiquei feliz porque fui brincar com meu filho no parque', né? Então hoje consigo conversar um pouco mais. E fica: 'Ah, hoje consegui comprar uma lingerie', às vezes, conversa com uma amiga, sabe? (...) Normalmente você só conversar sobre aquilo que é... o problema que tá acontecendo... não conversa sobre como é que é... sobre o sexo ser tão bom na vida". Deste modo, para Mariana o sexo deveria ser integrado à conversas do cotidiano enquanto algo integrante da vivência humana, revelando a necessidade de espaço de escuta sobre a temática da sexualidade.

Ao longo de todo o seu depoimento, Mariana sempre demonstra interesse acerca de conhecer aspectos relacionados à sexualidade, inclusive na dificuldade experimentada de apresentar pouca disponibilidade para o sexo. Este movimento de Mariana parece ter aberto uma tendência na busca externa de sentidos, encontrando na especialidade os recursos para compreender o que acontece no foro íntimo: "Eu acho que... as pessoas deveriam ter um 
acesso mais facilitado com um especialista, que seja um psicólogo, um psiquiatra, o que for, pra conseguir entender umas coisas que a gente mesmo não consegue entender, da gente, é difícil, né?... Sei lá, que eu acho que esse acesso é importante porque eu acho que é importante porque ajuda você sofrer menos com os problemas e... aproveitar mais os momentos bons". A especialidade acaba sendo vista por Mariana como o lugar privilegiado e autorizado para a concepção de significados e de sentidos para a própria vivência sexual. $\mathrm{O}$ cuidado a ser tomado é para que este lugar não sirva para desautorizar pessoas a reconhecerem suas próprias singularidades e vivências enquanto referenciais privilegiados que se constituem na experiência compartilhada.

Neste sentido, Mariana propõe que deve existir um empenho para: “...Convencer as pessoas de ver que um especialista ou um psicólogo... você não tá... é... que as pessoas ficam com vergonha: 'Ah, que eu tô indo no psicólogo'. Eu percebo isso... é... no meu bairro, porque é um bairro simples, de pessoas... de classe média-baixa (...) que tem um... é... precisa falar que sexo, é uma coisa vulgar. (...) Daqui [local onde trabalha] (...) tem toda a facilidade de falar: 'Ah, eu tô fazendo análise com um psicólogo', ou: 'Ah, eu vou ao psicólogo conversar', né? 'Ah, vou num psicólogo que é maravilhoso!'. Não fala sobre o assunto em si, mas fala que tá indo. E isso já, no... já com pessoas mais simples... acha que, de repente, ir pro psicólogo é... é sei lá, é que você tá doido ou porque... vai tentar se curar sozinho, né?... Quem vê pensa que você tá rico! Então o que eu vejo que tem essa diferença. Eu acho que essa ajuda é muito legal, legal ter alguém pra te ajudar, um profissional, eu acho, uma ajuda profissional é bom". Dois pontos podem ser destacados nesta fala de Mariana que diz respeito a como classes populares lidam com a procura de ajuda psicológica, além de ser associada à "loucura", também é vista como serviço destinado a um segmento mais abastado. Já no trabalho, Mariana sente-se "autorizada" para falar sobre a busca do serviço.

Mariana finaliza seu depoimento sintetizando como percebe a sua sexualidade: " $E u$ acho que a minha vida sexual foi muito complicada. Eu acho que ainda é...”. Indicando que a sua vivência sexual é vista como forma problematizada, ou até mesmo desesperançada, de maneira que vive um problema que não se resolve. 


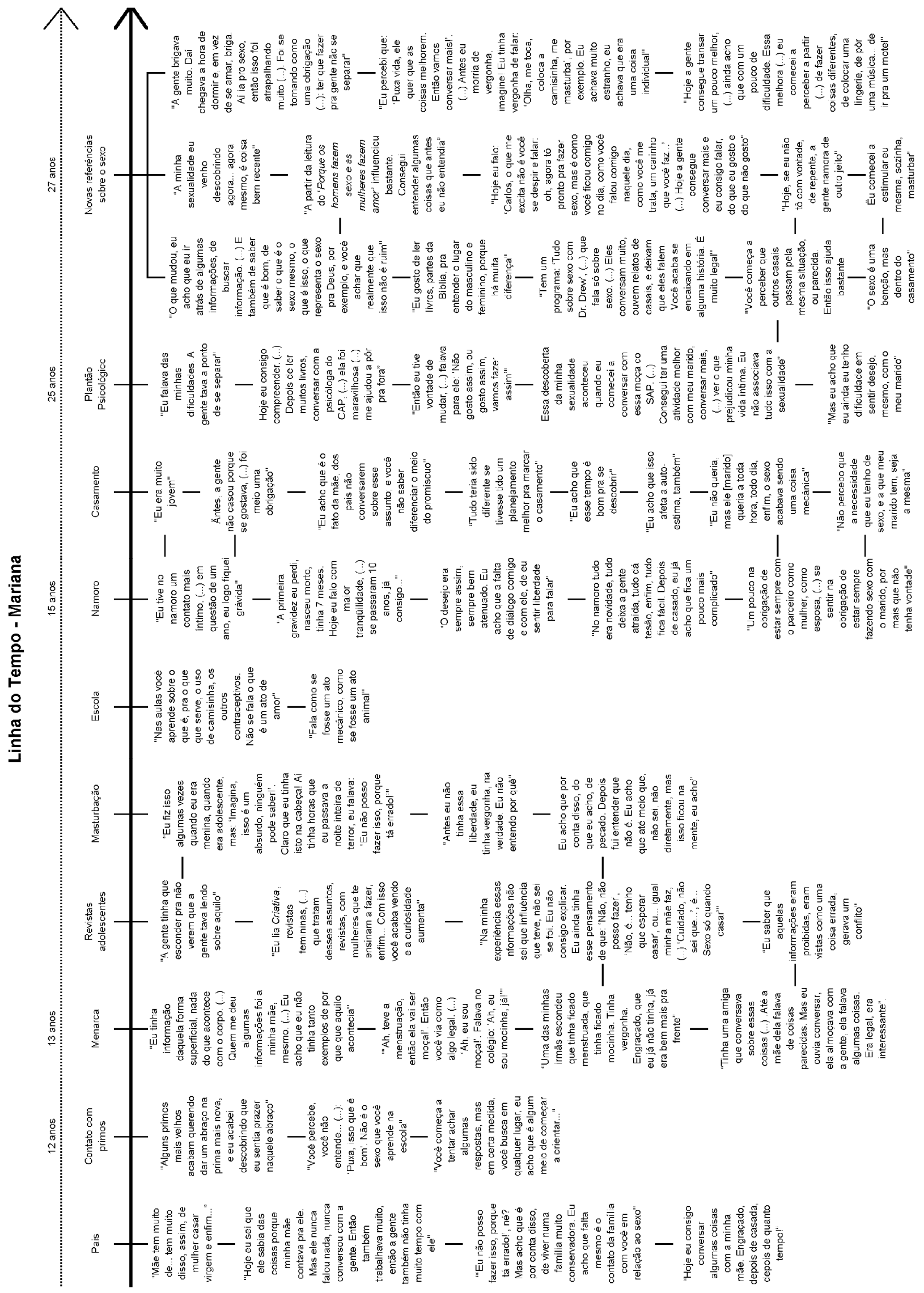

Figura 6 - Linha do tempo da trajetória de Mariana 


\section{$\begin{array}{llllllllllllllll}\text { C } & \text { A } & \text { P } & \text { I } & \text { T } & \text { U } & \text { L } & \text { O } & \text { V } & \text { I }\end{array}$}

\section{SIGNIFICADOS E SENTIDOS DAS EXPERIÊNCIAS}

No contato com as experiências dos colaboradores e colaboradoras emergem as singularidades de vivência e os diversos modos de negociação no contexto social. A sexualidade está imbricada nessas formas peculiares de estar no mundo em relação, o que confere múltiplos significados e sentidos à sua constituição e vivência. A proposta adotada neste capítulo é a do resgate de diferentes significados e sentidos das experiências de temas e cenários, privilegiando a maneira com que os colaboradores e colaboradoras descrevem, explicam, compreendem e vivenciam temáticas relacionadas à sexualidade e ao gênero, assim como temas e momentos significativos nas trajetórias de vida associadas a tais temáticas. Assim, os depoimentos dos colaboradores, enquanto representantes do meio social em que vivem, tornam-se exemplares para revelar as normas e valores sociais e sexuais vigentes, conferindo formas particulares e simbolizadas de construção de roteiros sexuais e de gêneros.

Os significados e sentidos apresentados podem ser compreendidos na perspectiva dos roteiros sexuais propostos por Gagnon (2006) enquanto resultantes da interpretação de normas sociais, dos mitos culturais e formas de conhecimento da corporalidade. Neste sentido, a sexualidade se constitui enquanto realidade integrada à vida social - com suas realidades estruturais políticas, econômicas e sociais -, e com os aspectos biológicos e físicos da vida humana (Escoffier, 2006). Esta perspectiva vai ao encontro do proposto por Foucault (2001) para quem a sexualidade não é essencial da natureza humana ou do gênero, mas sim de uma construção sócio-histórica.

A pergunta disparadora favoreceu o contato com as primeiras associações dos colaboradores, despertando as mais diferentes reações e respostas, embora surpresa e 
embaraço predominassem. Inicialmente as respostas dos colaborados tendiam estritamente à questão da vivência sexual, ao ato sexual. Ao longo dos depoimentos as narrativas se ampliavam, marcando a presença de uma vivências identitárias.

Seguindo a proposta de Spink e Frezza (2000), longe de buscar definições que limitam o fenômeno da expressão afetivo-sexual, priorizou-se conhecer convenções, práticas e peculiaridades, na perspectiva de compreendê-las como regras construídas e socialmente localizadas, englobando as transformações sociais. Nesta perspectiva, o recorte da interpretação dos depoimentos seguiu a seqüência cronológica - baseada nas linhas do tempo - de cada colaborador no sentido de conhecer os diferentes pontos de vista sobre temas e cenários. Com isso, pretende-se favorecer uma visão panorâmica sobre os significados e sentidos da experiência emocional e social da sexualidade. Na perspectiva dos roteiros sexuais, a socialização da sexualidade não segue uma perspectiva linear, ou seqüencial primeira infância, infância, adolescência, maturidade e velhice -, mas compreende a aprendizagem de conteúdos nos vários estágios do desenvolvimento a partir de variados contextos socioculturais e históricos. Ao longo do processo de desenvolvimento, os conteúdos apreendidos nem sempre são ensinados, mas observados, apreendidos, outras vezes inferidos, variando em cada estágio da vida, de acordo com as circunstâncias histórico-culturais (Gagnon, 2006).

Ao longo dos depoimentos, surge um "eu presente" que se constitui a partir do (re)arranjo do passado e do presente, tomando os recursos culturais que lhe são disponíveis. Este eu presente é incorporado nos desdobramentos futuros ao longo da interlocução da pessoa com o meio social, apontando que os roteiros sexuais apresentam uma flexibilização que atendem às mudanças individuais e sociais (Gagnon, 2006). A trajetória de vida condensa uma série de episódios e estados, abrigando cenários e atores envolvidos em cada evento e relação que apresentam à moldura social que enquadra o exercício da sexualidade (Heilborn, 2006). Como será visto a seguir, compreender a sexualidade a partir da trajetória de vida vai ao encontro e reforça a idéia do fenômeno da sexualidade que se constitui a partir dos encontros e desencontros vividos no cotidiano, que é metabolizada emocionalmente pelos indivíduos. 


\section{Impressões iniciais sobre a sexualidade}

Eu perguntei para a minha mãe como funcionava e ela explicou abertamente, inclusive me deu uns livrinhos da coleção "Vida Sexual", acho que dos anos 70 ou 80, que é separado por faixa etária, e acho que eu tinha 8 ou 9 anos, já era um pouco velho (Jorge, 22)

Hoje eu me considero como um homossexual passivo, se bem que eu tenho um pouco de atração (...) por mulheres, e também por vontade de ser ativo, mas como o usual é por homens, que é bem mais forte, é o que eu me considero sendo isso (Thiago, 23)

$\mathrm{Na}$ descoberta rolou muita incerteza (...). Acho que 12 anos, 10, 11 anos, foi aí, com masturbação. Normal. (...) No começo tinha uma sensação meio de, assim, era estranho, mas... depois passou, ficou normal, e eu tive minha primeira namorada (André, 21)

É meio complicado... Porque conheci o sexo muito cedo, aos 7 anos. (...) Durante vários anos... ai, eu não sei como dizer isso... Foi assim, foi abuso sexual... entendeu? Então, bastante complicado. Mas eu vim descobrir (...) a gravidade do que eu estava vivendo, aos 16 anos (Melina, 21)

Foi com 12, 13 anos. (...) Acho que foi um pouco tarde... É, porque as pessoas falavam muito, a minha mãe falava muito desde o meu primeiro beijo. (...) A minha relação sexual eu tive a primeira com 18 anos (...), e o primeiro beijo acho que foi com 13. (...) Uma coisa que, tudo bem, foi tardia, assim, pensando socialmente, mas para mim acho que foi meu momento, e... acho que foi isso (Sofia, 20)

A minha sexualidade, assim, foi muito com que tinha que ver com outros colegas, de comentários, de tudo o mais... de televisão. E como eu venho de uma família religiosa de Minas Gerais, então, a minha mãe tem muito de... tem muito disso, assim, de mulher casar virgem e enfim... (...) Eu comecei a sexualidade com meu marido mesmo (Mariana, 27)

A sexualidade é compreendida a partir das mais diferentes perspectivas, assim como durante muito tempo ela foi compreendida dentro da produção das ciências humanas. De acordo com Loyola (1999), as diferentes perspectivas de sexualidade estão associadas a esquemas conceituais utilizados em função de diferentes ângulos pelos quais esta temática é abordada. Deste modo, de acordo com a autora, a sexualidade pode estar associada: 
Em relação à família, ao parentesco, ao casamento e à aliança como constitutiva e, ao mesmo tempo, perturbadora da ordem social (antropologia e sociologia). Ela pode ser abordada, ainda, como constitutiva da subjetividade e/ou da identidade individual (psicanálise) e social (história e ciências sociais em geral); como representação (antropologia) ou como desejo (psicanálise); como um problema biológico/genético (medicina); ou ainda como um problema político e moral (sociologia, filosofia) ou, mais direta e simplesmente, como atividade sexual (p.32).

Independentemente da área relacionada, Vance (1995) ressalta que a produção no campo da sexualidade consiste em "uma área simbólica e política ativamente disputada, em que grupos lutam para implementar plataformas sexuais e alterar modelos e ideologias sexuais" (p.15). Neste sentido, a sexualidade aqui é compreendida enquanto um desdobramento particular de uma dada cultura, constituída por um conjunto de práticas, representações e atitudes em torno das trocas eróticas que traduz uma dimensão interna dos sujeitos (Piscitelli, Gregori \& Carrara, 2004), sendo que o seu desenvolvimento, assim como todos processos de ordem psicossocial da experiência humana é um processo, ou uma construção social, datado historicamente e culturalmente localizado.

Este contato com a diversidade de perspectivas da sexualidade dentro de áreas do conhecimento é conferida quando lançamos um olhar sobre as primeiras associações dos colaboradores enquanto resultado desta interlocução da pessoa e sua cultura. Logo no início do seu depoimento, Jorge remete-se à sua infância, quando tinha por volta de 8 anos de idade, no momento em que questionou sua mãe sobre o tema da sexualidade. Em suas palavras, ela "explicou abertamente", além de ter oferecido livros sobre sexualidade separados por faixa etária. O pai, definido por Jorge como "religioso", não demonstrava abertura para falar sobre o tema e foi inspiração para o roteiro de Jorge: "pra mim ficava aquela coisa pra depois, de preferência quando eu fosse adulto, quando eu tivesse de 15 a 16 anos. Então, não me interessava". Os colegas da escola também eram referências importantes, porém, a interação de Jorge com esses colegas era precária, dado o roteiro de não lidar com sexualidade naquele momento de vida.

Nas impressões iniciais de Jorge fica em evidência o significado de que o sexo gera embaraço e que não é tema para criança por ser "coisa de adulto". A idealização para o 
contato com a abstração da "sexualidade" era algo que para ele ganhava a dimensão de tabu, ainda mais para um não-adulto, sendo que, nessa perspectiva, tudo se esclareceria naturalmente quando chegasse aos 15 anos de idade. Esta atitude de "esperar o momento certo" fornecia subsídios para manter seu roteiro de não contato com aquilo que compreendia como parte do universo da sexualidade. Apesar de estimulado pelas conversas com a mãe e os livros fornecidos por ela, a figura do pai foi significativa para Jorge, no sentido de fornecer sentidos para a sexualidade como algo de que não se fala. Deste modo, a referência com o tema da sexualidade existia, mas não a autorização para que este contato se desse de uma forma livre de tensão. Jorge não fornece elementos que possibilitem avaliar o conteúdo da bibliografia recomendada pela mãe, ou outros, sobre seus contatos iniciais com o campo da sexualidade. Contudo, como mostra Bernardi (1985), as lições ou os “encontros" dedicados à educação sexual apresentam basicamente dois caminhos, o biológico e o moral. De acordo com o autor, em ambos os caminhos, por mais que a sexualidade seja o pilar, a perspectiva é de "dessexualizar o indivíduo" (p.16), sendo quase sempre esvaziada de seu conteúdo humano de amor-prazer.

Thiago foi mais contundente na sua associação sobre a descoberta na sexualidade, remetendo-se a uma perspectiva identitária. Ele iniciou seu depoimento a partir do momento presente, em que experimenta intensa vivência do desejo afetivo-sexual, e afirmou: "sou homossexual passivo". A tônica de seu depoimento foi explicitar o processo de assumir publicamente sua homossexualidade e o estabelecimento de contato e integração à rede social, fortalecendo a sua identidade. Este movimento vai ao encontro da identidade de resistência, em que os atores sociais constroem trincheiras de resistência e sobrevivência a partir de posições ou condições desvalorizadas e/ou estigmatizadas pela lógica da dominação (Castells, 1999). Thiago descreve a forma com que saiu do silêncio socialmente imposto, para o encontro com pares.

Tal processo de transformação identitária era recente no momento da coleta do depoimento e fora potencializado com sua participação na Parada do Orgulho Gay, na qual encontrou possibilidades de delimitação para a sua identificação com o universo homossexual: “...Eu gostei muito de estar lá, tanto por que eu gosto da música, como pelo fato de me sentir bem ali. E eu tive uma visão de que eu estava meio que tipo numa família, meio que entre irmãos, uma coisa divertida, não muito consciente, mas tranqüila assim. E nesse dia, na Parada desse ano, eu resolvi assumir". O senso de identificação com o coletivo 
foi evidenciado no depoimento de Thiago, seja pela participação na Parada, seja na sua participação em um grupo virtual - e-Groups - voltado para o público jovem gay.

Em um sentido de justificar a escolha da vivência "homossexual passiva", Thiago remete-se à sua orientação do desejo sexual embasada no ter "...um pouco de atração, se bem que bem fraco, por isso que eu nem considero, por mulheres, e também por vontade de ser ativo, mas... Como o usual é por homens, que é bem mais forte, é o que eu me considero sendo isso". Deste modo, a "homossexualidade passiva" de Thiago ganha contornos pelo fato de ter pouca atração por mulheres, assim como pela pouca motivação de assumir a posição daquele que penetra - "ativa" - e, em contrapartida, ter uma atração mais intensa por homens. A vivência de Thiago compartilhada com o contato social - e virtual - favoreceu o início de namoro com rapaz que conheceu por meio do site do grupo virtual citado anteriormente.

Thiago faz uma associação da descoberta da sexualidade com a orientação do desejo afetivo-sexual, não só pelo desejo voltado para pessoas do mesmo sexo que o dele, mas também pelo pouco desejo que sentia por pessoas do sexo oposto. Esse quadro ganha contornos de uma identidade homossexual passiva, ou seja, de quem é penetrado pelo parceiro. Essa realidade é reforçada pela pouca disponibilidade, ou interesse, de Thiago em penetrar o parceiro. A idéia desta tensão entre "atividade" e "passividade" aponta para o deslocamento do modelo heterossexual vigente para o modelo homossexual, onde tem-se a "atividade" masculina e a "passividade" feminina. Lembrando o modelo chave-fechadura, a "atividade" é reconhecida pelo "comer" - papel masculino ao penetrar a mulher durante o coito -, em oposição ao "dar" - submissão passiva da mulher ao ser penetrada pelo parceiro. Neste padrão, nem sempre se leva em consideração a possibilidade da "passividade" daquele que penetra e nem a "atividade" daquele que é penetrado, reforçando a idéia da "atividade" em torno do pênis, que contribui para a identidade do homem viril.

Esta percepção do homossexual passivo vai ao encontro de uma concepção de homossexualidade na cultura brasileira, fundada numa lógica hierárquica de gênero e regulada na díade passividade versus atividade, sendo a classificação do homossexual vinculada ao passivo (Fry \& McRae, 1991; Parker, 1991; Bozon, 2004). Ainda incide nesta questão da homossexualidade o que foi aprofundadamente estudado por Costa (2002), que aponta para os riscos do uso do conceito homossexual que pode incitar à associação desta expressão afetivosexual com os referenciais médico-patologizantes, com vistas à normatização moral a partir 
de uma perspectiva heterocentrada. Por outro lado, a adoção da identidade homossexual favoreceu Thiago no encontro de pares, ampliando seu trânsito pelo espaço social na vivência afetivo-sexual.

Para André foram breves, mas marcantes, nas primeiras associações que fez sobre a descoberta da sexualidade, registrando a incerteza, a confusão e o estranhamento, marcas do conflito, substrato da angústia, companhia intensa da sua vivência sexual. Para ele, o prazer erótico está intrinsecamente relacionado com a descoberta da sexualidade que, por sua vez, está vinculada à masturbação "normal", e com o primeiro relacionamento sexual que aconteceu quando tinha por volta dos 15 anos. André refere-se a este primeiro relacionamento sexual enquanto um "problema" sexual que experimentou com a sua então namorada. A situação gerou tal reação em André que ele justifica dizendo que: “...Acho que eu ainda tava um pouco confuso na cabeça. Com a minha primeira namorada não foi realmente uma experiência”. A fala de André remete à compreensão da situação vivida com sua namorada como algo que nem deveria ser considerado relevante para a sua vivência sexual, porém, essa frustrante experiência, assim como outras, permeia seu depoimento.

O depoimento de André aponta limitações no início da vida sexual. A questão que emerge não é meramente a falta de referenciais para o encontro afetivo-sexual, mas o medo e a angústia associados a esta experiência. Este medo é apontado por Bernardi (1985) como um desdobramento de um discurso anti-sexualidade em que o "prazer erótico é inimigo inconciliável de todo o sistema autoritário" (p.101). Por outro lado, Gagnon (2006), em sintonia com o pensamento foucaultiano, mostra que não é a repressão que marca o início da vida sexual, mas a

(...) falta de um conjunto de circunstâncias instigadoras, inclusive roteiros sexuais e de gênero, sobretudo para as mulheres, mas também para os homens, que pudessem converter a competência orgásmica num desempenho orgástico satisfatório (p.131).

A pressão da auto-cobrança experimentada por André faz sentido ao longo da sua trajetória, em que os roteiros sexual e de gênero não apresentavam flexibilidade, o que desfavorecia o encontro afetivo-sexual enquanto uma descoberta de possibilidades no contato com o outro. $\mathrm{O}$ 
foco para ele seria aquilo vinculado ao modelo homem-ativo e mulher-passiva, conforme ele mostra na sua percepção dos gêneros.

Este cenário de inabilidade social e sexual, associado à ansiedade crescente, contribuiu para a restrição da experiência afetivo-sexual de André. Isto revela outra particularidade na construção do gênero masculino em que a vigilância no que se refere a atitudes e comportamentos é constante, pois não podem recair sobre homens quaisquer dúvidas sobre a masculinidade, o que contribui para legitimar a imagem coletiva do "machão". Não corresponder a este estereótipo significa correr o risco de ser associado com à imagem estigmatizada do homossexual passivo ou efeminado.

Dado que seu depoimento foi feito em dois momentos ${ }^{46}$, André diz que sua percepção mudou depois do primeiro depoimento: "Uma coisa é certa, a idéia que eu tinha naquela outra entrevista não é a mesma de agora". O sentido de mudança foi decorrente daquilo que pôde organizar melhor na forma de percepção da sua trajetória no universo da sexualidade. A partir desta observação de André dois pontos podem ser destacados. O primeiro, de perspectiva ético-metodológica, diz respeito ao impacto e desdobramentos que uma pesquisa pode representar para o colaborador da pesquisa, no sentido de mobilização de conteúdos e de articulações dentro de sua realidade vivida, exigindo atitude de atenção e de cuidado do pesquisador no encontro com o colaborador. $\mathrm{O}$ outro ponto, mas específico à pesquisa, é quanto à característica mutável da sexualidade (Gagnon, 2006).

Alternando entre o embaraço e a desenvoltura, Melina remete-se ao período de abuso sexual $^{47}$ enquanto primeira associação sobre a descoberta da sexualidade. Tal evento representa para ela o início precoce da sua vida sexual - "conheci o sexo muito cedo" -, a qual percebe como "bastante complicado". A constatação do abuso sexual somente emergiu aos 16 anos, portanto, depois de cerca de 9 anos de uma situação que Melina descreve como um

\footnotetext{
${ }^{46}$ Como pontuado anteriormente, os dados da primeira coleta do depoimento de André foram perdidos. Para fins de interpretação, optei por considerar somente os dados registrados na segunda coleta do seu depoimento.

47 Ao longo do texto manterei o uso do termo "abuso sexual", porém, registrando a proposta da psicóloga Edilene Almeida (2005) que prefere o uso dos termos "revelação não aceita" e "revelação aceita" por serem mais adequados para o entendimento, identificação, acolhimento e tratamento das situações de abuso sexual. A "revelação aceita" seria aquela que se configura na revelação que é aceita como efetivamente ocorrida no espaço intrafamiliar, sendo que a "revelação não aceita" remete-se às expressões não verbais - a exemplo daquelas manifestadas pelo corpo e pela emoção, ou verbais - verbalmente expressas, mas desqualificadas pelo adulto. Neste sentido, a autora também se opõe ao uso corrente e exclusivo de termos como "síndrome do segredo" ou "revelação do segredo".
} 
período em que estava "sempre calada, sempre agüentando, sempre calada". O sentido desta conduta está vinculado à sua percepção de que "tivesse sido destinada para aquilo", ou seja, submeter-se às sevícias do padrasto, representando o varão naquele cenário. Esta idéia de "estar destinada" alicerçava outra, a de que, quando fosse maior, aos 18 anos, poderia desvencilhar-se daquela situação.

A experiência de Melina não se remete a referências formais, conversas com adultos, identificação com grupos, e nem mesmo com conflito, mas com a vivência crua de ter conhecido o sexo muito cedo como se este fosse o seu destino. $\mathrm{O}$ abuso sexual pelo padrasto, aliado ao sentimento de filiação, abriu espaço para que imperasse o silêncio que velava o desamparo. Ao longo do depoimento, Melina mostra de forma mais contundente esse desamparo e a impossibilidade de sinalizar para o mundo aquilo que acontecia. $\mathrm{O}$ silêncio não era opção, mas uma imposição de submeter-se, à espera da chegada do mundo adulto, quando poderia dar um fim àquilo.

Na primeira associação feita por Melina quanto à descoberta da sexualidade, a submissão a que estava exposta revela a desigualdade de poder nos primeiro contatos com as sensações provenientes da interação sexual.

A coerção visa atender às necessidades de quem coage e não de quem é coagido. Os roteiros sexual e de gênero da criança não estão formados, ou organizados, de modo que não podem escolher relacionamentos sexuais com adultos. No depoimento de Melina observa-se que no contato com o padrasto há conotação de acolhimento e compreensão, reforçando a idéia do abuso. O papel de distanciamento da mãe, que tinha ou não consciência do que ocorria, favoreceu que o abuso perdurasse por longos anos. Tanto que, quando soube do fato por Melina, em um tenso momento de discussão familiar, além de não aceitá-lo, ainda afirmou que: "Se você for embora talvez a minha vida fosse melhor". Posteriormente, quando Melina já estava noiva, a mãe lhe disse: "Você não tem trauma, pois se você tivesse trauma, hoje você não teria relação com o seu noivo", mais uma vez rejeitando o abuso e o sofrimento vivido pela filha.

Ao longo do depoimento de Melina, transparecem o medo, o conflito e a angústia que vivia, mais intensos a partir do momento em que pôde atribuir à situação o sentido de "abuso sexual" e passou a sofrer ameaças do padrasto de matar a ela e a mãe caso viesse a revelar o 
que vinha acontecendo. Lembrando que os roteiros sexuais de Melina, em tenra idade, são influenciados pelo meio social, o abuso pode ter contribuído para que em fases posteriores do seu desenvolvimento o sexo fosse associado aos sentimentos negativos de angústia, medo, dor e desprazer que ela viria a experimentar no contato íntimo com seu atual noivo. Gusmão, Schiavo e Jurberg (2003) apontam que a própria circunstância do abuso sexual legitima o adulto abusador, mediante a força do prazer - e não da força física do abusador -, e que a criança, proibida ela própria de realizar, sente-se dividida, angustiada, diante do medo da denúncia do ato, e a culpa pelo prazer da sensação. Os autores também mostram que o "efeito traumático" do abuso é potencializado diante do medo da descoberta e, mais tarde, pelo sentimento de quebra de normas morais e sociais.

Para Sofia, a necessidade de corresponder às expectativas dos roteiros sociais foi a tônica da sua associação com a descoberta da sexualidade, sempre pontuando o caráter tardio desta vivência - "Acho que foi um pouco tarde... mas acho que foi um pouco tarde..." -, mesmo com a participação da mãe, e de outras pessoas, com conversas incentivadoras sobre o primeiro beijo e outros aspectos da sexualidade. A associação de Sofia sobre a descoberta da sexualidade mostra o quão significativos podem ser os roteiros sexuais do convívio social para moldar atitudes e comportamentos. Por outro lado, ao mesmo tempo em que as conversas a incentivavam, também tinham a conotação de cobrança. A primeira associação feita por Sofia foi sua primeira relação sexual, aos 18 anos, e seu primeiro beijo, aos 13, motivados pelo fato de as colegas já terem beijado e já terem se relacionado sexualmente: " $O$ meu primeiro beijo, ah, as minhas amigas já tinham feito, e eu ainda, não; aí a primeira relação sexual, já tinham feito também". Ao mesmo tempo que os percebe como eventos tardios, Sofia acredita terem acontecido de acordo com o "seu momento". Como aponta Gagnon (2006), ao longo do desenvolvimento, os roteiros sexuais vão sendo apreendidos de acordo como cada singularidade se apropria das referências do meio social, de acordo com os próprios referenciais e circunstâncias. Na sua singularidade, Sofia experimentava o peso de corresponder aos roteiros de gênero e roteiros sexuais do grupo de pares, sendo a cobrança e angústia decrrentes ao longo da constante comparação de si com o outro.

Sofia teve acesso às mais diferentes fontes sobre o universo da sexualidade, seja em casa, com a mãe, seja no convívio social. O incentivo recebido se confunde com a pressão. $\mathrm{O}$ senso de cobrança e de necessidade de corresponder às expectativas, modelador de seu roteiro sexual, se fazem presentes ao longo do seu depoimento. A vivência do primeiro beijo e da 
primeira relação sexual remetem-se a experiências já tidas pelo grupo de iguais, e pouco descreve o sentido destes eventos para si.

A percepção de Mariana segue perspectiva semelhante à de Sofia, porém, sem o sentimento de pressão em atender a modelos externos. Ao contrário, faltava-lhe acesso à informação, que ela passou a buscar em diversas fontes, como colegas, TV, revistas, entre outros. Essa busca era feita de forma encoberta, dada a forte moral religiosa de sua família, em que não são bem-vindos temas relacionados ao sexo. Mariana também apresenta o convívio social como um espaço significativo para a apreensão dos roteiros sexuais e, mesmo sabendo ir contra uma moral implícita, ela identifica-se com o grupo: “...Foi muito com que tinha que ver com outros colegas, de comentários, de tudo o mais...”.

A tônica desta primeira associação de Mariana é justamente e negociação entre suas necessidades e a moral implícita proveniente da cultura familiar. Numa sociedade que a virgindade ainda é um valor esperado em uma mulher solteira, Mariana declara não ter se casado virgem. Sua primeira relação sexual aconteceu com seu marido atual, quando ainda eram namorados, sendo que no passado tinha experimentado "carícias diferenciadas" com outro namorado, sem avançar para a penetração em si. Mariana segue seu depoimento sobre a descoberta da sexualidade, na tensão entre a experiência vivida e a moral internalizada. Os roteiros de gênero desestimulam a mulher a ter experiência sexual, enquanto o homem é autorizado a esta vivência (Gagnon, 2006; Weeks, 2000).

Seja no universo masculino, seja no universo feminino, tornam-se marcantes os pontos de tensão quando a questão é a "descoberta da sexualidade". Cada pessoa de forma específica e particular problematiza de algum modo esta vivência categorizada enquanto "sexualidade". Em todos os discursos a sexualidade é apresentada como um contato entre o individual e o coletivo, o que reforça a idéia de transmissão de práticas, idéias, valores e interditos dentro de um fenômeno amplo e complexo intimamente relacionado com o corpo, com os prazeres, e com a cultura e o momento histórico.

Os roteiros sexuais são apreendidos das mais diferentes formas. No universo dos homens, Jorge tem um contato formalizado com a sexualidade, concomitante com a interdição dando um sentido de inadequação à sua faixa etária, sendo que apresenta juízo de valor com relação à "mãe sem vergonha", que se permitia falar sobre o assunto, em oposição ao pai que 
se calava na sua religiosidade. Thiago apresenta um sentido de contato com o meio social - e virtual - ao adotar um roteiro na vivência do seu desejo afetivo-sexual, dentro de um senso de pertença. Para André, o conflito decorrente do contato com a sua primeira namorada é tamanho, que ele prefere nem considerá-lo como parte de sua experiência sexual, vivenciando a sexualidade permeada por incerteza, confusão e estranhamento.

No universo das mulheres, o contato com o contexto social é marcado no depoimento de Melina na crueza do abuso sexual, que ela apreende como uma complicada forma de ter conhecido o sexo muito cedo, numa situação em que a desigualdade de forças - ou de poderes - que, mais tarde, associava o contato sexual com o medo e angústia. O contexto social para Sofia é significativamente importante a ponto de seu roteiro seguir a perspectiva de atender às expectativas que apreende da experiência de outros jovens de idade próxima à sua. Esta tensão entre sua própria experiência e a experiência do grupo é tamanha que a auto-cobrança torna-se inevitável a ponto de acreditar que teve uma vivência tardia da sua sexualidade, fornecendo espaço para o sentimento de inadequação e rebeldia. Mariana apresenta de forma contundente a tensão entre a necessidade de encontrar referenciais para o seu roteiro sexual e o senso moral conservador internalizado de sua família. Esta tensão não impediu que Mariana fosse ao encontro de referências, seja de colegas, seja da mídia, que lhe concedessem sentidos para a sua vivência afetivo-sexual.

Por mais que a genitalidade mostre-se de forma explícita nos discursos de André, Melina e Sofia, as primeiras associações com a descoberta da sexualidade fornecidas pelos colaboradores remonta à idéia de que a sexualidade transcende esta genitalidade, adquirindo um caráter ficcional, em que cada um apreende este universo de modo específico e particular, o que torna a sexualidade uma construção social, historicamente datada e culturalmente localizada (Parker, 1991, 1993, 2000, 2002; Heilborn, 1994, 1999; Weeks, 2000). Deste modo, como lembra Chauí (1991): "nenhuma cultura lida com o sexo como um fato natural, bruto, mas já o vive e compreende simbolicamente, dando-lhe sentidos, valores, criando normas, interditos e permissões" (p.22).

Esta característica multifacetada da sexualidade vivida nos mais variados contextos, situados historicamente, aponta para a necessidade do cuidado e da atenção para a singularidade humana em relação com o contexto mais amplo e complexo. A genitalidade e a sua vivência são partes da expressão da sexualidade, mas não contemplam o todo desta 
realidade. Esta perspectiva discursiva da sexualidade enquanto construção cultural, consiste em um processo complexo e dinâmico, resultante de múltiplos elementos discursivos (Foucault, 2001). Deste modo, abre-se espaço para a reflexão sobre a redução da idéia de uma sexualidade problematizada nas "disfunções sexuais" que pressupõe uma "funcionalidade dos órgãos genitais para o sexo", em uma perspectiva essencializada da sexualidade, que naturaliza suas formas de expressão em padrões e moldes pré-estabelecidos, que nem sempre vão ao encontro das necessidades da vivência singular, assim como àquelas apresentadas pelos colaboradores deste estudo. No atendimento clínico, no âmbito da sexualidade, é fundamental considerar a identidade de gênero, a subjetividade e o corpo, de forma positiva e humana.

Diante das impressões iniciais dos colaboradores no início de seus depoimentos, notase a presença marcante do senso de problematização da descoberta da sexualidade, cada um do seu modo, cada um de acordo com os referenciais que têm à mão, cada um de acordo com a vivência da cultura familiar e da cultura grupal. A fim de favorecer a apreensão de significados e de sentidos das vivências da sexualidade, cabe o enfoque no início da trajetória dos colaboradores com referência a como percebem a relação com os pais.

\section{A percepção das figuras maternas e paternas}

Minha mãe era aberta e até sem-vergonha (...), e o pai religioso, fechado. (...) Se não fala, é melhor eu não falar também (Jorge)

Eles não se relacionavam muito bem, e eu fui criado pela minha mãe, então eu tinha sido criado por uma mãe superprotetora (Thiago)

Acho que eles não entendem o problema psicológico que eu tenho... (André)

Eu vim de uma família pobre e eu fui criada só pela minha mãe até uma certa época, e a mãe que tem a obrigação de ser mãe e pai é complicado. (...) Como que [um pai] aceita que um cara que fez isso com a minha filha, e eu marco um churrasco com a pessoa na minha casa? (Melina) 
Esse meu pai que é separado da minha mãe, na verdade, eu não sou filha dele, eu sou filha de uma outra pessoa que eu conheci no ano passado e, assim, eu, tipo, foi uma coisa meio ruim, assim, para mim. (...) Aí qualquer probleminha que eu tinha, assim, qualquer coisa que acontecia ela [a mãe] já achava que era por causa disso. E aí eu fiquei meio que super-protegida em casa (Sofia)

Minha mãe tem muito de... tem muito disso, assim, de mulher casar virgem... (...) Meu pai não sabia de nada, de menstruação. Hoje eu sei que ele sabia das coisas porque minha mãe contava pra ele. Mas ele nunca falou nada, nunca conversou com a gente (Mariana)

O primeiro contato da criança com o mundo social acontece, geralmente, por meio da figura dos pais, importantes referências da ideologia de gênero e dos papéis sexuais tradicionais (Nunes \& Silva, 2006). Opto por manter o conceito "pais", com a ressalva de não restringir este papel ao pai e à mãe, sejam eles biológicos, ou não, mas buscando considerar as diferentes constituições de família formadas por um pai e uma mãe, um pai ou uma mãe, dois pais, ou duas mães. Esta concepção vai ao encontro do reconhecimento das transformações da família que transcendem o propósito econômico ou reprodutivo. Neste contexto, também deve ser considerada a realidade de crianças institucionalizadas sejam elas órfãs ou abandonadas.

A partir do momento em que o afeto passou a ser incluído na idéia de família na Constituição Federal, a concepção de família foi alargada, contemplando a união estável a partir de laços de afetividade (Dias, 2005). Nesta perspectiva jurídica, a função básica da família é proporcionar condições para que seus membros possam estruturar a personalidade, desenvolver identidade, inclusive a sexual, prover seus recursos pessoais, afetivos e relacionais, intelectuais, pautados no respeito às suas diferenças (Groeninga \& Dias, 2001).

Na teoria da medicalização da sexualidade apresentada por Foucault (2001), a família torna-se ponto de apoio para alavancar o enquadre da sexualidade dentro de uma perspectiva de controle social da sexualidade das crianças.

Os dramas familiares em maior ou menor grau se fazem presentes nos depoimentos dos colaboradores, sendo que no universo das mulheres a referência às suas famílias nos depoimentos é mais presente do que nos depoimentos dos homens. O depoimento de Thiago foi o que menos fez menção à figura dos pais, referindo-se a eles de forma superficial. 
As atitudes e comportamentos do pai, especificamente no âmbito da sexualidade, constituíram referências importantes nos roteiros de gênero de Jorge, influenciando sua forma de lidar com a sexualidade ao longo da infância e adolescência, tendo como base "se [o pai] não fala é melhor eu não falar também". Em contrapartida, a mãe era "aberta e semvergonha". Interessante esta percepção de que a abertura para falar se sexualidade resvala para o território da sem-vergonhice, indicando outros aspectos dos roteiros de gênero. Jorge mostra em seu discurso a admiração pelo pai que, dadas as circunstâncias, esta figura ganha condição de anti-exemplo desdobrando-se para o território do conflito silencioso entre pai e filho. O pai deixa de ser o super-herói para ganhar condição de simples mortal quando Jorge descobre que ele aprecia revistas de um tipo de erotismo mais picante do que a revista Playboy, ou mesmo quando ele deixou de ser aquele pai fã de música sertaneja para gostar de Jimi Hendrix. A percepção de referências antagônicas representadas pelo pai e pela mãe serviu como esteio para que Jorge continuasse o desenvolvimento do seu roteiro sexual e de gênero. Esse desenvolvimento se deu quase sempre de forma velada, predominando o silêncio do mundo virtual, como será visto adiante.

Nos depoimentos de André e de Thiago, a figura materna também ganha destaque, porém, com ênfase na intensidade do cuidado. Na breve referência que Thiago faz dos pais, ele informa que se separaram quando ele tinha 2 anos de idade, restringindo-se ao "eles não se relacionavam muito bem", descrevendo a mãe como "superprotetora", e o pai como "ausente". O pai mora com sua atual esposa e Thiago mora com a mãe. É como se Thiago é como se ele estivesse fazendo referência a um discurso baseado na teoria psicanalítica de que a origem da homossexualidade está vinculada à influência destas duas figuras da mãe protetora e do pai ausente. Longe de buscar "origens" da orientação do desejo afetivo-sexual, mas no sentido de compreender a interação de fatores a partir de vivências e a superproteção materna pode estar relacionada com a sua percepção sobre a diferença do filho com relação às demais crianças, passando a protegê-lo de forma mais intensa frente aos conflitos na relação do filho com o pai e com as outras crianças. Deste modo, a mãe superprotetora, mas a conseqüência.

No tocante à busca das origens da orientação do desejo sexual, Gagnon (2006) tece críticas à visão determinista da homossexualidade, argumentando que a homossexualidade está intrinsecamente relacionada às convenções culturais e que as afirmações de fundo causal 
ou motivacional "atendem a interesses mais do que puramente científicos" (p.195). Como pontua Weeks (2000), a questão que vai além da origem das "causas", tanto da heterossexualidade, quanto da homossexualidade, é justamente a tendência cultural de privilegiar uma e marginalizar - quando não discriminar - a outra.

Ainda com referência ao depoimento de Thiago, em determinado momento ele diz que o pai soube da sua homossexualidade por intermédio de outra pessoa. A reação do pai foi favorável, ou menos traumática do que Thiago esperava: “...Contaram. Ele perguntou para mim e eu falei. Ele falou que não esperava aquilo. Eu sabia que ia ser difícil, eu pensava que a reação dele fosse pior, mas... por isso foi... foi só aquele dia e hoje a gente não fala do assunto. Mas ele tende a aceitar. A minha mãe ainda não sabe. Ela está viajando e ela vai saber quando voltar". O silêncio se faz presente na relação entre pai e filho no que tange o aspecto da sexualidade, porém, em nenhum momento do depoimento este silêncio torna-se sinônimo de não-aceitação ou de ausência. Visto que sua mãe estava viajando, a tensão de Thiago era voltada para a reação dela no momento em que soubesse sobre sua homossexualidade.

No depoimento de Thiago, tem-se a impressão de que ele se encontra em uma suspensão temporária sobre como serão os desdobramentos de ter comunicado a sua homossexualidade aos pais. No cenário descrito por ele, emerge a representação de que homossexualidade e heterossexualidade são pólos opostos. Jurandir Freire Costa (1995), em A inocência e o vício, que faz um aprofundado estudo sobre a construção histórica do sujeito homossexual, aponta esta polarização como um mecanismo de moralização e normatização que não contempla a pluralidade da sexualidade humana, pois ela sempre será historicamente datada e culturalmente localizada. O cenário apontado por Thiago corresponde à tensão da estigmatização da homossexualidade em um mundo em que a homofobia se faz presente. No contexto familiar, a tensão entre pais e filhos homossexuais revela as dificuldades em lidar com modelos que não correspondem a uma hegemonia heterossexual.

Dentre os depoimentos dos colaboradores homens, a presença da figura da mãe é mais marcante no depoimento de André. Nele, André pontua a postura superprotetora e invasiva da mãe, diante da qual ele buscava estabelecer limites: "Minha mãe que falava [de sexo], meu pai falava pouco, mas falava. (...) Hoje eles me enchem o saco um pouco quando a minha mãe tenta ter abertura comigo, pra falar coisas... assim, sei lá, que minha mãe intromete 
muito na minha vida, então... me... deixa nervoso. (...) Ela é meio superprotetora e acha que ainda é o filhinho... então, meio deslocado, assim". Apesar desta aparente aproximação dos pais, André não percebe que haja comunicação e um contato afetuoso. Ao contrário, não se sente compreendido: "Acho que eles [os pais] não entendem o problema psicológico que eu tenho... (...) O problema está relacionado aos pais, mãe superprotetora, quer tudo de jeito dela, mima muito e pai é distante, alcoólatra".

A psicoterapia que André iniciou aos 12 anos, para tratar o problema de enurese noturna, aos poucos deslocou-se para o tema do afastamento entre ele e, particularmente, o pai: "Sinto uma ausência dele e hoje o que mais dá rolo. (...) [O objetivo na terapia] Tentar arrumar essa ausência, tentar me aproximar dele, e é o que eu menos consegui até agora, porque... tudo bem, ele é... ele é super bom em certos momentos, ele... me... ele... mas ele... o problema é que ele me enche de dinheiro e acha que isso resolve". A compensação do silêncio se dá por meio da "linguagem" do dinheiro. O significado da figura do pai, enquanto aquele que "tem o dinheiro", entendido como "tem o poder", e da figura da mãe, enquanto aquela que é "aberta" e "cuida da casa", traz referências significativas no roteiro de gênero e permeará a vivência de André nos relacionamentos afetivo-sexuais futuros. Mais adiante no seu depoimento, quando André faz referências às aproximações afetivas com as garotas, este lugar de poder do homem se faz presente de forma intensa. Assim, cabe ao homem "chegar junto" à garota, dado seu papel de dominador, assim como a sua mãe faz com seu pai. André vê a mãe como a dominadora dentro de casa, enquanto o pai assume uma postura de dominado. Neste cenário, André percebe o pai como aquele que "perdeu a hombridade", justamente por quebrar com as regras de conduta do gênero masculino.

No universo das colaboradoras, a complexidade no contato entre pais e filhas e os diferentes significados do silêncio se fazem presentes das mais diferentes formas. No drama familiar vivido por Melina, a mãe mostra-se distante e, em alguns momentos, é tida como antagônica. Melina percebe a mãe como uma pessoa conversadora, nervosa, distante, que inspira pouca confiança. Ela ressalta que a mãe batia no lugar de dar carinho, dando mostras da tensão no contato entre mãe e filha: “...era direto eu levando surra, levando surra, mesmo, que você perde a confiança". Uma frase que ilustra esta tensão é quando sua mãe lhe diz que: "Se você for embora talvez a minha vida seria melhor". Melina estava sendo seviciada pelo padrasto e, naquele contexto familiar, a mãe demonstrava uma reação hostil batendo agredindo fisicamente a filha, não dando a perceber o que acontecia debaixo do próprio teto. 
Neste cenário, é como se a mãe e Melina fossem adversárias de cotidiano hostil em que o abuso sexual se fazia presente e o sentido encontrado pelo núcleo familiar era a manutenção do sufocante silêncio.

Melina apresenta duas figuras paternas, ambas envolvidas pelo conflito, seja com o pai biológico, seja com o padrasto. O pai biológico abandonou sua mãe para viver com outra família, ter outros filhos, e, possivelmente, reproduzir no futuro este mesmo roteiro. Melina aponta este padrão do pai: "E da mesma forma que ele fez comigo, ele fez com a outra mulher que ele teve crianças, ele também se separou, e agora com essa que ele está agora talvez faça a mesma coisa”. Já o padrasto é aquele que fornece carinho, algo raro no contexto vivido por Melina: “...Quando discutia alguma coisa de escola era sempre muito compreensivo, ele dava ouvidos. E com a minha mãe eu nunca tinha isso". Mas este carinho proveniente do padrasto não era gratuito, sendo que a moeda de troca seria o prazer sexual dele. É intenso o sentimento de desamparo que transparece no depoimento de Melina, em uma situação em que, por um outro lado, não tinha a quem recorrer sobre o que acontecia e, por outro lado, tinha o carinho do padrasto, no contexto do abuso, o que corroborava para que se mantivesse em silêncio. A violência não era apenas no sentido sexual, Melina era alvo da violência física por parte da mãe. Era tamanho o sentimento negativo diante da mãe que, quando ela saía para trabalhar, Melina desejava que ela não voltasse para casa: "Não quero que ela volte, não, porque para voltar e me bater eu prefiro que não volte".

Depois que a situação do abuso extrapolou as paredes de casa e passou a ser de conhecimento de mais pessoas, Melina expressa sua indignação e tristeza com relação à reação de conivência do pai diante da atitude do padrasto: "Como que aceita que um cara que fez isso com a minha filha, e eu marco um churrasco com a pessoa na minha casa? (...) ...mesmo que não tenha um contato, é filho, é sangue, entendeu? E assim, uma coisa é... é, vamos supor, eu ter me oferecido para ele, eu falar 'Eu quero você, e... vem'. E outra coisa é você corromper uma criança de 7 anos, entendeu? Para mim é uma coisa muito grave, é muito monstruoso de se fazer para depois eu chamar, e saber que voc... e depois vem aqui na minha casa...". Melina traz a questão do sangue, que representa o valor da família em proteger, em dar segurança, que foi ignorada em prol da reunião festiva do pai biológico, padrasto, e amigos, em torno do churrasco. O consumo da carne ocupa o espaço do valor familiar intrínseco do sangue. O sentimento de monstruosidade se faz presente na representação que Melina tem do pai. Apesar de mais adiante Melina tentar diversas formas 
frustradas de aproximação, opta pelo perdão negado durante anos devido ao abandono: “ $E u$ nunca consegui perdoar, nem sei se perdoar, mas esquecer o que meu pai me abandonou durante toda a minha infância".

Um dado importante fornecido por Melina e que se refletirá nos seus roteiros sexuais e de gênero é quanto ao papel da mãe na relação com o padrasto, quando se "entregou de corpo e alma", e "abdicou a vida dela para ele, renunciou a tudo o que era dela em prol dele...". Para Melina, o erro da mãe foi "agir mais pela emoção do que pela razão". A relação dela com o noivo é marcada pela tensão entre o afeto por ele e a expectativa de uma família e aquilo que sonha para si mesma, seus projetos individuais. O silêncio, a submissão, o abandono, a solidão, constituem alguns pontos a serem considerados na constituição do roteiro sexual e de gênero de Melina, que se refletem em questões atuais da sua vida.

No depoimento de Sofia, também é encontrado um cenário em que os pais são separados. Os pais se separaram quando ela ainda era bebê. A mãe iniciou outro relacionamento quando a menina tinha 3 anos de idade. Mas, o homem com quem sua mãe estava não era seu pai biológico e sim um outro: "Esse meu pai que é separado da minha mãe, na verdade, eu não sou filha dele, eu sou filha de uma outra pessoa que eu conheci no ano passado e, assim, eu, tipo, foi uma coisa meio ruim, assim, para mim”. Sofia acredita que por esse fato sua mãe, psicóloga, insistia para que fizesse psicoterapia. Para Sofia, a mãe carrega sentimento de culpa pela situação, visto que ficou grávida aos 18 anos, de um homem então casado. Para ela, este sentimento de culpa alimenta uma atitude de superproteção que é alvo dos protestos da irmã mais nova, fruto do relacionamento da mãe com o homem que Sofia acreditava ser seu pai.

Sofia percebe a mãe como aquela que "superprotege", e complementa: "...Minha mãe é meio espontânea demais, às vezes, eu acho, ela fala umas coisas que ela não devia falar, até. Ela briga mesmo, sabe, se tem que brigar, ela briga. Minha mãe fala umas coisas que vai lá no cérebro".

Sofia fala pouco daquele que acreditava ser seu pai e refere-se mais ao pai biológico, a quem considera a "causa" da sua dificuldade de envolver-se afetivamente com outros garotos, ou mesmo estabelecer relações de amizade. Resolveu conhecer o pai, porque a mãe insistia nisso. Por outro lado, enquanto a mãe referia-se ao pai biológico como uma "pessoa 
intelectual", Sofia percebeu-o como "meio capitalistazinho". Nota que o pai não gosta do jeito da mãe e tende a criticá-la. Este comportamento do pai é inadmissível para Sofia que, por sua vez, o hostiliza. Nos últimos encontros, a qualidade do contato entre eles melhorou e ela percebeu mudanças na forma de apresentação dele a qual não gostava, a exemplo do gostar de impressionar e não ser humilde.

Para Sofia, a figura da mãe é evidenciada pelos seus comportamentos e atitudes associadas à independência e à governança das questões profissionais e do lar, que faz com maestria. Sofia tem uma identificação significativa com a mãe, o que pode tê-la motivado para ingressar no curso psicologia, mesma profissão da mãe, sendo uma mostra da identificação. A figura do pai é distante, quando não, ausente. Ela nada falou daquele que acreditava ser seu pai - o então segundo relacionamento da mãe -, enfatizando o pai biológico como alguém que, de acordo com a sua descrição, sugere uma pessoa que beira a futilidade. Os roteiros de gênero também apontam para o feminino associado à independência e à autonomia.

O depoimento de Mariana retrata um modelo tradicional de constituição da família, em que valores conservadores são presentes e rígidos; por exemplo, na representação de que a mulher deve se casar virgem, e de que o pai não se envolve nas questões íntimas das filhas, cabendo isso à mãe. Neste contexto desfavorável em suprir suas dúvidas ou curiosidade, a sexualidade ganha uma aura de proibição, de marginalidade. Isto fica ilustrado quando Mariana diz que "Eu não posso fazer isso, porque tá errado!". O roteiro sexual e de gênero de Mariana foi constituído por meio de outras referências que não os pais, ou mesmo as irmãs mais velhas, que desenvolvem seus próprios códigos de conduta. Os encontros e desencontros ao longo desta constituição são inevitáveis. Por mais que existisse falta de um canal de diálogo com os pais, Mariana não relata nenhuma manifestação ostensiva de repressão com relação às suas descobertas no âmbito da sexualidade. Por outro lado, um dado importante é que a disciplina de controle dos corpos e dos prazeres acontece tanto de forma explícita e quanto implícita (Foucault, 2001). Os códigos, valores e representações desta cultura familiar conservadora ficaram impressos em Mariana na sua forma de estar no mundo. Esta forma de contato enfatiza a mensagem de que a vivência afetivo-sexual é quase sempre associada ao proibido, ao que é marginal. 
Só quando Mariana se casou é que percebeu que a conversa com a mãe tornou-se mais tranqüila, com um sentimento de liberdade: “...Hoje eu consigo conversar algumas coisas com a minha mãe. Engraçado, depois de casada, depois de quanto tempo!... (...) Eu percebo mais liberdade em conversar do que antes". Esta autorização de Mariana para o contato com o âmbito da sexualidade se dá a partir do momento que se casa, o que faz sentido na cultura conservadora da família. O sentido apreendido no roteiro de gênero de Mariana é de que uma mulher jovem, solteira, não deve ter acesso a este universo da sexualidade, o que indica uma lógica hierárquica e assimétrica dos gêneros, visto que desde cedo os homens são estimulados para o contato com este universo (Bozon, 2004; Gagnon, 2006; Heilborn, 2006). Mariana deixa de ser uma jovem moça virgem para adentrar no mundo de uma madura mulher casada que passa a conhecer os segredos do sexo. Porém, esse conhecimento, prático, a partir do tocar e ser tocada, no estimular e ser estimulada, exige a elaboração de comportamentos e atitudes, exige uma atualização paulatina do roteiro sexual e de gênero. Mariana mostra em seu depoimento que este desdobramento do roteiro sexual não acontece automaticamente assim que a pessoa se casa. Ela própria percebe que as dificuldades afetivo-sexuais experimentadas são decorrentes de uma trajetória de vida, ou melhor, constituem um modode-ser possível naquele contexto.

A diversidade de constituiçõos familiares, e as dinâmicas que se desdobram a partir destas constituições, fornecem referenciais para a roteirização (Gagnon, 2006). Nos depoimentos dos homens, o silêncio é um recurso muito presente no drama familiar, por mais que existam tentativas superprotetoras das mães em falar sobre aspectos da sexualidade, como no caso de André, ou até mesmo fornecendo livros especializados no tema, como no caso de Jorge. Somente no caso de Thiago é que a relação não fica tão explícita, porém, ele mesmo aponta a mãe como superprotetora ao longo do curso de sua vida.

Nos depoimentos das mulheres, Sofia percebe a mãe como superprotetora e, ao longo do depoimento, não surge nenhum impeditivo para o contato com o universo afetivo-sexual. O mesmo não acontece com Melina e Mariana. No drama familiar vivido por Melina, as figuras de mãe, pai e padrasto se confundiam como a manifestação do poder que oprime, que sufoca, que impõe uma dor silenciosa. A mãe de Melina, distante e até competitiva, despertava o sentimento de desamparo que era suprido pelas sevícias do padrasto. Já o depoimento de Mariana mostra a mãe distante das questões da sexualidade, mas uma mãe afetivamente presente na vida da filha. 
É notável nos depoimentos dos colaboradores e das colaboradoras a presença da figura da mãe no que diz respeito à interlocução sobre os aspectos afetivo-sexuais dos filhos. Um aspecto a ser considerado é que a maior parte das mães dos entrevistados são donas-de-casa o que, além de contribuir para esta proximidade com os filhos, revela um aspecto do roteiro de gênero. Bozon e Heilborn (2006), em pesquisa compreendendo mais de 4.000 jovens de São Paulo, Rio de Janeiro e Salvador, destacam a proximidade das mães com os filhos, especialmente com as filhas, marcando a diferenciação dos gêneros ao longo da socialização da sexualidade, sobretudo nas questões relacionadas à gravidez e à contracepção.

De acordo com Bozon e Heilborn (2006), o pai também funciona como referência para os filhos e tem papel quase nulo com relação às filhas. Nos depoimentos a presença do pai não é tão presente ao longo da trajetória dos filhos sendo, em diversos momentos, alvo de críticas. No caso de André, o pai é visto como aquele que perdeu a "hombridade", pelo fato de a mãe comandar os assuntos domésticos, e o pai se restringir a trazer os recursos financeiros para casa. Isto revela que o "ser homem" vai além de meramente ser o provedor do lar, sendo esperado no seu papel uma postura que o destaca perante os outros familiares. Esta qualidade de ser homem perdida pelo pai é reforçada pelo seu uso abusivo do álcool. A comunicação de André com o pai é precária, de forma que o canal de contato entre ambos é o fornecimento pelo pai de recursos financeiros para que o rapaz continue seus estudos e que mantenha seu conforto. O silêncio parece ser mais uma escolha, ou uma possibilidade, de André para não abrir mão da própria intimidade. O silêncio, no caso de Thiago, toma outra direção, a de algo que não cabem desdobramentos. A figura do pai de Thiago surge após ter conhecimento da homossexualidade do filho por meio de outra pessoa. Apesar de não existir a aceitação por parte do pai frente à sexualidade do filho, a relação entre ambos não é abalada; por outro lado, o assunto é dado por encerrado.

A relação entre Jorge e seu pai é mais conturbada, devido à tensão entre idealização e realidade, ora o pai sendo representando como exemplo, ora como contra-exemplo. O conflito não é tão evidenciado, embora o contato de Jorge seja significativamente maior com a mãe. $\mathrm{O}$ isolamento é uma saída para que Jorge continue suas buscas de referências para compreender o universo afetivo-sexual. 
A figura do pai nos depoimentos das colaboradoras também ganha destaque de distanciamento. No caso de Mariana, não se destaca conflitos com seu pai, mas ele pouco significou enquanto referência para as transformações do seu corpo - menstruação -, ou quanto ao contato com o universo afetivo-sexual. Já no depoimento de Sofia, as figuras paternas não se fazem muito presentes. Quando o pai biológico surge em sua história, a associação é negativa, ainda mais quando Sofia percebe que ele quer manchar a imagem que ela faz da mãe. Esta atitude do pai provoca a indiferença de Sofia. Por outro lado, no depoimento de Melina, as figuras do padrasto e a do pai são marcantes na sua trajetória, não pelo apoio e carinho, mas pela imposição do poder, seja por meio do abuso sexual, por parte do padrasto, seja pela indiferença, por parte do pai biológico.

O canal de comunicação para a discussão sobre aspectos da sexualidade é mais acessível para os homens do que para as mulheres, existindo um maior senso de autorização, ou mesmo de incentivo, para que os filhos tenham contato com o universo afetivo-sexual. Com exceção do depoimento de Sofia, esta "autorização" não ocorre com as outras colaboradoras, para quem o silêncio tende a ser regra para que a sexualidade continue velada. Esta autorização virá somente mais tarde, quando a menina for uma mulher. Nota-se, neste aspecto, que os homens têm à mão mais referências do que as mulheres na constituição de seus roteiros sexuais. $\mathrm{O}$ acesso a estas referências não significa que eles se apropriarão delas. Da mesma forma, no caso das mulheres, o fato de os referencias serem poucos, não significa que elas não encontrarão formas alternativas de contato, pois a constituição da sexualidade sempre está associada na existência social (Bozon, 2004; Gagnon, 2006; Heilborn, 2006).

Ao longo das referências, percebe-se que os modelos de pai e mãe da modernidade, assim como as diferentes constituições familiares, muito se distanciam dos moldes que no passado se acreditava ser o ideal de uniões estáveis entre homem e mulher. Este modelo mais tradicional é representado na relação dos pais de Jorge, André e Mariana. No caso de Thiago, Melina e Sofia, existe um mosaico familiar. Estas diferentes constituições familiares, e estes diferentes referenciais de papéis de pai e de mãe, constituem as primeiras referências para os colaboradores no âmbito da composição dos seus roteiros sexuais e de gênero. Quando o assunto é sexualidade e seus desdobramentos, a interlocução entre pais e filhos aponta para a tensão, o silêncio e a dificuldade no contato. As marcas adquiridas ao longo do contato com os pais são significativas para os filhos, porém, não determinantes para os roteiros futuros que dependerão da inter-relação extra-familiares. A forma de perceber e de se apropriar dos 
referenciais do mundo são mutáveis; em outras palavras, se atualizam a cada instante, incidindo na própria dinâmica da constituição da identidade, como bem mostra Ciampa (2001), na perspectiva da Identidade Metamorfose, em que a identidade é compreendida enquanto um fenômeno dinâmico que passa por transformações - ou atualizações - do início até o final de uma vida, sempre dependente do meio e do contexto social do qual uma pessoa faz parte.

Deste modo, as figuras de pai e a de mãe tornam-se referenciais importantes para os filhos e são ressignificadas ao longo da interação da pessoa no meio social (Nunes, 2006). Esta perspectiva segue a definição de Ciampa (2001) sobre pessoa que é compreendida por a partir de um conjunto das relações sociais dentro da História, envolvendo aspectos sociais, políticos, econômicos, históricos, entre outros. Além de representar, a identidade engendra, ou seja, origina, gera, produz a pessoa.

\section{Os contatos com o mundo social na infância, a escola e a percepção da sexualidade}

Eu tinha um monte de assunto que eu não podia falar e esse [o sexo] era mais um desses... (Jorge)

Eu tinha algumas coisas que os outros garotos não tinham: alguns cuidados a mais que acho que eram mais característicos de mulheres, de garotas, de meninas até... (Thiago)

Eu era muito pequena... muito pequena, então assim, eu nunca fui de amigos, nunca fui de amizades, eu sempre fui muito quieta, muito na minha (Melina)

E eu acho que também, alguns primos mais velhos acabam (...) querendo dar um abraço na prima mais nova. E eu acabei descobrindo que eu sentia prazer naquele abraço (Mariana)

A socialização da criança é um processo no qual ela apreende e vivencia os valores, crenças e normas do mundo do qual faz parte. Os primeiros contatos sociais na infância contribuem 
para a ampliação da percepção de mundo e, conseqüentemente, para a ampliação da rede social, elementos importantes para a constituição identitária da pessoa, a partir de onde se coloca e de onde se é colocada neste âmbito social, da noção de eu no mundo (Giddens, 1993; Ciampa, 2001; Hall, 2002). Neste sentido gregário, é por meio desses contatos que a criança ou o jovem - com seus pares encontra e constrói novos papéis, fornecendo sentidos e significados de sociabilidade e, assim, para a elaboração de roteiros sociais. A partir dos significados e sentidos do contato da pessoa com o mundo social, discursos e práticas são despertados, matérias-primas para a unicidade e subjetividade identidade (Castro, Abromovay \& Silva, 2004).

Esta perspectiva da identidade construída na relação com o meio e contexto social é reforçada pela proposta da sociedade em rede, proposta por Castells (1999), que também ressalta que a inter-relação da pessoa e sociedade, considerando o impacto da globalização na formação de identidades, em um contexto marcado pela revolução tecnológica da informação e da reestruturação do capitalismo, que são refletidas nas formas de trabalho e na organização cultural. Seguindo a perspectiva da idéia de identidade flexível e dinâmica, Castells (1999) mostra a possibilidade de existência de identidades múltiplas, sendo que tal pluralidade é "fonte de tensão e contradição tanto na auto-representação quanto na ação social" (p.22). O autor pontua que estas identidades múltiplas inserem-se em três formas de identidade que são marcadas pela relação do poder, conforme já pontuado em capítulo anterior, que consistem na identidade legitimadora, a identidade de resistência e a identidade de projeto.

A trajetória dos colaboradores nos primeiros contatos com o mundo social, mais especificamente com seus pares, ilustra os referenciais provenientes desta sociedade em rede em que valores, idéias, discursos, práticas, enfim, identidades plurais se inter-relacionam, reproduzindo ou vivenciando novos papéis, sempre em uma perspectiva atualizante de ser no mundo em relação. Por se tratar do período que compreende a infância, nesta etapa de vida dos colaboradores, prevalece o início da vivência de uma identidade legitimadora, porém, já apresentando traços de uma identidade de resistência. Quando Jorge fala de sua infância, ele remete-se ao seu "amigo precoce", de idade próxima à sua que, pela maneira aberta em expressar a sua curiosidade com relação à sexualidade, coloca em tensão o referencial de Jorge de "quando eu for adulto, aí vou entender melhor". Esta tensão fica ilustrada quando 
Jorge diz que tinha acesso a material pornográfico na internet ${ }^{48}$, embora na presença deste amigo Jorge procurasse "não mostrar nenhuma emoção". O roteiro de espectador marcado pelo distanciamento, seja racional, seja emocional, era mantido na presença deste amigo. Por outro lado, quando só, Jorge se permitia dar vazão à curiosidade e ao interesse. Tal movimento vai ao encontro de um roteiro em que a sexualidade deveria ficar para um momento posterior, ao menos na sua vivência no âmbito social. A tensão também ficava presente na sua vida escolar, na interação com seus pares que insistiam em falar sobre a sexualidade, embora seu roteiro continuasse sendo ouvir-muito-falar-pouco, mas sempre atento e receptivo àqueles referencias que circulavam nas relações sociais. Os pares percebiam a indisponibilidade de Jorge para esses assuntos: “...Por algum motivo, que me colocava assim, era tido como o mais distante, o mais fechado, então nem falava nisso [sobre sexo]. (...) ...Quando eles falavam disso, eles sabiam que eu não ia comentar, então, nem me perguntavam, nem me colocavam na roda e... foi assim". A transgressão de escutar conteúdo sobre sexualidade já era de bom tamanho para o seu roteiro. Neste período, Jorge era avesso em mostrar o corpo, condizendo com o roteiro em que se considerava "tímido". Ele descreve uma situação em que, num jogo de futebol, para seu desespero e angústia, ele faria parte do time-sem-camisa. Nessas situações, ele procurava uma justificativa para não participar, ou para esconder o corpo. Expor o próprio corpo era algo que Jorge continua a não apreciar até hoje, num sentido de preservar ao máximo sua privacidade.

Thiago segue uma perspectiva que ressalta a questão da identidade de gênero, na qual o corpo é experimentado como fonte de prazer. Nos primeiros contatos no âmbito escolar, Thiago percebe a diferença que existe entre ele e seus pares no que diz respeito à maneira de ser, aos papéis desempenhados naquele meio social. As características de delicadeza e de nãoviolência, provenientes do que ele chamou de "cuidado-que-a-mamãe-é-superprotetora", eram tidas como femininas, o que em nada conferia com aquilo que vislumbrava de rudeza e de violência, características tidas como masculinas, que percebia nos outros garotos. Assim, Thiago se apropria da sua "delicadeza maior", tornando-se alvo de "zoiera", por não corresponder aos códigos de conduta daquele grupo social. Desde cedo, para lidar com as adversidades, Thiago tem a postura de resistência como algo implícito em seu roteiro. O sentimento de solidão, isolamento e não-pertença faziam parte do seu cotidiano.

\footnotetext{
${ }^{48}$ O papel da internet será retomado em outro momento, por consistir em um recurso significativo na idéia de sociedade em rede, promovendo a difusão de discursos e práticas sociais.
} 
O sofrimento que Thiago nesse isolamento da infância apresenta sentido diferente daquele enfrentado por Jorge. Enquanto Jorge mantinha-se à parte e era tido como "fechado", ou "tímido", Thiago, pelo próprio modo de ser, destoava dos padrões daquele grupo social, sendo apontado pejorativamente como "filhinho da mamãe". Assim, o sentido transmitido por esse grupo social é de que o filho homem deve ser o "filho do pai" e que deve reproduzir a virilidade esperada deste papel. A tristeza e a ideação suicida faziam parte do cotidiano de Thiago, tamanha a tensão em seu contato com os outros meninos. A discriminação e o preconceito serão elementos presentes em outros momentos de sua vida, imbricando na constituição de sua identidade. A tensão vivida, tanto por Jorge, quanto por Thiago, apontam para a restrição de espaços de convivência de socialização para expressões sexuais e de gênero que transcendem o modelo heterossexual. Deste modo, pela discordância com os valores do grupo, tornam-se alvo de pressão social, sendo levados a desempenhar aquilo que Fry e MacRae (1991) apontam como variações pouco ortodoxas dos papéis sociais normalmente atribuídos a homens e mulheres.

André, Sofia e Melina pouco ou nada falam sobre os contatos com pares na infância focando mais período da adolescência. Melina remete-se a uma idéia de ser pequena, revelando o sentimento de fragilidade diante de um mundo adulto marcado pela força. Da mesma forma que Jorge e Thiago, o isolamento e o manter-se à margem do grupo de pares também foi algo que Melina experimentou em sua trajetória. Ela justifica este isolamento e esta quietude enquanto reflexos de ter sido molestada desde os 7 anos de idade, mantendo-se "sempre calada, sempre agüentando, sempre calada". Mariana também não fornece muitas referências desses contatos com pares na infância, mas remete-se à interação física com os primos mais velhos, em que pôde perceber sensações prazerosas a partir do abraço. A referência mais importante sobre sexualidade, para ela, aconteceu mais tarde, quando estava na escola.

Em termos de diferenças entre gêneros, os depoimentos indicam que desde cedo a expectativa e a cobrança para que o menino assuma e se auto-afirme com valores tidos como masculinos. Enquanto a fragilidade e a delicadeza das meninas não seja algo indesejado, por serem características atribuídas ao universo feminino, o mesmo não acontece no universo masculino. Assim, a não correspondência às expectativas geram o isolamento. Jorge adotou a estratégia de manter-se no silêncio, o que não destoava das regras do grupo que o identificava como "tímido". As atitudes e comportamentos de Thiago destoavam do grupo, gerando 
tensão, além de manifestações de discriminação e de preconceito. Isso concorda com Fry e MacRae (1991), para quem a partir da rigidez na percepção de masculinidade e de feminilidade, qualquer comportamento que o grupo considere "desvio" é reprimido a fim de manter ou recuperar o "bom comportamento".

A delicadeza e a fragilidade são características do roteiro de gênero de Mariana. Mesmo que o diálogo sobre os roteiros sejam restritos, dadas as normas e os valores da sua cultura familiar, Mariana se dispõe para a experimentação de sensações como aquelas provenientes dos abraços com os primos mais velhos. A expressão do carinho ou ternura dos primos não transpunha os limites do erótico, mantendo um equilíbrio neste encontro. $\mathrm{O}$ mesmo equilíbrio não aconteceu na trajetória de Melina, em que não foi respeitado o limite entre a expressão afetiva e o sexo. Uma frase de Melina revela o seu sentimento no que diz respeito ao seu sufocante sofrimento e à desigualdade, seja na idade, seja no gênero: "É como se eu tivesse sido destinada para aquilo (...) não tinha como mudar, era daquele jeito ali e ia ser aquilo sempre”. A submissão é o sentido apreendido por Melina, conferindo uma idéia de uma destinação passiva. As marcas do abuso sexual serão refletidas nos relacionamentos de Melina, limitando a vivência plena da sua expressão afetivo-sexual.

\section{A masturbação e a descoberta de sensações prazerosas com o corpo}

Eu lembro que foi bom, foi tanto que teve outras vezes que eu me masturbei, (...) quando não tinha ninguém em casa, especialmente. (...) Deu certa culpa quando eu comecei a ejacular (Jorge)

...Era bom, só depois que eu me converti é que passou a ser errado. Aí eu passei a querer evitar. Eu ficava uns 10 dias sem fazer $e$ 'nooossa!...' e não agüentava. Fazia e me sentia na 'nóia'. Eu me sentia culpado, sujo, errado, assim... Fora que tudo você... por eu ser homossexual é como se eu valesse menos, entendeu? (Thiago)

Acho que eu fiz primeiro, depois que eu tive mais informação. Depois disso, sei lá, ver filme pornô com meus primos... (...) Tinha ouvido amigos e primos falarem sobre esta prática. (...) Era meio estranho... Não, não é estranho... Estranho é você tentar fazer isso com a sua namorada (André) 
É um meio de você se conhecer mais, até porque é uma fase legal da vida. (...) Eu sentia umas coisas, assim, aí eu achava que tinha poderes. (...) ...Um dia eu estava lendo uma revista (...), aí eu vi que chamava 'masturbação' (riso) Aí eu até fiquei meio frustrada... (...) ...De uns tempos para cá eu estou me tocado mais, assim... tenho sentido prazer, mas não orgasmo... mas está bem melhor (Sofia)

Eu fiz isso algumas vezes quando eu era menina, quando era adolescente, eu fazia, né, eu ia tomar banho, né, mas: 'Imagina, isso é um absurdo, ninguém pode saber!'. (...) Aí tinha horas que eu passava a noite inteira de terror, eu falava: 'Eu não posso fazer isso, porque tá errado!', né? (Mariana)

Como apontado por Foucault (2001), na genealogia da sexualidade, a masturbação ${ }^{49}$ foi objeto de intervenção médica e pedagógica durante os séculos XVIII e XIX, fortalecendo o ideal do sexo heterossexual e conjugal, relegando para a marginalidade aqueles que, até então, não recebiam nenhum rótulo na multiplicidade das sexualidades:

(...) tais comportamentos polimorfos foram, realmente, extraídos dos corpos dos homens, dos seus prazeres; ou melhor, foram consolidados neles; mediante múltiplos dispositivos de poder, foram solicitados, instalados, isolados, intensificados, incorporados (p.47).

A descoberta das sensações prazerosas provenientes do corpo retoma os roteiros sexuais e de gênero previamente aprendidos e apreendidos no meio social, "combinados com componentes sexuais novos que são mentalmente exibidos, em coordenação com a auto-estimulação genital ou de outra natureza" (Gagnon, 2006, p.133). A proposta, neste momento, é lançar um olhar sobre esta descoberta das sensações e sobre algumas associações feitas pelos colaboradores. A masturbação torna-se um recurso para o conhecimento do corpo e das sensações provenientes dele, que servirão de referências futuras para os roteiros sexuais para o estabelecimento de relações. Porém, a forma deste desvelamento nem sempre é livre de conflitos.

Em seu depoimento, Jorge aponta que, por volta dos 13 anos, o acesso secreto às revistas eróticas do pai, as conversas testemunhadas dos colegas de escola e o material

\footnotetext{
${ }^{49}$ A masturbação é adotada nesta pesquisa em um sentido amplo que engloba sensações prazerosas mediante a manipulação dos genitais. Esta observação vai ao encontro que Nunes e Silva (2006) para quem a manipulação dos genitais praticados pelas crianças proporciona a apropriação sensorial do corpo e das suas potencialidades, sendo que não deve ser confundida com masturbação propriamente dita.
} 
acessado da internet forneceram subsídios para iniciar a prática da masturbação. Ele não se sente à vontade para compartilhar seus achados com seus pares, optando por ficar à parte das conversas. Sua postura pode indicar a ausência de uma pessoa enquanto referência com a qual se sentisse à vontade para compartilhar os significados e sentidos vivenciados. A partir do momento em que começou a ejacular, a culpa devido à masturbação passou a ser companhia ainda mais constante. O conflito entre o prazer obtido e a culpa constitui para Jorge um elemento a mais a ser conciliado ao longo da vivência da sua sexualidade.

Thiago fornece poucas referências de como aprendeu a se masturbar, mas apresenta uma forma de vivência do conflito a partir da tensão entre o desejo de masturbar e a interdição moral dessa prática. Esse conflito se intensifica, ganhando a conotação de "pecado", quando da sua conversão religiosa. A necessidade de experimentar o prazer levava-o à masturbação, mesmo com o sentimento de inadequação posterior ao ato, percebendo-o como algo "sujo", "errado", que o deixava na "nóia". Este caráter de estar fazendo algo "errado" se potencializava com o fato de reconhecer-se homossexual, revelando uma auto-percepção negativa por não corresponder à maioria dita heterossexual. No seu depoimento, Thiago apresenta mais ênfase nos jogos eróticos da infância do que na masturbação. Contudo, a discriminação e o preconceito se fizeram presentes quando foi flagrado com outro menino, dando sentidos para o sentimento de não pertença e de isolamento influenciando diretamente os seus roteiros sociais.

As referências provindas do meio social muitas vezes são introjetadas, tomando um sentido de "algo natural". A mera informação não garante a seleção crítica do que o indivíduo apreende (Nunes \& Silva, 2006). Para André, a percepção da masturbação se dá como uma descoberta solitária, que ele chama de "instinto", sendo que a troca de experiência e de informação com o grupo de pares contribuiu como referência para o aprendizado desta prática. Os filmes eróticos fornecem subsídios tanto para seu roteiro quanto para o roteiro de outros jovens da sua idade, o que fica ilustrado quando André reflete sobre suas referências sexuais: “Tipo: 'Como faz isso?', tipo: 'O que é...'. Talvez venha daí! Talvez não...”. Deste modo, a construção do sentido sexual ocorre gradativamente no conjunto de sensações, situações, palavras e estados corporais experimentados pela pessoa. No lugar da culpa experimentada por Jorge e Thiago na prática da masturbação, o senso de estranhamento se faz presente na experiência de André. Um ponto que chama a atenção no discurso de André é quanto à identidade e à relação de gênero, sendo que o "estranho" é acessar informações 
sobre sexo junto com a namorada - a exemplo dos filmes pornô -, o que revela um sentido de roteiro de gênero em que o homem sempre deve estar em um plano privilegiado de informação e que não pode apresentar desconhecimento sobre o assunto com a sua parceira que, por sua vez, não é socialmente tão estimulada para esse acesso, quando não é proibida.

Já no universo das colaboradoras predomina o sentido de distanciamento da prática de masturbação enquanto algo desejado ou aceitável. Na perspectiva da construção dos gêneros, as colaboradoras revelam que nos primeiros contatos com a sexualidade existe maior restrição com relação às mulheres do que com os homens. As referências de roteiros sexuais são restritas, quando não negativas, com relação a esta possibilidade de reconhecimento do corpo e de sensações de prazer. $\mathrm{O}$ acesso à intimidade do próprio corpo poderia ser elemento a mais no desenvolvimento posterior dos roteiros sexuais, porém, como aponta Gagnon (2006), este acesso a roteiros masturbatórios não é componente necessário na emergência do desenvolvimento orgástico ou do sucesso no coito em qualquer dos sexos, sendo que tais roteiros acontecem de forma diferenciada nos gêneros. Nos homens, como já explorado, a prática da masturbação é mais freqüente do que a prática das mulheres.

Melina apresenta a masturbação como um meio de auto-conhecimento e uma "fase legal da vida", mas não fornece elementos sobre sua prática no momento atual de vida. Vale ressaltar que o sentido de Melina na esfera da sexualidade é o do silêncio, ilustrado pela sua fala: "sexo é uma coisa que não se comenta". Além do silêncio ser parte da situação do abuso sexual, o silêncio era uma atitude esperada no contexto social em que vivia, cujo valor era de que uma garota não deveria falar sobre sexo ou sexualidade. A menos que ela estivesse buscando por isso, o que era visto de forma depreciativa, consistindo em um referencial que determina a "boa" moça e a moça que não presta. Isto vai ao encontro da divisão moral entre as pessoas sexualmente acessíveis e sexualmente inacessíveis, que consistem em conteúdos apreendidos muito antes de as meninas terem idéia do que possa implicar o ato do coito num sentido direto ou concreto (Gagnon, 2006).

No depoimento de Mariana, a masturbação é uma prática até desejada, porém, não muito compensadora dado o peso da culpa pelo prazer obtido, evidenciando que no universo feminino o prazer quase sempre é acompanhado pela censura, culpa e sofrimento (Bernardi, 1985; Maia, 2004; Nunes \& Silva, 2006). De acordo com Heilborn, Cabral e Bozon (2006), a masturbação é moralmente condenada sobretudo quando é uma prática feminina. Por mais 
que a masturbação seja desejada, o roteiro apreendido por Mariana é de que ela, membro de uma família conservadora, não deveria fazer aquilo. A masturbação para ela também se insere em dado momento da vida, como infância e adolescência, sendo que em seu depoimento não existe indicativo de que a prática da masturbação esteja presente na fase atual de vida. As marcas trazidas pela experiência negativa com relação ao contato com o seu corpo pode estar relacionada às dificuldades atuais da vivência de Mariana com seu marido, de pouco desejo sexual e de dificuldade na obtenção de prazer ou orgasmo na relação sexual.

Sofia foi quem mais falou sobre a masturbação, até mesmo reconhecendo nessa prática uma gratificação maior do que aquela que experimenta no contato sexual com uma parceria. A princípio, as sensações prazerosas tinham um sentido mágico e poderoso, perdido quando teve contato com o conceito "masturbação" numa revista voltada para o público adolescente, embora tenha continuado a prática. Um dado interessante trazido por Sofia é o fato de que a princípio ela nada ou pouco sentia no contato das mãos ou travesseiro com sua genitália, porém, com a prática continuada, abrindo espaço para a percepção de que está no "caminho certo", ou seja, a experiência vem ganhando sentido no campo do prazer e da gratificação sexual. Outro dado relevante é que Sofia não apresenta em seu depoimento referenciais inibidores da experimentação, apontando para a ampliação de possibilidades nesta vivência na esfera sexual.

Nas referências fornecidas pelos colaboradores acerca da masturbação são reveladas as diferenças nas construções dos gêneros masculino e feminino e a desigualdade no acesso à essa experiência, sendo os homens mais estimulados, ou melhor, "autorizados" a ela, embora não deixassem de existir o estranhamento e a culpa. Enquanto que campo do masculino a masturbação é uma possibilidade a mais ao longo da experimentação da sexualidade, no feminino, ela não é algo que tenha destaque, o que aponta para o baixo ou inexistente estímulo para a prática desta possibilidade de prazer sexual. Heilborn, Cabral e Bozon (2006), observam que a masturbação integra o repertório masculino desde a sua iniciação, variando apenas de intensidade, conforme a aquisição de experiência sexual com parceiros e/ou o tempo transcorrido de vida sexual.

As referências religiosas, como no caso de Thiago e, indiretamente, no de Mariana, mostram ser mais intensas no combate a esta prática, que gera culpa e, por conseguinte, sofrimento psíquico. Para Thiago, a masturbação era boa até a sua conversão religiosa, 
quando ela passou a ser algo condenável. Para Mariana, os códigos e valores internalizados sinalizavam que aquilo que fazia solitariamente, no chuveiro, era algo "absurdo" para uma moça.

A masturbação não é o único recurso para a descoberta do corpo e das sensações prazerosas. No contato da pessoa com o espaço coletivo, no estabelecimento de relações, os códigos, valores e condutas ganham paulatinamente contornos. Thiago traz uma passagem em sua vida em que a partir das brincadeiras eróticas com outro garoto de idade próxima à sua existia a experimentação de sensações agradáveis do estar junto, que ganha dimensão de ternura e envolvimento. A experiência foi tão significativa ele lhe atribuiu condição de início da vida sexual: "Eu comecei a minha vida sexual aos 7 anos, com um amiguinho meu que tinha 6 anos". A experimentação do contato entre corpos era algo que proporcionava sensações agradáveis - "era gostoso" -, porém, ao serem flagrados pelos pais naquilo que hoje Thiago chama de "relação sexual", ambos foram severamente advertidos e impedidos de manter contato. A reação dos pais está vinculada aos referenciais por eles aprendidos e apreendidos ao longo de suas trajetórias no âmbito da sexualidade (Bozon, 2004, Nunes \& Silva, 2006).

Mariana também descreve uma passagem desta experiência de sensações, não a partir de um contato genital, mas da expressão afetiva quando acontecia o abraço entre ela e os primos mais velhos que passou a perceber aos 12 anos. Foi nesse contato com os primos que ela experimentou sensações prazerosas e que passou a buscar explicações e respostas: "Você percebe, não entende... (...) 'Puxa, isso é bom'. Não é o sexo que você aprende na escola". Mariana faz referência aos conteúdos formais dados na escola, que geralmente fazem parte do currículo da disciplina de Biologia, que trata a sexualidade quase sempre em uma perspectiva especificamente fisiológica. Nesta passagem de Mariana, a idéia dos roteiros sexuais e de gênero torna-se útil para a compreensão do papel do contexto social no fornecimento de sentidos para a vivência afetivo-sexual enquanto algo que vai além do entendimento, mas é algo percebido e vivenciado.

Seguindo uma perspectiva em que existia o incentivo social para o contato com seus pares, Sofia descreve uma passagem que aconteceu quando tinha 14 anos, o seu primeiro beijo: "Eu achava que as pessoas em volta cobravam isso de mim, de certa maneira, indiretamente acho que cobravam de mim. (...) A situação que eu convivia, sabe, as pessoas 
perguntavam e as pessoas comentavam como era, e eu não comentava porque eu nunca tinha beijado". Sua motivação decorria do fato de seus pares já terem experimentado o beijo, e ela não, revelando a necessidade de corresponder aos códigos e condutas do meio social na constituição do seu roteiro sexual: "A primeira sensação que eu tive foi ruim, porque eu não gostei daquilo, eu fiquei meio pressionada, assim, sem saber para onde ir, sabe, porque foi numa situação constrangedora. Mas depois que eu beijei, eu gostei de beijar (riso). Aí eu fiquei beijando, assim, acho que ele, sei lá, acho que nossos beijos combinaram e aí (riso)... por isso, eu gostei assim". Aquilo que era estranho a princípio torna-se algo familiar e desejado no roteiro de Sofia.

Nos primeiros contatos dos colaboradores no meio social mais amplo, entendido aqui como extra-familiares, mais especificamente na escola, os roteiros sexuais e de gênero são colocados em tensão e reelaborados, mediante a experimentação do contato com o outro e os desdobramentos de regras e valores do meio social. É perceptível que a restrição - ou desestímulo - direcionado às colaboradoras ao contato com conteúdos da sexualidade é maior do que acontece com os homens que, mesmo "autorizados" logo nos primeiros anos do desenvolvimento, associam a sexualidade com a "culpa" e com o "estranhamento" na prática da masturbação. No conjunto das colaboradoras, apenas Sofia refere-se à masturbação de forma positiva, mesmo quando a prática perde o seu encantamento, ao saber formalmente sobre ela por meio de uma revista voltada para o público juvenil feminino. A culpa também é algo associado à masturbação por Mariana, sendo que Melina não faz referência ao tema.

A masturbação é uma prática há longo tempo é perseguida e combatida por ser uma prática realizada solitariamente e não em pares (Foucault, 2001; Laqueur, 2001), tendo como base a idéia das igrejas de que o casamento legitima o sexo (Werebe, 1998). Como pontuado por Bozon (2004), os valores e normas sexuais é que servem de marco regulatório do que é "bom" ou "ruim", "certo" ou "errado", o que é permitido e o que é interditado, servindo como guia para interpretação do comportamento, auxiliando os indivíduos a se posicionarem e tomarem decisões em situações complexas. 


\section{A escola como referência de roteirização}

Eu tinha um monte de assunto que eu não podia falar e esse [o sexo] era mais um desses... (...) [Eu] era tido como o mais distante, o mais fechado, então nem falava nisso. (...) ...Quando eles falavam disso, eles sabiam que eu não ia comentar, então, nem me perguntavam, nem me colocavam na roda e... foi assim (Jorge)

A gente conversava um pouco, mas também era bastante complicado, porque se você é adolescente, (...) se você comenta muito de sexo, ou é porque você está a fim, ou porque já fez, então, você não pode falar de sexo porque você está com vontade e tudo mais (Melina)

As minhas primeiras informações sobre sexo eu, de fato, aprendi na escola, eu acho que na aula de ciências. Nas aulas você aprende sobre o que é, pra o que que serve, né, o uso de camisinha, quais são os outros contraceptivos. Não se fala... (riso) do que é um ato de amor. (...) Fala como se fosse um ato mecânico, como se fosse um ato animal. (...) Como eu sou um animal, eu vou fazendo também. Mas pra que a gente não tenha um monte de filhos como os animais, então use esta... (riso) pílula. (...) E agora que eu descobri que tem muita coisa na sexualidade (Mariana)

Os colaboradores pouco trazem de referências diretas sobre a escola na fase de suas em que entraram na adolescência. Em seu depoimento, Jorge mantém aquele perfil referido por ele quando da sua passagem no início do ensino fundamental em que percebia-se tímido e com tendência ao isolamento. No tocante à sexualidade, manteve a postura de protelar o contato, ao menos de maneira direta. Na mudança para outra escola, passa a fazer parte de um grupo que ele denominou de "meio nerds todos envergonhados". O senso de pertença ao novo grupo fica mais forte a partir da postura compreensiva dos pares, que não ofereciam pressão para a forma de ser, de permanecer no silêncio, porém, apreendendo novos referenciais. 
Melina também tinha em seus pares a referência sobre os códigos e condutas acerca da sexualidade e do gênero, porém, pelo fato de ser mulher, a forma de se posicionar diante do grupo exigia uma forma de silêncio - ou de negociação -, para que não se tornasse desvalorizada diante dos colegas. Esta característica do roteiro de gênero é comum nas sociedades ocidentais, na qual a representação da mulher é de passividade, cabendo ao homem a atividade de assumir e determinar o papel e desempenho de cada um dos parceiros nas atividades sexuais (Parker, 1993; Werebe, 1998; Bozon, 2004). Tais características, como afirma Bozon (2004), tornam implícitas representações associadas à reprodução e à sexualidade na construção tradicional dos gêneros, por serem

(...) experiências e representações mais universais da 'objetivação' simbólica das mulheres. O corpo das mulheres é percebido e tratado como um objeto e um receptáculo, de que os homens tomam posse através do ato sexual. A repetição dos atos vale a confirmação inicial. E a objetivação sexual das mulheres é que permite aos homens tomar posse da descendência trazida por elas (p.30)

Deste modo, no roteiro de gênero feminino tradicional, cabe à mulher preservar-se, o que significa restringir o seu acesso ao território da sexualidade e seus prazeres. Melina descreve uma cena em que isso fica patente quando tentou se aproximar de uma colega, acreditando ser possível um diálogo: "Eu tinha vontade de falar com as pessoas em casa, mas não podia de jeito nenhum, porque era tabu. Na escola, com as amiguinhas, poderia ser uma coisa 'light', mas não foi. Conversei, perguntei para as minhas amigas se elas faziam, mas elas falaram que não faziam. Teve uma que ficou horrorizada (riso), que até hoje eu penso: 'Como será a vida sexual da Camila', né, 'se naquela época pensava assim, imagina hoje!"'. Neste trecho do depoimento de Melina destaca-se a representação de que é valorizada em uma mulher a preservação e o não acesso ao universo da vida sexual. Melina lança dúvidas sobre como seria a vida de Camila nos dias atuais dada a sua postura distanciada dos temas da sexualidade. Ainda no tocante aos referenciais para o roteiro de Melina, as revistas voltadas para o público adolescente feminino foram importantes para ampliar significados e sentidos para a sexualidade, o que é citado por Melina como mote para buscar informações nos relacionamentos sociais. Foi quando percebeu que a abertura dada pelas revistas voltadas para os jovens não era a mesma abertura encontrada no seu contato com os pares. Melina percebe que a flexibilização é algo fundamental para a manutenção do seu lugar no meio social, sendo 
que em determinados momentos o diálogo sobre a sexualidade torna-se possível, sendo que em outros impera o impedimento.

A representação de Mariana é mais direcionada para o aprendizado formal de referenciais, ressaltando aspectos biológicos e contraceptivos no âmbito da sexualidade. Dada a mecanicidade da apresentação do conteúdo sobre sexualidade no meio escolar, Mariana associa, em tom irônico, que a mensagem transmitida é a do exercício da sexualidade humana pareada com a sexualidade animal. Esta mensagem, no passado, funcionou como alicerce para a idéia de que a sexualidade, por fazer parte do aspecto irracional do homem e da mulher, era algo que precisaria ser domado, justificando o controle sobre os corpos e prazeres. Nesta perspectiva naturalizada e instintiva, o caminho do animal racional humano é o conhecimento sobre a fisiologia e os métodos contraceptivos. No seu convício social, Mariana afirma que passou a perceber a sexualidade enquanto algo positivo e humanizado, atribuindo outros sentidos ao conteúdo aprendido na escola: "Você percebe que: 'Puxa, isso que é bom', né? Não é o sexo que você aprende na escola, né, mas você vê que: 'Não, eu não posso fazer', né, 'Eu não posso...', não é assim, né? Você começa a tentar achar algumas respostas, mas em certa medida, você busca em qualquer lugar, eu... eu acho que é algum meio de começar a orientar...". Neste sentido, Mariana lança-se à descoberta e à ampliação de possibilidades em seu roteiro sexual e de gênero.

Mariana chama a atenção em seu depoimento para o fato de não se falar de sexo como uma possibilidade a mais de expressão de afeto e ternura, ou seja, a escola não proporciona espaços de diálogo e reflexão sobre o exercício da sexualidade numa perspectiva ética e cidadã, privilegiando aspectos biológicos e fisiológicos. Esta mesma carência, de forma não explícita, é evidenciada por Jorge e Melina. Deste modo, a escola é percebida pelos colaboradores como um lugar em que a referência se dá predominantemente no sentido do aprendizado formal, privilegiando informações de conteúdo biológico e contraceptivo. Por outro lado, a interlocução e convivência com os pares é importante meio para a apreensão de códigos e condutas, fornecendo sentidos e significados, imprimindo em roteiros formas particulares de representação sobre a vivência da sexualidade e relação entre gêneros.

Ribeiro (1990) propõe que, no âmbito escolar, os aspectos fisiológicos sejam englobados, porém, como desdobramento da compreensão da sexualidade a partir do enfoque psico-sócio-cultural. Nesta proposta, o caminho adotado é de partir das 
(...) raízes subjetivas do comportamento sexual com os fenômenos sócioculturais que determinam a atitude do indivíduo frente à sexualidade, com o desejo, com a repressão e com a culpa. A parte anátomo-fisiológica é inserida nesse contexto para esclarecer o jovem, ampliar o seu conhecimento ou tirar suas dúvidas (p.2).

Deste modo, são privilegiados o senso crítico e o estímulo do jovem para encontrar possibilidades no lidar com seus questionamentos e angústias sobre o sexo e a sexualidade. A implementação da proposta de Ribeiro (1990) perpassa uma rede social complexa e que nem sempre oferece subsídios para as pessoas terem a autonomia sobre a própria sexualidade.

Vaccari (2002) faz um aprofundado estudo sobre o papel da escola na promoção da saúde sexual e relações de gênero a partir da representação de adolescentes sobre masculinidades e feminilidades. Em seu estudo, a autora pontua que a escola, sendo inserida num momento histórico-cultural específico, é um desdobramento do que a sociedade ou grupo se propõe, não sendo um fim em si mesma. Neste sentido, ela aponta a importância da promoção da saúde sexual no contexto da educação formal ter a participação de famílias, movimentos sociais, mídia, entre outros, sem que a responsabilidade deste papel recaia apenas sobre a escola, compreendida como uma instituição a serviço da sociedade, com a responsabilidade, seguindo Freire (1987), de apresentar o mundo às novas gerações.

Seguindo a perspectiva de Ribeiro (1990), Petchesky (1999) lança questionamentos acerca da tendência em manter um discurso ideologizado da sexualidade, dissociado de questões complexas e presentes do âmbito social:

Como seria possível haver uma verdadeira autonomia para tomar decisões sobre sua própria sexualidade sem plena informação sobre o sexo seguro, a sexualidade, o próprio corpo, os métodos contraceptivos e as maneiras de evitar as doenças sexualmente transmissíveis? Como será possível atingir a saúde sexual sem acesso aos métodos preventivos, aos cuidados e aos serviços de boa qualidade? Como será possível a diversidade habitacional se há falta de habitação decente, sem um lugar ou um espaço íntimo? Mais profundamente, como será possível a diversidade sexual e a eqüidade de gênero sem uma 
revolução cultural na qual a sociedade, os meios de comunicação e as instituições considerem 'as mulheres' e 'os homens'? (p.33)

A viabilização da educação sexual, enquanto tema transversal, assim como estabelecido nos Parâmetros Curriculares Nacionais - PCN -, carece da participação da coletividade para a transformação do espaço escolar no sentido da promoção do exercício da ética e da cidadania, incluindo aspectos relacionados à sexualidade e gênero enquanto realidades presentes no meio social que vão além da base biológica e dos métodos contraceptivos.

\section{O enamoramento e a vivência dos roteiros sexuais}

...Nos conhecemos aqui na faculdade, (...) e eu ainda não me aceitava como eu era, até no começo desse ano. Daí eu comecei a querer namorar ela, eu achava ela bonita, eu queria... sei lá, eu queria ficar junto com ela. E aí que a gente ficou um tempo. Eu falei que eu sentia por ela. Eu gostei muito dela, e ela correspondeu, e a gente começou a namorar (Thiago).

Ainda é um pouco confuso na cabeça. (...) A gente fazia sexo oral e... brincava. (...) Passou aí um ano de namoro, a gente já fazia de tudo isso e... com uma certa constância. (...) A gente estava os dois descobrindo juntos. Não foi só... só uma coisa... E era o único meio, porque não rolava transa por... pela parte dela (André)

Porque se meu psicológico já estava liberado nessa época e eu já tinha também passado um tempo considerável, e eu também estava disposta mais a curtir, a viver, então assim, com o fato de você estar bem, estar bem com a vida, aí as coisas fluíram, foi mais fácil e foi mais prazeroso (Melina)

Eu nunca fui de namorar, sabe, eu nunca gostei muito disso, assim. Eu queria, mas eu não conseguia namorar. (...) Sempre foi uma coisa meio assim, meio distante, nunca foi uma coisa afetivamente próxima (Sofia)

No namoro tudo era novidade e tudo... deixa a gente atraída, tudo dá tesão, enfim, tudo fica fácil. Depois de casado, eu já acho que fica um pouco mais complicado. (...) Acho que é uma pressão social se sentir na obrigação de [a mulher] estar sempre fazendo sexo com o marido, por mais que ela não tenha vontade. E eu passei por essa situação (Mariana) 
A fase do enamoramento marca para os colaboradores e colaboradoras o início do contato com o outro, a descoberta de possibilidades, a troca de afeto, além de ser campo fértil para a resignificação dos roteiros sexuais na perspectiva dos roteiros sexuais e de gênero, Gagnon (2006), afirma que nesse período:

(...) a ênfase recai sobre os processos psicossociais e as situações históricoculturais, que dão sentido ao comportamento, permitem a integração e a reorganização das informações e habilidades aprendidas em etapas anteriores do ciclo de vida e, a rigor, despertam num organismo pouco especificado as respostas culturalmente apropriadas a situações inéditas (p.124).

Vale a ressalva do autor de que na teoria dos roteiros a trajetória das pessoas não tem um caráter seqüencial marcado pelo uso tradicional do padrão que engloba a primeira infância, infância, adolescência, maturidade e velhice, sendo que existe uma gama de contextos socioculturais e históricos que oferecem referências de aprendizado para os estágios do desenvolvimento. $\mathrm{O}$ aprendizado acontece naquilo que é ensinado, naquilo que é observado, e naquilo que é inferido ao logo da vivência da pessoa com o meio social.

Jorge apresenta uma peculiaridade no seu namoro que torna-se exemplar na contemporaneidade no que diz respeito aos relacionamentos virtuais. Por este motivo este tipo de relacionamento será retomado em um tópico específico.

O enamoramento de Thiago teve início quando ingressou na universidade, com o desejo de ficar junto e pela beleza da colega de curso. Este desejo de ficar junto, de caráter afetivo, não era proporcional à atração física, de caráter sexual, menos intensa. O sentimento despertado nele quando se relacionavam sexualmente era de não realização, que se potencializava ao recordar-se da vivência sexual com outros homens: "Ia ser difícil realmente, por que eu estava sufocado, (...) era como se não estivesse sendo eu mesmo, parece que tinha algo que faltava". Transparece no depoimento de Thiago o quanto foi significativo o envolvimento afetivo, mesmo que não acompanhado do desejo sexual, o que foi percebido ao longo do tempo. O relacionamento era sobremaneira lastreado no afeto, a ponto de não ter sido foi rompido, mesmo Thiago revelando à namorada sua homossexualidade. 
Nota-se que o roteiro de André segue a perspectiva da dúvida e da angústia, sentimentos quase sempre presentes na sua trajetória, ganhando sentido naquilo que ele chama de "confusão". O discurso dele sobre sua vivência afetivo-sexual, há delimitação entre a vivência afetiva e a sexual. Tamanha é a intensidade da auto-crítica quanto ao seu comportamento e atitude que suas observações quase sempre têm conotação de reprovação. Esta situação contribui para aumentar sua angústia, tornando ainda mais escassas as possibilidades de vivência afetivo-sexual. No seu primeiro namoro, com Beatriz, afirma que ambos foram movidos pela curiosidade e pelo "tesão". Mesmo não mantendo relacionamento sexual com intercurso, respeitando o desejo de Beatriz, a experiência de André remete à reflexão sobre a relação de gêneros, sendo que o homem permite-se avançar mais para a vivência sexual, ao processo que a mulher tende a protelar mais essa vivência.

A auto-cobrança pela vivência sexual, sem deixar abalar sua auto-estima, aconteceu por volta dos 17 anos, quando veio morar em São Paulo. A experiência foi com uma garota de programa que André encontrou na internet. Enquanto o afeto restringia-se à sua relação com Beatriz, o sexo foi com a garota de programa. Assim, da mesma forma que ele não reconhece seu primeiro namoro com Beatriz como um marco na sua experiência, ele também não considera sua primeira relação sexual com a garota de programa como um marco na sua vida sexual. Após ter feito sexo com a profissional, ele sentiu "uma sensação estranha, não parecia que eu tinha transado" Considerando o momento de vida que atravessava, ele reconhece que a pressão sobre ele quanto à aprovação no vestibular, atrelada à sua frustração quando do seu ingresso, contribuiu para um estado de não-sentir: "Eu acho que eu já tava fechado (...), então acho que eu não senti nada". Ele descreve a experiência como algo "rápido", "estranho", "seco", "engraçado". Na perspectiva dos roteiros sexuais, André considera importante o encontro com uma mulher em uma situação sexual, mesmo que não estivesse envolvido afetivamente, pois não terá que prestar contas a ela: "Foda-se o que ela vai pensar de mim, ela está sendo paga. Ela tem que pensar no dinheiro". O roteiro de iniciação sexual de André parece corresponder ao contexto predominantemente conservador. Passados 6 meses da experiência com a garota de programa, André teve a sua primeira experiência sexual com Beatriz. Assim, ele foi para a relação com Beatriz como um “iniciado", legitimando seu papel dominante na relação, em termos de experiência.

A concepção de gênero norteia a vivência de Melina com o sexo oposto, quando refere-se ao termo "ficar". Castro, Abromovay e Silva (2004) mostram que o "ficar" está 
associado ao desejo de se relacionar de maneira própria e representa um meio de experimentação para o questionamento dos roteiros de gênero. Por outro lado, os autores pontuam que o "ficar" também é uma forma de legitimar uma racionalidade vigente daquilo que é próprio do homem e próprio da mulher. Isto é visto no depoimento de Melina quando diz que o "ficar" não é algo esperado no comportamento de uma mulher. O contrário acontece no caso dos homens, em que "ficar" é não só esperado, mas também estimulado, como aponta Melina: "Para eles [os homens] é você beijar e já ir para a cama". A fala de Melina remetese àquilo que se apresenta no imaginário social, de que quanto mais cedo se der a iniciação do homem na vida sexual, mais experiência e eficiência os rapazes levarão para a vida adulta em uma perspectiva da "naturalização" de fazer sexo (Castro, Abromovay \& Silva, 2004).

Neste momento da vida, Melina sentia-se mais livre para o envolvimento efetivosexual: “já tinha também passado um tempo considerável, e eu também estava disposta mais a curtir, a viver, então assim, com o fato de você estar bem, estar bem com a vida, aí as coisas fluíram, foi mais fácil e foi mais prazeroso". Este sentimento favorecia sua aproximação do outro. Foi quando começou seu namoro com um rapaz, aos 15 anos. Dois anos mais tarde, conheceu Pedro, seu atual noivo, com quem iniciou sua vivência sexual. Ao longo do desdobramento da relação, as marcas deixadas pelo abuso sexual ficavam mais evidentes, gerando reações angustiantes em Melina: “Toda a vez eu chorava. (...) Uma forma, ou um toque, era o mesmo toque que a pessoa fazia. Então, estava o maior clima legal, mas quando eu me sentia tocada de uma certa forma e já vem tudo aquilo na cabeça". Aquilo que havia sido incorporado aos seus roteiros intrapsíquicos passam a nortear atitudes e sentimentos com seu noivo. Com o passar do tempo e da vivência com Pedro, a relação dialogada e o prazer sexual vão sendo incorporados como algo possível dentro dos roteiros sexuais de Melina e ela passou a ter uma vida sexual ativa e prazerosa com Pedro.

Sofia traz em seu depoimento um sentimento de não seguir padrões hegemônicos, a exemplo de não se perceber bonita, ou mesmo interessante: "Eu era tipo meio louca, sabe, sei lá, eu ficava fazendo... eu fugia um pouco dos padrões de beleza”. Ela foi a colaboradora que mais trouxe detalhes de sua vivência afetivo-sexual, mas, nem por isso, esta temática para ela é livre de conflitos: “...eu nunca fui de namorar, sabe, eu nunca gostei muito disso, assim. Eu queria, mas eu não conseguia namorar". O roteiro de Sofia mostrava-se restrito ao envolvimento afetivo-sexual; porém, por um sentimento de pressão social, ela se lançava à experiência. Mas o arrependimento a acompanhava depois da experiência, quando percebia 
que o rapaz tinha feito coisas além daquilo que ela havia imaginado. Foi quando ela passou a freqüentar festas e a ficar com diferentes parceiros, no que ela se refere como: "uma época que eu despiroquei, mesmo, eu surtei". Esta experiência de estar com o outro não lhe despertava sentimento de tanta proximidade afetiva: "sempre foi uma coisa meio assim, meio distante, nunca foi uma coisa efetivamente, assim, é... próxima. Nunca tive muito proximidade, assim, sentimentalmente falando". Sofia descreve seus curtos namoros, dentre eles ela destaca aquele que aconteceu com Diego, que durou 3 dias, e o que aconteceu com Kadu, que durou 2 meses.

Esse período de "despirocar" $" 50$ foi um momento de aprendizado, em que ela se permitiu interagir com o outro. Com Diego, era estimulante para ela o fato de namorar um rapaz cortejado na academia que freqüentava rendia-lhe certo status junto às outras colegas. Isso lhe despertava certa excitação, que lhe despertava sentimento de atração. Sofia mostra em seu depoimento que as formalidades geram estranhamento, a exemplo de quando Diego foi até sua casa pedir-lhe em namoro. A resposta dela foi um "sim", por que "não tinha como dizer "não", e porque "achava ridículo eu falar: 'sim, estamos namorando"'. Para Sofia, o "estar namorando" era mais importante do que uma convenção que selaria aquilo que já acontecia.

Sofia relacionava-se mais na sua fantasia do que na realidade, pois buscava distanciarse do outro quando sentia qualquer ameaça: "eu acho que eu sou agressiva, olha que isso é uma característica minha". A hostilidade manifesta não favorecia gestos como trocar carinho. Embora o relacionamento com Diego fosse bom, não era algo que a levasse querer ir além do "ficar": "eu gostava de ficar com ele, até gostava de beijar ele, (...) mas eu não queria intimidade com ele. (...) O que as pessoas quando namoram fazem: dividem a sua intimidade. E eu não queria isso". Quando, no $3^{\circ}$ dia de namoro, em lugar daquela atração inicial passou a sentir repugnância, ela rompeu o namoro.

No depoimento de Mariana também fica evidenciado o roteiro de gênero, sendo a mulher aquela que precisa se resguardar da vivência sexual, dada a perspectiva conservadora de sua família. Por outro lado, a curiosidade, o desejo e a disponibilidade para o envolvimento afetivo-sexual foram base para que iniciasse seu primeiro namoro. Nele, houve possibilidade

\footnotetext{
50 "Despirocar" refere-se ao "fazer perder ou perder a razão; endoidar, enlouquecer, pirar", também podendo significar "agir de modo estranho, descontrolado ou fora do seu padrão habitual; baratinar" (Houaiss, 2001).
} 
de a troca de carícias avançar para o ato sexual com penetração, porém, dado seu roteiro naquele momento, o "medo" e o "pavor" predominavam e ela interrompeu o desdobramento do encontro. Mariana aponta a falta de informação como justificativa para esta reação. A informação neste caso não se restringe apenas ao conteúdo formal, mas também ao vivencial, pois naquele momento e situação o ato sexual não lhe fazia sentido. Diante da negativa dela, o namorado rompeu o relacionamento com ela, mas, transcorrido um ano, ele a procurou novamente e reataram. Mariana pontua que ele sempre queria "avançar o sinal", e, para ela, aquilo "era uma ofensa", pois era indicativo de que o rapaz queria apenas sexo com ela.

Na perspectiva de Mariana, o relacionamento no namoro é mais tranqüilo do que no casamento. Neste caso, “depois de casado, eu já acho que fica um pouco mais complicado. Você tem que se espelhar na mulher, que se sente um pouco na obrigação de estar sempre com o parceiro como mulher, como esposa, (...) às vezes se sentir na obrigação de estar sempre fazendo sexo com o marido, por mais que ela não tenha vontade. E eu passei por essa situação, né?". Assim, no casamento a situação torna-se mais tensa, dado o comprometimento entre parceiros. Agora, a mulher não mais sinaliza os limites do "avançar o sinal", mas embora tenha consciência do sinal, ela deve preencher as expectativas do parceiro, além de corresponder à sua percepção do que é uma "boa esposa". Assim, mesmo sem desejo, aceita relacionar-se sexualmente com o parceiro, a fim de corresponder a um roteiro de esposa. Neste sentido, Mariana percebe os diferentes papéis e os diferentes roteiros ao longo da trajetória, a Mariana-namorada e a Mariana-esposa, sendo o peso mais sentido nesta última.

A partir dos relatos dos colaboradores, o enamoramento é percebido como um momento de ampliar horizontes que desperta os mais variados sentimentos, desde os de confusão, pavor, medo, até os de descoberta, fluidez e prazer compartilhado. O peso da diferenciação na construção dos gêneros é observado de forma mais contundente nos primeiros contatos afetivo-sexuais. Porém, mediante este novo universo, os roteiros sexuais e de gênero entram em tensão com aquilo apreendido e aquilo que se apresenta, contribuindo para a resignificação do que é ser homem e do que é ser mulher, e nas diferentes formas de interlocução. A tensão gerada pela vivência com o outro contribui também para a apreensão de novos significados no mapeamento de sensações e sentimentos.

Estes contatos com o outro são os mais diversos conforme vistos nos depoimentos. No sentido de invenção e de reinvenção de novas possibilidades de contato, Jorge apresenta uma 
forma singular de namoro em que a internet se apresenta como um recurso para a sua experiência não só no namoro, mas como referência para a formação identitária.

\section{A internet e a vivência afetivo-sexual}

Achei mais interessante o texto, porque o texto contava a história inteira, tudo o que acontecia, e tinha também a parte das emoções, não era só imagem. (...) E achei até mais interessante o texto (...) porque contava a história inteira, tudo o que acontecia, e tinha também a parte das emoções, não era só imagens. Tinha o que eles estavam pensando, o que eles diziam, durante, antes... Eu achei aquilo fantástico! Eu achei muito melhor do que uma imagem (Jorge)

Vídeo pornô vem da internet. Antes eu pegava mais, sei lá, era adolescente, 14 anos... Tinha mais foto, naquela época. (...) Era essa informação sexual, mesmo, que eu tinha, sem ser com sexo, mesmo (André)

Foi fácil encontrar o grupo, na internet tem alguns grupos. (...) Aí que eu comecei a me perguntar porque que eu não queria assumir, então, foi uma imagem que eu estava construído para mim mesmo que aquilo seria uma coisa meio que de fraqueza, ou alguma coisa assim, que eu tinha passado antes e também porque eu, antes disso, eu estava num grupo evangélico. (...) Eu conheci e entrei no e-groups de jovens de homossexuais para estar fazendo amizades, porque até então todos os meus amigos eram héteros, e algumas coisas não davam para conversar muito bem com eles. Aí, então, eu conheci pessoas com uma cabeça diferente... (Thiago)

A internet é um novo recurso na contemporaneidade que amplia horizontes e possibilidades para as relações humanas, por ser constituída pelos mais diversos segmentos socioculturais. Enquanto um recurso a mais na comunicação, a internet possibilita o contato com outras pessoas por meio do hipertexto - conferido principalmente nas salas de bate-papo - e o acesso a textos, imagens, filmes, com os mais variados assuntos. Não me deterei aqui em aprofundar nas vantagens e desvantagens deste meio de comunicação, ou mesmo na veracidade das informações veiculadas na internet. Por outro lado, conforme apontam os depoimentos, o acesso à internet contribuiu para a apreensão de referenciais e serviu de palco para a 
experimentação de modo-de-ser por meio de personagens criadas para interagir com outras personagens. Mais especificamente na comunicação por meio de hipertexto, Castro (2006) realiza um estudo sobre aquilo que denominou "persona on line" e sobre como a linguagem hipertextual nas salas de bate-papo constrói múltiplas identidades sem risco de uma atuação "ao vivo". A autora apresenta a plasticidade da identidade nesse meio:

(...) na infinita possibilidade de se criar e mudar de identidade, tanto quanto se queira, esse território demonstra a multiplicidade de personae, que se autoconstróem, se desintegram, para se construírem novamente, por meio de roteiros aprendidos e apreendidos dos papéis sociais (p.231-2, grifo da autora).

Neste sentido, real e virtual, em termos identitários, interagem entre si, sendo que no virtual existe a suspensão do contato presencial, possibilitando ensaios ou experimentações no contato com o outro, contribuindo para a formação de comunidades virtuais.

A internet pode funcionar como uma trincheira de resistência e sobrevivência, conforme descrito por Castells (1999), de atores sociais que se encontram desvalorizados e/ou estigmatizados pela lógica da dominação dadas as suas posições/condições. Esta perspectiva vai ao encontro dos dados da minha pesquisa de mestrado (Toniette, 2003), nos quais a internet foi significativa para um militante homossexual ampliar formas de (com)vivência, inclusive no plano presencial, revelando a possibilidade de aceitação e de acolhimento de identidades. Deste modo, como conclui Castro (2006), as salas de bate-papo da internet constituem território fértil para a associação entre linguagem, sexualidade e identidade, abrindo possibilidades de vivências múltiplas em que estão presentes códigos sociais aprendidos e apreendidos.

Nos depoimentos de Jorge, Thiago, e André, a internet funcionou como um recurso importante para a obtenção de referências no âmbito da sexualidade. Dado a internet ser um meio em que a publicação de informações é livre para qualquer pessoa que tenha acesso a este meio, é válido que o seu conteúdo passe por crítica e reflexão. A partir de um estudo de conteúdo de textos e orientações publicadas na internet voltada para o público jovem, Facchini, Maia e Maia (2004) apontam que os temas são tratados de forma superficial, não promovendo a devida informação e reflexão, mas sim visões distorcidas e até preconceituosas a partir de estereótipos e concepções sexuais vigentes. Todavia, a internet, enquanto criação 
social, carrega consigo os códigos sociais vigentes em diferentes contextos socioculturais, o que justifica o debate e a reflexão sobre seu conteúdo. Da mesma maneira que este meio oferece referenciais educativos e significativos, também pode oferecer referenciais que legitimem sentidos enviesados ou negativos com relação à sexualidade e aos gêneros, opostos a uma perspectiva ética e cidadã, de conscientização do sujeito sobre a sua própria condição e sobre a sua sexualidade.

O depoimento de Jorge revela o quanto este recurso pode ser um poderoso meio para o desenvolvimento dos roteiros sexuais e de gêneros. A princípio, a curiosidade de Jorge se voltava para as figuras eróticas e, aos poucos, essa curiosidade passou a envolver os textos que, por sua vez, ampliavam os sentidos das imagens, fornecendo referências para o pensar, $o$ sentir, e o agir, no universo da sexualidade e do gênero, incentivando o diálogo ao confrontar suas crenças e valores.

Apesar de Jorge compartilhar de forma visual a experiência da internet com o amigo, ele não compartilhava sentimentos ou impressões despertados a partir dos conteúdos acessados. Para Jorge, aquilo que estava sendo visto na internet tinha um sentido de algo proibido e, portanto, algo que deveria lidar com certo limite e pudor. Mas, aos poucos, conforme continuou o acesso à internet de maneira solitária, o sentido de algo proibido foi cedendo lugar a um sentimento de familiaridade: "olhar aquilo, para mim, (...) perdeu aquele impacto".

A internet contribuiu também para que Jorge desse novos rumos para sua idéia primeira de que o sexo é algo que despertaria por si quando fosse adulto. Incentivada pela curiosidade e cumplicidade do "amigo precoce" - aquele que despertava o senso de "ter sido iniciado" - e pelas referências do mundo cibernético, a tensão entre a razão e a emoção foi potencializada, favorecendo o abrandamento da associação da sexualidade com a proibição, assim, contribuindo para a resignificação do seu contato com o universo da sexualidade. $\mathrm{O}$ que antes era a idéia de que um filho era gerado depois de uma noite de sono de um homem com uma mulher, agora é desvelado a partir do referencial erótico que fornece novos sentidos de vivência. Além da infinidade de temas encontrados na internet, Jorge indica o papel dela enquanto referência para o universo masculino no que diz respeito à ampliação do acesso ao material erótico e/ou pornográfico que, no passado, era restrito a revistas masculinas. 
No depoimento de André a internet também é citada como referência no roteiro sexual e de gênero, por meio de imagens e filmes pornôs. André também associa essa atividade à aura de proibição ou mistério, tão contundente no depoimento de Jorge. Ele pontua que os aspectos formais para o aprendizado da sexualidade, a exemplo do uso da camisinha, aconteciam no âmbito escolar, sendo que sua mãe também se dispunha para o diálogo sobre o assunto. Contudo, André diz que a conversa com os pais, inclusive na esfera sexual, era superficial, o que o impulsionava para a apreensão de significados e sentidos acerca da sexualidade em outras instâncias, com parentes, amigos e internet. André destaca os filmes eróticos como forma de contato no âmbito da sexualidade: "quando a gente é jovem, homem, é sempre assistindo a filme pornô", revelando um aspecto da construção do gênero masculino.

A internet foi um dos meios que contribuiu para a constituição dos roteiros sexuais e de gêneros não só a partir do material publicado, mas também pelo contato com grupos, dentro da perspectiva de rede, fortalecendo identidades, favorecendo o contato com pares. Esta perspectiva fica evidenciada no relato de Thiago que aponta para uma carência de referências e de diálogo para compartilhar sua vivência. Os sentidos para sua experiência estavam eram atrelados à discriminação e ao preconceito pelo fato de não corresponder às premissas heterossexistas. Seu sentimento de solidão é atenuado quando passa a acessar a internet na busca de pares e de outros referenciais que fizessem sentido para sua vivência. Como visto no relato de Jorge, a internet, além de ser um meio para a resignificação e ampliação de roteiros, contribuiu para que Thiago encontrasse pares por meio do Orkut e de grupos de discussão e de apoio específicos do meio GLBTTs, favorecendo a sua identificação, e fortalecendo o senso de familiaridade e de pertença, e fornecendo novos contornos para sua identidade.

O Orkut e os grupos de discussão da internet possibilitam o acesso a comunidades. O sentido do termo "comunidade" compreende aquilo que está associado ao "estado ou qualidade das coisas materiais ou das noções abstratas comuns a diversos indivíduos", e também tem o sentido de "um conjunto de indivíduos organizados num todo ou que manifestam, geralmente de maneira consciente, algum traço de união” (Houaiss, 2001).

Thiago passou a questionar-se sobre os sentidos do seu sofrimento enquanto desdobramento de mensagens negativas sobre sua homossexualidade. Além das mensagens negativas com que teve contato desde a infância, Thiago destaca as de quando da sua 
participou em um grupo evangélico. Ele diz que a igreja foi um importante lugar para o exercício da fé, mas não se sentia acolhido e apoiado com relação à sua sexualidade.

Para Thiago, as comunidades virtuais contribuíram para a sua auto-aceitação a partir do engajamento em atividades do grupo de jovens homossexuais, fazendo amizades e participando de discussões de assuntos que até então sentia-se impossibilitado de discutir com seus "amigos héteros".

Thiago aponta para o papel do avanço tecnológico da internet na vida das pessoas: "Hoje, você não precisa sair de casa, você pode entrar em contato naquele momento com pessoas que estão distantes, com lugares, como grupos de discussão, como o chat”. Por outro lado, Thiago ressalta que o acesso intenso e prolongado às páginas da internet pode fortalecer o distanciamento dos relacionamentos presenciais. O anonimato é assegurado no mundo virtual, permitindo a experiência de compartilhar com os pares idéias e possibilidades de vivências. Esse compartilhar no anonimato adquiriu outros sentidos ao longo do tempo, dando espaço para a necessidade mais intensa do contato presencial com o outro: "Agora se você só fica virtualmente, pode ser ruim. É bom ter um diferencial, fazer alguma outra coisa junto. (...) Tem um excesso de informação danado, mas... acho isso legal na Internet, de ter contato com pessoas e também aprender muito". A internet pode funcionar, portanto, como um meio para o aprendizado de roteiros sexuais, apresentando possibilidades de vivência, mesmo que exista a tensão entre o virtual e o real - no sentido presencial - sendo que existem regras específicas nestes dois universos que não necessariamente são compatíveis, a exemplo do anonimato.

Retomando o depoimento de Jorge, depois de ter contato com outras possibilidades de roteiros, ele passou a conhecer os jogos on-line, do tipo RPG, que permitem a interatividade entre jogadores do mundo todo. Aqui se mostra uma outra particularidade importante na perspectiva dos roteiros de gênero de Jorge. Ele deveria escolher entrar no papel de uma personagem, do gênero masculino ou feminino. A forma com que Jorge vestiu a personagem feminina, sob o codinome Larissa, foi tão intensa que os outros jogadores, homens e mulheres, acreditaram que realmente estavam dialogando com uma jogadora. $\mathrm{O}$ temor de ser descoberto só não foi maior do que seu desejo de continuar na ficção e experimentar a vivência, mesmo que virtual, de ser mulher. Sua fixação na personagem de Larissa foi tamanha que Jorge afirma que foi uma época em que vivia para jogo e, por conseguinte, para 
sua nova identidade virtual: "Ficou tão profundo o jogo na minha vida que era a parte principal, vida real, secundária”. Isto representou abrir mão de uma série de atividades no mundo real, sendo-lhe prioritário nessa época, como ele disse, comer e ir à escola.

A intensidade com que ele se rendeu ao jogo on-line, mostra a importância dos roteiros apreendidos nas imagens e nos textos eróticos a que Jorge havia tido acesso, aliados à constituição da nova identidade. De tão convincente, Larissa-Jorge recebeu cartão de "Valentine's Day" ${ }^{51}$ de admiradores de outros países. A vida real ficou cada vez mais em segundo plano, ao passo que a virtual cada vez mais se fortalecia diante das possibilidades que se apresentavam. $\mathrm{O}$ temor de ser flagrado por familiares quanto ao conteúdo erótico que tinha acessado na internet transformou-se no medo de ser descoberto, seja por representar o gênero feminino, seja pelo material erótico coletado entre textos e fotos.

Nos contatos que fez ao longo do tempo, Jorge conheceu uma jogadora americana, Raquel, com quem estabeleceu diálogo mais intenso e por quem sentiu desejo de se aproximar em termos afetivos. Com isto, ele reviu a ficção que vivia e optou por compartilhar a farsa com Raquel, mediante a possibilidade de ela se tornar a sua nova namorada virtual. Foi Raquel quem apontou a possibilidade de Jorge ser transexual. Temendo não ser mais aceito por Raquel, ele lhe enviou uma longa mensagem eletrônica sob o título "Demise" resposta, ela pediu que ele confiasse mais nela, sinalizando a possibilidade de manter o relacionamento. Jorge experimentou uma nova forma de perceber-se, fornecendo novos contornos para a sua identidade, o que culminou na "morte de Larissa" e o nascimento de "Jean-Luc". Depois de um ano de relacionamento, Raquel desapareceu, mas Jorge não entrou em detalhes sobre o rompimento da relação virtual. Ele sofreu como se fosse o rompimento fosse de um namoro presencial.

Agora como Jean-Luc, Jorge conheceu uma inglesa, com quem iniciou namoro. Jorge percebeu que não conseguia desempenhar satisfatoriamente o gênero masculino na nova personagem. Com o passar do tempo Jean-Luc-Jorge recebeu a mensagem dessa inglesa: "I

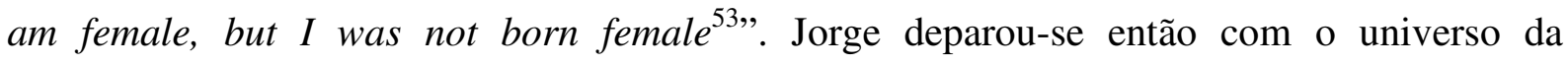
transexualidade em uma nova perspectiva. Isto aguçou sua curiosidade e ele passou a

\footnotetext{
${ }^{51}$ Do inglês, "Dia dos Namorados".

${ }^{52}$ Do inglês, "morte".

${ }^{53}$ Do inglês, "Eu sou mulher, mas não nasci mulher".
} 
pesquisar o assunto em profundidade. Identificou-se com esse universo, associando sua timidez e dificuldade de expor seu corpo em público à sua familiaridade com gostos e atitudes femininas, embasado na idéia de que "transexual nasce biologicamente homem e tem a mentalidade de mulher". Na travestilidade, os homens travestis comportam-se e se apresentam como mulheres, porém, não rejeitam sua condição biológica de homens e nem pensam mudar de sexo. Diferentemente da transexualidade masculina, a experiência é da pessoa estar no interior de um "corpo trocado", como uma "alma" feminina aprisionada em um corpo masculino (Picazio, 1991; Costa, 1994). Por sua vez, a transexualidade diferenciase da intersexualidade, ou hermafroditismo, que está relacionada com o desenvolvimento dos órgãos sexuais externos de forma dúbia, em que os dois sexos estão fundidos (Picazio, 1991; Costa, 1994).

No contato com a inglesa que desejava submeter-se à cirurgia de transgenitalização ${ }^{54}$, Jorge descobriu uma nova possibilidade: "Puxa! Se ela é, então é possível, funciona, dá prá consertar. Será que eu sou também?”. A questão que surge é quanto ao que Jorge gostaria de "consertar", seu corpo ou sua identidade. Mesmo que corpo e identidade sejam fatores que se inter-relacionam, fica evidenciada a tensão entre estes dois fatores. A partir da sua experiência, Jorge identificou-se com a categoria transexual, porém, no seu repertório, parece não existir a possibilidade de que o gênero masculino também pode comportar a sensibilidade, ou mesmo timidez, como com atributo. A transexualidade mostra ser uma possibilidade de ele trazer sua vivência virtual para o plano do real.

O que fica ressaltado na questão envolvendo a internet é o seu caráter de oferecer os mais diferentes recursos e referenciais e a possibilidade daquilo que Castro (2006) indicou como espaços em que se aniquila qualquer identidade ao desligar o computador, mas que torna-se espaço onde é possível vivenciar ou experimentar valores e condutas que a hegemonia social proíbe ou condena, de forma isenta de qualquer penalização. Por outro lado, a partir do encontro com o outro, o espaço virtual representa uma possibilidade a mais, que complementa as formas de comunicação entre as singularidades, mas não substitui as formas presenciais de relacionamentos. Valores, normas, condutas, roteiros sexuais e de gêneros são inventados e reinventados, sempre na existência social.

\footnotetext{
54 A transgenitalização consiste em um procedimento para a criação de uma cavidade vulvar neocolpovulvoplastia -, no caso de mudança de homem-para-mulher; ou de uma proeminência semelhante ao pênis - neofaloplastia -, no caso de mulher-para-homem, além de outros procedimentos complementares sobre gônodas e caracteres sexuais secundários (Brasil, 2002).
} 
No tocante ao papel da internet na ampliação de roteiros sexuais e de gêneros é interessante notar que somente os colaboradores homens fizeram referência a este meio, sendo que as colaboradoras não citaram a internet, mas sim, outros meios enquanto referências sobre o universo da sexualidade e do gênero, a exemplo da TV e revistas predominantemente voltadas para o público feminino.

\section{A mídia como referência para os roteiros sexuais e de gênero}

Então eu li bastante revistas quando eu era adolescente e tinha vontade de falar com as pessoas em casa, mas não podia de jeito nenhum, porque era tabu (Melina)

Eu achava que eu tinha o dom para despertar aquilo [sensações prazerosas a partir da auto-estimulação], aí um dia eu estava lendo uma revista, dessas de adolescentes, 'Capricho'... sei lá que revista que era, aí eu vi que chamava 'masturbação'. Aí eu até fiquei meio frustrada, assim, falei: 'Que pena, né?' (Sofia)

Eu também procurava informação em revista. Adolescente lê revista. (...) Você passa a revista, e você vê alguma coisa sobre sexo... você lê. Lembro que eu lia... acho que é Criativa... (...) Essas revistas tratam desses assuntos, (...) tipo mulheres que te ensinam a fazer, enfim... Com isso você acaba vendo, né, e fala... A curiosidade aumenta, né?"

"Tem um programa: 'Tudo sobre sexo com Dr. Drew', na TV à cabo, (...) que eu descobri agora, que fala só sobre sexo. (...) Eles conversam muito, ouvem relatos... relatos de casais, e deixam que eles falem também, e tentam falar em cima... então você acaba se encaixando em alguma história. É muito legal, eu acho legal (Mariana)

A mídia, aqui referida pelos meios impressos ou televisivos, foi citada pelas colaboradoras mulheres. Este meio de comunicação não foi citado de forma significativa pelos colaboradores homens, o vai ao encontro de Bozon e Heilborn (2006) que mostram que as revistas femininas são mais citadas pelas mulheres como fonte de informação do que os homens ao citar revistas masculinas. Por outro lado, isso pode estar relacionado com o mercado editorial oferecer mais revistas ao público jovem feminino do que ao masculino. 
Em sua pesquisa de mestrado sobre a questão do merchandising social nas telenovelas, Ali (2008) traz aspectos sobre os discursos ideológicos presentes nestas produções. O merchandising social, como parte da mídia, é compreendido enquanto um instrumento de educação para as massas com um suposto embasamento "científico", entremeado com a "arte" para preservar a manutenção da hegemonia e do status quo. O autor reserva uma parte da sua pesquisa para abordar o tema da sexualidade no merchandising social, apontando os fundamentos ideológicos da promoção de valores, normas e condutas dos meios televisivos. Neste aspecto, o autor indica que é a proposta da "educação" é o que justifica o merchandising social enquanto serviço prestado à população, onde a idéia de “comportamentos socialmente desejáveis pode se ocultar como manipulações normatizadoras, ‘conformadoras' e impositivas de suas subjetividades” (p.114).

Essa perspectiva pode ser ampliada para os meios midiáticos de forma geral. A mídia, mais especificamente aquela voltada para as questões da sexualidade, pode levar a informação, a exemplo das campanhas de prevenção do HIV/AIDS e das demais DSTs, mas também conteúdos que atendem a discursos vigentes na sociedade que não necessariamente correspondem a diferentes demandas das subjetividades. Um destes discursos seria o da medicalização da sexualidade, que concede elementos para o controle dos corpos e dos prazeres, difundido na mídia e nos mais diversos segmentos sociais, conforme pontuou Foucault, na História da sexualidade ${ }^{55}$.

Melina não fala de forma muito aprofundada sobre as revistas, mas ressalta que davam-lhe acesso a algo que não era conversado em casa por ser considerado tema tabu. Com as amigas o assunto também era restrito, o assunto visto que a regra do grupo era que garota que fala sobre sexo quer fazer. A fala de Melina é contundente no sentido de mostrar a carência de informação e diálogo sobre sexualidade de forma ampla, cabendo-lhe permanecer no silêncio a fim de que não ser desvalorizada diante do grupo, revelando uma faceta de como a sexualidade é constituída na inter-relação da pessoa com o meio social.

Sofia, em seu depoimento, atribuiu um sentido "mágico" à experiência das sensações provenientes da auto-estimulação, quebrado quando descobriu numa revista que aquilo era

\footnotetext{
${ }^{55} \mathrm{O}$ interesse principal era compreender a relação entre a sexualidade e verdade, poder e conhecimento, tendo como princípio norteador a construção histórica e social da sexualidade (Foucault, 2001).
} 
algo comum e se chamava "masturbação". Ela permaneceu por um período com sensação de "meio-nada-a-ver", quando se estimulava. Atualmente ela retomou a auto-estimulação e vem experimentando sensações agradáveis que não chama de orgasmo: "Está sendo bem melhor do que as minhas relações sexuais (riso), estou me virando melhor com a minha (riso). Eu acho que eu estou no caminho certo". O sentimento de estar no caminho certo aponta para uma forma de contato com o próprio corpo que gera bem-estar e satisfação. O roteiro adotado por Sofia não está diretamente vinculado a uma fonte externa, mas acontece a partir das descobertas e da apropriação da sua experiência. Deste modo, ela não ficou vinculada à forma descrita-explicada da "masturbação", mas ao longo da sua trajetória passou a experimentar sensações a partir do contato com o próprio corpo. Aquilo que tinha um aspecto mágico, ganha contornos de prazer sexual.

No depoimento de Mariana a mídia é citada de forma mais contundente. Ela já havia relatado as poucas referências que tinha sobre sexualidade, inclusive a falta de diálogo na família, que considerava o tema inadequado. As revistas femininas compradas pela irmã mais velha funcionavam como referências importantes dos roteiros sexuais de Mariana, porém, continuava forte a mensagem de que se tratava de algo a que não deveria ter acesso: “...Eu ainda tinha esse pensamento de que: 'Não, não posso fazer', entende? Ou: 'Não, é... tenho que esperar casar', ou... igual minha mãe faz... eu não falava nada, eu fazia isso: 'Cuidado, não sei que...', é... 'Sexo só quando casar', enfim, só isso que se falava”. Mesmo diante deste conflito entre a curiosidade e as rígidas regras da família, Mariana continuou a buscar informação, às escondidas. As informações provenientes da mídia influenciaram, de certa maneira, os roteiros sexuais e de gênero, favorecendo a tensão interna com os próprios modelos e valores adquiridos ao longo da vida.

Mariana também cita um programa da TV a cabo voltado para as questões sexuais, no qual o apresentador entrevista casais e fornece orientações para melhorar a vida sexual. Ela não fornece elementos de como se dá esse debate e nem da forma com que o conteúdo, em termos de modelos, é transmitido. O fato de o telespectador ver outras pessoas ou outros casais falando acerca de como lidam - ou gostariam de lidar - com suas dúvidas, dificuldades e outros aspectos da sexualidade contribui para a identificação, seja fortalecendo padrões, seja reformulando os próprios, inventando e reinventando sentidos e significados acerca da sexualidade e do gênero. É nesta perspectiva que a identidade ao longo da vida se transforma - ou se atualiza -, no sentido da identidade metamorfose (Ciampa, 2001). Assim, uma pessoa 
não só internaliza modelos ou padrões, mas aprende e apreende um sentido de acordo com suas necessidades e valores que elabora por meio do diálogo interno, concedendo os mais diferentes contornos para a vida, em todos os aspectos.

A mídia, enquanto parte de um segmento social, é mais uma das instâncias que contribui para a formatação de discursos acerca da sexualidade, para as formas de pensar e conhecer o corpo. A comunicação de massas, enquanto prática social numa cultura disciplinar, segue na perspectiva do mecanismo específico do conhecimento e poder centrados no sexo, no sentido da vigilância e de controle social na promoção de "corpos dóceis" (Foucault, 1987). A prática social da linguagem, escrita ou falada, é que torna possível a convivência social, na contextualização de discursos, na construção conceitual sobre corpos e identidades. É por meio da linguagem, portanto, que códigos sociais são partilhados, modificados, mantidos, inventados, reinventados pelas sociedades, na vivência de costumes, práticas, regras e relações.

\section{A religião e a manutenção de normas e padrões}

'Tem a Virgem Maria. Por que ela é virgem? Aliás, o que é virgem?'. [Resposta do pai]: 'Ah! É porque ela nunca namorou... ela não se casou... (...). Porque ela teve um filho sem namorar, e que o filho dela não veio de um homem, veio de Deus' (Jorge)

Em vez de ficar no meu quarto, sozinho, eu resolvi me converter. (...) Comecei a freqüentar a igreja (...): 'Olha, se você deseja homem, não entra no reino de Deus'. Tudo o que me tornava homem, eu acreditava, chegava ao desespero, seja o jeito de falar, qualquer coisa era pecado. Não dava para perceber quem eu era, porque eu me repreendia. (...) É como se não fosse bom aos olhos de Deus um homem se interessar por outro homem. Seria algum desvio do que Deus teria criado igual à semelhança dele mesmo, mas que pela fé você poderia mudar. (...) Acredito em Deus. Não freqüento mais igrejas, hoje, e isso não foi por causa de minha orientação sexual (Thiago)

O que mudou, eи acho, que eu ir atrás de algumas informações (...): saber o que é o sexo mesmo, o que é isso, o que representa o sexo pra Deus, por exemplo. (...) Eu gosto de ler livros, partes da Bíblia, pra entender o lugar do masculino e feminino, porque há muita diferença. 
(...) Hoje eu sou cristã, sou evangélica. Mas a gente tem uma visão diferente. Não que seja uma visão diferente, mas vem cá, a gente entende que (...) o sexo realmente é melhor que seja com uma pessoa com quem seja casado. (...) Não é religião, é Bíblia. Você pode procurar que isso você encontra, que o sexo é realmente uma benção, é visto como uma benção, mas dentro do casamento (Mariana)

Na perspectiva da história da sexualidade, Foucault (2001) mostra que no século XIX os mecanismos de vigilância da igreja ${ }^{56}$ ganharam reforço da pedagogia e da terapêutica, incitando os discursos com finalidade de controle, dentro de uma perspectiva moral, que fortaleceu a concepção do "certo" e do "errado", e da decência, legitimando aquilo que seria o alicerce da prática religiosa: a culpa. A exigência da confissão dos desejos e dos atos pecaminosos e avaliação do da sua gravidade por meio da discussão geraram o discurso sexual. Segundo a adesão da jurisprudência e da medicina, o discurso sobre o sexo foi sendo constituído enquanto desvio e perversão, tendo a masturbação - dentre outras - como a principal prática a ser combatida.

O mecanismo da confissão e da penitência torna-se recurso disciplinar para controlar os corpos e os prazeres, dado que os indivíduos eram incentivados à confissão de todas as suas culpas, de todos os seus desejos e intenções. A confissão, enquanto mecanismo de poder, possibilitava a censura e a punição, formatando aquilo que Foucault (2001) aponta como "corpos dóceis". Deste modo, o sexo era considerado assunto da alçada da igreja, sendo que ele deveria ser restrito ao casamento e à reprodução, considerando que, fora deste âmbito, o sexo era tido como pecaminoso.

De acordo com Parker (1991), as noções de masculinidade e de feminilidade codificam um sistema particular de valores culturais a partir dos tipos anatômicos opostos baseados numa série de formas simbólicas que moldam o corpo humano e suas práticas. No tocante à construção da sexualidade brasileira, o autor aponta que os discursos sobre gênero foram difundidos no discurso popular de maneira informal, carregando consigo uma série de interdições religiosas direcionadas para o corpo e seus atos e nas suas implicações para a alma:

\footnotetext{
${ }^{56}$ Vale o esclarecimento de que, nesta pesquisa, a adoção de "Igreja" contempla os diferentes segmentos do cristianismo, a exemplo da igreja católica e da igreja evangélica. Todavia, as ampla gama de práticas religiosas funcionam como agente de socialização, assim como a escola e a família, apresentando conjuntos de normas e regras particulares.
} 
Desde o início do período colonial até nossos dias, um sistema de proibições religiosas relativamente formal, se bem que nem sempre inflexível, reforçou as divisões de gênero e, ao mesmo tempo, ampliou o significado implícito das próprias práticas sexuais, envolvendo-as numa economia simbólica diferente, questionando-as em termos não apenas de seus significados na vida cotidiana normal, mas de suas repercussões na vida eterna (Parker, 1991, p.15).

Ainda hoje o papel da religião é marcante no âmbito social, principalmente no que diz respeito ao campo reprodutivo, a exemplo do aborto e do uso de preservativo. Nesta última, diversos setores sociais repudiaram o posicionamento da igreja católica, considerando que o preservativo consiste em um importante aliado na prevenção contra o HIV e de outros organismos patogênicos. Esta perspectiva da igreja vai ao encontro da idéia do sexo enquanto algo "autorizado" dentro do casamento e com vista à reprodução, ou seja, dentro de uma moral patriarcal heterossexual. Por outro lado, como lembra Paiva (1996), na igreja existem setores tanto conservadores quanto progressistas, sendo que estes últimos mantêm sintonia com os "libertários", constituídos pelos movimentos feministas, homossexuais e sociais. Levar, portanto, a discussão da sexualidade para o âmbito da moral é atender a uma pauta moralista acerca dos comportamentos e da conduta, naquilo que Foucault (2001) chamou de disciplinarização do sexo.

Thiago foi o participante que mais se referiu à religião de forma contundente no sentido de encontrar referências para sua identidade e, por conseguinte, para seu roteiro sexual e de gênero. Mariana também faz referência à religião no sentido de busca de respostas para sua vivência afetivo-sexual. Jorge traz a questão da religião mais no sentido de compreender as contradições diante de dogmas ${ }^{57}$ representados no seu depoimento pela figura da Virgem Maria.

Mas, afinal, como pode ser virgem se ela teve um filho? Apesar de saber ser isto possível, pois o sêmen derramado na entrada da vagina pode levar à gravidez, não cabe aqui a discussão sobre a figura religiosa de Maria, mas a uma peculiaridade do contato de Jorge com seu pai a quem via como "religioso, fechado e constrangido". Neste exemplo de diálogo,

57 "Dogma", vem do grego dógma,atos, que significa daquilo "que nos parece bom", sendo um "ponto fundamental de uma doutrina religiosa, apresentado como e certo e indiscutível, cuja verdade se espera que as pessoas aceitem sem questionar" (Houaiss, 2001). 
Jorge aponta para as contradições que permearam seu discurso quando refere-se ao pai. Vale retomar o contraste desta postura do pai com a postura aberta e até "sem-vergonha" da mãe. A referência de Jorge, portanto, é que a postura conservadora do pai era condizente com as idéias e valores religiosos que não tocava no tema relacionado à sexualidade. Em contrapartida, a mãe apresentava o tema da sexualidade de forma mais explícita. De maneira geral, a religião parece não ter oferecido influência direta nos roteiros sexuais e de gênero de Jorge.

Certamente que num mundo ocidental fundado na cultura judaico-cristã, a religião se faz presente nos mais diferentes contextos, em diferentes graus. Dentre os colaboradores, Thiago e Mariana foram os que mais fizeram referência à influência e à importância da religião em suas vidas, no sentido de contribuir para a construção de significados e sentidos para o aspecto identitário e afetivo-sexual. No depoimento de Thiago, o sentido da religião é de um espaço onde sentiu-se acolhido, mesmo que uma das mensagens contundentes fosse a de que "homem não pode desejar outro homem". Já no depoimento de Mariana, a religião tem um sentido de ampliar horizontes com a visão privilegiada em que o sexo é uma bênção, e não algo que deve ser reprimido, com a ressalva de que seja uma realidade dentro da instituição do casamento. Nos dois casos, revela-se a perspectiva da disciplina sobre os corpos e os prazeres, revelando uma orientação moralista.

A partir do depoimento de Thiago, verifica-se que a falta de referenciais empáticos e de apoio social contribuíram para que ele se isolasse em seu mundo próprio, cercado por seres imaginários, protegido de um mundo exterior em que predominavam a rejeição e a hostilidade. Ao longo do tempo, este universo mágico aos poucos deu espaço para o senso de espiritualidade e de religiosidade. Foi quando Thiago experimentou ir a um terreiro de candomblé, a convite da empregada que trabalhava em sua casa. Foi esta mesma empregada que, dado o seu momento de transição religiosa, incentivou Thiago a ir à igreja evangélica. Ele aponta que não foi a questão da homossexualidade que o motivou a alternar-se entre as quatro igrejas que freqüentou, ou ter deixado de freqüentá-las, mas sim uma "questão de fê", algo que experimentava desde a infância e que evoluiu para o que percebe como "espiritualidade". Esse estado de "espiritualidade" não mais se vincula ao âmbito da religião, dando a ele um sentido de independência no exercício da fé. 
Tornar-se adepto de um grupo religioso, freqüentar uma instituição religiosa, representam não só contato com um novo universo, mas também revisão de valores e crenças dando contornos, sentidos e significados para o senso de existir a partir da transcendência. Esta vivência favoreceu em Thiago o sentimento de pertença a uma comunidade com regras e valores que ainda lhe gerariam mais tensões. As tensões entre estas referências e a realidade interna foram inevitáveis, ainda mais pelo fato de os grupos religiosos estarem fortemente fundados na polarização entre o bem e o mal, o certo e o errado, o céu e o inferno, a condenação e a absolvição, entre outros pólos que norteiam atitudes e comportamentos alicerçados no senso de pecado e de culpa.

Uma passagem do depoimento de Thiago remete à tensão entre o desejo e a culpa que ele vivenciava: "Não dava para perceber quem eu era, porque eu me repreendia. Quando eu via que começava, quando eu adorava um menino, mas não olhava muito, não mexia", sendo que ele afirma o seu "temor a Deus". Em outro momento ele percebeu que não tinha o controle que gostaria do impulso de olhar para outros rapazes, apesar de racionalmente insistir que não deveria fazer aquilo, baseado na idéia de que: "Se você deseja homem, não entra no Reino de Deus". Não cabe aqui aprofundar na discussão a contradição entre essa mensagem difundida pelas igrejas cristãs com seus preceitos, a exemplo da solidariedade, fraternidade, caridade e perdão. Não entrar no Reino de Deus pelo fato de amar - ou desejar - outra pessoa do mesmo sexo confere caráter homofóbico e discriminador a alguns segmentos das igrejas. Thiago, por mais que viesse de uma trajetória marcada pelo preconceito e pela estigmatização da sua realidade afetivo-sexual, consegue conciliar as contradições e focar no senso espiritual, na medida do possível, filtrando aquilo que dava sentido às suas necessidades, inclusive a de sentir-se integrado e aceito por uma comunidade.

Embasado nos dogmas e roteiros heterocêntricos promovidos pelo universo religioso, e pelo movimento de fazer parte deste universo, Thiago iniciou namoro com uma garota. Ele não aprofunda seu relato sobre este relacionamento, mas destaca a importância de se sentir amado por ela, o que o fortaleceu. Em termos do roteiro sexual de Thiago, destaca-se não só o fato de ele ter iniciado um relacionamento com uma mulher, mas também o fato de que a expressão afetiva tornava-se mais intensa na sua trajetória, funcionando com um diferencial importante no seu universo em que predominava o embate de forças racionais antagônicas do certo e do errado. A experiência afetiva abriu-lhe novos horizontes para sentir-se forte e integrado, aliviando as marcas do preconceito vivido até então. 
Apesar de Thiago afirmar não ter deixado de freqüentar a igreja devido à sua orientação afetivo-sexual, aquele espaço deixou de fazer sentido para ele, que optou por uma espiritualidade independente, ou, como visto em sua trajetória, ele novamente precisou construir um mundo próprio só que, agora, a partir de uma forma negociada no contexto social. A vivência social possibilitou-lhe fortalecer seu senso de pertença e expandir suas fronteiras no contato social. Ele não precisaria se fechar no quarto com bichos de pelúcia e companheiros imaginários sendo possível o contato com outras pessoas e grupos afins, em um sentido de comunidade, em que pôde viver o senso de familiaridade, a partir dos grupos virtuais do segmento GLBTTs.

Mariana em seu depoimento também se identifica com uma igreja evangélica. Para ela, a religião tem um sentido que fortalece a pertença, indo ao encontro do seu roteiro sexual e de gênero. Os pontos de tensão não foram tão contundentes quanto os apresentados no depoimento de Thiago, porém, isso não quer dizer que a idéia de repressão e de controle sobre o corpo e sua subjetividade não estivessem presentes. Na experiência de Mariana nota-se a conciliação entre sua realidade e as mensagens religiosas. A mensagem que ela apreende da igreja, baseada no escritos bíblicos, é de que o "o sexo é realmente uma benção", desde que aconteça "dentro do casamento". A partir da sua trajetória num lar conservador, em que a mulher é distanciada do universo do corpo e dos prazeres até o momento da união matrimonial, o novo universo não gera tensões significativas, mas, sim, torna-se espaço que amplia significados e sentidos da vivência afetivo-sexual, dentro do espaço da instituição do matrimônio.

A partir dos depoimentos dos participantes que mais citaram o papel da igreja em suas vidas, é contundente a maneira como o universo religioso fornece significados e sentidos para a vivência. Assim como outras instituições, a exemplo da família e da escola, a religião influencia nas mudanças de contornos de identidades e de práticas e, por conseguinte, dos roteiros sexuais e de gênero. A partir da interlocução da pessoa no meio social, surge a tensão entre códigos de conduta apreendidos e aprendidos e os códigos estabelecidos pela instituição, influenciando a pessoa em posicionar-se e ser posicionada no mundo (Parker, 1991). Os corpos são significados e continuamente alterados pela cultura, funcionando como âncoras para a construção de identidades múltiplas e dinâmicas. 


\section{0. $O$ ingresso na faculdade e o contato com pares}

...Bem depois que eu entrei na faculdade, eu falei: 'Chega de ser Larissa'. Na faculdade é outro ambiente, cortei [os cabelos]. Passou um tempo curto. Aí conheci a Ângela. Voltou esse papel de transexual e ficou comprido de novo (Jorge)

...Na faculdade é um mundo diferente, de pessoas diferentes. Eu não participei das coisas da faculdade, das festas... Mas não foi um problema. Eu me sentia cobrado pelos meus pais que cobravam uma namorada, mas algumas parentes, algumas amigas mais próximas já cobravam (Thiago)

...Eu estava em dúvida, tinha muita raiva da [faculdade] quando eu entrei porque eu estava acostumado com faculdade do interior, e não sei... Meus amigos todos ficavam lá e é uma festa, toda hora, uma bagunça. A [faculdade] é bem diferente disso, acho que eu sofri muito quando eu entrei. (...) Um problema que eu tinha, que a gente estudou na terapia que eu (...) fechava os sentimentos, ou eu vivia para as pessoas acharem isso ou aquilo (André)

...Na minha família, eu não tenho valor, primeiro porque eu suportei um abuso durante vários anos e não contei para ninguém, e segundo porque eu escolhi pensar e não simplesmente amar. (...) Para a minha mãe e pra minha tia, não é bem assim, então é tanto que eu sou a largada, ninguém me respeita, ninguém me ouve, como se eu fosse uma ovelha-negra, porque eu não escolhi o mesmo caminho (Melina)

Eu saí com um professor da minha faculdade. A gente saiu algumas várias vezes, (...) nada nojento, foi a relação sexual mais confortável que eu tive. (...) Não foi maravilhosa, porque eu não sentia aquela coisa que todo mundo sente, mas foi boa, eu gostava de ficar deitada lá, e ficar com ele, entendeu? (Sofia)

A entrada na faculdade representa um marco importante na vida dos colaboradores, com a ampliação da rede social e com o conseqüente aumento da tensão a partir do contato com esta pluralidade e valores hegemônicos que se apresentam. Neste novo cenário, os colaboradores se situam e são situados, favorecendo novos contornos para possibilidades de ser em relação com um contexto amplo.

Jorge aponta em seu depoimento que a faculdade foi um espaço em que sentiu-se respaldado, de alguma forma, para conciliar seu modo-de-ser com as personagens 
experimentadas no mundo virtual, em especial, a Larissa. Na faculdade, inicia namoro com Ângela, na qual Jorge encontra apoio para sua forma singular de ser e de apresentar com seus cabelos longos, unhas compridas, além das roupas folgadas, abstendo-se de explicitar atributos do gênero masculino ou feminino. $\mathrm{O}$ ambiente universitário, para Jorge, tem um sentido de palco de experimentação. De início, a partir das marcas da identidade JorgeLarissa, ele parece ser impactado pela grandiosidade daquele novo universo, optando por uma adequação a este espaço, cortando os cabelos, seguindo os apelos que há muito tempo amigos lhe faziam. Depois de um tempo, deixa os cabelos e unhas crescerem novamente, tomando posse da identidade Jorge-transexual. Visto não se sentir enquadrado em uma identidade de gênero específica, adotou uma forma de interação que não implicava a assunção de um gênero, a exemplo de quando agradecia a alguém adotando a expressão: "grazie" ou "thank you", com identidade de gênero indefinida.

Thiago, na universidade sente-se compelido a encontrar uma namorada, correspondendo às mensagens vindas de pais, parentes e amigos. A idéia de que "homem que deseja homem não entra no Reino de Deus", internalizada quando da sua participação em cultos religiosos, e a cobrança por um relacionamento heterossexual contribuíam para que se sentisse ainda mais pressionado. Em certo momento, ele inicia namoro com uma colega, mas isto será mais bem abordado adiante. A fala de Thiago indica a precariedade e falta de referências para a vivência homossexual e o incentivo para a vivência heterossexual. Considerando que Thiago vinha de vivências afetivo-sexuais mais restritas, ele mantém um modo de ser mais reservado, optando por não participar de festas e eventos da faculdade. Assim, os desdobramentos do relato de Thiago não circunscrevem apenas na sua tendência à introversão, mas também à falta de respaldo no meio social universitário para que surgissem possibilidades para essa interlocução. Por outro lado, a restrição no envolvimento na universidade não foi mais angustiante do que a cobrança de pais, parentes e amigos para que tivesse uma namorada.

André sente uma ruptura com o cotidiano familiar ao entrar na faculdade. Proveniente de uma cidade do interior de São Paulo, ele deixou na sua cidade natal uma rede social importante, representada pelos muitos amigos. O cenário da universidade mostra-se bem diferente do ambiente estudantil que conhecia. As festas e bagunças não mais existiam e a cobrança por desempenho acadêmico elevado favoreceu o surgimento de sentimento de raiva, desamparo e frustração, dando espaço para o que ele chamou de André-máquina. Esta 
imagem ilustra um momento de angústia crescente, a partir da tensão entre aquilo com que ele havia sonhado e a realidade. A vivência afetivo-sexual seguia a mesma linha. Sentindo-se mais independente por estar longe dos pais, André teve sua primeira relação sexual completa. Deste modo, mesmo envolto de significativo sofrimento, André ampliou suas fronteiras, favorecendo o senso de independência e soltura, ainda mais quando percebeu o quanto enfatizava a correspondência às expectativas alheias.

O sentido de busca por independência nem sempre é circundado por sofrimento, mas por sentimentos de libertação, de quebra das amarras de valores e idéias, como é visto na trajetória de Melina. Os papéis de submissão relatados por ela em relação às mulheres de sua família, ou mesmo a sua situação de silêncio diante de anos de abuso sexual, são revistos quando da sua entrada na universidade, concomitante à sua entrada no mercado de trabalho. $\mathrm{O}$ preço pago por Melina por não dar continuidade aos roteiros de gênero de sua família é ser colocada no lugar de "ovelha negra", de "largada", dando margem à idéia de que o estudo não é algo valoroso para a vida, ainda mais para uma mulher que, espera-se, terá o papel de cuidar do marido - a exemplo do papel de sua mãe -, ou abrirá mão do trabalho, para cuidar de marido e filhos - como fizeram suas irmãs. Para Melina, a universidade contribuiu para que, a partir da contestação das idéias e valores internalizados, se auto-afirmasse em um espaço onde encontrou respaldo para seu modo-de-ser, mesmo diante da falta de apoio da família. Deste modo, são significativas as mudanças geradas em seu roteiro de gênero, experimentando, enquanto mulher, questionar, refletir e trilhar novos rumos no mundo social, encontrando nos estudos a possibilidade da emancipação ou, ao menos, da ampliação de horizontes tão almejada.

Sofia refere-se ao ingresso na faculdade de maneira indireta, mas fica evidenciada a ampliação do roteiro sexual e de gênero a partir da descoberta de possibilidades e do contato com novas idéias e valores. Ela destaca o contato que teve com a perspectiva fenomenológica, dando contornos positivos para seu sofrimento, visto que "o sofrimento é mais verdadeiro do que a felicidade". Esta experimentação de possibilidades de Sofia não segue uma linearidade, mas um movimento de expansão e de retração, no encontro com o novo. Na faculdade, ela teve um contato sexual com um professor, na qual sentiu-se gratificada e solta, apesar de não ter sido uma experiência "maravilhosa", por não ter sentido "aquela coisa que todo mundo sente". Neste trecho do seu depoimento, Sofia fala de uma experiência que só não foi mais gratificante por supor que não sentiu o mesmo que as outras pessoas. Isto revela as maneira 
como corpos e prazeres são formatados na inter-relação com a existência social, sendo que o grupo fornece referências sobre formas e maneiras de sentir prazer. Aquilo que Sofia aprendeu e apreendeu - de forma idealizada - de como seria sentir-se gratificada numa relação sexual não acompanhou sua vivência, o que, pelo tom de sua voz, revela a sua frustração.

A partir dos relatos nota-se que o ingresso no cenário universitário representa possibilidades de experimentação, descoberta, auto-afirmação, formatando identidades, roteiros sexuais e de gêneros. $\mathrm{O}$ ambiente universitário constitui um espaço que favoreceu a ampliação da rede social e de estabelecimento de relacionamentos de namoro. A vivência compartilhada tornou-se mais intensa, indicando que o ambiente universitário realça a tensão, cobrança, contestação e fortalecimento de modos-de-ser. As vivências de diferentes momentos particulares de socialização - família, escola, mídia, internet, religião, entre outros - e de diferentes variáveis conformadoras de identidades - gênero, idade, classe social, entre outros - indicam diferentes formas de construir e de significar a sexualidade.

\section{Namoros e vida afetivo-sexual na fase adulta}

Eu tinha vasta experiência de viver como uma garota. Então, bom... então, ela [Ângela] disse que (...) até hoje, ela me vê como uma garota. A gente tá conversando e ela se refere a mim no feminino... muitas vezes. E com o tempo eu aceitei, tudo bem... Pronto! Eu sou uma garota. Aqui na faculdade eu resolvo isso, sei lá... faço um tratamento depois (Jorge)

Nos conhecemos aqui na faculdade, e eu na época eu ainda não me aceitava como eu era, até no começo desse ano. (...) Eu queria ficar junto com ela. E aí que a gente ficou um tempo. Eu falei que eu sentia por ela. Eu gostei muito dela, e ela correspondeu, e a gente começou a namorar. (...) Mas eu percebi que havia uma certa falta de atração física por ela, e isso acabou prejudicando, na hora de se tocar, (...) então, eu contei para ela o que eu era, e ela ficou chocada, mas a gente continuou o nosso namoro. Não parou porque a gente volta e meia queria ficar junto (Thiago)

Tinha uma amiga minha, muito amiga, a Mônica, que quando eu era criança eu gostava dela, tal, mas era muito amiga mesmo... (...) Já tava 
meio próximo da gente ficar, assim, já tava segurando porque achava que ia dar rolo, porque era amiga, e tal... Deu (risos). Tô contando o final da história. Cortou um pouco a amizade, assim, bastante assim... foi estranho. A gente transou na boa, mas... foi estranho (André)

Foi um pouco complicado a relação em si, e principalmente o ato sexual, e no meu atual foi muito complicado, porque assim, a gente já tinha uma amizade de tempo e... já rolava aquela coisa, rolava mesmo o tesão, mas não tinha o ato sexual, não rolava. Toda a vez, é... eu chorava, ou, às vezes, uma forma, ou um toque, era o mesmo toque que a pessoa fazia, entendeu? Então, assim, estava o maior clima legal, mas quando eu me sentia tocada de uma certa forma e já vem tudo aquilo na cabeça (Melina)

Meus relacionamentos sempre foram assim, o garoto que eu ficava, ficava apaixonado assim por mim, não sei porque que isso acontece (riso), ele meio que se interessava bastante por mim, assim, até que eu não queria nada com ele, eu falava: 'Não, até parece!'. Aí depois que eles me desprezavam... (...) Aí eu sempre faço isso. Depois que passa, eu sempre ligo para as pessoas e tal, não-sei-quê, e já não é a mesma coisa (Sofia)

Hoje eu posso dizer que o que mais marcou minha sexualidade, na verdade, foi o namoro. Porque é algo muito horroroso, né, porque era meio proibido, meio gostoso... então era... era legal. Estou me referindo ao meu marido. Ah, eu segurava a mão dele. Era legal ir pra Igreja... e tava só nós dois... Ah, era tudo muito conturbado. (...) A minha primeira relação sexual foi com meu marido (Mariana)

As normas e os códigos socioculturais influenciam os rituais de corte, de namoro e de relação sexual. O namoro envolve uma ampla gama de fatores, mas destaca-se o sentimento de amor, ou paixão, que envolve a intimidade, a experiência do gostar e do ser gostado, do cuidado e carinho com o outro e com a relação (Peres et al., 1999). O namoro é uma das formas de interação amorosa que pode seguir-se de relação sexual. Assim como as diversas relações sociais, namoro apresenta diferentes significados e sentidos ao longo dos tempos. Há algumas décadas a relação sexual somente acontecia depois que o homem estabelecesse a relação com a mulher, e a mulher poderia conceder progressivamente a prática sexual. $\mathrm{O}$ modelo de namoro tradicionalmente conhecido contempla a relação de exclusividade entre dois parceiros, sendo uma possibilidade de vivência afetivo-sexual (Heilborn, 2006).

O namoro envolve a intimidade entre duas pessoas. Giddens (1993) refere-se a esta intimidade enquanto uma "comunicação emocional, com os outros e consigo mesmo, em um 
contexto de igualdade interpessoal" (p.146). As aproximações afetivas e formação de pares perpassam as transformações pelas quais atravessaram os papéis de gênero masculino e feminino, e faz distinções entre amor romântico e amor confluente. O amor romântico está relacionado à "paixão", que depende "da identificação projetiva do amour passion, como o processo pelo qual os parceiros potenciais tornam-se atraídos e, então, unem-se" (p.72), criando-se uma sensação de totalidade com o outro. Esta forma de amor vem sendo fragmentada nas últimas décadas em consequiência da pressão e autonomia sexual feminina. $\mathrm{O}$ amor confluente é compreendido como "uma amor ativo, contingente e, por isso entra em choque com as categorias 'para sempre' e 'único' da idéia do amor romântico" (Giddens, 1993, p.72). Ressalta o autor que em uma sociedade separada e divorciada, a tendência é a do amor confluente consolidar-se em detrimento da busca da "pessoa especial" em prol da valorização do "relacionamento especial" e real.

Na discussão das implicações do amor romântico e do amor confluente na vida afetivo-sexual, Giddens (1993) aponta que no amor romântico o roteiro consiste em um amor sexual em que a satisfação é garantida pela força erótica, fantasiada na forma de romance. Já no amor confluente, a satisfação sexual está intrínseca pela introdução da "ars erótica no cerne do relacionamento conjugal e transforma a realização do prazer sexual recíproco em um elemento-chave na manutenção ou dissolução do relacionamento" (p.72), sendo que esta forma de amor ultrapassa as barreiras do relacionamento heterossexual, incluindo masculinidades e feminilidades nas parcerias constituídas pelo mesmo sexo. Nesta perspectiva do amor confluente, Giddens (1993) também lança sentidos e significados para o cultivo de habilidades sexuais, sendo que:

(...) a capacidade de proporcionar e experimentar satisfação sexual, por parte de ambos os sexos, tornam-se organizados reflexivamente via uma multiplicidade de fontes de informação, de aconselhamento e de treinamento social (p.73).

A iniciação sexual quase sempre não é um evento planejado (Bozon \& Heilborn, 2006). Como mostra Bozon (2004), a autonomia sexual precede e anuncia a autonomia social, indicando que a passagem da juventude para a vida adulta sofreu grandes transformações durante o século XX. Deste modo, o autor afirma que: “A juventude é um percurso duplo, que 
leva o indivíduo, por um lado, da escola para o trabalho e, por outro, da família de origem em que ele foi criança - para a família de procriação - em que ele é pai ou mãe” (p.67).

Esta incursão na vida sexual tem um significado de rito de passagem na vida de pessoas e de coletividades, sendo que seu exercício acontece a partir das possibilidades e dentro do marco cultural delimitado por preconceitos e ritos (Castro, Abromovay \& Silva, 2004). Neste meio e contexto, a partir da experiência afetiva e sexual com outras as pessoas, os roteiros de sexuais e de gênero vão sendo revistos, experimentados, modificados, atualizados, permitindo diferentes configurações identitárias a partir do espaço dialogado na existência social.

Os contatos com os pares acontecem entremeados pelo estranhamento e pela tensão, o senso de descobrir e conhecer prevalecem, circunscritos em uma atmosfera de prazer compartilhado. Seja no relacionamento heterossexual, seja no homossexual, os encontros surgem como possibilidade de compartilhar desejos, sonhos, incertezas, expectativas, além do próprio prazer, em uma perspectiva de parceria.

No encontro de duas singularidades, a possibilidade da troca contribui para novos significados e sentidos dos roteiros sexuais e de gênero de cada uma, sendo que ninguém sai ileso do encontro com outra pessoa, ainda mais quando a troca afetiva é intensa. Estas marcas deixadas pelo encontro são ainda mais potencializadas na medida da intensidade da intimidade experimentada. A complexidade e a imprevisibilidade acompanham não apenas a singularidade, mas a relação estabelecida com a outra singularidade, constituindo um terceiro lugar ocupado pelo relacionamento, entendido como "a capacidade de conviver bem com seus semelhantes" (Houaiss, 2001).

A disposição de Jorge em traduzir a experiência do mundo virtual para o mundo real contribuiu para que houvesse o encontro com uma colega de turma da faculdade, que culminou no seu namoro com Ângela. O relacionamento de Jorge revela o quanto é possível a complexidade e pluralidade de possibilidades de vivência afetivo-sexual, no arranjo dos diferentes roteiros sexuais e de gênero. Jorge se identifica como transexual, apresenta-se socialmente de maneira andrógina, e tem estreita familiaridade com o roteiro feminino. Estas características vão ao encontro da singularidade de Ângela, que se identifica enquanto bissexual, e se dispõe a tratá-lo como se fosse do gênero feminino, assumindo uma 
flexibilidade de roteiros de gênero. No relacionamento sexual, Jorge relata que assume o papel "ativo", ou seja, daquele que penetra, e que ambos têm prazer. Isso aponta para o fato de que Jorge não apresenta conflitos com seu corpo de homem, incluindo seu genital, no contexto da identidade transexual que ele assume.

Na vivência de Thiago, a experimentação se faz presente, motivada pelas mensagens dos pais, amigos, igreja, que cobravam um namoro dele com uma mulher. Na faculdade, começou a namorar uma colega de turma. Thiago afirma que esse relacionamento foi gratificante para ele, pois sentiu-se amado, aceito na sua singularidade, e teve vivência afetiva compartilhada. Embora as relações sexuais acontecessem, o desejo afetivo predominava, em detrimento do desejo sexual de Thiago pela namorada. Um sentimento de "sufocamento" motivou-o a revelar para a namorada o seu desejo por outros homens. $\mathrm{O}$ afeto falou mais alto e eles ficaram juntos por mais um tempo, indicando aquilo que Giddens (1993) chamou de amor confluente. Naquele momento, a namorada o incentivou a procurar o Plantão Psicológico, na esperança de aquilo fosse superado.

No depoimento de Jorge e de Thiago, vale ressaltar os roteiros sexuais e de gênero previamente vividos de forma precária, em que o isolamento e preconceito eram presentes de forma intensa. A partir da aproximação afetivo-sexual que tiveram com as namoradas, possibilitaram a apreensão, ou a expansão de significados e sentidos de expressão afetivosexual, indicando a flexibilidade desta expressão que acontece na experiência compartilhada. Grosso modo, tanto a identidade transexual de Jorge quanto a identidade homossexual de Thiago não os remetem a relacionamentos com outros homens, de forma exclusiva, indicando que o relacionamento afetivo-sexual não segue um modelo previamente traçado. Ao contrário, é um modelo que dinamicamente se atualiza, à medida que acontece o encontro, ainda mais quando há a aceitação da diferença do outro, mais uma vez, no sentido do amor confluente. Vale destacar que esta perspectiva vai ao encontro de Foucault (2001) para quem a o eu é socialmente construído, da mesma forma que a sexualidade é configurada por meio da coordenação corporal e da interação simbólica de sujeitos sociais.

A percepção de gênero de André é fortemente relacionada ao modelo patriarcal em que o homem não pode demonstrar fraqueza, ou mesmo errar, o que o leva por veredas mais pedregosas e áridas. O estranhamento, sempre presente, perpassa seu relato sobre os relacionamentos amorosos. A princípio namorava Beatriz, com quem percebia que estava 
"conhecendo juntos" o território da vivência afetivo-sexual, porém, por escolha dela, sem intercurso e com sexo oral, o que aborrecia André.

O desejo de André de ter uma relação sexual com penetração vaginal era tão intenso quanto sua ansiedade com relação ao próprio desempenho sexual. O estranhamento relatado por André transmite a idéia de que as imagens e referências relacionadas ao universo erótico eram antogônicos, abrindo espaço para a confusão e o sentimento de opressão. $\mathrm{O}$ acompanhamento psicológico é relatado por André como um aliado para que se fortalecesse a partir da compreensão das expectativas e medos experimentados diante da situação que envolvesse o encontro sexual.

Gagnon (2006) aponta como esta precariedade dos roteiros sociais e sexuais ao longo da adolescência influencia na interação de caráter íntimo com outras pessoas. Recorrer a uma garota de programa foi um meio encontrado por André para aprender mais sobre o roteiro sexual em uma época marcada pela tensão e angústias provenientes das exigências acadêmicas e a ansiedade com relação ao desempenho sexual. André não reconhece essa experiência enquanto iniciação sexual, pelo fato de ter sido com uma garota de programa. Ele relata que a experiência com esta garota foi tão estranha que parecia que ele nem tivesse transado. O interesse de André era pura e simplesmente pelo sexo, sendo que o fato de ele situar-se no lugar daquele que paga - onde o poder é implícito -, o isentaria de ter seus desempenho sexual como alvo da garota de programa. A experiência não foi integrada como algo que trouxesse satisfação, mas, por outro lado, ele apreendeu a experiência de maneira que reconhece como a sua primeira relação sexual. Com esta experiência, André sentiu-se preparado para retomar a idéia de ter relações sexuais com Beatriz.

A percepção da falta de afinidade e de entrosamento entre ele e Beatriz convenceu-o de que estava insistindo em uma história que não teria um bom desdobramento. Ele reconhece seu desejo de provar para si mesmo que conseguiria transar com Beatriz, o que contribuía para o aumento da sua ansiedade e conseqüente dificuldade de ereção. Esta dificuldade durante muito tempo acompanhou o roteiro sexual de André, o que consumia sessões de psicoterapia.

O relacionamento social de André contribuiu para que iniciasse namoro com Mônica, antiga amiga de infância, porém, constatou que amizade e envolvimento afetivo-sexual não 
são conciliáveis. De um lado, o afeto e o desejo nutridos por Mônica foram fatores para que tivesse um envolvimento afetivo-sexual pleno e prazeroso. Por outro lado, a relação de amizade do passado sofreu transformações, enfraquecendo o senso de amizade. Esta tênue diferenciação entre as formas de interação seriam o novo desafio para André.

A tensão diante de possibilidade da vivência afetivo-sexual também acompanhou a trajetória de Melina, impregnada com imagens e marcas deixadas por anos de abuso sexual. As sensações provenientes da troca de afeto com o namorado remetiam Melina para a vivência passada. Importante salientar que o depoimento de Melina não está envolto por um sentido do que poderia ser chamado de vitimismo, mas por uma força propulsora de seguir adiante, sem com isso esquecer as marcas da experiência ao longo da sua trajetória. Deste modo, as escolhas de Melina não se basearam no fato de ter sofrido abuso sexual, mas na sua busca por autonomia. Mais tarde, a tensão gerada por esta busca levará Melina a uma bifurcação: ou seguir seus anseios de partir para uma universidade fora do Brasil e continuar seus estudos, ou permanecer com seu noivo, casar e constituir família, visto que a relação dela com noivo era gratificante para ambos.

Retomando a questão do contato afetivo-sexual de Melina com o namorado, ela relata que apreciava a troca de carícias até determinado ponto, sendo que, após esse limite, sobrevinha o choro. O desejo sexual era presente, porém, Melina relata que não conseguia dar continuidade à interação sexual: “...Estava o maior clima legal, mas quando eu me sentia tocada de uma certa forma e já vem tudo aquilo na cabeça". Ao longo do contato com Pedro, estas marcas, partes de seu roteiro sexual, foram dando lugar à possibilidade de vivência afetivo-sexual positiva. A desigualdade de poder do modelo vivido na situação de abuso sexual cede espaço para a vivência afetivo-sexual com eqüidade e dialogia.

A experiência de Sofia com o namoro foi marcada pelos contrastes da experimentação, entre aproximar-se e afastar-se, entre aprovação e reprovação. Esta experiência é ilustrada por Sofia quando relata que empenhava-se na conquista do rapaz, mas, assim que percebia o interesse do outro, afastava-se. Os papéis se invertiam, o outro passando a querer reconquistála. Depois de tentativas em vão, o rapaz desinteressava-se. Esse desinteresse instigava Sofia a procurar reconquistá-lo. Este jogo na relação ilustra a dinâmica de encontros e desencontros, conquistar e ser conquistada, na experiência de interação dos gêneros e da forma de administrar a intimidade. 
No relato de Sofia, se destacam as experiências que não seguem a uma expectativa social de que a garota esteja disposta e disponível para o namoro, sendo o seu incômodo o fato de "não ligar para as pessoas", ou, como ela retoma em dado momento, a ponto de não querer arrumar namorado. A postura de Sofia tem um sentido de não aceitação de regras sociais, mostrando a tensão entre uma maneira singular de ser e o desacordo com as normas e condutas sexuais vigentes. Este estranhamento da própria postura foi que a motivou na busca de ajuda no Plantão Psicológico. Sofia tem na sua irmã um dos modelos mais próximos da vivência de feminilidade. O distanciamento de modelos e valores esperados de uma garota, até mesmo inspirada pelas atitudes e comportamentos da irmã, contribuiu para que Sofia vivenciasse o sentimento de negatividade, seja pelo que via na irmã, seja pelos incentivos da mãe para que arranjasse um namorado.

A conciliação do roteiro no contexto é a todo o momento negociada e renegociada pela pessoa. Na experiência de Sofia, marcada pela sua maneira singular de ser-no-mundo, ou, como ela própria se define, "tipo meio louca", encontra espaço no mundo e sua rede social que, aos poucos, torna-se cada vez ainda mais ampliada. Na sua maneira singular, o encontro com o outro torna-se possível e ela "fica" com o antigo namorado.

Mariana estava familiarizada com um modelo mais conservador, em que a expressão sexual não é estimulada, sendo a mulher disciplinada para a o cuidar, com vias de preparar-se para a vida com marido e filhos. Para ela, o namoro foi um espaço para a experimentação de possibilidades de interação e de obtenção de novos sentidos para seu roteiro sexual. A experiência foi tão marcante para ela considera o namoro um marco na descoberta da sua sexualidade, por vivenciar algo "horroroso", "proibido", mas também "gostoso". Sua disponibilidade no início do relacionamento era reduzida, devido à pouca experiência, porém, sua curiosidade e interesse eram crescentes. Mariana estabelecia para si que a interação afetiva era permitida, embora não se sentisse disposta a permitir que essa interação se desdobrasse para a relação sexual com penetração.

No seu depoimento, Mariana avalia como acertada a sua decisão de não ter relações sexuais, ainda mais considerando que o então namorado estava mais interessado no sexo do que na relação afetiva. Isto a motivou a romper a relação. Esta passagem do depoimento de Mariana revela a percepção das relações entre os gêneros. No seu roteiro, a vivência sexual 
não poderia ser dissociada da vivência afetiva. Assim como apontado por Melina, a mulher jovem que se relaciona com um rapaz - ou mais - tem sua índole questionada socialmente, ou seja, "fica falada". Em contrapartida, como mostra Del Priori (2006), desde o passado as relações de homens com várias mulheres, além de permitidas, eram freqüentemente desejadas, revelando aspectos do roteiro de gênero presentes nos dias atuais.

Quando Mariana conheceu seu atual marido e a vivência afetiva tornou-se mais intensa, ela sentiu-se mais disposta e disponível para experimentar a vivência sexual, mesmo antes do casamento. Assim, nota-se uma flexibilização daquilo que é internalizado dos códigos sociais. Essa percepção de relação entre os gêneros contribuiu para formatar o sentido até mesmo de sua religiosidade. O segmento da religião evangélica adotado é percebido como aquele compatível com seu modo-de-ser, diferentemente da perspectiva católica que, até então, era referência da sua família de origem. Os preceitos religiosos são compartilhados com o marido, com quem Mariana experimenta a vivência sexual, sem ter conflito com os valores e padrões internalizados.

Até este ponto está sendo privilegiado o encontro em um sentido de aproximação afetiva, que contribui para a apreensão de referencias para os roteiros sexuais. Obviamente que a vida sexual não necessariamente está vinculada à relação afetiva aprofundada - a exemplo da passagem de André com a garota de programa -, porém, em um relacionamento afetivo, geralmente, existe o direcionamento para a vivência sexual. Isto dependerá da negociação e de como os parceiros se dispõe para a relação, conforme lembra Gagnon (2006): "A conduta sexual compartilha com outros aspectos da conduta humana o dilema das divergências dos roteiros e das motivações práticas entre as partes implicadas nos mais exitosos desempenhos concretos" (p.148).

O encontro das diferentes trajetórias recria possibilidades de vivência compartilhada onde o coito vaginal é apenas um elemento possível em pluralidade que contempla diferentes formas de encontro onde o prazer compartilhado é presente. Os referenciais do encontro afetivo-sexual são presentes nos roteiros intrapsíquicos em maior ou menor clareza (Gagnon, 2006). Neste contexto de situar-se e ser situado o roteiro sexual é (re)modelado a partir dos elementos presentes no encontro com o outro conferindo uma complexidade própria de experiência. Assim como os roteiros sexuais e de gênero, pode-se dizer que a identidade também é (re)modelada a partir deste encontro com o outro. 
A universidade, para a maioria dos colaboradores, representou um catalisador para mudanças na maneira de perceber-se e de estar no mundo. O contato com diferenças e diferentes torna-se cenário até mesmo para a busca de pares, inclusive da ordem afetivosexual. Foi neste contexto que Jorge, Thiago, André, Melina, Sofia e Mariana mobilizaram-se por iniciativa própria, ou incentivados pelas parcerias, para a busca de orientação ou ajuda psicológica. O Plantão Psicológico surge como um lugar possível para atender às necessidades emocionais e/ou sofrimento dessas pessoas, inclusive aquelas relacionadas à sexualidade.

\section{Ser homem, ser mulher: a percepção dos gêneros}

A percepção do ser homem e do ser mulher fornece elementos importantes para a compreensão da tensão que acompanha a temática da sexualidade nos depoimentos dos colaboradores. A compreensão da construção dos gêneros torna-se referência para o reconhecimento da pluralidade sexual - as sexualidades - pois fornecem sentidos de como acontece a interlocução entre a singularidade da pessoa e a pluralidade do contexto social e político do qual ela faz parte, revelando modos-de-ser, a partir dos roteiros sexuais e de gêneros.

A percepção de ser homem e de ser mulher apresentada pelos colaboradores traz alguns elementos para perceber o quanto o papel de gênero é amplo, pois é atravessado por religião, escola, classe social, faixa etária, entre outros, que consiste em "formas de conceber as individualidades no masculino e no feminino, o que passa por vivências e idealizações sobre relações sociais entre os sexos" (Castro, Abramovay e Silva, 2004). Diante da diversidade de formas na expressão da sexualidade, emerge o questionamento de modelos fixos do que é ser masculino e do que é ser feminino - masculinidades e feminilidades. Essa idéia se apóia no fato de que temos machos e fêmeas na espécie humana, sendo que a qualidade de ser homem e de ser mulher é condição construída socialmente (Heilborn, 1994; Barbieri, 1991). A construção dos gêneros está ancorada no sistema particular de valores culturais, a partir de um conjunto de práticas, formas simbólicas, representações, normas e 
valores sociais, que moldam o corpo humano e suas práticas em noções de masculinidade e feminilidade (Barbieri, 1991; Parker, 1991).

A pessoa cria uma ficção ao construir a sua autobiografia, destacando personagens e as passagens que lhe são mais significativas e que fornecem sentidos para a realidade vivida. A constituição das sexualidades e dos gêneros não segue uma trajetória linear, mas é (re)inventada a todo o momento a partir do interjogo das relações.

A fim de clarificar esta percepção da maneira como cada colaborador percebe os universos de masculinidades e feminilidades, na ocasião da entrevista, indaguei-os sobre pessoas da esfera pública que representassem, mesmo que parcialmente, a sua percepção de gênero. As citações destas pessoas públicas não encerram a percepção dos colaboradores sobre os gêneros, mas configuram referências outras que concedem sentidos para a percepção de gêneros.

\subsection{Percepção de masculinidades e a associação com o domínio}

Vai no bar, toma cerveja, trai a mulher, vê futebol. (...) Aquilo que provavelmente me é cobrado, (...) aquele que trabalha, que ganha seu próprio dinheiro, que vai, que tenta ser independente... (...) Pelo o que eu vejo, a sociedade, entre aspas isso, espera mais que um indivíduo seja mais um macho do que um homem. (...) Para que os homens continuassem sempre a se manter: 'Eu sou garanhão, eu jogo bola'. Pessoas representativas: Ator Tarcísio Meira - Cara quadrada, jeito de paizão, patriarca, é uma visão arcaica até (Jorge)

Você ser masculino é não ser efeminado; é você estar na busca daquela imagem típica do homem bronco. (...) É você não falar mole, é você usar roupas que fazem se sentir como homem. Você pode até ser aquele cara durão, mas não necessariamente isso é um padrão de masculino, mas você não vai andar rebolando, usar maquiagem, fazer algumas coisas... (...) Você nasce homem e não importa se você gosta de homem ou se gosta de mulher, se você é efeminado, ou masculinizado, você vai ser homem e não mulher. (...) Seria o não ser feminino.

Pessoas representativas: Ator Brad Pitt - Características mistas, (...) passa a idéia de força, parece ser alguém mais sensível com as emoções de outras pessoas (Thiago) 
Ser homem, eu acho que... é... sei lá... homem é difícil, pô! Eu que sou homem, então, falar isso... (...) Ser homem não é (...) só transar, entendeu, só enfiar sem sentir nada. (...) Eu me sinto homem, (...) meio que abraçar uma mulher assim... não abraçar simplesmente, mas... (...), meio que aquela história do padrão de qualidade, (...) você precisa só sexualmente satisfazer ela, entendeu? Claro que é bom, também, mas... acho que me sinto homem quando eu... eu tenho ela por inteiro. (...) De uma forma mais ampla, racionalmente, ser homem é ter 'masculino' no RG. (...) Ser homem é ter alguns valores, (...) ser uma pessoa boa, (...) ser bem sucedido, (...) o cara é um pouco mais formal, rigoroso, (...) ter uma seriedade, (...) algo meio rústico, mas não muito. Não é verdade, sabe, pensando... Por isso que eu tô confuso.

Pessoas representativas: Presidentes Jorge W. Bush e Luiz Inácio Lula da Silva, e governador José Serra - Remete a alguém sério, um governador, pela idéia de que tem poder (André)

O homem para mim é a mesma coisa, porque ser homem não é você lá... com pênis e tudo o mais: é ter atitude, ter o comportamento, ter a maturidade de homem, no sentido de saber diferenciar as coisas, no sentido de fazer algo errado e depois assumir e... aceitar ser corrigido a voltar atrás e tudo o mais. Então, assim, é um grupo de atitudes maduras.

Pessoas representativas: Político José Dirceu - A história dele eu acho muito bonita apesar dos pesares agora ${ }^{58}$. Mas apesar de ser jovem de classe média, agarrou aquele sonho e correu atrás (Melina)

Eu acho o homem uma coisa mais autêntica do que a mulher (...), se preocupa menos com determinadas coisas, por exemplo, com tudo, eu acho. (...) É meio complicado generalizar, (...) o homem é mais sincero espontaneamente. (...), ele não sabe o que é sinceridade, mas ele está sendo sincero. Eu acho que o homem é mais puro do que a mulher. (...) Eu não sei se é porque ele é, ou se é porque o mundo é assim, a sociedade deu essas possibilidades para ele, entendeu, e tirou essas possibilidades da mulher.

Pessoas representativas: Músicos Jim Morrison, Mick Jagger, e Kurt Cobain - Eu acho que eles sofrem pelos méritos, pelos jeitos com que eles optaram viver (...), uma busca que só eles entendem... Eles querem cantar, eles querem pular, eles querem se drogar... (Sofia)

Pensa em sexo a toda hora... homem só pensa em sexo. Não é?... Eu acho que é essa coisa do animal, de trazer o mantimento pra casa. Por mais que a mulher trabalhe, mas eu ainda consigo ainda ter essa visão de que a responsabilidade maior da casa é o homem de trazer, teoricamente, suprimento da família, ser a força da casa, do carinho, do apoio, na responsabilidade, enfim, ser o forte da família, é o forte.

Pessoas representativas: Ator Reinaldo Gianecchini - Oh, homem lindo, meu Deus! Alto, sensual, forte... Bem, mas não é só isso; personagem

\footnotetext{
${ }^{58}$ Referindo-se ao envolvimento com o escândalo do "mensalão" -compra de votos no Congresso em 2005-, que culminou na cassação do seu mandato de Deputado Federal, tornando-o inelegível até 2015 (FOLHA DE SÃO PAULO, São Paulo, 01 dez. 2005).
} 
de filme - Era um advogado que tinha objetivo de ajudar o outro. Eé casado com uma esposa maravilhosa, tem uma filha, muito carinhoso com a filha, muito carinhoso com a esposa (Mariana)

O "ser homem" é percebido basicamente pelos colaboradores homens de modo associado a estereótipos representados por atributos relacionados com: independência, atividade, força, ganha próprio sustento, dominação, ter hábitos definidos, transmitir segurança, ter firmeza nas decisões, não ser efeminado, usar roupas de homem, ter valores, boa pessoa, bem sucedido, formal, rigoroso, sério, e pouco rústico. As colaboradoras mulheres também seguem a mesma representação: ter atitude, ter comportamento, ter a maturidade, diferenciar as coisas, assumir erros, aceitar ser corrigido, mais autêntico do que a mulher, mais puro do que a mulher, pensa em sexo a toda hora, provedor, ser o forte da família.

Scott (1988) aponta que a vida social está pautada na dicotomia de gênero, que implica na hierarquização da diferença e da desigualdade. Na percepção do ser homem para os colaboradores homens os atributos podem ser resumidos como força e independência. As colaboradoras mulheres, de forma contundente, atribuem ao ser homem lugar de destaque e, em alguns momentos, tomando a si próprias de forma hierarquicamente inferior. Isto fica mais evidenciado no depoimento de Sofia, que expressa sua percepção de homem comparando com a mulher, atribuindo ao homem a autenticidade, a sinceridade, a pureza, sendo que a mulher, como será visto adiante, é forjada para ser enrustida, ou uma fragilidade que esconde uma coisa determinada.

Fica evidenciada uma hierarquização nas concepções dos gêneros sendo o homem associado à atividade, e a mulher com a passividade. Esta concepção vai ao encontro do percebido por Parker (1993) sobre a estrutura conceitual central que os brasileiros têm usado na articulação e interpretação do significado de sua experiência sexual enfatiza não só as práticas sexuais em si mesmas, mas também o relacionamento destas com os papéis sexuais: "atividade" masculina e "passividade" feminina como modelos centrais para a organização da realidade sexual. O sistema classificatório funciona como um quadro de leitura para as condutas. Sobre os homens é exercida uma vigilância constante de seus gestos e comportamentos, de maneira que sobre eles não recaia sombra de dúvida sobre sua masculinidade. 
Esse lugar de "força" torna-se penoso para o próprio homem na medida em que precisa corresponder a esta condição. André, por exemplo, reconhece que sua percepção rígida da "atividade" do papel masculino influenciou negativamente no estabelecimento de relações com o sexo oposto, dando espaço para o que chamou de controle de qualidade, ou seja, ele tomar para si o papel de dar prazer à parceira, exigindo de si um desempenho, que prejudicou a forma de contato com sua parceira. Por outro lado, Melina também revela em seu depoimento que um homem que não tem desejo sexual é um homem que tem problemas, algo que vai ao encontro da percepção de Mariana para quem o homem só pensa em sexo. A mulher, neste aspecto da prática sexual, acaba não apresentando tanto cobrança quanto ao homem que, por sua vez, espera-se que atenda à esta representação de atividade centrada no potencial sexual.

No depoimento de Jorge e de Thiago, percebe-se uma flexibilização da tensão dos atributos do ser homem e do ser mulher. Jorge diz que não consegue ter para si uma definição clara sobre o ser homem e o ser mulher, cabendo à pessoa comportar-se de acordo com gênero com o qual se identifica. Para ele, a força e a independência são características do universo masculino, porém, a mulher tem a opção de adotar, ou não, esses atributos sem com isso colocar em jogo o seu lugar de ser mulher.

Para Thiago, tanto o ser homem, quanto o ser mulher, está relacionado aos padrões culturais preestabelecidos. Em seu depoimento, ele chama a atenção para a questão da orientação do desejo sexual que não determina a masculinidade de um homem. Hetero, homossexual, o homem não deixará de pertencer ao este gênero masculino.

Os representantes escolhidos pelos colaboradores são relacionados à aparência física e àquilo que eles transmitem por meio de suas atitudes e comportamentos: Tarcísio Meira, Brad Pitt e Reinaldo Gianecchini. Tarcísio Meira foi escolhido pelo tipo "paizão", Brad Pitt, por situar-se entre gêneros e transmitir idéia de "força", e Reinaldo Gianecchini, pela "beleza" e "força". Mariana lembra de um personagem de filme que chamou a sua atenção com relação à "fidelidade" à mulher e ao filho, indo ao encontro da sua representação de ser homem. Ainda na categoria artística, mais especificamente na musical, foram citados Jim Morrison, Mick Jagger e Kurt Cobain, tendo característica predominante a liberdade de escolha de estilo de vida, baseada na rebeldia e na contestação de valores sociais. Figuras políticas também foram 
lembradas, como Luiz Inácio Lula da Silva, Jorge W. Bush e José Serra pela determinação em alcançar ideais e pelo poder.

As percepções descritivas, ou mesmo aquelas relacionadas à figuras exemplares do universo masculino revelam ao longo dos depoimentos dos colaboradores homens a contundente cobrança experimentada na necessidade do enquadramento neste universo de masculinidade. A rigidez dos estereótipos patriarcais é sentida pelos colaboradores como uma forma de cobrança e de pressão. Jorge relata a cobrança de parentes e amigos para que adote uma apresentação masculina cortando cabelos e unhas compridas e, de preferência, que goste de futebol. Neste quesito, ele percebe que a sociedade quer mais um estereótipo de homem o macho - do que alguém que tem uma forma peculiar de ser homem, que não esteja rigidamente vinculado a este estereótipo, consolidando sua identidade singular.

Jorge aponta para algo que vai além das diferenças masculinas e femininas, que é uma forma de aceitação das diferenças e dos diferentes modos-de-ser homem. Sua postura no interjogo social é de não estar rigidamente relacionado nem ao estereótipo do ser homem e nem ao estereótipo do ser mulher, mas em uma zona de fronteira que lhe permita o transitar entre os gêneros. Por outro lado, a tensão volta à tona quando ele procura o enquadramento do próprio corpo ao corpo feminino quando volta-se para a cirurgia de transgenitalização. Vale lembrar que na sua percepção de gênero feminino, como será visto a seguir, existe maior flexibilidade de escolha de formas de apresentação, sem com isso colocar em questão o próprio gênero feminino, fornecendo sentidos para que Jorge "em um corpo de mulher", tenha fortalecida a liberdade de trânsito entre os gêneros.

Thiago associa o ser homem com a questão presente na sua vida, que é o (re)estabelecimento de relações sociais a partir da sua escolha pessoal em adotar um estilo de vida homossexual, situando-se enquanto homem. Assim, essa escolha em nada significa que Thiago deixa de ser homem pelo fato de sentir desejo afetivo-sexual por outro homem. A percepção de corpo de Thiago não é motivo de tensão, assim como visto em Jorge. Esta tensão é deslocada para o interjogo vivido nas relações sociais relacionadas com pessoas que não seguem um estilo de vida heterossexual.

Homens e mulheres fazem parte do mesmo meio sócio-histórico-cultural e partilham os mesmo estereótipos de gênero. Independentemente da questão da orientação do desejo 
sexual, do corpo, da identidade sexual, da performance sexual, a tensão no ser homem se faz presente à medida que cabe a ele, a partir do seu estar no mundo, legitimar este lugar de ser homem. A cobrança parte também das mulheres, que esperam dos homens certos atributos também relacionados a estereótipos que envolvem a força, a determinação, o domínio da situação, e, especificamente na questão do performance sexual. Espera-se dos homens a constante disponibilidade para a atividade sexual, legitimando a cobrança por um bom desempenho. Além disto, conforme mostra Scott (1988), o processo de diferenciação e de distinção, que exige a supressão de ambigüidades e de elementos de oposição, faz parte dos sistemas de significado na constituição da subjetividade das identidades, a fim de assegurar uma coerência e uma compreensão comum, mesmo que em um sentido ficcional.

\subsection{Percepção de feminilidades e a associação com a passividade}

Na periferia as meninas que 'ficam' tem uma imagem muito feia para as pessoas, principalmente das mães das amigas, principalmente o pessoal que tem mais idade, que teve outra situação. (...) [A mulher de classe média e alta] está bem mais resolvido no psicológico essa coisa de você ter um relacionamento e sair com outra pessoa, do que para o pessoal da periferia, talvez por causa desse lado conservador que tem. (...) O que difere mesmo, assim, é além do comportamento, daquela coisa que já vem, que a gente já nasce com isso, que a sociedade já impõe isso, da delicadeza, da compreensão.

Pessoas representativas: Política Heloísa Helena - não só pela questão política, mas pela sua maturidade e atitude, por querer e defender esse querer; atriz Maria Fernanda Cândido - por demonstrar ser uma pessoa madura e não explorar sua beleza de maneira fútil; atriz Malu Mader parece mulher... quando eu olho o jeito dela se vestir, porque ela não tem a coisa devassa na forma com que ela fala (Melina)

Uma coisa mais terna, assim... um eufemismo do masculino é a mulher. (...) É um modelo que está teoricamente colocado, que é uma coisa frágil... Mas, ao mesmo tempo que é frágil é uma fragilidade que esconde uma coisa determinada. (...) Eu percebo a mulher de uma forma meio enrustida. (...) Eu acho que deve ser mais vantajoso ser mulher do que homem... (...) Eu acho que aprendemos a ser estrategistas. (...) A mulher aprendeu com o tempo a ser mais forjada, o que faz com que ela seja mais experiente. (...) O que que forja a mulher acho que ela é meio privada da liberdade. (...) O que eu acho ruim disso é que eu me sinto prisioneira disso, disso que talvez se chama de regras. 
Pessoas representativas: Tia materna - está desempregada, está sofrendo, está muito mal, mas que ela está assim, sabe, porque ela está sentindo isso. (...) Ela não quer ajuda. (...) Eu acho isso bonito, (...) isso é autenticidade humana; atriz Ana Paula Arósio - eu gosto do jeito dela, (...) eu gosto do sofrimento porque eu acho que o sofrimento é mais verdadeiro; cantoras Vanessa da Mata e Adriana Calcanhoto são exemplos de equilíbrio. (...) Elas entenderam o desequilíbrio delas e aprenderam a viver com esse desequilíbrio. (...) São pessoas calmas, doces... (Sofia)

Ser mulher é... ter o poder maravilhoso de ter filhos, eu acho que é lindo, maravilhoso, excepcional. Ah, é essa... é ser vaidosa, apesar de eu não ser. (...) Acho que transmitir, expressar mais amor do que... diferentemente do homem, né, o amor de formas diferentes. (...) Eu acho que a mulher tem mais afeto. Mulher é ser guerreira, poder fazer muitas coisas ao mesmo tempo, poder trabalhar, ter filho... ser mulher... eu acho que é ser o multiuso, é fazer tudo mesmo. Você acaba virando em mil, eu acho. (...) Eu me sinto um pouco mais cobrada. Ah, cobrada pra ser dona de casa, cuidar do filho... Marido se sente, também, que tem que ser cuidado, sabe? Tem que estudar, tem que trabalhar, tem que ajudar, enfim, eu acho... Eu fiquei com a cobrança um pouco maior pra atender a família. E eu acho que essa cobrança vem de mim mesma...

Pessoas representativas: Própria mãe - porque ela é muito de cuidar de todo mundo, quer fazer tudo, e também puxa muita responsabilidade para si sem necessidade; atriz Cláudia Raia - É uma mulher que trabalha muito, lutadora, tem os seus filhos, consegue ser uma mãezona, e por ser uma mulher sensual... pelo menos não trocou de marido (Mariana)

Bonitinha, não andar torto, ser elegante. (...) Tem a opção de ser ativa, independente, mas também não ser cobrada, não ser colocada para fora por ser dependente, que é a opção de feminino. Não ter que manter a pose de dominante o tempo todo, como podem achar. É manter a sua própria coisa de status feminino. Tem que manter a sua própria pose (...), se definir como: 'Eu me visto bem, eu sou bonita, eu sou magra'.

Pessoas representativas: Atriz Nicole Kidman - pela sua beleza; jornalista Ana Paula Padrão - bonita (...) e parecer auto-suficiente, independente, bem ativa, mas ela tem ainda um quê de mulher (Jorge)

Eu tenho visto mulheres reclamar de feminilidade. (...) Há uma quebra nesses padrões e eu perdi um pouco dos meus referencias, nisso. (...) $O$ velho padrão da sociedade do que é ser feminino: é aquela que a mulher fica em casa, mas... mas eu nem concordo com isso, pois acho que isso é feminino também. (...) Feminilidade transmite a idéia de sensibilidade, vaidade, inteligência emocional. Mas esses limites são cada vez mais questionados e tênues, desaparecendo em alguns casos.

Pessoas representativas: Angelina Jolie - Características mistas, (...) passa a idéia de força, parece ser alguém mais sensível com as emoções de outras pessoas (Thiago) 
Elas também podem ser sérias, mas acho que aí acho que foge de ser mulher, porque elas não são muito sérias, sério de sério... (...) Mulher consegue entender várias coisas, assim, fazer várias coisas ao mesmo tempo. (...) Eu acho maravilhoso você sentir que ela é mulher, sabe, que tem um charme ali, se cuida diferente e tem aquele cheiro bom, usa perfume, tá preocupada com isso, com aquilo, a aparência... Acho aquilo interessante, muito interessante. E isso, pra mim, é uma mulher, nessa... nesse aspecto de visão. (...) A mulher está mais pra aconchegar, está ali de braços abertos (...) na hora do sexo aparece muito.

Pessoas representativas: Gisele Bündchen - bondosa, carinhosa... ela é bonita. A televisão só passa beleza, então, mais bonita, mais mulher (André)

As colaboradoras fazem referência à influência social na formatação de roteiros sexuais femininos. Dentro destes roteiros figuram a ternura, a moralidade, a maternidade como elementos principais. De acordo com as colaboradoras, o ser mulher está associado com: delicadeza, compreensão, forma meio enrustida, eufemismo do masculino, fragilidade que esconde uma coisa determinada, forma meio enrustida, estrategista, experientes, privada da liberdade, poder ter filhos, vaidade, expressar mais amor do que o homem, ter mais afeto, guerreira, multiuso - fazer mil coisas ao mesmo tempo -, e cobrança social. Os colaboradores homens seguem perspectivas semelhantes de associação, porém, dando mais ênfase à forma de apresentação e à flexibilidade de adoção de papéis: bonitinha, não andar torto, ser elegante, ter opção de ser ativa e independente, não ser cobrada, não ter que manter a pose de dominante, sensibilidade, vaidade, inteligência emocional, flexibilização de limites, ficar em casa, aconchego, poder ser sérias, entender várias coisas ao mesmo tempo, ter charme, se cuidar, ter cheiro bom, usar perfume, e ter braços abertos. Essas associações seguem perspectivas semelhantes às apresentadas pelas colaboradoras quanto aos atributos de ser mulher.

Apesar de Sofia descrever de forma exaltada os atributos masculinos em detrimento dos femininos, ela afirma que é mais vantajoso ser mulher. Assim como Melina e Mariana, Sofia percebe a influência social na construção da feminilidade, revelando a tensão existente entre aquilo que é socialmente estabelecido e o significado que cada mulher apresenta para esta tensão. Assim, ela fala de algo enrustido da mulher apontando para um sentido de que a submissão não é algo que necessariamente se reflete na experiência. Retomando a idéia de 
Focault (2001) de que o poder é algo inerente a toda pessoa, sendo que a diferença está na possibilidade do exercício desse poder em maior ou menor intensidade. Em um cenário de maior privação de liberdade do que os homens, Sofia afirma que as mulheres aprendem a ser mais "estrategistas", conferindo maior experiência ao lidar com as limitações, nas mais diferentes situações.

No depoimento de Sofia, nota-se que ela experimenta as mais diferentes situações no sentido de adquirir experiência mediante o interjogo das relações. Apesar de sentir-se cobrada, Sofia coloca em evidência o sonho do namorado ideal - o "príncipe encantado" -, como apontado pela sua mãe -,exercitando a sua liberdade em aproximar-se das situações de acordo com a sua disponibilidade e as possibilidades do contexto. A angústia, o sofrimento, são sentimentos venerados por Sofia que compreende as limitações deste modo de estar no mundo com parte de sua própria existência.

A percepção de Melina, dentro desta perspectiva em que o social forja o feminino, revela que, para ela, a questão das diferenças de classe social são fatores que influenciam nesta questão, sendo que nas classes de menor poder aquisitivo a mulher é mais cobrada com relação à permissividade sexual do que as mulheres pertencentes à classes mais abastadas. Assim, a mulher que "fica", ou seja, mantém relacionamento por algumas horas com alguém, sem compromisso de estabilidade ou fidelidade amorosa (Houaiss, 2001), acaba sendo alvo de críticas e de condenações, tolhendo a sua liberdade e estabelecendo regras específicas de roteiro sexual e de gênero. Melina não faz referência à influência do fator étnico na sua experiência em ser mulher, tomando como foco a inter-relação social nesta construção social que vincula o ser mulher à "delicadeza" e à "compreensão".

Ao longo da trajetória de vida de Melina o abuso sexual foi um fato em que ela era coagida a ficar no silêncio. Melina cresceu num meio social em que as mulheres são educadas para cuidar do lar e dos maridos, vale lembrar, como exemplo, a conversa entre mulheres em que sua tia teceu com orgulho: "Olha a sua prima Raquel, de 10 anos, limpa uma casa do jeito que tem muita dona-de-casa que não limpa". Melina aponta que as mulheres desde cedo são educadas para este papel. A mãe e as irmãs são percebidas como aquelas que abriram mão dos empregos para cuidar do lar e dos maridos. Melina trilhou um caminho diferente em que o ingresso na universidade e no mercado de trabalho representou uma ruptura - e ainda mais tensão - com os valores do seu meio social. Os desdobramentos são vividos por Melina ainda 
hoje quando questiona a continuidade do relacionamento com o atual noivo ou dos seus estudos. Para ela, parece ser ainda impossível conciliar casamento e família com realização pessoal por meio dos estudos e trabalho. Ou seja, realidades incompatíveis com o meio social em que vive, em que o roteiro de gênero feminino é rigidamente definido, tornando confusa esta conciliação dentro do seu projeto de vida.

Mariana aponta para a desigualdade naturalizada da mulher em relação ao homem, tendo a mulher o poder maravilhoso da maternidade. Interessante notar o "poder" da maternidade que custou ao longo da história o enclausuramento da mulher no âmbito doméstico, sob a égide do "instinto materno", como se esse também não fosse construído socialmente (Badinter, 1985). Mariana percebe esse dom da maternidade como algo maravilhoso na sua experiência. Por outro lado, na sua associação do ser mulher, Mariana torna clara a sua percepção do quanto sente-se cobrada pelo fato de ser mulher. Para ela, o ser "multiuso", entendido como responsável por cuidar da casa, do marido, dos filhos, dos estudos, do trabalho, correspondendo às expectativas do mundo, torna-se algo pesado para ela. A cobrança acaba sendo naturalizada de maneira que ela a assume para si e ela própria torna-se aquela que cobra o desempenho no cotidiano, e não mais a sociedade.

No depoimento de Mariana percebe-se que a correspondência aos valores e crenças do meio social por um lado auxiliam no sentimento de pertença na medida em que consegue conciliar diferentes realidades, sendo que, em primeiro lugar mantém seu papel de esposa e mãe. Esta necessidade de correspondência às expectativas do lugar de "multiuso", por outro lado, prejudica outras áreas, a exemplo da vida sexual. Agregue-se a isto o fato de ela sentirse cobrada por não corresponder ao apetite sexual do marido e sentir-se deficitária em informações sobre o campo da sexualidade. Neste cenário, de uma forma racionalizada, seu roteiro é da busca constante pela melhoria performática no sexo. Quando Mariana percebe a dificuldade de comunicação dela e do marido, e sua dificuldade de ter contato de forma prazerosa com seu próprio corpo, novos sentidos são apresentados na experiência do prazer sexual compartilhado.

A percepção do "ser mulher" para os colaboradores homens também vai ao encontro de uma representação em que a forma de expressão e algumas atitudes são atributos importantes. Vale ressaltar que a percepção dos colaboradores segue uma perspectiva de uma flexibilização do papel feminino, mais especificamente nas falas de Jorge e Thiago. Na fala de 
André, a mulher pode até ter atitudes e comportamentos próximo ao do homem, porém, isto gera certo estranhamento, visto que os atributos do ser mulher, para ele, estão bem próximos ao papel maternal em que a mulher sempre está de braços abertos para a acolhida. No seu depoimento, André fala sobre este estranhamento quando refere-se ao relacionamento de seus pais, sendo que a mãe assumia o papel daquela que administra a vida do casal. Isto, para André, é algo que desqualifica o pai no papel de homem.

A imagem dos pais de André revela que, apesar da maior flexibilidade dos papéis masculinos e femininos, e a tênue inter-relação entre eles, homens e mulheres percebem os papéis de forma definida, sendo que as pessoas se apropriam destes modelos de formas peculiares, de acordo com a inter-relação com o meio e contexto social. Estas formas de apropriação, como, no exemplo citado, o lugar da mulher, não são questionadas caso a mulher assuma uma postura mais de comando, sendo que, o homem nesta condição de ser comandado torna-se menos homem. Deste modo, os roteiros sexuais masculinos são mais direcionados para o acesso ao poder do que as mulheres.

Com relação aos representantes escolhidos pelos colaboradores estão mulheres ligadas ao campo artístico, como as atrizes Maria Fernanda Cândido e Malu Mader, pela expressão de maturidade que elas transmitem e pela maneira de valorizar o aspecto feminino sem ser "uma coisa devassa". A atriz Ana Paula Arósio é citada pelo sofrimento vivido na ocasião da trágica morte de um namorado. A atriz Cláudia Raia é citada como a mulher envolvida com o lado profissional e familiar sem perder a sensualidade e sem trocar constantemente de marido. Nicole Kidman foi citada pela beleza e Angeline Jolie por transmitir força e empatia com outras pessoas. A jornalista Ana Paula Padrão foi citada pela beleza e por transmitir autosuficiência, independência e atividade; a modelo Gisele Bündchen pela bondade, carinho e beleza; as cantoras Vanessa da Mata e Adriana Calcanhoto pelo misto de equilíbrio e desequilíbrio das letras de suas canções, sem perder a calma e a doçura. Do campo político, somente Heloísa Helena foi citada, pela maturidade e determinação. Apesar de não constituírem figuras públicas, foi menciona a própria mãe, pelo fato de cuidar e envolver-se em diversas atividades, chamando para si a responsabilidade pelo bem-estar dos familiares; e, também, a tia, pela opção em viver o sofrimento sem aceitar ajuda externa.

Os representantes escolhidos pelos colaboradores vão ao encontro daquilo descrito na suas percepções de gênero. Longe de encerrar os modos-de-ser homem e os modos-de-ser 
mulher em categorias - como se isto fosse possível -, vale ressaltar que as relações não são lineares e que existem as mais diferentes formas de inter-relação entre os gêneros. Porém, cabe ressaltar que, mesmo diante de um universo de possibilidades do ser homem e do ser mulher, ainda são presentes os estereótipos de gênero seja de masculinidade, seja de feminilidade, gerando tensão com novas possibilidades de ser homem e de ser mulher. Meu propósito é justamente registrar as diferentes formas de experiência emocional e social de homens e mulheres ao longo da vivência das suas sexualidades.

Os significados e os sentidos dos gêneros são complexos e ilimitados, de forma que serão apontados os que considerei mais significativos e exemplares ao longo das trajetórias dos colaboradores. Neste sentido, na ocasião das entrevistas, no sentido de valorizar as experiência, julguei interessante o registro de como os colaboradores imaginam, ou propõem, que as pessoas vivessem a sua sexualidade da forma mais plena possível, o que será retomado a seguir.

\section{A busca pelo atendimento no Plantão Psicológico}

'Então você é gay?'. Não. 'Então você é uma menina?'. Não. 'Então o que você é? Você gosta de mulher?'. Sim, eu tenho uma namorada, gosto. 'Então você é homem?'. Não sei, talvez eu seja mulher, talvez eu seja lésbica. (...) O atendimento não deu em nada, porque acho que o assunto surpreendeu o psicólogo. Ele não esperava. Eu não esperava que alguém soubesse o que fazer. (Jorge)

Por mim não precisava [vir ao Plantão], mas a minha ex-namorada estava insegura: 'Vai lá!...'. Daí: ‘Tá, bom...'. (...) Foi nesse período, (...) que eu efetivamente assumi para mim mesmo. Daí eu me dei alta, porque eu me sentia bem. (...) Considero ter sido [o Plantão] um tipo de catalisador para um processo que já tinha começado. (...) Quando eu conversei com a psicóloga daqui, (...) foi muito positivo porque me fez pensar em algumas coisas que eu não pensava antes, e reconsiderar outras coisas. (Thiago)

Não era estresse, era... depressivo, mesmo, sabe? Eu estava mal, não tava no lugar certo... Era horrível. Às vezes, eu pensei: "Pô, fui fraco, devia ter agüentado, sei lá, o que aconteceu”. Um momento que me dá um negócio doido, eu fico mal no lugar que eu estou, que eu quero 
fugir. (...) Depois teve um momento desses que eu vi que tinha alguma coisa errada, que eu vim aqui no Plantão. (...) [A psicoterapia e o Plantão Psicológico] abriu muito minha cabeça, e mudou muitas coisas, então, tipo, eu acho que agora eu estou mais correto, não sei, mas tá diferente, pelo menos (André)

Eu ia dormir, escutava algum barulho na rua, eu ficava com medo. Eu parei de estudar aqui à noite porque eu ia embora com medo de que alguém viesse... porque o meи medo não era vir ele [padrasto] e fazer alguma coisa comigo, mas ele mandar alguém fazer algo comigo. Toda a pessoa que se aproximava de mim e ficava com aquela desconfiança, 'Será que ela não foi mandada por ele, para vir atrás de mim me matar?'. (...) Agora já passou o período mais tenebroso, agora vou viver a minha vida. (Melina)

Quando eu vim procurar o serviço eu estava preocupada com essa questão de que eu queria arrumar namorado, sabe? Porque eи me sentia sozinha (...), precisava de alguém, mas eu não conseguia fazer essa aproximação. Aí surgiu uma série de questões: 'Será que o problema é comigo?', (...) 'Será que eu gosto de mulher?', porque era possível, mas eu tenho um desejo por homem. (...) Eu me tornei consciente de algumas coisas que eu precisava me tornar. (Sofia)

A gente brigava muito, (...) daí chegava a hora de dormir e, em vez de se amar, briga. (...) Aí foi se tornando como uma obrigação. Era essa a impressão que eu tinha: ter que fazer [sexo] pra gente não se separar. Não era pra dar prazer. (...) Essa descoberta da minha sexualidade aconteceu a partir de quando eu comecei a conversar com essa moça do SAP. (...) Consegui ter uma atividade melhor com meu marido, conversar mais com ele, (...) me ajudou a pôr pra fora. (Mariana)

A proposta do Plantão Psicológico é de um espaço de escuta no mesmo momento que se procura a ajuda, propiciando a elaboração da experiência da pessoa a partir do sofrimento psíquico vivido, e a possibilidade de ajuda (Schmidt, 1999). O enfoque dado pelo Plantão Psicológico é na pessoa que se queixa e no significado que esta queixa representa para esta singularidade. A proposta do Plantão Psicológico é baseada no cuidado e na atenção, a partir de uma escuta atenta, no qual se privilegiado o encontro.

O Plantão Psicológico não constitui espaço para o atendimento de queixas particularizadas, mas de um lugar de fronteira, um lugar de passagem, espaço de acolhimento, de escuta, cuja proposta é de auxiliar a pessoa na compreensão da dificuldade, angústia, ou mesmo esclarecimento de algo circunscrito a algum momento da sua vida. Morato (1999) mostra que o lugar de fronteira é compreendido como uma região de passagem, do cruzar de 
um lugar específico para outro, no qual tudo e todos podem ser e pertencer. Nesse sentido, Schmidt (1999) afirma que o atendimento nesta região de fronteira remete-se à "fronteira das práticas que tradicionalmente são identificadas como clínica-pedagógicas e educacionais, e fronteira de recursos teórico-práticos de diversas disciplinas afeitas aos assuntos humanos (p.97). É contemplado no atendimento, de acordo com a autora,

(...) o esforço de responder às demandas por ajuda psicológica através de uma compreensão psico-sociocultural destas demandas e, ao mesmo tempo, através da potencialização de recursos psicossociais na clientela (p.97).

O Plantão Psicológico, enquanto lugar de fronteira, torna possível para a pessoa a suspensão temporária da sua jornada, mediante o encontro com alguém que se propõe estarjunto naquele momento, sem a pretensão de psicoterapia, de "cura", ou de meramente resolver o problema, mas, como dito, esclarecer a uma demanda apresentada pela pessoa. Neste lugar de passagem, Mahfoud (1987) afirma que:

A experiência de plantão como momento significativo da pessoa ante sua problemática tende a se tornar referência existencial: portas abertas que podem significar facilitação para um novo pedido de ajuda ou facilitação para suportar a espera do início de um outro processo (p.82).

Uma imagem que ilustra bem a proposta do Plantão Psicológico foi fornecida pela Profa. Dra. Henriette Morato, quando do meu ingresso no SAP, enquanto supervisor voluntário: $o$ Plantão Psicológico pode ser compreendido como uma "planta grande", uma árvore, que oferece ao viajante seus frutos para aliviar a sede e a fome, e sua sombra para que descanse, se recomponha, e retome a sua jornada. A proposta do Plantão Psicológico vai muito além e diferencia-se de uma idéia de triagem ou mesmo de um serviço de ambulatório.

A proposta da presente pesquisa era fazer um recorte das pessoas que procuraram o Plantão Psicológico com alguma queixa relacionada à sexualidade. Deste modo, quando os colaboradores buscaram o Plantão Psicológico o fizeram devido às demandas daquele momento de suas vidas em que existia alguma associação ao aspecto afetivo-sexual. Interessante observar que, a partir deste momento, mesmo o Plantão Psicológico não tendo a pretensão de um trabalho específico na esfera da sexualidade, ou de qualquer outra, funcionou 
como espaço para a (re)apropriação da sexualidade enquanto experiência-vivida em um sentido mais amplo.

O Plantão Psicológico é representado pelos colaboradores sob diferentes perspectivas. A partir dos relatos dos colaboradores, o Plantão Psicológico é percebido como um espaço de interlocução que favoreceu para que a vivência afetivo-sexual fosse integrada à experiência vivida como um todo, favorecendo novos sentidos para o sofrimento, contribuiu para aquilo que era percebido como um problema afetivo-sexual ser resignificado de forma a ampliar possibilidades de vivência pertinente com a singularidade da experiência vivida da pessoa.

Ao longo da trajetória de vida de Jorge o questionamento sobre a identidade sexual e da forma de estar-no-mundo sempre foram presentes. Este questionamento tornou-se ainda mais intenso a partir da aproximação afetiva com sua namorada. A forma tranqüila e satisfatória com que o relacionamento iniciou e desdobrou-se retomava a questão do seu lugar no mundo. Os rótulos sexuais não serviam para ele situar-se neste lugar: Gay? Mulher? Homem? Lésbica?... Os roteiros que Jorge compreendia acerca destes papéis não correspondiam àquilo que percebia a partir da sua experiência. Neste sentido, o fato de ele ter familiaridade com o roteiro feminino não o fazia nem mulher, nem gay; por outro lado, a familiaridade com o roteiro masculino não o fazia nem homem, nem lésbica. A experiência de relacionamento de Jorge e de sua namorada tornava-se tão singular que não era explicada pelos roteiros sexuais apreendidos até então, sendo cenário para a apropriação de seus próprios roteiros.

Cada cultura, em dado momento histórico, compreende de forma particular os roteiros sexuais, no que se refere ao gênero do que é ser homem, do que é ser mulher, assim como os roteiros sexuais dos relacionamentos, sejam eles hétero, homo ou bissexuais. Vale a ressalva de que o sentido de "ser homem" e "ser mulher", aqui adotado, segue a perspectiva das masculinidades e das feminidades em um sentido amplo do termo, não ficando circunscrito a uma esfera rígida que define os gêneros, mas às formas de conceber as individualidades no masculino e no feminino, que perpassa vivências e idealizações sobre relações sociais entre os sexos (Castro, Abramovay \& Silva, 2004). No que se refere à identidade, há de se acrescentar os roteiros travestis, transexuais, e andróginos. Durante a entrevista, quando apresentei a Jorge a idéia de androginia, enquanto uma forma de estar-no-mundo, ele prontamente a rejeitou, afirmando não se enquadrar nesta categoria. A questão que se desenhou é quanto à 
relevância para Jorge em ter uma resposta que enquadre seu modo-de-ser. Uma alternativa possível para esta pergunta é que, diante da profusão de categorizações, sejam elas de cunho biomédico, ou político. Para Jorge, torna-se importante uma definição que delimite um espaço e que desponte um senso de pertencimento.

A reação de embaraço do estagiário percebida por Jorge quando da sua passagem pelo Plantão Psicológico não foi motivo de espanto. Jorge já antevia este tipo de reação, a partir de conversas com outras transexuais quando estas se referiam às reações de médicos e outros especialistas. A percepção de Jorge é a de que ninguém sabe o que fazer diante da situação de pessoas transexuais. Se nos remetermos à história da sexualidade fundada na díade homemmulher, uma outra possibilidade, representada pelas pessoas transexuais, desestabiliza a organização dos gêneros, revelando o que os modelos dados não correspondem à diferentes realidades possíveis. A tentativa, por diversas vezes buscada por pessoas transexuais é o enquadre no gênero masculino e feminino.

A busca de Jorge por uma dialogia, de um encontro com o outro, era freqüentemente frustrante para ele. Outra questão surge: a queixa apresentada por Jorge é circunscrita à esfera sexual, ou diz respeito à esfera relacional em que a sexualidade, enquanto parte de uma experiência maior, se faz presente? Neste sentido relacional, em que existe essa complementaridade, a questão não diz respeito somente no fato de Jorge buscar saber onde categoricamente se encaixa, mas a uma outra: a sociedade fornece espaço para a singularidade de Jorge? A trajetória de Jorge mostra o quanto são restritos tais espaços de inter-relação.

Jorge aponta em seu depoimento um sentido encontrado para esta questão a partir das referências aprendidas e apreendidas no seu contato com o mundo: assim que terminar sua graduação, submeter-se-á a um acompanhamento visando a cirurgia de mudança de sexo, mesmo tendo uma relação afetivo-sexual satisfatória, em que o pênis é um elemento importante para a obtenção de prazer. Em um processo de acompanhamento pré-cirúrgico, neste momento de vida, o laudo para a mudança de sexo não seria favorável, pois a questão não vai ao encontro de um roteiro transexual no qual o pênis, ou melhor, o fenótipo masculino, é motivo de rejeição. Por outro lado, na experiência de Jorge, a cirurgia de mudança de sexo é uma possibilidade no sentido de ajudá-lo a sentir-se enquadrado enquanto homem ou enquanto mulher. A definição cirúrgica dar-lhe-ia o substrato para sentir-se pertencente a um gênero. 
A perspectiva de uma definição de identidade sexual se faz presente no depoimento de Thiago. Ao longo de uma trajetória de vida em que a rejeição se fez presente, de forma sutil ou explícita, Thiago também procurou espaços que favorecessem o senso de pertença. Na fala dele, o sentido que se apresenta é de que "nem tudo são flores" e o amor e a amizade nem sempre são presentes na aridez da realidade, ainda mais quando descobre a atração por pessoas do mesmo sexo e não encontra caminhos para abertamente demonstrar essa atração.

Apesar de não haver muitos elementos para a compreensão das marcas deixadas pelo Plantão Psicológico na experiência de Jorge, é possível questionar de como a formação de profissionais da área da psicologia - e também da saúde - o tema da sexualidade, em um mundo em que as diferenças e diferentes são realidades que nem sempre são contempladas no ensino formal. O que fica em evidência é justamente a forma como que acontece o encontro em que a tensão se faz presente. De um lado Jorge, consciente da sua diferença e dos questionamentos quanto a sua identidade sexual, e de outro o estagiário diante de uma demanda que possivelmente extrapolava seus próprios naquela situação de atendimento.

Thiago revela um sentimento de alívio, que fica representado quando diz que "foi como saísse uma carga", levando consigo a sensação de "sufocamento de eu não ser eu mesmo", o que lhe possibilitou deixar entraves e impedimentos para a vivência afetivo-sexual. O sentimento de superação de um problema era tamanho que compartilhou com a sua namorada os novos sentidos de estar-no-mundo. A então namorada motivou-o a procurar o Plantão Psicológico, pois ela própria havia sido ali atendida. Thiago compreendeu a atitude da namorada como "insegurança", pois, ele próprio não sentia a necessidade deste tipo de ajuda. Ele teve êxito em adequar seu roteiro sexual aquilo esperado dentro de uma hegemonia heterossexual, porém, a falta de sentido desse roteiro exigia uma nova configuração, foi quando procurou o Plantão Psicológico.

Este sentimento de não pertencimento a determinadas categorias, ou modos-de-ser, também foi a base da queixa levada por Sofia ao Plantão Psicológico. Ao longo do seu depoimento, Sofia transmite um sentido de descoberta, de experimentação, sem necessariamente vislumbrar um objetivo final de uma categoria, apenas viver conforme as possibilidades que se apresentam. O sexo, ou a sexualidade, não se tornam objetivos a serem alcançados, mas parte de uma forma de estabelecer e viver a relação com sua rede social. A 
ida ao Plantão Psicológico teve como motivador a gratuidade do serviço - a mãe não queria mais pagar sua terapia particular - e a dificuldade em encontrar namorados. No contato com o seu depoimento percebe-se que o contato com rapazes acontece, porém, até o limite o início do envolvimento afetivo-sexual, quando ela se afasta.

A tensão vivida por Sofia abre espaço para o questionamento sobre a orientação do seu desejo sexual: "Será que o problema é comigo? (...) Será que eu gosto de mulher? Porque era possível, mas eu tenho um desejo por homem". O fato de ela querer, mas não ter encontrado um caminho para a vivência afetivo-sexual estável um outro homem, atrelado ao fato de que suas amigas já atravessavam por essa experiência, contribuiu para que ela experimentasse um senso de inadequação, problematizando, assim, a questão da sua sexualidade. O senso de normalidade e anormalidade se faz presente a partir de referenciais de roteiros vigentes na rede social e não na própria experiência de descoberta ou desvelamento do universo afetivosexual. A cobrança por determinados comportamentos, ou roteiros sexuais, era tão intensa que tornava dificultoso o processo de encontrar um sentido para a própria experiência, na sua relação com o mundo. Neste cenário envolvendo a idéia de "normalidade" vs "anormalidade", Gagnon (2006) destaca três processos para compreender o estabelecimento de referenciais que reforçam estas idéia no âmbito da sexualidade:

(1) a mudança no nível de estigmatização e controle social voltados para formas específicas de conduta sexual; (2) os agentes sociais responsáveis pela explicação e pelo tratamento; e (3) a mudança no caráter da prática terapêutica. Essas mudanças fazem parte dos cenários culturais que nos instruem sobre como agira esses 'problemas' ou 'não problemas', bem como dos roteiros interpessoais em que a conduta se expressa ou é abordada com problemática (p.259-260).

A busca do Plantão Psicológico por Melina não estava diretamente relacionada à sexualidade. Importante focar a experiência de Melina em uma perspectiva que privilegie a sua trajetória de forma integral, e não apenas como um desdobramento dos anos de abuso sexual, embora o sentimento de persecutoriedade fizesse presente quando foi procurar o serviço. Este sentimento ficava evidenciado quando saía da faculdade, à noite, e se dirigia para o ponto de ônibus na volta para casa. A proximidade de qualquer pessoa a remetia para a possibilidade de algum ato violento a mando de seu padrasto. Ao longo do atendimento no 
Plantão Psicológico, Melina percebeu que as marcas deixadas pelo abuso sexual também interferiam no seu relacionamento com o noivo. Quando aconteciam carícias mais íntimas, Melina experimentava reações de choro e retraimento. As relações sexuais aconteciam, mas eram entremeadas por estas reações que remetiam à angústia e ao sofrimento.

A busca por ajuda no Plantão Psicológico foi a primeira na vida de Melina, que até então, lidava de maneira solitária com tudo aquilo que acontecera em sua vida. Apesar de ela Melina ser expressiva a sua entrevista, ao longo da sua trajetória de vida, vê-se que o silêncio foi companhia constante. Na percepção de Melina, mediante aquela referência masculina que oferecia proteção e afeto, em uma atmosfera de pseudo-segurança, ao longo dos anos de abuso sexual, era coagida pelo padrasto a não contar nada para a mãe. O abuso não era percebido como um problema para Melina. Por outro lado, não tinha necessidade de comunicar à mãe o acontecido, pois não sentia o respaldo - inclusive afetivo - por parte dela. Pelo contrário, Melina reconhece que a mãe considerava-a uma rival dentro de casa, chegando a ponto de dizer-lhe que as coisas seriam melhores caso ela fosse embora. O roteiro sexual e de gênero de Melina, a partir da vivência do abuso sexual, na infância, forneceu sentido de sexo associado ao exercício do poder, da subjugação, da falta de dialogia.

A busca pelos serviços do Plantão Psicológico por André e por Mariana apresenta um sentido direcionado para a queixa relacionada à resposta sexual. Porém, vale o adendo de que a questão sexual jamais é apresentada de forma isolada, mas sempre associada à dificuldade afetiva, a qual, por sua vez, está associada com a inter-relação da pessoa com os pares no meio social de maneira mais ampla e complexa.

Quando André procurou o Plantão Psicológico seu grau de sofrimento era intenso, dadas as transformações que experimentava devido à entrada na universidade. A nova realidade - inclusive acadêmica - exigia mais de si, então longe dos pais e amigos da sua cidade natal. O baixo desempenho nos estudos, entremeado com questões afetivo-sexuais, aumentava sua angústia. A intensa auto-cobrança de André, como visto anteriormente, refletia-se na sua atual forma de compreender seus relacionamentos e o mundo. A ansiedade por um desempenho idealizado, de ereção plena, acompanhou André desde o início de sua vida sexual. Este tema levado ao Plantão Psicológico já era trabalhado na sua psicoterapia. 
Ao longo do seu atendimento no Plantão Psicológico, André tem contato com seu roteiro sexual que incluía a auto-imagem viril legitimada pelos seus pares na sua cidade natal. Essa imagem era tão entranhada que a dificuldade sexual jamais era tema de conversa com amigos, transmitindo a impressão de que os contatos com as mulheres sempre eram plenos e satisfatórios, condizendo com o roteiro sexual. André cita em seu depoimento a um trecho de psicoterapia em que foi trabalhado seu mecanismo de "padrão de qualidade" da relação sexual e do quanto esse mecanismo gerava mais empecilhos do que facilidades para o prazer compartilhado.

As marcas que André obteve ao longo da sua trajetória influenciaram para o roteiro sexual enrijecido, dificultando a apreensão de novas marcas a partir da experiência vivida. Neste universo interno prevalecia a idéia de "ser forte" e de "ser fraco", sendo que espera-se de um homem ser viril e, portanto, sempre ser forte. O próprio fato de ter buscado ajuda, para ele, representou uma forma de fraqueza de não ter conseguido resolver seu problema com seus próprios esforços.

De acordo com o depoimento de André, os filmes eróticos foram suas principais fontes de referência do contato sexual entre os corpos. Esse tipo de produção, além de não apresentar homens ou mulheres com dificuldades sexuais, também são editados, algo que nem sempre o espectador leva em consideração. Os encontros nesses filmes são apresentados com altamente satisfatórios, o que nem sempre acontece na vida real.

O movimento de André de garantir um "padrão de qualidade" a todo o custo, desconsiderando o contexto vivido, contribuía para que a dificuldade se mantivesse, não só em termos sexuais, mas também acadêmicos. Esta pressão proveniente de um conjunto de cobranças para ser um homem-funcional no mundo abria espaço para a angústia e a depressão. A experiência de André remete à idéia de que o roteiro sexual do homem é mais pesado do que o da mulher, pois o homem a todo o momento, de alguma forma, é chamado para provar sua virilidade (Vaccari, 2002; Bozon, 2006). Afinal, nunca se ouve alguém desafiando uma mulher para provar que é mulher.

Mariana buscou o Plantão Psicológico quando passou a reconhecer seu baixo desejo sexual diante do elevado desejo de seu marido. A situação do relacionamento chegou a ponto do quase rompimento dada a insatisfação sexual tanto dela quanto do marido, que era motivo 
para brigas do casal. Como a própria Mariana ilustra no seu depoimento, na hora de ir para cama "em vez de se amar, briga". A queixa de Mariana, sem dúvida alguma, não se circunscrevia à esfera da inibição do desejo sexual, mas abrangia também uma dificuldade de comunicação do casal e um roteiro sexual que não favorecia o entre parceiros.

A proposta dos roteiros sexuais e de gêneros contribui em diversos sentidos para a compreensão dos sentidos e significados da queixa de Mariana. Ao longo da sua trajetória, ela pouco teve acesso a referenciais a respeito do universo da vida sexual, até mesmo pelas mensagens da família, embasadas no modelo patriarcal de que a mulher deve preservar-se ou seja, não deve ter acesso a qualquer conteúdo de cunho sensual ou erótico. Mesmo nesse contexto, Mariana procurou, mesmo de forma velada, informações em revistas voltadas para o público adolescente. Sua vivência sexual aconteceu com o marido, quando estavam prestes a se casar. Portanto, um dado de extrema relevância é sua pouca experiência e o sentimento de cobrança diante do marido. Sua trajetória aponta para o fato de os roteiros de gênero feminino, até o casamento, serem pouco estimulados para o desenvolvimento dos roteiros sexuais. A situação se inverte depois que se casam, sendo mais cobradas por um desempenho sexual que muitas vezes não têm, sendo necessário um período para o aprendizado de contato com o corpo no sentido de obtenção de prazer.

A questão não é meramente Mariana ter mais experiências, mas que tenha condições para que ela apreenda a experiência sexual de forma compartilhada com o marido. Ao longo do seu depoimento fica evidenciada sua busca constante por uma vida sexual de maior qualidade. Agora, casada, e com a "autorização" para que tenha contato com o prazer sexual, Mariana também busca na TV a cabo, em programas especializados, as informações, dicas e recursos para o constante aprimoramento da "qualidade" da vida sexual. Uma questão importante é quanto ao bombardeio de informações, talk-shows, fórmulas e procedimentos, entre outros. Estes meios podem auxiliar as pessoas apropriem-se de seus corpos e prazeres de uma forma singular e plena, como também estabelecer roteiros sexuais e de gênero específicos e pré-formatados, funcionando como referência para o "bom desempenho".

Ao longo do seu depoimento, Mariana mostra que a busca de sentidos que empreendia no mundo externo era tão intensa que mal percebia o que acontecia na sua intimidade. Além do contato com o próprio corpo visando o conhecimento ou mesmo o prazer. Mariana passou a perceber melhor as mensagens negativas internalizadas sobre a vivência do prazer, inclusive 
o sexual. A isto ela chamou de "pedra psíquica". Apesar Mariana sentir-se aliviada do peso desta "pedra psíquica", parece que a questão não se resolve, pois o movimento de busca continuou.

\section{A passagem pelo Plantão Psicólogo: o olhar para a experiência}

Hoje, eu não me identifico, eu não concluí nada, tanto que eu uso meus cabelos compridos. E me perguntam: 'Por que você tem as unhas compridas?', e eu falo que é tradição russa. (...) Eu me sinto cobrado, sem dúvida. Meus pais e alguns amigos me falam: 'Corta esse cabelo, corta essas unhas, vista-se como um homem'. Ah!... Sempre falaram isso. Desde bem antes de eu fazer qualquer coisa eles já falavam isso: 'Falem o que quiser, eu não tô ligando'. (...) Tem hora que bate uma coisa do tipo: 'Puxa... bem que eu poderia ser uma garota de verdade, bonitinha...'. Eu ando... se eu saio andando pela rua, eu me sinto mal, por estar na rua. Eu acho que eu estou andando torto, estou deselegante, que estou deselegante... que as pessoas estão reparando. Não gosto de me expor. Acho que talvez a coisa ficaria mais fácil, não mais fácil, mas seria mais confortável para mim (Jorge)

Ainda ficaram marcas disso. Eu ainda não superei todas. Eu ainda sou uma pessoa tímida, às vezes, quero fazer tal coisa e eu me sinto um pouco inseguro, de falar... de repente... sei lá, de expressar de alguma coisa, de me vestir de uma forma, assim, coisa que eu tenho que superar. Mas todos aqueles problemas eu tive com as dificuldades, eu tive que enfrentar para superar aquilo, sem ser resignado. (...) Depois que eu me assumi, foi como saísse uma carga, vários bloqueios psicológicos que eu tinha dificuldade foram caídos (Thiago)

O que mudou comigo não é só com o sexo. Teve uma... com tudo, né, teve uma liberação. (...) Tudo tava dando errado, então talvez eu me cobrava mais. Sexo dava errado, com minha namorada, algo, tipo, três anos programando, aí na hora, no momento, que eu fiquei mesmo muito mal. (...) [O Plantão Psicológico] abriu muito minha cabeça, e mudou muitas coisas, então, tipo, às vezes... eu acho que agora eu tô mais correto, não sei, mas tá diferente, pelo menos (André)

Hoje tenho medo de chegar a esta idade e não encontrar alguém pra casar. Sabe, é difícil na casa dos 30 arrumar marido. Às vezes, penso em ficar só, às vezes, penso em casar com o Pedro mesmo. (...) Sei lá, estou muito confusa em relação a casamento! Mas estou achando que ficarei sozinha, embora ache que isso não seja o ideal... (Melina) 
Teoricamente, eu já me tornei mais consciente de algumas coisas que eu precisava me tornar, (...) por exemplo, de que eu preciso aceitar as pessoas do jeito que elas são, e eu preciso me propor a isso para arrumar um namorado... entendeu? Eu preciso me sentir mais envolvida, me permitir me sentir mais envolvida. Mudou um pouco no meu pensamento. (Sofia)

Na verdade eu ainda acho que falta, pelo menos pra mim, de repente, continuar conversando com alguma pessoa, especialista mesmo, pra falar algumas coisas. (...) Acho que por esse muito tempo, e eu ainda ser jovem, e não entender muito sobre o assunto... eu acho que atrapalhou um pouco. Não tive muitos outros namorados, não tive nenhum outro contato sexual. (...) Essa descoberta da minha sexualidade aconteceu a partir de quando eu comecei a conversar com essa moça do SAP. (...) Consegui ter uma atividade melhor com meu marido, conversar mais com ele. Por conta dessa pedra psíquica, a gente descobriu isso na conversa. E eu não associava tudo isso com a sexualidade, essas coisas. (...) Mas eu acho que eu ainda tenho dificuldade em sentir desejo com o meu marido. Na hora do deita e rola, já cai nisso. (Mariana)

Apesar de o encontro no Plantão Psicológico não ter acontecido a contento, no lance de olhar para a sua experiência vivida, Jorge compreende sua sexualidade associada à tensão entre a forma como se percebe e aquilo que a sociedade espera dele. Nessa tensão, o elemento corpo, mais especificamente a forma com que Jorge se apresenta socialmente, ganha destaque, o que fica exemplificado nos longos cabelos e unhas, a "tradição russa", resposta que utiliza para evitar aprofundar em justificativas de como escolheu se apresentar fisicamente.

A forma de apresentação física de Jorge, agregada aos seus comportamentos e atitudes, contribui para que socialmente ele seja situado tanto no território masculino, quanto no território feminino. Por outro lado, a partir de sua fala, a tensão acaba sendo mais intensa em como ele se sente percebido pelo outro do que como ele próprio se percebe. Porém, este situar-se e ser situado, é algo que significativamente influencia na construção e na vivência da identidade. No caso, a falta de parâmetros no meio social que possibilitem que Jorge se identifique o impele para a idéia de que não se identifica com nada. Por um lado, ele tem atributos físicos femininos estereotipados - cabelos e unhas compridos -, e atitudes que não o enquadram em um gênero específico - a exemplo de agradecer substituindo a expressão "obrigado" por "grazie" ou "thank you" - mas, por outro lado, quando sai à rua, no espaço 
público, ele se percebe como "eu estou andando torto, estou deselegante (...) que as pessoas estão reparando".

Mesmo situando-se nesta região fronteiriça entre os gêneros, na sua existência social, Jorge não sente-se pertencente ao gênero masculino ou feminino. Longe de uma perspectiva de localizar causa e efeito, vale aqui retomar a familiaridade de Jorge com a vivência virtual no papel feminino enquanto algo gratificante para ele, o que concede mais intensidade a esta tensão, ainda mais quando tem uma vivência real - entendida aqui como "presencial" - com uma mulher e é tratado por ela no gênero feminino.

Por mais que Jorge consiga estabelecer um relacionamento afetivo-sexual, o senso de incompletude se faz presente. A idealização surge na imagem de que "bem que eu poderia ser uma garota de verdade, bonitinha...(...) Acho que talvez a coisa ficaria mais fácil, não mais fácil, mas seria mais confortável para mim”. Assim, a experiência fica associada ao vir a ser, algo vinculado a uma realidade que extrapola o aqui-e-agora-em-relação, legitimando a tensão tanto na sua concepção de ser homem, quanto na sua concepção de ser mulher. Por sua vez, esta tensão dificulta a percepção de uma identidade que esteja de acordo com o contexto social, dando margem ao "eu não me identifico". Por outro lado, Jorge administra a tensão presente com humor: “...Isso é tradição russa” e, de sobremaneira, situando-se: "Falem o que quiser, eu não to nem ligando". Neste sentido, Jorge se posicionando diante do seu conflito, aponta para a apropriação da sua existência singular no contexto histórico-sociocultural do qual faz parte.

Esta mesma perspectiva de apropriação da experiência é vista no depoimento de Thiago, que faz referência à sua passagem pelo Plantão Psicológico enquanto possibilidade de ganho de sentido de maior segurança para ser, evidenciando mudanças no seu roteiro sexual, favorecendo o estar-no-mundo. Thiago reconhece as marcas do seu contato com o mundo e a insuportabilidade das cobranças daquilo que era esperado dele. A tensão entre o seu roteiro sexual e o mundo era vivida desde a infância com as reações negativas do meio e do contexto social, como visto anteriormente, contribuindo para o seu isolamento. A timidez ou introversão, desdobramentos desta tensão com o mundo, são comportamentos que podem ser relacionados ao cenário em que Thiago não se sentia respaldado na sua forma de ser. Tamanha era a precariedade da situação que a insegurança e a baixa auto-estima eram companhias certas. 
Como visto ao longo do seu depoimento, a internet foi um meio onde o contato social passou a ser mais fortalecido, assim como também foi a sua frequiência aos cultos religiosos. A diferença é marcante entre estes dois cenários apontados, sendo que, por meio da internet, Thiago pôde ter contato com outras pessoas que atravessavam pelos dramas semelhantes aos seus; e, na igreja, com as regras e valores daquilo que não era afim, ou seja, com aquilo que deveria enquadrar-se. Nesta tensão do seu modo-de-ser com os cenários sociais, a identidade de Thiago foi adquirindo novos contornos que lhe fizessem mais sentido no estar no mundo.

Apesar de Thiago não se aprofundar em como foi o seu atendimento no Plantão Psicológico, fica patente que a postura empática do atendimento contribuiu para que ele percebesse novas possibilidades de vivência, tornando-se mais seguro para a sua escolha dos novos passos. A sua fala de que o Plantão Psicológico "foi muito positivo porque me fez pensar em algumas coisas que eu não pensava antes, e reconsiderar outras coisas", abre espaço para a imagem de que a atendimento contribuiu para que ele se apropriasse da sua experiência vivida, incluindo perspectivas que não contemplava até então. Uma possibilidade de compreensão para esta apropriação de Thiago se apresenta mediante o encontro com o outro em uma perspectiva dialógica.

No depoimento de André, a cobrança também é presente e recai no seu desempenho sexual. A concepção de papéis rigidamente traçados do que é ser homem e do que é ser mulher contribui para que suas atitudes e comportamentos acompanhem este perfil. Deste modo, o modelo de roteiro sexual e de gênero esperado de um homem é internalizado de uma forma que torna dificultoso o reconhecimento da própria masculinidade.

Dentre os colaboradores homens, André foi o que levou de forma mais delimitada a queixa do desempenho sexual, mais especificamente a dificuldade de obter e manter a ereção nas relações sexuais. Esta queixa foi apresentada em um momento de crise pelo qual atravessava. No atendimento no Plantão Psicológico, André percebe que a questão não está circunscrita apenas na esfera sexual, mas a um desdobramento da própria situação vivida naquele momento. $\mathrm{O}$ choque da mudança da sua cidade natal, no interior, para a cidade grande; o deixar de ser cuidado no lar dos pais, para cuidar-se solitariamente em um apartamento; o deixar de perceber-se como o aluno que tem um excelente desempenho nos estudos, para a realidade fria da universidade... A auto-cobrança por dar conta de tudo isso, 
afinal, "sou homem", era parte de uma pressão maior pelo desempenho em todas as esferas de sua vida. Até mesmo a procura pelo atendimento, para André, foi percebido enquanto uma fraqueza por não ter podido superar as dificuldades sozinho. O estado de "fraqueza" de André pode aqui ser compreendido como um estado de fragilidade em que o sofrimento se fazia presente na sua forma de se inter-relacionar com o mundo, cuja tensão fica evidenciada na intimidade da relação sexual, espaço de negociação por excelência. O enfoque do Plantão Psicológico favorece esta apropriação da experiência em uma modalidade de atendimento que não toma o diagnóstico como pré-condição para que aconteça o atendimento, mas que se constitui ao longo do processo, sendo que o trabalho não se circunscreve apenas na queixa apresentada, mas no modo como aquele momento de conflito interfere nas outras esferas da vida da pessoa e vive-versa (Eisenlohr, 1999; Cautella Jr., 1999; Schmidt, 1999; Almeida F., 2005).

No momento crítico de sua crise, André encontra na expressão "foda-se" o sentido de romper com padrões idealizados de roteiro sexual e de gênero, de formas de ser, experimentando o processo de apropriar-se da sua experiência vivida em relação com o mundo. Percebe que a forma rígida de olhar para o mundo contribuía para que percebesse que "tudo tava dando errado". Neste momento, de um extremo de auto-cobrança, ele vai para o outro extremo de liberar-se, de fazer "tudo o que me dava na cabeça", que não o aliviou da angústia. Este movimento do "foda-se", adotado por André, ganha sentidos na sua passagem pelo Plantão Psicológico, percebendo como espaço que contribuiu para the ter "aberto a cabeça", mudando muito sua forma de olhar para a sua experiência. O sentido com que André percebe sua experiência é de que, agora, está "mais correto", ou, como ele, retoma "diferente, pelo menos". Nesta fala fica patente que a cobrança continua presente, porém, de forma menos rígida a ponto de possibilitar outras maneiras de olhar para a própria experiência e estar-no-mundo.

Melina em seu depoimento não fixa o discurso na sua passagem pelo Plantão Psicológico, tornando não tão claro o significado da sua passagem pelo serviço. As marcas deixadas pelo abuso sexual na infância não a impossibilitaram de estabelecer relacionamentos, sendo até criticando quando se relacionava. Sua queixa foi apresentada no momento de angústia sobre o fato de passados os 30 anos de idade ainda não ter se casado. A tensão é presente entre o corresponder a um modelo de roteiro sexual e de gênero hegemônico de se casar e constituir família e o aventurar-se nos estudos em outro país, algo incompatível 
com os códigos do meio social em que vive. Por um lado, o ideal de casamento e, por outro, o real desejo de ficar só.

A queixa de Melina quando da sua busca pelo Plantão Psicológico era relacionada à dificuldade da interação sexual com seu noivo, sendo que a reação de choro quase sempre acompanhava este momento, com as lembranças do abuso sexual vivido na infância. Ao longo do depoimento, Melina mostra que a dificuldade foi superada. A questão que fica em aberto, é quanto à sua forma de perceber a convivência com um parceiro com que o prazer sexual é compartilhado. As questões de Melina não circunscrevem à esfera sexual, mas ao relacionamento de gênero. Melina a todo o momento refere-se à tensão existente entre as figuras masculinas e femininas, sendo que as femininas quase sempre se submetem as masculinas. Torna-se, portanto, exemplar o episódio de abuso sexual que aconteceu por anos, em que o afeto da figura masculina é condicionado à sevícia sexual. A tensão do relacionamento junto ao seu namorado mostra que a situação tornou-se outra na sua fala de que, socialmente, o homem pensa que manda, mas, entre quatro paredes quem manda é a mulher.

Já no depoimento de Sofia a dúvida com relação à sua sexualidade se faz presente enquanto desdobramento da dificuldade de não encontrar namorado. A problematização desta situação gera a angústia, principalmente quando testemunha o namoro duradouro da irmã mais nova. Assim, como já havia tido experiências com beijos em outras garotas em festas, ela não descarta a possibilidade de sentir-se atraída afetivo-sexualmente por outras mulheres. Por outro lado, mesmo esforçando-se no campo da fantasia para se colocar nesta situação, ela percebe que sente-se mesmo atraída por homens. $\mathrm{O}$ foco da sua questão recai na dificuldade experimentada nos relacionamentos e a tensão vivida a partir do seu modo-de-ser. Vale retomar que, para Sofia, a ênfase dada aos roteiros sexuais, quando queixa-se que na sua experiência foi sempre foi tudo tardio, ou mesmo, a título de exemplo, quando em dado momento da sua vida, todas as suas amigas já tinham beijado, somente ela que não.

O senso de pertença ganha status na experiência de Sofia, sendo, portanto, fundamental a sua correspondência aos roteiros de sua rede social. Esta correspondência funciona como base para a auto-cobrança e para a idealização de situações. Por um lado, Sofia mostra um roteiro sexual desvinculado de padrões, por outro, a necessidade desta correspondência, revelando movimento de encontro e desencontro. A representação do 
"príncipe encantado", até então alimentada por Sofia, aos poucos vai sendo resignificada. Sofia percebe que ao mesmo tempo que pretende um namorado, por outro, não se dispunha para este encontro, como se o príncipe virasse sapo.

As marcas que Sofia aponta por ter passado pelo Plantão Psicológico de onde mais se sentiu mobilizada e percebeu a mudança em seu curto espaço de tempo. Nesta colocação, Sofia faz referência ao longo tempo de psicoterapia que desde a infância se submeteu, sem reconhecer mudanças significativas. Sofia afirma que no Plantão Psicológico, "teoricamente", se tornou consciente de coisas, dando margem para a compreensão de que ela se situa em pleno processo de experimentação desta tomada de consciência em seu cotidiano.

Para Mariana, o Plantão Psicológico significou um marco para o contato com a própria sexualidade. Ao longo da sua trajetória em que foi escasso o diálogo sobre a temática da sexualidade com os pares, no atendimento do Plantão Psicológico, Mariana encontrou um espaço que favoreceu a exposição de suas angústias e dúvidas sobre o campo da sexualidade. O momento que Mariana procurou o Plantão Psicológico foi aquele em que seu casamento estava imerso na crise. A crise foi dada principalmente pelo elevado desejo sexual do marido e pelo baixo desejo dela. Aqui cabe uma consideração sobre esta diferença de desejo ao sexo, sendo que o equilíbrio está na satisfação do casal, e não no "elevado" ou no "reduzido" desejo. Porém, quem procura o serviço é Mariana e não o marido. O elevado desejo sexual, portanto, não é reconhecido como algo que precisa ser administrado em prol do equilíbrio da relação, mas, sim, a responsabilidade recai sobre Mariana, que se mobiliza para conquistar mais desejo sexual.

Certamente que o sexo não é uma realidade apartada da realidade humana. O fato de Mariana ter tido pouco acesso a situações em que pudesse apreender a vivência sexual não quer dizer que ela esteja fadada a uma experiência limitada no campo da sexualidade. Por outro lado, há de se privilegiar o contexto do qual Mariana faz parte e as condições para a sua vivência. Assim, a tripla jornada de estudar, trabalhar e cuidar do lar consiste em situações que, por si, já exigem de Mariana uma energia que poderia ser canalizada para o sexo. A divisão de tarefas do lar poderia ser uma grande aliada, além da conversa com o marido sobre troca de referências no aspecto afetivo-sexual, seria aliada importante para o encontro de uma situação de equilíbrio do casal. 
No atendimento no Plantão Psicológico, Mariana permitiu-se ter acesso à sua intimidade, às suas sensações, ao prazer. Ela sentiu-se autorizada a tocar o próprio corpo com a finalidade de conhecer e de sentir prazer. Esta consciência de sensações favorecem no processo de auto-descoberta e no processo de comunicar ao parceiro a forma com que gosta de tocar e ser tocada no encontro sexual, fornecendo novos sentidos para o roteiro sexual. Contudo, neste sentido dialógico da relação, a participação do marido no processo de trnasformação torna-se fundamental.

Um aspecto notado no depoimento de Mariana é quanto à sua mobilização de busca constante de referências, em um sentido de saciar uma sede eterna. Os programas de TV, as revistas, o desejo de ser atendida por um especialista, revela a necessidade de sentir-se pertencida em uma "normalidade" sexual. Apesar da sua abertura para conhecer o próprio corpo e sensações, algo que lhe seria útil é o foco na sua experiência vivida, no aqui-e-agora, pois é no momento presente que se torna possível discriminar aquelas referências que fazem sentido para si, ou não, no seu processo de individualização do seu roteiro sexual e de gênero, na relação com seu marido, daí a importância de um processo que aconteça com e no casal.

Pode-se dizer que o atendimento no SAP foi um catalisador do processo de descoberta de novas possibilidades no pensar e no sentir que a própria Mariana se predispunha, promovendo a melhoria do diálogo e do contato com marido. Além disto, de acordo com ela, o atendimento no SAP, seguindo a sua trajetória de vida, auxiliou-a em compreender que diversos outros fatores - a "pedra psíquica" - influenciam na vida do casal e, deste modo, que a vida do casal não é uma ficção que acontece à parte da vida de ambos.

Ao longo das percepções dos colaboradores quanto a passagem pelo Plantão Psicológico, a auto-cobrança por um enquadre em uma idéia de normalidade é presente, revelando os códigos sociais vigentes na esfera da sexualidade e do gênero. A auto-cobrança surge nas mais diferentes formas, de acordo com as experiências vividas. Mariana tem uma auto-cobrança pela otimização da performance da vida afetivo-sexual, em uma busca por cada vez ter mais e mais referências. O sentido da auto-cobrança de André segue também a perspectiva do aprimoramento da vivência sexual, porém, com a pressão da valorização da sua virilidade neste processo, ou seja, não ter ereção, ou não ter um bom desempenho, significa, na sua perspectiva perfeccionista, ser menos homem. No relato de Jorge e Thiago fica mais patente a temática da idéia de identidade, sendo que, para Jorge, a tensão se situa na 
zona de fronteira entre os papéis e, no relato de Thiago, a tensão segue a perspectiva de estabelecer relações e alianças com os pares na vivência homossexual, algo que, até então era privado, por não corresponder ao universo heterocêntrico.

O relacionamento entre gêneros e suas tensões é mais presente nos relatos das colaboradoras. Mariana, Melina e Sofia em maior ou menor grau focam seus depoimentos na experiência afetivo-sexual. Deste modo, a negociação de papéis é tema freqüente nos relatos das colaboradoras. Todas sentem-se cobradas nos seus roteiros de gênero, nas suas formas de ser, gerando tensões: Mariana na busca do aprimoramento da vivência sexual, tomando como referência o alto desejo do marido; Melina dividida entre a conquista da sua feminilidade emancipada e a intensa referência social do casamento e da constituição de uma família; e Sofia entre a liberdade de experimentar conforme as suas necessidades e anseios e a corrida para alcançar o "tempo certo" estabelecido socialmente para a vivência afetivo-sexual.

Os depoimentos revelam a tensão existente na questão das vivências afetivo-sexuais singulares no contexto social. A partir dos depoimentos, a passagem pelo Plantão Psicológico, de certo modo, revelou ser uma possibilidade de apropriação da sexualidade pela experiência vivida, contribuindo para que tomasse decisões no contato com o mundo. A vivência afetivosexual, apresentada enquanto queixa, teve atenuada a associação com saúde/doença, normalidade/anormalidade, para dar espaço a uma consciência ética e política da vivência afetivo-sexual, enquanto parte da própria existência.

O olhar para os passos dados dos colaboradores mostra que a queixa afetivo-sexual não se encerra na sua passagem pelo Plantão Psicológico. Pelo contrário, possibilidades outras se apresentam para a resignificação da sexualidade na experiência vivida em relação com o mundo, no sentido da tendência atualizante proposta por Rogers $(1975 ; 2001)$, a partir da psicologia organísmica de Kurt Goldestein, de que se uma pessoa tiver condições favoráveis, ela se direciona de forma a suprir as próprias necessidades no sentido de crescer, existir e agir, confiando mais no próprio organismo, em uma maior independência e auto-responsabilidade. Esta ressignificação vai ao encontro da teoria dos roteiros sexuais, e da identidade metamorfose em que são flexíveis, ou mutáveis, as formas de ser-no-mundo-em-relação, na dinâmica de a todo o instante de situar-se e ser situado, impulsionando homens e mulheres para serem protagonistas das suas histórias e sujeitos das suas vidas. 
A passagem dos colaboradores pelo Plantão Psicológico, independente da duração do atendimento, com ou sem encaminhamento para atendimento externo por outros profissionais, revela o potencial deste serviço enquanto possibilidade de cuidado e de atenção do humano, em um espaço em que é possível o contato com os significados e sentidos relacionados à queixa apresenta pela pessoa na perspectiva da sua experiência vivida e não circunscrevendo atendimento apenas à queixa. Sem ter a pretensão de trabalhar em um dado segmento da experiência humana, a partir da fala dos colaboradores, foi facilitada a integração da "sexualidade" às respectivas experiências vividas, permitindo uma melhora de consciência e de possibilidades de estar-no-mundo.

\section{Propostas para uma vivência mais plena da sexualidade}

As queixas apresentadas poderiam ser rotuladas e categorizadas em um rol de disfunções ou desvios, o que tornaria necessário voltar à funcionalidade ou ao bom caminho. Visto ser a proposta compreender a dificuldades afetivo-sexual como forma de expressão da pessoa mediante a sua existência social, a queixa contém uma série de significados decorrentes da aprendizagem e da apreensão de códigos sociais relacionados à sexualidade e aos gêneros que, de certo modo, fornece contornos para a experiência vivida, o que repercute de forma conflituosa no contato com o próprio corpo e no contato com o outro. Partindo da premissa da sexualidade enquanto construção social, a queixa sexual segue a mesma perspectiva, sendo ela circunscrita a uma cultura e a um demarcado período histórico.

Por vivência sexual mais plena entende-se não segue a uma perspectiva de potencializar a vivência de sensações e de prazeres, mas de contribuir para que estas sensações e prazeres aconteçam a partir de necessidades e de peculiaridades individuais no contexto social. Assim, o pleno diz respeito aquilo que satisfaz, ao que desperta a sensação do prazer seja ele compartilhado ou solitário, mas que seja livre para acontecer e ser vivenciado. As referências e modelos de formas de vivência de sensações e de prazeres constituem um leque de possibilidades a serem vivenciadas e não necessariamente adotadas ou suprimidas. Neste sentido, cabe abordar em uma perspectiva ética e política para a compreensão do fenômeno da sexualidade. 
Os colaboradores na sua totalidade indicam o diálogo como forma de auxiliar na vivência da sexualidade. Neste diálogo, Jorge aponta para a necessidade dos pais de não criarem os filhos como "machos" ou "fêmeas", de maneira a flexibilizar os papéis de gênero. Assim, ele aponta para as limitações de regras e de padrões preestabelecidos, que apesar de funcionem como referências dentro do cenário social, não atendem às necessidades de todas as pessoas, gerando sofrimento e angústia.

Thiago aponta para a necessidade de um espaço dialógico sem a interferência do juízo de valor, em que exista uma postura de aceitação e de respeito pelo outro. Thiago também segue esta perspectiva apontando a importância do conhecimento e a abertura para a conversa sobre o tema da sexualidade "sem malícia". Seguindo Houaiss (2001), o termo "malícia" consiste na: "aptidão ou inclinação para fazer o mal, malignidade, maldade, habilidade para enganar, despistar".

A fala de Thiago remete à questão da maldade imposta àqueles que não se enquadram numa hegemonia heterossexual, como ele próprio, que sentiu na pele a discriminação e o preconceito em diversas passagens de sua vida. Neste sentido, considerando papéis rigidamente preestabelecidos, conforme apontados por Jorge, temos que existe maior tendência a um discurso discriminatório e marginalizante, restingindo possibilidades de (con)vivência.

Por mais que André seja um dos colaboradores que mais se aproximam de um modelo de masculinidade heterossexual, ele apresenta que a liberação ajudaria as pessoas na vivência das suas sexualidades. O sentido que dá a liberação é com relação às travas que associava à vivência da sua sexualidade. De acordo com ele, o sexo não deve ter proporções dramáticas, mas algo possível de ser vivenciado pelas pessoas - "todo mundo faz, todo mundo vai fazer" , de acordo com o seu tempo e suas condições, assim como foi na sua experiência. Deste modo, como o próprio André aponta, "o problema é se preparar muito e se cobrar muito, igual eu fiz e... se ferrar", revelando que não é necessária apenas a informação para a vivência plena e positiva da sexualidade, mas a orientação da maneira como as pessoas se apropriam destas informações, inseridas nas especificidades socioculturais em que vivem. 
Para Mariana, determinados pontos da experiência sexual devem ser velados. Na sua percepção de que o homem somente pensa em sexo, ela não acha adequado saber o que ele faz ou deixa de fazer, pois a busca pelo sexo é algo inerente ao universo masculino. Por outro lado, o diálogo se torna importante no aprendizado compartilhado dentro do universo afetivosexual. O lugar do homem, na perspectiva de Mariana, é daquele que não tem dúvidas sobre a sexualidade, sendo que a mulher não tem privilégios neste campo, cabendo a ela procurar ajuda para se equiparar ao padrão masculino.

Mariana adota uma postura de se adequar ao elevado desejo sexual do marido atributo que acredita ser inerente ao masculino - e, para isso, busca nas mais diferentes fontes as referências para melhorar o seu desempenho sexual. Em dado momento ela mesma reconhece o quão sacrificante é buscar este desempenho, que não significa necessariamente encontrar uma situação mais favorável para o prazer compartilhado. Por outro lado, esta busca de Mariana rendeu-lhe frutos, pois passou a permitir-se experiências que antes não aconteciam, a exemplo de tocar-se na intenção de obter prazer, favorecendo a tomada de consciência do próprio corpo e de suas sensações, além do exemplo de que ela e o marido passaram a conversar mais, de maneira específica sobre a vivência afetivo-sexual no relacionamento, ou seja, dentro da realidade vivida em uma perspectiva do amor confluente (Giddens, 1993).

No seu depoimento, até mesmo nesta dinâmica da busca por novas referências, Mariana valoriza a figura do especialista enquanto aquele gabaritado para fornecer essas referências. Neste ponto, cabe a reflexão não sobre a busca da especialidade em si, mas de qual perspectiva as novas referência - novos códigos, valores, condutas - serão apresentadas. No lugar de uma perspectiva médico-moral, cabe o constante debate sobre formas de viabilizar os direitos sexuais em uma perspectiva ética. De acordo com Giami (2007) afirma que, atualmente a sexologia cede lugar a uma "medicina sexual", cuja prática visa focar nos transtornos da função sexual. De acordo com o autor, o

O termo sexualidade é cada vez menos utilizado no universo médico e científico, sendo substituído pelas expressões função sexual e saúde sexual, que permitem abordar 'cientificamente' um ou outro aspecto deste campo, de contornos mal-definidos, que constitui 'a sexualidade' (p.304). 
Esta perspectiva sustenta a idéia apresentada por Foucault (2001) sobre o controle dos corpos e dos prazeres. Giami (2007) afirma que a função sexual - que naturaliza e normaliza a dimensão fisiológica - vem ganhando mais destaque do que a função erótica que poderia indicar de maneira mais precisa a autonomização da realização do prazer. Assim, a tensão entre a função sexual e a função erótica deve ser considerada no atendimento de questões relacionada à sexualidade, com vias a reconhecer roteiros sexuais e de gênero da pessoa e do contexto sociocultural do qual faz parte.

Sofia aponta para o autoconhecimento enquanto caminho para aliviar a conturbação da experiência. Ela traz o questionamento de orientação do desejo sexual de forma difusa, expressando seu interesse em compreender como isso se articula no universo heterossexual e homossexual. Apesar de ela partir para a teoria psicanalítica para compreender o desejo, ela se apercebe que não cabe no momento encerrar o seu trânsito no universo desta questão, mas viver essa questão assim como percebeu ao ser atendida no Plantão Psicológico.

Melina e Sofia apresentam em suas falas a necessidade da compreensão das diferenças e dos diferentes dentro de uma atmosfera de respeito e compreensão. Melina enfatiza a interrelação entre pessoas, enquanto Sofia destaca o autoconhecimento para a aproximação entre pessoas. Deste modo, a partir do respeito com relação à própria singularidade, torna-se possível o respeito com a singularidade do outro, sendo que esse respeito se dá na relação. No tocante à relação dos gêneros, Melina mostra que a empatia não necessariamente perpassa a mulher querer ser homem, e nem o homem ser mulher, mas de (re)conhecerem a feminilidade e a masculinidade que não se encerra no estereótipo da mulher-frágil ou do homem-bruto. Sofia acredita que quanto mais autoconhecimento menos conturbadas se tornam as relações.

As falas dos colaboradores revelam a necessidade de um espaço de escuta em que sintam-se livres para romper com o silêncio sufocante das dificuldades e angústias relacionadas à experiência, incluída a sexualidade. O Plantão Psicológico constituiu espaço profícuo aos colaboradores para o acesso à escuta atenta em que aconteceu o acolhimento e o respeito às experiências vividas, possibilitando compartilhar suas vidas sem o julgamento ou crítica. Interessante notar que no Plantão Psicológico, que não adota uma perspectiva de diagnóstico e de intervenção, muito menos focado na sexualidade ou a qualquer outra esfera da vida humana, revelou ser uma perspectiva de cuidado e atenção que favoreceu um movimento de contato, para uns mais positivos do que para outros. A sexualidade é percebida 
enquanto parte da experiência vivida, onde é privilegiado o encontro dialógico entre aquele que busca ajuda e aquele que se propõe ao cuidado e atenção do outro, auxiliando o outro a compreender a sua demanda e vislumbrar novos caminhos a serem trilhados. 


\section{$\begin{array}{llllllllllllllllll}\text { C } & \text { A } & \text { P } & \mathbf{I} & \text { T } & \text { U } & \text { L } & \text { O } & \text { V } & \text { I } & \text { I }\end{array}$}

\section{CONSIDERAÇÕES FINAIS}

É delicada a tarefa de finalizar um trabalho após o "estar junto" com pessoas com diferentes trajetórias de vida e acompanhar os percalços vividos ao longo das suas existências no território afetivo-sexual. Mais do que conclusões, o que se apresenta é um horizonte de possibilidades e de questões trazidas pelos colaboradores que experimentaram e/ou experimentam angústia ou sofrimentos na vivência afetivo-sexual. Esta vivência, por si, já remete ao desafio de compreender a sexualidade enquanto um fenômeno imbricado nas dimensões social, cultural e existencial.

O método dos relatos orais revelou-se um recurso de utilidade para a interlocução com os colaboradores a fim de compreender significados e sentidos relacionados às sexualidades e aos gêneros. A escuta atenta e receptiva ao longo da coleta dos depoimentos rendeu um material fecundo e extenso, apontando para a diversidade de nuances e para a pluralidade na vivência afetivo-sexual. O processo de interpretação dos depoimentos consistiu em um recorte, dentre diversos outros possíveis, para conhecer as experiências vividas nos diferentes contextos sociais. Tendo em vista que esta pesquisa segue uma proposta qualitativa a partir de uma pequena amostra intencional de pessoas com queixas afetivo-sexuais atendidas na modalidade de Plantão Psicológico, não cabe a generalização dos resultados obtidos para outras realidades socioculturais.

Os relatos dos colaboradores remetem à reflexão sobre a tensão gerada diante de roteiros e comportamentos - códigos, normas e valores - nas diferentes instâncias sociais que, por um lado, fornecem parâmetros para as expressões e manifestações da sexualidade, por outro lado, reforçam o sofrimento e a angústia no âmbito da vivência afetivo-sexual. Ao longo 
da vivência dos colaboradores no campo social percebe-se a existência de limites e de limitações - a exemplo da discriminação e do preconceito -, a existência do abuso de poder a exemplo do abuso sexual e pedofilia -, assim como a tendência rígida de seguir determinadas formas específicas de conduta sexual "normal", em uma perspectiva essencialista e reguladora da sexualidade.

As experiências trazidas pelos colaboradores indicam que a sexualidade consiste em uma expressão e manifestação que acontece no contexto social a partir das mais diferentes negociações e articulações que conferem contornos para a expressão do desejo, dos sentimentos, das emoções, das condutas e práticas corporais. Neste sentido, nos diferentes contextos, determinadas formas de expressão e de manifestação são tidas como aceitáveis e outras não aceitáveis, o que é legitimado pela ideologia produzida pelo saber especializado e meios de comunicação. $O$ foco nas diferentes experiências mostra que a vivência da sexualidade se transforma - no sentido da metamorfose - considerando desde os referenciais trazidos da infância que vão sendo resignificados, inventados e reinventados ao longo da vivência com e na trama das relações socioculturais.

Nesta existência social, outro fator imbricado na vivência da sexualidade são as diferentes construções e relações dos gêneros que conferem distintos significados para os corpos e os prazeres, a partir de valores e normas entranhadas que concebem formas específicas de viver a sexualidade. Nos depoimentos percebe-se que ainda é presente a tendência a estereótipos rígidos sobre o que é ser homem - atividade - e o que é ser mulherpassividade - ancorados em modelos patriarcais e que estabelecem a hierarquização entre homens e mulheres. Este quadro fica representado pelo depoimento de André quando busca por uma boa qualidade sexual - que ele próprio associa a uma máquina -, evidenciando a internalização da mensagem de que os homens necessitam de uma vida sexual ativa; por outro lado, o depoimento de Mariana reflete a tendência contrária, de que as mulheres precisam abster-se ao máximo da vida sexual ativa até o casamento. Os demais depoimentos revelam as diferentes maneiras em lidar com estas concepções de gênero, sendo que Jorge remete-se principalmente para a questão da identidade sexual, Thiago para a vivência do desejo afetivosexual homoerótico, Melina para as diferenças de gênero, e Sofia para as expectativas sociais frente à sua conduta sexual. A reflexão e o trabalho clínico com pessoas com dificuldades afetivo-sexuais, portanto, devem considerar aspectos peculiares nas construções de gênero e seus desdobramentos na existência social de condutas e comportamentos. 
A percepção da sexualidade, enquanto algo aprendido e apreendido na existência social, se apresenta cercada de curiosidade, fascínio, prazer, mas também por tensão, insegurança, estereótipos, medo, moralismo, entre outros, sendo que, na maioria dos casos, o início do processo de conhecer os aspectos do erotismo aconteceu de forma marcada pela solidão e silêncio. Os pais e mães têm importância na transmissão de códigos e valores relacionados à sexualidade, porém, os depoimentos destacam as instituição de ensino - da escola fundamental até a universidade -, além da rede social fora do âmbito familiar, como espaços que viabilizaram a troca de percepções e de vivências, além da aproximação de pares.

Outro referencial destacado pelos colaboradores é com relação aos meios de comunicação, a exemplo das revistas, livros, programas de TV, internet para o acesso ao universo sexual e, com isso, a diferentes roteiros sexuais e de gênero. Os colaboradores homens citaram a internet como meio para o acesso a vivências, encontro de pares e ampliação da rede social. Já as colaboradoras citam as revistas e programas de TV como meios de comunicação para o acesso a informações sobre a sexualidade. No tocante à internet, caberiam mais pesquisas sobre os impactos para a construção de gêneros e de formas de relacionamento social e sexual, pois assim como viabilizar os contatos via computador, pode também intensificar o isolamento social.

Os meios de comunicação têm relação próxima com as ideologias vigentes em uma contexto sociocultural. Neste aspecto da ideologia moldar condutas e comportamentos sexuais, Foucault (2001) em sua obra faz um estudo aprofundado sobre os dispositivos da sexualidade em que é incitado o seu discurso no sentido de controle sobre os corpos e os prazeres. Deste modo, a reflexão sobre a medicalização da sexualidade é uma questão emergente para o trabalho com a sexualidade seja no âmbito educacional, seja no âmbito clínico. As experiências trazidas pelos colaboradores remetem a uma idéia de "problema sexual", que, por sua vez, remete a uma dinâmica de busca pela adequação. Neste sentido da medicalização da sexualidade, a questão que se apresenta é sobre as formas de compreender os discursos sobre saúde sexual. Assim como o conceito de sexualidade faz parte de um território disputado por diferentes segmentos sociais, assim também é o próprio conceito de saúde. A junção destes dois conceitos, resultando na saúde sexual, deve ser amplamente debatida a fim de que não reproduzir modelos rígidos e totalitários, como também dogmáticos, pois iria de encontro com a perspectiva da diversidade de identidades e vivência 
sexuais em diferentes culturais e em diferentes espaços de tempo. Certamente que existem situações em que a singularidade de vivência da sexualidade resvala para o território do ilícito, a exemplo do abuso sexual e da pedofilia, o que carece de medidas para prevenir e conter tais práticas. Por outro lado, não há como negar que ao mesmo tempo que se fala de uma saúde sexual, implicitamente - e fatalmente - é apresentado aquilo que não é considerado saúde, logo, uma disfunção ou patologia a ser tratada visando voltar a uma funcionalidade ou a uma situação saudável.

Partindo da sexualidade enquanto área do saber torna-se fundamental a constante reflexão e debate para a não imposição de verdades, ou de condutas sexuais específicas desejos intensos, ereções rígidas e plenas, controles ejaculatórios, orgasmos múltiplos, relações sexuais obrigatórias e prazerosas. A questão que se apresenta não é da apreensão de um "roteiro perfeito", ou um conjunto de normas e valores "corretos", pois isto remeteria a uma visão estreita e empobrecida das sexualidades em uma perspectiva profilática e higienista, resvalando para a assepsia em prol do bom comportamento e do bom sexo. A partir desta perspectiva, o cuidado recai na necessidade de que o universo da sexualidade não fique circunscrito à díade saúde-doença, ou função-disfunção, mas que seja compreendida em um sentido ético, parte da experiência humana.

Os colaboradores procuraram ajuda no Plantão Psicológico apresentando a queixa afetivo-sexual, porém, ao longo do desdobramento do atendimento destacou-se o sofrimento e a angústia na esfera existencial, gerando o sentimento de não pertencimento a uma sexualidade idealizada que consiste em um padrão, mesmo que difuso, onde se espera que as pessoas façam sexo e que se comprazam nesta prática. Os arranjos e as negociações com as parcerias contribuíram para o aprendizado de possibilidades satisfatórias de relacionamento sexual.

Em linhas gerais, a modalidade do Plantão Psicológico de atendimento psicológico privilegia o encontro, o cuidado e a atenção da experiência humana, não se propondo a promover a "cura", a adequação, ou mesmo um estado de tranqüilidade livre de angústia, mas de favorecer para que a pessoa tome consciência do seu lugar no espaço sociocultural - onde se coloca, onde é colocada - no sentido do encontro de possibilidades de existir. No lugar do diagnóstico e posterior tratamento específico, o plantonista tem como propósito auxiliar a pessoa a compreender a sua demanda e elaborar seu ponto de vista com relação à mesma. $\mathrm{O}$ 
Plantão Psicológico apresentou-se como um espaço profícuo para a inflexão sobre as tensões vividas no âmbito da vivência afetivo-sexual, funcionando como uma modalidade de atendimento que certamente contribui para a reflexão e o debate de formas de trabalho nas diferentes áreas do saber com as questões da sexualidade, seja no âmbito clínico, seja no âmbito educacional.

A passagem dos colaboradores pelo Plantão Psicológico aponta para diversos aspectos da busca de ajuda psicológica, inclusive da carência do saber especializado no acolhimento e no cuidado com determinadas realidades vividas. Exemplo disto é a experiência de Jorge que percebe a falta de respaldo de um espaço para "algo ser feito" nos serviços de saúde com relação à transexualidade. Também foi no Plantão Psicológico que André pôde identificar de maneira mais significativa a sua necessidade de buscar a qualidade sexual a todo o preço, como uma máquina. Este movimento também foi o de Mariana que na sua busca incessante parece não reconhecer em si uma angústia que parece não se resolver com relação ao seu desejo sexual. O depoimento de Sofia destaca a não aceitação de regras sociais que delimitam a hora certa para o primeiro beijo, para a primeira relação sexual, para as maneiras corretas de sentir prazer, entre outros, mostrando a tensão entre uma maneira singular de ser e as normas e condutas sexuais vigentes. No depoimento de Thiago é apresentada a tensão a partir da necessidade de auto-afirmar a identidade homossexual em um contexto social que sempre ofereceu resistência ao seu modo-de-ser. Melina apresenta no seu depoimento o conflito frente aos modelos de relação de gênero com os quais está familiarizada, e os novos modelos que se apresentam, ampliando horizontes para a realização pessoal. Seguindo os depoimentos, as dificuldades sexuais afetivo-sexuais experimentadas imbricam-se nos conflitos vividos na existência social. Isto posto, a pesquisa remete para a necessidade de que a formação de profissionais da área de saúde e da educação contemple estudos e pesquisas sobre a sexualidade em uma perspectiva que vai além do modelo médico-normativo, compreendendo significados e sentidos da sexualidade em uma perspectiva histórica.

Diante das marcas desta experiência de pesquisa movida pela companhia de colaboradores e colaboradoras, parceiros de jornada na produção de conhecimento, é hora de partir para novos horizontes. O contato com as experiências singulares de Jorge, Thiago, André, Melina, Sofia e Mariana, apontam para a necessidade dos profissionais da área da saúde cada vez mais se engajarem em meios que favoreçam o existir em um mundo em que a pluralidade seja respeitada como marca da riqueza humana. Isto sinaliza a pertinência de 
continuarmos insistindo em propostas e em pesquisas para que a sexualidade não fique estanque no território moral ou médico-normativo, muito menos no campo cientificista, mas que ao longo do tempo possamos, mesmo a pequenos passos, olhar para a sexualidade além das condutas e modelos rígidos, em uma perspectiva ética e cidadã. 


\section{REFERÊNCIAS BIBLIOGRÁFICAS}

ALI, Nabil S. A. Análise do discurso ideológico no merchandising social. 2008. 119p. Dissertação (Mestrado em Psicologia) - Instituto de Psicologia, Universidade de São Paulo, São Paulo. 2008.

ALMEIDA, Edilene J. Crianças e adolescentes vítimas de abuso sexual: trajetória da denúncia desde a "revelação não aceita" à "revelação aceita". In: Revista Brasileira de Sexualidade Humana, v.16, n.2., p.299-310, jul./dez. 2005.

ALMEIDA, Fernando M. de. Ser clínico como educador: uma leitura fenomenológica existencial de algumas temáticas na prática de profissionais de saúde e educação. 2005. 215p. Tese (Doutorado em Psicologia) - Instituto de Psicologia, Universidade de São Paulo, São Paulo. 2005.

ARENDT, Hannah. A crise na educação. In: Entre o passado e o futuro. [Between past and future] Trad. Mauro W. Barbosa. 5.ed. São Paulo: Perspectiva, 2001. Cap.5, p.221-247. (Debates, 64).

ARENDT, Hannah. A condição humana. [The Human condition] Trad. Roberto Raposo. Rio de Janeiro: Forense Universitária, 1981. 338p.

AUGÉ, Marc. Por uma antropologia dos mundos contemporâneos. [Pour une anthropologie dès mondes contemporains] Trad. Clarice Meireles; Leneide Duarte. Rio de Janeiro: Bertrand Brasil, 1997. 192p.

BADINTER, Elisabeth. Um amor conquistado: o mito do amor materno. [L'amour em plus] Trad. Waltensir Dutra. Rio de Janeiro: Nova Fronteira, 1985. 370p.

BARBIERI, Teresita de. Sobre la categoría género: una introducción teórico-metodológica. In: AZEREDO, Sandra; STOLCKE, Verena (Coord.). Direitos reprodutivos. São Paulo: FCC;DPE, 1991. p.25-45.

BERGER, Peter L.; LUCKMANN, Thomas. A construção social da realidade: tratado de sociologia do conhecimento. [The social construction of reality] Trad. Floriano de Souza Fernandes. 24.ed. Petrópolis: Vozes, 2004. 247p. 
BERNARDI, Marcello. A deseducação sexual. [La maleducazione sessuale] Trad. Antonio Negrini. São Paulo: Summus, 1985. 144p. (Novas buscas me educação, 21).

BOARINI, Maria L. O "ensino" da sexualidade e a (des)informação do adolescente contemporâneo. In: RIBEIRO, Paulo R. M. (Org.). Sexualidade e educação: aproximações necessárias. São Paulo: Arte \& Ciência, 2004. p.181-199.

BOM MEIHY, José C. S. Manual de história oral. 4.ed. São Paulo: Loyola, 2002. 246p.

BOZON, Michel; HEILBORN, Maria L. Iniciação à sexualidade: modos de socialização, interações de gênero e trajetórias individuais. In: HEILBORN, Maria L. et al. (Org.). $\underline{\mathrm{O}}$ aprendizado da sexualidade: reprodução e trajetórias sociais de jovens brasileiros. Rio de Janeiro: Garamond, 2006. Cap.5, p.155-206.

BOZON, Michel. Sociologia da sexualidade. [Sociologie de la sexualité] Trad. Maria de Lourdes Menezes. Rio de Janeiro: Fundação Getúlio Vargas, 2004. 170p. (Família geração e cultura).

BRANDÃO, Carlos R. Identidade e etnia: construção da pessoa e resistência cultural. São Paulo: Brasiliense, 1986. 173p.

BRASIL. Ministério da Saúde. Cresce uso de preservativo na primeira relação sexual dos jovens brasileiros. Brasília, 09 dez. 2005. Disponível em: <http://portal.saude.gov.br/portal/aplicacoes/noticias/noticias_detalhe.cfm?co_seq_noticia=22715>. Acesso em 28 jan. 2007.

BRASIL. Secretaria de Educação Fundamental. Parâmetros Curriculares Nacionais: terceiro e quarto ciclos: apresentação dos temas transversais. Brasília, MEC/SEF, 1998. 436p.

BRASIL. Secretaria de Educação Fundamental. Parâmetros Curriculares Nacionais: apresentação dos temas transversais, orientação sexual. Brasília, MEC/SEF, 1998b. p.285335 .

BRASIL. Conselho Federal de Medicina. Resolução CFM no. 1.652/2002 de 6 de novembro de 2002. Dispõe sobre a cirurgia de transgenitalismo e revoga a Resolução CFM n ${ }^{\circ}$ 1.482/97. Brasília, 6 nov. 2002. Disponível em: <www.portalmedico.org.br/resolucoes/cfm/2002/1652_2002.htm>. Acesso em 10 fev. 2009.

BRAUN, Susane. Violência sexual infantil na família: do silêncio à revelação do segredo. Porto Alegre, Age Editora, 2002. 102p. 
BRUNER, Jerome. Atos de significação. [Acts of meaning] Trad. Sandra Costa. Porto Alegre: Artes Médicas, 1997. 130p.

BUROW, Olaf A.; SCHERPP, Karlheinz. Gestaltpedagogia: um caminho para a escola e a educação. [Gestaltpädagogik: eine chance für schule und erziehung] Trad. Luiz Alfredo Lilienthal. 2.ed. São Paulo: Summus, 1985. 184p. (Novas buscas em educação, 20).

BUTLER, Judith. Corpos que pesam: sobre os limites discursivos do "sexo". In: LOURO, Guacira L. O corpo educado: pedagogias da sexualidade. Belo Horizonte: Autêntica, 2000. p.151-172.

CASTELLS, Manuel. O poder da identidade. [The power of identity] Trad. Klauss Brandini Gerhardt. 2.ed. São Paulo: Paz e Terra, 1999. 530p. (A era da informação: economia, sociedade e cultura, 2).

CASTRO, Mary G; ABRAMOVAY, Miriam; SILVA, Lorena B. da. Juventudes e sexualidade. UNESCO Brasil, 2004. 428p.

CASTRO, Regina A. L. de. Salas de bate-papo da internet: espaço onde as mulheres tecem suas identidades através da linguagem. 2006. 258p. Tese (Doutorado em Letras) - Faculdade de Filosofia, Letras e Ciências Humanas, Universidade de São Paulo, São Paulo. 2006.

CAUTELLA JR., Walter. Plantão psicológico em hospital psiquiátrico. In: MORATO, Henriette T. P. (Org.). Aconselhamento psicológico centrado na pessoa: novos desafios. São Paulo: Casa do Psicólogo, 1999. Cap.9, p.159-173.

CHAUÍ, Marilena. Convite à filosofia. 12.ed. São Paulo: Ática, 2002. 440p.

CHAUÍ, Marilena. Senso comum e transparência. In: LERNER, Júlio, ed. O preconceito. São Paulo: Imprensa Oficial do Estado, 1996/1997. p.115-132.

CHAUÍ, Marilena. Repressão sexual: essa nossa (des)conhecida. 12.ed. São Paulo: Brasiliense, 1991. 234p.

CIAMPA, Antonio da C. (1987). A estória do Severino e a história da Severina: um ensaio de Psicologia Social. $7^{a}$ reimpressão. São Paulo: Brasiliense, 2001. 247p.

COSTA, Jurandir F. Ordem médica e norma familiar. 5.ed. Rio de Janeiro: Graal, 2004. 
COSTA, Jurandir F. A inocência e o vício: estudos sobre o homoerotismo. 4.ed. Rio de Janeiro: Relume-Dumará, 2002. 195p.

COSTA, Jurandir F. A construção cultural da diferença dos sexos. In: Sexualidade, gênero e sociedade. 2(3), jun. 1995. p.4-8.

COSTA, Ronaldo P. Os 11 sexos: as múltiplas faces da sexualidade humana. São Paulo: Gente, 1994. 213p.

CRITELLI, Mára D. Analítica do sentido: uma aproximação e interpretação do real de orientação fenomenológica. São Paulo: EDUC; Brasiliense, 1996. 140p.

CROCHÍK, José L. Preconceito: indivíduo e cultura. São Paulo: Robe, 1997.

DEJOURS, Christophe. Por um novo conceito de saúde. Revista Brasileira de Saúde Ocupacional, v.54, n.14, p.7-11, 1986.

DEL PRIORI, Mary. História do amor no Brasil. 2.ed. São Paulo: Contexto, 2006. 331p.

DIAS, Maria B. A evolução da família e seus direitos. In: Revista Brasileira de Sexualidade Humana, v.16, n.2, p.277-285, 2005.

DUARTE, Luiz Fernando D. A sexualidade nas ciências sociais: leitura crítica das convenções. In: PISCITELLI, Adriana, GREGORI, Maria F.; CARRARA, Sérgio. Sexualidade e saberes: convenções e fronteiras. Rio de Janeiro: Garamond, 2004. p.39-80. (Sexualidade, gênero e sociedade).

EISENLOHR, Maria G. V. Serviço de Aconselhamento Psicológico do IPUSP: breve histórico de sua criação e mudanças ocorridas na década de 90. In: MORATO, Henriette T. P. (Org.). Aconselhamento psicológico centrado na pessoa: novos desafios. São Paulo: Casa do Psicólogo, 1999. Cap.7, p.133-141.

ESCOFFIER, Jeffrey. Apresentação. In: GAGNON, John H. Uma interpretação do desejo: ensaios sobre o estudo da sexualidade. Trad. Lucia Ribeiro da Silva. Rio de Janeiro: Garamond, 2006. p.13-30. (Sexualidade, gênero e sociedade).

FACCHINI, Giovana; MAIA, Ana C. B.; MAIA, Ari F. Análise de aspectos relacionados à sexualidade em site para adolescentes. In: Revista Interação em Psicologia, v.8, n.1, p.57-66, 2004. 
FERREIRA, Ricardo F. Uma história de lutas e vitórias: a construção da identidade de um afro-descendente brasileiro. 1999. 281p. Tese (Doutorado em Psicologia) - Instituto de Psicologia, Universidade de São Paulo, São Paulo. 1999.

FIGUEIRÓ, Mary N. D. O professor como educador sexual: interligando formação e atuação profissional. In: RIBEIRO, Paulo R. M. (Org.). Sexualidade e educação: aproximações necessárias. São Paulo: Arte \& Ciência, 2004. p.115-151.

FOUCALT, Michel (1975). Vigiar e punir: história da violência nas prisões. [Surveiller et punir] Trad. Lígia M. Ponde Vassalo. 9.ed. Petrópolis: Vozes, 1987. (Biblioteca de Filosofia e História das Ciências). 277p.

FOUCAULT, Michel (1988). A história da sexualidade I: a vontade de saber. [Histoire de la sexualité I: la volonté de savoir] Trad. Maria Thereza da Costa Albuquerque; José Augusto Guilhon Albuquerque. 14.ed. Rio de Janeiro: Graal, 2001. (Biblioteca de Filosofia e História das Ciências).

FOUCAULT, Michel (1979). Microfísica do poder. Trad. Roberto Machado. 20.ed. Rio de Janeiro: Graal, 2004. (Biblioteca de Filosofia e História das Ciências). 295p.

FREIRE, Paulo. A pedagogia do oprimido. 17.ed. Rio de Janeiro: Paz e Terra, 1987. (O mundo, hoje, 21). 184p.

FRY, Peter; MACRAE, Edward. O que é homossexualidade? 7.ed. São Paulo: Brasiliense, 1991. 125p. (Primeiros Passos, 81).

GAGNON, John H. Uma interpretação do desejo: ensaios sobre o estudo da sexualidade. Trad. Lucia Ribeiro da Silva. Rio de Janeiro: Garamond, 2006. 455p. (Sexualidade, gênero e sociedade).

GEERTZ, Clifford. Uma descrição densa: por uma teoria interpretativa da cultura. In: $\underline{A}$ interpretação das culturas. Rio de Janeiro: LTC, 1989. Cap.1, p.13-41.

GERGEN, Kenneth J. The social constructionist movement in modern Psychology. American Psychologist, v.40, n.3, p.266-275, 1985.

GIAMI, Alain. Permanência das Representações do Gênero em Sexologia: as inovações científica e médica comprometidas pelos estereótipos de gênero. Physis: Revista de saúde coletiva, Rio de Janeiro, v.17, n.2, p.301-320, 2007. 
GIAMI, Alain. A medicalização da sexualidade. Foucault e Lantéri-Laura: história da medicina ou história da sexualidade? Physis: Revista de saúde coletiva, Rio de Janeiro, v.15, n.2, p.259-284, 2005.

GIDDENS, Anthony. A transformação da intimidade: sexualidade, amor e erotismo nas sociedades modernas. [The transformation of intimacy: sexuality, love and eroticism in modern societies] Trad. Magda Lopes. São Paulo: Universidade Estadual Paulista, 1993. 229p. (Biblioteca básica).

GRANDESSO, Marilene A. Sobre a reconstrução do significado: uma análise epistemológica e hermenêutica da prática clínica. São Paulo: Casa do Psicólogo, 2000. 422p.

GROENINGA, Giselle; DIAS, Maria B. A mediação no confronto entre direitos e deveres. In: Revista do Advogado, n.62, p. 59-63, mar. 2001.

GRUPO de Trabalho e Pesquisa em Orientação Sexual, Associação Brasileira Interdisciplinar de AIDS, Centro de Estudos e Comunicação em Sexualidade e Reprodução Humana. Guia de orientação sexual: diretrizes e metodologia da pré-escola ao $2^{\circ}$ grau. São Paulo: Casa do Psicólogo, 1994.

GUARESCHI, Pedrinho. Alteridade e relação: uma perspectiva crítica. In: ARRUDA, Ângela (Org.). Representando a alteridade. Petrópolis: Vozes, 1998. p.149-161. (Psicologia Social, 3).

GUSMÃO, Verônica L. D. R. de; SCHIAVO, Marcio; JURBERG, Pedro. A educação sexual e a proteção contra o abuso. In: Revista Brasileira de Sexualidade Humana, v.14, n.2, p.47-60. 2003. Número especial.

HALBWACHS, Maurice. A memória coletiva. [La mémoire collective] Trad. Beatriz Sidou. São Paulo: Vértice, 1990. 198p.

HALL, Calvin S.; LINDZEY, Gardner. Teorias da personalidade. [Theories of personality] Trad. Lauro Bretones e Aidyl Macedo Queiroz. São Paulo: EPU, 1973. 620p. (Ciências do Comportamento).

HALL, Stuart. Quem precisa de identidade? In: SILVA, Tomaz T. da; HALL, Stuart; WOODWARD, Kathryn (Org.). Identidade e diferença: a perspectiva dos estudos culturais. Petrópolis: Vozes, 2000. p.103-133. 
HEILBORN, Maria L. Experiência da sexualidade, reprodução e trajetórias biográficas

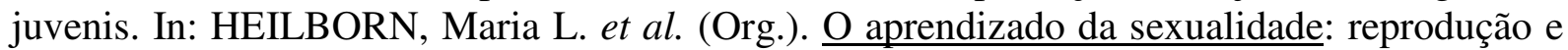
trajetórias sociais de jovens brasileiros. Rio de Janeiro: Garamond, 2006. Cap.1, p.29-58.

HEILBORN, Maria L. Sexualidade no plural: o direito à diferença. 2005. Disponível em: $<$ www.clam.org.br/publique/cgi/cgilua.exe/sys/start.htm?infoid=34\&tpl=printerview\&sid=4> . Acesso em 25 jan. 2007.

HEILBORN, Maria L. Construção de si, gênero e sexualidade. In: HEILBORN, Maria L. (Org.). Sexualidade: o olhar das ciências sociais. Rio de Janeiro: Jorge Zahar, 1999. p.40-58.

HEILBORN, Maria L. De que gênero estamos falando? In: Sexualidade, gênero e sociedade, v.1, n.2, p.1-8, dez. 1994.

HEILBORN, Maria L. Usos e abusos da categoria de gênero. [Apresentado no Seminário Gênero e Raça na América Latina]. São Paulo: 1990. Mimeografado.

HEILBORN, Maria L.; BRANDÃO, Elaine R. Ciências sociais e sexualidade. In: HEILBORN, Maria L. (Org.). Sexualidade: o olhar das ciências sociais. Rio de Janeiro: Jorge Zahar, 1999. p.7-17.

HEILBORN, Maria. L.; CABRAL, Cristiane S.; BOZON, Michel. Valores sobre sexualidade e elenco de práticas: tensões entre modernização diferencial e lógicas tradicionais. In:

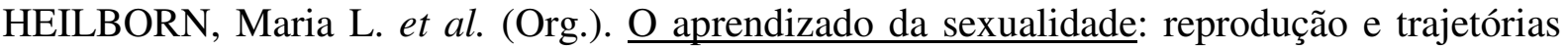
sociais de jovens brasileiros. Rio de Janeiro: Garamond, 2006. Cap.6, p.207-266.

HEKMA, Gert. Uma história da sexologia: aspectos sociais e históricos da sexualidade. In: BREMMER, Jan (Org.). De Safo a Sade: momentos na história da sexualidade. [From Sappho to De Sade: moments in the history of sexuality] Trad. Cid Knipel Moreira. Campinas: Papirus, 1995. p.237-264.

HOUAISS Dicionário eletrônico da língua portuguesa. Dicionário. v.1.0., sl., Objetiva, 2001. 1 CD-ROM.

JAPIASSU, Hilton. Introdução à epistemologia da Psicologia. 5.ed. São Paulo: Letras \& Letras, 1995. 208p.

KANUTH, D. et al. Sexualidade juvenil: aportes para as políticas públicas. In: HEILBORN, Maria L. et al. (Org.). O aprendizado da sexualidade: reprodução e trajetórias sociais de jovens brasileiros. Rio de Janeiro: Garamond, 2006. Cap.10, p.399-415. 
KAPLAN, Helen S. A nova terapia do sexo: tratamento dinâmico das disfunções sexuais. [The new sex therapy] Trad. Oswaldo Barreto e Silva. Rio de Janeiro: Nova Fronteira, 1977. 494p. (Experiência e Psicologia).

LAMOUR, Martine. Os abusos sexuais em crianças pequenas: sedução, culpa, segredo. In: GABEL, Marceline (Org.). Crianças vítimas de abuso sexual. [Les enfants victimes d'abus sexuels] Trad. Carlota Gomes; Sonia Goldfeder. 2.ed. São Paulo: Summus, 1997. p.43-61.

LAQUEUR, Thomas W. Inventando o sexo: corpo e gênero dos gregos a Freud. [Making sex: body and gender from the greeks to Freud] Trad. Vera Whately. Rio de Janeiro: RelumeDumará, 2001. 313p.

LASH, Christoper. Refúgio num mundo sem coração: a família - santuário ou instituição sitiada? [Haven is a heartless world: the family besieged] Trad. Ítalo Tronca; Lúcia Szmrecsanyi. Rio de Janeiro: Paz e Terra, 1991. 252p.

LATOUR, Bruno. Jamais fomos modernos. [We have never been modern] Trad. Carlos Irineu da Costa. Rio de Janeiro: 34, 1994.

LEIBLUM, Sandra R.; PERVIN, Laurence A. Princípios e prática de terapia sexual. [Principles and practice of sex therapy] Trad. Álvaro Cabral. Rio de Janeiro: Zahar, 1982. 536p.

LILIENTHAL, Luiz A. Educa-são: uma possibilidade de atenção em ação. 2004. 217p. Tese (Doutorado em Psicologia) - Instituto de Psicologia, Universidade de São Paulo, São Paulo. 2004.

LOURO, Guacira L. Gênero, sexualidade e educação: um perspectiva pós-estruturalista. 4.ed. Petrópolis: Vozes, 2001. 179p.

LOYOLA, Maria A. A sexualidade como objeto de estudo das ciências humanas. In: HEILBORN, Maria L. (Org.). Sexualidade: o olhar das ciências sociais. Rio de Janeiro: Jorge Zahar, 1999. p.31-39.

MAHFOUD, Miguel. A vivência de um desafio: plantão psicológico. In: ROSENBERG, Raquel L. (Org.). Aconselhamento psicológico centrado na pessoa. São Paulo: EPU, 1987. p.75-83. 
MAIA, Ana C. B. Orientação sexual na escola. In: RIBEIRO, Paulo R. M. (Org.). Sexualidade e educação: aproximações necessárias. São Paulo: Arte \& Ciência, 2004. p.153179.

MARTINS, Joel; BICUDO, Maria A. V. A pesquisa qualitativas em psicologia: fundamentos e recursos básicos. 2.ed. São Paulo: Moraes, 1994. 110p.

MEIHY, José C. S. B. Manual de história oral. 4.ed. São Paulo: Loyola, 2002. 246p.

MORATO, Henriette T. P. Aconselhamento psicológico: uma passagem para a transdisciplinariedade. In: MORATO, Henriette T. P. (Org.). Aconselhamento psicológico centrado na pessoa: novos desafios. São Paulo: Casa do Psicólogo, 1999. Cap.3, p.61-88.

MOSSE, George L. Masculinidade e decadência. In: PORTER, Roy; TEICH, Mikuláš (Org.). Conhecimento sexual, ciência sexual: a história das atitudes em relação à sexualidade. [Sexual knowledge, sexual science: the history of attitudes to sexuality] Trad. Luiz Paulo Rouanet. São Paulo: UNESP, 1998. p.291-308.

NUNES, César; SILVA, Edna. A educação sexual da criança: subsídios teóricos e propostas de práticas para uma abordagem da sexualidade para além da transversalidade. 2.ed. Campinas: Autores Associados, 2006. 136p. (Polêmicas do nosso tempo, 72)

NUNES, César. Desvendando a sexualidade. 6.ed. Campinas: Papirus, 2006. 141p.

PAIVA, Vera. Fazendo arte com a camisinha: sexualidades jovens em tempos de AIDS. São Paulo: Summus, 2000. 309p.

PAIVA, Vera. Sexualidades adolescentes: escolaridade, gênero e sujeito sexual. In: PARKER, Richard; BARBOSA, Regina M. (Org.). Sexualidades brasileiras. Rio de Janeiro: Relume Dumará, 1996. p.213-234.

PAN American Health Organization / World Health Organization. Promotion of Sexual Health: recomendations for action. Guatemala, 2000. 58p.

PARKER, Richard. Abaixo do Equador: culturas do desejo, homossexualidade masculina e comunidade gay no Brasil. [Beneath the Equator: cultures od Desire, male homosexuality and emerging gay communities in Brazil] Trad. Ryta Vinagre. Rio de Janeiro: Record/[Contra.luz], 2002. 380p. 
PARKER, Richard. Homossexualidade masculina. In: RIBEIRO, Marcos (org.). Educação sexual: novas idéias, novas conquistas. Rio de Janeiro: Rosa dos Tempos, 1993. p.329-342.

PARKER, Richard. Corpos, prazeres e paixões: a cultura sexual no Brasil contemporâneo. [Bodies, pleasures and passions: sexual culture in contemporary Brazil] Trad. Maria Therezinha M. Cavallari. 2.ed. São Paulo: Best Seller, 1991. p.9-35.

PERES, Camila; BLESSA, Cely R. B.; PAIVA, Vera; GONÇALVES, E. M. V.; SILVA, R. de C. Fala Educador Fala Educadora. São Paulo: Organon; Programa de DST AIDS SES, 1999. 162p.

PETCHESKY, Rosalind P. Direitos sexuais: um novo conceito na prática política internacional. In: BARBOSA, Regina M.; PARKER, Richard (Org.). Sexualidades pelo avesso: direitos, identidades e poder. Rio de Janeiro: IMS/UERJ; Ed. 34, 1999. p.15-38.

PICAZIO, Claudio. Diferentes desejos: adolescentes homo, bi e heterossexuais. São Paulo: Summus, 1998. 164p.

PISCITELLI, Adriana; GREGORI, Maria F.; CARRARA, Sérgio. Apresentação. In: PISCITELLI, Adriana; GREGORI, Maria F; e CARRARA, Sérgio. Sexualidade e saberes: convenções e fronteiras. Rio de Janeiro: Garamond, 2004. p.39-80. (Sexualidade, gênero e sociedade).

PORTO, Maria do R. S. Função social da escola. In: FISHCHMANN, Roseli (Org.). Escola brasileira: temas e estudos. São Paulo: Atlas, 1987. p.36-47.

QUEIROZ, Maria I. P. de. Variações sobre a técnica de gravador no registro da informação viva. São Paulo: T. A. Queiroz, 1991. 171p. (Biblioteca básica de ciências sociais; Série 2 textos; v. 7).

REIS, Giselle Volpato dos; RIBEIRO, Paulo R. M. A institucionalização do conhecimento sexual no Brasil. In: RIBEIRO, Paulo R. M. (Org.). Sexualidade e educação: aproximações necessárias. São Paulo: Arte \& Ciência, 2004. p.27-71.

RIBEIRO, Márcia; FERRIANI, Maria das G.; REIS, Jair N. Violência sexual contra crianças e adolescentes: características relativas à vitimização nas relações familiares. Cadernos de Saúde Pública, Rio de Janeiro, v.20, n.2, p.456-464, mar./abr. 2004. 
RIBEIRO, Paulo R. M. Os momentos históricos da educação sexual no Brasil. In: RIBEIRO, Paulo R. M. (Org.). Sexualidade e educação: aproximações necessárias. São Paulo: Arte \& Ciência, 2004. p.15-25.

RIBEIRO, Paulo R. M. Educação sexual além da informação. São Paulo: EPU, 1990.

ROGERS, Carl (1961). Tornar-se pessoa. [On becoming a person] Trad. Manuel José do Carmo Ferreira e Alvamar Lamparelli. 5.ed. São Paulo: Martins Fontes, 2001. 489p.

ROGERS, Carl (1951). A terapia centrada no paciente. [Client-centered therapy] Trad. Manuel do Carmo Ferreira. São Paulo: Martins Fontes, 1975. 527p. (Psicologia e Pedagogia).

ROSE, Hilary. Gay brains, gay genes and feminist science theory. In: WEEKS, Jeffrey; HOLLAND, Janet., ed. Sexual cultures: communities, values and intimacy. London, MacMillan Press, 1996. p.53-72.

RUBIN, Gayle. Reflexionando sobre el sexo: notas para una teoría radical de la sexualidad. In: VANCE, Carole (Coord.). Placer y peligro: explorando la sexualidad feminina. Madrid, Editorial Revolution SA, 1989. p.113-190.

RUBIN, Gayle. The traffic in women: notes on the 'political economy' of sex. In: REITER, Rayna (Org.). Toward anthropology of women. Nova York, Monthly Review Press, 1975.

SCHMIDT, Maria Luisa S. Pesquisa participante: alteridade e comunidades interpretativas. Psicologia USP, v.17, n.2, p.11-41, 2006.

SCHMIDT, Maria Luisa S. Ensaios indisciplinados: aconselhamento psicológico e pesquisa participante. 2005. 231p. Tese (Livre Docência) - Instituto de Psicologia, Universidade de São Paulo, São Paulo. 2005.

SCHMIDT, Maria Luisa S. Aconselhamento psicológico e instituição: algumas considerações sobre o serviço de aconselhamento psicológico do IPUSP. In: MORATO, Henriette T. P. (Org.). Aconselhamento psicológico centrado na pessoa: novos desafios. São Paulo: Casa do Psicólogo, 1999. Cap.4, p.90-104.

SCHMIDT, Maria L. S. A experiência de psicólogas na comunicação de massa. 1990. 212p. Tese (Doutorado em Psicologia) - Instituto de Psicologia, Universidade de São Paulo, São Paulo. 1990. 
SCHMIDT, Maria Luisa S.; TONIETTE, Marcelo A. A relação pesquisador-pesquisado: algumas reflexões sobre a ética na pesquisa e a pesquisa ética. In: GUERRIERO, Iara C. Z.; SCHMIDT, Maria Luisa S.; ZICKER, Fabio (Org.). Ética nas pesquisas em Ciências Humanas e Sociais na Saúde. São Paulo: Aderaldo \& Rothschild, 2008. Cap.5, p.102-108. (Saúde em debate, 188).

SCOTT, Joan. Gênero: uma categoria útil de análise histórica. Educação e realidade, v.20, n.2, Porto Alegre, p.71-99, jul./dez. 1995.

SPINK, Mary J. P. Psicologia social e saúde: práticas, saberes e sentidos. Petrópolis: Vozes, 2003. 339p.

SPINK, Mary J. P.; FREZZA, Rose M. Práticas discursivas e produção de sentidos: a perspectiva da Psicologia Social. In: SPINK, Mary J. (Org.). Práticas discursivas e produção de sentidos no cotidiano: aproximações teóricas e metodológicas. 2.ed. São Paulo: Cortez, 2000. p.17-39.

SPINK, Mary J. P.; MEDRADO, Benedito. Produção de sentidos no cotidiano: abordagem teórico-metodológica para análise das práticas discursivas. In: SPINK, Mary J. (Org.). Práticas discursivas e produção de sentidos no cotidiano: aproximações teóricas e metodológicas. 2.ed. São Paulo: Cortez, 2000. p.41-61.

SPINK, Mary J. P.; MENENGON, Vera M. A pesquisa como prática discursiva: superando os horrores metodológicos. In: SPINK, Mary J. (Org.). Práticas discursivas e produção de sentidos no cotidiano: aproximações teóricas e metodológicas. 2.ed. São Paulo: Cortez, 2000. p.63-92.

TONIETTE, Marcelo A. Homossexualidade: significados e sentidos de uma construção social a partir de trajetória de um militante. 2003. 208p. Dissertação (Mestrado em Psicologia) Instituto de Psicologia, Universidade de São Paulo, São Paulo. 2003.

TONIETTE, Marcelo A; LILIENTHAL, Luiz A. (Re)pensando pontos de partida no trabalho com as dificuldades sexuais a partir da Curva de Contato proposta por Joseph Zinker. In: CONGRESSO BRASILEIRO DE SEXUALIDADE HUMANA, 10., 2005, Porto Alegre. Anais... Porto Alegre: Sociedade Brasileira de Sexualidade Humana, 2005. p.129.

TONIETTE, Marcelo A.; SCHMIDT, Maria Luisa. S. Sexualidades e alteridade: aproximações possíveis a partir dos relatos orais. In: CONGRESO LATINOAMERICANO DE SOCIEDADES DE SEXOLOGÍA Y EDUCACIÓN SEXUAL, 12., 2004, Santiago. Anais... Santiago, Federación Latinoamericana de Sociedades de Sexologia y Educación Sexual, 2004. 1 CD-ROM. 
TONIETTE, Marcelo A.; SCHMIDT, Maria L. S. Relatos orais e sexualidades: uma possibilidade metodológica para o estudo da diversidade sexual. In: CONGRESO LATINOAMERICANO DE SOCIEDADES DE SEXOLOGÍA Y EDUCACIÓN SEXUAL, 11., 2002, Isla de Margarita, Federación Latinoamericana de Sociedades de Sexologia y Educación Sexual, 2002. 1 CD-ROM

VACCARI, Vera L. Saúde sexual, escolas promotoras de saúde e relações de gênero: representações de adolescentes sobre masculinidades e feminilidades. 2002. 149p. Dissertação (Mestrado em Saúde Pública) - Faculdade de Saúde Pública, Universidade de São Paulo, São Paulo. 2002.

VANCE, Carole S. A antropologia redescobre a sexualidade. Physis: Revista de saúde coletiva, v.5, n.1, p.7-31, 1995.

WEEKS, Jeffrey. O corpo e a sexualidade. In: LOURO, Guacira L. (Org.). O corpo educado: pedagogias da sexualidade. 2.ed. Belo Horizonte: Autêntica, 2000. p.35-82.

WEREBE, Maria J. G. Sexualidade, política e educação. Campinas: Autores Associados, 1998. 217p.

WORLD ASSOCIATION FOR SEXOLOGY'S DECLARATION OF SEXUAL RIGHTS, 1999. In: Pan American Health Organization / World Health Organization. Promotion of Sexual Health: recomendations for action. Guatemala, 2000. p.37-38. (Appendix I).

WORLD HEALTH ASSOCIATION. Defining sexual health: report of a technical consultation on sexual health; 28-31 January 2002, Geneva. Geneva, 2006. (Sexual health document series). 30p.

ZINKER, Joseph C. A busca da elegância em psicoterapia: uma abordagem gestáltica com casais, famílias e sistemas íntimos. [In search of good form: gestalt therapy with couples and families] Trad. Sonia Augusto. São Paulo: Summus, 2001. 322p. (Novas buscas em psicoterapia, 61). 
ANEXO 


\section{TERMO DE CONSENTIMENTO LIVRE E ESCLARECIDO}

Decidi participar da pesquisa Trajetórias de vidas e sexualidades: um estudo a partir de depoimentos de homens e mulheres atendidos no Plantão Psicológico do Serviço de Aconselhamento Psicológico do IPUSP, que tem como objetivo conhecer significados e sentidos da construção social de masculinidades e feminilidades a partir de depoimentos sobre a trajetória de vida e a experiência de homens e mulheres. O presente estudo é dirigido pelo pesquisador Marcelo Augusto Toniette, pós-graduando do curso de doutorado pelo Instituto de Psicologia da Universidade de São Paulo (IPUSP) - tel. (xx)xxxx-xxxx / xxxx-xxxx -, orientado pela Profa. Dra. Maria Luisa Sandoval Schmidt, do Programa de Pós-Graduação em Psicologia Escolar e do Desenvolvimento Humano (PSA) - tel. (xx) xxxx-xxxx.

A metodologia para obtenção de dados para a pesquisa consiste em utilizar entrevistas que serão gravadas, posteriormente transcritas, e utilizadas no corpo da tese. A identidade do/da participante será mantida em sigilo, sendo que ele/ela poderá escolher um pseudônimo que desejar.

Estou ciente de que: (a) a qualquer momento poderei entrar em contato com o pesquisador para esclarecimento de eventuais dúvidas; (b) posso deixar de participar da pesquisa a qualquer momento; (c) caso eu queira, poderei ser informado/a de todos os resultados obtidos com a pesquisa; (d) a participação na pesquisa não corresponde a atendimento psicológico; e (e) não haverá compensação financeira relacionada à minha participação.

$\mathrm{Eu}$, abaixo assinado, declaro que, após convenientemente esclarecido/a pelo pesquisador e ter entendido o que li - ou o que me foi lido -, concordo de livre e espontânea vontade em participar voluntariamente da presente pesquisa, na qual prefiro que o meu depoimento seja identificado pelo pseudônimo

Nome:

Sexo: $\square \mathrm{M} \square \mathrm{F} \quad$ Data nascimento: ___ _ _ _

RG no:

End.:

E-mail:

Cidade /Estado:

CEP:

Bairro:

São Paulo, de de 20

Tel.: 